UNIVERSIDAD NACIONAL DE LA PLATA

FACULTAD DE HUMANIDADES Y CIENCIAS DE LA EDUCACIÓN DOCTORADO EN CIENCIAS SOCIALES

\title{
EN SU LUGAR Y EN SU NOMBRE. DISPUTAS POR LA REPRESENTACIÓN EN EL ESPACIO PÚBLICO MEDIATIZADO.
}

La gestión de colectivos en discursos políticos y discursos periodísticos durante el "conflicto del campo" (marzo-julio de 2008)

Autor: Mariano Fernández

Director: Dr. Martín Retamozo

Co-director: Dr. Gastón Cingolani 
$(2)$ 
A mi mamá, Catalina A mi papá, Luis por el ejemplo impecable 
AGRADECIMIENTOS.................................................... 12

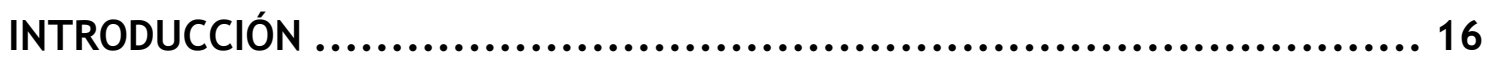

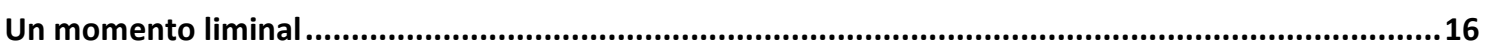

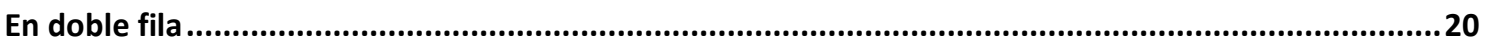

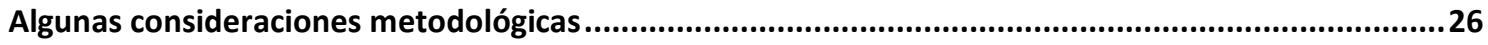

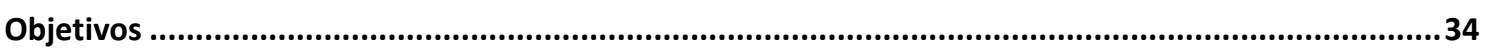

Presentación de la estructura del trabajo ............................................................................................35

PRIMERA PARTE: DISCUSIONES TEÓRICAS Y PROPUESTA ANALÍTICA ....... 41

CAPÍTULO 1: MEDIATIZACIÓN: UNA PERSPECTIVA TEÓRICA................ 44

Introducción. La mediatización como proceso, contexto y teoría. ................................................44

1.1. Mediatización: ¿un proceso contemporáneo?...................................................................49

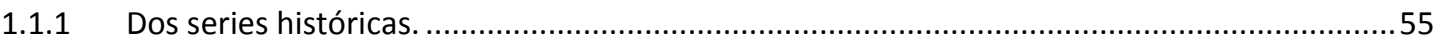

a- Una "serie larga": la mediatización como constituyente antropológica ...............................55

b- "Una serie corta": la mediatización como proceso de la "alta modernidad" ..........................59

1.2. Mediatización de la política: hacia un concepto ampliado ....................................................64

1.2.1. Sobre la primacía de la “lógica mediática” ...........................................................................65

1.2.2. Mediatización: campos problemáticos ................................................................................ 71

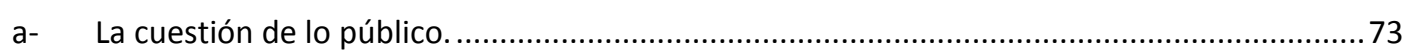

b- Del periodismo partisano al periodismo profesional, de los periódicos a los medios: la estructuración frágil de un lugar de enunciación.

c- $\quad$ La mediatización como mecanismo de base de funcionamiento de los discursos en el espacio público

1.3. Niveles analíticos para el estudio de la mediatización...............................................................87

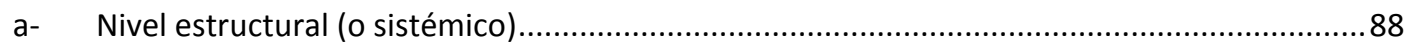




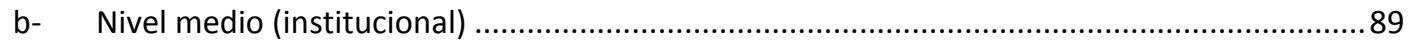

c- $\quad$ Nivel micro (o de la interacción y las prácticas) ..............................................................91

1.3.1. Niveles analíticos para el estudio de la mediatización de la política .......................................91

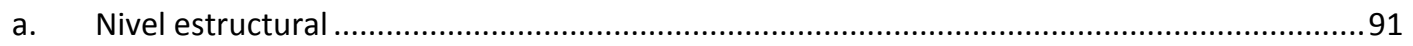

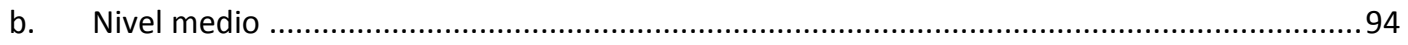

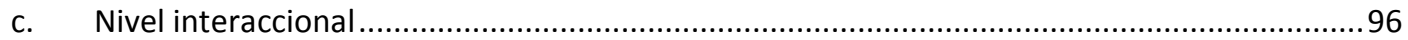

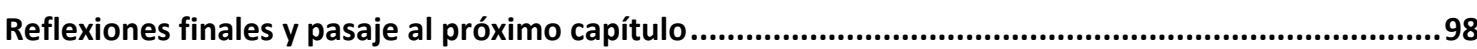

\section{CAPÍTULO 2: EL ESPACIO PÚBLICO MEDIATIZADO. PROPUESTA ANALÍTICA PARA EL ESTUDIO COMPARADO DE LOS DISCURSOS POLÍTICOS Y LOS DISCURSOS PERIODÍSTICOS .............................................103}

Introducción: escenas de la mediatización, o la heterogeneidad del objeto de estudio ...................... 103

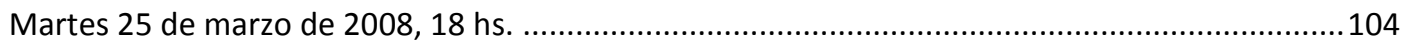

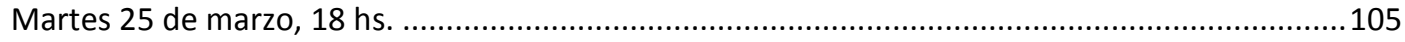

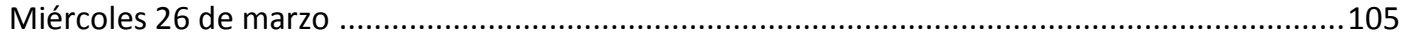

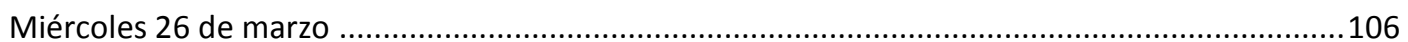

2.1. El espacio público mediatizado: una constelación de arenas públicas, un horizonte de destinación

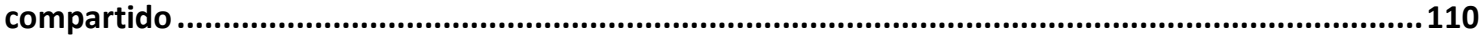

2.1.1. El Público como Tercero y principio regulador............................................................... 118

2.2. La gestión de colectivos: definición conceptual y aplicación al análisis ......................................120

2.2.1. Los "colectivos": construcciones bajo restricción .............................................................. 122

2.2.2. Los colectivos en el juego de discursos sociales: posiciones de observación ...........................125

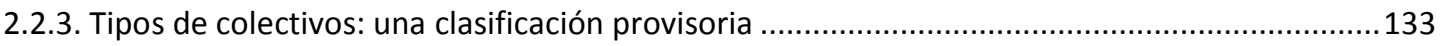

2.3. Dispositivos de enunciación de los discursos políticos y periodísticos......................................135

2.3.1. El dispositivo de enunciación: una herramienta analítica ...................................................137

2.3.2. Los dispositivos de enunciación en relación a los tipos de discurso, los soportes materiales y las

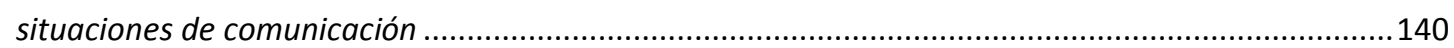

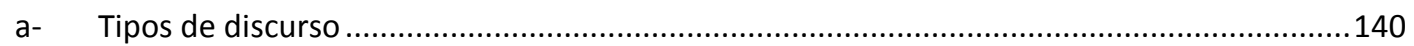

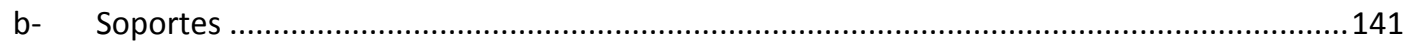

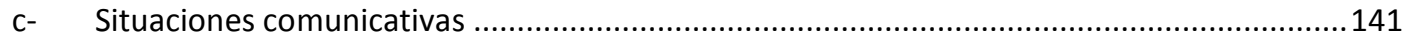

2.3.3. Dispositivos de enunciación: las relaciones con los destinatarios........................................145

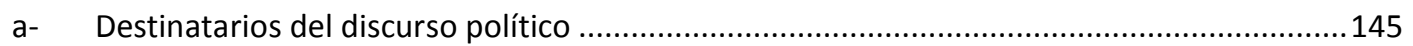

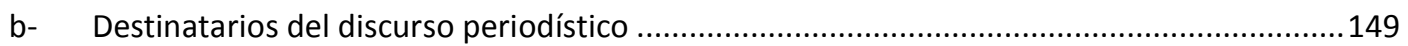

Reflexiones finales y pasaje al próximo capítulo ..................................................................... 151 


\section{LA INVARIANTE KIRCHNERISTA (2003-2008). LA MODALIZACIÓN LITIGIOSA}

DE LA MEDIATIZACIÓN POLÍTICA

3.1. Política y medios en el kirchnerismo (2003-2008): políticas de medios y comunicación política 165

3.2. Políticas de comunicación: legislación y distribución de la pauta oficial.

3.2.1. La lógica continuista.

3.2.2 Publicidad oficial: "quid pro quo"

- $\quad$ Aumento del monto absoluto de publicidad oficial. 180

- Distribución de pauta oficial a los medios ya existentes

3.3. La modalización litigiosa de la comunicación política.

pítulo

\section{EL CONFLICTO DEL CAMPO: LUGARES, OBJETOS Y SUJETOS DE UNA} CUESTIÓN LITIGIOSA 
4.2. La coyuntura y sus pre-condiciones: el modelo sojero y las transformaciones de la estructura socio-productiva agraria.

4.3. Vínculo lógico de las determinaciones y modalidades de encarnación de lo colectivo. Las condiciones sociales del litigio.

CAPÍTULO 5

\section{REPRESENTACIÓN POLÍTICA, REGÍMENES DE VISIBILIDAD Y ACTIVACIÓN LITIGIOSA EN LAS INTERVENCIONES PÚBLICAS DE CRISITNA FERNÁNDEZ DE KIRCHNER

5.2.1. La economía discursiva de la representación: construcción del liderazgo y persona representativa.

5.2.2. La representación disputada: competencia con el discurso de los dirigentes rurales y reinstalación de los "indicadores de certeza”

5.3. Intervenciones sobre el espacio público y regímenes de visibilidad.

5.3.1. Estructuración de los regímenes de visibilidad: variación en las figuras del liderazgo y en sus principios de legitimidad

a- Monólogo esotérico (con rasgos polémicos). ....................................................................289

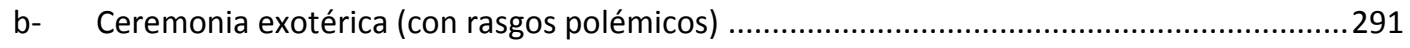

c- Movilización ceremonial (con rasgos antagonistas) ........................................................2292

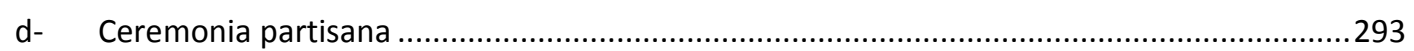

5.3.2 Intervenciones sobre el espacio público: una dialéctica mediatizada...................................296

5.4. La definición del conflicto como activación litigiosa: construcción de un lazo adversativo asimétrico. 
CAPÍTULO 6

\section{DESDE ARRIBA Y DESDE ABAJO: LA GESTIÓN DE COLECTIVOS EN LA PRENSA GRÁFICA EN EL CONFLICTO DEL CAMPO .................................310}

Introducción .310

6.1. Posiciones de observación y dispositivos de enunciación en el estudio de la prensa gráfica ........314

6.1.1. Gestión de colectivos y posición de observación. ..............................................................315

6.1.2. Dispositivo de enunciación: desdoblamiento en la emisión................................................317

6.2. Ascenso en generalidad: definición del conflicto, identificación de los colectivos y tematización de los escenarios de la disputa.

6.2.1. Posicionamiento de los diarios entre el 11 de marzo y el 25 de marzo. ................................325

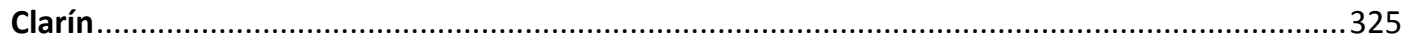

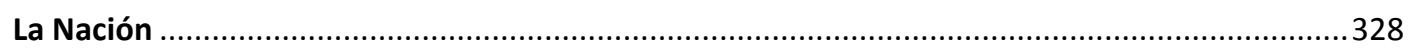

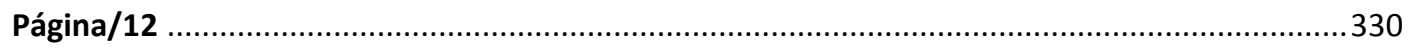

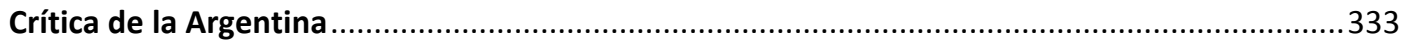

6.2.2. Los diarios en reconocimiento: efectos de los discursos de CFK entre el 25/03 y el 4/04........335

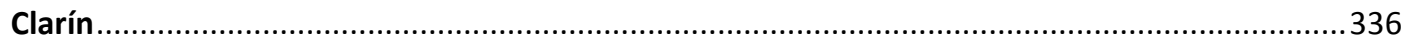

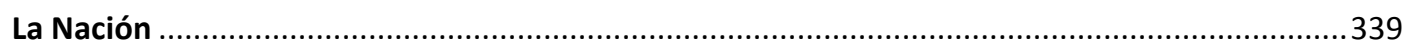

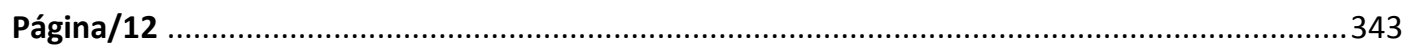

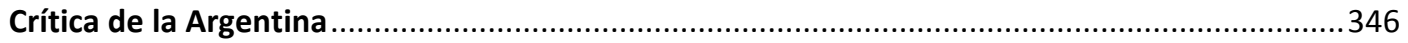

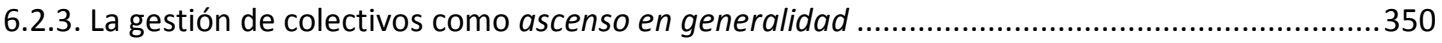

6.3. Los pequeños productores según los diarios: la representación por descenso en singularidad. ...351

Clarín .354

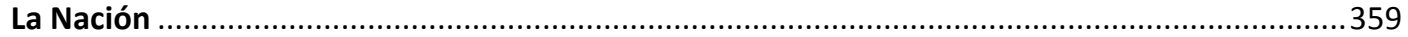

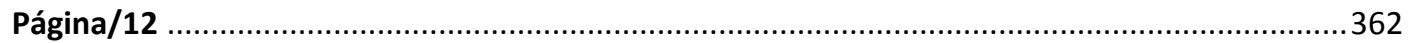

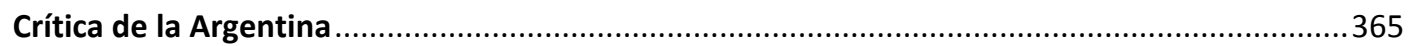

6.3.1. Las instituciones mediáticas: la representación como política de la presencia y el individuo

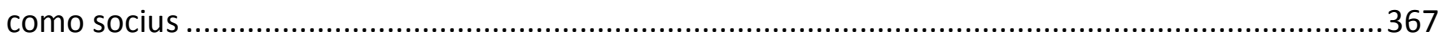

Reflexiones finales y pasaje al próximo capítulo...............................................................370

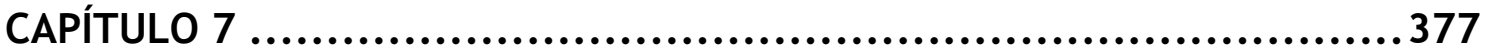




\section{LA DISPUTA POR LA REPRESENTACIÓN, ENTRE LOS PÚBLICOS POLÍTICOS Y}

LOS PÚBLICOS MEDIÁTICOS...................................................377

Introducción: entre la disputa por el relato y la disputa por la representación ....................................377

7.1. Acción y reacción: la confirmación de un imaginario institucional dominante ..............................379

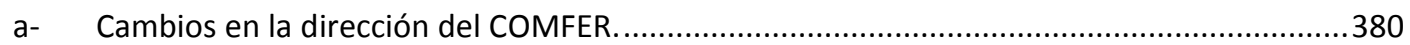

b- Generales multimediáticos y mensajes cuasi-mafiosos .........................................................381

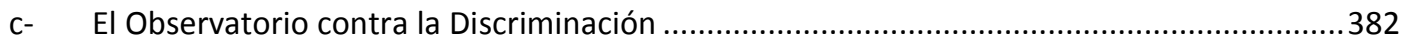

d- Mariotto al COMFER: la madre de todas las batallas ...........................................................385

7.1.2. Cuatro gramáticas revelan un funcionamiento ideológico..........................................................386

7.2- Operaciones de representación y encarnación de entidades del imaginario político. ...................392

7.2.1. Contextos enunciativos de la comunicación en el espacio público ............................................393

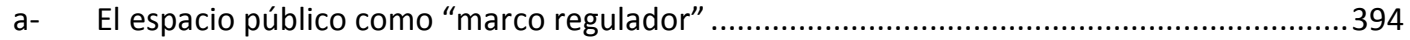

b- El "lugar" enunciativo estabilizado por cada medio....................................................................35

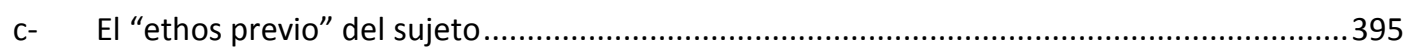

7.2.2. El "público" encarnado: la "sociedad” y los "argentinos" ............................................................398

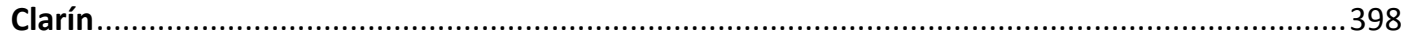

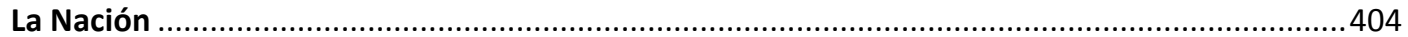

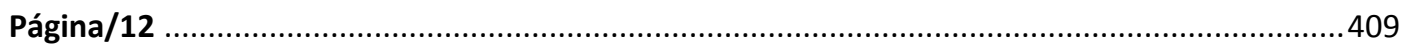

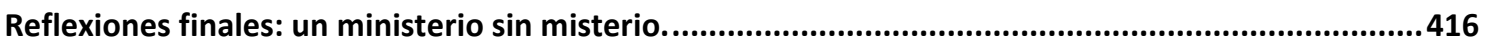

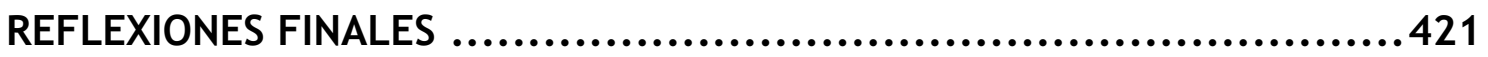

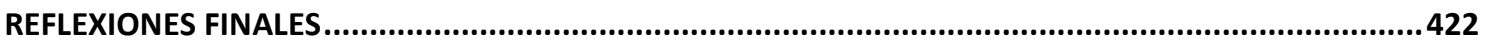

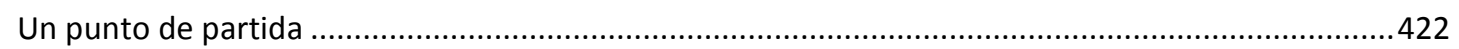

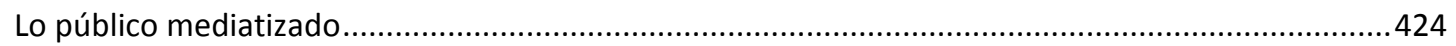

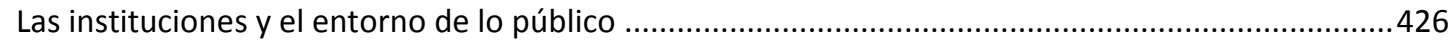

Zona de intermediación: una reflexión que cierra para volver a empezar.....................................431

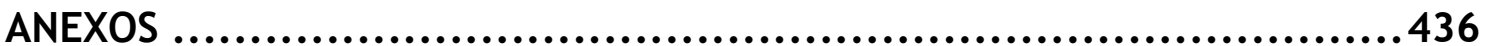

ANEXO I: SOBRE ALGUNAS DIFICULTADES EN LA DEFINICIÓN DE CRITERIOS

DE SELECCIÓN DEL CORPUS DE PRENSA GRÁFICA .........................437

ANEXO II: CORPUS DE ARTÍCULOS PERIODÍSTICOS .......................441 
BIBLIOGRAFÍA 


\section{AGRADECIMIENTOS}

Una tesis doctoral es un trabajo de muchos años. Si en lugar de medir el paso del tiempo con el calendario lo pondero en relación a ciertas experiencias vitales tengo la sensación de que en el transcurrir de la escritura de este texto he vivido muchas vidas. Y como agradecer es, inevitablemente, mirar al pasado, y en esas vidas que atravesé desde que inicié este trabajo lógicamente fueron muchas las personas que -de modos diversos, no siempre por incidencia directa sobre la investigación, pero sí sobre mí- me acompañaron y fueron y son necesarios, imprescindibles, es a ellos, a ellas, que agradezco, por las siguientes razones.

A Martín Retamozo, quien fue mi director de beca, mi profesor de doctorado, y mi director de tesis, por la predisposición, por la paciencia ante mis vaivenes, por el criterio de sus correcciones y por el aliento constante frente a mis inconstancias regulares.

A Gastón Cingolani, co-director, pero ante todo maestro y amigo. Los años de trabajo en conjunto (en la Facultad de Periodismo de la UNLP y en el Área Transdepartamental de Crítica de Artes de la UNA), fueron y siguen siendo instancias vitales de mi formación profesional.

A las autoridades del Instituto de Investigación en Humanidades y Ciencias Sociales de la Facultad de Humanidades y Ciencias de la Educación (Idihcs), por el trabajo profesional constante. A los trabajadores docentes y no docentes del Doctorado en Ciencias Sociales de la Facultad de Humanidades y Ciencias de la Educación, que fue el ámbito en el que desarrollé mi formación de posgrado.

A mis compañeras y compañeros del Centro de Investigaciones Socio Históricas (CISH). 
Al Consejo Nacional de Investigaciones Científicas y Técnicas que me otorgó dos becas doctorales gracias a las cuáles realicé mi doctorado.

A los colegas de la Red Nacional de Investigadores de Comunicación, por los años de aprendizaje y encuentros.

Al Centro de Investigación en Mediatizaciones (CIM) de la Universidad Nacional de Rosario y, en particular, a quienes lo han creado y lo sostienen como un espacio muy activo de investigación y debate.

A tantos con quienes, a lo largo de estos años, hemos compartido espacios de reflexión, escritura, informales sesiones de catarsis sobre los efectos colaterales de las tesis, y de la vida. Entre ellos, a Julia de Diego, Irene Gindín, Tomás Lüders, Mati López y Soledad Stoessel.

A Agustín Casagrande, Javier Planas y Leandro García, con quienes iniciamos este camino.

A mis ex compañeros de la Secretaría de Coordinación Militar de Asistencia en Emergencias del Ministerio de Defensa de la Nación. Todos y todas, en esos dos años en los que esta tesis fue un archivo de word hibernando en un disco rígido, se interesaron y me alentaron para retomarla y terminarla.

A los amigos de la vida Augusto Zocco, Pato Golia, Franco Nicoletti, Juan Bellusci, Juan Ferrero, Yuli Goñi, Santiago Maissonave, Leo Marzano, Germán Cornejo, Martín Van Dam, Mauro Cricco y Patricio Zamora. Un lazo invisible une lo disperso en el espacio y en el tiempo.

A Inés Barboza, por la amistad inoxidable. Hubo un momento, que ahora se me aparece casi con el fulgor de una epifanía, en que tus consejos (¿o fueron órdenes?) me empujaron a elegir, y eso era lo que necesitaba.

A Omar Crespo, por la guía espiritual desde La Plata o desde El Lejano Oeste. 
A mi hermana, Sofía y a mi hermano, Andrés. La fraternidad no es un lazo de sangre: se hereda y se elabora y se aprende. Con paciencia y con tolerancia, a los gritos y con carcajadas. So, Andi: juntos y a la par.

A Simona, al Negro, a Tina y a Olivia, que con insistencia gatuna y perruna me sacaron, día tras día, de mi burbuja metafísica.

Y especialmente a Joaquina, mi amor. Nadie mejor que vos sabe lo que hay detrás de estas páginas, que se convirtieron en un anexo -una habitación, un escritorio, un montón de papeles, pilas de libros- de nuestra propia vida cotidiana. Nadie mejor que yo sabe lo necesaria que fuiste, y lo imprescindible que sos. Entonces, Joa, gracias: por la paciencia, por la generosidad, por el ánimo, por las sonrisas. Por los días felices y el porvenir.

La Plata, 30 de septiembre de 2016 


\section{INTRODUCCIÓN}

\section{Un momento liminal}

El paso del tiempo y el devenir de los procesos sociales suelen matizar el valor de eventos que, en la memoria y en la experiencia personal, se asientan con el peso de una presencia absoluta. Benjamín Arditi (2007) ha escrito que "la hegemonía en el sentido fuerte de la palabra es una experiencia fugaz que se verifica en momentos liminales cuando la política parece dominar nuestras vidas". Esos momentos tornan visible "el excedente metafórico de luchas particulares", generan las condiciones para que "vivamos la experiencia de una identidad supra-grupal". Esos momentos no marcan el ritmo de la vida ordinaria de las sociedades; más bien, la trastocan y compendian. Y aun así, medidos por el sistema métrico de la historia, son "experiencias fugaces", “coyunturas excepcionales”, una suerte de “carpe diem-colectivos”, después de los cuales -como también antes, y como también durante y como seguramente después- "la gente sigue con sus vidas asistiendo a clases, yendo a la huelga por mejores condiciones de trabajo, buscando un ascenso, quejándose de la calidad de los servicios públicos o hablando de política y pensando en cómo cambiar el mundo" (Arditi, 2007).

Esta tesis tiene como marco de referencia contextual, aunque no necesariamente como objeto de estudio, un momento liminal; un acontecimiento breve, intenso y significativo de la Argentina contemporánea. Uno de esos momentos en que se perfila con cierta nitidez una polarización de colectivos que alcanzarían, circunstancialmente, para colmar el espectro de los posicionamientos políticos de coyuntura, con la suficiente fuerza como para imponer alineamientos o para convencer que esos alineamientos constituyen la necesidad (ética, política, pragmática) ineluctable del presente. Los “hechos”, “actores”, “acciones” y “discursos” que hilvanan la trama de ese acontecimiento forman parte, ya, del catálogo de la memoria pública nacional. Podemos incluso evitar hablar de "historia", porque, como 
ha escrito Borges, "la verdadera historia es más pudorosa y sus fechas esenciales pueden ser durante largo tiempo secretas", pero lo seguro es que el llamado "conflicto del campo" es un hito dramático de la vida política de la primera década del siglo XXI.

Entre el 11 de marzo y el 17 de julio de 2008 el Gobierno nacional argentino enfrentó un proceso sin precedentes de protestas -movilizaciones, cortes de ruta, cese de comercialización de bienes, asambleas- liderado por las cuatro organizaciones políticas más importantes del sector agropecuario ${ }^{1}$. Un amplio repertorio de acciones directas, recurso habitual de los sectores subalternos, víctimas inefables de las crisis económicas y políticas, se desplegaba sobre los espacios públicos pero los protagonistas eran productores agropecuarios, empresarios y otras tantas figuras de la economía agropecuaria.

Las protestas, que comenzaron como una clásica reacción sectorial frente al aumento en las alícuotas de los derechos de exportación de granos (en particular, de la soja), trascendieron rápidamente el reclamo puntual hasta convertirse en una impugnación política al gobierno de Cristina Fernández de Kirchner, quien había asumido la presidencia de la Nación apenas tres meses antes $^{2}$.

El pasaje acelerado ${ }^{3}$ desde un reclamo corporativo y circunscripto, a una movilización política transectorial, se visibilizó en la concurrencia de actores políticos, empresariales y gremiales no directamente implicados en la medida, pero también de franjas de población de los centros urbanos, predominantemente de sus sectores medios y altos. Este doble movimiento de expansión de la base social y despliegue geográfico de la protesta y de

\footnotetext{
1 Sociedad Rural Argentina (SRA), Confederaciones Rurales Argentinas (CRA), Federación Agraria Argentina (FAA) y Coninagro (Confederación Intercooperativa Agropecuaria)

${ }^{2}$ Cristina Fernández fue electa presidenta de la Nación el 28 de octubre de 2007 con el $45,29 \%$ de los votos, en una fórmula integrada por el radical Julio Cleto Cobos. El 10 de diciembre de 2007 asumió como la primera Presidenta elegida por el voto ciudadano.

${ }^{3}$ Si bien volveremos con detalle sobre el desarrollo del conflicto en el capítulo 4, conviene recordar que las entidades agropecuarias nucleadas en lo que se denominó Mesa de Enlace Agropecuario anunciaron un cese de comercialización el 11 de marzo y que una semana después se registraban 300 cortes de ruta, y que ya el 25 de marzo se produjeron las primeras protestas en los centros de las principales ciudades del país: Ciudad de Buenos Aires, Rosario, Santa Fe, entre otras.
} 
ampliación de las manifestaciones de apoyo extra-sectorial (incluidos partidos políticos con representación parlamentaria) tornaron verosímil la emergencia y consolidación del "campo" como un actor político organizado, a tal punto que los dirigentes agropecuarios tomaron como interlocutor a la "ciudadanía" en su conjunto, frente a la cual llegaron a proponer "otro modelo de país".

Por su propia contextura, pero también por sus efectos, el "conflicto del campo" puede reclamar para sí varios capítulos en la vida pública de la Argentina contemporánea. Le corresponde, sin dudas, un lugar central en la saga de las relaciones entre el sector agropecuario y el Estado nacional, en las articulaciones políticas de las organizaciones y actores sectoriales y en el intento por proyectar más allá de los límites de la representación corporativa su voluntad de orientar un proceso político (Barsky, 2008; Sartelli, 2008; Gras, 2011). Pero también, en retrospectiva, el conflicto puede ser considerado un hecho clave en el devenir del kirchnerismo como una identidad política singular, el punto de contraste entre dos "ciclos" (Novaro, 2011: 110), tanto por el modo en que el conflicto habilitó una racionalización ex post facto de la inserción del kirchnerismo en una tradición nacional-popular (Svampa, 2011: 19) cuanto porque, recortado sobre el fondo del período de gobierno de Néstor Kirchner, fue la primera vez desde 2003 que el gobierno nacional encontraba un antagonista encarnado en actores con capacidad de movilización actual, que impugnaron globalmente la legitimidad del gobierno nacional apenas 100 días después de asumida Cristina Fernández ${ }^{4}$.

\footnotetext{
4 Está claro que hablar de "kirchnerismo" implica hacer referencia a una identidad distinguible, a un colectivo con capacidad de auto-imaginarse y de generar identificaciones. Como una identidad política se va configurando en un proceso de diferenciación externa y homogeneización interna, de enlazar prácticas heredadas, de implementar nuevas medidas, de redefinir la orientación de las políticas públicas (Aboy Carlés, 2005) la identificación de "un momento" es de antemano incorrecta. Es probable que el conflicto con el sector agropecuario haya generado las condiciones para el kirchnerismo se identificara de manera coherente con la tradición nacional-popular ("momento" que, para Svampa se consolida con la aprobación de la Ley de Servicios de Comunicación Audiovisual, en 2009, y con el fallecimiento del ex presidente, en octubre de 2010), pero sólo pudo hacerlo porque en el período previo -digamos, en la segunda mitad de la presidencia de Néstor Kirchner- ya se había empezado a consolidar un imaginario político que Montero y Vincent sintetizaron con el nombre de "el kirchnerismo puro" (2013: 141-144).
} 
La alegoría del "momento liminal" que propone Ariditi permite comprender, en otro nivel, un rasgo que se vincula directamente con el tipo de experiencia intersubjetiva que produce la mediatización de la vida social. Porque "liminal" es también aquello que abarca los límites de un campo perceptivo del espacio público y aquello que puede efectivamente ser percibido. Lo que se denomina actualidad no sólo es un temario -una agenda sino también, en igual medida y en sentido amplio, un horizonte perceptual. Resulta imposible, por lo tanto, concebir la "liminalidad" de un acontecimiento -por ejemplo, del conflicto del campo- por fuera de su mediatización -de su despliegue en las diferentes superficies mediáticas- y de manera independiente a las instituciones de medios.

Precisamente, en ese gran proceso contencioso, la intervención de los medios de comunicación de alcance nacional se tornó un fenómeno central: es decir, tendió a ocupar el centro de los debates. Por un lado, oficiaron como superficies de amplificación de la protesta, escenarios paralelos a las rutas, plazas, calles y mesas de negociación. Por el otro, el accionar de algunas instituciones mediáticas fue rápidamente identificado por el gobierno como políticamente interesado, lo cual derivó no sólo en referencias explícitas y directas sino en una dinámica de debates cruzados por la cual los propios medios fueron asumiendo y ejerciendo un rol protagónico.

En el marco del conflicto, en sucesivas intervenciones públicas la Presidenta de la Nación identificó a ciertas empresas de medios de comunicación como responsables por la propia deriva del proceso. Estos cuestionamientos al "rol de los medios" -que no eran las primeras, ni de parte de la Presidenta, ni de parte de su antecesor, Néstor Kirchner- no se agotaron en diatribas públicas y encontraron eco y apoyo en otras instituciones (organizaciones de la sociedad civil, facultades, organizaciones sociales, sindicatos). La percepción generalizada fue, entonces, no sólo que los medios de comunicación (para no abusar: los más importantes) estaban apoyando, cuando no incentivando una movilización destituyente, sino que, por su mismo accionar, estaban fomentando y legitimando la oposición a las políticas del gobierno, 
convirtiéndose -sin asumirlo- en agentes de esa oposición. Si por su intensidad la confrontación abierta resultó en un escenario inédito, el marco general de esta disputa reactivaba viejos y diversos interrogantes relativos al lugar institucional y la función de los medios en las democracias, al condicionamiento que las relaciones de propiedad tienen sobre las agendas informativas, a la legitimidad que investía sus intervenciones, al poder de los efectos y a su capacidad de influencia en las personas.

\section{En doble fila}

Como podrá advertirse esta investigación trata sobre temas y problemas saturados en los discursos públicos (sean académicos o no) sobre el presente. Si se hiciera un recuento, necesariamente parcial, de todo lo que se ha investigado, escrito y publicado sobre el conflicto del campo, este trabajo ocuparía un lugar -uno más- en la larga fila de aquellos que se interesaron particularmente por el rol que los medios de comunicación actuaron desde el 11 de Marzo de aquel año ${ }^{5}$. También, uno más en la fila de aquellos que se han interesado por uno de los debates públicos emergentes del enfrentamiento, a propósito del estatus de la representación y la legitimidad de la palabra y las decisiones tomadas en nombre de otros ${ }^{6}$.

Por el lugar que los medios masivos de comunicación ocupan (incluso todavía hoy, en pleno proceso de dilución de ese rol intermediario privilegiado) como estructuradores del espacio público (Ferry, 1989) el periodismo es un interlocutor predilecto de los actores políticos y es en ese espacio que unos y otros ponen en ejercicio operaciones de representación y mediación de

\footnotetext{
${ }^{5}$ Mucha bibliografía enfocada sobre algún aspecto del "rol" de los medios en el conflicto, se publicó en el período inmediato y mediato posterior al conflicto: Fair Rezak (2008); Goulu; Koziner (2008); Rubiano (2008); Ibáñez y Cabral (2008); Martínez Fabiana (2009); Becerra y López (2009); Cremonte (2010); Zunino (2010).

${ }^{6} \mathrm{Sin}$ hacer mención especial a las instituciones de medios, Eduardo Rinesi sintetizó con claridad este punto. El conflicto con la entidades agropecuarias habría reactualizado algunos grandes temas y problemas que habían signado, bajo otras formas, la presidencia de Alfonsín. Entre ellos, destaca, en primer lugar "la diferencia entre la legitimidad del poder de decisión de los representantes votados por el pueblo y la ilegitimidad de las reivindicaciones particularistas de los dirigentes de las corporaciones" (Rinesi, 2010: 47).
} 
colectivos sociales. Pero mientras que la "legitimidad" de las instituciones de medios y del periodismo, el conjunto de principios o condiciones que lo habilitan -o son expuestas como habilitantes- para hablar en nombre de una generalidad social, parece estar sostenida por su "rol externo" al juego político, por su rol de observador (rol plenamente ideológico y que puede constatarse en las expectativas sociales sobre su deber profesional), una vez que queda colocado como contrincante, como competidor en la arena política, el problema de cómo validar su legitimidad cambia de estatus: el periodismo ve cómo le son transferidas las exigencias de legitimidad que operan tradicionalmente sobre las instituciones del sistema político.

Este es uno de los aspectos problemáticos de la mediatización de la política, aspecto que adquirió, a lo largo de todo el período kirchnerista, una relevancia notable, ya que tanto Néstor Kirchner (2003-2007) como Cristina Fernández (2007-2011) hicieron de la tematización pública del rol del periodismo uno de los ejes de sus discursos, primero, y de sus energías políticas, después. Es plausible pensar que, desde el principio, el kirchnerismo -incluso antes de que esa identidad se hubiera encarnadointentó de manera persistente arrastrar al periodismo a la contienda política; mostrarlo como un actor más en esa contienda y equipararlo a otros "poderes" fácticos cuya legitimidad no encuentra su fuente en el aval ciudadano. Si las políticas de comunicación del kirchnerismo, al menos hasta el año 2008, se revelaron pragmáticas, transaccionales o punitivas según los casos, otras tantas intervenciones públicas permiten entrever que el tanto Néstor Kirchner como Cristina Fernández habían desarrollado una concepción no meramente instrumental de las relaciones entre los medios masivos, el periodismo y el sistema político: que entendían que allí había una disputa por el contacto con los ciudadanos, y por lo tanto, una disputa institucional: había que confrontar los lugares instituidos de enunciación en el espacio público, especialmente aquellos que, como dijimos, podían atribuirse la expresión de porciones de la ciudadanía ${ }^{7}$.

\footnotetext{
${ }^{7}$ Que el correlato político cotidiano de esta idea fuera un escarceo tenso con los periodistas, o, en una escala más trascendente, el incremento exponencial de la pauta publicitaria y su direccionamiento arbitrario (con consecuencias a la postre dramáticas para muchos
} 
Esto, por supuesto, no significa desconocer o menospreciar el valor determinante que la disputa de intereses, derivada de cambios profundos en la matriz socioproductiva del sector agropecuario tuvo y tendrá en su relación con el Estado. Pero también es innegable que todos los debates contemporáneos al conflicto y los análisis posteriores que discutieron, interpretaron, explicaron y volvieron a discutir la heterogeneidad de las identidades contenidas bajo el símbolo "campo" (discusiones hechas de imágenes televisivas, de discursos políticos, de voces de observadores) 0 aquellas otras sobre cómo distinguir un "pequeño productor", ya por la cantidad de hectáreas como por sus bienes de consumo, ilustra bien este problema, al tiempo que es apenas una de sus manifestaciones. Lo que interesa en el contexto de este trabajo, es que esa controversia está -en uno de sus niveles de producción- sometida necesariamente a su mediatización.

El problema general de nuestra tesis es la disputa por la configuración pública de las identidades colectivas, y, en ese marco, las disputas por la gestión colectiva de las representaciones sociales entre las instituciones del sistema político y las instituciones del sistema mediático. De ahí que busquemos discutir con las concepciones que circunscriben "la mediatización de la política” a la circulación de la información o de “recursos cognitivos", cuya distribución equitativa redundaría en la toma de mejores decisiones políticas. Tampoco queremos abordar el rol de los medios en términos de "construcción del acontecimiento", o de "cobertura" (como lo han intentado hacer, por ejemplo, Becerra y López, 2009, Cremonte, 2010; o Aruguete y Zunino, 2011, 2012), del mismo modo que buscamos evitar el abordaje de los discursos políticos como recursos de una estrategia de persuasión. Al proponer como objeto de estudio, una zona de interacción (al menos, aquella que funciona en superficie, y que puede, o no, ser una derivada de los acuerdos no mediatizados, sean estos ideológicos, económicos, coyunturales o de largo plazo) asumimos que podemos comprender algo del funcionamiento

trabajadores de prensa una vez que esa pauta, con el cambio de gobierno producido en 2015, modificó los criterios de distribución) no inhabilita el punto de vista expuesto. Se trata, para nosotros, de $\mathrm{n}$ mismo y único fenómeno. 
institucional, tanto del sistema político como del sistema de medios, precisamente allí donde los medios han venido a intervenir conflictivamente sobre el espacio público: como mediadores privilegiados de la ciudadanía política.

El concepto de mediatización (que, como intentaremos mostrar en el capítulo 1, identifica de manera superpuesta un proceso, una perspectiva y una hipótesis sobre el funcionamiento de lo social) nos interesa porque nos permite reflexionar y desarrollar herramientas de análisis para estudiar una de las formas de conflicto entre los discursos intermediarios en el espacio público. Para sintetizar ahora lo que desarrollaremos después: para estudiar los discursos de representación (como lo son, cada uno a su modo, los discursos políticos y los discursos periodísticos) hay que considerar sus condiciones sociales productivas estables, y entre ellas, su funcionamiento mediatizado. Por muchas razones, y por una en particular: la mediatización, en especial aquella que producen los medios masivos (que no es la única) revela con claridad la naturaleza triangular de la discursividad pública, su orientación constitutiva hacia un tercero; y, en el caso que aquí estudiaremos, ese tercero puede concebirse como un regulador simbólico, un interpretante del imaginario político.

Si, como afirma Latour (2008:48) "nuestra experiencia más común del mundo social es que ese mundo se ve acometido simultáneamente por varios llamamientos posibles y contradictorios a reagruparse", los discursos políticos y los discursos periodísticos son dos operadores continuos de ese llamamiento. De modo que cabría considerarlos (en tanto variantes de la producción discursiva de dos sistemas sociales) por el modo en que cada uno hace funcionar la gestión y la mediación de colectivos sociales en el espacio público, es decir, aquella zona de enunciación que se instaura en todos los discursos que ponen en juego la existencia de agregados (grupos, agrupaciones), organizada en torno a la relación entre lo individual y lo colectivo, y entre colectivos entre sí. 
Recordemos que uno de los problemas que el conflicto propuso a los directos interesados, pero también a los analistas políticos y a la ciudadanía, tuvo que ver con la heterogeneidad de sectores congregados en torno al rechazo de las retenciones y con el tipo de vínculo que otorgaba, al menos circunstancialmente, cierta homogeneidad a la protesta. Primero, por la confluencia de la Federación Agraria Argentina y de la Sociedad Rural en la Mesa de Enlace, entidades que históricamente simbolizaban intereses contradictorios en el sector; luego, por la repercusión de la protesta en el seno de las grandes ciudades, con la consecuente ampliación de la iconografía rural que había servido de soporte de la protesta como exclusivo reclamo sectorial; más tarde, por la incorporación de partidos políticos de signo diverso (e incluso antagónico) a las movilizaciones en contra del Gobierno.

El conflicto visibilizó transformaciones en la dinámica productiva del sector agropecuario y agro-industrial, así como permitió detectar emergentes en las redes de sociabilidad de los sectores involucrados. Pero mientras se desarrollaba y se debatían los "intereses" en pugna ("retenciones", "distribución de la riqueza”, "política fiscal del Estado", "evasión impositiva del sector primario"), la pregunta por la identidad de los actores fue igualmente importante. El pudor con que se utilizó, en muchos casos, la palabra "campo" -así, entrecomillada- es signo (está, literalmente, en lugar de otra cosa) de una percepción estrictamente sociológica: definir quiénes estaban disputando se tornó, una y otra vez, un ejercicio constitutivo de la confrontación.

Puestos a rastrear -incluso sin método, aunque orientados por esa duda- en la superficie mediática, durante nuestros primeros acercamientos al corpus de esta investigación, nos encontramos con muchos indicadores de esa controversia. Leemos que en respuesta a una resolución ministerial que modificaba el esquema de retenciones a la exportación de soja, girasol, maíz y trigo, las "cuatro entidades rurales" adoptan una medida de fuerza, un "lock-out", "un paro", una "protesta". Se nos dice que se trata de "la protesta del campo", pero también que se trata del "paro de las $4 \times 4$ ". 
Desde el principio se trata de definir quiénes se están enfrentando. Motivos, parece, no faltan: la Presidenta de la Nación habla de "piquetes de la abundancia", explica que se trata de un "conflicto económico", pero luego también expresa que se trata de un "conflicto político" con "aquellos sectores que condenan nuestra política de derechos humanos y aquellos que han perdido las elecciones". Un editorialista expresa su malestar semántico porque "se llama "campo" al conjunto de entidades representativas de los productores, excluyendo tácitamente del pronombre colectivo a los castigados asalariados"; en el mismo diario se afirma que las "medidas de fuerza" las ha tomado "la Sociedad Rural". Sin embargo, desde otro diario, un empresario agropecuario nos habla de “la protesta de 'El Campo'”, también así, entre comillas, y se explica: “defino “El campo" como 400.000 pymes, los pueblos del interior que en su mayoría viven del campo, los maestros, los trabajadores de Uatre, los camioneros que transportan granos, la industria y los servicios relacionados que según algunos estudios casi $40 \%$ de la mano de obra de la argentina". Otro diario se dispone a entrevistar a algunos protagonistas de la "protesta": dos “chacareros" de un pueblo santafesino que aseguran sentir "bronca por tener que hacer esto, lo nuestro es trabajar el campo, no protestar, no somos piqueteros"; días después, el mismo diario nos cuenta que entre quienes protestan existe un grupo de "piqueteros que no responden a ninguna organización”, y especifica: “una red de gringos autoconvocados", que son "pequeños y medianos productores", que "se organizan por teléfono y por mail". Sin embargo, desde otro periódico se nos explica que "los chacareros chicos y medianos" que "fueron la base social de la protesta", que en "los medios fueron presentados como los "productores", aquellos que se levantan con el sol y trabajan con sus manos la tierra", en realidad son otra cosa: “quienes cortaron las rutas no son los productores, los que trabajan, sino los que gestionan el trabajo ajeno. Lejos de su imagen mediática, no sudan en la cosecha: se limitan a vigilar el trabajo de los operarios que ni siquiera dirigen en forma directa". Y podríamos extender esta ejercicio caprichoso con infografías, estadísticas, fotos, fotomontajes, tomas en primer plano de "productores" tomando mate a la vera de la ruta, 
planos generales del "pueblo argentino" convocado en Plaza de Mayo en señal de apoyo al Gobierno.

¿Qué hacer con esta enumeración? En principio -y esa es nuestra propuestatomar en serio los elementos que encadena; asumir que lo que ella indica es el estatus político que está en juego. Como dice Bourdieu (1999:96) la acción política:

\begin{abstract}
"pretende producir e imponer representaciones (mentales, verbales, gráficas o teatrales) del mundo social capaces de actuar sobre él actuando sobre la representación que de él se hacen los agentes. 0 , más concretamente, pretende hacer o deshacer los grupos -y, al mismo tiempo, las acciones colectivas que esos grupos puedan emprender para transformar el mundo social de acuerdo con sus intereses-, produciendo, reproduciendo o destruyendo las representaciones que corporeizan esos grupos y les hacen visibles para los demás".
\end{abstract}

Es precisamente este nudo el que queremos desatar en este trabajo: describir y explicar cómo, en el contexto del "conflicto del campo", el discurso político y el discurso periodístico intervinieron en y sobre la controversia por la formación y la identidad de los grupos sociales y las facciones en pugna, considerando lo mediático no como un tipo de discurso particular, sino como un conjunto de condiciones de producción de la discursividad del espacio público.

\title{
Algunas consideraciones metodológicas
}

A lo largo de la tesis, y particularmente en los capítulos finales -que son los que dedicamos al análisis empírico de los discursos que componen nuestro corpus- fuimos apuntando algunas explicaciones epistemológicas y metodológicas. Por lo tanto, aquí solo queremos informar sobre ciertas decisiones generales importantes.

En primer lugar, nuestra investigación puede considerarse una variante de estudio de caso, fundado en el interés por estudiar un fenómeno general a 
partir de un caso de observación que se nos presentaba con características ejemplares, paradigmáticas. Stake ([1995] 1999: 16-17) distingue entre tres tipo de estudio de caso: intrínseco, instrumental y colectivo. En el estudio de caso instrumental el caso cumple el rol de mediación para la comprensión de un fenómeno que lo trasciende. Así, el propósito de la investigación va más allá del caso, que es utilizado como instrumento para evidenciar características de algún fenómeno o teoría. El caso es considerado, entonces, como ejemplar, o típico.

En segundo lugar, toda investigación cuyo corpus esté compuesto por "discursos" se ve sometida a la exigencia de justificar el pasaje entre ese nivel empírico (textos de diarios, alocuciones presidenciales) a generalizaciones que, como es nuestro caso, implican poner en cuestión disputas ancladas, también, en funcionamientos y relaciones institucionales. De modo que, especialmente aquí, se vuelve pertinente esta pregunta: “¿En qué medida el análisis de los discursos asociados a estructuras institucionales determinadas permite comprender mejor los mecanismos de dichas instituciones, su naturaleza y sus transformaciones?" (Verón, 1987:14). La respuesta del propio Verón es que "hay niveles de funcionamiento de los procesos políticos a los que solo podemos acceder a través del análisis del discurso". Como los tipos de discursos (y los discursos políticos y periodísticos son, en principio, tipologías diferenciadas) que circulan en la sociedad están articulados, por un lado, a estructuras institucionales complejas que operan como sus soportes, y por el otro, a relaciones sociales cristalizadas de ofertas y expectativas (que deben funcionar como los correlatos de esas estructuras institucionales) es necesario dar cuenta de esa doble articulación (que es un efecto histórico, y por lo tanto, sometido a transformaciones) para poder estudiar el modo en que la gestión de los colectivos de identidad se produce en un contexto determinado y bajo condiciones sociales de producción caracterizadas, en un nivel fundamental, por la mediatización del espacio público. 
En el nivel epistemológico, nuestro proyecto toma como referencia algunas premisas de la teoría de los discursos sociales de E. Verón (2004a). De la propuesta de Verón retomamos, en primer lugar, su concepción como una teoría no lineal de la producción de sentido (2004b). En relación a nuestro objeto de estudio, esto nos interesa porque implica que la posición del observador es la del intercambio discursivo concebido como sistema de relaciones: en esta escala, el sentido está afectado de indeterminación, la circulación no puede ser causal. De allí que uno de los aportes más importantes de la teoría de Verón sea la diferenciación entre dos puntos de vista irreductibles para analizar la producción de sentido: la producción y el reconocimiento. El sentido, entonces, no es ni subjetivo (no es encuentra en la intención de un actor) ni objetivo (no está en la lengua): "es una relación (compleja) entre la producción y la recepción, en el seno de los intercambios discursivos" (2008). Si esto nos interesa es porque esa "zona de interacción" entre el discurso político y el discurso periodístico que nos hemos dado como objeto de estudio sólo puede reconstruirse, primero, en el nivel de su discursividad, y segundo, tiene la forma de un "sistema de intercambios discursivos", sin que esto implique interlocución directa de los actores.

Por otro lado, retomamos la importancia de una doble hipótesis que explica su concepción de los fenómenos sociales como procesos de producción de sentido: "toda producción de sentido es necesariamente social: no se puede describir ni explicar (...) un proceso significante sin explicar sus condiciones sociales productivas"; en sentido inverso, "todo fenómeno social es, en una de sus dimensiones constitutivas, un proceso de producción de sentido, cualquiera que fuere el nivel de análisis (más o menos micro o macro sociológico)"( 2004a). La teoría de los discursos sociales, en este sentido, ofrece un recorte por nivel de pertinencia (la dimensión significante de los procesos sociales): sólo en el nivel de la discursividad el sentido manifiesta sus determinaciones sociales y los fenómenos sociales develan su dimensión significante (Verón, 2004a). Pero, al mismo tiempo, el análisis de los discursos no puede ser autosuficiente: reclama, según sea el tipo de discurso estudiado (publicitario, científico, religioso, periodístico, político) información extra- 
discursiva (en relación al discurso analizado) que ella misma no está en condiciones de proveer y que suministra criterios de selección del corpus. ${ }^{8}$

Para realizar la investigación trabajamos sobre dos series de corpus que demandaron tratamientos analíticos diferentes.

Por una parte, estudiamos los 124 discursos de Cristina Fernández de Kirchner, pronunciados entre el 11 de marzo y el 20 de julio de 2008. Sobre ese total, realizamos posteriormente un doble recorte: a) sobre aquellos discursos en los que hizo una referencia explícita al conflicto con el sector agropecuario y luego b) sobre aquellos discursos que fueron realizados como intervenciones directas sobre el conflicto, tanto actos y movilizaciones como anuncio de medidas. En todos los casos, trabajamos sobre las transcripciones de esos discursos disponibles en el entonces sitio web oficial de la Casa Rosada. Por otra parte, realizamos un análisis de los registros audiovisuales de 15 de estos discursos, registro que incluye a los principales actos y movilizaciones protagonizadas por la entonces presidenta entre el 11 de marzo y el 17 de julio de 2008. En estos casos, trabajamos sobre los archivos disponibles en la plataforma Youtube (y que adjuntamos en el CD que acompaña esta presentación).

A su vez, tal como lo proponemos en el capítulo 5, los discursos de CFK se comprenden mejor como intervenciones públicas condicionadas por la propia dinámica del conflicto, y en particular por las expresiones públicas de los dirigentes de la Mesa de Enlace. Por eso, consideramos necesario, en algunas instancias, recuperar esos discursos de la dirigencia agropecuaria. A lo largo del conflicto hubo cuatro actos masivos que concluyeron con discursos de los dirigentes de la Mesa de Enlace: en Guleguaychú, el 2 de Abril de 2008; Rosario, el 25 de Mayo; Armstrong, el 2 de Junio y Palermo, el 15 de Julio de ese año. El acto en Armstrong no responde a esa característica pero su inclusión en la serie está fundamentada por el contexto en que fue realizado y

\footnotetext{
8 "Si carecemos de criterios externos (referidos a las condiciones de producción, es decir, a los mecanismos de funcionamiento de la sociedad) no podemos siquiera elegir textos susceptibles de ser comparados" (1973:243).
} 
por su repercusión posterior. A esto agregamos 8 comunicados emitidos por la Mesa de Enlace Agropecuario entre el 19 de marzo y el 17 de julio de 2008. Un análisis más detallado y comparativo de estos actos fue realizado en Fernández y Stoessel (2012), trabajo que utilizamos como referencia para esta tesis.

La otra serie textual analizada es la del conjunto de los artículos publicados por las ediciones impresas de los diarios Clarín, La Nación, Página/ 12 y Crítica de la Argentina entre el 11 de marzo y el 20 de julio de 2008. Al elegir estos diarios no pretendimos ser originales. Aquí se impone una aclaración casi idiosincrática. La opción por Clarín y La Nación podría justificarse por su peso específico, al ser los diarios de interés general más importantes del país ${ }^{9}$; en particular Clarín, por su lugar de referencia en la orientación editorial del conglomerado de medios del Grupo del que es propiedad ${ }^{10}$. Pero la importancia pública relativa de un medio no se deriva mecánicamente de sus números de venta. Otras razones, de orden circunstancial, también podrían esgrimirse: en un caso - La Nación- se había convertido en el adversario predilecto del Gobierno de Néstor Kirchner, y también en un interlocutor polémico de la propia Cristina Fernández antes de su asunción como Presidenta ${ }^{11}$; en el otro-Clarín, el diario, pero en general el Grupo- porque el conflicto marcó una transición: de aliado necesario a enemigo público número uno $^{12}$. Así como La Nación es el medio gráfico que, históricamente, ha

\footnotetext{
${ }^{9}$ Según los datos del Instituto Verificador de Circulaciones, organización civil que audita la circulación de periodismo impreso, en el año 2008 Clarín vendió un promedio anual por edición de 379.649 ejemplares, con picos de 700.000 los días domingo. La Nación, fundado en 1870 por Bartolomé Mitre, por su parte, vendió 157.700 ejemplares en promedio durante ese año.

${ }^{10}$ El Grupo Clarín es el conglomerado de medios más importante de Argentina; posee diarios, revistas, canales de TV en todo el país; es propietario de las empresas más importantes de distribución de televisión por cable. Por sus dimensiones y por su propia lógica de expansión comercial y empresarial, es un actor con peso político y económico trascendente, tal como puede verse en los libros de Sivak y Mochkofsky mencionados. Desde el año 2006, fue organizador, junto al grupo La Nación, de la feria Expoagro la muestra anual más importante de maquinarias, insumos y productos del sector agropecuario del país.

11 Un estudio muy completo y cuidadoso de las controversias públicas entre el diario y NK y CFK puede leerse en Vincent (2013).

12 Luego del conflicto del campo, el interés por Clarín y su historia se intensificó notablemente, casi obsesivamente. En cualquier caso, de entre lo publicado, se destacan dos libros que por el aporte documental, se convirtieron en referencias: Clarín. La era Magnetto, publicado por Martín Sivak en el año 2015, como segundo tomo de una historia completa del
} 
expresado el pensamiento de las elites (conservadoras, de derechas, liberales) $)^{13}$ Página $/ 12^{14}$, desde su fundación en 1987 , se consolidó como un actor insoslayable como referencia de lo que sin precisión pero sin alternativa descriptiva rápida, se denomina "progresismo", o "centro-izquierda", y que, luego del 2008, se consolidó como un espacio muy afín al gobierno de Cristina Fernández, desde donde se defendieron sus políticas y, muchas veces, se desplegaron argumentos que luego el propio gobierno asumió como propias. Se suele asumir que La Nación y Página/ 12 anclan los polos del arco ideológico del espacio público político nacional, y creemos que, al menos en el contexto del conflicto del campo, esto fue efectivamente así. El caso del diario Crítica de la Argentina es diferente: se publicó por primera vez el 2 de marzo de 2008, una semana antes de que se iniciara el conflicto; si bien su fundador, el periodista Jorge Lanata, ya se había posicionado como una voz crítica al Gobierno, también mantenía, aún, una batalla personal con el Grupo Clarín, del que también era un crítico público implacable. La composición del staff del diario era ideológicamente heterogénea, y su línea editorial -en ese marzo de 2008- una promesa, o un anuncio publicitario. Su inclusión en nuestro corpus responde a esa indefinición, ya que nos permitía contrastar con las posiciones más consolidadas $-\mathrm{y}$, a priori, previsibles- de los demás diarios ${ }^{15}$.

El corpus de textos de los diarios resultó de una selección realizada sobre un primer corte de alrededor de 3500 artículos de los cuatro medios, conjunto indefectiblemente heterogéneo si se lo considera en función del género (editoriales, tapas, notas de opinión, notas de análisis, entrevistas, notas informativas), variación que a su vez se diversifica en función de los rasgos propios - del estilo, en términos de Steimberg (1998)- de cada diario; de su lugar en la jerarquía editorial de cada medio; del "peso específico" del autor

diario desde su fundación en 1945; y Pecado original. Clarín, los Kirchner y la lucha por el poder, escrito por Graciela Mochkofsky, publicado en 2011.

${ }^{13}$ La referencia ineludible al respecto es el libro La política mirada desde arriba. Las ideas del diario La Nación (1909-1989), de Ricardo Sidicaro.

${ }_{14}^{14}$ Del que no se conocen los números de venta, ya que no está auditado.

${ }^{15}$ Crítica dejó de editarse en mayo de 2010, un año después de que Lanata renunciara a la dirección. Un relato lúcido y descarnado de esa experiencia, pero también de la relación de los medios y el kirchnerismo, puede leerse en Años de rabia. El periodismo, los medios y las batallas del kirchnerismo, publicado por Eduardo Blaustein (que fue periodista de Crítica) en 2013. 
de esas notas. De ese primer registro, realizamos una selección de la cual resultaron poco más de 600 artículos, en función de un criterio general: que en ellos pudiéramos identificar operaciones de gestión de colectivos.

En consecuencia, el criterio de selección no podía ser ni aleatorio ni representativo ${ }^{16}$; fue intencional, y directamente vinculado a un criterio de corte establecido después de una lectura general y en función del análisis del conflicto que desarrollamos en el capítulo 4. Las notas que conformaron el corpus fueron aquellas en las que se planteaban las preguntas "litigiosas": sobre la identidad de los protagonistas, sobre sus razones, sobre su historia, sobre sus estrategias. Puntualmente, aquellas notas a través de las que se puede reconstruir el modo en que se va configurando el colectivo "campo" y el colectivo "pequeños productores", que finalmente fueron analizadas en el capítulo 6. En el Anexo I exponemos algunas reflexiones sobre las dificultades que enfrentamos para la composición de este corpus, en los capítulos 6 y 7 exponemos algunas precisiones metodológicas del análisis discursivo, y en el Anexo II se puede revisar el listado de artículos, ordenados por diario, por mes y por día.

A propósito de los cuatro diarios que vamos a analizar, cabe señalar que tienen un peso relativo desigual si se considera su posición en el mapa mediático en general, en el mercado de la prensa gráfica en particular, en su capacidad de influencia sobre el sistema político y también en relación a su inserción en el espectro ideológico de los consumos informativos. En un sistema de medios concentrado como el argentino, esa posición diferencial tiene un correlato en el vínculo de las empresas de medios con el Estado y con el Gobierno ${ }^{17}$. Si además, como sucede con el Grupo Clarín, por su

\footnotetext{
${ }^{16}$ Como lo explica Archenti (2007: 246) para referirse a los estudio de caso, tanto la selección del caso (o de los casos) como del material nunca se realiza por azar como en los método estadísticos, porque se parte de la no equivalencia entre los casos, que se destaca a través de la propuesta orientada a la comprensión de la especificidad de cada caso. El proceso de selección está basado en criterios teóricos, en experiencias de observación y en las expectativas depositadas en la unidad seleccionada, en términos de su potencialidad para proveer una base empírica relevante para la interpretación y comprensión del fenómeno estudiado.

${ }^{17}$ El posicionamiento frente al gobierno, o bien hacia alguna de las medidas del gobierno, se puede considerar como un fenómeno que tiende a regular la zona de competencia directa en
} 
envergadura comercial y su modelo de expansión y de supervivencia empresarial, se ha constituido como una suerte de garante de gobernabilidad -al menos, para sostener los indicadores volubles del favoritismo de la opinión pública- la caracterización formal por niveles de la intervención en el conflicto puede parecer una abstracción impertinente, ya que las lógicas de la información se resuelven por las clásicas vías mundanas: llamados telefónicos, encuentros informales, presiones o promesas, simpatías, etc.

Para el tipo de estudio que estamos llevando a cabo, es importante, al menos como precepto analítico inicial, relegar la descripción singular de cada medio en favor de la identificación de los rasgos que los tornan equiparables. Entre esos rasgos, resulta central el de definirlos, siguiendo a Borrat (1989: 9), como periódicos independientes de información general. La "independencia" se refiere -y por eso nos interesa la definición- a la relación del medio con el Gobierno, un partido, un sindicato o la Iglesia. "En el periódico independiente (...) la dependencia es con respecto a una empresa editora autónoma; la lógica empresarial cubre todo el espacio que en los otros ocupa la lógica del poder gubernamental, partidista, sindical, eclesiástico". Así entendida, no garantiza la ausencia de favoritismos, sino una posición a priori: la voz del medio no se confunde con la de los protagonistas.

En segundo lugar, se presenta la cuestión, vinculada a la anterior, del posicionamiento político e ideológico de cada medio, de su línea editorial, y de cómo ponderar ese hecho en el momento de estudiar los mecanismos discursivos de gestión de colectivos. Esto plantea el problema de la posición que cada medio asume frente al conflicto. Retomando el planteo ya clásico de Borrat, hablamos de los "niveles de intervención". Se trata de un problema clave no sólo porque remite al posicionamiento político sino también al "lugar" y a la "función" de los medios como instituciones diferenciadas. La idea de que ese "lugar", usualmente "externo" a los actores en disputa, es en realidad una impostura, resultado de un discurso ideológico que le ha dado

la que los periódicos de interés general ingresan diariamente para "disputar" el lectorado, o bien para consolidar el lectorado fidelizado. 
carta de ciudadanía al periodismo bajo los postulados de la "independencia", "neutralidad", "objetividad", no debe hacer olvidar que aunque “dependientes", "parciales” y "subjetivos", los "periódicos independientes de información general" tienen una vida civil como instituciones autónomas irreductible a los intereses de los que, se subraya, pueden ser representantes o ventrílocuos o mascarones de proa. Si se pretende reconstruir mecanismos discursivos anclados institucionalmente no se puede perder de vista este principio.

\section{Objetivos}

Nuestro objetivo general fue, desde el principio, doble: contribuir a la reflexión teórica sobre la mediatización de la política y a su investigación empírica, tomando como referencia un proceso particular -el conflicto que entre marzo y julio de 2008 enfrentó al Gobierno Nacional argentino con actores y organizaciones del sector agropecuario.

A partir de esa doble formulación, en el plano teórico buscamos realizar una revisión del concepto de "mediatización" para desarrollar una perspectiva de análisis orientada al estudio empírico de los discursos sociales (mediatizados). A medida que avanzamos en ese objetivo (cuya realización queda expuesta en el capítulo 1) entendimos que era necesario dar un paso más: el estudio comparado de discursos políticos y discursos periodísticos no puede entenderse sino por referencia al "lugar" y las "condiciones de producción" en que esos discursos se producen y circulan. Buscamos, entonces, desarrollar una definición del concepto de "espacio público mediatizado" (capítulo 2).

En el plano del análisis empírico nos propusimos estudiar las intervenciones públicas de Cristina Fernández de Kirchner durante el conflicto, para reconstruir sus estrategias de representación y las figuras de liderazgo que fue encarnando. 
$\mathrm{Y}$, como contraparte, procuramos estudiar la intervención de la prensa gráfica en el conflicto del campo, considerado en su dimensión de litigio político. Nos preguntamos cómo construyeron las instituciones políticas y las instituciones mediáticas las figuras de sus destinatarios. En este sentido, ¿pueden identificarse "lógicas políticas" y "lógicas periodísticas" o, en aquel contexto de alta conflictividad, también los medios trabajaron según "lógicas políticas" de mediación, por ejemplo produciendo una polaridad nosotros/ellos?

Buscamos entonces reconstruir comparativamente el modo en que los cuatro diarios que tomamos como referencia empírica (Clarín, Crítica de la Argentina, La Nación y Página/12) fueron configurando en sus páginas un imaginario político del conflicto. En ese marco, nos propusimos identificar modos regulares de configuración de las entidades de ese imaginario, es decir, de los colectivos que protagonizaron las protestas en estos cuatro meses, y cuya existencia, forma, identidad, historia, fueron puestas en cuestión, discutidas, afirmadas y negadas.

Un último objetivo, central para nuestra investigación, se derivó del siguiente interrogante: ¿cómo se manifiesta, en el plano del discurso, la disputa por la representación? Esto concierne, directamente, a la comparación entre las dos series discursivas. Sospechamos -y no podemos presumir de originalidad- que una de las formas de esa disputa se podía verificar en los intentos por hablar de y en nombre de los mismos colectivos.

\section{Presentación de la estructura del trabajo}

Esta tesis está organizada en tres grandes bloques. En el primero, conformado por los capítulos 1 y 2 , desarrollamos la perspectiva teórica y presentamos los principales conceptos analíticos de la investigación.

El objetivo del capítulo 1 es presentar la perspectiva teórica de nuestra tesis, sostenida en el concepto de mediatización. Buscamos exponer los presupuestos, las categorías, los criterios de relevancia que delimitan la 
problemática que vamos a estudiar. El movimiento expositivo que pretendemos realizar tiene una forma circular: queremos empezar deslindando el término mediatización de su identificación -en apariencia inevitable- con la noción de medios masivos de comunicación para, finalmente, volver sobre esa relación desde una perspectiva diferente. Ese movimiento, por otro lado, es necesario: como el uso del término tiende a ser referencial el trabajo analítico de distinción se vuelve necesario para definir una perspectiva teórica y orientar la indagación empírica

Precisamente en el capítulo 2 presentamos una serie de principios analíticos, con una relación de mutua implicancia aunque de diverso alcance conceptual y empírico, que nos servirán para dos efectos: circunscribir el planteo general y teórico del capítulo anterior, por una parte; y presentar algunos conceptos y herramientas de análisis de los que haremos uso en los capítulos siguientes, por otra. Buscamos, específicamente, desarrollar un enfoque de análisis a partir de la hipótesis de que el espacio público mediatizado funciona como condición de producción de los discursos políticos y periodísticos, en particular por un rasgo estable y constitutivo: no hay espacio público si no hay un tercero. Ese tercero (frente al cual los discursos hablan, argumentan, explican, discuten) funciona como un "meta-destinatario": no es un sujeto sociológico identificable en la topografía social sino un principio regulador de los discursos (no sólo, claro está, de los discursos políticos o periodísticos). Ese rol regulador del "público" se vuelve un rasgo trascendente cuando se pretende estudiar las disputas por la mediación y la representación en los discursos políticos y periodísticos. ¿Cómo se materializan, en el discurso, los "sujetos representados"? Esta pregunta nos remite la configuración de un imaginario político, una trama semiótica cuyos nodos son las entidades que llamaremos "colectivos".

En el segundo bloque optamos por encuadrar contextualmente las dos grandes problemáticas que atraviesan la tesis: las relaciones medios/política durante el período 2003-2008 (capítulo 3) y el "conflicto del campo" propiamente dicho (en el capítulo 4). 
El recorte temporal de nuestro trabajo coincide con el inicio y la clausura (formal, al menos) del conflicto entre el gobierno y el sector agropecuario. Como posición de observación de las relaciones entre el kirchnerismo y los medios resulta una perspectiva incómoda, pues es un período de transición acelerada desde una pragmática de convivencia (y connivencia) a un vínculo decididamente adversativo, en particular con el Grupo Clarín. Se ha hecho mucho hincapié en esa ruptura, que tuvo un efecto revulsivo sobre el escenario político. En el capítulo 3, sin embargo, nos interesa matizar esa mirada recuperando lo que para nosotros ha sido la invariante en las relaciones públicas del kirchnerismo con los medios. Buscamos desarrollar una serie de observaciones sobre la relación entre los medios de comunicación y el gobierno nacional en el período 2003-2008 desde la perspectiva de la mediatización de la política. Si tuviéramos que darle una fórmula a un problema "típico" de la mediatización en el kirchnerismo, diríamos -y esta es nuestra hipótesis- que se trata de la disputa por y con los "discursos intermediarios", y en particular, con el discurso intermediario más importante desde el punto de vista de la interlocución colectiva: el del periodismo en los medios. Esa disputa es, para nosotros, una invariante del kirchnerismo. Y, por las formas que adoptó, hablamos de modalización litigiosa de la mediatización política: el intento de extender la pregunta que moviliza a todo vínculo delegativo (¿en nombre de quién, de qué otros agentes nos están hablando?) al campo de los medios.

El conflicto tiene, para nosotros, una función específica en relación a la argumentación del trabajo, pues la tesis no versa sobre él sino que lo considera como el trasfondo de la disputa por la representación entre los discursos políticos presidenciales y los discursos de la prensa gráfica. En el capítulo 4, entonces, si bien lógicamente retomamos los análisis de la bibliografía especializada en conflictos agrarios y rurales que han analizado las facetas del conflicto, proponemos un corte analítico en relación a lo que llamamos "la controversia por la identidad de los grupos" que, para nosotros, 
se corresponde con la definición del conflicto en términos de "litigio político" (tal y como define a este concepto Rancière, [1996] 2007).

En el tercer bloque procedemos al análisis de las intervenciones públicas de Cristina Fernández de Kirchner (capítulo 5) y de las modalidades de gestión de colectivos en el discurso de la prensa gráfica (capítulo 6 y 7), para reconstruir estas las estrategias a través de las que el discurso del periodismo ejerce, cotidianamente, diversas formas de la representación. Esto es, las formas en que el periodismo, y a través de él los "medios", habla de, hace hablar y habla por otros actores sociales.

En el capítulo 5 vamos a realizar un análisis discursivo de las intervenciones públicas de Cristina Fernández de Kirchner (en adelante, CFK) a lo largo del conflicto con el sector agropecuario. Estas intervenciones fueron instancias de fuerte activación litigiosa, de reposición insistente de la controversia sobre la identidad de los actores, del objeto de las protestas y de los escenarios en los que esta se producía o debía producirse. Nuestro objetivo es reconstruir, a través del estudio de sus estrategias enunciativas y de los regímenes de visibilidad configurados en aquellas intervenciones, una serie de tópicos que signaron también el devenir del propio conflicto: el estatus de la representación política; el fundamento de la legitimidad de las decisiones y acciones fundadas en un interés común; y, como hilo conductor entre esos dos tópicos, la escenificación (y la auto-tematización) de posiciones de liderazgo político.

En el capítulo 6 nos proponemos reconstruir la intervención de la prensa gráfica en el conflicto del campo, considerado en su dimensión de litigio. Nos interesa, en particular, identificar modos regulares de configuración de esos colectivos -concebidos como entidades del imaginario político- que protagonizaron las protestas en estos cuatro meses, y cuya existencia, forma, identidad, historia, fueron puestas en cuestión, discutidas, afirmadas y negadas. En este capítulo nos interesa reparar en dos de esos colectivos: el campo y los pequeños productores. Para eso, trabajaremos en la 
identificación y descripción de dos modalidades de gestión de colectivos: de ascenso en generalidad, de descenso en singularidad.. Esas operaciones se deslizan, no siempre con solución de continuidad, desde el tratamiento de las figuras más abstractas de la generalidad social ("la sociedad", "la gente”, "la ciudadanía") al despliegue de una gama variada pero finita de recursos discursivos que llamaremos, en conjunto, de descenso en singularidad. Si en el primer caso veremos la puesta en escena de una protosociología elaborada muchas veces a partir de clasificaciones pre-teóricas (o sustraídas de algún discurso teórico que suele permanecer implícito), en el segundo constataremos que el discurso periodístico -casi con independencia de su orientación o simpatías políticas- procede por inmersión en la particularidad: en las biografías, los nombres, las fechas, las vestimentas, etc. Parafraseando a Rosanvallon (2007: 275), podemos decir: el discurso periodístico promueve lo banal a las dimensiones de lo social, le otorga consistencia, carnalidad, provee una plataforma de objetivación a aquellas figuras de la generalidad social que, de otro modo, solo parecieran existir como abstracciones o idealizaciones .En conjunto, contrastadas y sistematizadas, estas operaciones nos permitirán aprehender, en un nivel empírico, el solapamiento espaciotemporal en la gestión pública de una misma zona del imaginario político, entre las propias instituciones mediáticas y los discursos de CFK que analizamos en el capítulo 5 .

Finalmente, en el capítulo 7 buscaremos reconstruir en detalle los tópicos que, en el marco del conflicto, adquirió, por un lado, el cuestionamiento oficial al rol de la prensa gráfica, del periodismo y los medios, como efecto expansivo de la confrontación del propio Gobierno con el Grupo Clarín; y, por el otro, los efectos que esos cuestionamientos públicos, sumados a una serie de decisiones políticas puntuales, se fueron registrando en los discursos de la prensa gráfica. Pretendemos mostrar cómo, en el ida y vuelta entre discursos presidenciales y discursos de la prensa gráfica, se definen concepciones cruzadas sobre las mutuas "relaciones" entre el Estado y la prensa (y los medios). En ese marco, vamos a analizar los modos efectivos en que los diarios ejercen su pretendido rol intermediario. Es en esas modalidades de la 
representación, cuando los diarios pueblan su imaginario de entidades colectivas que también son las entidades que el discurso político busca encarnar. En esa superposición el espacio público mediatizado se revela como la zona de cohabitación y competencia por un "horizonte de destinación" que corresponde con el interpretante democrático de la "ciudadanía" 


\section{PRIMERA PARTE:}

DISCUSIONES TEÓRICAS Y PROPUESTA ANALÍTICA 
) 


\section{CAPÍTULO 1}

\section{MEDIATIZACIÓN: \\ UNA PERSPECTIVA TEÓRICA}




\section{CAPÍTULO 1: MEDIATIZACIÓN: UNA PERSPECTIVA TEÓRICA}

Introducción. La mediatización como proceso, contexto y teoría.

El uso del término "mediatización" se ha estabilizado en tres referencias complementarias pero que corresponden a niveles de análisis y de uso analítico distintos: por un lado, se designa un fenómeno histórico identificado con el desarrollo de las tecnologías mediáticas 0 , en términos más circunscriptos, con la constitución de los medios de comunicación de masas; en segundo lugar, se la suele invocar como "contexto" en el que se desarrollan una serie de prácticas sociales; finalmente, el término define una perspectiva teórico/sociológica de análisis.

Como descriptor factual, su uso es ambivalente. Por un lado, distingue un proceso, de modo que su estudio debe desplegarse en diacronía. En tanto que proceso, la mediatización indica la diferencia o contraste entre épocas y formaciones sociales según las tecnologías de comunicación y los fenómenos mediáticos que le son característicos, y según la amplitud con que esas tecnologías y esos fenómenos se inserten en las condiciones productivas del funcionamiento del sentido en esas sociedades. La escritura fue, hace unos seis milenios, la primera tecnología de comunicación (Ong, 1982) pero durante miles de años su despliegue social fue limitado; permaneció como un recurso en manos de las élites gobernantes o de grupos culturalmente privilegiados (Goody y Watt, 1963). La imprenta, desde la segunda mitad del siglo XV, al habilitar la reproducción mecánica de textos, generó las condiciones para la circulación de discursos -libros, panfletos, libelos- en escalas colectivas ampliadas, pero esa potencialidad permaneció contenida, entre otros factores, por la limitante de una alfabetización restringida.

Pero "la mediatización" también se manifiesta en sincronía, como contexto de fenómenos específicos. Esta es la variante más transitada en sus usos académicos: se la pre-supone como el estado de situación del cual se pretenden estudiar manifestaciones puntuales. Puede, por lo tanto, 
identificarse en un momento determinado, a propósito de un problema determinado: la socialización política, el aprendizaje escolar (Rawole y Lindgard, 2014), las actividades lúdicas (Hjarvard, 2014), las prácticas religiosas (Lövheim, 2014), los intercambios comerciales (Lundby, 2014). En estos casos, el proceso histórico se circunscribe a un conjunto de condiciones productivas que afectan las formas de producción, circulación y reconocimiento de los discursos sociales, sean las maneras de acceder a la información sobre temas públicos que pueden definir prácticas ciudadanas o los efectos que las tecnologías de comunicación tienen sobre la institución escolar y su relación con sus entornos. No es casual que identifiquemos, incluso de manera intuitiva, mediatización y medios de comunicación de masas; no es casual ni tampoco errado, a condición de que se acepte que también las organizaciones de medios y sus prácticas están condicionadas, a su vez, por la emergencia de tecnologías de comunicación y por las modalidades de apropiación y uso que cada sociedad hace de ellas.

Como perspectiva teórica el desarrollo del concepto ha sido dispar. En los últimos quince años, y particularmente en Europa, se publicaron varias investigaciones y reflexiones que intentan sistematizar la perspectiva, definir sus postulados básicos, historizar las maneras en que ido tomando forma (Mazzoleni y Schulz, 1999; Schulz, 2004; Kepplinger, 2006; Krotz, 2007; Strömback, 2008; Hjarvard, 2008 y 2014; Entman, 2009; Livingstone, 2009; Marcinkowski, 2014).

En términos generales, parece haber acuerdo en que se trata de un "concepto procesualmente orientado" (según la expresión de Schulz, 2004), que describe el efecto transformador de las instituciones de medios durante el siglo XX, o incluso un "meta-proceso" característico de la modernidad occidental, estructuralmente equiparable a la globalización (Krotz, 2007). Hjarvard (2008:132) propone pensar la mediatización como un "proceso societal" propio de la modernidad, a la par de la urbanización y la individualización, en el cual los medios contribuyen a desvincular las relaciones sociales de los contextos inmediatos y a re-vincularlas en contextos más amplios, un doble 
movimiento equivalente al que Eliseo Verón identificara como "ruptura de escala” y “descontextualización del sentido" (2001: 132).

A pesar de estos enfoques descriptivos y analíticos, persiste la tendencia a usar el concepto como expresión de una cosmovisión normativa, una axiología que condena los efectos de las tecnologías y las organizaciones mediáticas - y, casi exclusivamente, de la televisión- sobre las esferas de acción social sometidas a su influjo (Kepplinger, 2006; Entman, 2009), de tal manera que se describe esa influencia como "colonización" de la "lógica política" por la "lógica mediática". Es mucha la bibliografía ${ }^{18}$ consagrada a estudiar los vínculos entre medios y política, y especialmente, entre la televisión y la política, signada por la percepción de que la TV ha significado la imposición a la política de reglas de funcionamiento que le eran, antes de su llegada, extrañas. Es decir, se trataría de un vínculo atravesado por la tensión entre lo propio de la política y lo impropio introducido por la televisión. Además, si se atiende a la secuencia histórica en que se produce ese vínculo, se trataría de un proceso sometido a brutos saltos de discontinuidad ${ }^{19}$.

En la tradición de estudios sobre las relaciones entre medios y política en Argentina, la mediatización no se ha consolidado como perspectiva de análisis ni ha tenido un desarrollo específico. Ha sido, en general, una referencia marginal, en algunos casos obligada (se invoca el término "mediatización" como contexto presupuesto), y en otros estrictamente referencial, pero rara vez un fundamento teórico o analítico. Esto puede verificarse en algunas valiosas investigaciones sobre los efectos o la incidencia de los medios (en particular, la televisión) sobre el funcionamiento del espacio público, de las instituciones políticas y el discurso político (Landi, 1988 y 1992; Schmucler y

\footnotetext{
18 Algunas referencias bibliográficas de autores que abordan el problema desde esa perspectiva: Sartori (1998), Sánchez Ruiz (2005), Gubern (1991), Virilio (1998), Edelman (2002), Cerbino (2003), Durán Muñoz (2004). También esta idea está presente en muchos de los trabajos compilados por Gauthier, Gosselin y Mouchon (1998), aunque ese volumen ofrece un panorama de la complejidad que implica la mediatización de la política, algo que otros de los aquí citado o desconocen, o no están dispuestos a aceptar.

${ }^{19}$ Sin dudas, hay razones históricas que explican la tendencia a encarar el problema desde esta óptica. La primera -obvia en su formulación, pero cuya importancia no podemos menospreciar- es eminentemente cronológica: la "política" precede a su "mediatización", de modo que el pensamiento sobre la mediatización de la política no pudo sino constituirse sobre la base de la pregunta del impacto de la primera en la segunda.
} 
Mata, 1992; Mangone y Warley, 1994; Muraro, 1997; Ruiz, 2008; Vommaro, 2008a y 2008b; Cheresky, 2009; Sorj, 2010; Waisbord, 2013). Algunos de estos autores estudian lo que para nosotros son procesos de mediatización sin recurrir al concepto, como por ejemplo Landi o Muraro; otros, como Vommaro o Waisbord, utilizan el concepto aunque en su definición mezclan niveles de análisis que, en este capítulo, procuraremos distinguir.

Por ejemplo, para Landi ([1992] 1993:53) en la primera etapa de la recuperación de la democracia en Argentina "la prensa escrita asumió (...) funciones sustitutivas de las frágiles instituciones: presentó y legitimó a los políticos, instaló cierta agenda de temas y se constituyó en foro de debates”. La televisión, por su parte, durante la campaña presidencial de 1983, "acompañaba el contacto directo de los políticos con la gente, era un soporte comunicativo de los rituales renacientes de la democracia, pero su prestigio y credibilidad como enunciador estaban severamente cuestionados". Según su diagnóstico, "la televisión argentina en aquellas circunstancias fue más el escenario que un actor directo de la política" ([1992] 1993: 58). Su potencial importancia iba a ser definida en relación directa con el sistema institucional y con las características de los partidos políticos.

En su estudio sobre la televisión y la política en el período 1983-2008, Vommaro sostiene que por mediatización entiende al "fenómeno de legitimación de ciertos espacios privilegiados para hacer política y como dinámica productora de acontecimientos público-políticos con consecuencias sobre la distribución del poder simbólico y del apoyo social (2008:10). Waisbord, en su análisis de la relación entre los gobiernos "populistas" y los medios de comunicación, sostiene que "la mediatización de la política y la politización de los medios están inscriptas en el ADN de los gobiernos populistas y determina fuertes condicionantes a la labor periodística, y el objetivo de fortalecer el "presidencialismo comunicacional" (Waisbord, 2013b: 52). En un caso, la "mediatización" se restringe al análisis de los "medios" como lugares de intervención política; en el otro, se la designa 
como un fenómeno casi voluntario y circunscripto a un modo de ejercer el liderazgo en regímenes democráticos.

El concepto ha recibido un tratamiento más detenido por parte de algunos investigadores de los discursos mediáticos formados en el campo de la semiótica y el análisis de los discursos, que han dedicado algunos artículos a reflexionar sobre las implicancias conceptuales del término (Fernández, 2002; Carlón, 2004; Petris, 2005; Cingolani, 2009 y 2014). Tal vez sea sintomático que ninguno de estos autores se haya especializado, en principio, en las relaciones entre las prácticas políticas institucionalizadas y los medios de comunicación. Más allá de matices, todos estos autores trabajan bajo el supuesto de una distinción necesaria entre dispositivos tecnológicos e instituciones de medios, un movimiento analítico necesario y útil, del que por lo demás vamos a servirnos, pues permite trascender la identificación consuetudinaria entre mediatización y medios de comunicación.

Para nosotros, considerado este estado de situación, lo importante no es arribar a una definición unánime (pretensión, por lo demás, innecesaria, y seguramente imposible). Sí nos interesa ofrecer una lectura crítica del estado del arte sobre el concepto de "mediatización" que, además, pueda derivar en un planteo analítico para el caso específico de la mediatización de la política, que para nosotros funciona como condición de producción y circulación de los discursos en el espacio público. Ese es propósito de este primer capítulo.

Nos proponemos, entonces, someter a una revisión analítica el concepto de "mediatización", con especial énfasis en lo que podría considerarse una subvariante, "la mediatización de la política". En lo que sigue, el capítulo estará organizado en tres grandes apartados. En el primero, nos concentramos en la temporalidad de la mediatización; en el segundo, reparamos en algunos aspectos centrales de la mediatización de la política; y por último, a modo de cierre, presentamos una propuesta de cortes analíticos para el estudio de la mediatización. 


\subsection{Mediatización: ¿un proceso contemporáneo?}

Tres siglos, con saltos, discontinuidades e intermitencias. El término “mediatización" fue acuñado por el derecho alemán del siglo XIX para designar un modo de reorganizar la soberanía entre un estado dominador y los gobiernos de los territorios anexados. A fines de la década de 1980, ya bien entrado el siglo XX y sin relación directa aparente con el uso originario, el término fue adoptado como neologismo para nombrar el impacto que los medios de masas -y en particular, la televisión- empezaban a tener sobre el funcionamiento de las instituciones políticas y sobre los modos del ejercicio de la ciudadanía. $Y$ en los albores del siglo XXI, cuando las instituciones mediáticas dominantes en el siglo pasado parecen transformarse por el impacto de Internet y la proliferación de dispositivos móviles multifuncionales las investigaciones sobre la mediatización avanzan en la reflexión teórica que, tal vez, termine por restringir la expansión semántica del término, y por dotarlo, entonces, de identidad y capacidad explicativa. 0 no, y entonces seguirá siendo una suerte de clave de ingreso o un operador interpretativo genérico.

En su sentido original, la "mediatización" es una transferencia de soberanía. Se produce cuando un estado soberano es anexionado por otro, que sin embargo otorga algunos derechos (por ejemplo, la conservación de los títulos nobiliarios) a los estados subordinados. Históricamente, es un proceso que se extendió entre 1794 y 1815, cuando Napoleón, por el Tratado de Campo Formio, anexó a Francia todas las tierras del Sacro Imperio Romano Germánico situadas al oeste del $\operatorname{Rin}^{20}$.

Livingstone (2009) sugiere un vínculo entre esta acepción y la impronta negativa que suele estar adosada a un término que, en sus usos contemporáneos, se ha aplicado, en muchas ocasiones, para describir los

\footnotetext{
${ }^{20}$ Una explicación correcta sobre este sentido original puede consultarse en http://es.wikipedia.org/wiki/Mediatizaci\%C3\%B3n_y_Secularizaci\%C3\%B3n\#Mediatizaci.C3.B3 n. De los autores revisados para la confección de este capítulo, sólo Sonia Livingstone (2009) menciona este antecedente.
} 
trastornos que la primacía mediática provoca sobre el funcionamiento de otras instituciones -como la escuela, la familia, la justicia etc.--, que pierden su capacidad de orientación moral y de proveedoras de información: se vuelve heterónomas.

La sugerencia de Livingstone es verosímil: los primeros usos académicos del término parecen referir a otro modo de subordinación, el que las instituciones mediáticas ejercen sobre los modos de aparición pública de los actores políticos. En su artículo The mediatization of society (2008), el investigador danés Stig Hjarvard prueba un rastreo bibliográfico para dar con la aparición y evolución en el uso del concepto ${ }^{21}$. Sostiene que “mediatización” fue originalmente un concepto aplicado al impacto de los medios en la comunicación política. Según esta versión, el primero en utilizarlo fue el sueco Kent Asp en 1986, quien habló de "mediatización de la vida política" para nombrar el proceso por el cual "el sistema político, en un grado cada vez mayor, es influido y se adapta a las demandas de los medios masivos y su cobertura de la política”. Asp, por su parte, reconoce su deuda con el sociólogo noruego Hernes quien, en 1978, había acuñado la expresión “mediatwisted society", para describir el tránsito de una sociedad en situación de escasez de información a una en la que la información abunda. Según Hjarvard, el denominador común a estos primeros intentos es una postura reactiva, marcada por una axiología negativa: lo que se transforma, se degrada, se diluye, empeora.

Esa axiología subyace en las versiones más divulgadas del término. Como tantos otros, el de “mediatización” es utilizado en un sentido referencial y descriptivo pero también para definir una perspectiva de análisis. Muchas veces, la perspectiva funciona encubierta en el uso. Así, “mediatización” refiere a cualquier fenómeno que involucre, en alguna de sus dimensiones, a

\footnotetext{
${ }^{21}$ Es conveniente aclarar que ese rastreo bibliográfico, lúcido y completo, tiene sin embargo un límite de sesgo, ya que el autor se limita a reconstruir el uso del concepto en investigadores angloparlantes (algunos, como Hjarvard, provenientes de países nórdicos, como Dinamarca, Noruega o Suecia), muchos de quienes, a su vez, se citan entre ellos, lo cual termina por configurar una suerte de sistema de lectura cerrado, inmune a las contribuciones que, simultáneamente, se fueron realizando en otros países de diferentes regiones, tanto en Europa como en Estados Unidos y América Latina.
} 
los medios de comunicación, y particularmente "a la influencia que los medios ejercen sobre la sociedad y la cultura" (Hjarvard, 2008:105). Por lo tanto, el concepto termina por describir la dirección de una influencia ejercida como desde fuera de determinados campos de prácticas (culturales, políticas, educativas, públicas y privadas) y los medios, como fuerzas singulares externas, aliens intrusos en las más diversas esferas de la vida privada y pública. Tal como lo ha dicho Krotz (2007: 87-8) la mediatización comparte la suerte de otros "izaciones" (globalización, individualización, etc); como ellos, se ha convertido en un "instrumento de afirmaciones críticas sobre el cambio social con la función latente de expresar una cierta actitud o posición política".

Un buen ejemplo de esa orientación es el de los estudios sobre la denominada mediatización de la política, que por lo demás ha sido la problemática a propósito de la cual se han desarrollado las primeras investigaciones que han tomado al concepto como clave interpretativa. Glosando aquella "actitud o posición política” que refiere Krotz, Mazzoleni y Schulz (1999) ${ }^{22}$ explican que:

\begin{abstract}
"en su declinación concreta, un sistema democrático manejado por los medios $^{23}$ es pensado como la causa de la decadencia del modelo de la organización política nacido con el estado liberal, al tiempo que los partidos políticos pierden sus vínculos con los dominios sociales de los cuáles habían sido espejos y con los intereses que estos mismos partidos tradicionalmente habían representado" (1999: 247).
\end{abstract}

Más aún, los medios habrían puesto en riesgo de extinción, o peor aún, reemplazado, los espacios comunes y las figuras clásicas del imaginario liberal: en lugar del debate de ideas, el mundo del espectáculo; en lugar de la autodeterminación intelectual, la fácil manipulación de la opinión pública; en lugar del ciudadano, el consumidor; en lugar de las calles y las plazas, las pantallas ${ }^{24}$. En síntesis, según esta versión crítica, “los medios habrían

\footnotetext{
${ }^{22}$ Vale la pena señalar que este artículo es citado como referencia de orden fundacional al menos entre investigadores europeos y norteamericanos.

${ }^{23}$ La expresión inglesa es "media-driven democratic system", cuya traducción al castellano es imposible, pero que engloba etiquetas como: videocracia, democracia mediática, etc.

${ }^{24}$ Un buen ejemplo es el artículo de Isidoro Cheresky titulado: "La política, de la calle a la pantalla" (2001). Como lo plantea en términos de reemplazo, se priva de estudiar la coexistencia entre las modalidades de intervención pública desde "la política".
} 
distorsionado los procesos políticos al convertir la política en un juego de mercado que humilla a los derechos y la dignidad de los ciudadanos y ridiculiza las palabras de los líderes políticos" (Mazzoleni y Schulz, 1999: $248)^{25}$.

Lo que no parece estar en cuestión es el carácter moderno, o mejor tal vez contemporáneo, de la mediatización. $Y$ esto está directamente vinculado con una definición "procesualmente orientada" (Schulz, 2004). Dicho rápidamente: para la mayoría de los autores que utilizan el término, la mediatización es un fenómeno histórico propio del último cuarto del siglo XX.

Mazzoleni y Schulz sostienen que la mediatización de la política es una tendencia central de la década de 1990, que se remonta a la introducción de la televisión, pero que ha ganado velocidad con la expansión y comercialización de los sistemas de medios y la modernización de la política. Pero quien mejor lo ha expresado es Hjarvard, el autor que ha hecho el esfuerzo más sistemático para darle al término una fundamentación teórica:

La mediatización no es un fenómeno universal que caracterice a todas las sociedades. Es, primeramente, un desarrollo que se ha acelerado particularmente en los últimos años del siglo veinte en las modernas sociedades occidentales altamente industrializadas, tanto en Europa, Japón, Australia, Estados Unidos (Hjarvard, 2008: 109).

Así cerrados sus límites temporales, "el concepto de mediatización es aplicado exclusivamente a la situación histórica en la cual los medios, al mismo tiempo, han adquirido autonomía como instituciones sociales y se han entrecruzado con el funcionamiento de otras instituciones" (Hjarvard, 2008: 110; cursivas nuestras).

Como puede apreciarse, la definición conceptual está directamente anudada a la historización, y por lo tanto, a los contrastes de época que avalan la idea según la cual la mediatización es un fenómeno del siglo XX. Esta idea debería

${ }^{25}$ Es importante mencionar que, en este trabajo, los autores proponen el término "mediatización" para diferenciarse de las concepciones que cuestionan. En lugar de hacer hincapié en "los medios", apuntan a un proceso que sí es global: que la comunicación política no puede producirse sino por intermedio de los dispositivos mediáticos. Este mismo argumento, aunque propuesto como propio, puede leerse en Wolton (1998). 
ser matizada, al menos por dos motivos. En primer lugar, porque los modernos medios de comunicación fueron, hasta bien entrado el siglo XX, organizaciones que operaban como anexos funcionales o como herramientas indisolubles de las estructuras políticas, que por lo tanto ya estaban -en algunas dimensiones de su praxis- mediatizadas ${ }^{26}$. Menospreciar este dato puede llevar a declarar transformaciones (es decir, producir comparaciones) sin el sustento necesario para demostrar un contraste. Así, el estado de cosas modificado se suele suponer, o pre-suponer, de modo que en lugar de ser el panorama contra el cual se contrasta una situación actual funciona como una utopía en reversa. Como ha escrito Strömback:

La situación actual, cuando la política es mediada y mediatizada, es implícita o explícitamente comparada con una suerte de edad dorada -el tiempo exacto que es conspicuamente ausente de la mayoría de los estudios- cuando la política era más verdadera con sus ideales, cuando la gente era cívicamente responsable, o cuando los medios facilitaban, en lugar de erosionar, el camino de la comunicación política y el trabajo democrático" (2008: 229) ${ }^{27 .}$

Por otro lado, porque sea que se piense en términos de "influencia", "impacto" o "transformación", han sido estudiados y analizados fenómenos mediáticos previos que han modificado los modos de acumulación de la información (Goody, 1995), de producción del conocimiento (Goody, 1987), de organización de la herencia cultural, de enfrentarse a los "hechos del mundo" (Ginzburg [1981], 1994) ${ }^{28}$, de redefinir los tiempos y los espacios de los

\footnotetext{
${ }^{26}$ Al menos en lo que concierne a la "mediatización" de la política parece necesario revisar con mucho detalle las investigaciones históricas sobre el rol de la prensa (partidaria, partisana, facciosa, política) en la segunda mitad del siglo XIX. Tanto en Argentina (Duncan, 1980; Alonso, 2010, entre otros) como en EE. UU (Pasley, 2001: 3-10) la reconsideración de la prensa política como una institución constitutiva del sistema político permitiría reflexionar con más elementos empíricos sobre qué es lo que se transforma (o bien: lo que se va transformando) con la emergencia de los medios de masas, porque habilita un examen mejor pertrechado sobre cómo la incidencia creciente de esa prensa también funcionó como un indicador de lo que Alonso (2010: 46) llama la "republicanización" de la política, "arrebatada de los confines de la intimidad del salón, del comité, del banquete y, a veces incluso, de la correspondencia privada, para ser lanzada a la vida pública a través de los periódicos".

${ }^{27}$ Original en inglés. La traducción nuestra.

28 Desde este criterio de lectura, el estudio de Carlo Ginzburg sobre el proceso de enjuiciamiento del molinero friulano Domenico Scandella (Menochhio), es un hermoso ejemplo para estudiar la mediatización de las prácticas sociales en sociedades pre-modernas, y para entender cómo los fenómenos mediáticos sólo tienen efectos bajo determinadas condiciones irreductibles a la utilización de un dispositivo de mediatización (como por ejemplo el libro) pero imposibles sin ese dispositivo. En las declaraciones de Menocchio ante el tribunal que lo enjuicia, y particularmente en la explicación de su "cosmogonía" Ginzburg detecta el remanente irreductible de la cultura oral. Y aclara: "Para que esta cultura distinta
} 
vínculos personales y colectivos. Si en lugar de centrar la atención en la escala de los procesos, nos detenemos en las pequeñas mutaciones en la naturaleza de algunas prácticas es posible detectar "efectos de mediatización" (esto es, transformaciones asociadas a las formas de institucionalización de prácticas en las cuáles las tecnologías de comunicación operan como condición de posibilidad) que servirían para "afinar" los alcances analíticos del concepto.

Sin embargo, ha sido la institucionalización de los medios de comunicación y la conformación de sistemas mediáticos en la primera mitad del siglo XX (lo que Hjarvard llama la "concurrencia intensificada" de periódicos, radio y la televisión) lo que parece haber tornado visibles los efectos de mediatización:

Vista en perspectiva histórica, la falta de interés por los medios entre los sociólogos clásicos no debería sorprender. A lo largo del siglo XIX, los "medios" no eran visibles por derecho propio; eran tecnologías específicas y separaban fenómenos culturales (libros, periódicos, telégrafo) considerados instrumentos en manos de otras instituciones, como literatura, ciencia, política y comercio. (Hjarvard, 2008:132)

Por estas razones, entendemos que es necesario ordenar los fenómenos comprendidos por el término en dos series históricas que son, también, dos modos de construir el concepto y los "sub-conceptos" que de los que se nutre: el de medios y el de proceso. Como desde el punto de vista cronológico ambas series terminan por coincidir -en realidad, una queda incorporada a la otra- se trata menos de optar por modos paralelos y excluyentes de describir y explicar los fenómenos y procesos, que por brindarle al concepto un alcance expansivo y otorgarle una historicidad que hasta el momento ha quedado acotada a un fenómeno mediático (institución, dispositivo y medio: la televisión) o, a lo sumo, a un período extendido al que se le concede el estatus de pre-historia (el desarrollo y consolidación de los medios de comunicación de masas a partir de la segunda mitad del siglo XIX).

pudiese salir a la luz, tuvieron que producirse la Reforma y la difusión de la imprenta. Gracias a la primera, un sencillo molinero había podido pensar en tomar la palabra y decir sus propias opiniones sobre la Iglesia y el mundo. Gracias a la segunda, dispuso de palabras para expresar la oscura e inarticulada visión del mundo que bullía en su fuero interno. En las frases o retazos de frases arrancadas a los libros encontró los instrumentos para formular y defender durante años sus propias ideas, primero ante sus paisanos, luego ante los jueces armados de doctrina y de poder" (Ginzburg [1981], 1994: 99). 


\subsubsection{Dos series históricas.}

Decíamos, entonces, que es posible dar cuenta de dos series históricas y conceptuales de la mediatización. Desde ya, se trata de una propuesta todavía balbuceante, lo cual no le resta validez, sino que nos obliga a seguir explorando sus alcances.

a- Una "serie larga": la mediatización como constituyente antropológica

Esta serie se corresponde con un concepto ampliado que desborda el fenómeno de los llamados "medios de masas" instituidos entre fines del siglo XIX y principios del siglo XX. En sus últimos estudios dedicados a darle un fundamento teórico al concepto, Eliseo Verón $(2012 ; 2013)$ ha identificado a la mediatización como una invariante de la dimensión antropológica del sapiens, que, así concebida, se confunde, o directamente se solapa, con la historia de la técnica o aún más, con una teoría de la evolución técnica (Stiegler, 2002) o con lo que Leroi Gourhan (1988) denomina tecnología, como rama disciplinar de la etnología. En cualquier caso, la mediatización desbordaría, también, una concepción instrumental de las técnicas y podría como un capítulo en la historia de la evolución o la "sucesión" de los sistemas técnicos $^{29}$ (Stiegler, 2002: 45-50), al menos en relación a los dispositivos que han servido y sirven para activar procesos de descontextualización del sentido, acumulación del saber, exteriorización de la memoria y desenganche espacio-temporal de las interacciones comunicativas.

Las tecnologías mediáticas serían entonces constituyentes antropológicas, en tanto habilitan las condiciones para la diferenciación entre sistema psíquico y sistema sociales, lo que Stiegler (2002:48) concibe como "exteriorización de la memoria" y que para Verón $(2007 ; 2012)$ inaugura el largo proceso de la individuación humana. Sobre esa invariante, hay que concebir la emergencia

\footnotetext{
${ }^{29}$ Para Stiegler (2002: 54), "Un sistema técnico constituye una unidad temporal. Es una estabilización de la evolución técnica en torno a un punto de equilibrio que se concretiza en una tecnología particular".
} 
de fenómenos mediáticos derivados de la creación de soportes tecnológicos autónomos ${ }^{30}$ de comunicación desde la talla en piedra al códice, desde el libro hasta el ordenador personal y las demás interfaces digitales, que han operado como aceleradores evolutivos. Por eso, en su último libro, dedicado a sistematizar una teoría histórica de la mediatización, Verón (2013: 145-149) la define en el contexto evolutivo de la especie "como la secuencia de fenómenos mediáticos históricos que resultan de determinadas materializaciones de la semiosis, obtenidas por procedimientos técnicos" (cursivas en el original). Y explica que un "fenómeno mediático" ocurre a partir del momento en que los signos poseen, en algún grado, las propiedades de autonomía tanto respecto de la fuente como del receptor, y de persistencia en el tiempo. La materialidad que hace posible la autonomía y la persistencia de los signos necesita la intervención de operaciones técnicas, más o menos complejas, y la fabricación de un soporte.

Por lo dicho, desde la lógica de su periodización, esta serie abarca al menos seis u ocho milenios (considerando la aparición de las protoescrituras; Ong, 1982; Calvet, 2007), y permite incorporar, como fenómenos mediáticos de interés y precursores (en relación a la serie que ya comentaremos) las escrituras/los productos manuscritos, los productos escrito-impresos, etc. ${ }^{31}$

Indagar en procesos de mediatización a partir del concepto de "fenómenos mediáticos" y no del de "medios de comunicación" tiene consecuencias trascendentes en la delimitación del concepto de mediatización y, por lógica, en los criterios de relevancia que definen lo límites de las problemáticas que pueden ser estudiadas a partir de esta perspectiva, es decir, tiene consecuencias epistemológicas importantes. Una de ellas, como estamos

\footnotetext{
${ }^{30}$ Autónomos respecto del individuo, sea considerado como emisor o receptor.

${ }^{31}$ Sobre la importancia de la escritura como una "tecnología" (antes que como un "medio de comunicación") vale recordar aquí las palabras de Stiegler (1990) "La escritura alfabética es, ya, una tecnología de la memoria. Estamos inclinados a olvidarlo: hemos hecho de esa tecnología, en tanto que occidentales, nuestra segunda naturaleza, mientras que, por otra parte, tenemos la tendencia a ver la tecnología sólo allí donde son visibles aparatos materiales".
} 
viendo, es la amplitud del corte temporal, la delimitación del proceso histórico.

Si nos ceñimos a una concepción de la mediatización como el estudio de los fenómenos mediáticos podríamos pensar que, considerando el proceso histórico de su desarrollo, afecta, en principio, sólo esferas circunscriptas de prácticas sociales -la contabilidad y la legislación del estado (Goody, 1995); la producción y acumulación del conocimiento académico y literario (Chartier, 1995); la circulación de novedades relativas a los círculos de poder (Darnton, 2003)- y, a lo largo de la historia, se expande como en formas concéntricas hasta superponerse con los límites mismos de la sociedad, de tal manera que, como sucede en la actualidad, casi no hay esfera de acción, de prácticas y de relaciones que no esté "atravesada” por un fenómeno mediático.

La aceleración mediática del siglo XX, encarnada paradigmáticamente en los "medios de comunicación de masas", en particular con el avance de la electrónica, acentuó el contraste de épocas: le imprimió un efecto de ruptura, como si no pudieran trazarse continuidades con el pasado. Este sólo reconocimiento obliga a revisar con extremo cuidado las concepciones que (de manera tácita o explícita) dan por sentado que la mediatización se inicia con la emergencia de la televisión como dispositivo mediático central del sistema de medios, al menos en las sociedades industriales desarrolladas de Occidente.

Por otro lado, esta "serie larga" puede articularse, creemos que sin problemas, con la perspectiva sociológica de Luhmann (1998: 153-161) para quien los medios son logros evolutivos que arrancan en los puntos de ruptura de la comunicación: la escritura como "solución" a los límites del entendimiento; los fenómenos derivados de la invención de la imprenta, soluciones a los límites del alcance; y los llamados medios de comunicación simbólicamente generalizados, soluciones a los límites del éxito de una comunicación ya descontextualizada de los entornos inmediatos espaciotemporales de interacción. Esta integración de perspectivas debería 
completarse con una descripción sobre la "escala" de las transformaciones provocadas y el análisis de los contextos específicos en los que tuvieron lugar.

Al respecto, pueden ser sugerentes guías los estudios de Goody y Watt (1963), Goody (1985) y Ong (1982) entre otros, quienes sostienen la tesis de que la escritura tuvo efectos sobre "los modos de pensamiento" y los procesos cognoscitivos, por una parte, y sobre las formas institucionales de organización social, por la otra. Se trata de partir de la descripción de procesos en escala reducida, que gradualmente expanden sus radios de incumbencia de manera correlativa al despliegue de procesos simultáneos y concurrentes (como la alfabetización o la escolarización).

Una versión temporalmente más acotada ( $\mathrm{y}$ tal vez, en este aspecto, más fácilmente asociable a la concepción contemporánea de la mediatización) es la que ofrece John B. Thompson (1998), cuya teoría sobre la modernidad toma como eje el desarrollo de las tecnologías de comunicación. Thompson considera que desde el siglo XV "las pautas de comunicación e interacción empezaron a cambiar de manera profunda e irreversible. Estos cambios, que comprenden lo que en sentido amplio podría ser llamado 'mediatización de la cultura', tuvieron unas claras bases institucionales: es decir, el desarrollo de las organizaciones mediáticas que aparecieron en la segunda mitad del siglo XV y que desde entonces han expandido sus actividades" (1998: 72). El corte que propone Thompson se inicia con la aparición de la imprenta, una "tecnología revolucionaria"32, que, al permitir la producción y reproducción mecánica de discursos, amplió de un modo desconocido hasta entonces las posibilidades de comunicación e interacción entre un número cada vez más amplio de personas y a través de extensas distancias. El estado, la esfera pública, la ciencia, son, para Thompson, derivados, más o menos directos, del invento de Gutenberg.

\footnotetext{
32 Sobre el carácter "revolucionario" de la invención de la imprenta ver Eisenstein (1990). Allí, la autora plantea una alternativa conceptual entre dos maneras de concebir una "revolución". O bien como "ruptura brusca" con una tradición o bien "proceso irreversible prolongado", cuyas consecuencias se intensifican cuanto mayor es su duración.
} 
b- "Una serie corta": la mediatización como proceso de la "alta modernidad"

Esta serie se corresponde con un concepto restringido en sus alcances: la mediatización se refiere a la historia de los modernos medios de comunicación de masas, y más específicamente, a las transformaciones por ellos inducidas sobre el funcionamiento de las instituciones y las prácticas políticas (Hjarvard, 2014: 79). Considerando la periodización histórica, esta serie considera inaugurado el proceso de mediatización hacia fines del siglo XIX, con la emergencia de la prensa gráfica de masas, y se ha centrado en la consolidación de la televisión a mediados del siglo XX como instancia definitoria del proceso, ya que, como explica Valdettaro (2007) "es la televisión el medio que, por excelencia, logra producir un pliegue en el proceso de mediatización tornándolo omnipresente, ubicuo y consonante". También Schulz ha reparado en este aspecto, equiparando "mediatización" con la "era de la comunicación masiva" y aún más: "la mediatización, la dependencia mediática y las hipótesis relacionadas son productos de la era de la televisión", al punto de sugerir que con "el advenimiento de Internet y la declinación supuesta de la televisión" deberíamos, para ser consecuentes, dar por cerrado el proceso de "mediatización" "en tanto el prerrequisito esencial del concepto desaparece, por lo que esto resulta en una pérdida de su valor analítico" (Schulz, 2004: 91).

En cualquier caso, esta serie ha prevalecido, hasta el momento, como referencia no cuestionada para los estudios sobre la mediatización. En ella, podemos identificar al menos dos perspectivas, que coinciden en este recorte temporal aunque implican dos modos diversos de abordar los fenómenos mediáticos modernos y contemporáneos.

Por un lado, una perspectiva ocupada casi exclusivamente a la mediatización de la política, y con un desarrollo estrictamente europeo, que se ha preocupado principalmente por analizar los grados en que los medios de comunicación se instituyen como la fuente dominante de acceso a la 
información política, el grado de independencia de los medios en relación a las instituciones políticas, y el grado en que el contenido de los medios es definido por una lógica política (o sea, ligada a la preocupación por el bien común) o a una lógica mediática (Hjarvard, 2012; Entman, 2009; Wijfes, 2009; Livingstone, 2009; van Aels et al, 2008; Hjarvard, 2008; Strömback, 2008; Krotz, 2007; Kepplinger, 2006; Schulz, 2004; Mazzoleni, 1987; Altheide y Snow, 1979).

Cierto es que muchos de estos autores han intentado, como ya lo comentamos, generalizar el uso del término. Krotz, por ejemplo, define a la mediatización como "los desarrollos históricos que tuvieron y tienen lugar como un cambio de la comunicación mediática y sus consecuencias, no sólo con el nacimiento de nuevas formas de medios sino con cambios en el significado de los medios en general" (Krotz, 2007: 258) y la ubica junto a otros tres meta-procesos ${ }^{33}$ que caracterizan a las sociedades contemporáneas: globalización, individualización y la industrialización. Schulz (2004), por su parte, considera que mediatización se refiere a "cambios asociados con los medios de comunicación y su desarrollo", y propone una distinción analítica de cuatro tipo de procesos que están incorporados, como efectos, al de mediatización: "extensión" (de los límites naturales de la capacidad de comunicación humana), "amalgamiento" (en tanto los medios permean otras esferas de actividad, diluyendo los límites entre lo mediático y lo no mediático), "sustitución" (de actividades e instituciones) y "acomodación" (ya que "el solo hecho de que los medios existan induce cambio social).

Pero, como lo hemos señalado, esta corriente se ha ido consolidando alrededor del interés por la mediatización de la política y se ha consagrado a investigar las consecuencias de este proceso a partir de la oposición entre una “lógica mediática” y una "lógica política”. Como volveremos con más detalle

\footnotetext{
${ }^{33}$ La noción de "meta-procesos" se refiere a "desarrollos que duran centurias y que no necesariamente se confinan a un área o a una cultura dada" y para los cuales "no es claro en qué punto en el tiempo comienzan o terminan, o si tienen una dirección definida o qué pertenece a ellos o no" (2007: 257). Esta sola definición, aún genérica, podría abrir el marco temporal de la indagación, pero al menos en el trabajo citado, Krotz no explora esa posibilidad.
} 
sobre este grupo de autores, baste con señalar que por "lógica mediática" entienden la combinación entre un código marcado por los valores noticiables y una técnica de narrar (que privilegia la simplificación, la estereotipación, la polarización, la personalización, la visualización, etc.; Strömback, 2008; Schulz, 2004); mientras que por la lógica política se designa el esfuerzo por lograr soluciones, sostenidas desde las instituciones del estado, a partir de programas de acción consensuados y el esfuerzo por alcanzar legitimidad.

Por otro lado, ubicamos una serie de trabajos de Eliseo Verón ${ }^{34}$ que sin tener ningún punto de contacto con los autores citados, comparte el criterio de corte temporal. Al menos tres razones nos llevan situar estos trabajos de un solo autor en un aparte. La primera es una razón de validez -digamossubjetiva: fue a partir de estos escritos de Verón que nos ha llegado el interés por el estudio de la mediatización, e inclusive, las claves de lectura con las que hemos trabajado durante mucho tiempo. En segundo lugar, porque en los circuitos académicos donde la teoría de los discursos sociales elaborada por Verón ha tenido efectos productivos, estos trabajos son una referencia recurrente. En tercer lugar, porque son trabajos publicados previamente o en simultáneo ${ }^{35}$ a los ya comentados (lo cual, por sí solo, no resulta un mérito) y están informados con recursos teóricos, incluso epistemológicos, ausentes en la corriente europea, y con particularidades que impiden asimilarlos a ella ${ }^{36}$

Verón utilizó el término para explicar la dinámica histórica iniciada entre mediados y fines del siglo XIX, período a lo largo del cual las prácticas sociales

\footnotetext{
${ }^{34} \mathrm{Si}$ bien hemos glosado pasajes de textos más recientes del propio Verón para fundamentar una "historia larga" de la mediatización, conviene aclarar que el propio autor, en los primeros textos en que hace referencia al fenómeno, lo circunscribe históricamente del mismo modo que los estudios de la corriente europea. En los últimos años, Verón fue desarrollando su teoría de la mediatización como proceso que acompaña el desarrollo evolutivo del sapiens.

${ }^{35}$ Solo para ejemplificar esta "antelación": “Le corps signifiant” (1978); “Le séjour et ses doublés: arquitectures du petit ecran" (1984; publicado en castellano en el libro El cuerpo de las imágenes, 2001); "La mediatización" (1984; serie de tres conferencias dictadas en la UBA, y publicadas ese mismo); "Les médias en réception: les enjeux de la complexité" (1991; publicado en castellano en Fragmentos de un tejido, 2004b)

${ }^{36}$ Es importante señalar que se trata de trabajos escritos mientras Verón vivía en Francia por lo cual no sería incorrecto remitir también sus ideas a una derivación europea. A su vez, en la mayoría de los casos, se trata de textos que nos han llegado por su posterior traducción, en algunos casos con quince años de distancia con los originales.
} 
y los conflictos políticos empiezan a transformarse a medida que se consolida la instalación progresiva de dispositivos tecnológicos de comunicación en el tejido $\left(2004[1988 ; 1991]^{37}\right)$. El término mediatización describe, entonces, el pasaje de sociedades industriales a las sociedades post-industriales mediatizadas. Una sociedad mediática "es una sociedad donde las tecnologías de comunicación se implantan progresivamente en el tejido social"; tal sociedad es el efecto de la instalación de la prensa gráfica y del advenimiento de la fotografía, el cine, la radio, de la televisión: "soportes tecnológicos cada vez más complejos se han vuelto socialmente disponibles y han dado nacimiento a nuevas formas de discursividad". (2001 [1984]: 13).

El paso de las sociedades mediáticas a las sociedades mediatizadas (proceso gradual que se acelera luego de la Segunda Guerra) "expresa en realidad la adaptación de las instituciones de las democracias industriales a los medios, que se transforman en los mediadores insoslayables de la gestión de lo social" (Verón, 2004b: 225). Las sociedades mediatizadas, pues, son aquellas en que las prácticas sociales (las modalidades de funcionamiento institucional, los mecanismos de toma de decisiones, los hábitos de consumo, los comportamientos más o menos ritualizados) "se transforman por el hecho de que existen los medios" (2001 [1984]: 41). El resultado de un proceso como este sería -o mejor dicho, podría ser- "la transferencia total de las prácticas colectivas al universo de los medios; la vida privada-cotidiana definida, por diferencia, como el conjunto de los campos significantes no mediatizados".

Hay una diferencia de naturaleza entre la sociedad mediática y la sociedad mediatizada: "la mediatización de la sociedad industrial hace estallar la frontera entre lo real de la sociedad y sus representaciones. $Y$ lo que se comienza a sospechar es que los medios no son solamente dispositivos de reproducción de un 'real' al que copian más o menos correctamente, sino más bien dispositivos de producción de sentido” (2001 [1984]: 14-15). Lo que

\footnotetext{
${ }^{37}$ Insertamos las fechas originales por dos motivos: para distinguir los artículos específicos dentro del mismo libro y para señalar la relación de antelación o contemporaneidad con los trabajos publicados por la corriente europea.
} 
cambia, entonces, son las condiciones productivas significantes, esto es, los modos en que se articulan la producción, circulación y reconocimiento de discursos en la sociedad, algo que en trabajos posteriores Verón definiría como "cambios y rupturas de escala":

\begin{abstract}
A medida que las condiciones de producción se vuelven complejas con la intervención de los dispositivos tecnológicos, crece el desajuste entre la producción y el reconocimiento: la principal consecuencia de la transformación social de las condiciones tecnológicas de producción discursiva sobre la teoría del sentido fue, quizás, iluminar la existencia de este desajuste constitutivo, que permanece "invisible" cuando funcionan la producción y el reconocimiento en el mismo nivel, como es el caso de los intercambios interpersonales. Los que se puede llamar el paso a una sociedad mediatizada consiste precisamente en una ruptura entre producción y reconocimiento, fundada en la instauración de una diferencia de escala entre las condiciones de producción y las de reconocimiento. (2004a: 150).
\end{abstract}

Estas series, volvemos a subrayarlo, no son modos excluyentes de apropiarse de un término, entre otras razones porque no corresponden a epistemologías incompatibles o que deban reubicarse en una relación jerárquica. Probablemente, la primera serie soporte mejor las definiciones genéricas del concepto, que son las que han prevalecido hasta el momento; aquí entraría con comodidad, por ejemplo, la caracterización del concepto como "metaproceso", tal y como lo propone Krotz (2007).

Pero si quiere evitarse la tendencia a declamar una "excepción contemporánea" de la mediatización (que parece ser consecuencia de que el desarrollo del concepto se haya dado, originalmente, en investigaciones sobre el fenómeno, él sí contemporáneo, de la televisión), es necesario integrar los estudios sobre la historia de los medios de comunicación. Por lógica, entonces, la segunda serie debe quedar incorporada a la primera, en lugar de ser asumida como momento inaugural de la mediatización. Es necesario ubicarla como un momento (central, sin dudas: un período de "aceleración" y cambio notable, cualitativa y cuantitativamente más intenso que el período precedente) en el despliegue histórico de las tecnologías de comunicación y de las instituciones que han surgido de ellas. 
El caso específico de la mediatización de la política muestra las ventajas que surgen de la integración de ambas series: mientras que las propiedades que definen el fenómeno -y que a continuación trataremos- sólo parecen volverse visibles luego de la segunda mitad del siglo XX, hay investigaciones que proponen una mirada temporalmente más extensa sobre la relación entre dispositivos mediáticos y las transformaciones en la institucionalidad política; entre ellos, los ofrecidos por los estudios sobre los fenómenos mediáticos anteriores a la consolidación de un "sistema de medios" e incluso antes de la profesionalización del periodismo. Son excelentes ejemplos de esto las investigaciones sobre el surgimiento de la "opinión pública", el "espacio público" y los sistemas de información en la segunda mitad del siglo XVIII, (Baker, 1987, Darnton, 2003, Popkin, 2008; en Argentina, Duncan, 1980; Zimmerman, 1987; Román, 2003; Alonso, 2010) Estos estudios muestran el potencial transformador de una tecnología de comunicación como el escrito impreso en el contexto de una sociedad que, obviamente, carecía de medios de comunicación tal y como los conocimos luego. Y nos sugieren, además, que "el proceso de mediatización no progresa al mismo ritmo en los diferentes sectores del funcionamiento social; aunque parece cierto que el aparato del Estado ( $\mathrm{y}$, en general, el campo de lo político) es uno de los sectores donde esa mediatización es particularmente visible" (Verón, 2001 [1988]).

\subsection{Mediatización de la política: hacia un concepto ampliado}

En lo que sigue, vamos a avanzar en la indagación conceptual de la mediatización centrándonos en la mediatización de la política, para acercarnos a una formulación teórica y analítica coherente con nuestro propio problema de estudio. Para eso, vamos a centrar nuestra discusión en el concepto de "lógica" mediática, que se ha convertido, en los estudios más importantes sobre el tema, en una suerte de eje sobre el que giran las indagaciones empíricas y las definiciones teóricas. 


\subsubsection{Sobre la primacía de la "lógica mediática"}

Los trabajos pioneros de mediados de la década de 1980 y sus epígonos contemporáneos montaron sus análisis sobre la oposición entre una "lógica política" y una "lógica mediática". Lo que sigue es un compendio representativo, creemos- de esta perspectiva ${ }^{38}$ :

- "La lógica mediática consiste en una forma de comunicación; el proceso a través del cual los medios presentan y transmiten información. Elementos de esta forma incluyen varios medios y distintos formatos. Formatos, en términos de cómo el material es organizado, el estilo según el cual es presentado, el énfasis en características particulares de comportamiento, y la gramática de la comunicación mediática" (Altheide y Snow, 1979, citado por Strömback, 2008: 233).

- "La lógica mediática puede ser entendida como el dominio en los procesos societales de los valores noticiosos y de las técnicas narrativas que los medios utilizan para tomar ventaja de sus competidores en la captura de la atención del público" (Stromback, 2008: 33)

- La lógica mediatica implicaría "simplificación, polarización, intensificación y personalización”, así como también "la estereotipación y el encuadre de la política como un juego estratégico (Mazzoleni, 1987).

- "La lógica mediática ha infiltrado el proceso político, en gran parte puenteando y disminuyendo los centros tradicionales de poder como los sindicatos, las iglesias y los partidos políticos. La contraparte de esta mediatización de la política es que la consultoría especializada en imagen mediática desplaza la anticuada lealtad ideológica y la participación organizada como bases de la política de partidos” (Entman, 2009: 64).

- "El término mediatización denota las concomitancias problemáticas o las consecuencias del desarrollo de los modernos medios de masas. Se distingue

${ }^{38}$ Los textos originales están en inglés. Las traducciones son nuestras. 
de la mediación, que refiere en un sentido neutral a cualquier acto de intervención, transmisión o reconciliación entre diferentes actores, colectivos o instituciones (...) Hablar de la política moderna como mediada es meramente un enunciado descriptivo (...) Caracterizar a la política como mediatizada trasciende la mera descripción de los requerimientos del sistema [político] La política mediatizada es política que ha perdido su autonomía, se ha vuelto dependiente, en sus funciones centrales, de los medios de masas" (Mazzoleni y Schulz, 1999: 250)

- “Por mediatización de la sociedad entendemos el proceso por el cual la sociedad, en un grado cada vez mayor, se somete $a$, o se vuelve dependiente de, los medios y su lógica. Este proceso es caracterizado por una dualidad en la que los medios se han integrado a las operaciones de otras instituciones sociales, al tiempo que han adquirido el estatus de institución social por derecho propio. Como consecuencia, la interacción social -con las instituciones respectivas, entre instituciones y con la sociedad en generaltiene lugar a través de los medios” (Hjarvard, 2008: 113).

Queremos realizar una serie de observaciones críticas sobre estas citas como primer paso para el desarrollo de un concepto ampliado de la mediatización de la política; ampliado, decimos, en dos sentidos: en función de las problemáticas que podrían ser estudiadas a partir de este concepto y de las perspectivas teóricas y empíricas que puedan articularse en su estudio.

En primer lugar, el campo semántico desplegado alrededor de la noción de “lógica mediática” no es homogéneo. Refiere tanto a efectos institucionales (el desplazamiento de los espacio de influencia pública, desde las organizaciones políticas, el Parlamento o las calles a las pantallas y estudios de televisión), a efectos discursivos (la dilución del discurso político en las operaciones retóricas que imponen los géneros mediáticos como la simplificación, estereotipación, y otras técnicas narrativas) y a efectos sobre la circulación de la "información" (es decir, a la distribución de los "recursos cognitivos" para la toma de decisiones, o para la formación de opinión de los actores sociales). 
Está claro que el concepto de "lógica mediática" es un operador de síntesis, aunque eso no alcanza para excusar su uso, en tanto no logra captar los diferentes aspectos esbozados. Atento a esta dificultad, Marcinkowski (2014: 10) cuestiona los estudios que hablan de una lógica mediática. Para el autor, existe una pluralidad de lógicas mediáticas, entendidas como reglas y rutinas que inciden en la producción de comunicación pública y que funcionan como "sistemas de control interconectados para seleccionar, narrar e interpretar las informaciones que tratan los medios de comunicación y el periodismo". Y aunque tal vez el problema sea la propia noción de "lógica" -más parecida a un "puente" terminológico para saltear una dificultad que una solución conceptual precisa- lo cierto es que la propuesta de Marcinkowski es válida (circunstancialmente, tal vez) para evadir los enfoques lineales que cuestiona.

En segundo lugar, notamos la ausencia de una definición teórica del concepto de "medios". En la mayoría de los casos, lo que se ofrece es una definición referencial: por "medios" se entiende -o se sobreentiende- medios masivos de comunicación: prensa escrita, radio y televisión. A priori, esto no puede objetarse, ya que es coherente con el recorte temporal que ya hemos analizado, y también es funcional a los propósitos explicativos de estos investigadores. Pero lo cierto es que una definición teórica del concepto de "medio de comunicación", es decir, que permita desagregar elementos que a su vez puedan ser remitidos a referentes empíricos es un paso necesario (ya volveremos sobre este punto en el próximo parágrafo).

En tercer lugar nos resulta cuestionable el sesgo que implica aislar a "los medios" sin tomar en cuenta otro tipo de fenómenos que inciden como condiciones sociales de la política mediatizada, tales como la ampliación de la educación universitaria, las transformaciones en los modos de ejercicio de la ciudadanía, la crisis de la capacidad de contención y socialización política de las organizaciones que venían encuadrando las identidades colectivas (sindicatos, partidos políticos), los cambios en la economía del sector de comunicaciones, etc. El denominador común de las citas que hemos trascripto 
es que tienden a acentuar una relación causal: la mediatización debería leerse como el efecto de la presión proveniente de una fuerza externa que actúa como variable independiente, al extremo de que la "influencia de los medios" (o directamente: la mediatización) se concibe como correlato del desarreglo en el funcionamiento del sistema político. ${ }^{39}$

Por supuesto, no se trata de menospreciar las articulaciones, solapamientos y cruces entre estos fenómenos. El problema es que la bibliografía dedicada a analizar el impacto de la mediatización en los modos de participación política tiende a asumir que la presencia de los medios debilitó, por su propia fuerza, la capacidad de inserción social y movilización de las organizaciones políticas, así como también la supuesta politización de la ciudadanía. Es probable que la simultaneidad histórica de estos dos fenómenos haya alentado una concepción como esa. Mazzoleni y Schulz (1999:252), en esta línea, consideran que la crisis del sistema de partidos y el ascenso de modalidades sofisticadas de ejercicio ciudadano son variables independientes en la modificación de las condiciones de interacción entre los medios masivos y las instituciones políticas, y factores que relativizan los efectos de una "excesiva" mediatización.

En cambio, coincidimos con Novaro (2000:39), para quien la "massmediatización" genera las condiciones de circulación pública de "recursos de deliberación, información e identificación" que exceden los esquemas con los que, durante mucho tiempo, las organizaciones políticas habían producido sus lazos de representación. Novaro apunta, también, que esa multiplicación de demandas e intereses que acceden al espacio público y que no pueden ser absorbidas en conjunto por el sistema político, "colabora a que se disipen las fronteras entre el plano interno y el externo de los partidos, porque éstos

\footnotetext{
${ }^{39}$ Muestras ejemplares de esta perspectiva en Argentina son Sorj (2010): "cuando fallan las estructuras de mediación entre los ciudadanos y el sistema político, se pasa a la mediatización de esas relaciones"; o Cheresky (2008) para quien la escena pública -cuyos soportes son la televisión, la gráfica, la radio e Internet- "ha sustituido" a otras escenas institucionales, como el Parlamento, las reuniones de gabinete o los encuentros partidarios, en tanto lugares de enunciación política.
} 
pierden el control de la socialización y la educación política de los ciudadanos".

Señalamos que nos parecía llamativa la ausencia de una definición teórica del concepto de "medio de comunicación" en la mayoría de los autores de la corriente europea-anglosajona de la mediatización. Una excepción, en este marco, es la de Hjarvard quien en un libro posterior al artículo ya citado (del 2008), pero que recupera casi textualmente las líneas centrales de ese trabajo, define a los medios de comunicación como:

Las tecnologías que expanden la comunicación en el tiempo, en el espacio y en modalidades. Los medios de comunicación no constituyen apenas tecnologías, sino que adquieren formas sociales y estéticas que estructuran el modo según el cual serán utilizados en variados contextos. (...) No constituyen por lo tanto una fenómeno uniforme (Hjarvard, 2014:40).

Esta definición de Hjarvard refiere a fenómenos que no se circunscriben a los "medios masivos de comunicación" propiamente dichos; tal vez por eso roza lo que nosotros consideramos un aspecto central en la teoría de la mediatización: la distinción entre tecnologías de comunicación y lo que él denomina "formas sociales" y que nosotros preferimos llamar instituciones mediáticas. Sólo así es posible entender la distinción -fundante- entre "medios" y "fenómenos mediáticos".

Considerado en sincronía, se trata de una distinción analítica; pero en términos de indagación histórica, se trata de un problema empírico: como ya lo señalamos, antes de la conformación de los "medios" como organizaciones singulares, algunas tecnologías de comunicación ya habían inducido transformaciones que cabe considerar del orden de la mediatización.

Al respecto, es conveniente que explicitemos la definición de medios comunicación que es el fundamento de la perspectiva que desarrollamos. Tomamos esta definición de Eliseo Verón (1997; 2004):

Un medio de comunicación social es un dispositivo tecnológico de producciónreproducción de mensajes asociado a determinadas condiciones de producción y a determinadas modalidades o prácticas de recepción. Tecnología y medio 
de comunicación son expresiones que designan cosas diferentes. Un medio comporta la articulación de una tecnología de comunicación a modalidades específicas de utilización (tanto en producción como en recepción).

Como indicamos en relación a la definición de Hjarvard, el eje del concepto que propone Verón es la distinción entre dispositivos y medios. En este marco, dispositivos no tiene el valor expansivo que ha recibido por parte de la filosofía política (Foucault, 1977; Agamben, 1993) como entramado de prácticas, instituciones, normas y discursos que modelan la subjetividad y los procesos de subjetivación ${ }^{40}$. Aquí, la noción de "dispositivo" funciona como un “nivel de análisis", pues concibe a las tecnologías de comunicación en tanto habilitan o deshabilitan determinadas posibilidades de producción de sentido, de enganches 0 desenganches espacio-temporales y de relaciones intersubetivas lo cual tiene manifestaciones en niveles macro, meso y micro social $^{41}$.

Así considerado, el concepto de medios designa los "usos" de las sucesivas tecnologías de comunicación, tal como estos usos se estabilizaron a lo largo de la historia. Esa estabilización implica, también, a las estructuras institucionales y a los sistemas de normas articulados a la utilización de esas tecnologías. Esto explica que un mismo dispositivo (o conjunto tecnológico) no necesariamente explica el surgimiento de una práctica profesional (como el periodismo) hasta tanto no se articula con una serie de condiciones económicas (desarrollo de la economía capitalista industrial), sociales (urbanización, escolarización) culturales (configuración de mercados de “lectores”), y políticas (apertura política, paulatina autonomía de las organizaciones mediáticas en relación a las organizaciones políticas), y

\footnotetext{
${ }^{40}$ Agamben remite a una definición de Foucault, quien por dispositivo define "en primer lugar, un conjunto resueltamente heterogéneo que incluye discursos, instituciones, instalaciones arquitectónicas, decisiones reglamentarias, leyes, medidas administrativas, enunciados científicos, proposiciones filosóficas, morales, filantrópicas, brevemente, lo dicho y también lo no-dicho, éstos son los elementos del dispositivo. El dispositivo mismo es la red que se establece entre estos elementos." Y Agamben, a partir de esa definición, explica que llamará "literalmente dispositivo cualquier cosa que tenga de algún modo la capacidad de capturar, orientar, determinar, interceptar, modelar, controlar y asegurar los gestos, las conductas, las opiniones y los discursos de los seres vivientes

41 Desde las consideraciones de Anderson (1991) sobre el rol de los periódicos en la temporalidad de la Nación, hasta la experiencia de rituales políticos en tiempo real pero a distancia, y también la reformulación de las condiciones en que los políticos, por ejemplo, deben exponerse.
} 
tecnológicas (mejoras en técnicas de impresión, sistemas de comunicación que aceleran el tiempo de circulación de discursos y mercancías, como el telégrafo, el teléfono, el ferrocarril).

Un elemento que completa la definición es el de las condiciones de acceso a esos discursos. Verón sostiene que ese acceso no se da de cualquier forma: se trata de un acceso plural a los mensajes bajo condiciones de mercado, predominantemente un acceso pago. Ese acceso plural define una dimensión colectiva en el establecimiento histórico de los medios. La comunicación propiamente mediática implica la construcción, en producción de un destinatario que es un colectivo, nunca un individuo (1999: 139). Acceso plural no presupone una hipótesis cuantitativa, solo señala que un medio se constituye como tal cuando puede ser consumido por un público. Como veremos más adelante en este capítulo y en el capítulo 2, la figura del público y la cuestión de lo público es determinante de lo que entendemos por mediatización de la política.

\subsubsection{Mediatización: campos problemáticos}

Como lo dijimos, es discutible la naturalización de la contraposición entre una lógica política y una lógica mediática. De hecho, la misma existencia de dos "lógicas" no puede entenderse sin una hipótesis sobre la evolución histórica de la relación entre las instituciones mediáticas y la institucionalidad política. Si los medios y la política "trabajan" sobre la gestión de representaciones sociales según dos lógicas diferenciadas, ¿cómo han llegado a constituirse esas dos lógicas específicas? Y en particular: ¿cómo se constituyó una "lógica mediática", considerando que, en sus orígenes, los "medios" estaban funcionalmente integrados al sistema político; anexados, pues, a su "lógica", o sea, a las necesidades y los tiempos de las organizaciones políticas (Grandi, 2002; Pasley, 2001; Schudson, [1978] 2012)? 
Estas preguntas señalan, a un mismo tiempo, algunos puntos ciegos de los estudios sobre la mediatización de la política, en particular de aquellos que consideran que este proceso es un fenómeno específico del siglo XX, y más precisamente, que sólo se desarrolla bajo condiciones de desarrollo industrial avanzado (Stromback, 2008; Hjarvard, 2008); pero son también preguntas que pueden orientar un rastreo histórico en búsqueda de antecedentes y líneas de continuidad entre las transformaciones atribuidas a los medios electrónicos y los cambios que la tecnología de lo escrito impreso había generado en el funcionamiento de los sistemas políticos desde el siglo XVIII al menos.

Un rastreo de ese tipo está fuera del alcance de esta tesis. En cambio, sí podemos desarrollar nuestro argumento tomando algunas referencias históricas para hacer hincapié en lo que consideramos rasgos constitutivos de los procesos de mediatización, rasgos que tienen utilidad heurística en particular para nuestra propia investigación.

El concepto de mediatización de la política, entonces, no debe quedar atado al encuentro frontal entre "medios" y "política”. Por eso, queremos desagregar algunos rasgos conceptuales y asociarlo a una serie de campos problemáticos que, por cierto, guardan una relación sucesiva en términos históricos pero que nos interesan en particular porque nos permitirán tratar teórica y analíticamente aspectos importantes de nuestro propio problema de investigación. Esos campos problemáticos son los siguientes:

a) La mediatización está ligada, de manera inextricable, a los procesos de emergencia de la cuestión pública, tanto en su faz conceptual como en su calidad de fenómeno constitutivo de la conformación de los estados modernos al menos desde el siglo XVIII: la “opinión pública”, el “espacio público" y el "público", consideradas como fuentes de legitimidad externa al sistema político. Sin caer en ningún determinismo tecnológico, ni en una explicación monocausal, lo cierto es que si, tal como lo ha descripto Taylor “la esfera pública es un espacio metatópico, secular y extrapolítico" (1992: 248), la circulación de lo escrito-impreso fue (esto, lógicamente, ya lo había 
advertido Habermas) una de las precondiciones para su funcionamiento pleno.

b) A fines del siglo XIX y principios del siglo XX, el concepto de mediatización ayuda a entender el proceso de diferenciación gradual del sistema de medios masivos de comunicación en relación al sistema político: institucionalización de los medios y profesionalización del periodismo, proceso que, por su parte, incide en la configuración de la cuestión pública;

c) En tanto los dispositivos de comunicación que conforman la infraestructura del espacio público se expanden de manera ubicua en el tejido social, la mediatización se convierte en una dimensión constitutiva de las prácticas sociales; entre ellas, de los conflictos culturales, sociales y políticos cuyos protagonistas necesiten escenificarse, confrontar y exponer sus posiciones (ideas, argumentaciones) al conjunto de la ciudadanía en el espacio público.

En lo que sigue, vamos a desarrollar brevemente estos tres campos problemáticos.

a- La cuestión de lo público.

El vínculo entre espacio público, opinión pública y los dispositivos mediáticos es casi un vínculo genético y está directamente ligado a la emergencia de la figura del "público" no sólo como sujeto sociológico emergente de nuevas modalidades de socialidad (Habermas [1962] 2006: 69-70) sino también como un "principio de legitimidad exterior" al sistema político absolutista en la segunda mitad del siglo XVIII (Baker, 1987; Chartier, 1995).

Como forma de intercambio colectivo, el espacio público moderno es, desde su origen en el siglo XVIII, una práctica social mediatizada: está directamente articulado a la circulación de textos -periódicos, revistas- y a la discusión sobre textos -libros, obras de teatro, etc. Pero sobre todo, está signado por la emergencia de la figura del "público", que si bien no deja de ser el reverso 
estilizado de la pertenencia de clase (Fraser, 1997; Chartier, 1995), un colectivo con atributos excluyentes ${ }^{42}$-dotado de una racionalidad, de una moral, de un estilo- no puede reducirse sólo a eso.

En su estudio comparado sobre el surgimiento de la "opinión pública" en Francia e Inglaterra en la segunda mitad del siglo XVII, Keith Baker (1987: 4245), explica que la figura del "público" se consolida en Francia en el marco de una "política de la contestación"43 en los años 1750 que colocaba a la monarquía frente a constantes refutaciones bajo la forma de papeles impresos que circulaban de manera ilegal y clandestina, y que encontraba en un “público letrado una audiencia extraordinaria”.

Sin embargo, el propio Baker destaca que si bien la emergencia de este público “ está ligada a fenómenos sociológicos complejos tales como los cambios de largo plazo en los niveles de alfabetización, la expansión comercial de la prensa, la trasformación burocrática de un orden social particularista en una comunidad nacional fuertemente integrada", conviene resistir la tentación de comprender el concepto "simplemente en términos sociológicos", ya que, tanto desde la perspectiva de los agentes estatales como de los intelectuales que asumían su representación "el público" se manifestaba como :

forma abstracta de autoridad que invocaban los actores de una política de un tipo nuevo con el objetivo de consolidar la legitimidad de las reivindicaciones que no podían ser impuestas ya por un orden absolutista

\footnotetext{
${ }^{42}$ No se nos escapa que la discusión planteada por Fraser apunta no sólo a la composición efectiva del "público burgués" sino a la existencia de otros "públicos" no burgueses y a los conflictos entre estos otros públicos, o contra públicos (de mujeres de elite, de campesinos, de negros, de proletarios) con los públicos burgueses (Fraser, 1997: 105-106).

${ }^{43} \mathrm{Ver}$, al respecto, el estudio de Darnton (2003:371-429) sobre la dinámica de circulación de la comunicación pública en el París de las últimas décadas del siglo XVIII, donde el autor registra muchas variantes de lo escrito impreso (carteles, periódicos murales, cartas, pasquines, nouvelles a la main) que funcionaban como soportes de la información sobre el poder monárquico, sobre la vida privada de los reyes, o sobre disputas intestinas de la nobleza.
} 
Es este fundamento histórico el que refiere Luhmann cuando sostiene que el público es una diferenciación interna del sistema político ${ }^{44}$, y es interesante notar que el sociólogo alemán vincula esta emergencia con la difusión de la prensa escrita: "La prensa fue utilizada [al final del siglo XVIII] para lograr resonancia pública fuertemente ambiciosa en lo político", ya que lo que en ella se escribía se hacía público (Luhmann, 2000: 150). La circularidad del razonamiento revela la insolubilidad entre ese concepto ilustrado de "público" y la prensa escrita ${ }^{45}$. Lo cierto es que, como señala Baker, el modo de acceso o de contacto con esta entidad abstracta (que no se dejaba definir claramente en términos sociológicos o a ser reducido a "un referente social presupuesto entre las clases o los grupos específicos" ${ }^{46}$ ) fue, desde su origen, “la tecnología de lo impreso" (Baker, 1987: 44).

Según señala Nora Rabotnikof (2005: 39) el uso político del adjetivo "público" en los siglos XVII y XVIII irá marcando un cambio en las relaciones de la sociedad y el Estado con los individuos y grupos, y dará lugar a una progresiva diferenciación entre el Estado, la comunidad y el individuo. La autora apunta dos deslizamientos de sentido en el uso de la noción de "público". Antes en Inglaterra y luego en Francia, el "interés público" aparecerá como la voz que

\footnotetext{
${ }^{44}$ Esta idea de Luhmann podría ser impugnada con los mismos argumentos con los que, por ejemplo, Fraser (entre otros) ha cuestionado la reconstrucción del espacio público burgués elaborada por Habermas: en Luhmann, el público parece consistir en los interlocutores (burgueses, propietarios) de los sistemas políticos del siglo XVIII. Sin embargo, el criterio reduccionista no por excluyente es errado: hay muchos testimonios históricos (que pueden consultarse en los trabajos ya citados de Baker, Darnton, Gaïti y Chartier para Francia e Inglaterra, o Paula Alonso (2010) y Zimmerman (1997) para el caso argentino) de que los funcionarios de gobierno concebían al público como una entidad frente a la cual debían argumentar, o a la cual debían controlar y reprimir. Es decir, aquí se plantea un problema ya no de reconstrucción histórica, sino del punto de vista desde el cual se realiza esa reconstrucción. Que la esfera pública burguesa no funcionara según el ideal planteado por Habermas (y la estilización simplificada que muchos los críticos le endosan) no quiere decir que la figura del "público" no tuviera consecuencias que afectaran el proceso de toma de decisión de medidas políticas.

${ }^{45}$ Chartier (1995) recuerda que Kant distingue al uso público de la razón como "el que alguien hace de ella, en cuanto docto, y ante la totalidad del público del mundo de lectores" (Kant, 2004:35).

${ }^{46}$ Cierto es que, como lo ha señalado Chartier, ese público era, sociológicamente, uno "ilustrado", "burgués": "Aun cuando se defina como una entidad conceptual -o precisamente porque así se define- y no en términos sociológicos, la noción de opinión pública (...)actúa [a fines del Antiguo Régimen] como un poderoso instrumente de división o legitimación social (...) Universal en su esencia, el público capaz de hacer un uso crítico de su razón no lo es en términos de composición efectiva (...) La cesura entre pueblo y público es muy acentuada y (...) está identificada por la frontera entre los que pueden leer y escribir y los que no pueden hacerlo" (1995: 50).
} 
desde abajo desafía las pretensiones del gobierno autocrático. A la identificación de lo "común" con un Estado que parece sustraerse a la publicidad (...) le sucederá el paulatino acercamiento de lo público a lo social.

Esto cambió en el siglo XIX. Price (1994) explica que los primeros intentos por proporcionar un tratamiento científico social a la opinión pública y por explicar la naturaleza sociológica del "público" se corresponden a la inquietud que tanto sociólogos como psicólogos sociales experimentaron frente a nuevas manifestaciones de conducta colectiva que fueron tipificadas a fines del siglo XIX: multitudes espontáneas, huelgas, manifestaciones masivas y disturbios (1994: 40).

Se trata, en síntesis, de los procesos de cambio que Ferry (1989:17) ha denominado "el advenimiento de la cantidad": el avance de los sectores populares en la vida política y la consolidación de las democracias de masas. En lo que a nuestro tema refiere, la consecuencia capital de este proceso fue la mutación sociológica del espacio público que se intensifica, o más bien se asienta, por el advenimiento de la "sociedad de los medios un siglo después del de la sociedad de masas" (Ferry, 1989:19).

Para el propio Ferry, esa mutación exige una redefinición de la estructura y de las condiciones de funcionamiento del espacio público, ya que "la realidad actual del funcionamiento democrático depende de otras categorías" que aquellas que estructuraron y orientaron el pensamiento, clásico y moderno, sobre la política y el espacio público ((1989: 13). Estos pasajes del texto de Ferry suelen ser muy citados. Sin embargo, rara vez se asume, en toda su radicalidad, la definición que el propio autor (Ferry, 1998: 19-20) propone en su "redefinición sociológica" ${ }^{47}$ del EP.:

\footnotetext{
${ }^{47}$ El propio Habermas registra este cambio en el prefacio de 1990 a Historia y Crítica de la opinión pública, cuando comenta el cambio en la estructura de la publicidad, y de hecho ese libro es un intento por replantear sociológicamente el funcionamiento de la publicidad política desde una perspectiva normativa, aunque a diferencia de Ferry (y esto es más claro en los trabajos posteriores de Habermas), el pensador alemán diagnostica negativamente esa mutación pues significa una presión selectiva mayor debido a la emergencia de un nuevo poder: "el poder de los medios".
} 
El “espacio público"(...) es, en sentido lato, el marco “mediático” gracias al cual el dispositivo institucional y tecnológico propio de las sociedades posindustriales es capaz de presentar a un "público" los múltiples aspectos de la vida social (...) Por "mediático" entiendo lo que mediatiza la comunicación de las sociedades consigo mismas y entre sí (...) El "público" es, virtualmente, toda la humanidad y, de modo correlativo, el "espacio público" es el medio en el cual la humanidad se entrega a sí misma como espectáculo.

Volveremos sobre las consecuencias de esta definición cuando tratemos el tercer campo problemático que asociamos al concepto de mediatización.

b- Del periodismo partisano al periodismo profesional, de los periódicos a los medios: la estructuración frágil de un lugar de enunciación.

Un segundo campo problemático que puede explorarse a partir del concepto de mediatización y en estrecha relación con la conformación de la cuestión pública es la institucionalización de los "medios" como organizaciones diferenciadas del sistema político.

Como vimos, para la mayoría de los autores de la corriente europea, la mediatización en su fase moderna coincide con el proceso de desarrollo del periodismo como profesión (Hallin y Mancini, 2004: 78); podemos agregar, que eso significó la consolidación de los medios como un "lugar de enunciación" externo a las instituciones, organizaciones y actores políticos, y también la configuración de los "sistemas de medios" ${ }^{48}$ como resultado de un proceso de diferenciación social (aunque existen importantes diferencias en el modo en que cada autor conceptualiza ese proceso; ver Alexander, 1981; Luhmann, 2000; Hallin y Mancini, 2004; Marcinkowski, 2014 ${ }^{49}$ )

\footnotetext{
48 En el marco de este repaso, usamos el término "sistema de medios" en un sentido referencial, estrictamente empírico, para indicar el conglomerado de medios de comunicación (diarios, revistas, radios, televisión) que, al menos en relación a la producción y circulación de noticias sobre acontecimientos políticos, funcionan como en ensamble, no necesariamente de manera centralmente coordinada, pero sí con criterios de construcción de agenda similares por razones tanto políticas como de competencia interna.

49 De los autores citados, quizás Hallin y Mancini (2004, cap. 4, en especial pp. 75-85) son quienes a pesar de utilizar el concepto de "sistema" se ubican en una posición crítica o distanciada de la teoría de los sistemas funcionales a las que imputan -en un gesto un tanto indiscriminado, o bien injusto- una concepción lineal de la historia de los medios. Los autores reconocen la importancia de las teorías de la diferenciación (empezando por Durkheim) para el estudio de los sistemas mediáticos, pero prefieren las variantes de la "de-diferenciación", y en particular algunas ideas de Habermas y Bourdieu.
} 
En su fase moderna, entonces, el concepto de “mediatización” condensa el devenir de tres procesos superpuestos:

- el paso de los periódicos a los medios ${ }^{50}$, es decir, de soportes dedicados a la intervención pública en favor de una facción política, sostenidos por mecenas $u$ organizaciones políticas ${ }^{51}$, a soportes multitemáticos, con combinación de opinión e información, sostenidos por publicidad y venta al público;

- la profesionalización del periodismo, sintetizada usualmente como el paso de la prensa partisana a la prensa informativa dedicada a producir y vender "noticias" y de un periodismo orientado, al menos como imaginario dominante, por una serie de reglas deontológicas;

- y la consolidación gradual de "sistemas de medios de comunicación", es decir, de la estructuración de un mercado de medios, lo que supone la homogeneización y estandarización de productos, la competencia comercial pero también ideológica, y un consenso sobre formatos, estilos y géneros, y también sobre las modalidades de construcción de agenda.

Los estudios sobre el desarrollo del periodismo y los medios masivos muestran que, a pesar de diferencias que impiden una homologación absoluta en la forma y tiempos según las regiones, estos procesos se pueden verificar, en sus rasgos genéricos, en tanto en Europa (Weil [1944] 1962; Barbier, 1997; Hallin y Mancini, 2004; Barrera, 2004), como en Estados Unidos (Schudson [1978] 2012; Pasley, 2001; Mcchesney y Nichols, 2005; Waisbord, 2013) y en Argentina (Duncan, 1980; Zimmerman, 1997; Román, 2003 y 2010; Alonso, 2010; Becerra, 2010).

\footnotetext{
${ }^{50}$ Este proceso puede verificarse en la mayoría de los estudios sobre la evolución de lo escrito impreso desde el siglo XVII: Barrera (2004), Schudson (1978), Barbier y Lavenir (1997), Weil (1944), entre otros.

51 Una excelente descripción de las condiciones en que se ejercía el periodismo antes de la era de los medios en Argentina es la que ofrece Tulio Halperin Donghi (1985: 23-24) en su estudio sobre la vida de José Hernandez.
} 
No vamos a avanzar en un repaso histórico detallado. Nos conformamos con sintetizar cómo se estructuran estas etapas en el caso argentino, con un énfasis particular en el pasaje el periodismo partisano al periodismo profesional en las primeras décadas del siglo $\mathrm{XX}$, ya que ese pasaje resulta revelador sobre los debates no saldados, y por eso contemporáneos, sobre el rol y el lugar del periodismo como una "voz" externa al sistema político y en qué medida esa posición distanciada funda su propia legitimidad, en tanto los medios se conciben como dispositivos de intermediación de lo público.

Adaptando al caso argentino criterios de periodización propuestos por Van Cuilenburg y McQuail ${ }^{52}$, el investigador Martín Becerra ha propuesto un esquema que sintetiza el desarrollo de la evolución de los medios por etapas en la historia argentina:

52 "Media policy paradigm shifts: towards a new communications policy paradigm" en European Journal of Communicationvol. 18, n², Sage, Londres, p. 181-207.2003 
Tabla 1: Desarrollo de la institucionalidad mediática en Argentina

\begin{tabular}{|c|c|c|}
\hline ETAPA & PERÍODO & CARACTERISTICAS \\
\hline \multirow{2}{*}{$\begin{array}{l}1^{\circ}: \text { 1801-1900. Orígenes } \\
\text { de la prensa y } \\
\text { subordinación a las } \\
\text { disputas políticas }\end{array}$} & $\begin{array}{l}\text { Prensa dependiente sin } \\
\text { opinión pública }\end{array}$ & $\begin{array}{l}\text { Orígenes de la prensa en el } \\
\text { Virreinato del Río de la plata }\end{array}$ \\
\hline & $\begin{array}{l}\text { Surgimiento de opinión } \\
\text { pública. } \\
\text { política/periodismo } \\
\text { faccioso. }\end{array}$ & $\begin{array}{l}\text { Proceso de independencia, guerras } \\
\text { civiles y disputas internas. } \\
\text { Comunicación facciosa }\end{array}$ \\
\hline \multirow{3}{*}{$\begin{array}{l}2^{\circ}: \text { 1900-1976. } \\
\text { Periodismo profesional, } \\
\text { autonomía relativa del } \\
\text { sector de las industrias } \\
\text { culturales. Maduración y } \\
\text { estabilidad }\end{array}$} & $\begin{array}{l}\text { Prensa de masas (Crítica, } \\
\text { El Mundo, Clarín, entre } \\
\text { otros). }\end{array}$ & $\begin{array}{l}\text { Acumulación metropolitana. } \\
\text { Imaginario } \\
\text { independencia frente a las a las } \\
\text { facciones, objetividad frente a los } \\
\text { hechos. }\end{array}$ \\
\hline & $\begin{array}{l}\text { Radio/Cine/Mercado } \\
\text { editorial }\end{array}$ & $\begin{array}{l}\text { Emergencia y consolidación de una } \\
\text { industria cultural (mercado de } \\
\text { medios, canción popular, etc.) Era } \\
\text { dorada del cine nacional }\end{array}$ \\
\hline & Audiovisual & $\begin{array}{l}\text { Peronismo, antiperonismo y empate } \\
\text { hegemónico }\end{array}$ \\
\hline \multirow{3}{*}{$\begin{array}{l}3^{\circ}: 1976-2009 . \text { Crisis del } \\
\text { modelo de autonomía } \\
\text { relativa. Reformulación } \\
\text { de las reglas del sistema } \\
\text { de medios e industrias } \\
\text { culturales. }\end{array}$} & Multimedios & 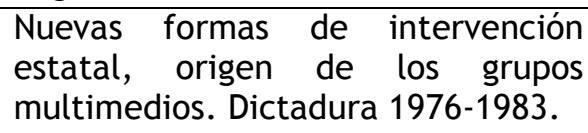 \\
\hline & Fin de la censura & $\begin{array}{l}\text { Proceso de abolición de la censura } \\
\text { explícita a partir de } 1983 . \\
\text { Limitaciones para revertir la } \\
\text { herencia legal de la dictadura. } \\
\text { Primacía cultural de los medios. }\end{array}$ \\
\hline & $\begin{array}{l}\text { Reforma del } \\
\text { convergencia, } \\
\text { concentración, } \\
\text { centralización. }\end{array}$ & $\begin{array}{l}\text { Retracción del consumo editorial. } \\
\text { Crecimiento de la TV. Aparición de } \\
\text { la FM. Regulación como mecanismo } \\
\text { de asignación discrecional de los } \\
\text { recursos. Nueva ley de medios } \\
\text { audiovisuales en } 2009 \text {. }\end{array}$ \\
\hline
\end{tabular}

Fuente: Becerra, Martín (2010: 6)

Hacia fines de la primera década del siglo XX empezó a tomar forma en nuestro país un periodismo profesional, auto sustentado y cuyo centro de gravitación dejará de ser solo la política. Mientras tanto, este tipo de prensa que Duncan (1980) llama “prensa política” se convirtió en un elemento central del funcionamiento del sistema político del cambio de siglo. Para este historiador, existen "razones para sostener que una interpretación de la prensa como un componente clave del sistema político anterior al fin del siglo es mucho más ajustada históricamente que las interpretaciones que ignoran este hecho" (1980: 775).

En el caso de Duncan, sus motivos tienen que ver con circunstancias puntuales de la Argentina del 1880: un acuerdo sobre los principios liberales concebidos 
como la base de la civilización y no como un programa ideológico entre otros en pugna. Había un acuerdo de base entre los hombres de la generación del 80 sobre la necesidad de la formación de un hombre republicano, argentino, civilizado. Duncan sostiene que para esta tarea se requerían dos pares de herramientas: doctrina y práctica, educación y estrategia, y que había una suerte de expectativa en que una prensa libre "supliera ambos tipos de herramientas", en el sentido de que sirviera como foro de discusión entre facciones que, sin embargo, compartían una cosmovisión ideológica (1980: 777).

En un estudio que toma como referencia el trabajo de Duncan, Eduardo Zimmerman (1997) explica que la prensa política, en el Buenos Aires finisecular, cumplía dos funciones. Por un lado, en un sentido puramente instrumental, la función de esta prensa política era la de ser "una herramienta de propaganda necesaria a toda facción para alcanzar algún resultado político favorable". Estaba sostenida por agrupaciones políticas. Por otro lado, tenían una función dentro del sistema político como "expresión de una nueva forma de sociabilidad política", por un lado, y como ámbitos de discusión y elaboración de propuestas políticas a ser defendidas.

Tim Duncan describe esas dos funciones (en las luchas facciosas y en la relación entre el sistema político y una incipiente "opinión pública") como "el guerrero y el pensador". Zimmerman explica que en esa época se asiste a una "cultura de la movilización" que caracteriza la formación de la esfera pública en Buenos Aires en las últimas décadas del siglo XIX ${ }^{53}$. Añade Zimmerman (1997:4) que "oficialismo y oposición, en sus distintas expresiones, apelaban a la opinión pública como una fuente de legitimación política, y en esos intentos se reflejaba que el concepto mismo de "opinión pública", a la que

\footnotetext{
53 "En este sentido se ha señalado acertadamente que esa participación de los diarios no sólo como canal de información sino como instrumento formador de opinión y de ampliación del debate público refleja que 'la política era una cosa pública, que se hacía no sólo en los cenáculos del poder sino también en el seno de la opinión, comprendida ya como cuarta fuerza del estado (...) Era tan importante "hacer opinión" como representarla. El voto medía, cuantificaba la participación política pero a la opinión había que movilizarla' (la cita dentro de la cita corresponde a Ema Cibotti, en un artículo sobre Sufragio y opinión pública en Buenos Aires a fines del siglo XIX").
} 
tan frecuentemente las partes combatientes recurrían como arbitrio de sus disputas, era interpretado de muy distintas maneras".

Como lo explica Paula Alonso (2010: 45): "En su ejercicio de la difusión del chimento y el anuncio de reuniones, los diarios políticos "republicanizaban" la política, convirtiéndola en una cosa más pública. La política era, así, en gran medida, arrebatada a los confines de la intimidad del salón, del comité, del banquete, y a veces, incluso de la correspondencia privada, para ser lanzada a la vida pública a través de los periódicos".

Esta mención a la opinión pública contiene, sin dudas, la presencia cada vez más importante de los lectores concebidos como público. No está de más apuntar que en el ya mencionado "despegue" del sistema mediático respecto del sistema político sería preciso analizar la doble función operada por la figura del público: como signo de apertura del sistema político, que a partir de la Ley Sáenz Peña ya no puede resolver sus contiendas de manera ensimismada; y como referente potencial y fuente de legitimidad del discurso de la prensa, que ya no se dedica a un diálogo cerrado con sus contradictores.

Hacia fines del siglo XIX y los primeros años del siglo XX el imaginario periodístico argentino empieza a replicar los estándares de los países industrializados. En su libro sobre el diario Crítica Silvia Saítta señala que en el umbral del siglo XX empieza a notarse el impacto del modelo periodístico norteamericano, que comienza a disputar la hegemonía al modelo francés ${ }^{54}$. Sin embargo, Saítta subraya lúcidamente una contradicción entre el imaginario que empieza a proyectarse con las condiciones en que se desarrolla efectivamente el periodismo: un periodismo que se ha modernizado en su aspecto formal y en sus estrategias de interpelación del público, funciona, simultáneamente, todavía como una institución dependiente del sistema

\footnotetext{
54 Por modelo norteamericano entiende el modelo de financiamiento, comercialización, difusión y construcción de "agenda" de los periódicos: profusión de avisos, una amplitud de noticias que abarcan variedad de temas y un servicio telegráfico bien organizado con corresponsales en las ciudades más importantes de América y Europa.
} 
político por su forma de financiación, su personal, su perspectiva de supervivencia y su estilo $(1998: 27)^{55}$.

A propósito de esas contradicciones, Saítta explica, en relación al caso puntual de Crítica:

Junto con un alto grado de profesionalización y la incorporación de secciones que buscan atraer a nuevos sectores del público, Crítica mantiene un modo faccioso de intervenir políticamente a partir del cual no se piensa como un diario informativo sino como un periódico de opinión, crítico del accionar político, en el que busca incidir. Esta postura lo lleva a intervenir en verdaderas campañas contra el posible y "temible" crecimiento de los nuevos partidos: el radicalismo y el socialismo" (1998:43).

Como un síntoma de los tiempos por venir, en 1920 Crítica se transforma, luego de un período de crisis derivada del modo en que había decidido posicionarse en el mercado periodístico y en relación a la política. Uno de los factores de este cambio, es, para Saítta "el hecho de estar ligados a una facción política ya no funciona periodísticamente: el modelo del siglo XIX entra en crisis y desaparece (solo se mantiene en los diarios partidarios, cuya relación orgánica con un partido permite lazos más estables con los lectores)". A partir de los cambios introducidos por la ley Sáenz Peña, la política ya no se hace entre pocos, y se empieza a consolidar el peso de los ciudadanos recién llegados a la política. Intentar un periodismo que mantenga el modelo del siglo anterior, esto es un periodismo que implícitamente propone un diálogo solo entre diarios políticos, ya no funciona ni política ni periodísticamente.

c- La mediatización como mecanismo de base de funcionamiento de los discursos en el espacio público

\footnotetext{
${ }^{55}$ Por lo pronto, pasada la primera década del siglo, empieza a consolidarse propiamente hablando un mercado de medios. Ya en la Guía Periodística de 1913, Saítta encuentra indicios de la existencia de un mercado periodístico regulado por principios autónomos; la Guía está dirigida al "lector, el avisador, el comerciante" (1998:29). Lentamente, las dos primeras décadas del siglo asisten al proceso de configuración de "un campo específico de relaciones donde el periodismo escrito se particulariza como práctica, se separa formalmente del poder del Estado y de los partidos políticos y sienta las bases del periodismo moderno, masivo y comercial característico del siglo XX" (1998: 30).
} 
Un tercer campo problemático conectado con el problema de la mediatización de la política es el que se abre al considerar los condicionamientos que las instituciones de medios le imponen a los actores que pretenden intervenir sobre la escena pública.

Ferry (1989), propone considerar directamente que el espacio público es el "marco mediático" gracias al cual el dispositivo institucional y tecnológico propio de las sociedades posindustriales es capaz de presentar a un "público" los múltiples aspectos de la vida social. Al proponer una redefinición sociológica (por lo tanto conceptual) el autor está proponiendo, desde nuestro punto de vista, volver a una suerte de grado cero analítico del EP, al menos en la zona de funcionamiento que corresponde a la comunicación política.

Hablamos de grado cero en un sentido histórico y conceptual. Histórico, porque hay que tomar la mediatización como un dato a partir del cual reflexionar sobre el espacio público para evitar que el "punto ciego" analítico sea eso que Ferry (1989: 18) llama "nostalgia de un espacio público tal como habría podido ser". Y conceptual, ya que es necesario reconsiderar los conceptos de análisis con los que se pretende estudiar y caracterizar el complejo institucional de los medios de masas (particularmente, ciertas nociones que han guiado la investigación: "influencia", "manipulación", "efectos", etc). Los medios no pueden ser concebidos como meros "anexos funcionales" de otros sistemas, pero tampoco como un "poder" en el sentido en que lo entenderá Habermas.

En primer lugar, porque desde el punto de vista del procesamiento de la información, las organizaciones de medios progresivamente conquistan una semi-independencia (Hjarvard, 2014); en este sentido, se vuelven instituciones diferenciadas: han desarrollado un código específico que modela su inserción en la vida social. En segundo lugar, porque se han vuelto transversales: si la producción de discursos mediáticos tiende a la centralización que impone la misma lógica de producción empresaria, los dispositivos tecnológicos sobre los que se asientan los medios atraviesan, pero 
de modo ubicuo, el tejido social. De esta manera, es posible afirmar que "lo mediático" se convierte, especialmente luego de la segunda mitad del siglo $\mathrm{XX}$, en un conjunto de condiciones de producción que afectan a todo actor, individual o colectivo, que pretenda intervenir en el EP.

Desde ya, las instituciones mediáticas, y el periodismo en particular, mantienen el privilegio en la administración de la dinámica de ese espacio público mediatizado ${ }^{56}$, de modo que no se trata de trocar una concepción estilizada por otra: la expansión mediática del espacio público consolida (ahora de otra manera) el protagonismo de los medios en general y del periodismo en particular: le abre un espacio de "representación" fáctica del "público". En este punto, el debate sobre la opinión pública se vuelve central; como dice Ferry ([1989] 1998: 22),

El recurso a esa norma de sustitución, que es la opinión pública en el sentido de los sondeos, reviste un significado sistemático: legitima de manera efectiva cierto poder político de la prensa, pues esta es la que, por excelencia, puede "representar" en calidad de "opinión pública" un aspecto de la sociedad civil sociológica y políticamente distinto del "cuerpo electoral".

Precisamente este último punto debe destacarse como eje conflictivo entre los actores e instituciones del sistema político y del sistema mediático. Si algún valor heurístico tiene hablar de la prensa como "cuarto poder" (es decir, si ese término en algo puede ayudar a comprender la inserción del periodismo en la vida social) es en la medida en que -tal y como lo hacen las instancias políticas institucionales- apunta a una comunicación privilegiada con su "público" potencialmente interesado en los problemas de la vida política. Pero ese "público" no puede ser reducido a la imagen del "target", del blanco identificado mediante técnicas de marketing. Incluso si la construcción de discursos periodísticos siguiera estas estrategias de elaboración de la información, cuyo efecto negativo sería una despolitización

\footnotetext{
56 Precisamente, es ese privilegio el que parece estar en riesgo con la irrupción y consolidación de internet. El propio Ferry señalaba en el artículo que estamos glosando (publicado en 1989) que las "tecnologías telemáticas" contenían un potencial renovador ya que abrían la perspectiva "de un espacio en que la comunicación política es mediatizada, pero sin que por eso el público deba estar representado", poniendo en crisis los fundamentos (sociales, tecnológicos) sobre los cuales el periodismo moderno había asentado su lugar de "portavoz" o de "mediador" de la opinión pública (Ferry, 1989: 25-27).
} 
de la comunicación pública (Habermas, 2005:458), ese "público" no puede ser entendido sólo como una magnitud empírica.

Por el contrario, en este aspecto, la comunicación del sistema de medios está sometida a la misma paradoja que Luhmann identificara en la relación entre el sistema político y "su" público: comunican un conocimiento público que es traslúcido, es decir, al que se puede acceder y el cual es visible, pero no pueden evitar la opacidad sobre el modo en que sistemas sociales u otros actores reaccionarán ante esa comunicación, esto es, "producen intransparencia de efectos mediante transparencia de conocimientos" (Luhmann, 2000:148). Habría que apuntar que también Habermas ha llegado a reconocer esta dificultad: "no está de ninguna manera claro cómo los medios de comunicación de masas intervienen en el inabarcable círculo de comunicación del espacio público político". En cambio, "más claras son las reacciones normativas al fenómeno de la posición de poder de los complejos mediáticos en la competencia por la influencia político-publicística" (Habermas, 2005:459).

Por lo dicho, puede sostenerse que "público", "ciudadanía” y "opinión pública" no coinciden, pero al mismo tiempo, al menos en la tradición democrática, la opinión pública tiende a encarnar, aunque de manera necesariamente imperfecta, al "cuerpo electoral" en los períodos no electorales. Cheresky, considerando este problema, sostiene que "el estado de la opinión medido por las encuestas y reflejado, e influido, por la televisión y otros medios de comunicación se fue convirtiendo crecientemente en el centro regulador de la vida política pública" (2009:24). Esto tiene, al menos en lo que respecta a nuestro tema, dos consecuencias: se realza la importancia del espacio público mediatizado, pues lo que allí sucede está disponible para orientar identificaciones, preferencias y opiniones de una ciudadanía que, mayoritariamente, ya no está encuadrada en relaciones de "disciplinamiento colectivo" (Cheresky, 2009:24); y aumenta el protagonismo del espacio mediático, como lugar de gestión de representaciones colectivas (Verón, 2004: 224). 


\subsection{Niveles analíticos para el estudio de la mediatización}

Para cerrar este primer capítulo vamos a proponer una distinción por niveles analíticos de pertinencia de la mediatización. Lo que buscamos es profundizar la autoreflexión conceptual intentando recuperar los aspectos polivalentes que hemos ido desplegando a lo largo del escrito y que nos servirán de fundamento para desarrollar nuestra perspectiva analítica en el próximo capítulo.

Pese a la utilidad -al menos, para este trabajo- de la distinción que vamos a desarrollar, hay un problema que plantea una división por niveles, y es que nos ha llevado a superponer elementos de diferentes perspectivas teóricas de las que no podemos presumir su complementariedad. En particular, este problema se podrá vislumbrar en el uso, por momentos yuxtapuesto, de ciertas soluciones analíticas tomadas de la teoría de la estructuración de Anthony Giddens (1995) y de otras provenientes de la teoría de los sistemas funcionalmente diferenciados de Niklas Luhmann (1995, 2000). Tanto como la yuxtaposición se nos podrá objetar, también, que en ningún caso somos consecuentes con el desarrollo completo de cualquiera de las dos teorías. Como tampoco pretendimos lograr una síntesis imposible, en nuestra defensa sólo podemos esgrimir esto: de los autores que tomamos como referencia para reconstruir el desarrollo del concepto de mediatización sólo dos de ellos fundamentan, con una exposición argumental orgánica, sus perspectivas en la teoría social. Hjarvard (2014) recurre a la teoría de la estructuración, y Marcinkowski (2014) hace lo propio con la teoría de Luhmann. En ambos casos, los autores buscan en la teoría social un soporte para la hipótesis de que sólo hay mediatización cuando se consolida el proceso de diferenciación social en las sociedades industriales avanzadas. En el caso de los medios masivos, Hjarvard opta por analizar su institucionalización; Marcinkowski, la emergencia de un sistema funcionalmente diferenciado. En lo que a nosotros respecta, la única manera de conservar aquellas ideas de ambos autores que 
nos resultaban más útiles fue hacer un uso heterodoxo de las dos perspectivas, apostando a que el desarrollo posterior del argumento y del análisis empírico pudiera justificar tal elección.

Hecha la aclaración, los niveles analíticos para el estudio de la mediatización son los siguientes:

\section{a- Nivel estructural (o sistémico)}

En primer lugar, es necesario aislar un nivel que llamaremos estructural, para subrayar que su aprehensión solo es posible por medio de la abstracción y la generalización. Tal y como lo propone Giddens (1995: 53-59 y 215-217) quien habla de "estructura" para referirse a propiedades articuladoras que habilitan las condiciones para que prácticas sociales similares existan a lo largo de segmentos variables de tiempo y de espacio y que presten a estos segmentos una “forma sistémica”. Podríamos hablar, también, de las “propiedades estructurales" de la mediatización, que como tal se actualizaría en una serie de prácticas (generalmente dispersas) y como “huellas mnémicas" que orientan la conducta de los agentes. Es el nivel en que la mediatización debe entenderse como la transformación de las condiciones de posibilidad de las prácticas sociales por la adopción de tecnologías de comunicación que, a su vez, habilitan posibilidades de interacción previamente imposibles: tornan probable lo improbable ${ }^{57}$. Esas propiedades estructurales deberían poder describirse en términos genéricos (expansión de los horizontes de experiencia individual, multiplicación de dispositivos que permiten el almacenamiento y la exteriorización de la memoria, descontextualización del sentido, rupturas de escala semiótica, etc. ${ }^{58}$ )

\footnotetext{
${ }^{57}$ Luhmann (1998: 159) denomina medios a los logros evolutivos que arrancan en estos puntos de ruptura de la comunicación y sirven funcionalmente para transformar lo improbable en probable. A cada improbabilidad (de entendimiento, de almacenamiento, de alcance) corresponden, en la evolución sociocultural, tres diferentes tipos de medios (lenguaje, escritura, imprenta, en el marco de reflexión de Luhmann) que se posibilitan, limitan y cargan con problemas sucesivos mutuamente.

${ }^{58}$ Y también, claro, como restricciones, constreñimientos o condicionamientos estructurales: "puesta de límites al espectro de opciones de que dispone un actor, o una pluralidad de actores, en una circunstancia dada o en un tipo de circunstancia". (Giddens, 1995: 207). Agrega que "tales propiedades estructurales presentan una similar 'objetividad' frente al
} 
b- Nivel medio (institucional)

En segundo lugar, un nivel medio, que afecta al funcionamiento de las instituciones. La discusión conceptual sobre la distinción entre actores, instituciones y organizaciones sería pertinente aquí a propósito de los medios masivos. Meltzer (citado por Acuña, 2013: 43) considera que "el término "actor" es un concepto abierto que el analista debe adaptar a los requerimientos de su estudio". Desde esta perspectiva, la opción conceptual no puede ser definitiva, sino que depende de la problemática estudiada. Como lo que nos interesa es entender las precondiciones para la consolidación de un lugar de enunciación en el espacio público, vamos a privilegiar la definición de los medios en tanto que instituciones.

Thompson (1998: 28 y ss.) entiende por instituciones "determinado conjunto de reglas, recursos, y relaciones con cierto grado de persistencia en el tiempo y cierta extensión en el espacio, unidas por el propósito de alcanzar ciertos objetivos comunes". A las instituciones que ofrecen plataformas privilegiadas para el ejercicio de ciertas formas de poder las llamará "instituciones paradigmáticas". Los medios de comunicación serían instituciones dedicadas a la producción, administración y difusión de poder o formas simbólicas, y, como tales, sería instituciones paradigmáticas. Esta definición, al implicar no sólo las reglas y recursos, sino también las relaciones o interacciones, se asimila a la definición de "organización", tal y como, por ejemplo, la propone Acuña (2013: 43) como estructura de interacciones encaminada a un propósito, de una lógica, pero no de una racionalidad (de la que sí, en cambio, goza el actor). La definición de Thompson nos permite, sin embargo, utilizar de manera indistinta los dos términos (instituciones/organización) aunque entendemos que, desde otros criterios teóricos, son analíticamente muy diferentes. 
Más allá de esa discusión, nos interesa retomar aquí una hipótesis de Eliseo Verón -muy genérica en su formulación pero heurísticamente fértil-, que ya hemos mencionado previamente, según la cual el paso de las sociedades mediáticas a las sociedades mediatizadas expresa la adaptación de las instituciones de las democracias industriales a los medios que se transforman en mediadores insoslayables de la gestión de lo social (2004: 224).

Desde este punto de vista la mediatización, en su forma contemporánea, se confunde con la historia de la emergencia de las organizaciones mediáticas y del periodismo profesional; es decir, de los discursos intermediarios (Traversa, 2011) con capacidad de gestionar, desde una posición de enunciación funcionalmente diferenciada el contacto con "el público" y de administrar el modo en que las otras instituciones deben hacerlo. La posibilidad de intervenir en el espacio público con discursos con altas pretensiones de generalidad está condicionada por el acceso y utilización de los dispositivos mediáticos, que operan como infraestructura del espacio público mediatizado y como "medios de producción" en manos de empresas y actores de poder.

Usualmente, esta cuestión se aborda desde la perspectiva de la economía política de la comunicación (relaciones de propiedad, regulaciones legales, etc.). Aquí nos interesa subrayar el fundamento sociológico de la institucionalidad mediática: una de las funciones históricamente emergentes de los medios de masas es la producción de temas que deben estar disponibles para la comunicación social: "sería inimaginable cómo pudiera funcionar una operación comunicativa social por encima de los horizontes de experiencia individual si eso no estuviera asegurado por el mismo proceso de comunicación" (Luhmann: 2000: 143).

A propósito, Marcinkowski y Steiner (2014: 92-93) sostienen que la mediatización es fenómeno supraindividual que ocurre en los sistemas no mediáticos, de modo que "el concepto no denota la sumisión pasiva de otros 
sistemas a la fuerza de los medios sino una activa utilización de los servicios mediáticos por parte de otros sistemas". Esa "activa utilización de los servicios mediáticos" sería una necesidad derivada de la imposibilidad estructural de aquellos otros sistemas para producir la publicidad que demanda la circulación masiva de discursos en el espacio público.

\section{c- Nivel micro (o de la interacción y las prácticas)}

Por último, distinguimos un nivel "microscópico", el nivel de la interacción. Este es el nivel en el que la mediatización se vuelve asequible para los actores individuales, y donde suelen registrarse los testimonios, anecdóticos o reveladores, sobre su impacto en las vidas particulares, en las rutinas diarias, en las prácticas profesionales. Hay mediatización tanto en el consumo de medios masivos como en la utilización de una aplicación de mensajería instantánea en el teléfono, o en la comunicación interindividual vía redes sociales. Escenas de la vida cotidiana signadas por la utilización de dispositivos que habilitan procesos de comunicación más allá de los límites impuestos por los condicionamientos espacio-temporales.

\subsubsection{Niveles analíticos para el estudio de la mediatización de la política}

Para cada uno de estos niveles -que no necesariamente están en una relación de implicación mutua vertical o jerárquica- es posible hacer una observación sobre el comportamiento de la mediatización de la política.

\section{a. Nivel estructural}

En el nivel estructural, la mediatización transforma las condiciones bajo las cuales el sistema político produce relaciones con sus entornos, y en particular, con lo que Luhmann llama el entorno de lo "público". No se trata de un fenómeno mecánico, sino que debe ser aprehendido en relación a las transformaciones en los modos de inserción comunitaria de las organizaciones 
y las instituciones políticas, de su rol en la socialización y educación política de los ciudadanos (Cheresky, 2009; Muraro, 1997). ${ }^{59}$

En la perspectiva de Luhmann, en los sistemas políticos evolucionados se puede observar una diferenciación estructural tripartita entre política, administración y público (2009:279-280). Esta diferenciación funcional es un logro evolutivo del sistema político: estos tres subsistemas en recíproca interdependencia se tratan mutuamente como entornos, de modo que permiten simplificar y filtrar procesos de comunicación. El público así entendido encontrará su topos en la diferenciación tripartita del sistema político (administración, sistema de partidos y público) y, en otro sentido, en el marco de la dicotomía gobierno/oposición, como tercero excluido. En ambos casos (tal vez sólo analíticamente distinguibles) funciona como observador, o mejor dicho, como espejo donde el observador (el sistema político) se observa a sí mismo (Rabotnikof, 2005: 253).

Desde la perspectiva de la teoría de sistemas de Luhmann, lo público se ubica entonces en los límites externos de los subsistemas sociales, pero en el límite interno al sistema sociedad. En este sentido, se trata de un concepto que describe "el lado inaccesible del otro" pero desde el cual se perciben estímulos. Para Luhmann el hecho central en la relación sistema político/opinión pública es el de la imprevisibilidad, el de la imposibilidad de un control sobre aquel que está "del otro lado". Retirado del campo semántico de la política, "lo público" así reflexionado se vuelve un concepto aplicable a todos los sistemas de funciones de la sociedad: "el mercado sería entonces el entorno interno económico de las empresas e interacciones de la economía; la opinión pública, el entorno interno político de las organizaciones

\footnotetext{
${ }^{59}$ En su análisis sobre el debilitamiento del llamado "voto clivaje" Muraro (1997: 113-119) señala que: "La tendencia hacia el voto volátil coloca a la farandulización de la clase política bajo una luz diferente. Desde esta óptica, la video-política, con toda su carga de personalismos y su fobia a las declaraciones de principios- no sería sino una forma de adaptación de los políticos profesionales a un entorno integrado por electores que son observadores de resultados más que tomadores de programas". Que las modalidades particulares de insertarse en los espacios mediáticos (en particular, en la televisión) sean más o menos frívolas, no anula el hecho de que, en conjunto, deben ser comprendidas como un modo de adaptación a esas nuevas condiciones de producir contacto con votantes cada vez más acostumbrados a definir su voto luego de diversos "procesos de racionalización instrumental de las relaciones sociales". (Muraro, 1997: 117).
} 
e interacciones políticas” (2000:149). En cualquier caso, el centro de gravedad de la discusión sería el siguiente:

"Contra todo lo que la tradición piensa, lo público no es garantía de un conocimiento validado, ni qué decir que sea una especie de cosecha de la razón. Más bien lo público es precisamente el símbolo de opacidad que se crea cuando lo que se comunica es justamente algo traslúcido" (2009: 308).

Nuevamente, coincidimos aquí con Marcinkoswki (2014) y Marcinkowski y Steiner (2014), en que la mediatización de la política debe entenderse como el grado en que las instituciones y los actores políticos (es decir, aquellos que participan del juego institucional del sistema político, como oficialismo y oposición, sindicatos, organizaciones sociales, etc.) están forzados a lidiar con la realidad de los medios de masas, pero no a causa del avance colonizador de las "lógicas mediáticas" sino por un déficit estructural del propio sistema político: la necesidad de atención pública, que en las sociedades contemporáneas no puede gestionarse sin pasar por los medios de comunicación o sin hacer uso de dispositivos tecnológicos de comunicación. Por esta razón, los autores conciben la mediatización como un aspecto del cambio social: la penetración de la sociedad por la lógica de la producción de atención pública puesta en práctica por los medios (lo cual, como se ve, no es lo mismo que hablar de la “lógica mediática”), proceso que corresponde con la diferenciación funcional de las sociedades modernas. En concordancia, sostienen que los saltos en el proceso de mediatización a lo largo de la historia no son producidos por los propios medios sino por las necesidades contingentes de atención pública de un determinado sistema combinado con su incapacidad para captar la atención pública con sus propios recursos. De modo que la mediatización, en lugar de trastornar las lógicas de la política, de obligarla a operar contra-natura, lo que hace es generar las condiciones de posibilidad de la política bajo condiciones de alta complejidad.

Conviene agregar que si "los medios" le ofrecen a los demás sistemas una solución probable a la dificultad para lograr "acceso público" no es porque ellos tengan solucionado ese aspecto definitivamente, sino porque su institucionalidad se asienta sobre la administración de dispositivos 
tecnológicos que producen lo público como entorno y conectan con el público como destinatario genérico de los discursos. Por eso, también los medios están aquejados por la presencia de lo público como lo inaprensible del entorno. Es precisamente a partir de este "problema compartido" que vamos a desarrollar, en el próximo capítulo, una propuesta analítica para el estudio de los discursos sociales que se producen y circulan bajo condiciones de mediatización en el espacio público.

\section{b. Nivel medio}

Esto nos lleva al nivel institucional. El concepto de "entorno de lo público" desarrollado desde la teoría de los sistemas funcionalmente diferenciados puede tornarse operativo para un análisis socio-semiótico si se lo concibe como un "horizonte de destinación" compartido -en el sentido de una cohabitación que no resulta de un acuerdo de partes- por el sistema político y el sistema de medios (desarrollamos esta hipótesis en el capítulo 2).

En términos generales, al hablar del "entorno de lo público" estamos aludiendo a dos problemáticas comunes para la producción de discursos políticos y los discursos periodísticos considerados desde la perspectiva de su producción: la imprevisibilidad de los efectos (que replica, en la escala colectiva, la no linealidad de la circulación del sentido) y la exigencia consecuente de poner en circulación puntos de vista generalizables, sostenibles públicamente, es decir, que se enfrentan a la imposibilidad de controlar el modo en que sus discursos son "entendidos" y deben lidiar, en cambio, con el fantasma de un destinatario que es siempre colectivo (Verón, 1999: 138).

Como lo dijimos, y como es consenso en los investigadores del campo, es posible concebir la mediatización como un proceso durante el cual los medios de difusión (como tecnologías que operan sobre la improbabilidad del alcance de la comunicación) se convierten en un sistema social diferenciado (Alexander, 1981). Por eso, la mediatización de la política es también la 
historia de la diferenciación del sistema de medios del sistema político (Hjarvard, 2014: 48). Es el camino que va de la prensa partisana al periodismo profesional, con una deontología propia, con reglas de procedimiento específicas, regulado por restricciones discursivas que permiten identificarlo como un lugar de enunciación diferenciado. Los tipos de discursos que circulan en la sociedad están, por un lado, articulados a estructuras institucionales complejas que son sus soportes organizacionales, y por el otro, a relaciones sociales cristalizadas de ofertas/expectativas que son los correlatos de estas estructuras institucionales. A su vez, las instituciones son inseparables de los sistemas de representaciones que estructuran el imaginario donde se construyen las figuras de los emisores y los receptores de los discursos (Verón, 2004: 196). El periodismo se institucionaliza, entonces, como un lugar de enunciación que puede asumir funciones de representación, puede hablar en nombre de otros colectivos sociales; puede intervenir sobre los imaginarios políticos. Sus destinatarios ideales son "los públicos" que también son los destinatarios de los discursos políticos.

El cambio ha variado en forma y extensión, pero parece haber sido generalizado a través de las fronteras nacionales (...). Ha implicado la creación de un discurso periodístico diferenciado de los discursos de los partidos y los políticos, la concepción de los medios como un guardián colectivo del poder público y la concepción del periodismo como representativo de una opinión pública generalizada que atraviesa las líneas de los partidos políticos y los grupos sociales ( Hallin y Mancini 2004: 271-272).

Pero así como los "destinatarios" no son los sujetos concretos que pueden formar "públicos" (como asociaciones estables, dotadas de una identidad, capaces de expresarse en el espacio público; Sorlin, 1992), lo público (del espacio público) debe comprenderse, desde la posición analítica de la producción de discursos, no como una entidad (el público, o mejor, los múltiples públicos) sino como un horizonte de diferentes perspectivas de los discursos que se orientan a circular en la interacción entre presentes y ausentes y una de cuyas condiciones de posibilidad son las formas institucionalmente organizadas de tecnologías de comunicación. (No se nos escapa que el concepto de horizonte de destinación está a mitad de camino entre la teoría de los sistemas y la fenomenología (tal como Nassehi, 2011, lo 
propone para definir el concepto de sociedad). Vamos a derivar una serie de consecuencias analíticas de esta idea en el próximo capítulo).

\section{c. Nivel interaccional}

En el tercer nivel, el de las interacciones y las prácticas (o microscópico, o interindividual), es donde parecen más visibles los efectos de la mediatización sobre la política, en sus múltiples facetas: el uso de encuestas (Vommaro, 2008 ${ }^{60}$ ); la reconfiguración del cuerpo del político en “arquitecturas” mediáticas (Verón, 2001); la consolidación de los expertos en comunicación como elenco estable de las organizaciones políticas (Manin, 1998), etc. La perspectiva de una “lógica mediática” única que condicionaría el modo de "hacer política" sólo puede corresponder a la perspectiva de un actor (político profesional, dirigente gremial, técnico experto, etc.) que se siente afectado y orienta su comportamiento de acuerdo a esta percepción. En relación a este punto, Marcinkowsky (2014:8) habla de “mediatización mental", para señalar que los propios comportamientos de los actores políticos en relación a los medios están condicionados por sus concepciones sobre los efectos que los propios medios causan en sus audiencias. En definitiva, una historia de las trayectorias personales y de las rutinas políticas y periodísticas podría darnos una idea de cómo han modificado los medios el

\footnotetext{
${ }^{60}$ Vommaro (2008: 119-123) analiza el uso de las encuestas por parte de los dirigentes políticos en Argentina desde 1983. Como su análisis se realiza desde la mirada de los actores, se entiende que las conciba como "una suerte de brújula para orientarse en la lucha política", y defina la creencia en las encuestas como "una actitud fundada en la utilidad del instrumento como medio de orientación práctica”. En su libro, cita una entrevista con una dirigente del Frente País Solidario (Frepaso, organización política argentina de la década de 1990 que conformó la Alianza que ganó las elecciones presidenciales en el año 1999), quien explica que antes de cada campaña, encarga un sondeo y hace un focus group "para ver si la percepción que yo tengo de lo que está pasando se corresponde con la percepción de la sociedad real". De esto, el autor concluye que "algo pasa en la realidad política que no puede ser aprehendido sino a través de encuestas". Esta misma cuestión puede ser analizada desde una perspectiva no subjetiva, centrada en los condicionantes de la propia mediatización (añadidos, claro está, a las propias dificultades que se le presenta a las organizaciones políticas con poco o nulo arraigo territorial). Podría pensarse, entonces, que "lo que no puede ser aprehendido" es lo que no puede ser observado. La utilización generalizada e institucionalizada de los sondeos de opinión, es una brújula para los actores; pero está claro que no puede ser concebida solo como brújula: hay una imposibilidad "estructural" de acceder a ese "otro lado" (donde los individuos articulan sus experiencias no mediatizadas familiares, grupales, laborales- con sus propias experiencias mediatizadas).
} 
cotidiano de la política, pero solo a condición de un contraste simultáneo con las transformaciones en los modos de socialización política, más acá y más allá de los medios

Un buen ejemplo de una perspectiva de análisis sociológica del espacio público mediatizado, pero abordada desde la perspectiva de los "intereses" de sus "actores" es la que propone Heriberto Muraro (1997) cuando describe la configuración de la dinámica del espacio público político. Muraro explica que "los tipos de actores normalmente involucrados son políticos, periodistas, intelectuales, representantes autorizados y "oficiosos" de las corporaciones, voceros de lobbies empresarios y movimientos sociales" (1997: 63). Para Muraro, estos actores "notables":

buscan volcar en su favor a los ciudadanos que, a manera de espectadores, se asoman periódicamente al espacio público. Lo que está en juego es el poder. $Y$ el acceso al poder en una democracia requiere ganarse algo que -de manera deliberadamente genérica- puede denominarse "el favor del público". ¿En qué consiste "el favor del público"? (...) Para todos los notables, el favor del público puede definirse como la aceptación de las propuestas de un actor determinado -persuasión-, la toma de decisiones a favor del triunfo de aquellas -selección-, y la realización efectiva de actos que contribuyan a lograr los objetivos elegidos -participación-.

El enfoque de Muraro enfatiza la lógica instrumental que guía a los diferentes actores. Como puede apreciarse, según el tipo de objetivo, es evidente que debe variar el modo de concebir a ese "público", o bien, a sus destinatarios que, en tanto que tales, son públicos compartidos. Por eso lo que no varía, lo que, a pesar de los propósitos diferenciales, funciona como invariante para todos los actores es precisamente la orientación hacia el público, que se constituye como un exterior al juego de competencia entre los "notables".

En ese marco, Marcinkowski (2014: 10-14) sostiene que, considerada como fenómeno multimodal, la mediatización de la política puede pensarse, en rigor, bajo tres dimensiones: la mediatización de la recepción de la política, la mediatización de la comunicación pública sobre la política y la mediatización de la política estrictamente hablando. Para el autor, esta última es la dimensión que corresponde a las discusiones sobre los "efectos" 
de los medios. Lo interesante del planteo es que en lugar de dirigir su mirada sobre las consecuencias cognitivas, modificaciones en el comportamiento individual o colectivo, en las tendencias de "opinión pública", el autor plantea que esos efectos deben ser concebidos como una mediatización de segundo orden, es decir, como la adopción, por parte de los actores e instituciones políticos, de mecanismos para producir y lidiar con las realidades mediáticas. Esto incluye, entre otros aspectos, la innovación institucional y organizacional, la adopción de regulaciones formales para manejar el contacto con los medios, decisiones sobre qué actividades son públicas o no, el tiempo y contenido de las presentaciones mediáticas, la formación de departamentos especializados en medios. La mediatización, así entendida, se incorpora en los presupuestos de las acciones políticas (con sus tácticas, con sus estrategias, con sus escarceos cotidianos, con sus negociaciones), al menos en aquellas que, tarde o temprano, deben derivar en el espacio público.

\section{Reflexiones finales y pasaje al próximo capítulo}

Volvamos sobre el planteo de este capítulo, cuyo propósito primero fue el de presentar, con énfasis en algunas discusiones puntuales, el concepto de mediatización; luego, mostrar el abanico de problemáticas que este concepto puede hilvanar, en particular en el caso de la llamada mediatización de la política.

Planteamos desde el principio que la mediatización es un proceso histórico y un contexto presente. Es, por un lado, un modo de indagar en el pasado, considerando como perspectiva privilegiada los efectos de las tecnologías de comunicación en el funcionamiento del espacio público, y en particular, la institucionalización progresiva de unas instituciones singulares, los medios de comunicación de masas. Como todo proceso histórico, sus consecuencias no son electivas: los actores (individuales, colectivos) se mueven en los límites de sus posibilidades. 
Pero la mediatización conforma, también, un "entorno" o un "ambiente" en el que los actores y las instituciones sociales se mueven. De modo que la mediatización se manifiesta como una serie de condiciones sociales productivas: como restricciones a las posibilidades y modalidades de producción de sentido. Incluso en la generalidad de este postulado, puede apreciarse un nivel de pertinencia, los temas y problemas en relación a los cuáles la mediatización puede ser considerada una variable explicativa.

Concebida como conjunto de condiciones productivas la mediatización corresponde a los mecanismos de base de funcionamiento del espacio público en las sociedades contemporáneas. Esto no significa, obviamente, que todas las manifestaciones del espacio público puedan ser reducidas a sus formas mediáticas, sino que difícilmente pueda ser pensado un marco institucional para los discursos que pretenden trascender los márgenes de coexistencia espacio-temporal y tener incidencia pública (o devenir pública), que no sea el marco definido por los dispositivos tecnológicos de comunicación y por las instituciones de medios. Habría que pensar, en principio, en dos formas de activación de lo público: una mediatizada y una no mediatizada. Ambas pueden coexistir temporalmente, entre ellas se producen pasajes, solapamientos y articulaciones, pero al mismo tiempo es útil reflexionar sobre las propiedades específicas que poseen.

Para darle viabilidad empírica a este postulado general, propusimos en este primer capítulo distinguir tres niveles analíticos para el estudio de la mediatización: nivel estructural, nivel institucional y nivel interindividual. Está claro que ni la caracterización de esos tres niveles, ni el hecho de que sean tres, resulta en sí mismo una novedad. Su utilidad heurística consiste en señalar que los tres niveles aíslan aspectos de una problemática que, sin embargo, debe -en algún momento- ser considerada en conjunto, más allá de los énfasis puntuales. 
Como cada nivel refiere a problemáticas específicas según el área de reflexión correspondiente se vuelve inevitable recurrir a herramientas teóricas heterogéneas. Esto genera un problema: es posible explicar lo específico de cada nivel, pero eso no asegura la integración explicativa entre ellos. Sin embargo, el intento nos parece inevitable.

Más allá de esa dificultad, lo que nos interesa es recuperar algunas ideas que tienen implicancias en nuestro problema de estudio. Al optar por centrarnos en la reflexión sobre la mediatización empezamos nuestro trabajo en el nivel de las precondiciones de alto nivel que pueden explicar, en un nivel empírico, aspectos o rasgos específicos del funcionamiento de los discursos políticos presidenciales y de la prensa gráfica durante el "conflicto del campo", pero que, como precondiciones, trascienden una coyuntura singular.

En el análisis empírico de los discursos la "mediatización" no aparece como un fenómeno observable. El análisis trabaja sobre fragmentos discursivos que, necesariamente, ha aislado de su situación de ocurrencia, de su inserción en estructuras discursivas, de la temporalidad, de los contextos.

Y sin embargo, el pasaje al nivel del análisis de los discursos (presidenciales y periodísticos) concebidos como discursos de institución, nos mostrará que la disputa por la gestión de colectivos (que es, en definitiva, una disputa por la configuración de los imaginarios políticos del conflicto) no puede hacerse sin referencia a los condicionamientos del espacio público mediatizado. De modo que es necesario indagar en cómo operan las condiciones de mediatización del espacio público en las intervenciones de los actores e instituciones políticas y periodísticas.

Por eso, a lo largo del capítulo 2 intentamos elaborar una propuesta analítica para el estudio comparado de "discursos políticos" y "discursos periodísticos", que toma como punto de partida la pre-existencia del espacio público bajo condiciones de mediatización. 


\title{
CAPÍTULO 2
}

\section{EL ESPACIO PÚBLICO MEDIATIZADO}

\author{
Propuesta analítica para el estudio \\ comparado de los discursos políticos y los \\ discursos periodísticos
}




\section{CAPÍTULO 2: EL ESPACIO PÚBLICO MEDIATIZADO. PROPUESTA ANALÍTICA PARA EL ESTUDIO COMPARADO DE LOS DISCURSOS POLÍTICOS Y LOS DISCURSOS PERIODÍSTICOS}

Introducción: escenas de la mediatización, o la heterogeneidad del objeto de estudio

El propósito de este capítulo es presentar una serie de principios analíticos, con una relación de mutua implicancia aunque de diverso alcance conceptual y empírico, que nos servirán para dos objetivos: circunscribir el planteo general y teórico del capítulo anterior, por una parte; y presentar algunos conceptos y herramientas de análisis de los que haremos uso en los capítulos siguientes, por otra.

Uno de los problemas que nos presenta esta investigación es la heterogeneidad de nuestro objeto de estudio, un objeto de difícil aprehensión empírica, pues no es equivalente al agregado de los dos corpus que vamos a analizar. Nuestro objeto no es el "discurso" de CFK; nuestro objeto no es el "discurso" de Clarín o el de La Nación o de Página/12 o el de Crítica de la Argentina. El estudio de esos discursos es para nosotros un pasaje obligatorio, una condición de posibilidad, para entender cómo se configura, de manera temporalmente contingente, una zona del espacio público mediatizado. Esta expresión plantea algunos problemas conceptuales, terminológicos y ciertamente empíricos que tenemos que resolver, relativos a su materialidad, a su configuración y a su condición de "público", que no solo refiere a su visibilidad, a la accesibilidad, sino también a una idea de destinación de los discursos (políticos, periodísticos, pero no sólo) que se despliegan en su superficie.

Si bien en este capítulo no procederemos a realizar un análisis empírico, tal vez sea útil ofrecer una suerte de miniatura del tipo de "objeto" que nos 
interesa. A continuación, entonces, vamos a hilvanar algunos momentos de constitución del espacio público mediatizado en el marco del conflicto del campo:

Martes 25 de marzo de 2008, 18 hs.

El 25 de marzo de 2008, en el marco de un acto de anuncio de obras, Cristina Fernández de Kirchner hizo su primera aparición pública para referirse al conflicto. El discurso de la Presidenta fue televisado por todos los canales de noticias (TN, América 24, Canal 26, Crónica) y algunos canales de aire (América TV y Canal 9). Para nuestro ejemplo tomaremos como referencia la televisación del canal TN del Grupo Clarín. A lo largo de la alocución presidencial, TN mantuvo una superposición de planos, cuya predominancia relativa fue haciendo variar. En una pantalla, se transmitía el acto en Casa de Gobierno; y en un recuadro más pequeño, ubicado sobre el vértice inferior derecho de la pantalla, se veían imágenes de algunos cortes de ruta y de los ruralistas "escuchando el discurso". El encuadre básico construyó una escena de interlocución que sólo fue posible merced el dispositivo televisivo y en función de la "contra-estrategia" (Cingolani, 2012) ${ }^{61}$ puesta en juego por el canal de noticias. En el único lugar en el que la Presidenta hablaba y los ruralistas escuchaban fue en esa escena televisiva. Pero ni la Presidenta podía ver a los ruralistas (pues la escena transcurría mientras ella hablaba a un auditorio de funcionarios y simpatizantes) ni los ruralistas, que escuchaban el discurso por radio, podían verse a sí mismos escuchando. En esa escena, tensionada por la interlocución construida por la superposición de pantallas, hay un tercero constitutivo, testigo necesario ${ }^{62}$, pero excluido: los

\footnotetext{
61 "Una contra-estrategia, explica Cingolani, no necesariamente es una estrategia contraria, opuesta (en este caso, desde lo político, a la estrategia presidencial): simplemente es otra, no prevista por la estrategia original, que introduce recursos que son atribuibles a la institución mediática".

${ }^{62}$ El acto oficial en el que la Presidenta da su discurso es una variante de lo que Landowski (1985) denomina "espacios públicos de la representación", para cuya existencia (su estatus de público) es fundante la presencia de un tercero ante quien y para quien ese acto se desarrolla.
} 
espectadores televisivos, que, en el caso de un mensaje presidencial, pueden considerarse los componentes empíricos del colectivo ciudadanía.

Martes 25 de marzo, $18 \mathrm{hs}$.

Nos movemos ahora de la pantalla televisiva a la alocución de CFK. Volveremos sobre este discurso con detalle en el capítulo 5 . Aquí sólo queremos recuperar un fragmento en el que la mención a los "argentinos" como interlocutores del discurso, en un acto en el que, sin embargo, la propia Presidenta se dirige directamente a los presentes sin mirar a cámara ${ }^{63}$, indica -permítasenos la expresión- la conciencia de que, en ese mismo momento, con el acto televisado además por una productora contratada por el Gobierno, sus palabras llegarían más allá del reducto de casa de gobierno:

¿Saben cuánto hemos invertido, argentinos, en obras hídricas que han permitido recuperar 8 millones de hectáreas que se anegaban? 3.600 millones de pesos. También es parte del superávit fiscal (...) Esto lo saben todos, pero lo saben también todos y cada uno de los habitantes que tienen un vecino o un amigo o un conocido en el pueblo en la ciudad que lo vieron siendo propietario, dueño de campo en el 2001, en 1999 y lo ven hoy, han visto cómo han podido reconstituir y recuperar su nivel de vida.

La ciudadanía, incorporada a aquella escena televisiva de interlocución como espectador de un doble diálogo (de la Presidenta con su auditorio presente; y de ese diálogo con las reacciones de los productores apostados en las rutas), reaparece interpelada en el discurso presidencial, en su condición de ciudadanos de una nación: los argentinos.

\section{Miércoles 26 de marzo}

Al día siguiente, el 26 de marzo, Página/ 12 tituló en tapa: "Campo minado" y la ilustró con tres fotografías: sobre el margen izquierdo, una de CFK mientras ofrecía su discurso; a la izquierda, dos fotos más pequeñas, una de unas gomas incendiadas sobre la ruta y, debajo, otra en la que se pueden ver varias personas (mujeres y hombres) golpeando sus cacerolas. Mario Wainfeld

${ }^{63}$ Un análisis pormenorizado de las estrategias de mediatización del cuerpo presidencial, enfocada específicamente en su escenificación televisiva puede consultarse en Cingolani (2012) y Cingolani y Fernández (2010) 
escribió una columna de opinión analizando los sucesos del día anterior. El artículo comienza así:

La cobertura televisada en vivo del discurso presidencial pretendió sugerir que las bazas se estaban dirimiendo. En realidad, las cartas de ayer estaban echadas, a la tardecita. Las entidades "del campo" anunciaron horas antes la prolongación de su lockout con cortes de rutas por tiempo indeterminado, hasta que se retractara la implantación de las nuevas escalas de las retenciones y su movilidad.

Y, como cierre, Wainfeld escribió:

El Gobierno debe tender la mesa y habilitar el diálogo, algo que le cuesta horrores. Y la dirigencia del "campo" debe hacerse cargo de la lesividad de su medida de fuerza. Esa lesividad cargará sobre la ciudadanía en su conjunto $\mathrm{y}$, por razones evidentes, gravará más a los de menos recursos.

No será la primera vez que, a lo largo del conflicto, Página/ 12 interprete la televisación de los acontecimientos como un discurso más del arco opositor al gobierno, ni tampoco la primera vez que señale entre comillas la artificialidad del nombre "campo". Tampoco, finalmente, la última vez que el conjunto de la “ciudadanía”, que el día anterior también miraba el discurso por televisión, sea invocada como principal víctima del lock-out agropecuario.

\section{Miércoles 26 de marzo}

El título de tapa de Clarín el 26 de marzo fue el siguiente: "Cacerolazos tras el duro discurso de Cristina”. En la tapa hay sólo una foto centrada, en la que se ve una pequeña multitud de espadas, mirando hacia la Pirámide de Mayo, portando algunas banderas argentinas. El Editor General del diario, Ricardo Kirchbaum, escribió:

Los productores reunidos en cientos de asambleas en las rutas y la Presidenta, se han expresado sin intermediarios. Así planteada la cuestión, se ha mostrado otra vez la inexistencia de escalones jerárquicos capaces de negociar y de interlocutores aptos y reconocidos. (...) La situación contiene riesgos concretos que devienen de la índole del enfrentamiento y de cómo debe resolverse en una sociedad democrática. La inexistencia de mediadores institucionales propone un juego del todo o nada, muy peligroso. 
¿Quién describe esa escena en la cual dos actores discuten "sin intermediarios"? ¿Desde dónde la describe? ¿Para quién la describe? Un observador externo le habla a un público, que, podemos suponer, mira la escena desde esa misma posición de exterioridad.

Todas estas escenas, estos momentos, estos textos están hilvanados no sólo porque, lógicamente, las citas de los diarios se refieren al acto y al discurso de CFK. La retoma interdiscursiva de los discursos los diarios reactivan una instancia del espacio público, extienden su temporalidad. Pero a su vez nos permiten preguntarnos si finalmente los textos de los diarios no se están dirigiendo, también, a los mismos destinatarios a los que, el día anterior, les habló CFK y para los cuáles TN elaboró esa escena de interlocución ad-hoc. Si así fuera, es en ese horizonte de destinación, sólo posible en el espacio público configurado por efecto de los dispositivos de comunicación, dónde los discursos políticos y los discursos periodísticos disputan la gestión de colectivos, la representación de los otros.

Considerando esta suposición, el plan argumental del capítulo entonces puede sintetizarse así:

- En primer lugar, queremos argumentar que el análisis comparado de los discursos políticos de Cristina Fernández de Kirchner y de los discursos de la prensa gráfica que componen nuestro corpus tienen como condición de posibilidad su concurrencia en el espacio público mediatizado. La conceptualización de ese espacio y de las restricciones de funcionamiento que implica son un requisito para el análisis posterior. En ese marco, vamos a reparar en el concepto de "público" desde una perspectiva semiótica compatible con el punto de vista adoptado.

- Como intentaremos mostrar, esto no significa desconocer la naturaleza sociológica y asociativa de los públicos, sino indagar en un aspecto a menudo desatendido: cuando se lo considera como horizonte de 
destinación, el público opera como una "ficción instituyente", como un interpretante de la vida democrática.

- Se habla frente a un "público", entonces, que antes de asumir formas definidas y concretas, si se quiere sociológicas y mensurables, puede concebirse analíticamente ${ }^{64}$ como un Interpretante de la discursividad pública; como un Tercero regulador cuya identidad es menos importante que el influjo ${ }^{65}$ de su presencia. Lo público parece activarse cuando se introduce un Tercero, no involucrado directamente en un intercambio discursivo (sea un diálogo, una controversia, una discusión) pero cuya presencia es necesaria para pasar de un módulo bipolar a uno abierto.

- Ese tercero (frente al cual los discursos hablan, argumentan, explican, discuten) funciona como un "meta-destinatario": no es un sujeto sociológico identificable en la topografía social sino un principio regulador de los discursos (no sólo, claro está, de los discursos políticos o periodísticos). Ese rol regulador del "público" se vuelve un rasgo trascendente cuando se pretende estudiar las disputas por la mediación y la representación en los discursos políticos y periodísticos. ¿Cómo se materializan, en el discurso, los "sujetos representados"? Esta pregunta nos remite la configuración de un imaginario político, una trama semiótica cuyos nodos son las entidades que llamaremos colectivos

- Siguiendo esta lógica de reflexión, se entenderá que cuando se habla de discursos mediáticos conviene no identificar como tales sólo a los discursos de los "medios" o de los periodistas. Si para intervenir (en un debate, en una mesa de opinión, como experto o testigo) en el espacio público son necesarios dispositivos tecnológicos, entonces todo discurso que se coloque en esa posición es, en una dimensión, un discurso

\footnotetext{
${ }^{64} \mathrm{Al}$ menos, para el estudio de los discursos sociales en producción.

${ }^{65}$ La noción de influjo la retomamos de Habermas (2005: 443), que la emplea en lugar de la de "influencia" utilizada por Parsons. En este caso, el influjo sólo puede verificarse en las modalidades prácticas de discursividad (reconocibles, por ejemplo, a través de estrategias enunciativas) que los actores sociales emplean para "hablar" sobre temas y problemas en el espacio público.
} 
mediático. La comunicación mediática implica la construcción, en producción, de un destinatario que es un colectivo, nunca un individuo. Cuando se aborda, asumiendo este principio fáctico, el estudio de discursos, se verifica que en ese horizonte de destinación público los enunciadores le hablan a interlocutores que construyen como "colectivos". Cuando los enunciadores construyen colectivos similares (por ejemplo, ciudadanos-espectadores interesados/implicados en una discusión o conflicto), se abre un espacio de disputa que es necesario reconstruir.

- Si el horizonte de destinación que se estructura por efecto de la mediatización del espacio público es indefinido ( pues quien habla no puede controlar las condiciones de circulación de su discurso, que queda disponible para ser retomado, intervenido, por otros agentes) las condiciones de producción de los discursos están, en cambio, estructuralmente condicionadas por funcionamientos institucionales precisos, al menos en el caso que nos ocupa: el del aparato institucional de la política y el del aparato institucional de los medios de comunicación. Esos condicionamientos tienen múltiples variables, irreductibles por definición al nivel discursivo. Pero como aquí lo que nos interesa es indagar en la dimensión significante de la disputa por la representación, es necesario desarrollar una herramienta que defina esos condicionamientos. Nuestra propuesta, aquí, será retomar un instrumento analítico de la teoría de los discursos de inspiración semiótica: el de los dispositivos de enunciación. Representar es colocarse de una determinada manera frente a otro, y hacerlo desde un lugar (de enunciación). Es construir una escena de comunicación. Por eso, es necesario definir algunos aspectos elaborados sobre los dispositivos de enunciación del discurso político y el discurso periodístico. 


\subsection{El espacio público mediatizado: una constelación de arenas públicas, un horizonte de destinación compartido}

El propósito de este capítulo no es terciar, para lograr una síntesis, en la inconmensurable tradición (o tradiciones: en la teoría política, la teoría jurídica, la sociología, la historia conceptual, etc.) sobre el espacio público ${ }^{66}$. Nos mueve una necesidad más acotada e instrumental: describir las condiciones que el funcionamiento estructural del espacio público mediatizado le impone a los actores (individuales y colectivos) para intervenir en los debates, discusiones, controversias... públicos; condiciones que -esta es nuestra hipótesis de trabajo- dejan marcas en los discursos de esos mismos actores. Pero no siempre. Precisamente por eso -porque no siempre hay marcas detectables sobre las superficies discursivas- es que se torna necesario establecer ciertos presupuestos teóricos que fundamenten el análisis.

El supuesto de una "disputa" por la gestión de colectivos -o de las condiciones de posibilidad necesarias para que esa disputa se actualice- entre los actores políticos y los actores periodísticos puede encontrar, en principio, un sustento histórico. El sociólogo Roberto Grandi entiende que partir de fines del siglo XIX se activó, en las democracias occidentales, una especie de "contrato simbólico" entre el sistema de los medios y el sistema político para la gestión de la relación con los ciudadanos/lectores/espectadores/electores ${ }^{67}$. En su análisis sobre el surgimiento de los "papeles de noticias", Eliseo Verón (2011) arriba a una conclusión similar ${ }^{68}$. Si se evita la noción de "contrato" que

\footnotetext{
${ }^{66}$ Un trabajo que nos ha servido de referencia y que constituye un esfuerzo intelectual notable, por la capacidad de síntesis analítica al respecto es el de Rabotnikof, 2005.

67 "Sin hacer generalizaciones a-históricas se puede sostener que para toda la fase del desarrollo de la prensa - una prensa dirigida a las elites - ha existido cierta complicidad entre los dos sistemas: cada uno desarrollaba un papel preciso en la formación de la opinión pública, con una fuerte dependencia del sistema de los medios al sistema político. Durante todo ese período esta relación, que más que de complicidad era de intereses comunes, ha permitido a ambos sistemas moverse según lógicas propias. Con el desarrollo tecnológico de los medios de comunicación de masas, en particular de la televisión, estas funciones centrales para la autonomía del sistema político han sido hibridadas por la lógica de los medios. (Grandi, 2002: 82)

${ }^{68}$ Verón (2011: 305) presenta una hipótesis similar: “Después de la Revolución Francesa en Europa, y de las sucesivas revoluciones de independencia en las Américas, los profesionales de la política y los profesionales de la información le hablaron durante mucho tiempo a un mismo colectivo: el colectivo de los ciudadanos (...) La disociación que el discurso político de las democracias republicanas operó respecto del sistema económico, impidió toda diferenciación y produjo en definitiva una nueva convergencia con el discurso de la
} 
propone Grandi (si por tal se entiende lo que suele entenderse cuando se habla de un contrato: un acuerdo previo, racionalmente concertado) podemos suponer, a partir de las observaciones realizadas en el capítulo anterior, que el proceso de institucionalización de los medios, consolidación de un sistema mediático y generalización en el acceso al discurso de los diarios, la radio y la televisión en el siglo XX, instala como dato permanente una concurrencia sobre ese horizonte que, al menos en este aspecto, es un horizonte compartido: tanto los actores políticos como los actores periodísticos están buscando incidir en una misma zona del imaginario sociopolítico. Considerado desde el punto de vista (metodológico) en que nos situamos, es decir, en producción, sus discursos aparecen regulados por el supuesto de un “público" potencialmente superpuesto, que lee, mira, escucha, relaciona, los mismos fragmentos de discursividad.

Esa "superposición" histórica está en la base de las discusiones sobre los “públicos políticos” y las “audiencias” o los “públicos mediáticos” (Dayan, 2000; Cefaï y Pasquier, 2003, Livingstone, 2004). Como ha escrito Livingstone (2004: 21) si bien hay una bibliografía abundante sobre la oposición entre estos conceptos, bibliografía que remite a tradiciones teóricas dispares, "en un mundo fuertemente conectado, audiencias y públicos, a la manera de las comunidades, las naciones, los mercados y las multitudes, están compuestos por las mismas personas. Esta observación, en apariencia banal, tiene su importancia desde el momento en que constatamos que es muy corriente definir las audiencias en oposición a los públicos"69

información: los políticos y los periodistas le hablan hoy a un mismo colectivo, despolitizado: el colectivo de los consumidores -consumidores de candidatos, de información y de muchos otros "bienes de consumo"

69 "Defenderé, dice entonces Livingstone, la tesis según la cual la evolución del entorno mediático y comunicacional caracterizado por la mediatización de los públicos y la participación de las audiencias torna esa oposición problemática; la emergencia de objetos curiosamente ambiguos situados entre los públicos y las audiencias es muy controvertida, y lo es menos porque el término "público" reenvíe a una comprensión compartida o a la integración en un fórum común -las "audiencias" pueden ser descritas en un sentido análogoque porque "público" implica también una cierta orientación a la acción colectiva y consensual, y necesita también el cumplimiento de esa acción para hacerse efectivo y apreciado" (Livingstone, 2004: 20). Original en inglés, traducción nuestra. 
Audiencias o públicos: está claro que la distinción habla menos sobre la composición efectiva de los colectivos que están del otro lado de los medios, que de los modelos con que se los interpreta. En cualquier caso, la mediatización del espacio público instaura dos condiciones de producción comunes a todos los discursos que buscan intervenir en el orden de lo público, sea en los medios o utilizando dispositivos tecnológicos de comunicación mediática:

- la imprevisibilidad de los efectos (que replica, en la escala colectiva, la no linealidad de la circulación del sentido postulada por la teoría de los discursos sociales como propiedad de toda interacción comunicativa)

- y la exigencia consecuente de poner en circulación puntos de vista generalizables (Luhmann, 2000), es decir, sostenibles públicamente, que se enfrentan a la imposibilidad de controlar el acceso a su discurso y deben lidiar, en cambio, con el "fantasma" de un destinatario colectivo (Servais, 2013).

¿Pero en qué sentido las instituciones de medios, y su interacción con otras instituciones sometidas a las reglas de la mediatización, producen lo público? Lo hacen produciendo, en primer lugar, la propia figura del Público ${ }^{70}$.

Para desarrollar esta idea, retomaremos algunas reflexiones de Malbois y Kaufmann (2015), quienes proponen la hipótesis del espacio público como una organización de comunicación, organizada y organizante, es decir, que funciona conforme a ciertas reglas enunciativas y ciertos repertorios de acción que se les imponen a los actores individuales, por un lado; y por el otro, pero simultáneamente, una organización que es el producto de los discursos que en ella se producen y circulan.

\footnotetext{
${ }^{70}$ La conceptualización del "público", como fenómeno y como problemática de investigación para las ciencias sociales, ha sido prolijamente desarrollado por Price (1994: 39-64), en el marco de un trabajo dedicado a la "opinión pública". Por razones claras, Price reconstruye el itinerario del tratamiento académico que consolida una concepción sociológica del "público", a partir de estudios empíricos.
} 
Al respecto, las autoras se preguntan:

¿Dónde está el espacio público? A esa pregunta, que es tanto sociológica como política, podemos responder que él está en las enunciaciones, las actividades de comunicación y los equipamientos, especialmente mediáticos, que constituyen y mantienen al Público en su lugar de aparición.

Una primera manifestación de lo público como organización mediatizada, entonces, es ser la superficie de emergencia de la propia figura del Público. Por eso, consideran que el espacio público es una organización

inmaterial y áfona, tanto como el ser colectivo fantasmático del cual es el espacio de constitución y de aparición: el Público. Una organización de este tipo no puede ser aprehendida sino por la intermediación de las palabras y de las prácticas que ella anima y orienta y que son testimonio, de manera indicial e indiciaria, de su poder propiamente organizante ${ }^{71}$.

En el marco de este planteo, la figura del Público tiene una doble valencia. Por un lado, es una "figura abstracta, sin cuerpo, sin palabra" que requiere de su materialización a través del "equipamiento" mediático para cobrar existencia. Por el otro, opera como un metadestinatario de las enunciaciones públicas: es la instancia de validación que esas enunciaciones presuponen implícitamente para fundar sus aserciones y justificar sus apreciaciones. De allí que las voces que circulan en el espacio público no pueden ser radicalmente singulares; con el propósito de sostener su enunciación, ellas tienen que reclamar como destinatarios, en última instancia, un público de ciudadanos:

Por eso, las enunciaciones públicas no se reducen a la configuración diádica que constituye el redoblamiento metaenunciativo, propiamente democrático, del Público: ellas no conciernen solamente al Público como interactuante, sino también como Tercero. En la escena de visibilidad compartida que constituye el espacio público, las acciones y las palabras públicas se

\footnotetext{
${ }^{71}$ Aquí tenemos claramente una diferencia con las autoras. Esa inmaterialidad, para nosotros, sólo puede concebirse en términos de que el "espacio público", tal y como ellas lo conceptualizan, no es un "hecho positivo", preexistente; no es un "lugar" localizable en la topografía social (una plaza, una calle, un estadio); y porque sólo "existe" como efecto de interacciones discursivas. Sin embargo, volvemos a señalar que si se lo considera desde el punto de vista del acceso a lo público mediatizado (es decir, si se repara en los modos en que los usuarios de medios acceden a las manifestaciones de lo público) es imprescindible atender a la materialidad de los dispositivos tecnológicos y de los medios.
} 
manifiestan necesariamente bajo la mirada o en referencia a un público de espectadores. (Kaufmann y Malbois, 2015: 4)

La oposición entre el Público como Tercero y el Público como interactuante señala precisamente la tensión insoluble entre la certeza de que del otro lado de los medios hay actores y colectivos sobre los que se pretende incidir (que tienen deseos, voluntades, ideas), y el hecho de que la propia mediatización impone un límite a la posibilidad de acceso directo, inmediato, controlado, a esos otros. Como intentaremos mostrar, la figura del Público como Tercero, si bien está inextricablemente ligada al funcionamiento del espacio público mediatizado, en realidad puede considerarse como un elemento constitutivo del espacio público como tal. Pero antes de desarrollar ese punto queremos detenernos en dos cuestiones que surgen del planteo de Kaufmann y Malbois y de la reflexión que nosotros mismos estamos proponiendo.

La primera reflexión se refiere al estatus del Público como un interpretante. Sobre este punto -es decir, sobre el tipo de entidad, y su naturaleza ontológica- Querè (2003: 114) escribió:

Podríamos decir, en sentido peirceano, que el hecho de que el público no exista como un individuo colectivo concreto, o un hecho positivo, no significa que no sea real: él puede pertenecer a la categoría de la terceridad, en el cual figuran las cosas genéricas, o las formas, tales como la ley, la regla, la intención, los hábitos y la significación, que son reales pero no existen bajo una forma individual -son reales en tanto se incorporan en las prácticas y los usos para darles forma y orientarlos.

El público, así entendido forma parte de un tejido conceptual que le brinda "interpretantes" a la vida política en las democracias. Una noción, dice Querè, "juzgada como muy jurídica o muy ideológica por las ciencias sociales, pero sin embargo dotada de un poder de ficción instituyente". Un pivote simbólico en los contextos en los cuáles se producen las acciones y se descifran los acontecimientos, se evalúan las instituciones y se formulan los problemas $^{72}$.

72 Desde otra perspectiva, también Habermas ha dado cuenta de este problema: "Pero el influjo político de los actores en la comunicación pública debe apoyarse en última instancia (la cursiva es de Habermas) en la resonancia y por cierto en el asentimiento de un público de legos igualitariamente compuesto. El público de los ciudadanos ha de ser convencido por 
Veamos a continuación un ejemplo -paradigmático, al menos en relación al planteo de los autores citados:

El control sobre los medios puede tomar diversas formas. Una, la más extendida, casi instintiva, es el juicio cotidiano que hace el público. Los elige o los descarta. Los toma como hábito y los incorpora a su vida familiar y laboral, o los desecha porque no cree o no se identifica con ellos. Otras formas tienen que ver con los límites que fijan las leyes, que todos estamos obligados a cumplir por igual. $Y$ otras más se remiten a formatos de matriz profesional y académica, como los observatorios de medios, que por su misma razón de ser se mantienen distantes de las empresas periodísticas y también de los gobiernos. (La miopía política contaminó un arma eficaz contra la discriminación, por Julio Blanck, Clarín, 11/04/2008)

En este punto, entonces, importa menos la consistencia sociológica de ese "público", o su forma social ${ }^{73}$, que el hecho de que su invocación sea necesaria para fundamentar un lugar en el juego de los discursos institucionales (en este caso, el del periodismo).

¿Pero qué significa que el Público funcione como uno de los "interpretantes" de la vida política en las democracias? Este término, retomado de la semiótica del norteamericano Charles Sanders Peirce remite al funcionamiento de la semiosis en todos los niveles de la interacción social. En términos simples, en la semiótica de Peirce, el Interpretante es uno de los componentes relacionales del signo. No es un "sujeto", un "individuo", ni una "mente". Señala que no hay sentido sin un tercero que -dicho esto en términos que no son de Peirce- ponga en relación a un discurso con su objeto.

En este sentido acotado, el concepto de Interpretante retoma una de las definiciones que ofrece Peirce, que es la del Interpretante como "ley", o como "hábito final". El concepto supone, entonces, una "capacidad reguladora" (que puede ser consuetudinaria o formalmente codificada) que

contribuciones que tengan interés para todos a propósito de temas que se perciban como relevantes. El público posee esta autoridad porque es constitutiva de la estructura interna del espacio de la opinión pública, en el que los actores pueden presentarse. (2005: 444)

${ }^{73}$ Quéré, por ejemplo, analiza a continuación otras definiciones de las figuras del "público": como colección de individuos, como club de discusión, como comunidad estética, como comunidad de aventura y como comunidad de control (2003: 117-118). 
trasciende los intercambios situados y específicos. En su lectura de Peirce, Verón (2004:119) se pregunta:

\begin{abstract}
¿Pero cuál es el verdadero fundamento de estos signos que son leyes y que expresan "la manera en que ese futuro que no tendrá fin debe continuar siendo"? Es ciertamente lo que Peirce llama hábito, que es al mismo tiempo el interpretante final ("una ley jamás puede encarnarse en tanto que ley salvo determinando un hábito") .Y el hábito no es ni más ni menos que los sociólogos $m$ mucho más tarde, llamaron la acción social: "El hábito formado deliberadamente por el análisis de sí mismo- debido a que se forma con el auxilio de los ejercicios que lo alimentan- es la definición viviente, el interpretante lógico verdadero y final...¿Cómo podría describirse un hábito sino describiendo el género de acción al que dará nacimiento, precisando claramente las condiciones y el móvil?"
\end{abstract}

En este punto en particular, la noción de Interpretante designa un modo de funcionamiento de ciertas entidades del imaginario político y social como ordenadores de los horizontes de destinación de los enunciadores en el espacio público. Verón (2001) los ha definido como "una entidad semiótica abstracta, compuesta por colectivos articulados de manera específica”. El Público no es el único interpretante en el imaginario político democrático. Lo son también el pueblo, la ciudadanía, la gente común. Su propiedad más importante es la capacidad para condensar a otros colectivos y para servir como referencia estable en el punto de la destinación. Un "interpretante" es un conjunto de colectivos articulados de manera específica. Los interpretantes tienen un mayor nivel de abstracción de los colectivos y ordenan el horizonte de reconocimiento de los discursos. Por ejemplo, “ciudadanía" es un interpretante que puede "habitarse" por diferentes colectivos (vecinos, trabajadores, estudiantes, productores).

Esto significa que mediante el estudio de corpus discursivos es posible reconstruir los interpretantes que regulan, en un nivel de abstracción más general, la configuración de los destinatarios (concebidos como figuras discursivas) de los discursos políticos y periodísticos ${ }^{74}$.

\footnotetext{
${ }^{74}$ Un excelente ejemplo de cómo funcionan los interpretantes en la configuración de la discursividad política fue analizado por José Natanson, durante la campaña presidencial del año 2015 en Argentina. Escribió Natanson, en una nota titulada "La política del hombre común" (El dilpló, № 194, agosto de 2015): "La idea central de esta nota es que la escena representativa de la campaña electoral está dominada por la figura del hombre común, convertido en el paradigma de interpelación de los medios, del objeto de deseo del marketing
} 
La segunda reflexión se refiere al potencial conflictivo implícito en nuestro planteo, que es el que pretendemos reconstruir en nuestro trabajo en términos de disputas por la representación a través de la gestión de colectivos. En efecto, por un lado, el espacio público mediatizado no es un preexistente topográfico; puede actualizarse en "lugares", pero su forma de manifestación es estrictamente significante, discursiva: se materializa en las voces que pretenden legitimarse frente a un público. En este sentido, es probable que la mejor manera de pensar ese "espacio público" sea como eso que Cefaï ([2002] 2012), desde la perspectiva de la sociología pragmatista, llama arenas públicas ${ }^{75}$. Las implicancias de este concepto exceden el uso que estamos haciendo de él. Lo que nos interesa es algo muy específico, que en el enfoque de Cefaï funciona como un condensador de propiedades, pues determina el marco general de la "publicidad" de las arenas, y es la idea de que deben ser tratadas como una configuración de relaciones triádicas:

En todos los casos, sus relaciones no son reducibles ni a relaciones de fuerzas, ni a relaciones de interés, ni tampoco a relaciones de pura reciprocidad porque se dirigen, en el centro mismo de sus interacciones los unos con los otros, a terceros, es decir a auditorios, presentes o ausentes, reales 0 imaginarios

$\mathrm{Y}$, al mismo tiempo, ese Público tampoco es hecho concreto, un colectivo sociológicamente definido, ya constituido: opera como un metadestinatario ideal (es decir, como un Interpretante). Por eso, cuando los enunciadores concretos, dotados como tales de un punto de vista particular (sea un periodista, sea un líder político, el dirigente de una organización popular o el vocero de una minoría) buscan inscribir su voz en el espacio social

comercial y la clave del éxito en las elecciones, a tal punto que los principales candidatos se muestran, ellos también, como hombres comunes. ¿Cómo es el candidato del hombre común? Es espontáneo y sincero, habla de problemas concretos ( es anti-abstracto) y tiene una cualidad empática que le permite identificarse con el ciudadano".

75 "Este concepto de arena tiene la doble connotación de un lugar de combates [lieu de combats] y de una escena de realizaciones [scène de performances] ante un público. Se diferencia del concepto de espacio público, que tiende a ser demasiado estático, sin esta connotación dramática". 
mediatizado, tensionan aquella figura del Público, porque buscan encarnarla.

\subsubsection{El Público como Tercero y principio regulador.}

Decíamos que al hablar del Público como un Tercero Kaufmann y Malbois están retomando simultáneamente dos perspectivas complementarias sobre el funcionamiento del espacio público mediatizado. Por un lado, explícitamente, refieren al estatus del Público como entidad del imaginario político-cívico-social, a su presencia como entidad del imaginario político y mediático que ofrece un primer principio ordenador de los horizontes de destinación para los enunciadores. Por el otro, menos visiblemente, están abordando un aspecto que deviene de la estructura triangular de los espacios públicos en general y del espacio público mediatizado en particular, que se torna particularmente importante en el marco de conflictos y enfrentamientos políticos. "¿Qué sería una manifestación que no fuera vista por nadie?, se pregunta Silvia Sigal, glosando a Pierre Fabre:

\footnotetext{
Si es imposible enumerar todos los destinatarios posibles, pueden mencionarse los "otros" -amigos y enemigos- y los participantes mismos -que se muestran su potencia y engendran (siquiera efímeramente) su calidad de entidad colectiva (...) Las demostraciones tienen in fine un tercer destinatario, un ojo público, que es simultáneamente la garantía de su existencia. La mediatización de la sociedad hace evidente, hoy, esa dualidad constitutiva (a la vez el designado de manera explícita y una audiencia indeterminada) que destruye la ilusión de simetría entre el sentido otorgado por los participantes y el reconocido por los destinatarios". (Sigal, 2006: 17)
}

Si la mediatización tornó evidente esa dualidad, lo cierto es que la cuestión del Tercero es un tema que ha recibido una atención irregular y despareja en las ciencias sociales. Aunque no se la puede remitir claramente a una tradición intelectual o disciplinaria, es posible rastrearla en estudios que cubren el arco que va desde la lingüística, el análisis de los discursos y la semiótica $^{76}$, pasando por la sociología ${ }^{77}$, la teoría y la filosofía política ${ }^{78}$,

\footnotetext{
${ }^{76}$ Algunas referencias de autores que se pueden encuadrar en esas disciplinas son los estudios de: Landowsky (1985); Zoppi Fontana (1992); García Negroni (1988); Plantin (1995), Charaudeau (2002). No hay necesariamente una perspectiva unificada, sino la adscripción declarada a esas disciplinas.
} 
llegando al análisis de la comunicación política ${ }^{79}$. Si bien no es posible afirmar que se trata el mismo concepto, sí, en cambio, nos parece que más allá de las diferencias -epistemológicas, disciplinarias- terminan por atribuir una misma función a esa entidad que, por definición, se ubica en una posición externa (y por eso constitutiva) frente a los acontecimientos que se desarrollan en el espacio público.

Al mismo tiempo, estos autores nos permiten delimitar un campo problemático que incumbe, necesariamente, a los medios de comunicación, precisamente porque los medios le plantean a la acción política y a la producción del discurso político el desafío del contacto con los colectivos que definen y organizan identidades sociales. Es plausible pensar que, en determinadas circunstancias (que es necesario reconstruir empíricamente) ciertos actores del sistema de medios y del sistema político están trabajando en la construcción de un mismo tipo de destinatario: un interpretante cuya dimensión más importante es su pertenencia a un colectivo social marcado por su propiedad de "ciudadanía política" 80 .

\footnotetext{
${ }^{77}$ Las referencias ineludibles aquí son los estudios de Simmel (2002) y Goffmann (1981); en el primer caso, el Tercero es constitutivo de las interacciones sociales en cuanto que tales; Goffmann, por su parte, lo incorpora como elemento analítico de las relaciones sociales en el "órden público".

${ }^{78}$ Por caso, Arendt $(1984,2003)$ y Rancière $(2006)$. En reflexiones sobre la filosofía política de Kant Arendt (2003:90 y ss.) reconstruye la función del "espectador" en la constitución del significado de los acontecimientos históricos. El marco general de la reflexión de Kant (y por extensión, de Arendt) es la oposición entre la acción y la percepción, entre la acción y el juicio. En Argentina hay autores que, retomando esa línea de reflexión, han actualizado algunas ideas de Arendt para el estudio de movilizaciones de acción colectiva. Naishtat $(1999,2004)$ señala que "la relevancia del espacio público y de los públicos democráticos" instaura condiciones de posibilidad para la acción comunicativa de las protestas sociales: por un lado, impide que una protesta se constituya como mera acción de fuerza; y, en consecuencia, hace que toda acción colectiva en el marco de un espacio público democrático, deba "producir una audiencia" (2004: 373, cursivas nuestras). También Nardacchione (2005:86 y 93) retoma la figura del "espectador" reconstruida por Arendt: "Aunque parezca paradójico, son los sujetos que no forman parte de la acción los que le otorgan su sentido último".

${ }^{79}$ La naturaleza triangular de la comunicación en el espacio público es reconocida también por autores que analizan la comunicación política y la construcción de liderazgos presidenciales en las democracias contemporáneas. Ver, por ejemplo: Wolton (1998), Helms (2008), Blants y Vommer (2012), Muraro (1997)

${ }^{80}$ Que la "ciudadanía política" puede considerarse un interpretante del espacio público político mediatizado queda claro en esta definición de Cheresky (1999):" El término ciudadanía ante todo tiene la significación de un estatus que alude al conjunto de derechos garantizados por la ley y en particular a los derechos políticos que están en la base de la representación legítima. En este sentido, la ciudadanía es una categoría abstracta que, con el solo requisito de la nacionalidad, reagrupa a los individuos con independencia de sus
} 


\subsection{La gestión de colectivos: definición conceptual y aplicación al análisis}

La hipótesis de que existe una zona de cohabitación y competencia que se produce en el espacio público por efecto de la mediatización da cuenta, en un nivel general, del rol intermediario que cumplen los medios de comunicación en la circulación de discursos del tipo que sea: publicitario, ficcional, religioso, académico, siempre que se trate de la puesta en circulación de esos discursos para su publicitación. En un nivel más circunscripto, que es el que aquí nos interesa, esa hipótesis puede ayudar a comprender mejor la intromisión estructural de los medios de comunicación en la actividad identificante de la política, una actividad que Pizzorno (1985: 33) considera como prerrogativa del discurso político: "la tarea de constituir, preservar, reforzar las identidades colectivas que aparecen sobre la escena política bajo sus múltiples formas (grupos, partidos, movimientos, asociaciones, estados, etc.)", en particular en contextos como los que aquí tratamos, como el conflicto del campo, es decir, en circunstancias conflictivas en las que la producción de identidades supragrupales, y la polarización de colectivos, tienden a ordenar los posicionamientos políticos.

En este sentido restringido los "medios" se convierten en una cuestión política en tanto que se instituyen como un discurso intermediario ${ }^{81}$, con capacidad para incidir en la circulación y en los modos de recepción de los discursos públicos y privados ${ }^{82}$. Por modos de recepción no nos referimos al

identidades particulares y los confronta a la sola reclasificación, que puede permanecer anónima, de sus preferencias políticas. Pero al decir ciudadanía se alude también a los individuos que participan de alguna forma de la deliberación pública y más específicamente de la vida asociativa política y político-social. En este segundo sentido, son ciudadanos aquellos que manifiestan interés efectivo en los asuntos públicos, es decir que traducen una condición potencial en alguna forma de actividad, aunque sea tan sólo la de constituir opiniones publicitadas".

${ }^{81}$ La noción de "discursos intermediarios", tal y como lo aplicamos, fue desarrollada por Oscar Traversa (2011) para designar la función articulatoria, en ningún caso sólo aplicable a la política, que la prensa de masas vino a desarrollar desde mediados del siglo XIX. Los "discursos intermediarios" intervienen tanto en el mercado de consumo, como en el de las ideas.

${ }^{82}$ Esta afirmación puede que peque de a-histórica. Si bien esa intermediación puede verificarse en distintas épocas, es probable que, al menos en Argentina, se haya acentuado 
problema de los "efectos", la "manipulación", la "influencia”, sino a que el discurso periodístico, en su rol intermediario, hace imposible un contacto directo entre el enunciador político, por ejemplo, y su audiencia. El discurso político circula por las superficies mediáticas intervenido ${ }^{83}$ por el discurso del periodismo. Incluso cuando se utilizan mecanismos para evadir la intermediación simultánea (por ejemplo, utilizando la cadena nacional, o las redes sociales) eso no asegura un contacto directo con la ciudadanía, ya que, aunque sea a posteriori, el discurso así enunciado será puesto a circular, como en un flujo de segunda instancia, en el sistema de medios: será analizado, editado, cuestionado o aprobado.

Por eso hablamos de intromisión "estructural" de los medios: no se trata de una variación incidental y episódica (aunque según las coyunturas pueda manifestarse de manera más explícita y profunda) sino un rasgo institucionalizado en el espacio público; rasgo que, por eso mismo, puede propender a transformarse si se modifican sus propias condiciones de posibilidad $^{84}$.

En este marco cobra importancia para nosotros lo que, siguiendo a Verón (1991; 1994; 1998; 2001), denominamos la gestión de colectivos. Es a través de la reconstrucción de las diversas formas de gestión de colectivos que despliegan los medios y los discursos políticos que buscamos estudiar la disputa por la representación y la intermediación en el espacio público en el conflicto del campo.

(como fenómeno político global) después de 1983. Esa es, al menos, la hipótesis de Landi, 1992.

83 Intervenido quiere decir: comentado, estilizado, contrariado, reafirmado, repetido, editado por el discurso periodístico.

84 Esa es como lo señalamos en el capítulo anterior la hipótesis de Ferry (1989): la consolidación de internet tiende a desconfigurar ese rol institucionalizado de mediador y "representante" de los medios masivos, al habilitar canales de comunicación interpersonal y colectiva que, aunque sí mediatizados, no caen en la órbita de intermediación de las instituciones de medios. 


\subsubsection{Los "colectivos": construcciones bajo restricción}

Si bien la de la "gestión de colectivos" es una problemática que Verón ha tratado en varios textos (en general, derivados de investigaciones aplicadas: 2001; 2008; 2013) no ha profundizado en una discusión conceptual sobre el término ${ }^{85}$.

Si se sigue la definición de Verón, los "colectivos" deben comprenderse como entidades semióticas (esto es, no meramente lingüisticas) que implican la identificación y categorización de una pluralidad de actores. Identificación y categorización son operaciones asociadas a estrategias de argumentación, sometidas, por tanto, a reglas de producción de discursos que pueden ser reconstruidas por el análisis ${ }^{86}$. Esta definición le cabe tanto a colectivos formales (ciudadanos) como a colectivos de identidad (proletariado, peronistas), a colectivos comunicacionales (la gente, el público), o a otros tantos de colectivos de enunciación que diariamente se disputan en el escenario de la política (la derecha, la izquierda, el progresismo, etc.).

Si bien nos guiaremos por esa definición, creemos que es necesario plantear algunas precisiones, o al menos hacernos cargo de las implicancias que conlleva para los estudios sociológicos, en tanto la misma noción aparece con frecuencia utilizada para designar las asociaciones y agrupamientos empíricamente registrables, y de allí se facilita una contraposición entre los colectivos como "discurso" y los colectivos como "grupos".

En cuanto al uso del término, nos interesa la justificación que, en un estudio dedicado a revisar el uso del concepto, ha propuesto Laurence Kaufmann

\footnotetext{
${ }^{85}$ Nos referimos, puntualmente, a que no ha contrastado sus propias definiciones con otras alternativas. Por lo demás, el de los "colectivos", ha sido una de sus preocupaciones centrales, al punto que la reflexión de cierre de su último libro está dedicada a plantear una serie de preguntas relativas a cómo Internet redefine las condiciones en las cuáles "el sistema social construye los colectivos de sistemas socioindividuales que son su entorno".

${ }^{86}$ Esto significa que, en lo que concierne a su forma mediatizada, esa configuración no puede captarse por medio del cómputo estadístico de la frecuencia de menciones de términos aislados (“campo", "argentinos”, “Gobierno", “Mesa de Enlace”, etc). Un análisis de ese tipo corre el riesgo de traducir mecánicamente una tendencia estadística en "ideologías", "tomas de posición", tal y como, cada uno a su manera, hacen Armony, (2005) y Aruguete y Zunino (2012).
} 
(2010). Ella señala que el término tiene la ventaja de ser "neutro", pues no tiene las connotaciones nobles del término "público" (en términos de su visibilidad y accesibilidad de un bien común), ni las connotaciones a veces negativas del término comunidad (valores heredados, tradiciones establecidas, pertenencias impuestas). En el corazón de la interrogación sobre la ontología de los colectivos se encuentran reconducidas las tensiones entre voluntad y restricción, naturaleza y artificio, libertad y obediencia, entre acción y pasión, entre participación y pertenencia que atraviesan las reflexiones teóricas clásicas sobre la naturaleza de los agrupamientos políticos modernos.

Ahora bien, si contrastamos la definición (metodológica) de Verón, con la justificación (teórica) de Kaufmann, es probable que nos encontremos frente a una confusión: ¿cuál es la relación entre una entidad discursiva y las relaciones que se configuran en el espacio social? ¿Cómo evitar que la potencialidad teórica del concepto termine siendo reducida al uso -banal, redundante- de una palabra (campo, pequeños productores, ciudadanía, gente)? Aquí se genera una confusión entre las posiciones de observación desde las que se analiza la configuración y gestión de los colectivos que debe ser aclarada.

En primer lugar, los "colectivos" son categorizaciones sociales, y como tales, son "construcciones bajo restricción", tal y como lo propone el filósofo JeanMarie Schaeffer (2004):

las categorizaciones sociales no pueden ser comprendidas substancialmente sino únicamente de manera diferencial: la extensión que corresponde a una categorización dada es siempre una función de la delimitación de sus fronteras, delimitación que comporta una dimensión performativa. Se abandona así la perspectiva de una "discontinuidad ontológica" ligada a "cualidades substanciales" y una "definición intrínseca" de las categorizaciones sociales, a favor de una concepción que reconoce a la vez su carácter construido y la existencia de restricciones cognitivas que se ejercen sobre esta construcción, restricciones ligadas a la historicidad misma de la categorización considerada: desplazar las fronteras presupone la existencia de líneas de fuerza ya instituidas, que hacen que no nos encontremos nunca frente a un real amorfo estructurable a voluntad; lo real 
está siempre ya estructurado y los desplazamiento que operamos son relativos a esta estructuración ya operatoria ${ }^{87}$

Las controversias sobre el uso arbitrario, deliberadamente homogéneo, “construido", del término “campo" por parte de las organizaciones rurales nucleadas en la Mesa de Enlace (expresada en el slogan: "Esta es la unidad del campo"), o por parte de algunos diarios (Página/12, por caso, usó siempre la palabra entrecomillada, para indicar su estatus "ficcional") deben ser revisadas a la luz de estas reflexiones. Las categorías sociales, y sobre todo aquellas que no son el producto de una invención episódica, son históricamente relativas (contingentes) y funcionalmente absolutas.

Dicho esto, desde una perspectiva de análisis discursiva, los colectivos no tienen el estatus de los actores colectivas (aunque toda identidad colectiva deba expresarse como “colectivo"), sino que son entidades localizables en los micro-funcionamientos discursivos de la acción política. Desde esta perspectiva la noción de "colectivos" no tiene el estatus de sujetos sociológicos definidos por una ubicación diferencial en la topografía social: los colectivos, tal como los concebimos, no pueden ser censados, pero tampoco se trata de responder la pregunta sobre cómo se constituyen asociaciones o agrupaciones en el nivel de las interacciones en el espacio social, o eso que Naishtat llama "la interacción cooperativa de individuos" (1999) o los diferentes modos de sociabilidad y articulación que devienen en experiencias de participación colectiva ${ }^{88}$. Si el problema que interesa se sitúa en el nivel de la discursividad es porque allí se manifiestan los problemas de adecuación entre los grupos sociológicamente determinados (nivel no significante) y los colectivos (las entidades semióticas que identifican a esos grupos, nivel significante).

\footnotetext{
87 Por eso, agrega Schaeffer, "el constructivismo duro corre el riesgo de encontrar las dificultades inversas a las del realismo esencialista: mientras que éste último fracasa cuando debe rendir cuenta del componente autorreferencial de las categorizaciones sociales, el primero no llega a explicar cómo ciertas representaciones, ciertos tipos de categorización sean eficaces y otros no". Y esa es la pregunta que debe responderse cuando se interroga la pregnancia del sintagma "campo" en lugar de presuponer una imposición artificiosa, desconectada de las "realidades" sociales.

${ }^{88} \mathrm{Ver}$ al respecto Kaufmann (2010) donde se realiza un exhaustivo examen comparativo de las teorías que buscan explicar el pasaje entre lo individual y lo colectivo y el modo de existencia colectivo propiamente dicho
} 
Aun así, esta distinción es insuficiente para explicar lo específico del análisis que pretendemos hacer. En primer lugar, porque no alcanza con postular la importancia del nivel discursivo, en tanto no hay colectivo, del tipo que sea, que pueda prescindir de su puesta en discurso para existir como tal, para sostenerse en el tiempo, para distinguirse de otros colectivos (Latour, 2002). $Y$ en segundo lugar porque tal como apunta Warley (2007:32) existe una cierta aleatoriedad en los modos de designación nominal por parte de los medios en general, y de los periódicos en particular, sobre todo en contextos convulsivos, donde aparecen actores para los que previamente no se han elaborado rótulos ${ }^{89}$.

Mientras que el riesgo señalado por Warley se puede compensar con el análisis contextual (como el que intentamos realizar en el capítulo 4) mostrando el despliegue de las disputas por designar y caracterizar colectivos por parte de una diversa cantidad de actores (cientistas sociales, técnicos estadísticos, dirigentes gremiales, dirigentes partidarios, y también periodistas) y mediante un análisis comparativo que reconstruya invariantes en los modos de gestionar los colectivos (tal como intentaremos hacer en el capítulo 6), el valor específico que puede reclamar un estudio centrado en las modalidades de gestión de colectivos en la prensa gráfica reside en la definición del lugar que ocupan los medios en el interjuego de los discursos sociales que intervienen en la definición y la construcción de los colectivos.

\subsubsection{Los colectivos en el juego de discursos sociales: posiciones de observación}

La cuestión es, por tanto, desde dónde son hablados los colectivos. El problema es indisociablemente epistemológico, metodológico y político: el tipo de entidad, consistencia e intencionalidad que conviene conferir a los colectivos. Al respecto, Kaufmann (2010) se pregunta:

\footnotetext{
${ }^{89}$ Warley cuestiona la tendencia de los estudios sobre medios a cristalizar esas calificaciones como si fueran el resultado de una caracterización sociológica y no un recurso apurado por la urgencia de nombrar, más allá del criterio con que se nombra.
} 
¿Los colectivos se caracterizan por las propiedades de alto-nivel suficientemente autónomas e independientes de los individuos que los constituyen como para merecer el estatus de "persona colectiva"? ¿Los colectivos se reducen a los pactos circunstanciales y efímeros de las asociaciones voluntarias o engloban otra modalidad de ensamblaje -una modalidad pre-reflexiva que el individualismo propio de la antropología liberal tiende a negar?

Kaufmann sostiene que los colectivos son entidades bi-faciales y que lo son en dos niveles. En el primero, son el producto siempre inacabado de un proceso de colectivización interna (reconocimiento mutual de sus miembros como integrantes de un nosotros); pero también son el producto de un proceso de individuación externa, como un "entre-nosotros" que se despliega en el espacio de visibilidad y de competición de los “nosotros" que, o bien se reconocen o bien pugnan por ser reconocidos como entidades pertinentes de acción y pensamiento. En el segundo nivel, correlativo, los colectivos son, simultáneamente, múltiples y unitarios:

un fenómeno dado puede ser tratado bajo una descripción que lo individualice desde fuera por la función que cumple en un entorno más vasto, o puede al contrario ser aprehendido bajo una descripción interna que lo identifique por los elementos de bajo-nivel (bas-niveu) que lo constituyen ${ }^{90}$.

Para existir verdaderamente en tanto que colectivo, un agrupamiento o una asociación no puede reposar solamente en el cómputo exógeno y cuantitativo de las similitudes objetivas que vinculan a los individuos por así decir, sin que ellos mismos lo sepan. Él debe revestir necesariamente la forma endógena y cuantitativa de un "nosotros" que se apoya sobre el trabajo de autoafiliación y de puesta en común que los miembros efectúan por su cuenta, sea de manera reflexiva o irreflexiva, implícita o explícita.

\footnotetext{
90 Un ejemplo sería el caso del colectivo Nación. Dice Kaufmann: gracias al principio de diferenciación de alto-nivel que constituye la comunidad de naciones, las naciones particulares pueden ser individualizadas como totalidades concretas, conforme a la fórmula, eminentemente política, según la cual "el todo es singular". En cambio, cuando la nación es tratada "desde dentro" y "por-debajo", no es más que el horizonte último de los miembros que la componen. Por eso, concluye Kaufmann: "La totalidad deviene el punto de fuga, el horizonte unificador de una realidad irrevocablemente múltiple, conforme al precepto según el cual la totalidad es un universal".
} 
Señala Kaufmann que una manera de constituir los colectivos, muy común en el mundo social y en las ciencias sociales, consiste en identificarlos por atributos y criterios extrínsecos. Los colectivos así definidos:

reposan sobre la homologación, generalmente estadística, de propiedades objetivas y de similaridades empíricas que supuestamente caracterizan a los miembros de una población dada. Estas caracterizaciones (identidades numéricas, colectivos taxonómicos) se apoyan sobre héterocategorizaciones, establecidas por los observadores externos, que definen los contornos en sí de un colectivo ${ }^{91}$.

Dicho esto, para cumplir el trabajo fundamentalmente político de producción de colectivos $^{92}$ no es suficiente que los individuos sean religados desde el interior por la interdependencia de sus opiniones y de sus prácticas. Es necesario, igualmente, que el grupo que ellos forman o creen formar sea reconocido como tal por los observadores, espectadores o intérpretes que les atribuyen desde el exterior el estatus de individuos colectivos.

Por eso, al mismo tiempo, para consolidar un "ser colectivo", la operación interna de colectivización, que constituye un proceso de ascenso en generalidad o de "puesta en plural", debe ser completado por una operación externa de individualización, que constituye a la inversa un descenso en singularidad. Desde este punto de vista, la existencia de un colectivo, y los modos en que esa existencia circula públicamente, depende fundamentalmente de su reconocimiento, un reconocimiento que es menos una cuestión moral que una cuestión lógica u ontológica: para existir en tanto que colectivo, un nosotros debe ser reconocido como un ellos o un de ellos

\footnotetext{
${ }^{91}$ Negritas nuestras. Kaufmann aclara que si bien es posible que las personas así definidas puedan adoptar una actitud reflexiva a partir de la puesta en escena de esas estadísticas, pueden descubrir sus atributos en común y a partir de allí formar efectivamente un colectivo, generalmente este tipo de definición es ante todo la ratificación distante de un colectivo en tercera persona.

${ }_{92}$ En este sentido amplio, Latour (2002) sostiene que "la constitución y el mantenimiento de un Nosotros, sea del tipo que sea, es ya un acto político pues la actividad política por excelencia es la crear y administrar un colectivo. Desde este ángulo, la política no se trata de contenidos, finalidades o de dominios de acción específicos; es un procedimiento de transformación de lo "múltiple en lo uno", que puede encontrarse en todas las tentativas de puesta en común". Una perspectiva como esta presenta, sin embargo, un problema importante: al reducir el arte político a una técnica de reunión de voluntades, de intenciones y de experiencias, ella no permite distinguir una comunidad religiosa y un club deportivo de un "verdadero" colectivo político".
} 
homogéneo por las instancias externas que le proveen de una identidad, lo dotan de un pasado y de un futuro, o sea, lo aprehenden como un individuo colectivo (Kaufmann, 2010).

Veamos brevemente un ejemplo que luego trataremos con detalle. Se trata de las discusiones en torno a la definición del "pequeño productor". Cuando a mediados de marzo de 2008 los cortes de ruta se multiplicaron en casi todo el territorio de la Pampa Húmeda y los medios (televisivos, gráficos y radiales) empezaron a enviar móviles y corresponsales, se hizo visible la figura del "pequeño productor", sometida a varias definiciones simultáneas: "productores" que se asumían como tales, y hablaban de sus costumbres, deseos, enojos y derechos; retratos que los propios medios hacían, buscando definir un "sujeto político" nuevo; y las propias entidades y el gobierno no se ponían de acuerdo para establecer un límite o criterio a partir del cual un productor empieza o deja de ser pequeño. Ya avanzado el conflicto, el 29 de marzo, el todavía Ministro de Economía Martín Lousteau declaró a la prensa luego de una reunión con dirigentes rurales: "Propusimos trabajar en determinar quién es el pequeño productor y cuáles son las necesidades del que siembre en las áreas marginales". Días más tarde, en Página/12, Alfredo Zaiat escribía: "En estos días en los que la figura del pequeño productor ha pasado a ocupar el centro de la escena del conflicto, la definición de quienes integran esa categoría no es tan clara. Ni para los funcionarios que prometieron compensarlos ni para los propios dirigentes del sector".

En este juego público de discursos, de las visibilidades y las atribuciones recíprocas "los colectivos-en lo sucesivo-entre ellos" conquistan la "manifestación” mutal necesaria para su existencia. La unidad de un colectivo depende de sus "cara-a-cara" exteriores, que le proveen la certificación pública de su existencia y que, al hacerlo, le permiten constituir un colectivo en primera persona, es decir, un nosotros (Sorlín, 1992; Dayan, 2000).

Por eso un "colectivo" no es un "hecho"; para ser lo que es requiere de un componente significante, sea que se comprenda en términos de Bourdieu, 
como "consagración y reconocimiento", o en términos de la teoría semiótica: el colectivo se constituye en un interjuego de hetero-identificaciones y autoidentificaciones sin las cuáles no se lo podría percibir como totalidad.

Ese componente significante no es inmaterial. Por el contrario, la materialidad de esas entidades del imaginario social que son los colectivos es enteramente discursiva, significante. Desde el punto de vista que adoptamos, esos colectivos no se pueden reducir a idealizaciones abstractas ni a ficciones inoperantes. Como señalan Kaufmann y Tron (2010: 13), los "colectivos":

[T]ienen un modo de existencia distinto de aquel, ficticio, del cual se benefician al interior de la esfera del derecho. Pues los colectivos informan constantemente nuestros razonamientos ordinarios y vienen al apoyo de nuestros compromisos cotidianos con el mundo social. Y en otros términos, las entidades colectivas no son "realidades supra-experimentales", que son postuladas sin poder ser observadas; la mayoría de ellos, al contrario, son "dados en la experiencia'

Cefaï (2006) propone tres modos (que son, también, tres puntos de vista metodológicos) de abordar la constitución y desarrollo de los colectivos:

- Intencional: reenvía al tejido de intenciones mutuas de participación, de coordinación y de acción que permiten a un ensamble de individuos realizar un objetivo común. "Bajo este ángulo, el criterio de la política se ubica en la naturaleza voluntaria y contractual de "la intención en nosotros", que preside a la colectivización de las intenciones individuales".

- Pragmática: esta dimensión reenvía a las modalidades de la experiencia que "nosotros" hacemos de los colectivos y del género de compromiso, menor o mayor, distante o "efervescente", activo o pasivo, al que está asociado.

- Semántica y praxeologica (para nosotros: semiótica): la emergencia y la actualización de las entidades colectivas depende de recursos del sentido común, lingüísticos y no lingüísticos, que permiten invocarlos, nombrarlos, instanciarlos y figurarlos. Se apoyan, en su "aparición", de operaciones 
prácticas, implícitas o explícitas, de categorización (por ejemplo, ciudadanía) y de identificación (como pronombre, nosotros; como sustantivo, la Argentina) que permiten reconocer la naturaleza política de ciertos colectivos.

Adaptando esa tripartición a un lenguaje que nos resulta más cómodo, proponemos en el cuadro siguiente una distinción por posiciones de construcción y gestión de los colectivos: 
Tabla 2 Posiciones de observación en la gestión de colectivos

\begin{tabular}{|c|c|c|c|}
\hline DIMENSIONES & PERSPECTIVAS & DINÁMICA RELACIONAL & EJEMPLO \\
\hline $\begin{array}{l}\text { Conformación, creación y } \\
\text { recreación de colectivos. } \\
\text { Proceso de colectivización } \\
\text { interna de las intenciones } \\
\text { individuales o grupales. } \\
\text { Construcción de un nosotros } \\
\text { como entidad diferente a la } \\
\text { suma de las intenciones } \\
\text { singulares. }\end{array}$ & Interna & & $\begin{array}{l}\text { "Queremos dejar en claro que esto impacto negativamente } \\
\text { en los productores más chicos y que en definitiva se van a } \\
\text { beneficiar los más grandes, aunque momentáneamente se } \\
\text { quejen porque les quitan rentabilidad". (Silvio Corti, } \\
\text { directivo de F.A.A de San Pedro. Entrevista con Crítica de la } \\
\text { Argentina, 24/03/2008) }\end{array}$ \\
\hline $\begin{array}{l}\text { Producción de identidad } \\
\text { colectiva en el interjuego (de } \\
\text { confrontación, cooperación, } \\
\text { distinción) con otros } \\
\text { colectivos. Entre-nostros. } \\
\text { Alteridad. Diferencia }\end{array}$ & Inter-grupal & & $\begin{array}{l}\text { "Asumimos que este es el paro de la unidad del campo. Por } \\
\text { ello nos dirigimos a todos aquellos productores que se } \\
\text { encuentran en las rutas reclamando justamente, y los } \\
\text { instamos a continuar con los reclamos tendientes a } \\
\text { solucionar los problemas que venimos padeciendo desde } \\
\text { hace largo tiempo, por políticas erróneas aplicadas para } \\
\text { granos, carnes, leche, trigo, economías regionales y un sin } \\
\text { número de actividades que realiza nuestro sector, que } \\
\text { comprometen al crecimiento del interior y del país en su } \\
\text { conjunto". (Primer comunicado de la Mesa de Enlace, } \\
23 / 03 / 2008) \text {. }\end{array}$ \\
\hline $\begin{array}{l}\text { Individuación externa, } \\
\text { heteroatribuciones, } \\
\text { taxonomizaciones. } \\
\text { Certificación pública de } \\
\text { existencia. La figura del } \\
\text { observador (O)es equivalente } \\
\text { al espacio público. }\end{array}$ & Externa & S & $\begin{array}{l}\text { Si la importancia global del campo como actor económico } \\
\text { debe ser relativizada, más aún su capacidad de construcción } \\
\text { política, condicionada por una heterogeneidad estructural } \\
\text { imposible de disimular: lo que se autodefine como "el } \\
\text { campo" es un amasijo contradictorio en el que unos } 200 \text { mil } \\
\text { agricultores familiares de bajísima productividad conviven } \\
\text { con los productores pequeños y medianos de la Pampa } \\
\text { Húmeda, los nuevos pools de siembra (los Grobo, con } 150 \text { mil } \\
\text { hectáreas, lideran el ranking) y empresas como Cresud } \\
\text { (395.429 hectáreas) (“iEl campo al poder?”, por José } \\
\text { Natanson, Página/12, } 1 \text { de junio de 2008) }\end{array}$ \\
\hline
\end{tabular}


En el cuadro se distinguen tres posiciones desde donde se produce la gestión de colectivos (subrayando que en todas esas posiciones se realiza la gestión discursiva, independientemente de su mediatización) y se intentan visualizar los procesos, muchas veces simultáneos, de constitución de colectivos, procesos que implican intercambios del orden de la transacción, la cooperación, la confrontación, entre esas posiciones de observación. En el primer ejemplo, el discurso de un productor señala el paso de la individualidad al colectivo. En el segundo, el comunicado de la Mesa de Enlace permite ver la conformación de un colectivo (el "campo") que, una vez designado, puede ser identificado en el interjuego de colectivos que pueblan el escenario político. En el tercer ejemplo, es el discurso de un observador (en este caso, un periodista) que observa aquel juego en el que los colectivos intervienen para disputar.

El valor de esa tripartición es que incorpora una instancia a menudo desatendida cuando se reflexiona sobre la constitución de identidades colectivas en el espacio público. Kaufmann reconstruye la dinámica en la conformación de un colectivo, que no supone dos, sino al menos tres instancias ${ }^{93}$. Para la autora, debe considerarse como una necesidad ontológica esta mirada externa, que le ofrece a los colectivos, bajo ciertas circunstancias, una “certificación pública de existencia”. Esta certificación, claro, supone también una modalización de esos colectivos, pues es directamente dependiente de un lugar de enunciación: desde esta perspectiva, a los colectivos -que, por su parte, hablan- también se los habla y se los hace hablar.

Es importante señalar, por lo demás, que esas posiciones de observación son relativas. Esto quiere decir que quien/es ocupe/n, circunstancialmente, la posición de observador/es externos, pueden, en otra ocasión ser observados

\footnotetext{
${ }^{93}$ Aboy Carlés (2005), por ejemplo, plantea que la identidad política se constituye por un proceso de homogeneización interna y diferenciación externa. "Toda identidad política se constituye y transforma en la doble dimensión de una competencia entre las alteridades que componen el sistema y de la tensión con la tradición de la propia unidad de referencia".
} 
como constituyéndose en tanto que colectivos, y que los propios colectivos autoreflexionan sobre su estatus (flechas curvadas). Esto se verifica tanto en el análisis de los discursos políticos presidenciales como, particularmente en el caso de los medios de comunicación.

\subsubsection{Tipos de colectivos: una clasificación provisoria}

Un tercer aspecto que merece ser desarrollado es el de los tipos de colectivos. En diferentes trabajos Verón ha propuesto clasificaciones disímiles. Por ejemplo, entre colectivos formales, aquellos cuya existencia depende de la formulación de un decreto o de una ley, es decir, de una operación performativa (por caso, el colectivo ciudadanos) de colectivos comunicacionales (aquellos que se derivan de la condición de consumidor/usuario de servicios y mercancías).

Más específica, es la distinción que Verón desarrolla en La Palabra adversativa. Allí distingue una serie de colectivos, a los que concibe como entidades del imaginario político. Estos son:

1- Colectivos de identificación (marcado por el "nosotros" en el plano enunciativo), aunque también un colectivo de identificación puede referirse a un adversario (e incluso, a un paradestinatario). Son entidades enumerables.

2- Metacolectivos: Entidades enumerables más amplias que los colectivos, y que no son operadores de identificación de los actores en presencia: “ciudadanos", “trabajadores”, “argentinos".

3- Meta-colectivos singulares: es decir, entidades que no admiten cuantificación y la fragmentación; metacolectivos porque son más abarcadores que los colectivos políticos de identificación. 
Ejemplo: “la Francia”, “el país”, “la república”, “el Estado”, “el mundo", "el pueblo".

Según esta clasificación, el modelo de tres instancias propuesto, en principio, sólo corresponde a la constitución de colectivos de identificación. Sin embargo, se presenta un problema cuando, por ejemplo, metacolectivos como "Argentina", "sociedad", "ciudadanos" son gestionados bajo la lógica de la identificación, como se podrá ver en estas dos citas:

Hay que sentarse a hablar ya. Es imperioso que baje la tensión. La sociedad toda lo está pidiendo más allá de cualquier discusión sectorial, que a estas alturas de los acontecimientos ha quedado relegada en importancia a un segundo plano. (...) Hay algo que en estas horas de desasosiego nos hermana a todos, a todos sin distinción alguna. Las mayorías silenciosas les están exigiendo a los protagonistas que demuestren que la paz entre los argentinos es un bien supremo, inalterable, que trasciende demandas, heridas y orgullos personales. (Hora de gestos de paz, por Fernán Saguier, La Nación 30/03/2008)

Yo creo que los argentinos tenemos derecho a reflexionar esencialmente sobre quiénes son los titulares del derecho a la libertad de información y de la libertad de prensa; si son realmente las grandes empresas de comunicación o es el ciudadano y la ciudadana de a pie que merece que todas las historias y todos los relatos diferentes y plurales que una sociedad tiene acerca de determinados acontecimientos sean difundidos de la misma manera. (Discurso de Cristina Fernández de Kirchner, 5 de abril de 2008)

Es en estos casos, según nuestra hipótesis, cuando se evidencia con mayor claridad la disputa por la representación entre el Gobierno y los medios de comunicación durante el conflicto del campo, cuando el observador externo muta en miembro de un colectivo o en su representante. Este último problema, de todos modos, ratifica la importancia distinguir entre posiciones de observación, ya que estas suponen lugares de enunciación, es decir, variaciones en las relaciones que se establecen entre el enunciador y los colectivos que gestiona. Esto nos lleva al último punto de este capítulo, referido a las condiciones estructurantes de los dispositivos de enunciación de los discursos políticos y de los discursos periodísticos. 


\subsection{Dispositivos de enunciación de los discursos políticos y periodísticos}

Volvamos muy rápidamente sobre nuestro planteo. El análisis que estamos proponiendo corresponde por entero al nivel que Verón (1987) denomina “entidades del imaginario político”. Es decir, en el nivel de análisis microdiscursivo se tratará para nosotros de analizar y contrastar cómo un discurso político (el discurso presidencial) y unos discursos periodísticos) intervienen en el espacio público mediatizado para identificar, describir, narrar, hacer hablar (es decir, para gestionar) a los colectivos que protagonizaron el conflicto del campo. Y nuestra hipótesis es que cuando se trata de la circulación de esas entidades en el espacio público los medios y las organizaciones y actores políticos pueden estudiarse como en términos de posiciones de enunciación que trabajan sobre una misma zona de ese imaginario, y lo hacen bajo pretensiones de generalidad, en dos niveles:

- en producción, porque quien enuncia no lo hace a título personal (y esto vale, como veremos, incluso cuando la Presidenta sitúe en primer plano su “yo" como garante de descripciones, afirmaciones, diagnósticos, etc);

- en reconocimiento, sus horizontes de destinación son siempre “colectivos" (el público, la ciudadanía, los lectores, la sociedad) nunca individuos aislados.

En este sentido, el discurso político y el discurso periodístico son, siguiendo a Bourdieu "discursos de institución": en ambos casos, quien pronuncia las palabras es o se asume como "el portavoz autorizado"; sólo puede actuar sobre otros agentes "en la medida en que su palabra concentra el capital simbólico 
acumulado por el grupo que le ha otorgado ese mandato y de cuyo poder está investido" (1999:69-71) ${ }^{94}$.

Este acercamiento, sin embargo, sólo nos sirve para un primer paso descriptivo, en el que nos interesa establecer condiciones de comparabilidad en los modos en que los actores políticos y los actores periodísticos disputan la representación de colectivos sociales. Por eso, tal y como lo señalamos en la Introducción, el planteo metodológico de nuestro análisis empírico consiste en concebir a los discursos de los diarios que vamos a estudiar como efectos en reconocimiento de los discursos presidenciales durante el conflicto (esto se verá claramente en el capítulo 7). De allí que optamos por empezar por el análisis de los discursos presidenciales y luego proceder al de los diarios en cuestión, ubicándolos en una secuencia temporal sucesiva ${ }^{95}$.

Ahora bien, la concepción de la mediatización como formando parte de las condiciones productivas del espacio público es relativa, en dos sentidos: en primer lugar, porque no es el único “mecanismo” que condiciona la producción de discursos; en segundo lugar, porque, consecuentemente, sólo permite acceder a la descripción de ciertas "gramáticas productivas" las propiedades de esos discursos. En relación a estos dos aspectos, el trabajo de reconstrucción del “contexto" en el que se manifiesta la disputa por la representación entre los discursos políticos de la presidente Cristina Fernández

\footnotetext{
${ }^{94}$ No se nos escapa que esto puede sonar absurdo si se comparan los valores formales de los actos delegativos de origen que sostienen la palabra en uno y otro caso. Pero desde el momento en que -como ha sucedido en Argentina durante el kirchnerismo- un actor legitimado y legalizado por el voto popular hace de la discusión por la legitimidad un eje de confrontación pública con poderes fácticos, se produce un terreno de lucha que debe reactivarse periódicamente.

${ }_{95}$ Esta decisión, como podrá apreciarse después, es arbitraria: los primeros discursos de Cristina Fernández durante el conflicto contienen referencias (es decir, son respuestas)al abordaje que algunos diarios y programas de televisión estaban haciendo del conflicto.

${ }_{96}$ Verón define las gramáticas como conjunto de reglas que definen operaciones de asignación de sentido. Al menos en su propuesta teórica, las gramáticas son un instrumento analítico que permite realizar el pasaje entre el nivel de las condiciones productivas y el producto analizado, en función de las invariantes y las variaciones atestiguadas en ese producto discursivo en su relación con aquellas condiciones.
} 
de Kirchner y los de algunos diarios, y entre esos diarios entre sí, es lo que intentamos realizar en los capítulos 4 de esta Tesis. Se trata, en lo que resta de este capítulo, de presentar los rasgos constitutivos y diferenciales de los dispositivos de enunciación políticos y periodísticos en sus aspectos formales, es decir, aquellos rasgos emergentes de la mediatización de esos discursos.

\subsubsection{El dispositivo de enunciación: una herramienta analítica}

Se trata de darnos una herramienta para abordar este problema: ¿cómo se vinculan, en sus discursos, la Presidenta y las instituciones de medios con ese más allá, ese horizonte de destinación compartido, competido, habitado por entidades del imaginario político que designan, categorizan, identifican a actores y organizaciones que intervienen en una disputa política?

Esa herramienta es el concepto de dispositivo de enunciación. Este concepto, que nosotros tomaremos desde la perspectiva semiótica de la teoría de la discursividad, es derivado de una larga tradición (o bien, a esta altura, de varias tradiciones) en lingüística y análisis del discurso, en particular de ascendencia francesa. No vamos a detenernos en la reconstrucción de los debates y ramificaciones disciplinares y en relación a los objetos de estudio porque nuestro interés aquí es estrictamente instrumental. Solo nos basta con señalar que el principio analítico de base de tal concepto es la hipótesis fundante de la teoría de la enunciación esto es: que la subjetividad se manifiesta también en el lenguaje. Esta tesis se ha desarrollado (a muy grandes trazos) desde un primer momento (Benveniste, 1999 [1977]) que concibió a la "enunciación" desde una perspectiva empirista ${ }^{97}$; luego, autores como Ducrot $\left(2001[1980]^{98}\right)$ presentaron

\footnotetext{
97 "Hay que atender a la condición específica de la enunciación: es el acto mismo de producir un enunciado y no el texto del enunciado lo que es nuestro objeto. Este acto se debe al locutor que moviliza la lengua por su cuenta. (1999: 83).
} 
una concepción analítica, que apuntaba a distinguir, en un enunciado, al Sujeto Empírico, al Locutor y al enunciador, aunque centrada (cerrada) en el estudio de lo textual ${ }^{99}$; y más tarde, siempre durante la década del 80, Kerbrat Orecchioni, $\left(1986^{100}\right)$, sistematizó, con mucha lucidez, las discusiones previas, proponiendo al mismo tiempo una apertura hacia problemáticas extralingüísticas ${ }^{101}$.

Sintetizando en extremo el núcleo de la perspectiva de la enunciación: se verifica una diferencia entre el sujeto hablante y las variaciones que, en función del contexto y de los interactuantes, se producen en su discurso en relación a su “identidad”. Un mismo "sujeto hablante" (sujeto biológico y psicológico, dotado de un cuerpo, de una voz, de una historia) puede presentarse bajo diferentes formas (como líder, como pedagogo, como guía espiritual, como analista) en un mismo discurso, y a la variación entre esas “imágenes de sí” corresponde, también, una variación en la imagen de sus destinatarios.

\footnotetext{
98 Una lingüística de la enunciación postula que muchas formas gramaticales, muchas palabras del léxico, giros, construcciones tienen la característica constante de que, al hacer uso de ellos, se instaura, o se constribuye a instaurar relaciones específicas entre los interlocutores" (2001: 134).

${ }^{99}$ Ducrot propuso su teoría polifónica de la enunciación, según la cual en un mismo enunciado hay presentes varios sujetos de estatus lingüístico diferentes: sujeto empírico, locutor y enunciador. Para Ducrot, la determinación del Sujéto Empírico no era un problema lingüístico. Los que le interesa al lingüista "es lo que está en el enunciado y no las condiciones externas de su producción". Lo cual, pese a las apariencias, no quiere decir que Ducrot desconociera las fuerzas sociales que operan sobre el sujeto, sino que no consideraba que la lingüística debiera encargarse de estudiar esa problemática. "El problema (importante) de la determinación del Sujeto Empírico es más bien preocupación de los sociolingüísticas o sicolinguistas que se formulan preguntas como: ¿por qué el señor $X$ dijo lo que dijo? Lo que a mí me interesa es sencillamente lo que dijo el señor X" (Ducrot, 1988: 17)

100 Para Orecchioni, "la perspectiva inmanente, ese horizonte metodológico hacia el cual la lingüística se ha esforzado por acercarse asintóticamente, parece hoy más reductora que productiva. Hoy en día la actitud más rentable en lingüística no es el ascetismo heroico sino una audaz apertura a las disciplinas emparentadas" (1986: 13). La autora declara que el libro en el que sistematiza su perspectiva, es una especie de proclama por una lingüística del discurso". Allí, define la problemática de la enunciación del siguiente modo: "es la búsqueda de los procedimientos lingüísticos (shifters, modalizadores, términos evaluativos, etc.) con los cuales el locutor imprime su marca al enunciado, se inscribe en el mensaje (implícita o explícitamente) y se sitúa en relación a él (problema de la 'distancia enunciativa')

${ }^{101}$ La bibliografía producida desde y sobre la teoría de la enunciación es muy vasta. Se puede consultar una reconstrucción sintética pero completa y bien argumentada, orientada además a analizar discursos políticos en la Argentina contemporánea en Montero (2012), particularmente capítulo 1 , donde también se desarrolla con detalle la categoría de "ethos".
} 
Por nuestra parte, no nos interesa específicamente la reconstrucción de las marcas de subjetividad en los discursos que vamos a analizar. Lo que sí nos interesa es reconstruir los modos invariante (en este sentido, las estrategias) en que un enunciador se coloca en relación con sus destinatarios y con las entidades del imaginario político que muchas veces son, también, aquellas con las que pretende vincularse.

Orientados por este propósito específico entenderemos por dispositivo de enunciación siguiendo a Verón ([1984] 2004: 173; 1987) ${ }^{102}$ a la constitución, en la superficie discursiva, de una escena comunicativa que implica la constitución de figuras (que son "objetos abstractos" reconstruidos por el analista) y de sus relaciones:

- la imagen de quien habla, el "enunciador";

- la imagen de aquel a quien se dirige el discurso, el "destinatario";

- la relación del enunciador con lo que dice y con su destinatario.

La noción de "dispositivo" le agrega a este planteo un valor sistemático, o más bien relacional: sea cual fuera la figura del enunciador, esta sólo puede definirse por el modo en que se establecen las relaciones con sus destinatarios y con los contenidos de su propio discurso. De allí que, como herramienta analítica, el dispositivo de enunciación anuda las dos dimensiones que el análisis suele identificar en todo discurso: el "enunciado" (el plano del contenido) y la “enunciación” (el plano de los “modos de decir”).

\footnotetext{
102 Verón también participó activamente (y contemporáneamente, y coterráneamente) en los debates franceses sobre la teoría de la enunciación. En su caso, su perspectiva está directa y decisivamente influida por el trabajo del lingüista Antoine Culioli (cuya perspectiva también está muy presente, por lo demás, en el trabajo de Kerbrat-Orecchioni). Más allá de eso, tal vez la diferencia más importante de la línea de trabajo de Verón es que se interesó muy pronto por desarrollar un concepto de enuncicación que fuera aplicable a objetos discursivamente heterogéneos, translinguísticos, especialmente mediáticos: el noticiero de TV, las tapas de semanarios, etc.
} 
Este planteo no tendría valor analítico alguno si no fuera porque supone, también, que los dispositivos de enunciación están anudados (restringidos, condicionados, determinados) no sólo por los contextos, sino por las reglas, normas y principios no siempre codificados de funcionamiento institucional y por las prácticas institucionalizadas en los que los actores sociales se desempeñan y se vinculan entre sí. Esto significa que los dispositivos de enunciación tienden a estabilizarse en función de los "contratos de comunicación" que las instituciones establecen con los individuos y con las demás instituciones y que, el menos en su estructura formal, tienen a sobre-imponerse a los actores.

2.3.2. Los dispositivos de enunciación en relación a los tipos de discurso, los soportes materiales y las situaciones de comunicación

Pensando específicamente en los discursos que forman nuestro corpus, y en la materialidad en la que se ponen en circulación en el espacio público, queremos reparar en las relaciones que mantiene aquella definición formal con una serie de conceptos analíticos elaborados por el análisis de los discursos sociales: los tipos de discurso, los soportes y lo que (entre otros) Charaudeau (2003) y Maingueneau (2005) denominan las situaciones comunicativas.

\section{a- Tipos de discurso}

La noción de tipo de discurso designa las propiedades enunciativas de los discursos asociados a los emplazamientos institucionales en que son producidos. El concepto -que es un concepto analítico, no un concepto empírico (Guespin, 1976)- presupone la posibilidad de una tipología de discursos, esto es, la hipótesis de que los discursos producidos bajo condiciones de funcionamiento institucional estabilizado tienden a poseer propiedades (discursivas) comunes y diferenciales. De modo que sería posible distinguir, por ejemplo, discursos 
políticos, discursos periodísticos, discursos publicitarios, discursos religiosos, discursos médicos, discursos educativos, discursos jurídicos, etc.

\section{b- Soportes}

Por soportes se entienden las superficies materiales en las que se manifiestan los discursos. Verón (2004: 126-127) explica que:

Esta materialidad del sentido define la condición esencial, el punto de partida necesario de todo estudio empírico de la producción de sentido. Siempre partimos de "paquetes" de materias sensibles investidas de sentidos que son productos; con otras palabras, partimos siempre de configuraciones de sentido identificadas sobre un soporte material (texto lingüístico, imagen, sistemas de acción cuyo soporte es el cuerpo, etc.) que son fragmentos de la semiosis. Cualquier fuere el soporte material, lo que llamamos un discurso o un conjunto discursivo no es otra cosa que una configuración espacio-temporal de sentido".

Que el soporte de los discursos es una variable (como condición de producción o como condición de reconocimiento) es algo que no debe pasar por alto. Lo veremos por ejemplo claramente en el capítulo 5: los discursos de Cristina Fernández de Kirchner fueron pronunciados en actos públicos televisados, es decir, fueron concebidos para su mediatización televisada, de modo que el análisis debe hacerse cargo de la composición compleja -en términos de la materialidad discursiva de esos discursos.

\section{c- Situaciones comunicativas}

Para Maingueneau (2003) una "situación de comunicación" implica considerar al discurso "desde el exterior", incluso desde un punto de vista sociológico. Una situación de comunicación supone:

- Una finalidad

- El estatus de los participantes 
- Las circunstancias apropiadas

- Un modo de inscripción en la dimensión temporal: periodicidad, duración, continuidad, caducidad.

- Un medio (en este caso, el autor se refiere a lo que ya hemos denominado soporte)

- Modos específicos de uso de la lengua.

Considerando las relaciones entre estos tres niveles, en primer lugar, es de suponer que una variación en el tipo de discurso (sea este político, periodístico, publicitario, religioso, científico) implicará una variación en los dispositivos de enunciación (es decir, que variarán la construcción de las imágenes del locutor, del destinatario y de las relaciones que mantienen entre ellos). De igual modo, si el soporte cambia (se trate de la prensa gráfica, de un programa de televisión, de una interacción interpersonal no mediatizada, sea una ceremonia religiosa o una clase en un aula) y también la situación comunicativa (por ejemplo, si la comunicación se lleva a cabo en un espacio privado o en uno público), habrá variaciones en el dispositivo de enunciación. Sin embargo, también es verdad que los sistemas productivos de discursos sociales tienden a estabilizarse, por lo cual tanto el tipo como el soporte o la situación comunicativa pueden considerarse, según el caso, como invariantes.

En el caso de la tipología (que es el que nos interesa particularmente aquí) en tanto se define por una imbricación entre emplazamientos institucionales y producción discursiva, su caracterización supone que los dispositivos de enunciación estén sobre-determinados por las lógicas de funcionamiento institucional. En este sentido, tal vez se pueda recuperar la propuesta de Charaudeau (2004) de distinguir tres niveles para observar analíticamente las relaciones entre lo institucional y lo discursivo: 
- el espacio comunicacional (cuyo dispositivo implica restricciones a priori sobre la identidad de los participantes, sus roles, su estatus y las relaciones que establecen entre ellos),

- el espacio discursivo de la enunciación (es, ya, el espacio “interno” del discurso, donde se van constituyendo los protagonistas del intercambio discursivo)

- el espacio interdiscursivo (que implica la reconstrucción de los intercambios discursivos en tanto imaginarios socio-discursivos).

La pregunta en este caso es si es posible englobar al discurso político y al discurso del periodismo en alguno de estos “espacios". Para eso es útil una distinción posterior que propone Charaudeau. Sostiene que el espacio comunicacional determina dispositivos estructurados en relaciones de triangularidad, que pueden tener diferentes formas: conversación, mediación, espectáculo y concurrencia. En todos estos casos, las relaciones están reguladas por un tercero, dependiendo de cada forma el lugar y el rol que le corresponde.

Hay ciertas limitaciones que presenta la perspectiva de Charaudeau para nuestros propósitos; la más importante es que, por el modo en que conceptualiza los dispositivos triangulares, cierra la puerta para incorporar discursos que no estén en una relación de co-ocurrencia o simultaneidad, tal el caso del discurso de la prensa gráfica que, por definición, se inserta en un desfase temporal entre la producción y el reconocimiento.

Aun así, quisiéramos servirnos de algunas ideas del autor -tal vez, forzando su planteo- para avanzar en nuestro propio argumento. Entendemos que quizás puedan combinarse, analíticamente, los dispositivos que él denomina de “mediación" y de "escena". Ambos suponen tres parteneires"103 : en el

\footnotetext{
${ }_{103}$ Sobre este concepto, Charaudeau explica, en nota al pie: "Recuerdo que los "partenaires" son, para mí, los sujetos que comunican e interpretan y que poseen, a la vez, una identidad
} 
dispositivo de mediación, dos de ellos están en relación de co-enunciación, uno de los cuales hace el rol de mediador, frente a un tercero (el público); en el dispositivo de escena dos de los parteneires están fìsicamente presentes en una co-enunciación, y un tercero (que puede estar ausente, o no) está en posición de escucha o de testigo pero que no toma la palabra.

En este nivel de generalidad, tal y como lo propusimos en los parágrafos anteriores, tanto el discurso del periodismo como el discurso político que se producen y circulan en superficies mediáticas se insertan en un dispositivo que supone un Tercero, pero en una instancia pre-discursiva: ese tercero debe ser concebido como un presupuesto, o bien una hipótesis reguladora, particularmente toda vez que un discurso interviene en el espacio público

Por lo dicho hasta ahora, debiera entenderse la opción por el concepto de “discurso periodístico" y no “discurso mediático" o “discurso de la información”. En el primer caso, porque lo mediático debería considerarse no como un tipo de discurso, sino como las condiciones de producción de ese discurso (y, en rigor, de todos los discursos que ingresan al espacio público vía su mediatización). Por otro lado, hablar de "discurso de la información" acarrea el problema de que así sólo se puede distinguir una parte ínfima de los discursos que se ponen en escena en los medios (aunque ciertamente, el discurso informativo se ha constituido como producción paradigmática del periodismo). Hablar de "discurso periodístico" permite evadir esas ambigüedades. Por un lado, el periodismo, como institución, está genéticamente vinculado a las tecnologías mediáticas. Por otro lado, su singularidad no le viene dada por ser portador de propiedades especiales, sino por sus condiciones institucionales y funciones instituidas, y por imaginarios

psico-social externa al proceso de enunciación y una identidad discursiva, que atraviesan el rol enunciativo que les es atribuido en la situación. Se los puede denominar, igualmente, ‘interactuantes' o ‘instancias de comunicación’ ”. Traducción nuestra. 
sociales efectivos que circulan en la sociedad. Una de esas propiedades es la de informar, pero también lo es el análisis, la opinión.

\subsubsection{Dispositivos de enunciación: las relaciones con los destinatarios}

A nivel discursivo, distinguir entre discurso político y discurso periodístico implica contrastar las hipótesis sobre los destinatarios genéricos de cada tipología, antes que sobre las propiedades (usualmente lingüísticas) de la producción discursiva de los actores e instituciones. Lógicamente, reconstruir la figura de los destinatarios obliga a un estudio cuidadoso, comparado y sistemático de las producciones discursivas, pero eso no equivale a buscar propiedades excluyentes -de orden retórico- que caracterizarían a un tipo de discurso por sobre otros.

Esta distinción es central, aunque no siempre se la somete a reflexión. Eso explica la dificultad inherente a los intentos por generar tipologías discursivas a partir de nociones que ya circulan asociadas a objetos de la vida cotidiana. Por un lado, se intenta mantener el uso consuetudinario -por la lógica razón de que se analizan los mismos materiales que ese uso identifica con esas nociones-, que naturalmente surge de la asociación intuitiva de determinados textos a las condiciones instituidas de producción; pero por el otro, se intenta aplicar criterios “discursivos" -es decir: técnicamente especializados- para lograr distinguir con pertinencia un tipo discursivo de otro.

\section{a- Destinatarios del discurso político}

En el caso del análisis del "discurso político" el resultado es ambiguo: los esfuerzos por generar criterios estrictamente discursivos terminan por mostrar que las "propiedades" específicas del discurso político (especialmente, las 
propiedades lingüísticas) se registran también en otros tipos discursivos terminan siendo una suerte de propiedad impropia- por lo cual el único criterio específico que sigue siendo útil es la intuición inicial: el discurso es político cuando es emitido por dirigentes $u$ organizaciones políticas.

Un ejemplo muy evidente de resignación descriptiva puede leerse en Charaudeau (2002) quien, en un texto dedicado precisamente al estudio del discurso político termina por decir que: "Existe un lugar más específicamente político: el que se proclama como tal y se organiza con vistas a esta misma finalidad". Al respecto, Fabbri y Marcarino (2002: 27) reconocen que "el problema embarazoso es que no hay ninguna especificidad del discurso político, si la especificidad es la discusión sobre el poder, porque precisamente esta modalidad es típica de toda clase de discurso".

El caso opuesto es el de Chilton y Schäffner, quienes luego de exponer las "propiedades específicas" de lo que consideran un "discurso político" admiten que se trata de modalidades discursivas habituales de la vida social en general que, al ser analizadas en términos de funciones estratégicas, llevan "a considerar políticamente dichos comportamientos, a politizarlos." (Chilton y Schäffner, 1997: 306), con lo cual la especificidad del tipo de objeto resulta prescindente: cualquier discurso puede ser tratado como político, en tanto se lo puede politizar mediante técnicas de análisis. Por lo demás, esa dificultad no depende necesariamente de la metodología o corriente de análisis que se utilice; prueba de ello es que un pionero del análisis del discurso de la escuela francesa, como Guespin, ha llegado a la misma conclusión que Chilton y Schäffner: "Tampoco es un defecto decir que lo que constituye un enunciado en discurso político es la lectura política que se hace de él”.

Los análisis del discurso político más productivos son, desde nuestro punto de vista, aquellos producidos desde la perspectiva de una teoría de la enunciación. 
Al menos, son lo que han logrado articular conceptualmente de modo coherente hipótesis sobre el funcionamiento del campo político y las propiedades de los discursos. Según una distinción que ha sido refrendada por otros autores (García Negroni, 1992 ${ }^{104}$; Arfuch, 1987; Montero, 2012) Verón ha definido la especificidad del discurso político en que le corresponde un dispositivo de enunciación que implica un desdoblamiento situado en la destinación ${ }^{105}$, esto es, que se trata de un discurso que supone al menos tres tipos de destinatarios según sea el vínculo o lazo de creencia presupuesto con el enunciador:

Desde este punto de vista, todo acto de enunciación política a la vez es una réplica y supone (o anticipa) una réplica. Construye, pues, una imagen del Otro positivo y una del Otro negativo. Se trata de un desdoblamiento que se sitúa en la destinación y el discurso político se dirige a ambos lados.

Al primero tipo de destinatario, Verón le llama Prodestinatario: corresponde a la figura del destinatario con quien el enunciador mantiene una relación de creencia presupuesta: un receptor que adhiere a los mismos valores, participa de las mismas ideas y persigue los mismos objetivos. En el discurso, la relación entre el enunciador y el predestinatario cobra la forma de una entidad que Verón llama colectivo de identificación, que se expresa en el nosotros inclusivo (pronombre personal)

Al segundo tipo de destinatario, Verón lo denomina Contradestinatario. La relación, en este caso, reposa en la inversión de la creencia. La presencia, siempre latente, de la lectura destructiva que define la posición del adversario.

\footnotetext{
${ }^{104}$ García Negroni habla de la "multiplicidad de destinación del discurso político", discurso que, en su funcionamiento lingüístico, considera portador de distintas fuerzas ilocucionarias (1992: 85).

${ }^{105}$ Usualmente, se considera que ese desdoblamiento se verifica en los discursos políticos en producción; es decir, el lugar en el que habría que buscar la figura de esos destinatarios (o las variantes de su figuración) es en los discursos políticos analizados. Habría que considerar, como paso previo, que ese desdoblamiento forma parte de las condiciones de circulación y reconocimiento: todo discurso (y no sólo político) que circula en el espacio público, casi independientemente de sus propiedades retóricas (por ejemplo, sus grados de polemicidad), está "condenado" a esas tres clases de lecturas.
} 
Sin embargo, el discurso político en el contexto de un sistema democrático revela la presencia de un tercer tipo de destinatario. Esta presencia en el discurso no es azarosa: "resulta de una característica estructural del campo político en las democracias parlamentarias occidentales, la presencia de sectores de la ciudadanía que se mantienen, en cierto modo, fuera del juego" (los “indecisos"). La relación que estos sectores mantienen con el enunciador es de suspensión de la creencia. Verón designa esta posición como Paradestinatario ${ }^{106}$.

En un trabajo posterior (1989), el propio Verón adiciona a ese modelo una hipótesis de nivel macro. Explica que el discurso político trabajaría sobre dos polos en el imaginario político: por un lado, la construcción, en un primer nivel, de un destinatario que llama "ciudadano nacional" (que se caracterizaría por participar en prácticas relacionadas con el sistema político, y por lo tanto, por tener expectativas en relación a su funcionamiento); por el otro, la construcción, tal como lo mencionamos, de un triple destinatario: el prodestinatario, el contradestinatario y el paradestinatario. Como se ve, los dos grupos de destinatarios no se ubican en un mismo nivel o dimensión: antes de ubicar a sus destinatarios según una relación de creencia específica, el discurso político los identifica como ciudadanos, en el sentido genérico de participantes interesados de la vida de la polis.

Al menos en relación a este modelo de análisis del dispositivo de enunciación del discurso político, el análisis de los discursos está atravesado por un fuerte consenso, y volveremos sobre estas cuestiones en el capítulo 5.

106 Sobre la base de esa distinción original García Negroni (1988) distingue entre destinatarios directos, encubiertos e indirectos. 


\section{b- Destinatarios del discurso periodístico}

En lo que respecta al "enunciador" el análisis del discurso del periodismo, y de la prensa gráfica en particular, presenta otras dificultades. Servais (2013) las ha identificado muy claramente: se habla de "enunciación vaga", pues los enunciadores no son reconocibles; de una "enunciación colectiva", en tanto reenvía al trabajo de reescritura, de corrección y edición; se habla de "polifonía enunciativa" y de "heterogenedidad enunciativa" (Charaudeau, 1997 : 178). El propio periódico, una suerte de sujeto enunciador formado, a su vez, por una pluralidad de enunciadores, sería un "espacio público fragmentado". Se habla, del periódico como un "mega-narrador" o una "meta-narración" (Awad, 2010: 46). En cualquier caso, lo importante, y en esto coincidimos con Servais, es que "todas estas concepciones dan cuenta de que la heterogeneidad enunciativa del discurso de la prensa no es de ninguna manera accidental, sino que es constitutiva de una escritura en la cual un sujeto produce una palabra que no le es propia":

La enunciación de la prensa (por ser una comunicación mediatica) está atravesada por la dimensión institucional del espacio público donde ella toma lugar, y es sobre esta dimensión institucional que reposa, in fine, su legitimidad, la de sus locutores y el crédito del cual gozan sus enunciados (...) Por esa dimensión pública e institucional, la norma y el colectivo toman lugar en el acto de enunciación mismo, y lo observamos en una multitud de formulaciones (el condicional, el solapamiento detrás de fuentes anónimas, el uso pletórico del se, el más utilizado de los pronombres personales), donde se trata de "decir sin decir", pero sin embargo de afirmar, porque el enunciado de prensa no es la formulación de una ley administrativa, sino, por el relevo de testigos, de actantes, de locutores diversos y múltiples, la afirmación de un hecho. (Servais, 2013: 4)

Para el análisis, la cuestión entonces es la siguiente: ¿a qué colectivo reenvían las voces que atreviesan el espacio mediático del diario, y de qué manera el propio diario reenvía a ellas, es decir, proponiendo qué tipo de vínculo con el lector espectador? Considerado con la ayuda de este cuadro teórico, la 
enunciación tiene una preferencia política inmediata, pues ella compromete la constitución de un "nosotros", del cuál habrá que determinar si es consensual -y de qué manera- o si al contrario él deja lugar al conflicto -al desencuentro, al diferendo, etc.

Siguiendo esa línea de razonamiento, ¿cómo orientar el análisis del discurso periodístico en la prensa gráfica? Para Verón (2004: 126), es necesario definir

Su articulación con la red tecnológica de los medios y con los sistemas de normas que rigen la profesión de periodista, y por otro, sus modalidades de construcción de un único destinatario genérico, el ciudadano habitante (asociado al colectivo "país", pero motivado por el colectivo "mundo") comprometido en rutinas diversas de apropiación del espacio tiempo de lo cotidiano. Si bien el destinatario genérico ciudadano-habitante está próximo, en algunos aspectos, al prodestinatario, el discurso de la información es ajeno al paradestinatario y al antidestinatario.

De modo que -podemos suponer- la "multiplicidad de la destinación" que caracteriza al discurso político no se encontraría en otros tipos discursivos, o no con la misma configuración de base amigo/enemigo, nosotros/ellos, con que lo hace en la política. Lo específico del discurso político, antes que el desdoblamiento en la destinación, es que ese desdoblamiento deriva de la propia configuración del campo (institucionalizado) de competencia política.

Quisiéramos matizar, a pesar del acuerdo general, estas observaciones de Verón considerando los tres niveles formales implicados en las definiciones que acabamos de dar:

- el que corresponde el polo de destinación más general: ciudadanohabitante. Este aspecto se refiere a la forma dominante que adopta Tercero en tanto que Interpretante del discurso de la prensa. Esa figura genérica pueda abarcar un amplio abanico que atraviesa el binomio de lo privado/público: la familia, la sexualidad, el deporte, el consumo, la vida 
cotidiana en la ciudad, etc., es decir la paleta temática que el periodismo de interés general trata diariamente. El punto es que en determinadas circunstancias - y el conflicto del campo es una de ellas- es factible pensar que ese destinatario genérico termine por superponerse con el destinatario que ordena el horizonte de destinación de los discursos políticos. Y más aún cuando la opción por un medio u otro se realiza en función de preferencias de corte ideológico.

- el que corresponde al polo de la destinación multiplicado según las relaciones de creencia. Las hipótesis de destinación institucionales están atadas a -al menos- dos variables: por un lado, el imaginario profesional, históricamente constituido; por el otro, por circunstancias coyunturales que, particularmente en el caso de los medios, los coloca en posición de activa intervención sobre el campo político.

- el que corresponde al enunciador, en tanto lugar institucional (Clarín, La Nación, Página/12, Crítica de la Argentina), y no a las diversas figuras que pueda asumir en el discurso.

\section{Reflexiones finales y pasaje al próximo capítulo}

En este capítulo buscamos desarrollar una propuesta analítica para el estudio comparado de los discursos políticos y periodísticos que conforman nuestro corpus, cuya característica genérica es que han sido producidos y puestos a circular en el espacio público bajo condiciones de mediatización. Por eso consideramos que la conceptualización de ese espacio público así recortado, y, de las condiciones productivas que se le imponen a los actores y organizaciones que intervienen en él para confrontar, dialogar, discutir, frente a los públicos era un punto de partida necesario. 
En ese marco quisimos articular problemáticas ciertamente empíricas pero aquí abordadas desde sus implicancias conceptuales: el estatus del público como un tercero que opera como hipótesis reguladora de los discursos sociales, cuya "presencia" (preferimos recurrir a un término más abstracto, desencarnado: influjo) no siempre aparece en marcas discursivas (por ejemplo, en el uso de vocativos y pronombres) porque se lo debe concebir, antes bien, como un interpretante (como un cuerpo indeterminado, empíricamente contrafáctico, pero instituyente pues impone reglas de composición de los propios discursos) que restringe las posibilidades de fundar argumentos en la radical singularidad de un interés o un punto de vista.

El público así concebido es un emergente histórico del proceso de mediatización del espacio público, que desde esta perspectiva (y considerado el recorte que operamos en nuestro objeto de estudio) puede ser pensado como una zona de cohabitación donde muchas veces (y el conflicto del gobierno nacional argentino y las entidades nucleadas en la Mesa de Enlace agropecuario fue una de esas veces) los discursos políticos y los discursos del periodismo disputan, compiten, por la gestión de colectivos, por la conformación de un imaginario político. Por eso planteamos -aunque ciertamente estas afirmaciones sólo se aclararán en los capítulos posteriores- que ese rol regulador del "público" se vuelve un rasgo trascendente cuando se pretende estudiar las disputas por la mediación y la representación en los discursos políticos y periodísticos.

Entendemos que la noción de colectivos definida como una entidad semiótica puede ser un concepto operativo muy útil para abordar este problema (todavía muy abstracto en nuestro planteo). Y que, consecuentemente, el estudio de dispositivos de enunciación, en tanto presupone que en las discursividades públicas se construyen escenas comunicativas (relaciones: con presentes, con 
ausentes, con entidades del imaginario), resulta un complemento necesario para el estudio empírico de esta problemática.

No hemos abordado aquí, sin embargo, una problemática muy importante. Incluso en el recorte que proponemos, y que deja fuera de nuestro alcance fenómenos mediáticos constitutivos del espacio público contemporáneo al conflicto (intervenciones en blogs, redes sociales, en radio, etc.) nuestra perspectiva analítica parece reducirse al estudio de discursos orales (alocuciones presidenciales) o escritos (los discursos de la prensa gráfica). ¿Qué lugar le corresponde, en este cuadro, a la televisión y a la discursividad televisiva, con su complejidad icónica, indicial y simbólica irreductible a un componente linguístico? A lo largo del conflicto del campo la televisión-como medio- fue una arena pública, un escenario central, protagónico. En muchos aspectos ${ }^{107}$, de los cuáles aquí nos interesa directamente uno: los discursos presidenciales fueron, todos, discursos televisados, de modo que esa dimensión no puede estar ausente del análisis. Dedicaremos a este punto un apartado específico en el capítulo 5.

Por lo pronto, los dos capítulos que siguen tendrán una modulación menos abstracta y teórica que los primeros. Buscaremos enmarcar el análisis de los discursos que desarrollaremos en los capítulos 5, 6 y 7 desagregando algunos de los elementos centrales: por una parte, estudiaremos la relación entre el gobierno nacional y el sistema de medios en el período 2003-2008, antes del comienzo del conflicto del campo (capítulo 3); por la otra, realizaremos una descripción cronológica detallada de dicho conflicto, bajo la hipótesis de que puede entenderse como un "litigio político" (capítulo 4).

\footnotetext{
107 Otro aspecto, igualmente importante, es el análisis de las intervenciones de los canales de noticias a lo largo del conflicto del campo.
} 
SEGUNDA PARTE:
ESCENARIOS 


\section{CAPÍTULO 3}

\section{LA INVARIANTE KIRCHNERISTA}

(2003-2008): LA MODALIZACIÓN

LITIGIOSA DE LA MEDIATIZACIÓN POLÍTICA 


\section{CAPÍTULO 3}

\section{LA INVARIANTE KIRCHNERISTA (2003-2008). LA MODALIZACIÓN LITIGIOSA DE LA MEDIATIZACIÓN POLÍTICA}

Introducción: la disputa por los lugares de enunciación pública.

La relación del gobierno de Néstor Kirchner (2003-2007) con los actores más importantes del sistema de medios masivos podría explicarse, en principio, por una suerte de astucia de la razón política: estratégica, instrumentalmente orientada, motivada por cálculos de relaciones de fuerza, asentada en un pragmatismo elástico, despreocupado por la coherencia programática y los principios declamados. Frente a ese tipo de solución explicativa -válida, necesaria- es posible que una "mirada teórica" no pueda sino caer en la interrogación infantil, esa que inserta la extrañeza en el lugar de lo obvio. Es un riesgo: el de quedar siempre por detrás de aquella astucia de la razón política, que suele encontrar un reflejo especular en otra razón, la periodística, atorada a veces por el relato de incidentes secretos y nombres propios ${ }^{108}$; y convencida, también ella, de que todo puede reducirse -"en última instancia"- a una contienda de intereses en la que se definen las condiciones de influencia sobre la voluntad ciudadana. El periodismo como continuación de la política, por otros medios.

En el presente capítulo vamos a interrogar una serie de acontecimientos cuyos detalles -nombres, escenas, situaciones- terminaron por componer el vademécum del anecdotario político cotidiano de los últimos años en Argentina, y

\footnotetext{
${ }^{108}$ Esto no implica, de nuestra parte, un desdén del análisis y la investigación periodística. Apenas si el señalamiento de un límite, que por otra parte nadie puede obligarle a cruzar. Por lo demás, es necesario consignar algunos trabajos periodísticos excelentes que han ayudado a comprender mejor el período, como por ejemplo Mochkofsky (2011) o Sivak (2013).
} 
pretendemos hacerlo desde la perspectiva de la mediatización. Esto significa que buscaremos proponer una lógica explicativa a partir de ciertos postulados previos. En ese marco, lo que nos interesa son las consecuencias del modo en que el kirchnerismo ha gestionado su política de medios, entre el 2003 y el 2008, en el período anterior al conflicto con el sector agropecuario.

Casi desde el momento mismo en que asumió la Presidencia de la Nación, el gobierno de Néstor Kirchner se caracterizó por la decisión intervenir sobre el espacio público mediatizado involucrando a las organizaciones de medios como actores políticos. Sin paradoja, conviven en esa opción lo ineluctable y lo deliberado ${ }^{109}$. La mediatización no es una opción: es el dato constitutivo del espacio público. Hay gestiones básicas de la acción política que no pueden prescindir de los dispositivos mediáticos ni de las instituciones de medios. Sin embargo, de eso no se sigue, por inercia, la decisión de establecer a aquellas instituciones en referentes adversativos y a la cuestión mediática como "la madre de todas las batallas" ${ }^{110}$. Sobre la base de unas condiciones históricosociales que se le imponían, el kirchnerismo generó, también los acontecimientos necesarios para producir el escenario en el cual se terminó moviendo.

Lo que nos proponemos es desarrollar una serie de observaciones sobre la relación entre los medios de comunicación y el gobierno nacional en el período 2003-2008 desde la perspectiva de la mediatización de la política. Si tuviéramos que darle una fórmula a un problema "típico" de la mediatización en el

\footnotetext{
109 Al plantear el diagnóstico en estos términos nos movemos con mucha ambigüedad entre la "semántica natural de la acción" (que identifica la "decisión" como un evento singular, una acción a cargo de un sujeto que ha optado entre alternativas) y una ontología de lo político (que concibe la decisión como instituyente), o mezclando los presupuestos de la política y lo político (De Ípola, 2000). Asumimos el riesgo de esa opción terminológica porque sigue siendo útil para entender algo específico del kirchnerismo, sin dejar de señalar que estamos hablando de un proceso (que, por lo tanto, no se manifiesta como una irrupción sincrónica) y de un espacio de interacciones que impiden reducir sus efectos a un cuerpo de acciones unilaterales.

${ }^{110}$ La frase corresponde a Gabriel Mariotto, quien la pronunció en abril de 2008, cuando en pleno conflicto con el sector agropecuario Cristina Fernández lo nombró interventor del COMFER, como indicio claro de un cambio en sus políticas de comunicación.
} 
kirchnerismo, diríamos -y esta es nuestra hipótesis- que se trata de la disputa por y con los "discursos intermediarios", y en particular, con el discurso intermediario más importante desde el punto de vista de la interlocución colectiva: el del periodismo en los medios. Esa disputa es, para nosotros, una invariante del kirchnerismo. Y, por las formas que adoptó, hablamos de modalización ${ }^{111}$ litigiosa de la mediatización política: el intento de extender la pregunta que moviliza a todo vínculo delegativo (¿en nombre de quién, de qué otros agentes nos están hablando?) al campo de los medios.

Pero, ¿por qué no explicar la conflictividad en simples términos de luchas de poder, relaciones de fuerza, disputa por intereses? Porque lo que resultó actualizado por el cuestionamiento al rol y la legitimidad del periodismo (que es una invariante de los discursos de Néstor Kirchner y Cristina Fernández, pero que también es un tópico importante en el discurso kirchnerista más allá de los discursos presidenciales y, también, más allá de Clarín) es un conflicto inherente a la mediatización, concebida en este punto como proceso de largo plazo: la consolidación del periodismo como discurso intermediario y de los medios como escenario inevitable de circulación de la palabra pública, sea política o no.

Esa modalización se puede explicar tanto por las tácticas elegidas para la comunicación política del gobierno como en las declaraciones públicas de los ex presidentes. La renuencia a conceder entrevistas, la predilección por actos públicos sin conferencias de prensa (consagrado por un funcionario del gobierno de NK como "el atril asesino), y más tarde, ya en la presidencia de Cristina Fernández, la utilización regular, normalizada, de la Cadena Nacional, se dejan

\footnotetext{
111 La noción de "modalización" ha sido ampliamente desarrollada por la teoría lingüística y por las teorías de la enunciación (Benveniste, 2004; Kerbrat Orecchioni, 1986; Maingueneau, 1980). La modalización es el conjunto de operaciones que van construyendo, en el discurso, la relación del enunciador con el "contenido", y que delinean la "subjetividad" (en el sentido de la actitud del enunciador hacia aquello que enuncia). En nuestro caso, recurrimos al término en un sentido genérico, para señalar cómo los gobiernos de NK y CFK fueron definiendo su relación pública con los medios de comunicación, asumiendo que esa relación no es un hecho electivo, menos para un presidente.
} 
entender como el intento por evadir la interacción directa, en público, con el periodismo y los medios que eventualmente pudieran incomodar con preguntas a los mandatarios. En definitiva, más allá de las valoraciones republicanas, cada una de esas opciones muestra la decisión deliberada y sostenida en el tiempo, en ese sentido estratégica, de menoscabar el rol intermediario del periodismo.

Luego, la constatación de que la abrumadora mayoría de las referencias públicas que, primero NK, y luego CFK, hicieron sobre los medios y el periodismo fueron críticas, cuestionamientos. De esos cuestionamientos, hay un tópico recurrente en los discursos de ambos líderes, referidos a la disputa por la representación y a la legitimidad de que está investida la toma pública de la palabra. Dos citas, correspondientes a discursos pronunciados por uno y otra, en el mismo año 2005, ilustran bien este tópico, en especial porque son reveladoras, por lo transparentes:

"El único sector de poder que va permanentemente a elecciones es la política; los poderes económicos no van a elecciones, el poder mediático no va a elecciones, sí hablan de todo pero no van a elecciones, el poder económico también opina sobre todo pero es el poder económico, tampoco se elige y los que permanentemente tenemos que ir a medir nuestra representatividad con la sociedad, somos nosotros". (Néstor Kirchner, Reunión con los integrantes de la Conferencia Permanente de los Partidos Políticos en América Latina, el $31 / 05 / 2005)$

"Ahora hay dos grandes sistemas de representación: el político y el de los grandes intereses económicos, a través de los medios de comunicación. Por eso, la tan mentada independencia de la prensa es de la política, no de esos grandes intereses" (Cristina Fernández, Seminario de comunicación política y marketing gubernamental "Experiencias exitosas: gobiernos que comunican y su relación con la prensa", Universidad George Washington. Publicado por diario La Nación, 17/09/2005).

No pretendemos proceder por abuso de generalización: estos discursos, estas afirmaciones, dicen lo que dicen en un momento determinado, en circunstancias determinadas. ¿Pueden interpretarse, sin embargo, como indicadores de una concepción, de una ideología, que subtiende las acciones políticas del kirchnerismo en relación a los medios? 
Se han ensayado explicaciones de diferente tipo para otorgar un fundamento no circunstancial a la relación regularmente tensionada entre los gobiernos kirchneristas y los medios de comunicación, en particular en el nivel presidencial.

Desde el periodismo, se han propuesto explicaciones formuladas en una fraseología psicológica: los Kirchner tenían una “obsesión” con la prensa, porque su lógica de gobernar se apoyaba la siguiente idea rectora: gobernar es editar la realidad (Fernández Díaz, 2005; Lanata, 2008; Zunino, 2009) ${ }^{112}$. Así lo relataba Jorge Fernández Díaz en el diario La Nación en enero de 2005:

Todas las mañanas, alrededor de las 8 , el Presidente y su jefe de Gabinete se sientan a leer juntos los diarios nacionales y extranjeros. Es un ritual inquietante que suele durar una hora y que está lleno de comentarios feroces, párrafos recitados en voz alta, intercambio de elucubraciones, rabietas íntimas y nerviosas llamadas telefónicas para pedir a un funcionario una explicación o para darle a un ministro una reprimenda. Néstor Kirchner es temible cuando la realidad publicada lo contradice. Tiene una habilidad extraordinaria para detectar las fuentes anónimas echándole un solo vistazo a una nota y posee una extraña paranoia que convierte la casualidad, el error o el simple ejercicio de la verdad informativa en fantasiosas conspiraciones ${ }^{113}$.

Como complemento, hay declaraciones de periodistas que imputaban a un supuesto provincialismo del matrimonio el trato desconfiado con los medios nacionales (ver, en particular, los comentarios relevados en D'Amico y De Diego, 2009). Si nos atenemos a esta variante explicativa, los argumentos desplegados en el espacio público serían sortilegios retóricos: una racionalización instrumental de impulsos esencialmente autoritarios contra la libertad de prensa para legitimar aquella obsesión y conjurar aquella inseguridad.

\footnotetext{
112 Esta "máxima", así escrita, nos resulta ridícula, pero decidimos consignarla porque no sólo es recurrente en varios textos, sino que se ha extendido como una lógica explicativa verosímil, reforzada desde el 2008 bajo la denominada lucha por el "relato".

113 "Cuando Kirchner no puede editar la realidad", por Jorge Fernández Díaz, diario La Nación, 09/01/2005.
} 
Otra clave de interpretación la ofrecen algunos analistas para quienes Kirchner necesitó, desde el inicio de su mandato, de una buena performance mediática, que supliera, al menos en una primera etapa, su escasa inserción territorial por un lado, y su escaso conocimiento público, por el otro. (Torre, 2003; Sarlo, 2011). Una vez que la construcción política del Frente para la Victoria se consolidó, en particular durante el 2005, se manifestó con más claridad la crítica a algunos medios. En este sentido, algunos investigadores especializados en la relación medios/política sostienen que la confrontación pública se explica, sobre todo, como lógica de construcción política: la necesidad de sostener una relación adversativa para definir una frontera de identidad (Vincent, 2011 y 2013).

Un tercer tipo de explicación se acerca más a la pregunta formulada. Silvio Waisbord plantea, en su libro Vox Populista, que las políticas de comunicación del kirchnerismo se explican por su adscripción populista. El “populismo mediático" ${ }^{114}$ consiste en una

"visión estatista de los sistemas de medios destinada a fortalecer el poder comunicacional de la presidencia y fundada en la lógica amigo/enemigo, como principio organizador. Esta postura es contraria al fortalecimiento de los medios y del periodismo como instituciones autónomas para el control de la acción presidencial y la mediación de la comunicación ciudadana”. (Waisbord, 2013: 29).

El populismo se caracterizaría entonces por una concepción en la que se destacan tres ideas matrices (2013: 31-40): el patrimonialismo mediático ("como dominio de la política de intereses particulares y debilidad de la dominación legal); por el instrumentalismo ("visión esencialista, en cuanto su premisa es la

\footnotetext{
${ }^{114}$ Este término indica el sesgo analítico de Waisbord, que explícitamente se propone estudiar la comunicación política de los populismos latinoamericanos, y no otras facetas de estos gobiernos (economía, trabajo, etc.). La definición que ofrece se resuelve más claramente por oposición: dice que no le atribuye un sentido normativo ni lo identifica con el caudillismo, la demagogia o el personalismo en la comunicación. El populismo se definiría, entonces, por "una forma particular de interpelar al pueblo" y por una visión binaria de la política; el populismo mediático, se define entonces por su concepción de los medios. (Waisbord, 2013: 24-25).
} 
existencia de intereses sociales previamente constituidos") y una visión materialista (que "refleja premisas del pensamiento latinoamericano en ciencias de la comunicación y de la crítica marxista de la economía política de los medios") ${ }^{115}$.

El libro de Waisbord es del año 2013: podemos decir que ha sido escrito con el “hecho populista” consumado. Por eso, mientras que su análisis descriptivo es verosímil su lógica explicativa encierra una trampa: habría que suponer que el devenir de un caso particular de populismo mediático (por caso, el del kirchnerismo en Argentina, entre 2003 y 2013) estaba ya anunciado en la conformación ideológica de sus líderes. Desde nuestro punto de vista, independientemente del acuerdo o el desacuerdo en la caracterización del kirchnerismo como populismo, la derivación explicativa que propone Waisbord (exponiendo primero una matriz ideológica que explica las políticas adoptadas) es en realidad un recurso ex post-facto: se vuelve verosímil porque su reflexión se monta en sucesos conocidos, pero no puede en ningún caso mostrar la relación de causalidad que sostiene su argumento.

Encontramos más satisfactoria la hipótesis propuesta Philip Kitzberger en un artículo titulado The media activism of Latin America's Leftist Government: Does ideology matter? (2010). El autor, en este estudio comparativo, prefiere la denominación de giro a la izquierda para designar a los gobiernos de Hugo Chavez en Venezuela, Lula da Silva en Brasil, Néstor Kirchner y Cristina Fernández en Argentina, Evo Morales en Bolivia y Rafael Correa en Ecuador. En su consideración, el componente “ideológico” común no explica, por sí solo, las similitudes en el tratamiento de la cuestión mediática: “las miradas comunes no

\footnotetext{
${ }^{115}$ Waisbord explica que estas tres ideas provienen del marxismo y de la economía política de la comunicación. Sin embargo, es interesante ver cómo Rosanvallon analiza la tensión entre el Segundo Imperio y la prensa en la Francia de mitad del siglo XIX. "Los bonapartistas, dice el autor, se convirtieron en los denunciadores implacables de la prensa como estructura capitalista" (Rosanvallon, 2008: 115).
} 
derivan de una esencia izquierdista compartida sino de los legados del neoliberalismo en América Latina. En el campo mediático, la “expansión, concentración y comercialización le dieron a las instituciones mediáticas una nueva relevancia en la vida política y social” (2010: 7). El vínculo directo de las empresas mediáticas con grupos económicos y las élites, expusieron a los medios como instrumentos del poder. En aquellos países cuyos gobiernos asumen una identidad o una agenda política de izquierda, esta visión compartida sobre los medios de comunicación penetró estrategias de gobierno, prácticas y agendas políticas.

Para Kitzberger, entonces, antes que la imputación a una ideología hay que prestar atención a las condiciones específicas de gobernabilidad, al menos en el nivel que concierne al espacio público, y al poder configurador de las empresas mediáticas consolidadas como conglomerados con intereses extrasectoriales. Un repaso de las investigaciones (en su mayoría, de índole periodística) sobre las relaciones entre los sucesivos presidentes argentinos desde 1983 y las empresas de medios (Waisbord, 1993; Blaustein, 2013; Sivak, 2015) nos habilita a suponer que la propia experiencia personal, el roce con las instancias de máximo nivel, la experiencia de pares sometidos a esas mismas situaciones, deben computarse como condiciones que definen -en combinación con otros elementos- algunas decisiones sobre cómo lidiar con el periodismo y cómo encarar una política de medios. Para sintetizarlo: se da una relación presupuesta entre buen trato mediático y estabilidad política. Como bien lo sintetizó Martín Sivak (2015:394):

[Néstor Kirchner] Continuaba la larga saga de los presidentes argentinos que desde la recuperación de la democracia le contestaban a esa primera plana, trataban de influir sobre sus contenidos, negociaban más o menos lugar en ella. La portada de Clarín era el fetiche de los políticos de las grandes ligas que asignaban a la prensa un poder importante. Aunque podían pelear por un sueltito, o el color de la luz del semáforo que juzgaba acciones o declaraciones, las tapas se mantuvieron como lo más importante. Clarín era la portada para extraños y propios. 
Agreguemos, por nuestra parte, un punto usualmente desatendido: las restricciones que la mediatización impone al ejercicio del liderazgo político y de los parámetros institucionales de sistemas políticos propensos al presidencialismo, como en Argentina, tanto para valorar su significación como para evitar la mirada que convierte a ciertas acciones en una anomalía institucional. Al respecto, Ludger Helms (2008) explica que mientras algunos líderes políticos pueden usar a los medios como instrumentos para sus objetivos (dependiendo de factores externos a la mera habilidad o pericia comunicacional), hay mayor evidencia, a partir de la investigación comparada ${ }^{116}$, de que los medios se suman a los múltiples constreñimientos ya existentes sobre los liderazgo ejecutivos en las democracias contemporáneas, haciendo el ejercicio del liderazgo más difícil que en el pasado.

\subsection{Política y medios en el kirchnerismo (2003-2008): políticas de medios y comunicación política}

Teniendo como referencia los interrogantes planteados, queremos situar nuestra investigación en relación a la bibliografía previa que ha estudiado la relación entre el Gobierno y los medios de comunicación en el período 2003-2008. Nos ocuparemos de dos dimensiones entre las que suelen presuponerse determinaciones sin que por eso los pasajes explicativos entre una y otra, a menudo implícitos, suelan ofrecer resultados satisfactorios.

Por un lado, la política de comunicación, cuya preocupación central son "las relaciones (particularmente las relaciones de poder) que constituyen la producción, distribución y el consumo de bienes simbólicos” (Mastrini y Bolaño, 2002: 43); por el otro, la comunicación política, que centra su atención sobre los

\footnotetext{
${ }^{116}$ Helms expone ejemplos de EE.UU y de Europa Occidental.
} 
problemas públicos y los usos de los dispositivos mediáticos en las relaciones entre las instituciones políticas y las instituciones de medios (Wolton, 1998: 110).

El principal desafío será equilibrar el juego de determinaciones que, en cada caso, se consideran relevantes para explicar los comportamientos de las instituciones de medios, por un lado, y del propio Gobierno, por el otro, a lo largo del conflicto, aspecto que trataremos con detalle en los capítulos 6 y 7 de nuestra tesis.

La aclaración es importante: el recorte temporal de nuestro trabajo coincide con el inicio del conflicto en Marzo de 2008 y con su cierre formal, en julio de ese año, cuando la Resolución 125 fue rechazada en el Senado con el voto de desempate del entonces vicepresidente Julio Cleto Cobos. Situados en ese presente, nos vemos obligados a maniobrar entre dos ejes de explicaciones concurrentes:

- aquellas que pueden identificarse como condicionantes previos (históricos, económicos, políticos);

- y aquellas que irrumpen según la lógica misma del acontecimiento y que no pueden consignarse, mecánicamente, como efectos de variables previas, o que no se dejan explicar por ellas, a no ser introduciendo explicaciones ex post facto, inválidas para el horizonte temporal del conflicto.

Para eso, vamos a privilegiar la reconstrucción de los factores que en la etapa inmediatamente anterior al inicio del enfrentamiento fueron delineando una disputa institucional por los lugares legítimos de mediación pública y representación del "público", lo que significa que rechazamos, a priori, una lectura orientada a encontrar, en las superficies discursivas, las réplicas dóciles de los intereses en pugna sin atender a otro tipo de determinaciones, como las 
que operan en el horizonte de recepción de los medios, sus contratos de lectura, sus destinatarios, etc., y otras que operan como restricciones del espacio público.

La exposición estará ordenada en tres partes:

- en primer lugar, buscamos reconstruir el estado de situación en la relación Gobierno/medios hasta el momento previo al conflicto, ya que el período abarcado por el enfrentamiento terminó por trastocar -esto sólo pudimos saberlo después- la lógica que había guiado esa relación;

- en el segundo, reflexionaremos sobre la política de comunicación kirchnerismo, haciendo especial hincapié las decisiones, expresadas en decretos o modificaciones legislativas, que apuntaron a la economía política del sector y al uso de la publicidad oficial en el período 20032008;

- en tercer lugar, vamos a reflexionar sobre la comunicación política del gobierno de Néstor Kirchner, en particular el modo en que se fue definiendo la mediatización de la figura presidencial y los modos en que el ex Presidente tematizó públicamente su propia relación con el periodismo.

\subsection{1. ¿La gran contradicción?}

Considerando el ámbito circunscripto de las relaciones medios/política, el 2008 fue un año de aceleración, que, según se mire, fracturó una lógica evolutiva o bien profundizó una línea maestra ya definida. 0 tal vez algo a mitad de camino, como lo ha expresado Novaro (2011:136), pues el conflicto inaugurado por la resolución 125 habría acentuado un giro que ya se venía gestando:

Con todo, aunque esta crisis dio paso a la autoidentificación del kirchnerismo como sujeto del "gobierno nacional y popular", profundizando la polarización y el 
abroquelamiento ideológico, no los inició: ellos empezaron antes y fueron fruto del agotamiento del ciclo de acumulación con recursos prestado, y el pasaje a uno nuevo, signados por la autonomización creciente de contenidos e instrumentos.

Las investigaciones y registros periodísticos que han reconstruido los entretelones de la ruptura del Gobierno con el Grupo Clarín (entre otras, Monchofsky, 2011; o Sivak, 2015) indican que la ruptura se debió a la negativa de Kirchner de habilitar la compra de Telecom Argentina por parte del Grupo, que, como respuesta, decidió informar negativamente sobre la actuación del Gobierno durante el conflicto. Con el ingreso a Telecom, el Grupo pretendía cerrar una fase de acumulación en el mercado de telecomunicaciones a través del servicio de tripleplay y de telefonía celular ${ }^{117}$.

Lo cierto es que inclusive varios años después de la ruptura entre el Grupo Clarín y el Gobierno, esa pregunta seguía siendo difícil de responder (seguramente porque la respuesta es una combinación irreductible a sus componentes singulares). A pesar de su extensión, vale la pena transcribir estas líneas publicadas por Horacio Verbitsky en Página/ 12 a propósito de los encuentros que el matrimonio Kirchner mantuvo, en los tiempos de concordia, con el CEO del Grupo Clarín:

"Ni Magnetto, ni Alberto Fernández, ni los dos presidentes Kirchner explicaron qué temas se tocaban en esas comidas develadas por Cristina. Es una lástima, porque conocerlo ayudaría a entender las cuestiones centrales de la política argentina actual. ¿Cómo se explica que el mismo sector político que en diciembre de 2007 prorrogó por diez años las licencias de radios y televisoras, llegara a la ruptura total en 2008/2009, con las referencias constantes en el discurso oficial a Magnetto y el "qué te pasa Clarín", las inspecciones

\footnotetext{
117 Cuando Telefónica de España adquirió una porción accionaria de Telecom Italia, la Comisión de Defensa de la Competencia argentina abrió una investigación para determinar si la firma española configuraba un monopolio en el mercado local. Si bien la Comisión dictaminó la obligación de Telecom Italia de desprenderse de las acciones de su filial local, las negociaciones estaban en marcha desde 2007. Según Maximiliano Montenegro (2011: 106-107) Kirchner y Magnetto siguieron negociando la venta de las acciones de Telecom argentina a Clarín inclusive meses después de finalizado el conflicto con el sector agropecuario.
} 
impositivas a empresas del grupo y la denuncia por lavado de dinero en el lanzamiento de sus acciones en la bolsa de Londres, el Fútbol para Todos, la investigación sobre el origen de Marcela y Felipe y la ley de servicios de comunicación audiovisual? En la Casa Rosada se afirma que Magnetto trató de convencer a Kirchner de que Cristina no podía ser candidata a la presidencia, que pidió ayuda oficial para quedarse con Telecom Argentina, que Cristina se opuso y que el Grupo se lanzó a operar para desleír su gobierno. Fuentes de la conducción del Grupo replican que fue Kirchner quien les propuso que se hicieran cargo de la filial argentina de Telecom Italia, y que Magnetto se rehusó por desconfianza en el gobierno"118.

Como sea, durante el año 2008, el Gobierno produjo dos desplazamientos con los que recompuso las coordenadas que había utilizado hasta entonces para interpretar, en el espacio público político, el devenir de la política, y esto tuvo efectos definitivos sobre el sistema mediático. Por un lado, instituyó como adversario al Grupo Clarín, al que transformó en el centro organizador del arco opositor, lo reubicó en la saga de la historia argentina siempre del lado de las tradiciones anti-populares e identificó un nombre propio (Magnetto), al que podía endosar la conducción de una estrategia opositora y mediante el que pudo producir un efecto de encarnación de un adversario que de otra manera tenía, para los no iniciados, una entidad fantasmática, heterogénea y diseminada, no fácilmente identificable con una cabeza.

Por otro lado, decidió avanzar en la promulgación de la Ley de Servicios de Comunicación Audiovisual (sancionada en octubre de 2009), medida que había tenido en gateras desde 2003, pero que nunca había sido presentada como prioridad política ${ }^{119}$. Ambos desplazamientos pueden concebirse sin dificultades como efectos del conflicto con el sector agropecuario, al punto que, hasta inicios

\footnotetext{
${ }^{118}$ Horacio Verbitsky, Página/12, 8/08/2010. Negritas nuestras

119 A lo sumo, aparecía como un rumor, como en Julio de 2006 cuando el Gobierno envió dos proyectos de ley al Congreso y algunos medios, en particular La Nación, se opusieron fervientemente. En ese entonces, pudo leerse que Kirchner estaba preparando "el terreno para instalar el debate sobre una nueva ley de radiodifusión que limitaría el alcance de los multimedios. El proyecto se analiza también en el Congreso". "Cómo funciona la red que mantiene alerta al Presidente", La Nación, 8 de Julio de 2006.
} 
de 2008, hubieran sido horizontes impensables, o no figuraban como movimientos previsibles en el panorama político.

Luego de 2008, al menos en lo que concierne a las relaciones entre sistema político/sistema de medios, nada puede entenderse si no es por referencia a esas decisiones.

Estos dos desplazamientos produjeron un efecto de contraste entre dos épocas. La primera, circunscripta entre 2003 a 2008, está marcada por una política transigente y de connivencia con los grandes actores empresariales y corporativos de la comunicación, y por lo tanto conservadora del status quo del mapa mediático heredado; y la segunda - que se fue desplegando desde el 2008que se ofrece como un reverso de la anterior.

En ese mismo período, sin embargo, el kirchnerismo había protagonizado una serie de confrontaciones públicas con el periodismo, y el propio presidente Kirchner había incluido a "los medios" como actores en sus discursos, incorporándolos como protagonistas de la disputa política, en el mismo nivel que otras instituciones $^{120}$.

Estos episodios, sumado a la tendencia de Kirchner a evitar la intermediación periodística (pero no, claro, la del dispositivo mediático) como estrategia de mediatización de su figura, generó la percepción inmediata de un rasgo novedoso

\footnotetext{
${ }^{120}$ Por mencionar algunas, que volveremos a mencionar: en agosto de 2005, Kirchner le dedicó cuatro discursos consecutivos a discutir con una nota del diario La Nación daba a entender que muchos de los concurrentes a los actos oficiales eran personas obligadas por los punteros peronistas a cambio de un plan social u otros beneficios módicos. Según Lucía Vicent (2013: 27) el diario no recibió pasivamente el embate presidencial, sino que asumió su rol de actor político, defendiéndose y atacando a su contrincante con notas informativas, columnas de opinión y editoriales, que en su totalidad fueron explícitas sobre la posición que el diario asumía en relación con el gobierno de Kirchner. Y en septiembre de 2006, en ocasión del debate legislativo sobre la llamada "ley de superpoderes", la entonces senadora Cristina Fernández cuestionó en varias intervenciones al diario La Nación y a varios de sus periodistas.
} 
-y negativo- por parte de los propios periodistas, entre los que sobresale la “obsesión” presidencial por las publicaciones periodísticas y un consecuente deseo de "editar la realidad".

Tenemos, pues, un cuadro interesante: mientras que los investigadores de la economía política de la comunicación insistieron en la continuidad conservadora de las políticas estatales en el campo de la comunicación durante el período 2003-2007, los profesionales del medio, sumergidos en las fricciones cotidianas con los agentes gubernamentales (cuando no con el propio Kirchner), destacaban los rasgos revulsivos del modo en que el kirchnerismo administraba su relación con los medios y los periodistas ${ }^{121}$.

De otro modo: mientras que, hasta principios de 2008 inclusive, ${ }^{122}$ las medidas políticas (regulaciones, distribución de publicidad, prioridad en la cobertura de acontecimientos) hacia el sistema de medios en general, y hacia el grupo Clarín en particular, habían seguido una lógica transaccional (Marino, 2005; O’Donnell, 2007; Mochofsky, 2011), de “acuerdos tácticos” (Kitzberger, 2010), en ese mismo lapso el Gobierno, y en especial Néstor Kirchner, había ubicado al periodismo como un tema recurrente en sus discursos públicos, ya sea cuestionando su función "mediadora" y la impostura prescindente, denunciando simpatías encubiertas o directamente el activismo político de las instituciones de medios, criticando la presión por marcar temas de agenda (Vincent, 2011).

En palabras de Guillermo Mastrini (2008:89), la "gran contradicción" de la política de medios del primer kirchnerismo es que "cuando se analiza el conjunto

${ }^{121}$ Ver Zunino (2009), Cremonte (2007), D’Amicco y de Diego (2009).

122 Vale recordar que en Febrero de 2008, un mes antes del inicio del conflicto con el sector agropecuario, Kirchner organizó un encuentro con Roberto Lavagna en la Quinta de Olivos, en el que formalizaban un acuerdo para la reorganización del PJ, y que el ya entonces ex presidente decidió darle la primicia a Clarín. Interesante, como muestra de las relaciones que mantenía el Grupo con Kirchner en ese entonces, es la nota publicada por Jorge Fontevecchia en Perfil, titulada: "El abrazo del oso" (Fontevechhia, 10/02/2008). 
de políticas de comunicación no se aprecia la confrontación que aparece a nivel de la agenda informativa". Como concluía Mastrini (2008: 94) en aquel artículo:

En términos generales, podemos señalar que los medios privados tuvieron un importante crecimiento durante el gobierno de Néstor Kirchner. La recuperación de la economía brindó una excelente oportunidad para que las principales corporaciones mediáticas se recuperaran luego de estar al borde del abismo en el año 2002. Si bien existieron confrontaciones con el ejecutivo por la construcción de un discurso cotidiano, no hay duda que las políticas de comunicación del gobierno fortalecieron su posición dominante

Pues bien, quisiéramos detenernos en aquella contradicción, utilizarla como recurso expositivo.

En efecto, frente a ella hay dos actitudes posibles: aceptarla como una evidencia, lo que lleva a concebir las confrontaciones públicas como meras apariencias, como el reverso inocuo de las luchas de intereses; o bien cuestionarla en tanto que contradicción, repensarla como la convivencia tensionada de dos modos de intervenir sobre el mundo mediático, simultáneas pero paralelas, ya que nos muestran dos dimensiones que no conviene analizar según la lógica de la determinación mecánica.

Mientras que la primera opción se detiene, necesariamente, frente a lo que considera incomprensible (¿por qué, habiendo operado con una lógica transigente en las mesas de negociaciones, el Gobierno insistió en disputar las agendas mediáticas?), la segunda opción nos permite identificar ciertos rasgos (quizás una cierta cosmovisión política) de los cuales el kirchnerismo se ha mostrado un portador coherente.

De modo que aquel contraste de épocas debe ser compensado, en el análisis, por lo que consideramos es una invariante en la relación del Gobierno con los medios de comunicación masiva desde la asunción de Néstor Kirchner en 2003: 
la disputa institucional por la legitimidad de los lugares de mediación pública entre colectivos sociales. Esa disputa está hecha de confrontaciones episódicas pero reveladoras de la concepción que, al menos el ex presidente, tenía del rol que juegan las instituciones mediáticas, o bien el sistema de medios, en los regímenes democráticos.

El desafío analítico, en fin, parece ser el de cómo realizar el pasaje entre un nivel, el de la política de comunicación, centrado en escalas estructurales, preocupado por las relaciones de propiedad, los flujos de capital, la gestión de relaciones comerciales y políticas como reaseguro del dominio y la supervivencia en el poder, que por lógica tiene prevalencia ya que aquí se definen las condiciones de posibilidad de la existencia de muchos medios; y otro nivel, el de la comunicación política, que debe detenerse sobre las superficies mediáticas, por lo tanto, en el nivel de la discursividad; pero no para contrastar las diferencias entre lo que los actores hacen y lo que los actores dicen sino para reconstruir esas configuraciones de sentido, ya que son el único modo de acceso a ciertas lógicas de funcionamiento de las relaciones políticas.

Lo que haremos a continuación será contrastar estos dos niveles analíticos de la relación Gobierno/Medios: a) el de la política de comunicación, en tanto conjunto de acciones del Estado en relación al sector, la regulación, el control, gestión medios públicos, manejos de la información pública hasta el 2008; y b) el del comportamiento del gobierno en las condiciones de mediatización que se le impusieron, con especial atención a las modalidades de comunicación política de NK.

3.2. Políticas de comunicación: legislación y distribución de la pauta oficial. 
Philip Kitzberger ha descripto la política de medios del Gobierno nacional en la etapa que va de 2003 a 2008 como un juego de disposiciones pragmáticas hacia los intereses sectoriales y de confrontaciones discursivas con los medios más importantes. En esto coincide el ya citado Mastrini (2008: 81) para quien, más allá de las disputas discursivas, "en el caso de las políticas de comunicación fueron más las continuidades y los acuerdos con las corporaciones de medios, que las modificaciones a favor de mayor democracia comunicacional”.

En una segunda etapa, que se abre durante el conflicto con el sector agropecuario y se consolida a lo largo de 2009, "el discurso crítico se transfiguró en radicalización contrahegemónica y reformista” (Kitzberger, 2011:175). El autor cuestiona los análisis que sobre-enfatizan la motivación instrumental de esa radicalización en la disputa por la Ley de Servicios de Comunicación Audiovisual. En cambio, considera que fueron necesarias ciertas condiciones de posibilidad sin las cuales la sola vocación de virar por conveniencia hubiera sido estéril:

El sostener una ofensiva contrahegemónica -entendida como intento sistemático de cuestionar públicamente el lugar de enunciación de los grandes medios privados- ha sido posible en virtud de la disponibilidad de una comunidad epistémica conformada por una red de instituciones de la sociedad civil, universidades, movimientos sociales, radialistas comunitarios, intelectuales, activistas y periodistas críticos (Kitzberger, 2011: 183).

En rigor, lo más probable es que se trate de una combinación equilibrada de ambas razones. De hecho, el impulso a la Ley de Servicios de Comunicación Audiovisual se manifestó, en primer lugar, a través de la renovación de las autoridades del COMFER en abril de 2008, empezando por el desplazamiento de Julio Bárbaro y la designación de Gabriel Oscar Mariotto (un licenciado en Comunicación y decano de la Facultad de Ciencias Sociales de la Universidad Nacional de Lomas de Zamora, con larga experiencia militante en el campo de la comunicación popular) como nuevo interventor. Aún más, días después anunciar 
estos cambios, y en el marco de la primera tregua del conflicto del campo, CFK se reunió con el entonces decano de la Facultad de Ciencias Sociales de la UBA, Federico Schuster, para discutir una resolución que, en los días previos, había rubricado el Consejo Académico de dicha institución con fuertes críticas al tratamiento mediático del conflicto ${ }^{123}$. Luego de esa reunión, CFK realizó un acto para presentar un plan de viviendas y en su discurso dijo: "Yo creo que los argentinos tenemos que reflexionar sobre quiénes son los titulares de la libertad de prensa: si son las grandes empresas de comunicación o es el ciudadano y la ciudadana de a pie".

Días después, el secretario de Medios, Enrique Albistur y el flamante interventor del COMFER se reunieron con la Multisectorial por la Radiodifusión Democrática para reactivar un Observatorio de Medios. Y el propio Mariotto, en una entrevista al diario Crítica de la Argentina, sostenía que "el Estado debe revisar el tema de Papel Prensa y su origen, que arranca con Lanusse y se instala con Videla", y luego declaraba que, para él, "La ley de radiodifusión es la madre de todas las batallas"124

\subsubsection{La lógica continuista.}

Pero hasta el 2008 el Gobierno siguió una política de comunicación que, en sus líneas maestras, había reforzado las características del mapa de medios heredado: alta incidencia del capital extranjero e importantes sectores sociales en particular, aquellos sin fines de lucro, como organizaciones populares de base o universidades- excluidos de la posibilidad de tener licencias de radiodifusión; gran parte del arco de la sociedad civil relegada a recibir información y

\footnotetext{
${ }^{123}$ En esa declaración, el Consejo Directivo de Sociales decía, entre otras cosas, que "algunos periodistas vertieron opiniones que llenan de vergüenza e indignación por sus contenidos clasistas y racistas".

124 "El Estado debe tener mayoría en Papel Prensa", entrevista de Diego Schurman. Crítica de la Argentina, 14 de abril de 2008.
} 
consumirla como mercancía, incapacitada de participar en los procesos de planificación de las políticas y de la gestión de los medios a partir de la exigencia de poseer fin de lucro para acceder a la licencia de un medio de radiodifusión, que implicaba la exclusión de las cooperativas ${ }^{125}$ y de muchos otros actores; un marco legal autoritario y centralista (por ejemplo, la intervención del COMFER definida directamente por el Ejecutivo).

Según explica Santiago Marino (2005): “Durante el gobierno de Kirchner se tomaron medidas que alteraron el marco legal que rige el sistema, sin que esto implique (...) una alteración de las negativas características de exclusión de ciertos sectores, altos niveles de concentración de la propiedad, elevados índices de participación del capital extranjero y escaso poder de control del organismo pertinente".

En términos generales, las críticas más extendidas a la gestión del sistema de medios durante el gobierno de Néstor Kirchner señalan la continuidad de las condiciones estructurales del sector respecto de las décadas anteriores, tanto en la intervención sobre las relaciones de propiedad de los medios concesionados durante el menemismo, como en la administración y gestión del Sistema Nacional de Medios Públicos ${ }^{126}$, la intervención del Comité Federal de Radiodifusión (COMFER) y en la distribución de la publicidad oficial. Solo a fines de ejemplificar este diagnóstico vamos a indicar una serie de hechos vinculados, por un lado, con

\footnotetext{
${ }^{125}$ Esta imposibilidad regía según el artículo 45 de la Ley de Radiodifusión sancionada durante la Dictadura. En 2003 la Corte Suprema declaró la inconstitucionalidad del apartado de este artículo que impedía a organizaciones sin fines de lucro prestar servicio de televisión por cable y operar frecuencias de radio de alcance limitado, pero recién en 2005 el Senado sancionó ley 26.053, que modifica el artículo 45. Sin embargo, en la redacción final las cooperativas que ya brindaran servicios públicos quedaron excluidas de la posibilidad de acceder a licencias de radiodifusión bajo argumento de evitar prácticas monopólicas. En los hechos, se trató de una concesión a las corporaciones de medios, ya que las cooperativas eran las únicas entidades que estaban en condiciones de invertir en las escalas que exige la televisión por cable y por lo tanto de competir con las empresas ya consolidadas.

${ }_{126}$ Que había sido creado durante la presidencia de Fernando De la Rúa, integrando Canal 7, Radio Nacional y sus repetidoras y el servicio Télam.
} 
modificaciones a la legislación vigente en materia de regulación propietaria del mercado mediático, y por el otro, en relación a las discusiones sobre la distribución de la pauta oficial.

Entre las medidas adoptadas por el Ejecutivo que beneficiaron a los grupos empresarios mediáticos se destacan las siguientes:

- El 18 de junio de 2003 (siete días antes de que se cumpliera el primer mes del nuevo gobierno) el poder legislativo sancionó la Ley n. 25.750 de “Preservación de Bienes y Patrimonios Culturales", para evitar que las compañías de medios fuertemente endeudadas en el exterior fuesen absorbidas por sus acreedores.

- El 30 de septiembre de 2004, por resolución 1226/04 del COMFER, se extendió titularidad de las licencias a Canal 13, y el 17 de Diciembre del mismo año a Canal 11. En ambos casos hasta el 2015. Sobre esta medida, Al respecto, decían Mastrini y Becerra (2006): “El Poder Ejecutivo (...) no vaciló en congraciarse con todos los grupos de comunicación a través de una dadivosa extensión de las licencias de radio y televisión sin exigir, de modo público, contraprestaciones que permitan mejorar el servicio y que habiliten el acceso de los usuarios al control de éste. La remanida "batalla por el rating" televisivo por parte de las dos emisoras líderes en audiencia, por la que se burla cotidianamente el compromiso de programación anunciado por las propias emisoras, es sólo una pequeña demostración de la anomia instalada en el sector".

- En mayo de 2005, por el decreto presidencial 527/05, se dispuso la suspensión del conteo del plazo de licencias de empresas de radiodifusión por 10 años, con lo cual cinco meses después de la renovación de 2004, las licencias quedaron automáticamente extendidas por un total de 20 
años ${ }^{127}$. Esta última medida favoreció a todos los licenciatarios, sea que hubieran adquirido la licencia durante la última dictadura militar (caso Canal 2 y Canal 9), a quienes la habían obtenido en el proceso de privatización o acababan de obtenerla. Según explica Marino (2005), el Decreto 527/05 se enmarca en una larga tradición que se remonta a principios de de los años noventa y que consiste en reglamentar sobre la radiodifusión por medio del recurso a los decretos de necesidad y urgencia, sin debate parlamentario, sin participación de sectores sociales, sin pluralidad de opiniones y sin tener en cuenta los intereses ciudadanos.

- En diciembre de 2007, por instrucción del propio Kirchner (Montenegro, 2011:98), se convalidó la fusión de Multicanal (operadora de cable del Grupo Clarín) y Cablevisión (principal competidora). Entre las empresas cubrían el 75\% del mercado de Capital Federal y GBA, el 85\% de Santa Fe y el $94 \%$ de Córdoba ${ }^{128}$. La resolución 257/07 llevó la firma de Guillermo Moreno y a pesar de que la fusión se había iniciado, de hecho, en enero de 2007, se le solicitaba al Comité Federal de Radiodifusión una opinión definitiva, que tardaría dos años en emitir. ${ }^{129}$

Hacia principios de 2008, este conjunto de medidas informaban un panorama desalentador para quienes aspiraban a promover una nueva ley de radiodifusión.

\footnotetext{
127 Esta medida fue ratificada por la Cámara de Senadores recién en Octubre de 2009. Ver Página/12, 29/010/2009. En este decreto quedaron incorporados otros medios, como Canal 2 y Canal 9 que no habían sido contemplados en el decreto de diciembre del año anterior. http:/ / www.pagina12.com.ar/diario/elpais/1-134308-2009-10-29.html

${ }_{128}$ El dictamen de la Comisión de Defensa de la Competencia llevó las firmas de dos vocales, mientras que José Sbatella, titular del organismo, emitió un dictamen propio en el que planteaba la necesidad de que el Grupo Clarín se desprendiera de los derechos de televisación del fútbol y vendiera los activos en las localidades donde Cablevisión -Multicanal eran los únicos proveedores de servicio (Montenegro, 2011:102-103).

${ }^{129}$ El 3 de septiembre de 2009 el entonces Comité Federal de Radiodifusión (COMFER) denegó la fusión de Cablevisión y Multicanal, pues infringiría el régimen de multiplicidad de licencias establecido en la Ley 22285
} 
Entre ellos, muchos de los investigadores aquí citados, que más tarde apoyarían la propuesta del Gobierno durante el $2009^{130}$, y que, una vez aprobada la ley, mantendrían una postura crítica a su aplicación imperfecta.

\subsubsection{Publicidad oficial: "quid pro quo"}

El otro nivel de análisis privilegiado por la economía política de la comunicación es el de la distribución de la publicidad oficial ${ }^{131}$, tema que generó muchos debates durante la primera presidencia de Néstor Kirchner. En este nivel también se definieron continuidades con los períodos anteriores, al menos en términos de los criterios según los cuales se efectuaba la distribución, que Becerra (2010) sintetiza con la locución latina "quid pro quo": el intercambio de favores, la prevalencia de la lógica de la transacción y la cesión mutua de beneficios. Menos que un análisis profundo sobre este tema ${ }^{132}$ nos interesa destacar algunos aspectos que modelaron la política oficial, que marcaron la agenda de discusiones al respecto entre los años 2003 y 2008 y que habían modelado las percepciones sobre la voluntad política democratizadora de los medios, que el propio gobierno había manifestado.

Nos limitaremos a consignar algunos datos relativos a la publicidad del gobierno nacional según tres ítems: la evolución del gasto absoluto, la distribución por medios existentes y el financiamiento a nuevos medios.

\footnotetext{
130 Sólo como ejemplo, pueden verse las posiciones de Marino (“iMasivos o corporativos?, Página/12 Miércoles, 4 de noviembre de 2009) y Becerra ("La inmaculada concepción de los medios", Página/12, 27 de Mayo de 2008).

${ }_{131}$ La Relatoría para la Libertad de Expresión de la Comisión Interamericana de Derechos Humanos (CIDH) en su Informe 2003 indicó que la publicidad oficial incluye "los anuncios pagados en la prensa, la radio o la televisión, el material de software y video producido por el gobierno o patrocinado por éste, la campañas a base de folletos, el material publicado en Internet, las exposiciones, etc.".

${ }_{132}$ Remitimos, en referencia al período aquí tratado, al informe preparado por Martín Becerra para Poder Ciudadano (Becerra, 2011), y al pre-informe del mismo organismo (2011). También pueden consultarse a Califano (2009), O'Donnel (2007) y De Diego y D'Amico (2009).
} 
- Aumento del monto absoluto de publicidad oficial.

El rasgo característico más general del período 2003-2008 fue el aumento exponencial del gasto absoluto en publicidad oficial: en 2003 se habían invertido poco más de 46 millones de pesos y en 2008395 millones de pesos ${ }^{133}$. Según explican Marino y Mastrini, en 2006 se destinaron algo más de $\$ 160.000 .000$ y en 2007325 millones de pesos. Por su parte, el Informe sobre la Publicidad Oficial del Poder Ejecutivo Nacional correspondiente al primer semestre de 2008, mostraba que el PEN había gastado casi 182 millones de pesos, equivalente al $75 \%$ del presupuesto previsto para todo el año ${ }^{134}$. Si bien mediante el Decreto 1172/03 el Gobierno (por primera vez en la historia) se había obligado (y, por lo tanto, comprometido) mediante la letra de la ley a informar sobre los destinos de los fondos de la publicidad oficial, los estudios sobre la orientación del presupuesto asignado a tal fin cuestionaron la falta de criterios públicos claros para la distribución de la pauta oficial, los que permitirían -más allá de su cumplimiento- evaluar desde otra óptica estas decisiones arbitrales. "De todas formas, escriben Mastrini y Marino, la campaña mediática que ha cuestionado las desprolijidades del gobierno, en algunos casos, se asemejan a formas de presión para obtener la misma publicidad gubernamental, y en ningún caso objeta las presiones ejercidas sobre los contenidos de los medios por la publicidad privada".

Este punto es importante porque aquí se inscribe uno de los argumentos utilizados por el propio Gobierno para justificar el manejo de la pauta: el potencial compensatorio del desequilibrio en la asignación de la publicidad

\footnotetext{
133 "Dimensión de la publicidad oficial en Argentina", informe de Poder Ciudadano. Disponible en http://poderciudadano.org/wp/wp-content/uploads/2011/12/Informaci\%C3\%B3n-preliminar-POPoder-Ciudadano.pdf

${ }^{134}$ El informe de la ADC discrimina el gasto según el organismo y el tipo de campaña. En el informe citado, señala que: "La suma total de las campañas ubicadas en la categoría "difusión de gestión" ascendió a 33.506 .646 pesos, durante el primer semestre de 2008, de los cuáles el $86,7 \%$ (29.062.649 pesos) corresponde a avisos encargados por la Presidencia de la Nación", directamente asociados al conflicto con el sector agropecuario.
} 
privada. De hecho, tal y como lo muestra el informe publicado por la Asociación por los Derechos Civiles, entre 2007 y 2008, el sector de la prensa gráfica -cuya torta publicitaria relativa es menor que la de la televisión- recibió más inversión publicitaria estatal que el sector televisivo y radial. En el período abarcado por nuestro estudio, los medios gráficos recibieron 58.165 .633 pesos un $32 \%$ del total invertido en los primeros seis meses de 2008.

\section{- Distribución de pauta oficial a los medios ya existentes}

Durante 2008 inclusive, el diario más beneficiado fue el de mayor tirada, Clarín, con \$24.879.240. Ese criterio -a mayor circulación, mayor cantidad de avisos- no fue, sin embargo, la regla. El segundo diario que más cantidad de pauta estatal recibió fue Página/12, con $\$ 20.082 .750$, un $42 \%$ más que en 2006 , aunque su tirada era sensiblemente menor que Clarín. Otros casos llamativos son el de Editorial Atlántida, que edita las revistas Gente y Para Ti, entre otras, que logró aumentar su pauta estatal en un 930\% respecto de 2006: \$6.200.430. La excepción es Editorial Perfil, crítica del Gobierno, que no recibió ni un solo peso de pauta oficial ${ }^{135}$.

Otro gran beneficiario de la publicidad oficial fue el diario BAE, que en octubre de 2006 pasó de manos de Daniel Hadad a Sergio Szpolski, consiguió 237\% más que en $2006(\$ 3.959 .953)^{136}$. Según el informe de la ADC que estamos citando, el

\footnotetext{
${ }^{135}$ Cabe recordar que Perfil le inició en el año 2006 una demanda al Estado Nacional por discriminación en la asignación de la pauta. En marzo de 2011 la Corte Suprema de Justicia ratificó el fallo emitido en primera instancia (apelado por el Estado) e intimó al Gobierno a colocar pauta en las publicaciones más importantes de la editorial: el bisemanario Perfil, la revista Noticias y la revista Fortuna.

${ }^{136}$ Bernardete Califano (2009) sostiene que “a cambio de un giro radical en el grupo, en tan sólo un año Canal 9 multiplicó la pauta recibida por diez: en 2003 cobró 650.000 pesos, mientras que en 2004 la suma ascendió a los 6 millones, cuando los líderes de audiencia en televisión abierta (Canal 11 y Canal 13) recibieron la mitad de dinero, aún siendo su tarifa promedio por segundo mucho mayor que la del canal de Hadad".
} 
Grupo Szpolski (que estaba conformado, además, por las revistas Veintitrés, Veintitrés Internacional, Asterisco, Siete Días, y Newsweek Argentina) en 2008 consiguió un 183\% más de publicidad oficial que en $2006(\$ 4.777 .708)^{137}$.

Más allá de los números, lo que nos interesa es sintetizar algunas lecturas sobre los criterios o lógicas con que se distribuyó la publicidad oficial. Una de las críticas más importantes apuntó a la ausencia de regulación sobre los criterios públicos que los gobiernos de todos los niveles (nacional, provincial y municipal) debieran respetar a la hora de decidir la distribución de la publicidad oficial, lo que genera el terreno propicio para la discrecionalidad parte de los agentes de gobierno, y la proliferación de las sospechas y las denuncias (luego, la judicialización) sobre la aplicación de una lógica de premio/castigo o de aprovechamiento faccioso de los beneficios correspondientes (Marino y Mastrini, 2008; Califano, 2009; Becerra, 2011) ${ }^{138}$.

En un repaso por los trabajos que hemos tomado de referencia, encontramos al menos tres núcleos argumentales en torno a los cuáles se producen los debates sobre la distribución de la publicidad oficial: sociológicos, ideológicos y económicos.

Por sociológico nos referimos a las hipótesis contenidas en la definición de la "publicidad oficial" sobre el rol de los medios en la puesta en circulación de discursos a lo largo del tejido social. Según la Relatoría para la Libertad de

\footnotetext{
${ }^{137}$ El de Sergio Szpolsky es un caso testigo y paradigmático de empresarios beneficiados por la publicidad oficial que no podrían demostrar correspondencia entre el dinero percibido y la performance comercial de sus proyectos, explícitamente orientados a apoyar la gestión oficial. En 2003 sólo tenía el diario universitario $\mathrm{La} U$, que se repartía gratis en universidades. Con la llegada del gobierno kirchnerista comenzó a lanzar y comprar medios, apalancado con cifras millonarias de pauta oficial. Desde 2004 compró la revista Veintitrés y Radio América ; relanzó Siete Días ; reprodujo localmente las revistas Newsweek, Lonely Planet y Forbes ; lanzó Diagonales , Miradas al Sur, Tiempo Argentino, El Argentino y La Gaceta del Cielo , así como los canales Vibra y $\mathrm{CN} 23$, entre otros.

${ }^{138}$ Ver, asimismo, el informe 2008 de la Asociación por los derechos Civiles (ADC). Disponible en: www.adc.com.ar
} 
Expresión de la Comisión Interamericana de Derechos Humanos (CIDH) “el uso de los medios de comunicación para trasmitir información es una herramienta importante y útil para los Estados y aporta una ganancia por publicidad imperiosamente necesaria para los medios de comunicación".

Por razones geográficas y demográficas los medios son un intermediario inevitable para la publicidad de las actividades de gobierno, tanto cuando se trata de anuncios focalizados como cuando se dirigen a la ciudadanía en su conjunto. Según el informe publicado por Becerra (2011) se advierte que los medios más grandes no sólo absorben una porción comparativamente mayor de la pauta publicitaria (que tiende a sobre-representar en su distribución a los medios de mayor alcance, en relación con su dominio de mercado) sino que también cuentan con una mayor visibilidad e impacto en el estamento político que los convierte en receptores potencialmente mejor posicionados que los medios más pequeños para aprovechas las ayudas por parte de políticas públicas de subsidios.

Por ideológico nos referimos al imaginario liberal y republicano en el que se funda la jurisprudencia sobre publicidad oficial: igualitarismo en la consideración de los medios elegidos, equidistancia de los mensajes en relación a las disputas de intereses partidarios, transparencia en los criterios de distribución, limitación del margen de arbitrariedad en la definición de los destinos de la pauta. Como lo explica Becerra (2011: 3) haciéndose eco de la ya mencionada Relatoría de la CIDH: "La necesidad de contar con criterios claros, objetivos, y públicos para el destino de recursos públicos a la publicidad oficial se corresponde con el propósito republicano de difundir las actividades de los gobiernos y es por ello que esta cuestión se incluye en la agenda de derecho a la comunicación". La discriminación en el reparto de la pauta oficial es considerada, en este marco, como una restricción indirecta a la libertad de expresión. 
Por económico nos referimos a la funcionalidad que la publicidad oficial tiene para la supervivencia de muchas empresas de medios. El tema es importante porque en las condiciones actuales del mercado de medios la supervivencia comercial depende, en buena medida, del aporte publicitario estatal (en mayor medida en los municipios y en las provincias) ${ }^{139}$. 0 a la inversa: la publicidad oficial puede hacer nacer, sobrevivir y triunfar a experiencias periodísticas que de otro modo (es decir, libradas a su performance comercial) estarían condenadas a la pronta extinción, sino a una impensable concepción. A su vez, se trata de que el Estado compense las desigualdades generadas por la distribución de la pauta en el mercado publicitario privado.

Según Becerra, “con la excepción de los medios privados más grandes, la mayoría de las empresas periodísticas depende en un porcentaje que en algunos casos supera al $90 \%$ de los ingresos, del avisador oficial. De este modo, se corrobora que en la Argentina habría un peligro serio de subsistencia para una importante cantidad de medios de gestión privada si el Estado reorientara su política de publicidad oficial: tal vez este argumento de tipo económico también incida como disuasor de la adopción de una regulación transparente y pública". (Becerra, 2011: 9)

Hasta aquí, entonces, el Gobierno de Néstor Kirchner había administrado la distribución de la pauta oficial sin un control intraestatal, sin criterios claros y públicos, y con una lógica estrictamente política: en términos generales, se negociaba pauta a cambio de buen trato a la gestión. Sin embargo, esa lógica, que no por impugnable es inusual, convivió con una propensión, ella si novedosa, a la disputa abierta con algunos actores del sistema de medios en la que se fue

\footnotetext{
${ }^{139}$ Solo para tener una idea de la importancia de la pauta oficial, baste mencionar que en 2010 , la publicidad oficial representó un $9 \%$ del total de la pauta publicitaria argentina, y que: "La participación relativa del gobierno nacional en la masa publicitaria general lo convierte en el primer anunciante, con el nueve por ciento (9\%) de la participación, seguido por Unilever, con el cinco por ciento $(5 \%)$ y Procter \& Gamble, con el cuatro por ciento (4\%). La fuente de la participación de Unilever y Procter \& Gamble es BrandConnection (2011)” Becerra: 2011).
} 
revelando una interpretación trascendente (digamos, irreductible a la compraventa de favores y simpatías) sobre la competencia de hecho entre las instituciones mediáticas y las instituciones políticas.

\subsection{La modalización litigiosa de la comunicación política.}

Lo primero que es necesario aclarar es que al hablar de la comunicación política estamos recortando deliberadamente el campo de observación a las interacciones entre instituciones políticas e instituciones mediáticas y a los modos de utilización de los soportes mediáticos para problematizar aspectos de la vida colectiva en el espacio público, en tanto, como sostiene Ludger Helms (2008), no sólo debe considerarse la relación entre medios y líderes, o medios y gobierno, sino también el rol de un tercer actor, el público, "sin el cual, el mismo concepto de comunicación política en las democracias representativas es inconcebible". La comunicación política, señala Helms, es un proceso de "naturaleza triangular".

Por otro lado, coincidimos con Wolton en que lo que está en juego en la comunicación política es la "selección de los temas y de los problemas sobre los cuales se ajustan los enfrentamientos cognitivos e ideológicos del momento" (1998: 111). Digamos que privilegia la interacción entre las tres instancias (sistema político, sistema mediático, opinión pública) que se encuentran en un "equilibrio inestable entre lógicas contradictorias, pero que da sentido a los enfrentamientos" en la democracia de masas (1998: 112).

Esta concepción nos permite retomar el hilo de nuestra argumentación en este capítulo. Recordemos: la "gran contradicción" del primer gobierno kirchnerista en relación al sistema de medios habría sido aquella entre una actitud transigente e instrumental en sus políticas de comunicación y una propensión al 
enfrentamiento explícito, enmarcado ideológicamente (Kitzberger, 2010), en el espacio de la comunicación política.

Una suerte de hiato explicativo se abre entre una y otra perspectiva, sobre todo si se ansía encontrar en una (la comunicación política) el efecto especular de la otra (la política de comunicación). Como ese hiato es insalvable, sólo resta el intento por explicar ese desdoblamiento sin pretender encastrar los niveles de análisis como si fueran piezas de un rompecabezas.

Por nuestra parte, hemos adelantado una posición: en el espacio de la comunicación política pueden detectarse los signos de una concepción sobre los medios y el periodismo que parece no haber variado, más allá de vaivenes episódicos e intensidades de coyuntura, desde el 2003. La invariante kirchnerista, entonces, en relación a la cuestión mediática, ha sido, creemos, la modelización litigiosa de la comunicación política.

Como lo ha explicado Dominique Wolton (1998: 120)

Cuantos más discursos hay en el espacio público, por obra de los medios y del uso de la palabra de los diversos actores, tanto más profundamente se les plantea a los periodistas el problema del criterio en nombre del cual dar la palabra a los actores. La comunicación exige pues una lógica de representatividad.

Entonces, se pone en juego el fundamento de la legitimidad, de los principios de la economía invisible (Rosanvallon, 2008) que dota a los actores que no han sido validados por un acto de delegación explícito y regulado de las condiciones para hablar en nombre de otros. Y si no está puesta en juego, se trata de una legitimidad que opera de hecho, bajo la forma de una enunciación autorizada. El 
kirchnerismo ha buscado someter a verificación ${ }^{140}$ los fundamentos de esa autorización: por eso hablamos de una modelización litigiosa.

\subsubsection{Una espiral conflictiva}

Tal vez podamos analizar esa modelización recuperando una anécdota. En julio de 2006, el gobierno de Néstor Kirchner impulsó dos proyectos de ley para ser tratados por el Congreso. El primero, dotaba al jefe de Gabinete de facultades especiales para administrar y asignar partidas presupuestarias; el segundo, pretendía modificar la reglamentación de los decretos de necesidad y urgencia. Durante las sesiones parlamentarias, Cristina Fernández, entonces senadora nacional, hizo un discurso en el que se quejó por el comportamiento de algunos medios, que "confunden los roles de quienes deberían difundir honestamente las posturas de lo que decimos acá adentro", con lo cual "no tenemos prensa, sino que tenemos una oposición que no fue votada" (negritas nuestras). Luego, planteó el nucleo de la cuestión: "Afortunadamente, la gente tiene otra forma de debatir y de resolver esos debates": en las elecciones ${ }^{141}$.

Ante la reacción periodística, y en particular la del diario La Nación (CFK había identificado con nombre y apellido a periodistas del matutino), Néstor Kirchner aprovechó un acto de inauguración de obras en Mar del Plata para cuestionar la “tendencia al monopolio" en el sector de medios y explicó: “Nosotros queremos tener un periodismo más autocrítico. ¡Que estudien más, que investiguen más, que dejen de hacer lobby!" ${ }^{142}$.

\footnotetext{
${ }^{140}$ Aquí "verificación" toma el valor que le ha dado Rancière cuando concibe "lo político" como "el lugar donde la verificación de la igualdad se convierte necesariamente en el manejo de un daño" (2000: 146). Donde la "verificación" -que aquí queremos traducir como una operatoria genérica- consiste en el acto de enjuiciar los supuestos que sostienen una situación de hecho.

141 "Somos censurados por los periodistas", La Nación, 6 de Julio de 2006.

142 "Otro duro ataque de Kirchner al periodismo", La Nación, 8 de Julio de 2006.
} 
Entre las respuestas que estas referencias explícitas provocaron, vale la pena detenerse en la de Joaquín Morales Solá, editorialista dominical de La Nación: “Kirchner, innecesariamente, ha decidido competir con el periodismo por el control de la opinión pública"143.

Es interesante notar que esa definición coincide con el diagnóstico que varios analistas habían ofrecido no sólo para explicar el vínculo que el Gobierno había instaurado con los medios desde el inicio de la gestión, sino como explicación a la performance pública eficaz de Kirchner en los primeros años de gobierno. Lo que el periodismo percibía como un giro de timón hacia la mitad del mandato, parece ser, en cambio, un dato inscripto en los orígenes del kirchnerismo.

En ese sentido, según Kitzberger (2010:83) “Kirchner inició su presidencia apelando a los sectores medios urbanos no peronistas, los "huérfanos" de la representación político-partidaria dejados por la crisis y, como consecuencia, a los más expuestos a la influencia de los medios en la presentación de la realidad política" (2010:83). De allí, entonces, el intenso activismo mediático desplegado por el presidente y la primera línea de gobierno.

Esa es, a grandes rasgos, la tesis compartida por varios autores (Sarlo, 2011; Cheresky, 2009; Torre, 2003). La tesis sería la siguiente: para contrarrestar la debilidad de origen en la arena electoral, partidaria y parlamentaria, el Gobierno debió producir una acción fuerte de interpelación la opinión pública, con un “sobreesfuerzo de autoestilización” (Kitzberger, 2005), lo que Cheresky (2008)

\footnotetext{
${ }^{143}$ Cursivas nuestras. También Eduardo Van der Kooy había expresado una percepción similar en Clarín, aunque compensando la crítica de la actitud de los Kirchner con un cuestionamiento, liviano, al rol ejercido por la prensa: "Está muy bien -de hecho ocurre con casi todos los mandatarios del planeta- que Kirchner y su esposa disientan y repliquen a la prensa. Pero ese disenso, al parecer, poco tendría que ver con los pensamientos y las ideas sino con la falsa percepción de una disputa de poder. El matrimonio presidencial asocia al periodismo con la oposición. Lo mismo hizo en su era Carlos Menem. El periodismo debería ser más responsable y riguroso que nunca porque está obligado hoy a deslizarse por un camino de cornisa". (Van der Kooy, "Kirchner, las peleas y el encierro", Clarín, 16 de julio de 2006).
} 
toma como paradigma de un "liderazgo de popularidad", asociado a la expansión del espacio público y a su sustento en la opinión pública, al decisionismo, al voluntarismo y a la centralización del poder $^{144}$. Como ha dicho Beatriz Sarlo (2011:205):

Kirchner sólo podía sostener el primer tramo de su gobierno apoyándose en la opinión (de sus votantes y sobre todo de quienes no lo habían sido). Para su fortuna, esto, que era inevitable, coincide con una estrategia sensible al clima de época". En ese marco "carente de estructuras territoriales partidarias, los medios de comunicación debían convertirse en su red territorial ${ }^{145}$

Pero ese despliegue en el "territorio mediático" -que habría que computar como un condicionamiento estable para el despliegue de la comunicación política gubernamental: la diferencia estribaría en cómo elegir transitarlo- no se dio sin fricciones. En un análisis temprano de este aspecto, Kitzberger (2005:57-58) señalaba que el kirchnerismo había producido una "polarización ideológica" en el sistema de medios, tensión que había estado ausente durante el menemismo:

Hoy hay una serie de cuestiones diversas que dividen a un sector importante de la prensa y al gobierno en el campo político: la seguridad y la contención de la protesta social, el significado de las libertades y las prioridades de los diversos tipos de derechos, la cuestión del pasado y la memoria.

\footnotetext{
${ }^{144}$ Que el activismo mediático tenga por efecto una acumulación eficaz de poder no puede inferirse de manera mecánica. Ya bien entrada la presidencia de Néstor Kirchner existía la - a falta de mejor expresión- "sensación" de que su activismo mediático había sido una variable independiente del éxito de su gobierno. Interesante, al respecto, resulta la entrevista que le realizara el diario Clarín a Eliseo Verón (3/09/2006). Allí, Verón afirma que "el capital de Néstor Kirchner es político, no mediático" y que "Kirchner no es mediático. Cada vez que habla se enoja con los medios, pero objetivamente no los explota en su propio beneficio".

${ }^{145}$ “En realidad, Kirchner sólo podía sostener el primer tramo de su gobierno apoyándose en la opinión (de sus votantes y sobre todo de quienes no lo habían sido). Para su fortuna, esto, que era inevitable, coincide con una estrategia sensible al clima de época. (...) Se trata de una combinación inestable de repercusión mediática y registro de la opinión en encuestas, de voces emergentes consideradas representativas y manifestaciones espontáneas de apoyo. El carácter encuestológico y mediático es su aspecto principal. Conquistar la opinión es, evidentemente, un trabajo inestable, inseguro e interminable, porque la opinión vive de dos fantasías: la expresión de los individuos como tales, su autonomía respecto de las estructuras; y el rechazo a sentirse representado en ellas". (Sarlo, 2011: 201-203)
} 
Esa polarización tenía como correlato un “debate tácito” (negritas nuestras) sobre "el rol político de los medios y del periodismo", alrededor de dos términos: “auténtico pluralismo” y “libertad de prensa”. “El gobierno apelaba al primero cuando advertía un sesgo en el tratamiento que recibía; los medios alertaban sobre las amenazas a la libertad de prensa cada vez que advertían el "activismo del gobierno en su relación con la prensa” (2005: 58). Y agregaba Kitzberger:

La tematización de un conflicto gobierno-prensa en los mismos medios y en la opinión pública es un hecho significativo en sí mismo. Salvo incidentes bastante aislados y que involucraron a medios o periodistas individuales, los demás presidentes del período abierto en 1983 no pasaron por experiencias similares ${ }^{146}$.

Así, y en términos generales, podría decirse que la relación del kirchnerismo con el sistema de medios, y con algunos medios en particular, estuvo ritmada, hasta el 2005, por dos ciclos: durante el primero (entre 2003 y 2004), los medios mantuvieron una posición expectante con el nuevo Gobierno, aunque en ese período se habían definido algunas posiciones: La Nación había sido (y como tal se había comportado) indicado como representante opositor en el sistema de medios y Página/ 12 había definido su sesgo oficialista aunque compensado por una propensión a tratar temas críticos al gobierno. El segundo ciclo se inicia en Marzo de 2004, con dos episodios simultáneos: el acto realizado en la Escuela de Mecánica de la Armada (ESMA) en conmemoración del Golpe de Estado, en el que Kirchner hizo un pedido de perdón en nombre del Estado y la marcha en protesta por el secuestro y asesinato de Axel Blumberg (que se conoció el 23 de Marzo).

Pero si extendemos el período hasta 2008 podríamos pensar esa relación bajo la forma de una espiral conflictiva: una primera etapa relativamente amable (salvo con La Nación); una segunda etapa durante la cual se van agudizando los

\footnotetext{
${ }^{146}$ Como todos estos temas y reflexiones se han convertido en un rasgo cotidiano de la discusión pública, vale la pena señalar que el valor de la cita de Kitzberger reside en que el texto del que la tomamos fue escrito en 2005, cuando el fenómeno descripto estaba, por así decirlo, adquiriendo forma.
} 
cuestionamientos cruzados, y una tercera que se inaugura durante el enfrentamiento con el sector agropecuario en 2008 y que toma forma de batalla abierta con la Ley de Servicios de Comunicación Audiovisual (aunque este proceso escapa a los límites temporales de nuestro trabajo). Desde ya, la conflictividad es más intensa con algunas empresas (La Nación, Perfil y Clarín, en orden temporal, según fue variando el mapa de las connivencias) y, por otro lado, es necesario describir las modalidades de intervención en la comunicación política que el Gobierno fue definiendo en ese mismo período.

\subsubsection{Breves notas sobre el activismo mediático del kirchnerismo hasta el 2008}

En el período 2003-2007, el activismo público mediático del gobierno se desplegó principalmente en dos niveles sin dispersión horizontal: por un lado, en el nivel del Poder Ejecutivo; por el otro, en el nivel de una segunda línea de funcionarios. Mientras que en el primer caso se trató de evadir la intermediación periodística, en el segundo, por el contrario, se produjo un intervencionismo intenso, con interlocuciones periódicas, en particular por parte de algunos ministros, como el Jefe de Gabinete, Alberto Fernández, y el entonces ministro del interior, Aníbal Fernández. A partir de 2008, como bien lo ha notado Kitzberger, el activismo mediático ya no fue practicado como ejercicio de presión vertical ejercido desde el poder Ejecutivo sino que se nutrió por la incorporación de sectores activos organizados de la sociedad civil afines al Gobierno, que han consolidado prácticas descentralizadas de intervención sobre “la cuestión mediática”.

No está claro que, en sus maneras de comunicación política, el gobierno de Kirchner haya innovado, como en cambio sí lo hizo posteriormente el de Cristina Fernández luego de 2008, por ejemplo convirtiendo a la Cadena Nacional, prerrogativa presidencial utilizada usualmente como un recurso extraordinario, 
en una instancia rutinaria de interpelación a la ciudadanía. Señalamos esto para evitar el paso fácil de confundir el efecto de extrañamiento ${ }^{147}$ que la voluntad de confrontación de Néstor Kirchner provocó en los propios periodistas y en algunos investigadores con un cambio profundo que, para ser tal, demandaba transformaciones institucionales y de la economía política del sistema de medios que, al menos en este período, no se produjeron.

En la etapa 2003-2007 conviven, en cambio, una voluntad deliberada de cuestionar la función de intermediación del periodismo y una utilización tradicional de los recursos mediáticos. Probablemente, el rasgo diferencial del kirchnerismo sea perceptible en las dos maneras en que se produjo el cuestionamiento de los roles instituidos (asumidos o atribuidos) por el periodismo, particularmente el de control del poder político o de accountability vertical (O’Donnel, 2004), que puede remitirse a una concepción arraigada sobre el rol imposiblemente neutral de las instituciones intermedias, siempre sospechosas de responder a intereses parciales.

En primer lugar, mediante la consolidación gradual de un modo de comunicación “directa” que, en principio, tomó una forma negativa: la sustracción del cuerpo presidencial de los escenarios de interlocución gestionados por el periodismo, la decisión de no ofrecer ni entrevistas ni conferencias de prensa ni siquiera a través de su vocero de prensa $y$, en cambio, definir otras instancias de enunciación pública, en particular eso que el ex secretario de Medios, Enrique Albistur, definió como “el atril asesino" ${ }^{148}$ y que, algunos periodistas entrevieron como una estrategia sistemática de comunicación. Esa modalidad debe explicarse según un doble movimiento: primero, supuso quitarle previsibilidad a las

\footnotetext{
${ }^{147}$ Señala Mastrini (2010: 270) que "cuando se rastrea en la historia, los presidentes no han salido a discutir la agenda informativa que presentaban los grandes medios de comunicación", tal como lo hizo desde el principio Néstor Kirchner.

148 "Los periodistas dejaron de ser intermediarios necesarios". Entrevista a Albistur, por Susana Reynoso, La Nación, 4 de Febrero de 2007.
} 
ocasiones rituales en que se pronuncia el Presidente (Cadena Nacional, actos patrios, inauguración de sesiones en el Congreso), para convertir cualquier acto (inauguración de obras públicas, mitines partidarios, lanzamiento de medidas, etc) en un momento propicio para ofrecer pronunciaciones públicas (Cremonte, 2010); en segundo lugar, se organizó un sistema de producción y circulación de esos mensajes, a través de productoras televisivas contratadas por la propia Secretaría de Medios (Califano, 2009).

El atril, entonces, fue un modo itinerante y en cierto modo imprevisible de insertar la palabra presidencial en el espacio público; y tal vez revela el intento por controlar la selección del tiempo justo de los eventos sin intermediación del periodismo, pero a través de los dispositivos mediáticos. La diferencia es importante y no considerarla puede llevar a tildar de paradójico lo que en realidad es una modo coherente -si no inevitable- de convivir con los medios. Por eso no coincidimos con Vincent (2011) quien ve en esa "dualidad” un fenómeno particular:

Se producía entonces un fenómeno particular: mientras que para él [Kirchner] los diarios eran distorsionadores de la realidad porque no transmitían fielmente lo que sucedía, la televisión era la encargada de mostrar las imágenes "tal cual son", como si en el pasaje al medio audiovisual no existiera posibilidad de distorsiones.

En realidad, menos que un problema de transparencia la cuestión parece ser la de definir las mejores condiciones de producción del propio discurso. El problema, más que la aparente paradoja, es que esta estrategia está aquejada por un factor de orden estructural. En efecto, aunque se pretenda insertar la palabra presidencial en el espacio público mediante la televisión pero sin intermediarios, la circulación de esa palabra -como no podía ser de otra maneraestará sujeta a su reinserción en el sistema de medios a través del discurso del periodismo (de sus recortes, interpretaciones, jerarquizaciones, etc.). De modo 
que la intermediación se producirá, tarde o temprano, aunque sea por el reflujo en segunda instancia.

En segundo lugar a través de la explicitación de esa percepción crítica del rol del periodismo en los discursos del ex presidente. Precisamente Vincent (2011) ha calculado que sobre un total de 862 discursos pronunciados por Kirchner desde su asunción el 25 de mayo de 2003 hasta la finalización de su gobierno, el 9 de diciembre de 2007, en 220 discursos el ex presidente hizo mención a los medios, lo que expresado porcentualmente da un $25 \%$ del total de sus alocuciones públicas. Del análisis de Vincent -el único que se ha encargado de revisar sistemáticamente los discursos de Kirchner sobre este asunto- es posible identificar una serie de tópicos recurrentes en estos discursos de Néstor Kirchner:

- La identificación del periodismo como un actor del sistema político, señalamiento que, en determinadas situaciones, implicaba directamente la definición de los medios como equivalentes funcionales de la oposición partidaria.

- La desautorización de los medios en tanto agentes de intermediación de los cuáles el político prescinde para comunicarse directamente con la ciudadanía.

- La sobre-enfatización del carácter político partidario de los medios, en especial de la prensa escrita y la sospecha de que el periodista opera como voz visible de sus empleadores, como ventrílocuo o como traficante de mensajes de terceros.

- La acusación del mal ejercicio de la profesión contra el buen ejercicio (por ejemplo, el que implica hacer críticas constructivas). 
- Identificación de los medios del establishment como personeros de las corporaciones y las políticas antipopulares, lo que llamaba "la vieja Argentina", la de la Dictadura y la de la década de los noventa.

- El cuestionamiento explícito al origen de la legitimidad que sostiene la palabra periodística.

También Vincent considera que el dato novedoso de la comunicación política durante el gobierno de Kirchner consistió en que la relación con la prensa "se convierta en un eje central de la estrategia del gobierno y que la discusión sobre el rol de los medios en la sociedad tenga un lugar preponderante dentro de los discursos presidenciales". El corazón de esa estrategia era el intento persistente por disputar la marcación de agenda. En este sentido, el diagnóstico se acerca a la conclusión de Morales Solá citada al inicio de este parágrafo: "el interés último del presidente era contrarrestar el poder mediático para afianzar su liderazgo y concentrar más el poder (Vincent, 2011: 50).

Vale la pena detenerse en este punto. La autora entiende que en la disputa por el establecimiento de la agenda, Kirchner fue exitoso (2011: 74). Esto podría verificarse en la pérdida de influencia de los medios, en la "relativización de su poder (...) como mediadores naturales entre el gobierno y la ciudadanía" (2011: 78).

No coincidimos con esta aseveración, por dos motivos. Primero, porque es muy difícil de comprobar: como bien lo ha explicado Schudson (1997) esa influencia no es un dato cuantificable (si por ella entendemos la capacidad de modelar la subjetividad ajena), sino que depende, en especial en el caso de los medios, de relaciones de creencia muy variables. Retomando lo que Davison denomina "efecto de tercera persona", Schudson explica que "la fuerza de los medios estriba en la idea que sostienen los expertos y quienes toman las decisiones de 
que el público en general está profundamente influido por los medios (...) El atractivo político que poseen los medios se basa menos en su capacidad de torcer las ideas que en su pericia para convencer a las elites de que las ideas populares pueden torcerse" (1997: 334).

En segundo lugar, porque Kirchner usufructuó de la potencia extrínseca que la palabra presidencial ejerce sobre la agenda mediática. Que lo haya hecho con efectividad es una discusión que no puede saldarse recopilando los pasajes en que el presidente explícitamente le sugiere a los medios qué temas deben ser prioritarios en el tratamiento de la información. De otro modo: no está claro que este proceder haya alterado la dinámica de las agendas mediáticas, como en cambio sí ha sucedido luego del conflicto del campo con el gobierno de Cristina Fernández ${ }^{149}$, pero no como efecto de una "estrategia" unidireccional sino como resultado de una dinámica relacional propensa a la polarización, y a la proyección de esa tensión sobre los criterios de inclusión y exclusión temática.

En definitiva, que Kirchner haya puesto en cuestión -es decir, tematizado públicamente- la función mediadora de las instituciones mediáticas no necesariamente debilita esa función, ya que ella no depende de una verbalización sino de un rol social instituido, cuya pretendida “influencia” está atada inextricablemente al funcionamiento institucional del sistema político. Que el ex presidente intentó problematizar (y, por lo tanto, deslegitimar) ciertos discursos periodísticos no caben dudas, pero lo hizo de la única manera en que podía hacerlo desde su posición: haciendo explícita la pregunta por los fundamentos de esa legitimidad.

\footnotetext{
149 El portal Diarios sobre diarios ha presentado un informe sobre lo que denomina "la partidización de la agenda" en los años 2009-2010, lo que se entiende mejor como la convivencia de, al menos, dos agendas según la posición de las instituciones de medios frente al Gobierno Nacional. Ver: www.diariosobrediarios.com
} 


\section{Reflexiones finales y pasaje al próximo capítulo}

Cuando sobrevino el conflicto con el sector agropecuario el Gobierno recién asumido de Cristina Kirchner mantenía un vínculo político relativamente equilibrado con los principales actores del sistema de medios, vínculo heredado del gobierno anterior. Se sentía cómodo en la confrontación con La Nación, porque le permitía polarizar posiciones ideológicas; le había facilitado al Grupo Clarín la fusión de Cablevisión y Multicanal (consolidando el principal negocio del Grupo), y había empezado a crear, sobre todo a través de la asignación de la pauta oficial, un esquema de medios que podían compensar una agenda eventualmente negativa. Es probable, en definitiva, que a la relación del gobierno con los medios le cuadre la misma observación que Tonelli (2012: 11) propone sobre los límites de la construcción política del kirchnerismo: desde el inicio, por condiciones que se le impusieron y por su propia lógica de acumulación, "se vio obligado a jugar, by default, con los jugadores políticos ya establecidos, a los que ha respetado religiosamente "sus" territorios y dominios funcionales".

En cierta forma, el Gobierno mantenía una suerte de relación de dos niveles: a nivel dirigencial mantuvo una relación amable con los dueños de los principales grupos mediáticos, ante quienes demostró voluntad de negociación ${ }^{150}$; pero al mismo tiempo, con los periodistas, en particular con aquellos que por trayectoria gozaban de cierto renombre y capacidad de decisión en sus empresas, la relación

\footnotetext{
150 Por ejemplo, como explica Martín Becerra (2013): “La Ley de Bienes Culturales fue un salvataje estatal a las empresas de medios que impregnó, como lógica de intervención, la primera etapa del ciclo kirchnerista. La renovación automática de las licencias televisivas más importantes de los dos principales grupos de medios, Clarín y Telefónica, en diciembre de 2004, y, sobre todo, la firma del Decreto 527 en 2005 mediante el cual Kirchner suspendió el cómputo de diez años para las licencias audiovisuales, constituyen indicadores explícitos (hay otros) de un Estado que socorrió a los debilitados capitales de la comunicación".
} 
fue tirante, aunque los episodios de supuesta censura, de presiones y discusiones rara vez trascendieron el círculo de directos interesados.

Aun así, tanto Néstor Kirchner como Cristina Fernández optaron por impugnar o cuestionar, públicamente, el rol que jugaban “los medios” en su afán por representar los intereses ciudadanos. Está claro que estas polémicas públicas no dañaron el vínculo mutuamente útil entre el Gobierno y las empresas de medios, pero sin embargo su reconstrucción resulta necesaria porque vista en retrospectiva puede ser reveladora. Aquella mutua conveniencia, que con un criterio pragmático Néstor Kirchner reprodujo incluso al tiempo que mantenía algunos entredichos públicos, se diluyó abruptamente una vez comenzado el conflicto con el sector agropecuario, y especialmente la ruptura con el Grupo Clarín.

Si esa ruptura era imposible de prever a fines del año 2007, e incluso hasta febrero de 2008, hubo un anuncio entrelineas, perceptible quizá sólo para oyentes atentos e interesados, de una confrontación por venir (que, claro, no necesariamente tenía que asumir las formas radicalizadas y profundas que asumió).

El 7 de diciembre, último día hábil de su presidencia, Néstor Kirchner firmó un decreto que convalidaba la compra de Cablevisión por parte de Multicanal, las dos mayores operadoras de cable del país. Con esa compra de 2006 la corporación manejada por Magnetto pasó de facturar 2100 a 3600 millones de pesos, y se quedó con el $51 \%$ de la televisión por cable.

Tres días después, en su discurso de asunción, el 10 de diciembre de 2007, Cristina Fernández expresó una idea programática que sólo adquirió una dimensión trascendente en los años posteriores: 
Creo también que no solo las instituciones del Estado en sus tres poderes deben abordar la reconstrucción de este nuestro país, creo que también otros estamentos de la sociedad, empresariales, dirigenciales, medios de comunicación deben saber que el hecho de no integrar el espacio público gubernamental, no los exime también de la tarea y de la responsabilidad que a cada uno de aquellos argentinos que tiene un poco más de poder, bastante más poder -diría yo- que el resto de los ciudadanos, tienen también obligación moral de construir un país distinto. Nos debemos también un relato diferente de nosotros mismos los argentinos, no autocomplacencia, no de ocultamiento, pero sí el necesario reconocimiento a los logros obtenidos y, en todo caso, a marcar lo que falta, pero reconocer lo que se ha logrado ${ }^{151}$

Releída años después, la confluencia, en un mismo párrafo, de la mención a los "medios de comunicación" como "estamentos" que deben asumir una responsabilidad cívica y de la necesidad de elaborar "un relato diferente de nosotros mismos" resuena con el eco de un presagio. Lo mismo podría decirse de las dos interpretaciones de ese discurso que hemos podido encontrar. Al día siguiente de la asunción presidencial, Julio Blanck escribió en el diario Clarín:

Lo que se propone Cristina, en uso legítimo de sus derechos y atribuciones, es una cruzada para adueñarse del relato -otra de sus palabras predilectas- de la Argentina de hoy. Esto significa admitir y, más aún defender, la idea de que la realidad y su percepción se construyen en base a estrategias comunicacionales determinadas, en las que los hechos comprobables son apenas un insumo, pero no el producto final.

Y un més después, en un artículo titulado La guerra por las agendas, Nicolás Casullo escribió en Página/12:

Pero lo cierto es que no se puede hacer politicología hoy sin esta escena completa -neocultural- de las narratividades actuantes, que supera en mucho la propia especificidad teórica de "la política" con sus actores y espacios clásicos. (...)La Presidenta no se equivoca cuando apunta que se trata de una disputa por los relatos. Ella lo dice con cierto eco del campo de los estudios políticoculturales, en el intento de darle mayores fronteras comprensivas, de abarcar un fenómeno social amplio y complejo (que fuga de las lecturas inmediatistas y abruma a la propia política). Hace referencia a una narratología que articulan las grandes corporaciones dominantes y sus voceros, en su tarea de tipologizar gentes, relaciones, negocios, rumbos, recetas y vaticinios, tarea que intenta hacerse dueña del día, de la semana, de la encrucijada. Patrimonializar la realidad es situar un relato como centro radiante. En todo caso el kirchnerismo, a

${ }^{151}$ Negritas nuestras. 
los biandazos y sopapos, fue la política que trató de diversas formas de no domesticarse a esa "Constitución Argentina" sin preámbulo ni artículos editados.

Hay algo de premonitorio en estas dos interpretaciones, las dos razonables a su manera. Revelan, ante todo, dos concepciones (inclusive, podríamos decir: dos epistemologías) sobre la relación entre los discursos y su objeto, la "realidad". En un caso, "relato" es el rótulo ostentoso para el deseo de enmascarar esa realidad, y para contrarrestar el discurso del periodismo, mejor predispuesto a informar y no a "construir". En el otro, la idea de que sin narración que articule ideas, argumentos, tradiciones históricas, que oriente, en definitiva, las percepciones mayoritarias no puede haber política. Si la reacción de Blanck adelanta los argumentos que, a lo largo del conflicto del campo, serán esgrimidos por los editorialistas de Clarín y La Nación (que, por lo demás, terminaron de consolidar una imagen peyorativa de la noción de relato) el argumento de Casullo adelanta la conformación de lo que Beatriz Sarlo denominó, años más tarde, como "el dispositivo cultural” kirchnerista. ${ }^{152}$

\footnotetext{
152 En un artículo de mayo de 2010, Sarlo le otorgó un orden interpretativo a lo que denominó una "batalla cultural por las capas medias". "Pero está en curso un proceso más novedoso. Lo llamaré dispositivo cultural kirchnerista, armado de partes heterogéneas que funcionan de manera más o menos independiente, aunque alineadas con el Gobierno. Se trata de un dispositivo cultural, y no de la Oficina Ideológica del Ejecutivo. Comprende iniciativas prácticas descentralizadas, aunque convergentes en sus objetivos, y una red de discursos e intervenciones que reúne instituciones del Estado, pero también formaciones de la sociedad civil. Sería conveniente pensarlo más allá de la batahola". Beatriz Sarlo, "La batalla cultural", diario La Nación, 29/04/2010.
} 


\section{CAPÍTULO 4}

EL CONFLICTO DEL CAMPO:

LUGARES, OBJETOS Y
SUJETOS DE UNA CUESTIÓN
LITIGIOSA 


\section{CAPÍTULO 4}

\section{EL CONFLICTO DEL CAMPO: LUGARES, OBJETOS Y SUJETOS DE UNA CUESTIÓN LITIGIOSA}

\section{Introducción: el conflicto como litigio político}

El presente capítulo se organiza en cuatro grandes apartados. En el primero, haremos una reconstrucción cronológica del "conflicto del campo"153. Buscamos inscribir las intervenciones públicas de CFK, que luego analizaremos en el capítulo 5, en el desarrollo del conflicto, e identificar algunos momentos claves para resaltar un componente que suele ser subestimado: a pesar de que se impone, en la memoria, con la fuerza de una totalidad, de un acontecimiento único, el conflicto se caracterizó por la intermitencia, la imprevisibilidad, las especulaciones tácticas y el cálculo de los efectos inmediatos, el tira y afloje entre la negociación institucional y la dinámica inmediatista de las acciones directas. Desde esta óptica nos permitimos sugerir que el conflicto no se "desenvolvió", no se desplegó en un sentido progresivo y ascendente, según una racionalidad clara. Una segmentación en etapas, como la que proponemos, es útil como recurso de intelección, pero no necesariamente se condice con la temporalidad del evento o de los eventos que lo componen.

\footnotetext{
${ }^{153}$ Ningún rótulo parece ofrecer una descripción abarcadora, multidimensional, que le haga justicia a la polivalencia de los acontecimientos que vamos a tratar. Entre otras razones, porque la definición legítima del tipo de conflicto (lock-out, paro, rebelión) y las identificaciones y autoidentificaciones de los protagonistas ("el campo", la "oligarquía terrateniente", "piquetes de la abundancia", "la rebelión del interior", "el pueblo argentino", "enfrentamiento interburgués") fueron uno de los objetos del enfrentamiento, y sólo la prioridad otorgada por el observador fundamenta la opción por una u otra. Conservaremos aquí, deliberadamente, un rótulo más bien genérico para luego problematizar, en este mismo capítulo, los fundamentos de las caracterizaciones que se han hecho del conflicto.
} 
En segundo lugar, después de ese acercamiento descriptivo, vamos a hacer una revisión de los diagnósticos académicos que se activaron para explicar el conflicto entre el Gobierno nacional y el sector agropecuario. En el contraste entre el análisis de coyuntura y la explicación de las causas históricas podremos recortar un debate específico que entre los especialistas en sociología y economía agropecuaria concitó una atención especial: la aparición en la escena pública de actores sociales emergentes del proceso de transformación de la estructura agropecuaria. El conflicto reveló toda una trama de sociabilidad que los estudiosos del tema venían investigando desde la segunda mitad de la década de 1990 y que provocó cierta extrañeza sociológica y un debate álgido sobre las definiciones correctas para caracterizar a sus protagonistas.

En particular, ese debate se centró en la figura del "pequeño productor", a propósito de la cual tuvieron lugar discusiones sobre la adecuación de los grupos económica o sociológicamente determinados, definidos por indicadores estadísticos, cuantificables, objetivamente compartidos, y los “colectivos”, es decir, las designaciones, clasificaciones y argumentaciones que identifican a ese actor. Esta figura del pequeño productor, apareció, al mismo tiempo, como una categoría funcional, definida por propiedades socio-económicas, y como una entidad del imaginario político.

A esta derivación dedicaremos el tercer apartado, que nos servirá para, finalmente, especificar la definición del conflicto como litigio, de tal manera que sea compatible -analíticamente- con el problema de nuestra tesis. Si aceptamos que la existencia misma de un conflicto de intereses entre el Gobierno Nacional y el sector agroindustrial se explica por condiciones objetivas -por ejemplo, restricciones impuestas por la balanza de pagos en el marco de una crisis financiera internacional, que obligaba al Gobierno a capturar ingresos de algún sector de la economía- y en una decisión sobre cómo enfrentar esas condiciones aumentar la alícuota de los derechos de exportación de granos en lugar de 
intervenir sobre las rentas de otros sectores- también nos resulta evidente que las formas específicas en que se desarrolló el conflicto son irreductibles a esas condiciones.

Por nuestra parte, lo que haremos será retomar la noción de "litigio político" propuesta por Jacques Rancière ([1996] 2007), pero redefiniéndola para que pueda operar como una categoría analítica. Desde ya, un intento como este implica ejercer sobre el término original una suerte de violencia heurística, con el riesgo de que, al final, sólo reste la etiqueta sin sus implicaciones conceptuales; el riesgo, entonces, de la mera cita de autoridad. Nos hacemos cargo de ese riesgo, pero señalando que la intervención sobre el concepto no es puramente arbitraria; se funda, por el contrario, en ciertas posibilidades que abren algunas ambigüedades en los planteos del autor $\mathrm{y}$, especialmente, porque la consideramos útil y coherente con la perspectiva de análisis que queremos desarrollar en esta tesis, particularmente en relación a la gestión de colectivos

El “conflicto del campo" fue un litigio político en la medida en que todo conflicto tiene un componente de litigiosidad, es decir, que no sólo pone en disputa poder o razones de poder (en un sentido restringido: como capital cuantificable para ejercer dominación sobre otro u otros), relaciones de fuerza mensurables, o intereses económicos objetivos (traducidos en millones de dólares, por ejemplo), sino que se estructura sobre la definición problemática del objeto en disputa, de la identidad de los grupos y de los escenarios en que se desarrolla. Queremos recuperar la noción de "litigio" en tanto puede funcionar como una figura analítica sin estar inserta, indefectiblemente, en el proceso de emancipación que Rancière define como "política”. No por capricho sino porque vislumbramos que ese concepto puede ser de utilidad más allá de los casos específicos a propósito de los cuáles el autor lo ha desarrollado. 
A su vez, esta ampliación que proponemos supone, como contracara, una limitación precisa: desde nuestro punto de vista, ningún conflicto puede reducirse a su variante litigiosa. Repetimos entonces que el litigio, así entendido, es una dimensión o nivel de análisis.

\section{1. Las etapas del conflicto: una cronología analítica}

La reorganización del conflicto en etapas tiene ante todo una función descriptiva, como organización visual del devenir del proceso. Según el nivel de análisis por el que se opte, puede pensarse en un despliegue, en un desarrollo acumulativo, o simplemente en una sucesión sin una coherencia evolutiva interna. Así, por ejemplo, si se atiende a las condiciones para que la conducción unificada de la protesta en la Mesa de Enlace pudiera proyectar su representatividad, el transcurrir del conflicto ciertamente ofrece una acumulación de elementos que acompañan el devenir cronológico: sólo con ese transcurrir del proceso fue posible para los dirigentes de la Mesa de Enlace la organización de movilizaciones masivas que le dieran entidad concreta a la interpelación transectorial y sustento a las pretensiones de liderar un movimiento de oposición impensado antes del 11 de marzo. También es posible realizar una reconstrucción en un sentido cronológico si prestamos atención a la institucionalización del reclamo -tanto en lo que refiere a las negociaciones oficiales, cuanto al involucramiento de las instancias gubernamentales de los diferentes niveles de gobierno, o a las alianzas con fuerzas políticas opositoras.

En cambio, el análisis de las cuestiones litigiosas no puede ceñirse al mismo curso evolutivo. Precisamente por el carácter recursivo del litigio, el conflicto se perfila como a contratiempo: los protagonistas, los portavoces y los analistas, plantearon, una y otra vez, las definiciones básicas sobre las causas, los objetos, 
los escenarios y los sujetos. Como escribió el periodista Mario Wainfeld, uno de los principales columnistas del diario Página/12:

La intransigencia de las cuatro entidades no se puede explicar por motivos económicos (a muchos de ellos les sigue yendo bomba) ni por estar "desbordados" por sus bases, argumento que ningún líder que aspira a negociar puede invocar gratuitamente. Digámoslo paradojalmente para luego explicarlo: ya no se discute lo que se discute ${ }^{154}$.

Si ya no se discute lo que se discute, entonces resulta que el objeto de discusión es la discusión misma. Cuando Rancière define al "litigio" dice que no es una discusión entre interlocutores, sino una interlocución que pone en juego la situación misma de interlocución ([1996] 2007: 127). Está claro que esa descripción no alcanza para definir un litigio, pero sí puede servir para identificar algunos rasgos salientes del propio conflicto del campo, y de las instancias oficiales y oficiosas en que debía dirimirse.

En el cuadro siguiente graficamos estas variantes. Para su elaboración retomamos, en principio, la estructuración del conflicto propuesta por Sartelli (2008:176-204) que identifica tres grandes momentos según la hipótesis de que entre el 11 de marzo y el 17 de julio se produjo el desarrollo de una fuerza social que brota desde reclamos corporativos y alcanza a darse una fórmula política de alcance nacional. De esta manera, los momentos guardan una lógica interna según la cual en una primera instancia se define el terreno y las líneas de choque; en la segunda, los contendientes tratan de producirse el máximo de

\footnotetext{
154 "Una giornata particolare”, por M. Wainfled, Página/12, del 26 de marzo de 2008. Es probable que cuando Wainfeld sugiere que hay una confusión intencional de los temas de debate, se refiera a algo que también señaló Silvia Naishtat en Clarín, y que desde luego había percibido CFK en su discurso del 25 de marzo: no sólo estaban en discusión las retenciones. Como lo explicó Naishtat en un recuadro titulado "Pase de facturas" el mismo 25/03/2008: "Pese a que las retenciones móviles tienen como blanco la soja, la medida movilizó a todos los productores. No importa si con el nuevo esquema el ganadero accede a un maíz más barato o si el tambero recibe subsidios. Hay otras facturas que le están pasando a Cristina Kirchner (...) Pero después de cuatro formidables cosechas, el campo está líquido y se siente con oxígeno para sostener la confrontación." 25 de marzo
} 
bajas y sumar, como contraparte, el mayor número de aliados; y en la tercera, se realiza la fuerza desarrollada y se establece el vencedor.

El gráfico está propuesto como una línea de tiempo en la que se inscriben los acontecimientos más importantes, se distinguen las etapas y se las caracteriza. A su vez, incorporamos la identificación de ciertos momentos significativos que reactivan las “cuestiones litigiosas”. El litigio, así entendido, se activa por la confrontación sobre las condiciones en las que se define el conflicto, el objeto de aquello por lo cual se confronta, la identidad de aquellos que confrontan y los escenarios de la confrontación. Cuando se atiende a la dimensión litigiosa, la temporalidad del proceso considerado no progresa, no se monta sobre un saber acumulado, no corre hacia adelante, sino que puede ser vista como una sucesión de re-comienzos, de retornos al punto de partida, de reconsideración permanente de la situación de origen. Si se acepta la distinción, podríamos decir que la temporalidad del litigio no es cronológica pero tampoco circular: es recursiva. Como dimensión de análisis el litigio no es una fase o instancia en una línea de tiempo, sino el "trabajo" reflexivo que acompaña la conflictividad.

Tal y como planteamos esta línea de tiempo y las etapas que en ella identificamos, el desarrollo evolutivo que plantea Sartelli queda matizado por la intermitencia de los períodos de predominancia de las acciones directas y aquellos períodos de "tregua" en los cuáles predominan las negociaciones oficiales u oficiosas. A continuación presentamos el gráfico y luego desarrollamos con más detalle las características de cada etapa. 
Ilustración 1 Desarrollo del conflicto e instancias de activación ligitiosa

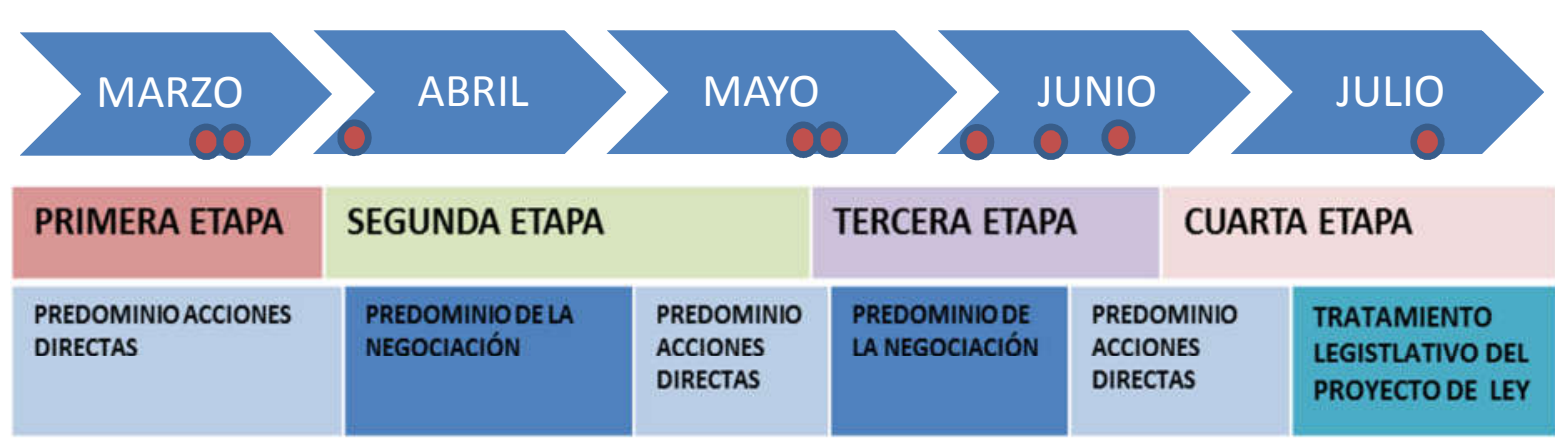

InStANCIAS DE ACTIVACIÓN LITIGIOSA

MARZO: Discursos de CFK (25, 25, 31 de marzo), -Cacerolazos (25, 26 de marzo) ABRIL: Acto en Plaza de Mayo (1 de abril), Acto en Gualeguaychú ( 2 de abril)

MAYO: Actos del 25 de mayo en Rosario y en Salta

JUNIO: Acto de la Mesa de Enlace en Armstrong ( 3 de junio), Discursos de CFK ( 9 y 16 de junio)

JULIO: Actos del 15 de julio en Plaza del Congreso y Rosedal de Palermo

En base a datos de Barsky y Dávila (2008); Giarraca, Teubal y Palmisano (2008); Sartelli (2008) 


\section{a- Primera etapa}

La primera etapa está delimitada por el anuncio de la resolución 125, el 11 de marzo de 2008, y por la primera "tregua", que duraría un mes, declarada por la Mesa de Enlace, el 2 de abril ${ }^{155}$.

La resolución ministerial $\mathrm{n}^{\circ} 125$ contenía dos medidas complementarias: por un lado, aumentaba la alícuota de los derechos de exportación para la soja (que pasaba del $35 \%$ al $44 \%$ ) y el girasol (del $32 \%$ al $39 \%$ ) y los reducía, en porcentajes muy pequeños, para el trigo y el maíz; al mismo tiempo, establecía un esquema de movilidad ordenado por una curva que aceleraba el porcentaje de retenciones ante un eventual escenario internacional dominado por precios extraordinarios. Si la soja superaba los 600 dólares por tonelada, del monto que estuviera por encima de ese precio el Estado se quedaba con el $95 \%$. De esta manera, el Gobierno lograba captar el excedente generado por el aumento exponencial de los precios internacionales de las commodities, justo en un año de vencimientos de deuda, pero lo hacía, por otra parte, en el momento previo a la cosecha, con lo cual les imponía a los productores nuevas condiciones de comercialización. En muchos casos, este último argumento fue el motivo esgrimido para justificar la participación en las protestas de los "pequeños productores".

Desde el momento mismo del anuncio, el Gobierno buscó fundamentar la medida en los niveles de rentabilidad del sector, la necesidad de contener el proceso de sojización de la agricultura y desacoplar los precios locales de los internacionales en un contexto de escalada inflacionaria (discurso de Martín Lousteau, $\left.11 / 03^{156}\right)$. Esta línea de fundamentación se fue politizando con el correr de los días luego de declarado el cese de comercialización por parte de

\footnotetext{
${ }^{155}$ Cabe recordar que ya desde fines de febrero se venían produciendo manifestaciones de rechazo a la política de precios del Gobierno, al punto que el 25 de ese mes, la Federación Agraria Argentina había amenazado con bloquear el acceso a puertos y molinos si sus afiliados no empezaban a cobrar el precio internacional del cereal. Diario La Nación, 26/02/2008. En http://www.lanacion.com.ar/990606-amenazan-con-bloqueos-a-los-puertos-si-no-sube-eltrigo

${ }^{\frac{t}{156} \text { Todas }}$ las citas corresponden a ediciones de los diarios Clarín, La Nación y Página/12.
} 
la recién creada Mesa de Enlace: fue incorporando la idea de que la medida se hacía en defensa de la igualdad, como reparación de un daño -la desigual distribución del ingreso- que afectaba a los argentinos en general y a los sectores más desfavorecidos, en particular. Así, desde el Gobierno se habló de las "inmensas ganancias" del campo, de la "actitud mezquina de la aristocracia del campo", de una "medida de corte patronal".

Frente a esto, si bien la primera reacción de los dirigentes agropecuarios fue rechazar la medida por "fiscalista y recaudatoria" (muy en línea con la posición doctrinaria de la Sociedad Rural desde el restablecimiento de las retenciones, en $2002^{157}$ ), rápidamente sus discursos empezaron a tratar temas más amplios, buscando una proyección representativa para abarcar públicos no sectoriales. Así, empiezan a hablar de una "agresión a un sector que trabaja en beneficio del país", y, una vez consolidadas las protestas, de "un ataque a los pueblos ya pobres del interior”. Como señala Roy Hora (2010: 86) la propia dirigencia de las organizaciones rurales no tenía una percepción clara del arraigo social de la protesta, y por lo tanto tampoco era capaz de orientar con claridad su propia capacidad de conducción ni la capacidad de los productores movilizados para sostener las acciones directas ${ }^{158}$.

Eso explica, también, que la dirigencia agropecuaria debiera justificar las propias acciones directas en motivos más amplios y "solidarios" que los de una mera reacción corporativa. Eduardo Buzzi, presidente de la Federación Agraria, sostuvo que la interrupción del comercio de granos -la principal medida de acción durante esos días- no buscaba "afectar a la sociedad sino defender la seguridad alimentaria del país"; y explicó que él representaba "a la gente que es sobreviviente de los 90 " al tiempo que denunció un "sistema feudal que perjudica a la interior".

\footnotetext{
157 Ver, por ejemplo, dos artículos publicados por Luciano Miguens, presidente de la SR, (Somos parte de la solución, Clarín, 31/12/2004) y Hugo Biolcatti, actual titular de la institución, (Kirchner y las retenciones, Clarín, 4/12/2004).

${ }^{158}$ Hora explica que la multiplicación de cortes de ruta de productores sin conducción directa de la Mesa de Enlace "pronto complementados por asambleas y reuniones a la vera de la ruta, no sólo sirvió para expresar el descontento que dominaba a muchos productores sino también para articularlo y potenciarlo, así como para ampliar el arco de solidaridades concitado por el reclamo agrario en los pueblos y ciudades de las provincias agrícolas"
} 
Desde la perspectiva que estamos desarrollando, en este período se produjeron dos acontecimientos de activación litigiosa que funcionaron como instancias de expansión de los tópicos en conflicto: la serie de cuatro discursos pronunciados por Cristina Fernández (el 25, 27, 31de Marzo y el 1 de Abril), y el acto del 2 de abril en Gualeguaychú, la primera movilización conjunta de las entidades de la Mesa de Enlace, que hasta el momento se había manifestado mediante comunicados escritos.

La importancia de los discursos "inaugurales" de CFK, que analizaremos con detalle en el capítulo 5 , es que consagraron públicamente las claves de interpretación del conflicto por parte del oficialismo. La persistencia de las protestas y su radicalidad, sumado a la incapacidad de las segundas líneas de Gobierno para negociar con la Mesa de Enlace una suspensión de las acciones directas, forzó la primera, y tardía, intervención pública de CFK quince días después de iniciado el conflicto.

En estos cuatro actos CFK desplegó las variantes de una simbología dual: la Presidenta habló en Casa de Gobierno, reafirmando su rol institucional (25 y 31 de marzo) y también lo hizo en dos actos en los que recibió el apoyo de su fuerza partidaria (el 27 de Marzo, en Parque Norte) y como líder de masas el 1 de abril, en Plaza de Mayo, que fue colmada con alrededor de 100.000 personas, muchas de ellas sin identificación partidaria explícita.

De estos actos tal vez el más importante, por su impacto posterior, haya sido el del 25 de Marzo de 2008. Allí, CFK no sólo fundamentó la necesidad “técnica”, la racionalidad económica de la medida, sino que caracterizó a las protestas como los "piquetes de la abundancia" contraponiéndolos a "los piquetes de la miseria" protagonizados por los sectores desocupados en la década de 1990; sostuvo que quienes llevaban adelante los cortes de ruta e impedían la circulación en las rutas pretendían "socializar las pérdidas" ya que tenían "una excelente rentabilidad sostenida por todos los argentinos"; agregó que eran los "mismos sectores que pedían represión en el 2001", y 
subrayó que iba a "seguir representando los intereses de todos los argentinos"159.

Este discurso se convirtió en el centro de los cuestionamientos durante las primeras manifestaciones de apoyo al reclamo agrario en Capital Federal por parte de sectores medios que, a través de cacerolazos organizados con anterioridad al discurso presidencial, capitalizaron el momento para expresar el descontento con la gestión gubernamental, más allá de la Resolución 125. Ahora, no sólo se trataba de negociar con un sector productivo, sino de discutir con franjas de los sectores medios urbanos que impugnaban la propia legitimidad del gobierno.

Por su parte, el mismo 2 de abril en que se anunció un cese de las protestas por 30 días con el objetivo de abrir una mesa de concertación con el Gobierno para tratar no sólo la resolución 125 sino también las políticas de carnes, leche y productos regionales, la Mesa de Enlace organizó en Gualeguaychú su primer acto y movilización conjunta, en el que se reunieron unas 20.000 personas ${ }^{160}$. Esa ciudad se había convertido en el escenario de uno de los cortes más combativos, liderado por el dirigente entrerriano de la Federación Agraria (FAA) Alfredo de Ángeli. En este acto, los dirigentes agropecuarios explicitaron una serie de demandas heterogéneas que excedían con mucho al cuestionamiento de las retenciones. Hablaron de la rentabilidad del sector y las políticas agropecuarias; también cuestionaron el centralismo, la falta de independencia de los poderes y hasta plantearon como propuesta y necesidad terminar con la pobreza en el interior del país. Ciertamente, se expresaron es esas demandas las diferentes líneas políticas contenidas en la Mesa de Enlace. Por ejemplo, en su intervención, Alfredo de Ángeli, convertido ya en un líder carismático y mediáticamente atractivo, se había responsabilizado en nombre de la dirigencia agropecuaria por la desunión entre las entidades

\footnotetext{
159 Toda esta estrategia discursiva es coherente con la descripción que hacen Muñoz y Retamozo (2008:135) sobre las coordenadas simbólicas con que el kirchnerismo construyó su hegemonía: la estrategia retórica [del kirchnerismo] siempre operó sobre un trasfondo: el reconocimiento de la "crisis" y, particularmente, la identificación del pueblo como una entidad dañada".

160 "Y en el medio de mi pecho, todo el rencor para Cristina", por Daniel Capalbo, diario Crítica de la Argentina, 3/04/2008.
} 
gremiales, en tanto, si bien "filosóficamente, con algunas de las otras entidades no coincidimos, sí tenemos claro que la rentabilidad no tienen bandería gremiales” ${ }^{161}$.

En estos primeros 21 días, se consolidaron las modalidades de protesta, en particular el "piquete" y las manifestaciones a los centros urbanos. Los "ruralistas" adoptaron el corte de rutas y la interrupción de la circulación de mercancías como acciones de presión sobre el Gobierno. Se registraron, durante ese período, más de 1600 cortes de ruta o de vía pública (Sartelli, 2008). A su vez, la protesta se extendió a nivel nacional: abarcó 15 provincias, aunque el eje de las movilizaciones fue la Región Pampeana.

La descripción de la modalidad de la protesta es importante porque, obviamente, impacta sobre las caracterizaciones del conflicto, una de las principales cuestiones litigiosas. Sin embargo, tampoco es una tarea simple. Si bien la premisa -negociada entre la cúpula de la Mesa de Enlace y las asambleas de productores- fue afectar sólo la circulación de los productos ligados a la ganadería y al cultivo de cereales sin suspender la producción, esa premisa no fue cumplida a rajatabla: cerca de la mitad de los cortes de ruta registrados a partir de la tercera semana de marzo fueron totales, es decir, no se limitaron a la circulación de mercancías específicas, sino que se impidió la circulación de todo tipo de vehículos, incluidos particulares y camiones con alimentos perecederos.

El 30 de marzo, en una columna en el diario La Nación, el periodista Joaquín Morales Solá escribía:

Los dirigentes del sector están mordidos por una tenaza: el Gobierno no les da nada que sirva y los productores los empujan a la protesta. La sociedad argentina podría sufrir en pocos días más las consecuencias del desabastecimiento de productos indispensables para vivir. Trabajadores de

\footnotetext{
161 Silvia Naishtat (Clarín, 28/03/2008) relata en un artículo las discusiones internas entre sectores radicalizados y sectores dialoguistas dentro de la Mesa de Enlace, y dentro de cada organización también. Y señala que "si bien hay un lenguaje común entre la dirigencia del campo, cada entidad tiene una interna al rojo vivo".
} 
pequeñas y medianas empresas vinculadas con la agroindustria comenzarían a ser suspendidos desde mañana mismo ${ }^{162}$.

Otro dato importante es que, en esta etapa, la fuerza de las protestas obligó a los intendentes de las localidades del interior afectadas por las movilizaciones a negociar directamente con las asambleas de productores sin esperar una orden del gobierno nacional; de esta manera, se fueron constituyendo instancias intermedias de negociación y construcción de alianzas que quedaron por fuera del alcance del Gobierno nacional. Para Sartelli (2008: 182), un primer balance:

obliga a concluir que estamos, ya en esta etapa, ante algo más que un paro. No se trata sólo de una medida que se limita a no vender o no comprar, sino que implica un grado de convocatoria más amplio, de estado deliberativo, de participación de la oposición y la Iglesia y de movilizaciones hacia el poder político local.

Fue en estas primeras semanas que adquirieron relieve dos colectivos que serían centrales en la configuración del imaginario político de la protesta e, inclusive, en su legitimación pública: “los pequeños productores” y los “autoconvocados”. Al respecto, escribió Hora (2010: 88):

Más que obra de la dirigencia sectorial (que, haya o no visto disminuida su capacidad de liderazgo en las décadas previas, carecía de los recursos organizativos necesarios para poner en marcha una protesta de esta envergadura), la expansión de los piquetes dependió de la movilización de activistas independientes pronto bautizados con el nombre de "productores autoconvocados". Gracias a la acción del heterogéneo conjunto de manifestantes que se reconocían en este nombre, la movilización agraria desbordó el reducido universo encuadrado por la dirigencia gremial, y encontró apoyos considerables en los pueblos y ciudades de la región sojera.

Es probable que tanto como la modalidad, la radicalidad y la violencia de las protestas, la gran novedad del conflicto del campo haya sido la emergencia de estas figuras de productores que no encastraban de manera lineal con el imaginario político del sector agropecuario, o en el imaginario político que al apelaba el Gobierno para descalificar a la protesta. Nos interesan estos dos colectivos por su valor simbólico, es decir, no sólo en tanto designan una

\footnotetext{
162 "Un ciclo de política que parece haber terminado", por Joaquín Morales Solá, diario La
} Nación, 30 de marzo de 2008. 
función productiva y una modalidad de participación política, sino porque fueron los soportes de una imaginería más amable que la que ofrecía la figura de "la oligarquía agropecuaria", y le otorgaron una encarnación a los estratos intermedios y a las bases de la protesta, más allá de las decisiones y discursos de los dirigentes de la Mesa de Enlace. Precisamente en relación a estas dos figuras jugaron un rol trascendente los medios de comunicación, tal como mostraremos en el capítulo 6.

\section{b- Segunda etapa}

Esta segunda etapa se inicia con el acto en Gualeguaychú ya mencionado y se cierra con otro escenario de activación litigiosa: el 25 de mayo de 2008, conmemoración de la Revolución de Mayo de 1810, fecha prevista por el Gobierno para anunciar el "acuerdo del Bicentenario", los ruralistas organizaron un acto paralelo en Rosario, donde reunieron alrededor de 200.000 personas. Desde el punto de vista de la acumulación de condiciones para disputar legitimidad y representatividad, el acto en Rosario marcó un pico en la agudización política del enfrentamiento. De hecho, la elección de Rosario como centro de este acto multitudinario remitía a una doble simbología, que condensaba muy bien la lógica del conflicto: no sólo por el símbolo de la creación de la bandera nacional, sino porque había sido catalogada como capital nacional de la soja.

En los primeros días de abril, luego de iniciada la tregua por 30 días $^{163}$, el Gobierno recibió a los dirigentes de la Mesa de Enlace para iniciar las negociaciones. Se organizó un esquema de comisiones por áreas específicas (ganadería, granos, leche, productos regionales) pero en ningún momento el Gobierno puso en consideración la posibilidad de suspender la aplicación de las retenciones móviles. Este hecho funcionó como un inhibidor que retrasó una solución consensuada y forzó, dos meses después, la salida parlamentaria,

${ }^{163}$ Como bien lo han señalado diversos analistas, esta tregua no sólo obedeció a una necesidad política. La tregua era poco menos que imprescindible, pues necesitaban comenzar la cosecha gruesa (soja y otros granos). Sin la reapertura de las rutas, la maquinaria agrícola, casi toda ella contratada a proveedores externos a las empresas agrarias, no podía desplazarse hasta los sembradíos donde debía comenzar su trabajo sin demora. 
a la que el Gobierno accedió a desgano: a posteriori, al ser un aspecto innegociable para las dos partes, terminó por anular los acuerdos puntuales que se fueron logrando.

El 15 de abril, en un discurso pronunciado en Tucumán, Cristina Fernández había reafirmado la lectura oficial del conflicto, poniendo en el centro de la disputa la puja por la redistribución del ingreso. Ese día, CFK explicó que no se trataba sólo "de una batalla económica, por intereses", sino de una "batalla cultural", pues "la redistribución del ingreso es la lucha para que los que más tienen entiendan, de una vez por todas, que es necesario que tiendan la mano solidaria hacia el pueblo que reclama trabajo, salud, vivienda y educación".

El 17 de abril se anunció un primer acuerdo para reabrir el registro de exportaciones de carne y para aumentar un $10 \%$ los volúmenes exportables a cambio de que los productores garantizaran el abastecimiento interno para contener el alza de precios y se comprometieran a mantener un tope máximo para los 13 cortes más populares. El día siguiente, 18 de abril, el Gobierno anunció que daría un reintegro de las retenciones a 62.500 pequeños productores dedicados a la siembra de soja y girasol. El reintegro se haría en base a la diferencia entre el 35\% de retenciones vigentes al 10 de marzo (es decir, antes de que se anunciara la Resolución 125) y el nivel de retenciones al momento de vender la cosecha. Sin embargo, la medida -que en realidad ya había sido anunciada por CFK el 31 de marzo- tuvo como respuesta un redoble de las presiones de parte de las organizaciones agropecuarias y, más aún, de sus bases ${ }^{164}$.

Durante esta etapa los ruralistas incrementaron su presión sobre los gobernadores e intendentes, y sumaron aliados políticos de relevancia. Ya el 6 de abril, Hermes Binner, por entonces gobernador de la provincia de Santa Fé, cuestionó el modo de administrar los ingresos provenientes de las retenciones,

\footnotetext{
${ }^{164}$ En Clarín, Van der Kooy escribía. "A la dirigencia rural también le cabe en el presente agravamiento su cuota de responsabilidad. Parece haber resignado el liderazgo de la protesta para convertirse en el furgón de cola de los manifestantes más rebeldes".
} 
sugiriendo que deberían coparticiparse. $\mathrm{Y}$ al día siguiente, el gobernador oficialista de Córdoba, Juan Schiaretti, que ya se había negado a posicionarse abiertamente en defensa de las políticas del Gobierno Nacional, anunció que su provincia reclamaría ante la Justicia por el envío de fondos provenientes de las retenciones y que, como tales, no son coparticipables. Progresivamente, el reclamo liderado por la Mesa de Enlace fue ganando aliados institucionales, tanto del oficialismo como, previsiblemente, de la oposición: el Pro, la Coalición Cívica, el Partido Nuevo de Luis Juez, el Partido Socialista; también gobernadores aliados al gobierno, pero presionados por la incidencia de la economía agropecuaria para la estabilidad política y económica de sus provincias: el mencionado Binner, Das Neves, Jaque, Oscar Jorge (La Pampa), Brizuela del Moral ( Catamarca), Busti ( Entre Ríos). En las provincias con mayor peso político y económico (Santa Fe, Córdoba y Buenos Aires) muchos intendentes, que debían lidiar directamente con los productores alzados, se declararon a favor del campo, en muchos casos participando de los actos y manifestaciones públicas ${ }^{165}$.

Se concretó, de esta manera, "la federalización de la protesta" que los dirigentes agrarios habían anunciado como eje de la estrategia de presión sobre el gobierno y de legitimación de las medidas de fuerza en las provincias y pueblos del Interior ${ }^{166}$. En una de sus performances televisivas, Alfredo De Ángeli, había exigido a los gobernadores, intendentes y legisladores nacionales "que se pongan la bandera del federalismo". Finalmente, el 13 de Mayo, legisladores de la oposición se reunieron con las entidades

\footnotetext{
165 La dinámica que adquirió el conflicto en cada localidad varió en función de diversos factores. Como lo explica Roy Hora (2010: 95): "Una movilización tan masiva, a la vez que extendida sobre una geografía muy diversa, no puede comprenderse cabalmente sin atender a las circunstancias específicas que en cada provincia, y a veces en cada localidad, contribuyeron a dotarla de tintes peculiares. Factores tales como la existencia de una tradición previa de participación ciudadana, el grado de empatía (u hostilidad) entre los manifestantes agrarios y las autoridades locales y provinciales, las relaciones entre el poder federal y el gobierno provincial, o la capacidad de liderazgo de las dirigencias de base, contribuyeron a definir un panorama de gran complejidad en cuanto a la amplitud, la mecánica y el impacto de la protesta agraria".

166 "Vamos a federalizar la protesta hablando con intendentes y gobernadores porque las provincias son las más perjudicadas por la entrega de la riqueza al poder central” dijo Luciano Miguens el 9 de Mayo.
} 
agropecuarias en el congreso y declararon la necesidad de derogar la Resolución 125.

El 7 de mayo, frente a la negativa del gobierno de suspender la aplicación de la Resolución $125^{167}$, la dirigencia agropecuaria decide retomar la protesta, pero esta vez nuevamente suspendiendo la comercialización de granos y oleaginosas y anunciado "una gran pueblada nacional" (en palabras de Eduardo Buzzi). El 19, en medio de negociaciones, los dirigentes de la Mesa de Enlace resolvieron suspender los cortes de ruta, pero la tregua duró poco. El 25 de mayo, el acto en Rosario volvió a expresar la voluntad política de la dirigencia agropecuaria que llegó a plantear explícitamente la compulsa por la representación popular: durante su discurso, Alfredo de Ángeli exclamó: "Va a quedar en la historia argentina, que en el 2008 hubo dos actos nacionales, el del gobierno oficial que gobierna para un sector, y el del pueblo del interior y del campo que está acá en Rosario".

Simultáneamente, en Salta, en el acto oficial en conmemoración de la Revolución de Mayo, la Presidenta no hizo ninguna alusión directa y explícita a los ruralistas pero cerró su discurso con una referencia obvia al conflicto, reafirmando la lectura esbozada ya el 25 de Marzo, durante su primer discurso:

Convoco a todos los argentinos que crean que es necesario seguir construyendo un país con redistribución del ingreso, a todos los que quieran ser parte de este país, donde hay lugar para hombres y mujeres de distintas historias: trabajadores, empresarios, estudiantes, comerciantes, productores. El único requisito es querer a esta Argentina. La otra condición es que aprendamos que antes que el sector, antes que nuestra propia individualidad están los intereses de la Patria.

167 “La etapa negociadora se había extinguido el martes a la noche cuando Fernández [Alberto, jefe de Gabinete de Ministros] desmintió públicamente lo que los dirigentes aseguran les había dicho en privado unas horas antes: que el Gobierno aceptaba efectuar retoques a las retenciones móviles, el detonante del primer paro". "El campo volvió al paro pero dicen que no habrá desabastecimiento", por Matías Longoni, diario Clarín, 8/05/2008. 


\section{c- Tercera etapa}

Los efectos de los actos paralelos del 25 de mayo fueron diversos. En realidad, el desafío planteado por los ruralistas -la declarada pretensión de estar "representando" al Interior, refrendada, en su perspectiva, por el multitudinario acto en Rosario- encontró respuestas divergentes, tal vez deliberadamente ambiguas, en el frente político del kirchnerismo.

Por un lado, se retomaron las negociaciones y el 29 de Mayo el Gobierno hizo anuncios importantes: modificó la curva de retenciones para habilitar los mercados a futuro y determinó que los reintegros a pequeños productores cuando las retenciones superaran el $35 \%$ las pagaran los municipios y gobernaciones, a quienes se les girarían los fondos correspondientes.

Pero a la concesión negociada le siguió, días después, un comunicado del Consejo Nacional de Partido Justicialista, que había sido reunido por Kirchner luego del acto en Rosario, y que acusó a las entidades de estar impulsando un "ataque antidemocrático con ánimo destituyente y falta de respeto a la voluntad popular", las protestas fueron calificadas como un "lock-out salvaje e interminable". La dirigencia agropecuaria utilizó esta declaración como excusa para mantener algunos cortes en varias rutas del país. Este vaivén, esta indefinición, signará las semanas siguientes, hasta que el 17 de junio, en un discurso pronunciado por cadena nacional, Cristina Fernández anunciará el envío del proyecto de retenciones móviles al Congreso Nacional.

El estado de conflictividad, a su vez, generó situaciones extrañas. Por ejemplo, el 3 y 4 de junio asociaciones de transportistas volvieron a bloquear una gran cantidad de rutas ... en protesta contra el paro del agro. En los días siguientes, se multiplicaron los llamados al diálogo, tanto por parte de la Iglesia como de otros actores institucionales, como el Defensor del Pueblo, Eduardo Mondino. Como respuesta, los ruralistas decidieron el 6 de junio no extender el paro. Y el 9, la presidenta ofreció un discurso -el primero que 
pronunció por Cadena Nacional- en el que presentó un plan social de construcción de hospitales, viviendas y caminos que se financiaría con el diferencial por retenciones superiores al 35 \% y subrayó que la ejecución de los fondos (nacionales, producto de las retenciones) sería descentralizada entre provincias y municipios.

En ese mismo discurso, CFK convocó al diálogo pero subrayó, como ya lo había hecho en varias oportunidades, la asimetría de la legitimidad de la que estaban investida ella, como representante electa en las urnas, y los dirigentes de la Mesa de Enlace: "El error fue creer que la distribución del ingreso se hace con una política que, pese a haber sido revalidada en las urnas, requería, tal vez, de una mayor explicación o tal vez de un mayor ejercicio de responsabilidad por parte de todos" $Y$ añadió: "Quien habla es la Presidenta de la República, no una parte; debe gobernar para todos los argentinos y cuando toma decisiones lo hace en beneficio de todos los argentinos".

Ese discurso parecía destinado a darle un cierre pacífico y concertado al conflicto. Como escribió Mario Wainfeld en Página/12 ${ }^{168}$ :

En un cuadro que muda día a día, el levantamiento (aunque no total) del corte de rutas y la propuesta presidencial abren un resquicio para mejorar el menú de discusión y procurar una metodología de negociación menos arrebatada. Parte del camino se indicó ayer en el Salón Blanco (sí que en germen): más política, una agenda más vasta, abrir el juego a gobernadores e intendentes.

Sin embargo, el 14 de junio la Gendarmería detuvo a Alfredo de Ángeli y a otros 18 ruralistas que mantenían cortada la ruta 14 en Gualeguaychú y sin esperar un pronunciamiento de la dirigencia, los productores decidieron retomar la protesta. El 16 de junio, volvieron a realizarse cacerolazos en Capital Federal, Santa Fe y Entre Ríos. El Gobierno, entonces, debió ceder y encauzar el conflicto por el carril institucional que había propuesto el vicepresidente Julio Cobos en una carta pública, que en retrospectiva resultó el

168 “Un horizonte más amplio”, por Mario Wainfeld, Página/12, 10 de junio de 2008. 
primer indicio del desvínculo y de la vocación de autonomía del ex gobernador mendocino: que fuera el Congreso el que definiera la suerte del proyecto de retenciones móviles.

En el acto de envío de las retenciones al parlamento -en el que se conmemoraron las víctimas del bombardeo a Plaza de Mayo en 1955- dijo CFK: "Esta medida de las retenciones móviles que tanto revuelo ha causado a un sector que hace 90 días corta rutas, voy a enviarla al Parlamento como proyecto de Ley por si no les basta que sea Presidenta, que hace seis meses obtuvo el $46 \%$ de los votos". Y definió a los dirigentes de la Mesa de Enlace como "cuatro personas a las que nadie votó y nadie eligió nos decían a los argentinos quién podía andar por las rutas" y en consecuencia sostuvo que "la clave está en presentar los modelos de país de cada uno ante la ciudadanía, y cuando ésta elige y vota, si ese voto no nos ha sido favorable, a mejorar la propuesta y esperar el próximo turno electoral"

\section{d- Cuarta etapa}

El 18 de junio, un día después de enviar el proyecto de ley al Congreso, el Frente para la Victoria organizó un multitudinario acto en Plaza de Mayo al que asistieron movimientos sociales, gremios, intendentes del conurbano y sectores medios no agrupados ${ }^{169}$. Allí, Cristina Fernández les pidió a "aquellos que, tal vez equivocados por la propia dinámica sectorial, creo que estuvieron confundidos, en nombre de la democracia, de la Constitución, que liberen las rutas y dejen que los argentinos volvamos a producir y trabajar." Si bien la primera reacción de los ruralistas fue de desconfianza -expresaron, incluso,

\footnotetext{
169 “Ante una Plaza de Mayo llena y expectante, que había reunido otra vez a columnas de gremios, movimientos sociales e intendencias del conurbano, pero con la incorporación de una visible porción de autoconvocados de clase media sin pertenencia orgánica, la Presidenta Cristina Fernández volvió a reclamar a las entidades del campo que levanten los cortes de ruta". "En el nombre de la democracia les pido que liberen las rutas", por Martín Piqué, Página/ 12, 19/06/2008.
} 
que se trataba de una trampa, ya que el proyecto podía ser ratificado o rechazado, pero no modificado- el 20 de junio decidieron levantar los cortes.

A partir de ese momento, el escenario de la protesta se trasladó a los pasillos del Congreso y la plaza ubicada enfrente del edificio legislativo, donde se instalaron sendas carpas en las que tanto el oficialismo como los ruralistas buscaron ganar apoyos.

Néstor Kirchner asumió la tarea de defender públicamente el proyecto de ley y de unificar a la fuerza oficialista. El 2 de julio, durante un acto en el Mercado Central, el ex presidente ironizó sobre "algunos sectores de la Mesa de Enlace o de desenlace" que dicen que se trata "de una lucha cívica y republicana. Estaba bien que nos dejaran sin comida, que no nos dejaran transitar, que muriera gente por los cortes de ruta" y habló de la "actitud desestabilizante" y "golpista de los que cortaron la ruta que, además, son los más beneficiados por este proceso".

La respuesta de los dirigentes de la Mesa de Enlace fue intransigente (y, en buen grado, contradictoria, cuando no cínica, considerando sus propias declaraciones sobre la necesidad de una ética republicana y del diálogo como principio de resolución de problemas): si se aprobaba el proyecto tal y como había sido enviado al Congreso, volverían a las acciones directas. En ese sentido, Eduardo Buzzi pidió "que se suspenda transitoriamente la Resolución 125 hasta tanto se pueda acordar un proyecto que sirva para resolver los problemas del sector. Si hoy se aprueba tal como está lo que el oficialismo dio a conocer, no se sale del conflicto".

El 3 de julio, el kirchnerismo logró que se aprobara en comisión el proyecto que había enviado CFK, y dos días después, la Cámara de Diputados aprobó las retenciones móviles, por 129 votos a favor, 122 en contra y 2 abstenciones. Una victoria ajustada, victoria al fin, pero que dejó como saldo una escisión importante en el espacio oficialista, que perdió a 14 diputados, que votaron en contra del proyecto, finalmente aprobado con modificaciones en los 
alcances de los reintegros y de las áreas geográficas beneficiadas con compensaciones por flete.

De cara al voto en el Senado, la Mesa de Enlace anunció un acto en el Monumento de los Españoles, en el barrio porteño de Palermo. La respuesta del oficialismo no se hizo esperar, y Kirchner anunció para el mismo día, 15 de julio, un acto en la Plaza del Congreso. El acto, finalmente, reunió alrededor de 90.000 personas. Allí hablaron Sergio Uribarri, Daniel Scioli y Kirchner, quien fue el principal orador. El ex presidente dijo que para defender la mesa de los argentinos hacía falta más democracia, acusó de golpista a la dirigencia rural y de actuar como un "grupo de tareas" y "comando civiles":

Hablan de democracia y cortan las rutas, hablan de democracia y desabastecen a los argentinos, hablan de democracia y nos queman los campos, y, como en las peores etapas del 55 y el 76, salen como comandos civiles o grupos de tareas a agredir a aquellos que no piensan como ellos en forma vergonzosa.

Al mismo tiempo, "el campo" llevaba adelante un acto masivo -asistieron alrededor de 200.000 personas- frente al Monumento a los Españoles, en Palermo. Sobre el escenario allí montado desfilaron los cuatro dirigentes de la Mesa de Enlace con el agregado (convertido a esa altura en un número fijo) de Alfredo De Ángeli. En sus discursos volvieron a presionar a los senadores y, como ya lo habían hecho en los actos previos, colocaron como interlocutor a la ciudadanía en su conjunto. Eduardo Buzzi explicó, en ese registro, que "ya no venimos a decir lo que no queremos, venimos a expresar también lo que hace falta... también hay que ser capaces de formular lo que este país necesita", y lo que necesita Argentina es "un modelo de país distinto".

En la madrugada del 17 de julio, con la votación empatada en 36 luego de 16 horas de debate, la responsabilidad recayó sobre el vice-presidente Julio Cobos, que terminó por sellar la suerte de la Resolución 125 a favor del sector agropecuario con un voto que definió como "no-positivo". En lo inmediato, la decisión de Cobos pareció abrir un escenario de crisis política pues más allá 
de la derrota parlamentaria el oficialismo había perdido votos entre senadores aliados $^{170}$.

Al día siguiente, el Jefe de Gabinete, Alberto Fernández anunció la derogación de la resolución y sus modificatorias. En esa conferencia, Fernández defendió "el uso legítimo de facultades constitucionales y legales por un gobierno electo en elecciones libres" y remarcó una de las líneas argumentales invariantes del gobierno a lo largo del conflicto: "No debe haber interés que pueda estar por encima del interés de la Patria, no puede haber sector que imponga coactivamente al conjunto sus propios intereses de lucro".

\subsection{La coyuntura y sus pre-condiciones: el modelo sojero y las transformaciones de la estructura socio-productiva agraria.}

Los estudios dedicados a analizar las diversas facetas del conflicto oscilan entre la admisión de lo excepcional y la confirmación de los diagnósticos previos sobre la transformación de la estructura productiva agropecuaria y de la trama de relaciones sociales que sostuvieron esa transformación. Digamos, la excepcionalidad del conflicto no impide entender ciertos elementos condicionantes, sino antes bien se interpreta como su corolario.

Una primera lectura inercial fue ubicar el conflicto como lo que, en principio, pareció ser: una de las periódicas protestas del sector agropecuario contra la políticas estatales de precios, impuestos (como los derechos de

\footnotetext{
${ }^{170}$ En la edición de Página/12 del 17 de julio, Mario Wainfeld escribió: “Una de las pocas tácticas encomiables del Gobierno, la derivación del conflicto con el sector agropecuario al Parlamento, derivó en el peor escenario que podía esperarle. Ni su peor enemigo podía haberlo dibujado más denso. Perdió la votación en el Senado, con una importante dispersión de la tropa propia. Y la decisión definitiva quedó en mano de Julio Cobos, quien le bajó el pulgar poniendo en jaque mucho más que la resolución 125. Entre otras variables, la sustentabilidad futura del oficialismo y la (convengamos tenue hasta ahora) existencia de la Concertación Plural. (...) Es la mayor derrota política de los Kirchner desde 2003, mención que debe redondearse evocando que no han tenido muchas".
} 
exportación ${ }^{171}$ ) o el establecimiento de nuevas condiciones de producción y comercialización; protesta que revelaba, una vez más, la repercusión directa de la economía del agro pampeano sobre el funcionamiento de la macroeconomía (Barsky y Dávila, 2008: 55).

Otra interpretación es la que analiza el conflicto como la actualización también periódica- de las disputas por la apropiación de la renta diferencial o extraordinaria (Aisain, 2008; Giarraca, Teubal y Palmisano, 2008; Ortiz, 2010) o como corolario de la consolidación del patrón de acumulación financiera que, en el caso de la economía agropecuaria, se expresa en el comportamiento de las rentabilidades relativas por efecto de un factor externo a la dinámica productiva del sector (el capital financiero internacional extra-agrario), con lo cual el diferencial ya no sería la tenencia de tierra sino la posesión de recursos tecnológicos y financieros (Arceo y Basualdo, 2009; Aroskind, 2010). ${ }^{172}$

Esta bibliografía ha intentado reconstruir las condiciones de posibilidad que habilitaron un acontecimiento imprevisible y excepcional tanto por su duración, por la modalidad de la protesta (sostenida sobre la base de acciones directas propias de repertorios ajenos a la tradición de la praxis política sectorial), por la expansión geográfica de las manifestaciones, y principalmente, por la repercusión urbana y la unidad de las organizaciones

\footnotetext{
${ }^{171}$ Evitamos deliberadamente entrar en un debate específico sobre la función económica de las retenciones. Más allá de su legitimidad y necesidad como políticas de estado, durante el conflicto se reactivó el debate sobre su importancia como medida anti-inflacionaria y sobre sus efectos macro-económicos como un mecanismo (tal vez el más importante con el que contaba el Gobierno en 2008) para contrarrestar la tendencia al cuello de botella externo, sosteniendo el superávit fiscal con divisas para poder cumplir con el pago de intereses de deuda sin ingresar en el círculo vicioso del endeudamiento externo. Ver, al respecto, Aroskind (2010)

172 Para estos autores, "la confrontación del año 2008 indica la intención del agro pampeano de terciar en la disputa por la distribución del ingreso y al mismo tiempo de subordinar a los asalariados y a la producción industrial a su propio proceso de acumulación de capital" (Arceo y Basualdo, 2009: 75). Una lectura como esta, que atribuye una intención objetiva a un conjunto tan heterogéneo de actores, puede ser verosímil en el cálculo resultante de la aplicación o no del aumento de retenciones, pero no necesariamente sintetiza claramente las diversas racionalidades que se desplegaron a lo largo de los cuatro meses del conflicto.
} 
agropecuarias, que pocas veces en la historia habían coordinado movilizaciones conjuntas, y nunca antes por un tiempo tan prolongado.

En algunos casos, esas condiciones de posibilidad han sido interpretadas como signos de una racionalidad a priori, en la cual estaban inscriptos los movimientos, los discursos, las acciones, las causas y las consecuencias de la protesta encabezada por la Mesa de Enlace. En otros, esas condiciones son el recurso explicativo postrero de un conflicto que, se asume, operó como revelador de transformaciones de la estructura y en los modos de producción agropecuaria, en sus redes de intercambio económico, en las estrategias de gestión, administración y financiamiento, en las maneras de sociabilidad, en las relaciones políticas sectoriales y en su morfología institucional.

Digamos, entonces, que, por un lado, es posible identificar un consenso en relación a las características del modelo productivo dominante en el agro argentino y en los factores que le dieron forma. Pero, por el otro, existen respuestas divergentes en relación a los interrogantes que activó el conflicto: ¿cómo fue posible sostener la unidad en la acción de organizaciones y actores que son afectados diferencialmente por las políticas estatales, tales como las nucleadas en la Mesa de Enlace? ¿Se trató de una mera conveniencia circunstancial o sólo pudo resultar de condiciones objetivas previas? ¿Qué factores hicieron posible que la heterogeneidad de la estructura productiva, en particular de la Región Pampeana, se tradujera en un movimiento relativamente homogéneo que, al menos durante el período en de la protesta, provocó un deslizamiento del significante “campo”, que pasó de operar como un mero descriptor sectorial a identificar -o a intentar hacerlo- a un "sujeto político”? ¿Es correcto plantear esa dualidad (heterogeneidad de la estructura productiva/homogeneidad del planteo político)? ¿Existe una relación lógica entre ambos niveles? ¿Cómo definir -con qué categorías, según qué criterios, en relación a qué variables- a los actores que sostuvieron la protesta, cómo se inscriben en el modelo productivo dominante, qué relaciones mantienen entre ellos? ¿Qué clase de racionalidad orientó a aquellos actores que, 
aparentemente, se hubieran visto beneficiados por las mismas medidas que combatieron durante cuatro meses?

Responder a estas preguntas obliga a estabilizar una serie de variables que remiten a la estructura social agraria y a las determinaciones derivadas. Buena parte de la bibliografía dedicada al estudio del conflicto ha intentado, lógicamente, reconstruir las condiciones de posibilidad de un proceso que como dijimos fue imprevisible y excepcional. Cabe recordar que, al menos en el período post-convertibilidad, desde que se reinstalaron los derechos de exportación en 2002, las cuatro entidades que compusieron la Mesa de Enlace habían realizado cuatro protestas, pero nunca habían logrado unificar la conducción política: en marzo de 2003, durante la presidencia de Eduardo Duhalde, los exportadores encabezaron un paro de cinco días en protesta contra la suspensión de reintegros por IVA adeudados por el Estado; en julio de 2006, Confederaciones Rurales Argentinas (CRA) decidió convocar a un cese de la comercialización de hacienda, granos e insumos, en reclamo el cierre de las exportaciones de carne y las restricciones que alcanzaban a otros productos; la protesta tuvo impacto en las provincias del interior. En diciembre de 2006, y durante nueve días, CRA y Federación Agraria Argentina (F.A.A) promovieron una protesta que incluyó el cese de comercialización de hacienda, movilizaciones, tractorazos y cortes de ruta) también en reclamo contra la política de precios máximos para el trigo, la carne, y contra las restricciones a las exportaciones ${ }^{173}$.

\footnotetext{
173 "Es preciso recordar, explica Roy Hora (2010: 87), que, en el agro, la emergencia de nuevas organizaciones representativas tuvo lugar en el marco de tensiones y conflictos con las instituciones ya existentes. Así, la hostilidad hacia la más antigua de ellas, la Sociedad Rural Argentina (SRA), desde el comienzo constituyó un elemento central de la identidad de la Federación Agraria Argentina y la Confederación de Asociaciones Rurales de Buenos Aires y La Pampa (CARBAP), núcleo original de las Confederaciones Rurales Argentinas (CRA). Ello potenció las diferencias de intereses, escala, y tipo de empresas que históricamente dividieron a la comunidad de productores, dando forma a un patrón de relaciones interinstitucionales marcado por la rivalidad y la sospecha mutua".
} 
Tal vez por eso, el esfuerzo ha estado puesto en revisar y reconstruir las condiciones de posibilidad no circunstanciales del conflicto ${ }^{174}$. Si así puede decirse, la epistemología predominante para analizar el conflicto agrario ha sido estructural y sociológica: los acontecimientos que se sucedieron desde el 11 de Marzo, coinciden los autores, son los signos consecuentes de una serie de procesos que los preceden y deberían ayudar a entenderlos. Al respecto, hay un acuerdo de base en que el conflicto operó como un revelador de los efectos del "modelo sojero" (Gras y Hernández, 2009) o "modelo del agronegocio" (Giarraca, Teubal y Palmisano, 2008) sobre la estructura socioproductiva del sector agro-ganadero argentino y sobre las redes de sociabilidad y las identidades sociales de las ciudades, pueblos y centros urbanos del denominado "interior" de Argentina (Gras, 2010).

En ese sentido, como sostienen Barsky y Dávila (2008: 10), el conflicto resultó un "catalizador", pues condensó factores diversos que, en conjunto, refieren a la conformación del modelo productivo dominante en el agro argentino. En esto coinciden -no sin variantes- buena parte de los investigadores (Arceo y Basualdo, 2009; Aroskind, 2010; Giarraca, 2008; Hernández, 2011; Rofman, 2010; Sartelli, 2008): es imposible otorgar un marco de intelección al conflicto sin reconstruir la historia de las transformaciones -tecnológicas, económicas, comerciales, institucionales- que han modelado el funcionamiento del sector agropecuario al menos desde mediados de la década de 1990, con la introducción del llamado "paquete cerrado" o "paquete tecnológico", que reconfiguró el conjunto del sistema productivo agrario en general y de la soja en particular, y que resulta un condensador explicativo de otros tantos fenómenos que la preceden, como la expansión de la frontera agrícola, la modernización tecnológica, y de otros que son sus efectos, como la transformación en los modos de financiamiento de la actividad con la

\footnotetext{
174 Podemos señalar tres factores de coyuntura directamente vinculados a la decisión gubernamental de aumentar las alícuotas de los derechos de exportación: el aumento del precio de las commodities que se dispararon sobre fines de 2007 y principios de 2008; , la necesidad del gobierno de mantener el equilibrio fiscal para evitar un cuello de botella que lo obligara a tomar deuda para pagar los intereses a vencerse durante el 2008 y 2009; el descontento latente en el sector, derivado de la política de precios del gobierno y del aumento de retenciones que el propio gobierno había determinado hacia fines de 2007.
} 
presencia dominante de los llamados "pool de siembra", la emergencia de actores institucionales no corporativos dedicados a la promoción tecnológica, etc.

\subsubsection{El modelo del agro-negocio}

Dijimos que es posible identificar un consenso en relación a las características del modelo productivo dominante en el agro argentino y en los factores que le dieron forma. En el origen de estas transformaciones hay una serie de fenómenos que terminaron por converger a lo largo de la década de 1990 en la consolidación de lo que se ha dado en llamar "el modelo sojero" (Gras y Hernández, 2009) o “modelo del agronegocio” (Teubal y Palmisano, 2011).

Para la mayoría de los autores, el momento clave fue la introducción del denominado "paquete tecnológico" hacia mediados de la década de 1990, que, en el marco de las políticas de desregulación y apertura comercial impulsadas por el gobierno de Menem, facilitó la modernización acelerada de la agroindustria (Rofman, 2010). Sin embargo, esa transformación había tenido origen durante la década de 1970, durante la expansión productiva del agro pampeano. Tenemos, pues, tres procesos convergentes que le han dado forma al modelo sojero.

En primer lugar, la expansión productiva del agro pampeano, proceso que se inicia ya hacia mediados de la década de 1970 y que en el largo plazo ha significado la introducción de la agricultura (y puntualmente, de la soja) más allá del núcleo socio-ecológico tradicional. Así, el "modelo sojero" tuvo inicialmente a la Región Pampeana ${ }^{175}$ como escenario principal y luego avanzó

\footnotetext{
${ }^{175}$ Conformada por las provincias de Buenos Aires, Entre Ríos, Santa Fe, Córdoba, La Pampa y San Luis. Limita al Norte con la región mesopotámica y la llanura chaqueña, por el Oeste con las sierras pampeanas y la región de Cuyo y por el Sur con la Patagonia extra andina; el océano Atlántico y el río de la Plata forman su límite oriental. Es la región más importante del territorio argentino, desde el punto de vista económico ya que por sus características de clima y suelo la transforman en una zona agrícola y ganadera por excelencia La economía agrícola se basa en el cultivo del trigo, maíz, lino, avena, cebada, centeno, girasol y soja,
} 
a otras regiones, en particular el Norte y Noreste argentinos. Como consecuencia, se consolidó un esquema de especialización productiva cuyas actividades dominantes responden a los parámetros de internacionalización de la agricultura argentina y cuyos efectos sobre la estructura social agraria fueron determinantes.

Como explican Gras y Hernández (2009), entre el censo nacional agropecuario de 1988 y el de 2002, el número total de explotaciones agropecuarias disminuyó en cerca de un 21\%, a la vez que se incrementó el tamaño medio de las que continuaban en actividad en un 25\% para alcanzar 587 hectáreas en 2002. Respecto del tamaño de las explotaciones, la disminución alcanzó su mayor expresión (26\%) entre las unidades de hasta 200 hectáreas, al tiempo que las explotaciones de más de 1000 hectáreas aumentaron en su importancia relativa (en 2.3 punto porcentuales), en especial las que se ubicaban en el tramo de 1.000 a 2.500 hectáreas (8.5\%). A este resultado se refieren Barsky y Dávila (2008:81) como de “desconcentración sin dispersión"176, ya que la pérdida del control territorial de las grandes unidades no significó el crecimiento polarmente opuesto de las pequeñas, sino que reforzó las explotaciones ubicadas entre las 1.000 y las 5.000 hectáreas.

El segundo proceso fue la difusión masiva de la soja como cultivo durante la década de 1970. Esta década, de hecho, está marcada por dos hechos centrales: la introducción de las semillas mejoradas de trigo, maíz, sorgo y girasol, y la difusión masiva de la soja, lo que implicaba un novedoso y complejo paquete tecnológico para su producción adecuada. A partir de este momento, se registra un aumento de la productividad agrícola, y en particular

además de la explotación de la papa. También se desarrollan en la región la actividad ganadera (bovino y el ovino).

${ }_{176}$ Cabe destacar que si bien las explotaciones de mayor tamaño (más de 10.000 hectáreas) disminuyeron en cantidad (-4.5\%), controlaban mayores superficies (la variación es de $2.4 \%$ ): así, en 2002 este estrato que conformaba la cúpula del sector agrario representaba el $0.9 \%$ del total de explotaciones y controlaba casi el $36 \%$ de la tierra. 
del complejo sojero, que se aceleró, durante la década de 1990, con la adopción del paquete tecnológico, también llamado paquete cerrado. ${ }^{177}$

A principios de la década de 1980 la soja representaba el 10\% de la producción total de granos. Desde 2002, representa aproximadamente el $50 \%$ de ese total. La soja se convirtió entonces en el producto agrícola más rentable, tanto por el abaratamiento de los costos, la adaptabilidad a diferentes zonas y el crecimiento de la demanda internacional. En términos generales, luego de un descenso de los precios internacionales desde 1997, el complejo oleaginoso se recuperó hasta representar, hacia 2007 , un $25,7 \%$ del total de exportaciones, y de ese total, sólo la soja representó un 24,3\% (13.602 millones de dólares). Esto es, casi un cien por ciento del total de las exportaciones de oleaginosas (Barsky y Dávila, 2008: 68).

Ese "paquete", formado por la soja genéticamente modificada y el herbicida glifosato, indujo una serie de transformaciones en el medio agropecuario $y$ sus derivados de la cadena agroalimentaria (aceiteras y harineras) (Hernández, 2007): la conquista de nuevos espacios productivos (extensión de la frontera agrícola, sustitución de ciertos productos -ganadería y cultivos regionales- por el nuevo paquete, etc); la tendencia a la tercerización de servicios (con su correlato, la generalización de la figura del contratista); una importante concentración de la producción, una fuerte presencia del capital financiero; la transnacionalización del sector insumos (semillas, biocidas, fertilizantes, etc), y una resignificación del mapa socio-institucional (roles y representación de las instituciones tradicionales y la aparición de otras) ${ }^{178}$.

\footnotetext{
${ }^{177}$ Algo interesante que dice Hernández (2007: 333) sobre "la articulación de hecho" entre el paquete tecnológico y la siembra directa: "no es ni técnicamente necesaria (se puede aplicar el 'paquete' con labranza convencional y se puede hacer siembra directa con otros cultivos) ni temporalmente coincidente (la siembra directa era practicada por algunos productores desde mucho antes de que llegara la soja resistente al glifosato a la Argentina).

${ }^{178}$ Gras (2011: 47) ha hecho hincapié en la pérdida de importancia política de las formas tradicionales de organización de los intereses del sector, que fueron, paradójicamente, aquellas que se nuclearon en la Mesa de Enlace. Como contracara, se consolidaron las asociaciones profesionales cuya principal tarea es la promoción de cambios tecnológicos y el estímulo de las identidades empresariales.
} 
En tercer lugar, el resultado de estos procesos de transformación ha sido la "intensificación de las economías de escala" (Arceo y Basualdo, 2009), que genera una brecha de productividad entre grandes y pequeños productores. Como ha explicado Gras (2011: 44) a partir de la incorporación del paquete tecnológico se produjo "la expulsión de casi 90.000 unidades productivas entre 1988 y 2002, lo que equivale al 21\% de las explotaciones." Al mismo tiempo, señala la autora, se registró, en el período intercensal, un incremento del tamaño medio de las explotaciones, del $25 \%$ para el total nacional y del 35\% en el caso de la Región Pampeana.

Paralelamente, los profundos cambios tecnológicos que elevaron la escala de la producción fueron impulsando políticas de concentración del capital que resultaron en unidades de mayor tamaño para combinar distintas formas de acceso a la tierra. Particularmente luego de la devaluación del año 2002, los propietarios que pudieron capitalizarse ampliaron sus unidades productivas mediante el arrendamiento. Inversamente, como efecto del aumento del precio de la tierra, aquellos productores que no perdieron sus propiedades, se convirtieron en rentistas.

Por otro lado, la importancia de los contratistas -de máquinas y tomadores de tierras- facilitó la conformación de redes productivas, generalmente articuladas por profesionales con formación universitaria, financiadas bajo la forma, primero, de los Fondos de Inversión Agrícola Directa y, luego, de los llamados "pooles de siembra"179. Éstos implicaron el ingreso de capitales

\footnotetext{
179،En definitiva, tanto el predominio de la propiedad latifundista como el crecimiento de los pools de siembra en la escena agraria constituyen formalmente dos modos distintos de concentración del capital agrario. Aunque los pools no son los propietarios de la tierra y, por tanto, no actúan como los agentes inmediatos de su concentración en términos de la propiedad, sí se erigen como los concentradores de su uso y del control del proceso productivo global. Aunque la gran propiedad, en principio, no crezca aceleradamente, la aparición de los fondos financieros en el sector agrario determina que el proceso de concentración, lejos de detenerse, avanza adquiriendo nuevas formas" (Pablo Benchimol, en Página/12, 20/04/08. Disponible en http://www.pagina12.com.ar/diario/suplementos/cash/17-3460-2008-04-20.html).
} 
extra-sectoriales $^{180}$ y crearon canales de financiamiento e inversión y generaron estrategias de articulación entre propietarios, contratistas y rentistas; estas redes productivas les permitieron aumentar la productividad ${ }^{181}$ y maximizar ganancias en tanto no debían invertir en tierra y maquinaria (Gras y Hernández, 2009; Barsky y Dávila, 2008).

Barsky y Dávila (2008: 218-219) explican que además de las redes productivas que articulan a profesionales de la agronomía, propietarios, arrendatarios y capitales externos (pools de siembra) provenientes de asociaciones temporales (fondos fiduciarios y fideicomisos), esta dinámica involucra a proveedores de maquinaria agrícola, transportistas, servicios y casas comerciales, las gestiones de los municipios que dependen de la bonanza del sector para sostener la economía local, comercios zonales, etc.

Con este marco, puede tenerse una imagen de la compleja trama social sobre la que se asienta (y que a su vez es su efecto) el llamado modelo sojero, trama cuyos hilos parecieron anudarse durante el conflicto del año 2008.

\subsection{Vínculo lógico de las determinaciones y modalidades de encarnación de lo colectivo. Las condiciones sociales del litigio.}

Esta dinámica productiva es la que apareció representada, a lo largo del conflicto, por la Mesa de Enlace. Aquella compleja trama se reveló como el esqueleto del "campo". Las movilizaciones, las acciones directas, la dinámica asamblearia, pusieron de manifiesto un alto grado de convergencia de demandas y posturas de una amplia gama de actores cuya categorización en la bibliografía no es uniforme: desde los arrendatarios y propietarios a los

\footnotetext{
${ }^{180}$ De diferente tipo y tamaño, desde profesionales -médicos, abogados, comerciantes- que decidieron volcar al agro parte de sus ahorros, hasta grandes empresas que tradicionalmente habían operado en otros sectores económicos.

181 Entre 1994 y 2007, la superficie sembrada con cereales de exportación aumentó de 7 millones de hectáreas (40 millones de toneladas) a 16 millones de hectáreas sembradas (98 millones millones de toneladas).
} 
grandes y medianos empresarios, propietarios que combinan el trabajo en tierras propias con el arrendamiento, los chacareros y los contratistas.

De allí cierta estupefacción del análisis: ¿cómo es posible que tal heterogeneidad de actores, que entablan entre ellos vínculos estrechos de sociabilidad pero que, medidos por sus intereses, están objetivamente contrapuestos (como es el caso del rentista puro y el del arrendatario; o el del productor y el del contratista ${ }^{182}$ ) pudieran ofrecer, al menos durante cuatro meses, la imagen de un actor homogéneo y alentar las expectativas, o los temores, sobre la formación de un "partido del campo" (Ortiz, 2010).

Frente a este interrogante se han planteado respuestas divergentes que, entendemos, reflejan las in-determinaciones (en un sentido preciso: la irreductibilidad de los emergentes del conflicto a relaciones objetivas definidas por posiciones estructurales) sobre las que se asienta el litigio. Un breve repaso por algunas discusiones nos servirá de referencia para fundamentar la pertinencia de pensar el conflicto en el nivel de su litigiosidad.

Por ejemplo, Rofman considera que la Mesa de Enlace no representa "al campo" sino "al 'campo' plenamente capitalista con tecnología de punta, en establecimientos donde predominan la tercerización y en el que el $75 \%$ de las tierras son cultivadas por arrendatarios pequeños, medianos y grandes". Desde esta perspectiva, los que protestan "son 70.000 productores de la pampa húmeda". Pero hay "otro campo": de los pequeños productores, y de los campesinos donde se producen hortalizas, legumbres, verduras, frutas, caña de azúcar, tabaco, yerba mate, aceitunas, etc.

182 Como lo explica Gras (2011: 56): “Actores cuyas posiciones los ubican de manera antagónica entre sí (por ejemplo, el dueño de la tierra y el que arrienda, el contratista y el productor) se encuentran coyunturalmente asociados en el marco de las tareas de la campaña agrícola. 
Precisamente, son estas apreciaciones las que cuestionan Barsky y Dávila cuando explican que "el hecho de que los productores de los cuatro grandes cultivos cubran casi el 66\% del territorio implantado y de que en términos numéricos sean el $40 \%$ de las unidades agropecuarias, además de su peso gigantesco en términos del volumen de producción, abastecimiento del mercado interno y exportaciones, es suficiente para destacar la enorme base social y económica movilizada" (2008: 77).

Gras (2011: 58) ofrece una mirada más matizada. Se pregunta qué tipo de procesos están en la base de la conformación del llamado 'campo' nominación que, para la autora, instalaron los propios dirigentes en sus diferentes intervenciones públicas- como actor político. Y se responde que "lo que se activó principalmente en el conflicto no fueron las segmentaciones internas del sector, sino sus fronteras externas frente a otros sectores (el Gobierno, los exportadores, etc.)". Para la autora, el conflicto puede ser pensado como un "momento de interface" durante el cual las "asociatividades" emergentes del cambio tecnológico producen espacios de confluencia entre propietarios de tierra, de maquinarias, ingenieros agrónomos, inversores urbanos, etc. "Las diferencias entre grandes, medianos y pequeños empresarios, entre productores y contratistas, no estructuraban necesariamente la experiencia de conflictividad de los participantes".

Aronskind (2010:336), por su parte, sostiene que en la resistencia a la Resolución 125 "se conjugaron fuerzas de muy distinta índole que superan ampliamente una clasificación basada exclusivamente en criterios económicos, aunque incluye, obviamente -y como núcleo rector- a quienes se veían afectados por el eventual recorte de súper-ganancias que implicaba la aplicación de nuevas disposiciones".

Balsa y López Castro (2011: 142) terminan por creer que "la supuesta heterogeneidad de la estructura social agraria pampeana, de la que habíamos estado hablando la mayoría de los que nos dedicamos a los estudios rurales" 
finalmente no sería tal. Explican, en cambio, que "al menos los productores que dan cuenta del grueso de la producción pampeana no son tan diferentes entre sí, pues ha ocurrido cierta homogeneización en sus características centrales", en particular, lo que Balsa (2006) denomina "el aburguesamiento de los chacareros", categoría que aplica tanto a su lugar en la estructura productiva como a sus hábitos sociales y culturales.

Hubo, de todas maneras, una figura que concentró una atención inusitada, en especial porque fue la que encarnó el protagonismo en las acciones directas: “el pequeño productor", convertido, durante el conflicto, en un símbolo del imaginario político que permitió contrarrestar los intentos del Gobierno y los sectores aliados por caracterizar las protestas como un "lock-out patronal" y a sus protagonistas como expresiones de la "oligarquía" (Barsky y Dávila, 2008; Gras y Hernández, 2009).

Pero, ¿qué es el pequeño productor? ¿Cómo definirlo? Para Gras (2011 46) el conflicto expuso la "reconfiguración del lugar central que, más allá de la posesión diferencial de recursos, tenía el "productor", en el campo argentino, en particular por la profesionalización de la actividad agraria y el fortalecimiento de las identidades profesionales y empresarias ${ }^{183}$. Esa categoría, tradicionalmente, sintetizaba diferentes funciones socioproductivas: control, administración, producción, en tierras propias o arrendadas. Por lo cual, su preeminencia implica el reemplazo de otras denominaciones que, como las de "chacarero" o "terrateniente", se ubicaban en polos opuestos de la estructura agraria.

Para Sartelli, "el pequeño productor" es una denominación errada. Se trata, en realidad, de aquellos agentes que no pueden evitar el contratismo pues no tienen recursos para comprar nuevas máquinas o no tienen justificado el gasto de mantenimiento anual para la superficie que trabajan. Por eso, los

${ }^{183}$ En esto sí coinciden Balsa y López Castro para quienes "la racionalidad chacarera es reemplazada por una racionalidad crecientemente capitalista y los 'productores' se identifican cada vez más como "empresarios rurales". 
"productores", incluso los pequeños y "familiares" son, en realidad, "gerentes capitalistas de las explotaciones" (2008: 75), en tanto contratan trabajo asalariado y limitan su rol al control de las actividades productivas.

Como vimos, Rofman entiende que "el pequeño productor" es el agente central del campo capitalista, y que como tal expresa una fracción de la burguesía agro-industrial.

Balsa y López Castro, por su parte, lo conciben como una figura desdoblada: por un lado, están los "productores familiares modernos", que a su vez clasifican en dos subtipos del chacarero "puro": 1) pequeños productores con baja capitalización, que se dedican a una producción de subsistencia; 2) pequeños productores capitalizados, pero con límites en la capacidad de expansión productiva por la competencia con pooles de siembra y otros grandes inversores. A esta última franja se refieren como "chacareros aburguesados". Y, por otra parte, identifican a los "terratenientes capitalistas" como aquellos que se hacen cargo de la producción con asalariados y contratistas de labores.

Parados en este punto, tal vez pueda apreciarse que las condiciones objetivas de la litigiosidad, en términos de las disputas por la identidad de los actores, el objeto del conflicto y los escenarios legítimos de la protesta, reaparecen, también, en los debates académicos que buscaron explicar las "novedades" o los fenómenos emergentes del conflicto.

Esto, por supuesto, no significa desconocer o menospreciar el valor determinante que la disputa de intereses, derivada de cambios profundos en la matriz socioproductiva del sector agropecuario tuvo y tendrá en su relación con el Estado. Pero también es innegable que todos los debates contemporáneos al conflicto y los análisis posteriores que discutieron, interpretaron, explicaron y volvieron a discutir la heterogeneidad de las identidades contenidas bajo el signo "campo" (discusiones hechas de 
imágenes televisivas, de discursos políticos, de voces de observadores) o aquellas otras sobre cómo distinguir un "pequeño productor", ya por la cantidad de hectáreas como por sus bienes de consumo, ilustra bien este problema, al tiempo que son apenas una de sus manifestaciones visibles.

\subsection{El conflicto como litigio: ¿el "campo" como sujeto político?}

Retomemos ahora nuestro punto de partida: nos interesa el conflicto entre el Gobierno y el sector agropecuario en tanto puede analizarse, en el nivel de la discursividad, como un "litigio político". Lo cual no implica rechazar -siquiera discutir- otras caracterizaciones que se han ofrecido ("rebelión fiscal", "lockout patronal”, "protesta agraria") sino insistir sobre el carácter litigioso de esas definiciones y de sus supuestos implícitos:

- quiénes son los que protestan: ¿la oligarquía terrateniente?, ¿los pueblos del interior?, ¿los pequeños productores?, ¿la ciudadanía?, ¿las clases medias?

- sobre qué protestan, contra qué protestan: ¿las retenciones?, ¿la política de control de precios del Gobierno?, ¿el autoritarismo presidencial?, ¿la intervención confiscatoria del Estado?, ¿la ausencia de un Plan Agrario Nacional?, ¿la distribución equitativa de la riqueza?, ¿un intento necesario de captación de la renta extraordinaria?, ¿la prepotencia del poder central?, ¿la ausencia de deliberaciones democráticas?, ¿el modelo del agro-negocio?,

- cómo y dónde deben reclamar: ¿la acción directa, la mediación dirigencial, en el Congreso, en las plazas, en las calles, en las rutas, en la televisión?.

En toda discusión donde efectivamente hay algo que discutir, dice Rancière (2007: 75), está implicada una estructura en la que el lugar, el objeto y los sujetos mismos de la discusión están en cuestión y en primer lugar tienen que ser probados. El litigio, dice el autor, se refiere a la existencia de las partes como partes, y a la existencia de una relación que las constituye como tales.

Nuestra clave de lectura es que la noción de "litigio" tiene, al respecto, una doble valencia: es un descriptor fenoménico o factual, es decir, designa una 
"estructura específica de comunidad"184; pero también puede traducirse analíticamente, por lo cual es posible sostener que todo conflicto tiene, en un grado o medida que debe ser determinado específicamente, una dimensión litigiosa que obliga a poner en suspenso las determinaciones estructurales posiciones, funciones- e inclusive las asignaciones sociológicas -con sus categorías previamente definidas- y las relaciones de fuerza derivadas. No las anula, ni para el análisis ni en la realidad del acontecimiento, sino que las desplaza para colocar, en primer plano, la componente discursiva, las auto percepciones, las contra percepciones sobre los objetos, los lugares y los sujetos en conflicto.

La dimensión litigiosa se manifiesta por la detección de una controversia que pone en suspenso la entidad misma del conflicto y las entidades en conflicto. Empíricamente, se puede reconstruir en el análisis de funcionamientos microdiscursivos, en los interdiscursos polémicos. Pero esa puesta en suspenso no implica renunciar a definiciones precisas, sino que ayuda a recuperar lo que una mirada reconstructiva probablemente termine opacando: la temporalidad del proceso, sus indefiniciones, sus contingencias, sus deslizamientos, sus retrocesos. De allí su carácter recursivo: supone un "retorno" constante de la discusión sobre la entidad de los objetos en disputa (¿qué es lo que estamos discutiendo?), a la identidad de quienes están disputando (¿quiénes son los que discuten, quiénes son ellos y quiénes somos nosotros?) y a las situaciones y escenarios en que esa disputa se produce. Esto es lo que hemos identificado en la Ilustración 2 a través de los puntos rojos. La coincidencia de estos "retornos" con los discursos en el marco de actos públicos es, si se quiere, un recurso de método: es en esos momentos cuando la litigiosidad se objetiva y donde es posible recuperar su carácter repetitivo, su tendencia a encontrar un núcleo argumental que la sostenga. Y es allí también donde manifiesta plenamente su reflexividad.

\footnotetext{
184 "Antes de arreglar los problemas por medio de interlocutores sociales juiciosos, es preciso arreglar el litigio en su principio, como estructura específica de comunidad” (2007: 136)
} 
El litigio político, precisamente, es el punto de manifestación de la apariencia del sujeto político. Es una "discusión por la cuenta misma de las partes", en tanto supone una reconfiguración -o el intento por lograrlo- del "orden policial": de la transformación de identidades definidas e identificables en el orden natural del reparto de las funciones y los lugares, en instancias de un litigio.

La posibilidad de recuperar la noción de "litigio" para definir una dimensión presente, aunque con predominancia relativa, en todo conflicto político ${ }^{185}$, depende enteramente de la des-identificación de algunos conceptos con referentes específicos (subalternos-dominantes; pobres-ricos) y en radicalizar la formalización de este concepto que, de antemano, parece vedada por las problemáticas a propósito de las cuáles Rancière ha desarrollado su teoría (los trabajadores, las minorías culturales). Sin embargo, como no se trata de una tarea imposible, tal vez el intento sea necesario.

Precisamente, en el conflicto que aquí tratamos los lugares de la "policía" y de la "igualdad" fueron activados, de manera alternativa, tanto por el Gobierno como por las organizaciones agropecuarias, y precisamente aquello que se entendía por "igualdad" y la verificación de un daño fueron esgrimidos, simultáneamente, por "las partes" en conflicto o, mejor dicho, fueron los objetos en disputa para definir "las partes", esos segmentos discretos identificables ("los pooles de siembra", "Mesa de Enlace", "los pequeños productores”, "el sector agropecuario”, "grupo gobernante”, “los 80.000 productores agropecuarios", “los piqueteros kirchneristas”) y aquellos que no pueden ser contados pues arruinan la equivalencia entre el "nombre" y la diferenciación policial de lugares y funciones ("el pueblo argentino", "la ciudadanía”, “el Interior”, “el campo”, etc.).

\footnotetext{
${ }^{185}$ Inclusive en aquellos que se desatan a propósito de una disputa de intereses cuantificables y que, como sucedió en el conflicto del campo, ponen en la escena pública a grupos que, identificados por su lugar en los procesos productivos, son económicamente dominantes,
} 
Recuperemos algunas muestras ejemplares que refuercen el sentido con que estamos aplicando la noción de "litigio", fragmentos de algunos de los discursos más importantes pronunciados por los dirigentes agropecuarios y el contraste con fragmentos de discursos de Cristina Fernández.

El 31 de marzo de 2008, en su tercer discurso, en el marco de un anuncio de compensaciones a "pequeños productores", Cristina Fernández se encargó de ofrecer una cuantificación que rompiera con la pretendida generalidad del reclamo agropecuario. Dijo entonces:

\begin{abstract}
Ahora bien, ¿cuántos son los productores de soja y girasol, en la República Argentina? Son 84 mil. ¿A cuántos les va a llegar esta compensación, como hacemos con otras actividades que hoy anunciaba el ministro? A 62.500 productores que vuelven a tener la misma rentabilidad, no que vuelven a tener rentabilidad porque seguían teniéndola, que vuelven a tener la misma rentabilidad, como si no se hubiera dictado la resolución del 11 de marzo
\end{abstract}

Dos días después, los dirigentes agropecuarios realizaron un acto en la ciudad santafesina de Armstrong, en el cual anunciaron lo que sería, a fortiori, la primera tregua. Allí, Eduardo Buzzi, exclamó:

Esto que empezó siendo un conflicto por las retenciones de 48 horas, y que supuestamente a la reacción oficial del aquel 25 de Marzo (...) Aquel 25 de Marzo fue catalogado como los piquetes de la abundancia y los angurrientos lo que queríamos era ganar más plata y nada más... parecía que la cosa estaba focalizada ahí...Y aquello que empezó de esa forma por el tema de retenciones, está demostrado (...) que ya no es un problema de $\mathbf{8 0 . 0 0 0}$ productores sojeros, es un problema de millones de argentinos. Millones de argentinos que estamos viendo con preocupación el rumbo que está tomando esta situación ${ }^{186}$.

Se entiende que la distancia entre "84.000" productores y "millones de argentinos" pueda parecer un problema de magnitudes, es decir: una distancia mensurable. Sin embargo, el hiato no es cuantificable, porque es de orden cualitativo. Es la distancia que separa un problema sectorial -un conflicto de intereses- de un litigio. ¿Quiénes son los que protestan? La

\footnotetext{
${ }^{186}$ Negritas nuestras
} 
disyuntiva parece un problema contable: 84.000 productores de soja y girasol, he ahí una "parte" distinguible, diferenciable, sociológicamente recortable. Difícil sería contar, y más aun estadísticamente, a esos "millones de argentinos que estamos viendo con preocupación el rumbo que está tomando esta situación".

Pero no es sólo en la proliferación de los nombres ("pequeños productores", "argentinos") y de los desajustes entre éstos y las correspondencias presupuestas en el orden policial donde emerge el litigio. No al menos el que aquí tratamos. Esa proliferación, en todo caso, es lo que nosotros estudiaremos, en los capítulos siguientes, como gestión de colectivos. El litigio opera, también, como un ordenador de esa proliferación: por eso señalamos en el inicio de este capítulo que lo que pretendemos es reconstruir las condiciones productivas del intercambio discursivo que constituye nuestro objeto. Puede que así se comprenda mejor por qué insistimos en el capítulo 2 en que los "colectivos", como categorías, son "construcciones bajo restricción".

\section{Reflexiones finales y pasaje al próximo capítulo}

Si el conflicto desatado a partir del anuncio de la Resolución 125 puede ser pensado como litigio político es porque el nombre del "campo" pudo designar a una comunidad polémica; porque pudo (o pretendió hacerlo) designar a un "sujeto no identitario". La idea o el proyecto de un "partido del campo" (sea como estrategia de los dirigentes agrarios o como hipótesis sobre sus intenciones ${ }^{187}$,) por un lado, y las impugnaciones de esa totalización que, para rechazarla, señalaron la brecha lógica entre la uniformidad del nombre y las realidades diversas que componen la estructura productiva sectorial ${ }^{188}$ no

\footnotetext{
${ }^{187}$ La creación de un "partido del campo" fue incentivada por el grupo político Pampa Sur, incluso desde antes del conflicto de 2008. Durante el conflicto, y con la unidad de la Mesa de Enlace, esa posibilidad pareció tornarse concreta y hasta factible.

${ }^{188}$ Un solo ejemplo de entre tantos que podríamos evocar: "En el debate que se tuvo a lo largo de estos meses se extremó la dicotomía campo/gobierno, cuando en realidad "el campo" se remite a un sector altamente heterogéneo donde estos sectores a que hacemos
} 
hicieron sino confirmar que "el campo" fue el nombre de un objeto litigioso, cuya definición, cuya identidad, debieron definirse en el curso mismo del conflicto.

Sólo para ejemplificar este punto, que luego retomaremos con más detalle, podemos glosar algunos textos que circularon en aquellos álgidos meses de 2008. Cuando aún la presidenta CFK todavía no había intervenido públicamente, el periodista José María Pasquini Durán, escribió en Página/12:

Lo primero que debería ponerse en claro es que la denominación "campo" define realidades muy diferentes. No es lo mismo tener cien hectáreas en la Pampa Húmeda que en las provincias del Nordeste. Tampoco son equiparables la situación del chacarero con la del invernador de ganado, la del exportador a granel que la del que vende al acopiador, la del propietario que trabaja su tierra con la del que la alquila a cambio de una renta para que la explote alguna corporación nacional o extranjera, y así de seguido ${ }^{189}$.

Dos días después, en su primer comunicado, del 24 de marzo de 2008, la flamante "Mesa de Enlace Agropecuario" se presentaba con este diagnóstico:

Asumimos que este es el paro de la unidad del campo. Por ello nos dirigimos a todos aquellos productores que se encuentran en las rutas reclamando justamente, y los instamos a continuar con los reclamos tendientes a solucionar los problemas que venimos padeciendo desde hace largo tiempo, por políticas erróneas aplicadas para granos, carnes, leche, trigo, economías regionales y un sin número de actividades que realiza nuestro sector, que comprometen al crecimiento del interior y del país en su conjunto".

En la edición del 26 de marzo, en el diario La Nación, el empresario Gustavo Grobocopatel firmó una columna de opinión en la que escribió:

El 'campo' tiene una compleja realidad, tratar de estigmatizarla, ideologizarla, es un grave error. En el campo hay grandes y chicos, ricos y pobres, los que crecen o decrecen. Está muy atomizado: los 20 productores más grandes no llegan a sumar el 3 por ciento de la producción total. Hay gente de ideas muy diferentes, pero todos amamos lo que hacemos y nuestra forma de vida ${ }^{190}$.

referencia aquí son ampliamente mayoritarios (Giarraca, Teubal y Palmisano, 2008: 39). Cursivas nuestras.

189 “Recordatorios”, por José María Pasquini Durán, diario Página/12, 22 de marzo de 2008.

190 "El campo se siente decepcionado", por Gustavo Grobocopatel, diario La Nación, 26 de marzo de 2008. 
Y unos días después, el propio diario La Nación, en una columna editorial, decía esto:

Estas propuestas, así como los discursos de la presidenta Cristina Kirchner, demuestran que existe una intención política de dividir al campo. Los productores grandes, así como algunos medianos y chicos, integran un todo armónico e interactivo favorable a la productividad, fruto de la exitosa economía agraria del conocimiento, que tanto provecho ha dado al país ${ }^{191}$.

Rancière dice que "lo político" es el lugar de una "identificación imposible" porque la "subjetivación política" es "la formación de un 'uno' que no es un 'yo', sino la relación de un 'yo' con un 'otro'”, el proceso de subjetivación implica "una identificación imposible, una que no puede encarnar aquel o aquella que la profiere" ${ }^{\text {} 192}$.

Si retomamos los reparos que expresamos al inicio del capítulo a propósito del rótulo con el que designar el conflicto, no parece incorrecto hablar del "conflicto del campo", precisamente porque ese fue el nombre de la discordia, el nombre de un proceso que puso en disputa modos de subjetivación: la producción, mediante una serie de actos, de una instancia y una capacidad de enunciación que no eran identificables en un campo de experiencia dado, cuya identificación, por lo tanto, corre pareja con la nueva representación del campo de experiencia" (Rancière, [1996] 2007: 52).

Pero un proceso de subjetivación no necesariamente culmina con la emergencia de un "sujeto político". En este caso, con la ventaja del paso del tiempo de nuestro lado, podemos afirmar que "el campo" (o sus derivaciones: "los pequeños productores", "los autoconvocados”) no llegó a constituirse en un "sujeto político". En otras palabras: entre el 11 de marzo y el 17 de Julio de 2008 el conflicto tomó la forma de un litigio político en torno a una identidad supra-grupal que se fue despegando de su consistencia histórica ligada a la actividad productiva agropecuaria en el intento por identificar,

\footnotetext{
191 “La intención de dividir al campo", Editorial, Diario La Nación, 4 de abril de 2008.

192 "La subjetivación política es el planteamiento de la igualdad -o el manejo de un daño- por parte de gente que está junta en la medida en que está entre-medio. Es un cruce de identidades que descansa en un cruce de nombres que unen el nombre de un grupo o clase al nombre de ningún grupo o ninguna clase, que unen un ser con un no-ser o con un ser que-nolo-es-todavía" (Rancière, 2000: 149).
} 
consigo, la figura de un "país federal". Se generaron, en esos cien días de movilizaciones y protestas, las precondiciones para la formación de un sujeto político (el "campo") que, sostenido en el peso de su inscripción histórica en el imaginario nacional, sirvió de soporte inicial a la protesta.

Sin embargo, esas precondiciones, por las mismas razones que le dieron fuerza, se disolvieron en la coyuntura: una vez resuelto (al menos institucionalmente) el reclamo contra las retenciones, la movilización retomó la lógica diferencial (Laclau, 2005:108-109), o, en otras palabras, la lógica de la hegemonía tendió a ceder frente a la lógica del partido, y las demandas a reinscribirse en identidades previas ya constituidas ${ }^{193}$. Aunque también ese derrotero se agotó rápidamente. Coincidimos en este punto con Carla Gras (2009, 2011) en que la construcción del actor "campo" fue contingente, inestable, dependió casi exclusivamente de la conflictividad, y por lo tanto, se agotó -porque perdió un eje vertebrador- junto con la derogación de la resolución 125. Por la misma razón, disentimos con el planteo de Sebastián Ortiz (2010), quien reconstruye el período 2003-2008 en un sentido teleológico: como la preparación gradual del Partido del Campo, que habría quedado constituido finalmente en 2008.

Desde ya, estas apreciaciones sólo aplican para la coyuntura inmediata y específica del conflicto. Otra discusión es la que se plantea en torno a las condiciones de posibilidad "estructurales" e "históricas" para que un sujeto político tal fuera posible. En este sentido, para Sartelli (2008:227)

entre las debilidades de la fuerza [la alianza agraria] se encuentra su incapacidad hegemónica. Una fuerza que se estructura en torno a un programa que presupone la amputación de la plusvalía que permite la supervivencia de fracciones enteras del capital y de las fracciones obreras que les corresponden, difícilmente pueda organizar en torno a sí a un conjunto de intereses más generales.

\footnotetext{
193 Un modo de verificar este desenlace es reconstruir las trayectorias posteriores de las principales figuras de la dirigencia agropecuaria. Así, por caso, Mario Llambías fue candidato a Diputado Nacional por la provincia de Buenos Aires en la lista de la Coalición Cívica en las elecciones presidenciales de 2011. Obtuvo un magro 2,65\% de votos totales. Alfredo de Ángeli fue electo senador nacional por la provincia de Entre Ríos en la lista del partido PRO. Eduardo Buzzi apoyó abiertamente a Sergio Massa del Frente Renovador en las elecciones legislativas del año 2013; luego rompió con Massa y en las presidenciales del 2015 anunció su voto por el candidato del Frente Para la Victoria, Daniel Scioli.
} 
Esta imposibilidad también había sido lúcidamente percibida por José Natanson, cuando todavía el conflicto no se había resuelto y cuando la unidad del sector parecía llevar directamente a la conformación de una fuerza política nueva:

Si la importancia global del campo como actor económico debe ser relativizada, más aún su capacidad de construcción política, condicionada por una heterogeneidad estructural imposible de disimular: lo que se autodefine como "el campo" es un amasijo contradictorio en el que unos 200 mil agricultores familiares de bajísima productividad conviven con los productores pequeños y medianos de la Pampa Húmeda, los nuevos pools de siembra (los Grobo, con 150 mil hectáreas, lideran el ranking) y empresas como Cresud (395.429 hectáreas).(...) En estas condiciones, parece difícil que los productores agropecuarios puedan convertirse en -digámoslo de la vieja forma- una fracción de clase capaz de subordinar y poner en función de sus intereses al resto del poder económico, que es lo que parecen pretender algunos y sospechar otros ${ }^{194}$.

Podemos pensar, entonces, que aquellas precondiciones no terminaron por dar lugar a la constitución de una nueva "subjetividad política" (Rancière, 2007), o a un nuevo "pueblo" (en tanto actor histórico, Laclau, 2005), sin que esto afecte la consideración sobre la magnitud del proceso político ni sobre su lugar en la vida social, en la esfera política-institucional y en la economía argentina.

194 “¿El campo al poder?”, por José Natanson, Página/12, 1 de junio de 2008. 


\section{TERCERA PARTE: LA DISPUTA POR LA REPRESENTACIÓN}




\section{CAPÍTULO 5}

REPRESENTACIÓN POLÍTICA, REGÍMENES DE VISIBILIDAD Y ACTIVACIÓN LITIGIOSA EN LAS INTERVENCIONES PÚBLICAS DE CRISTINA FERNÁNDEZ DE KIRCHNER 


\title{
CAPÍTULO 5
}

\section{REPRESENTACIÓN POLÍTICA, REGÍMENES DE VISIBILIDAD Y ACTIVACIÓN LITIGIOSA EN LAS INTERVENCIONES PÚBLICAS DE CRISTINA FERNÁNDEZ DE KIRCHNER}

\author{
Introducción: intervenciones y discursos
}

En este capítulo vamos a realizar un análisis discursivo de las intervenciones públicas de Cristina Fernández de Kirchner (en adelante, CFK) a lo largo del conflicto con el sector agropecuario. Nuestro objetivo es reconstruir, a través del estudio de sus estrategias enunciativas ${ }^{195}$ y de los regímenes de visibilidad configurados en aquellas intervenciones, una serie de problemáticas que signaron, también, el devenir del propio conflicto y que tuvieron efectos en la progresiva constitución de CFK como líder político, en las decisiones de la Mesa de Enlace y en el tratamiento periodístico de los acontecimientos. Para decirlo retomando la propuesta de concebir al conflicto del campo como un litigio: las intervenciones de CFK -y los discursos allí producidos- fueron instancias de fuerte activación litigiosa, de reposición insistente de la controversia sobre la identidad de los actores, del objeto de las protestas y de los escenarios en los que esta se producía o debía producirse.

Pensamos aquellas problemáticas como tópicos o lugares comunes, en el sentido en que los define Amossy (2000): como temas consagrados, esquemas que se van actualizando según las circunstancias. En nuestro caso, esos

\footnotetext{
195 En el marco del estudio de discursos sociales, y en particular desde la perspectiva enunciativa, una estrategia no se define como plan deliberado que ordena los pasos intermedios (tácticas) con el propósito de alcanzar un fin, sino como las variaciones y las invariantes detectadas en un corpus que pueden remitirse a una variación (o a la estabilidad) de determinadas condiciones productivas. Nos diferenciamos, en este punto, de otros autores que también han trabajado sobre este mismo corpus de alocuciones presidenciales, como Raiter (2013) que concibe "las apelaciones al interdiscurso [en las alocuciones de CFK] son una estrategia, estrategia destinada, en este caso, a cumplir con la función del discurso político, lograr adhesiones".
} 
tópicos son los siguientes: el estatus de la representación política; el fundamento de la legitimidad de las decisiones y acciones; y, como hilo conductor entre esos dos tópicos, la escenificación (y la auto-tematización) de posiciones de liderazgo político.

Planteado el plan general del capítulo, se hacen necesarias algunas aclaraciones.

En primer lugar, sobre el tipo de abordaje elegido. El análisis de los discursos es, antes que nada, un modo de abordaje teórico-analítico. Esto implica dos cuestiones: en primer lugar, que "discurso" no designa, en principio, un referente empírico sino un modo de análisis de la dimensión significante presente, por hipótesis, en todo fenómeno social (Verón [1987] 2004: 124). Partimos, por tanto, de una epistemología semiótica para la cual sus materiales de análisis se construyen como objetos heterogéneos: tanto en su composición (icónica, indicial, simbólica) cuanto en las "relaciones" que pueden establecerse con sus condicionantes extra-discursivos:

La unidad posible de un análisis dado será pues el resultado de criterios exteriores a los textos estudiados [puesto que estos carecen de unidad intrínseca; son el lugar de manifestación de una multiplicidad de sistemas de restricciones],y esto es así sobre todo en dos niveles: a) el relativo a los criterios que presiden la selección de los textos; b)el relativo a la finalidad de la “lectura (Verón, [1975] 2004: 72)

Luego, incluso antes de ejercer el análisis (o de exponerlo) el analista realizó una tarea determinante: operó una abstracción (es decir, una separación) de un fragmento de "realidad" (en este caso, un discurso o un conjunto discursivo) al que, luego, buscará reincorporar o revincular, a través de ciertas hipótesis, con una serie de fenómenos extradiscursivos (extradiscursividad que es estrictamente metodológica: se define en relación al discurso de referencia analizado). Esta afirmación puede pasar por banal, y tal vez lo sea; quizás por eso, de hecho, se la suele olvidar. Ese olvido, en cambio, sí que no es banal: sus consecuencias se vislumbran tanto en la 
ontología social de la investigación cuanto en la epistemología que orienta al análisis ${ }^{196}$

En cuanto a los criterios de selección del corpus el propio conflicto, cuyo desarrollo extendido es para nosotros una invariante referencial, ofrece un criterio de selección de las intervenciones que vamos a analizar. Pero más allá, y considerando el enfoque adoptado en los primeros capítulos, esas intervenciones, y los discursos de CFK, nos interesan pues tienen, entre sus condiciones de producción, al espacio público mediatizado. En este punto, y tal como sostiene Verón ([1987] 2004: 87) “la conceptualización de las condiciones de producción siempre adquiere la forma de un conjunto de decisiones metodológicas". En este caso, menos que la selección de los discursos, este criterio ha guiado ciertas decisiones importantes para el análisis propiamente dicho.

Paso necesario, el trabajo sobre la transcripción de alocuciones orales, es un procedimiento insuficiente. En el devenir fáctico del conflicto -y esta afirmación podría generalizarse a otros contextos que exceden esta Tesis- los "discursos" de CFK se comprenden mejor como intervenciones sobre el espacio público. Digamos: si la tendencia del análisis del discurso es trabajar sobre la materia lingüística, reconociendo y mencionando su contexto, aquí intentaremos analizar discursivamente las intervenciones, que, en su repetición, van estabilizando una ritualización de lo político (Abèles, 1989: 140-141), tanto por su formalización (que sólo se verificará en los años siguientes) como por los alcances simbólicos de la escenificación de la relación del líder con su fuerza política, con sus simpatizantes y con la ciudadanía no orgánica.

\footnotetext{
${ }^{196}$ El olvido de esa tarea fundante (la abstracción) puede llevar a afirmar, como lo hace Charaudeau (2002), que "discurso y acción son dos componentes del intercambio social, cada uno de ellos con su propia autonomía". Para decirlo claramente: en el único "lugar" en el que discurso y acción son "componentes separados" y "autónomos" es en el discurso científico del analista de los discursos. Antes de la intervención analítica, ni siquiera es posible pensar esa separación; aún más, ni siquiera es posible concebir un objeto de observación tal como la "acción", por un lado, y el "discurso" por el otro.
} 
Como intervenciones, su dimensión semiótica no depende de una cualidad intrínseca, sino de un modo de analizarlas. Por eso no sólo interesan por el "contenido" de la palabra presidencial sino en tanto tienen efectos poderosos, transformadores, sobre la temporalidad del espacio público mediatizado (algo que podremos comprobar en los capítulos siguientes). Esto por varias razones. En primer lugar, porque implican una escansión de la agenda mediática, al introducir un elemento heterogéneo e imprevisto (en el sentido de que no es producido por el sistema mediático) que reorienta la discursividad posterior; en segundo lugar, porque esas alocuciones están insertas en lo que Landowsky (1985) llama un "régimen de visibilidad"; en tercer lugar, porque ese "régimen de visibilidad" (irreductible, por definición, al orden lingüístico) es un modo de escenificar el lugar del cuerpo presidencial en el juego de fuerzas sociales e institucionales que dinamizan el sistema político. Entendemos que un análisis de estos regímenes es una condición necesaria para estudiar el discurso propiamente dicho, algo por lo demás imprescindible

Nos resta aún otra aclaración, a propósito del "discurso presidencial". Se trata de un espécimen excepcional del discurso político. Por razones válidas, los estudios de análisis del discurso político han tratado al discurso de los presidentes como objeto paradigmático. Pero su excepcionalidad requiere al menos reflexionar sobre las cualidades específicas, únicas, de su dispositivo de enunciación, que no puede ser sin más equiparable al de otros discursos políticos $^{197}$. Si el campo político "está constituido (...) por una pluralidad de discursos y de posiciones de enunciación, a los que las instituciones definen como equivalentes, desde un punto de vista formal", y frente a los cuales también los ciudadanos son definidos como equivalentes, "en el momento del sufragio" (Sigal y Verón, 2008: 246), una vez definida una elección, el ganador (o ganadora) está en condiciones de re-vincularse con esos ciudadanos desde una posición privilegiada, exclusiva.

\footnotetext{
${ }^{197}$ Al respecto, Sara Pérez (2013: 159) dice que, como subtipo, el discurso presidencial es el más formal y planificado, a su vez, y el más asimétrico.
} 
La tercera aclaración corresponde a dos de las categorías de análisis que vamos a utilizar: dispositivo de enunciación y régimen de visibilidad.

Por dispositivo de enunciación, como lo explicamos en el capítulo 2, nos referimos a la constitución, en la superficie discursiva, de una escena comunicativa que implica la emergencia de figuras (que son "objetos abstractos" reconstruidos por el analista) y de sus relaciones: la imagen de quien habla, el "enunciador"; la imagen de aquel a quien se dirige el discurso, el "destinatario"; la relación del enunciador con lo que dice y con su destinatario. Este modelo ha sido aplicado para estudiar el discurso político. La hipótesis (clásica, a esta altura) de Verón (confirmada por estudios posteriores de los autores que aquí utilizaremos) es que el discurso político se caracteriza por estructurarse según dispositivo que supone un desdoblamiento situado en la destinación; ese desdoblamiento corresponde, por su parte, al funcionamiento del campo político (la política) en un sistema democrático. De modo que la política, en este marco, queda identificada con las instituciones de la democracia ${ }^{198}$ : el Gobierno, la oposición, el Parlamento, las elecciones, etc., y el "discurso político" como el registro -no solo lingüístico ${ }^{199}$ - que se pone en acto cada vez que un actor (individual o colectivo) moviliza, públicamente, alguno de los factores indisociables de esas instituciones: la producción de legitimidad, el ejercicio de la representación, el desarrollo de estrategias de persuasión, el afán de ocultar, o de subrayar, el ejercicio o la presencia de la dominación, la figuración del poder, la producción de los indicios de autoridad, la proposición de pactos o la asunción de compromisos.

\footnotetext{
198 Para decirlo en términos de la teoría post-estructuralista: el discurso político se estudia como registro significante del nivel óntico: del conjunto de prácticas e instituciones a través de las cuáles se crea un determinado orden, organizando la coexistencia humana, en el contexto de la conflictividad derivada de "lo político" (Mouffe, 2002: 16).

${ }^{199}$ Señalo con esta palabra no el tipo de abordaje, sino la materia que compone los objetos a los que preferentemente se dedicó el análisis del discurso político, sea que lo hiciera desde la lingüística propiamente dicha, desde la teoría de la enunciación, desde el análisis crítico del discurso, etc
} 
Pese a su probada utilidad heurística, considerado como concepto metodológico el "dispositivo de enunciación" ha corrido la suerte de otro concepto igualmente necesario, el de "ethos": su potencial explicativo, que apunta a captar algo del orden de la experiencia sensible de la discursividad, de lo que el propio discurso permite entender sobre las relaciones sociales en las que, al mismo tiempo, es producido, todo eso, al menos en el estudio de los discursos políticos kirchneristas, ha sido utilizado casi exclusivamente para trabajar sobre la materia lingüística (Couso, 2008; Raiter, 2009; Bitonte, 2010; Vitale y Maizels, 2011; Maizels, 2014). Todo lo que estos conceptos pudieran ofrecer para entender la corporalidad, la escenificación, la dramaturgia de la discursividad política (que, como lo dijimos, es, casi siempre, una discursividad pública) queda limitada por la vía metodológica que consiste en trabajar sobre la transcripción de las alocuciones orales ${ }^{200}$.

Para hacernos cargo de este límite es que vamos a recurrir a otro concepto metodológico, que Eric Landowsky (1985) ha denominado "régimen de visibilidad". Este concepto reenvía al problema de la construcción y de la puesta en escena de sujetos individuales y colectivos en función del par conceptual público/privado. Para Landowsky, el pasaje y el cruce de los pares conceptuales (individuo/colectivo, público/privado) obedece a "un principio común, relativo a la admisión o a la exclusión de una instancia testigo ("ellos")". En el nivel de la individualidad privada, "yo soy"yo" [je] en relación a un "usted" [vous]; pero aquí reunidos, "nosotros" [nous] nos

\footnotetext{
${ }^{200}$ No pretendemos iniciar aquí un debate innecesariamente polémico sobre dos conceptos realmente imprescindibles para el estudio de los discursos, de hecho, los estudios citados nos han sido de muchísima utilidad para complementar y fundamentar el nuestro. Sólo señalamos una tendencia preponderante en su aplicación, en particular porque se trata de conceptos que, originalmente, no han sido elaborados para estudiar sólo la materia lingüística. Como bien lo ha notado Maingueneau (1997) en una lúcida reflexión sobre el "ethos": "Es, en última instancia, una decisión teórica saber si se debe relacionar el ethos con el material propiamente verbal, dar el poder a las palabras, o si se debe integrar elementos como el vestuario del locutor, sus gestos, ver el conjunto del cuadro de la comunicación. El problema es mucho más delicado porque el ethos, por naturaleza, es un comportamiento que, es tanto tal, articula lo verbal y lo no verbal para provocar en el destinatario efectos que no se deben solo a las palabras, al menos no por completo". Y lo mismo podría plantearse sobre el concepto de "dispositivo de enunciación". Si bien, por ejemplo, Verón ha realizado estudios sobre la configuración de las escenas de comunicación en situaciones de intercambio televisivo entre periodistas y políticos, esa línea no se ha trasladado al estudio de las intervenciones públicas, las escenificaciones, los rituales políticos kirchneristas.
} 
delimitamos en función de un "ellos". En el nivel que nos interesa, el de la constitución de los "espacios públicos de la representación" ${ }^{201}$, se pueden delinear tanto un nosotros (colectivo público), como un yo, (la figura del individuo público, la persona representativa, ejerciendo un "rol social"). La vida social se constituye, en uno de sus niveles, como un entramado complejo de regímenes de visibilidad, sometidos a reglas de aparición y estrategias de comunicación en algunos casos estandarizadas.

Hechas estas aclaraciones, resta adelantar el orden de la exposición. El capítulo se desarrolla en tres grandes apartados: en el primero, vamos a analizar lo que llamamos la "dilemática de la representación" en los discursos de CFK siguiendo el modelo de análisis del dispositivo de enunciación del discurso político; en el segundo, buscaremos reconstruir los regímenes de visibilidad en los que se enmarcaron los discursos presidenciales para mostrar la escenificación de formatos de liderazgo y de órdenes de legitimidad que son inaprehensibles por el sólo análisis del discurso lingüístico; y en el último apartado, vamos a proponer, a modo de recuperación de los análisis previos, el seguimiento de las cuestiones litigiosas en los discursos de CFK, haciendo hincapié en las definiciones sobre el conflicto y en la construcción de los adversarios, para lo cual retomaremos el sentido cronológico del ordenamiento del conflicto en cuatro etapas propuesto en el capítulo 4.

\subsection{Las cuestiones litigiosas y la dialéctica del conflicto}

Pues bien, como lo mencionamos, la litigiosidad instaurada por los discursos de CFK tuvo dos núcleos centrales a lo largo del conflicto. Por una parte, se manifestó como una confrontación por el estatus de la representatividad ( $\mathrm{y}$, por añadidura, de los fundamentos de su legitimidad) a la que acceden quienes han sido electos por el voto popular contrastada con la legitimidad

${ }^{201}$ Conviene retener el plural para distinguir los escenarios diversos en los que la persona representativa toma cuerpo y ejerce su liderazgo. Y para subrayar que "lo público", en estos casos, es inescindible de las formas de la mediatización. 
restringida de la que están investidos los representantes de "intereses sectoriales". Como intentaremos mostrar, desde los primeros discursos, CFK había fundamentado su lugar de enunciación en la relación privilegiada que, como presidente, mantiene con el mecanismo de base de funcionamiento del sistema democrático: las elecciones.

Desde el principio, por lo tanto, el eje del enfrentamiento, tal y como es presentado en sus discursos, fue al mismo tiempo una puja por la redistribución del ingreso (definida por la propia CFK como una "lucha de intereses, natural en toda democracia"202) como la disputa por un "modelo de país", a la que le es inherente una tensión entre la legitimidad de la representación de los portavoces de esos "intereses" (que, por lo demás, se postulan también como hablando en nombre del bien común) y la legitimidad que sustenta la palabra presidencial, no como el portavoz de una fracción social, sino como representante de "todos los argentinos".

Pero esta dilemática de la representación política es irreductible a los argumentos desplegados por CFK en sus alocuciones. A lo largo del conflicto, las intervenciones públicas de la Presidenta no se limitaron a apariciones protocolares. El oficialismo apeló a la movilización partidaria y a la convocatoria de masas como muestras de apoyo de su propia fuerza política y de la ciudadanía extra partidaria, actos en los que se desplegaron modalidades de escenificación del liderazgo político que desbordan el presupuesto de la legitimidad otorgada por el triunfo electoral. Es necesario, por lo tanto, articular el análisis del discurso con la configuración de los regímenes de visibilidad que estructuraron las intervenciones presidenciales para constatar cómo cada nivel analítico permite acceder a modalidades diferentes de escenificación del liderazgo, de activación de los órdenes de

\footnotetext{
${ }^{202}$ Alejandro Raiter (2013: 115), en su análisis de estas mismas alocuciones, entiende que en estos primeros discursos CFK, decide colocar el peso de la discusión en el plano de la legitimidad, relegando, deliberadamente, el debate sobre la conveniencia y necesidad de las retenciones. Por nuestra parte, entendemos que esa tensión, si bien termina siendo consagrada por la Presidenta, ya se puede vislumbrar en las intervenciones de la Mesa de Enlace, de modo que CFK lo que hace es intervenir sobre una disputa ya planteada, y por lo demás nunca se resuelve definitivamente.
} 
legitimidad que lo sostienen y, en conjunto, a las variaciones en las relaciones que el enunciador construye con sus destinatarios

El segundo núcleo litigioso fue la definición del tipo de conflicto al que se estaba asistiendo, y por lo tanto, de la definición del objeto de la disputa, de la identidad de quienes estaban confrontando y de los escenarios en los que esa confrontación se estaba produciendo. Desde nuestro punto de vista es posible identificar una correlación entre la definición del conflicto (puja distributiva, disputa por el modelo de país) y el modo en que se resuelve el dilema de la representación democrática, particularmente en relación a los órdenes de legitimidad invocados como fundamento de las decisiones propias y de la legitimidad atribuida o negada a sus adversarios por parte de CFK. A una determinada caracterización del conflicto corresponde un modo de estructurar el dispositivo de enunciación, y por lo tanto, de construir las relaciones que el enunciador (en este caso, plenamente asumido como "persona representativa") establece con sus adversarios, con sus colectivos de identificación y con las demás entidades que le dan forma al imaginario político.

En lo que sigue, ordenaremos la exposición integrando dos criterios: uno de tipo analítico y otro de tipo cronológico. Entendemos que es la única manera de reconstruir las estrategias enunciativas sin desatender la dialéctica temporal entre las circunstancias inmediatas $y$ las intervenciones presidenciales. $\mathrm{Y}$ es la única manera, en particular, de respetar la importancia relativa que estas intervenciones tuvieron a lo largo del conflicto.

Para ser claros: si desde el punto de vista formal (es decir, desde el punto de vista que se elabora por efecto de la intervención normalizadora del analista) todos los discursos son equivalentes, desde el punto de vista funcional (esto es, considerados por los efectos específicos que cada intervención tuvo en el devenir del conflicto) la relación de equivalencia o bien se diluye o bien es 
impertinente ${ }^{203}$. Indagando en las fuentes de lo que llamó “la eficacia simbólica" de los rituales políticos, Bourdieu (1999: 71) sostuvo que los principios de esa eficacia no podían hallarse "en su lógica propiamente lingüística" sino que "están siempre condenadas al fracaso mientras no se establezcan la relación entre las propiedades del discurso, las propiedades de quien lo pronuncia, y las propiedades de la institución que autoriza a pronunciarlos". Esto vale muy especialmente para el estudio de discursos presidenciales, que pese a ser un ejemplar excepcional (y, en rigor, único), suelen ser el material predilecto de los estudios de análisis del discurso político. En cualquier caso, es importante conservar este principio de análisis: una variación en el tipo de intervención pública (sea un acto protocolar, un anuncio por Cadena Nacional, o una movilización masiva) produce una variación en las relaciones que se entablan entre esos tres factores ${ }^{204}$.

\footnotetext{
${ }^{203}$ Una buena manera de reflexionar sobre esta diferencia entre forma y función de las intervenciones públicas y del discurso político es la lectura de las crónicas periodísticas que van informando sobre la organización de estas intervenciones. Así, por ejemplo, en un artículo titulado "Contraataque K con otro acto en Plaza de Mayo". (página/12 16/06/2008) se anuncia: "Fiel al estilo del kirchnerismo de redoblar la apuesta en los momentos críticos, el oficialismo convocó a un acto el miércoles en Plaza de Mayo en el que hablará la Presidenta, según pudo saber Página/12. El acto fue convocado tanto por la Federación de Municipios, cuya conducción está en manos del núcleo duro de intendentes del Gran Buenos Aires, como por movimientos sociales kirchneristas. La manifestación -que, según prometen los organizadores, será multitudinaria- coincidirá con la jornada "de protesta nacional" a la que llamaron las cámaras agropecuarias para repudiar el intento de Gendarmería de liberar la ruta 14 anteayer, y con el último día previsto para el nuevo lockout que lanzaron ese mismo sábado a la noche. Esa parece ser la respuesta del Gobierno ante la creciente protesta de los ruralistas que, además de volver a convocar a no comercializar granos, ayer mantuvieron cortadas muchas rutas de las provincias agrícolas y ganaderas con la ayuda de los transportistas, que también hacen piquetes, pero en contra de la resolución de los productores de no vender sus cosechas".

204 Por caso, mientras que los actos oficiales corresponden al protocolo de la agenda presidencial más allá del conflicto (aunque, obviamente, el contenido de los discursos puede variar en relación a ese contexto) las movilizaciones a Plaza de Mayo (del $1^{\circ}$ de abril y 18 de junio) sólo se explican por la persistencia de las confrontaciones y por la necesidad de escenificar un respaldo masivo y medir las relaciones de fuerza en el espacio público. De allí la necesidad balancearnos entre una lectura circunstancial y el intento por recuperar las propiedades invariantes de los discursos de CFK.
} 


\subsection{Representación y legitimidad: definición de las estrategias enunciativas.}

Habían pasado casi dos semanas desde iniciada la protesta del sector agropecuario cuando el martes 25 de marzo de 2008 Cristina Fernández hizo su primera intervención pública para referirse al conflicto. En esas dos semanas se habían desplegado las modalidades de protesta que persistirían en los siguientes cuatro meses (cortes de ruta, cese de comercialización de granos y ganado, movilizaciones a las ciudades, asambleas de productores, tractorazos, etc.); los dirigentes de las cuatro entidades gremiales más representativas del sector (SRA, F.A.A, CRA y Coninagro), habían emitido, el 14 de marzo, un primer comunicado conjunto bajo el título: "El campo dice basta", en el cual postulaban el reclamo como una reivindicación del Interior e impugnaban el conjunto de la política agropecuaria del Gobierno nacional, y luego, el 24, habían conformado la denominada "Comisión de Enlace" (rótulo que sería reemplazado, por fuerza del uso, por el de Mesa de Enlace) con lo cual presentaban, pese a las diferencias internas, un reclamo unificado que trascendía el cuestionamiento puntual al contenido de la resolución $125^{205}$.

Se había planteado, entonces, una situación que sin esfuerzo podía interpretarse como desafío a la autoridad del Gobierno, y además -lo que para nosotros es, finalmente, precondición de análisis- se habían establecido ciertas “condiciones de simbólicas de posibilidad”"206 ((argumentos, figuras

\footnotetext{
${ }^{205}$ Cabe agregar que previo al discurso presidencial, la Comisión de Enlace había decidido extender la protesta durante la Semana Santa de ese año, impidiendo el paso de productos agropecuarios pero permitiendo la circulación de turistas. Esto redimensionó los alcances de la protesta, cuyos efectos en el abastecimiento de alimentos empezaban a sentirse en los centros urbanos. Desde el Gobierno se planteaba la posibilidad de aplicar la Ley de Abastecimiento y se condicionaba la apertura de una mesa de diálogo al cese de las acciones de fuerza. El lunes 24 , algunos diarios ya anunciaban la "urbanización" de la protesta a través de cacerolazos a favor del "campo".

${ }^{206}$ Escribe Bronislav Baczko ([1984] 2005: 17) que "es muy fácil constatar que en cada grave conflicto social -una revuelta, una guerra, una revolución- las acciones mismas de las fuerzas presentes tienen condiciones simbólicas de posibilidad" Esas condiciones, que por definición no pueden reducirse a una mera inventiva episódica (por lo cual el uso meramente instrumental de un acervo simbólico es una práctica objetivamente limitada), tampoco son acumulativas: no se las hereda como peso muerto, sino que se las actualiza como herencia en lo que debe considerarse una operación política fundamental.
} 
retóricas, invocaciones al pasado) que le comenzaban a dar forma al imaginario político del conflicto.

Desde el momento en que se anunciaron las retenciones móviles, el Gobierno privilegió la defensa de la medida, primero con argumentos técnicos/racionales (no socavaba los niveles de rentabilidad del sector, la necesidad de contener el proceso de sojización de la agricultura y de desacoplar los precios locales de los internacionales en un contexto de escalada inflacionaria). Esta línea argumental se fue politizando (si se nos permite, en el sentido de Rancière: fue incorporando la idea de que la medida se hacía en defensa de la igualdad, como reparación de un daño) gradualmente. Los funcionarios de primera línea del oficialismo y algunos aliados políticos agregaron, a las fundamentaciones técnicas, cuestionamientos políticos. El Jefe de Gabinete, Alberto Fernández, habló de la "rentabilidad extraordinaria" del campo; Hugo Moyano, de la "actitud mezquina y miserable de la aristocracia del campo"; Martín Lousteau, de una “medida de corte patronal” y Luis D’Elía y Edgardo Depetri anunciaron el retorno de "la pelea pueblo versus anti-pueblo".

Por su parte, los dirigentes agropecuarios, en particular los de la Federación Agraria Argentina (F.A.A) y de Confederaciones Rurales Argentinas (CRA) habían politizado, pero en sentido inverso, su reclamo casi de inmediato. Incluso el primer comunicado de las cuatro entidades, previo a su constitución como Comisión de Enlace, decía, en su párrafo inicial:

\footnotetext{
“Ante una nueva confiscación a la producción agropecuaria, con la excusa de "desacoplar" los precios internos de los internacionales, medida que conlleva una clara intención recaudatoria y de neto corte fiscal que discrimina a las provincias y a los pueblos del interior, las entidades de la producción expresamos nuestro rechazo y convocamos a medidas de protesta en todo el país". La cursiva es nuestra.
}

Si bien la dirigencia rural impugnaba la consistencia de los criterios implicados en la resolución, desde el primer día enmarcaron la protesta en un reclamo 
político, asumiéndose como representantes de un sector productivo discriminado, y más aún, de un colectivo con presencia permanente en el imaginario social pero intermitente como sujeto político, el Campo; y de su topos "natural" dentro del imaginario político, el Interior, y habían logrado (no sin dificultades) instituir una voz unificada que, a su vez, le otorgaba unidad a un reclamo de contenidos heterogéneos, cuando no contrapuestos.

Nos detenemos en estos detalles porque sólo así es posible entender cuál fue el efecto de la primera intervención pública de CFK. El más importante, en rigor: que no fue el haber servido de pretexto o justificación de las reacciones posteriores (en particular, los cacerolazos en la Ciudad de Buenos Aires) sino haber consagrado una serie de argumentos dispersos que sólo en su discurso y en su cuerpo podían conformar una voluntad política unificada ${ }^{207}$. En efecto, ese 25 de marzo, en el marco del anuncio de un convenio entre la empresa estatal Agua y Saneamientos Argentinos S.A. (AySA) y algunos municipios bonaerenses en Casa de Gobierno, CFK retomó la línea argumental ya expuesta por sus funcionarios, defendió el efecto redistributivo de las retenciones (a las que fundamentó con datos y estadísticas); consideró que estaba enfrentado "pujas redistributivas"; destacó el aporte de las políticas estatales a la bonanza del sector; "a los argentinos". Pero sobre el final del discurso, CFK hace una declaración reveladora que sería retomada casi como una fórmula en los discursos posteriores:

"La verdad es que todos deberíamos hacer un ejercicio de reflexión, pero sepan que voy a seguir representando los intereses de todos los argentinos, de los que me votaron y de los que no me votaron también, porque es mi deber como Presidenta de la República Argentina, y lo pienso ejercer con todos los instrumentos que la ley, la Constitución y el voto popular me han conferido" 208

\footnotetext{
207 Veremos en el próximo capítulo que la contraposición entre los piquetes de los desocupados durante el 2001 y estos "piquetes de la abundancia", así como la identificación del "lock-out" con intentonas de golpe militar ya habían sido desarrolladas, por ejemplo, en Página/ 12, antes del primer discurso de CFK.

${ }^{208}$ En adelante, toda vez que fragmentos de discursos aparezcan destacados en negritas se trata de un agregado nuestro.
} 
Pronunciado sobre el final de la alocución, este fragmento produce un movimiento reflexivo que modifica el conjunto del discurso: introduce como eje argumental el fundamento de las decisiones y de la autoridad que las ha tomado y, de modo más inmediato, la autoridad de quien está hablando.

Hasta ese pasaje, CFK había hecho descansar su argumento en un diagnóstico objetivo (desagregado de cifras, estadísticas, comparaciones interanuales de productividad, etc. ${ }^{209}$ ) aunque, es verdad, enmarcado en una voluntad política (la redistribución del ingreso). Es decir, el mismo diagnóstico que ya habían ofrecido los funcionarios del gobierno desde el anuncio de la resolución 125. Las palabras finales, sin embargo, producen un giro de $360^{\circ}$ y se posan en el inicio pues remite a la cuestión del origen de la autoridad: ¿en nombre de quién está hablando, de dónde le viene el derecho a la palabra?

Al momento de pronunciar su discurso, los argumentos técnicos apuntalados por la racionalidad económica de la resolución 125 ya habían sido rechazados por la dirigencia y las bases agropecuarias; la persistencia de la protesta y el afán de la dirigencia patronal por instituirse como cuerpo representativo ya no sólo sectorial sino de una fracción ciudadana llevaba implícita una impugnación de la autoridad política presidencial, a menos de cien días de su asunción. La puja redistributiva -un típico conflicto de intereses- quedaba subordinada a una discusión sobre la autoridad política, su legitimidad, los alcances del lazo representativo y los mecanismos institucionales y normativos que organizan el sistema de representación.

\footnotetext{
209 "Pero imaginemos, por un momento, que tampoco hubiéramos desacoplado los precios del combustible; el campo consume aproximadamente 4 mil millones de litros de gasoil, 4 mil millones de litros de gasoil, que no tienen a un precio internacional, sino a un precio argentino subsidiado por todos los argentinos, subsidiado por todos los argentinos. Pero sigamos imaginando, además, que los salarios no fueran en pesos argentinos o las tarifas no fueran en pesos argentinos, es el sector que exporta prácticamente todo. La soja se exporta, prácticamente, en un 95 por ciento, no se exporta en pesos argentinos, se exporta en euros, en dólares, pero los costos son argentinos que sostiene el peón rural, que es el peor pagado de toda la escala salarial. Lo sostiene el peor pagado y el que más trabajo en negro hay, de esto se puede dar fe, también, en el Ministerio de Trabajo, pese a las constantes inspecciones y contralor que se hace desde el Ministerio de Trabajo. Pero todos saben que lo que estoy diciendo es cierto".
} 
La importancia de este fragmento reside, por otra parte, en que anticipa el modo en que CFK construirá su posición enunciativa y la relación con sus adversarios. El mecanismo electoral ha consagrado una relación legítimamente asimétrica entre el representante y las expresiones políticas de los intereses sectoriales. Esa asimetría habilita la paradoja de que CFK asuma que le habla al conjunto de "los argentinos", entre los que incluye a “quienes no me votaron", en nombre de quienes, de todas maneras, también puede hablar. Lo que las elecciones consagran, pues, es una relación privilegiada, estrictamente jerárquica, entre el enunciador presidencial y los colectivos sociales. Esta “jerarquía”, que emana de una norma, tiene un correlato enunciativo en lo que podemos llamar la posición de mirada que debe tener un enunciador-presidencial. El privilegio deviene responsabilidad: como autoridad, debe

“mirar desde Jujuy hasta Ushuaia, desde Mendoza hasta el Río de la Plata, y además mirar con precisión a cada uno de los sectores para ver cuáles son las medidas razonables que defiendan el interés de la Nación y el interés del pueblo" (Discurso del 31/03).

Sin embargo, como mostraremos, esa no es la única variante de la relación de representación, ni la única “forma” que adoptará, a lo largo del conflicto, la figura de la "persona representativa", que en los discursos de CFK está notablemente anclada en su "yo", un "yo" que se desplaza permanentemente entre el "yo personal” y el "yo institucional"210. En cualquier caso, ese "yo" no refiere al individuo (como ser orgánico, biológico), ni a su "psicología”, sino un modo de actualizar su "liderazgo", de construcción de la "persona representativa”, que se consolidará en los meses posteriores ${ }^{211}$.

\footnotetext{
${ }^{210}$ Emilio de Ípola (1982: 148-150) ha identificado este juego pendular en el uso de la primera persona del singular en los discursos de Perón en el período previo a su consagración como líder popular y al posterior triunfo electoral de febrero de 1946. En su análisis De Ípola vincula ese juego pendular (que también Perón produce en el uso del "nosotros") con la posición el entonces Teniente Coronel, tensionado entre su pertenencia al Gobierno y a sus propias aspiraciones políticas.

211 Esta constante en los discursos de CFK de colocarse explícitamente como garante de las afirmaciones (con variaciones según lo que se esté relatando o argumentando) ha sido analizada en varios trabajos. Raiter (2013) identifica este paso del nosotros al yo como un
} 
Esta figura de la "persona representativa”, propuesta desde la teoría política y que refiere "no al individuo 'natural' o 'privado' sino a una persona política, pública, que se constituye y actúa dentro de un orden institucional” (Novaro, 2000: 142), nos parece directamente compatible con el postulado de la teoría de la enunciación que rechaza la identidad entre el "locutor" -individuo empírico- y “enunciador” -figura plenamente discursiva (Verón, 1987; García Negroni, 1988). Por lo tanto, resulta natural aplicar el modelo analítico del dispositivo de enunciación para realizar el pasaje de la discusión teórica al análisis empírico de los modos en que esa “persona” se manifiesta. Un líder político, explican Sigal y Verón (2008: 51-52):

no es jamás un personaje cristalizado, como si se tratara de una imagen estática que, poseedora de un poder "carismático", concentraría, por razones de "personalidad", la fascinación y la creencia de las masas. Abordar el problema del liderazgo político desde el punto de vista del dispositivo de enunciación permite comprender que un líder no es otra cosa que un operador (...) por el que pasan los mecanismos de construcción de una serie de relaciones fundamentales: del enunciador con sus destinatarios, del enunciadores con sus adversarios, del enunciador con las entidades imaginarias que componen el espacio propio del discurso político.

\subsubsection{La economía discursiva de la representación: construcción del liderazgo y persona representativa.}

Lo que deja planteado CFK, en el fragmento de su primer discurso que citamos más arriba, es algo que podemos denominar como la estructura básica de la economía discursiva de la representación. Lo que allí se definen son los lugares y las relaciones entre esos lugares. Esta estructura básica está fundada sobre el derecho a hablar en nombre de que proviene del "mandato"

recurso "que le permite romper barreras de cortesía". Vitale y Maizels (2011) reparan en este uso de la primera persona para la proyección de un ethos de la femineidad, de identificación de género, en los discursos de CFK. Por su parte, Beatriz Sarlo observó esa preminencia de la primera persona del singular revela la fusión que CFK operó entre "su vida y el poder": "Esta es la explicación menos psicológica, y más política, de las intercalaciones autobiográficas con que acostumbra poner notas de color en sus discursos presidenciales, transmitidos por cadena nacional. Está convencida de que todo lo que le concierne es materia de Estado". "El imperio del yo", diario La Nación, 14/06/2012. 
(al que corresponde un "deber"), respaldado por "la ley, la Constitución y el voto popular" que habilita al representante (electo en competencia con otros candidatos) a hablar en nombre del conjunto de los "argentinos" es decir, el único meta-colectivo que podrá englobar no sólo a quienes la votaron, sino también a aquellos que no la votaron, muchos de entre quienes, en este momento, cuestionan, con su accionar y sus expresiones, las políticas aplicadas por su gobierno.

Ahora bien, sería un error concebir a esta estructura básica como una suerte de regulador discursivo independiente de la dinámica del conflicto. Desde ya, en tanto se inscribe en los mecanismos que ordenan las relaciones políticas en un sistema representativo, este dispositivo de enunciación es independiente del individuo singular que, ocasionalmente, ocupa el "lugar vacío" del poder en un régimen democrático; ese dispositivo está, si así puede decirse, "disponible", pero de eso no se sigue necesariamente un modo específico de estructurarlo, de tematizarlo, ni determina a priori las estrategias concretas a través de las cuales se lo actualiza, es decir, se lo trae a la existencia visible, empíricamente registrable.

Sólo el devenir del conflicto, la continuidad de las acciones directas y las formas radicalizadas que adquirirán las manifestaciones opositoras a la Resolución 125, su centralidad persistente como tema de agenda mediática y particularmente la ampliación de la base social de la protesta que tuvo sus picos de expresión pública en los actos del 25 de mayo en Rosario y el del 15 de julio en el Rosedal de Palermo, en los que fue notoria la presencia de dirigentes de la oposición político-partidaria ${ }^{212}$, solo ese acumulado de factores, decíamos, pueden explicar el modo específico en que se fue "completando" esa estructura básica del dispositivo de enunciación: el modo en que CFK irá configurando su figura de líder nacional sostenida por un

\footnotetext{
212 Es importante recordar que en esos dos actos sucedieron en una "situación de competencia", pues se realizaron de manera simultánea a sendos actos oficiales.
} 
"pacto democrático" y sus relaciones con "el sector", por un lado, y con "los argentinos", "la Nación” y el "pueblo", por el otro.

En particular, el modo en que CFK va a "completar" esa estructura quedará subordinado al diagnóstico sobre el tipo de reclamos que está enfrentando y por lo tanto, a la definición del conflicto ya no sólo como disputa por el excedente de la renta agropecuaria, o como una puja redistributiva sino como una compulsa por modelos de país. Vamos a detenernos, pues, en esos discursos.

Recordemos que casi de manera simultánea al discurso del 25 de marzo, se inician cacerolazos en distintos puntos de la Ciudad de Buenos Aires y algunas ciudades del llamado "interior" (es decir, en localidades de provincias que no son Buenos Aires), protestas que si bien pudieron aparecer como reacciones al discurso (o a algunas expresiones propuestas allí por CFK) habían sido convocados desde el día anterior ${ }^{213}$. Aún más: la propia dirigencia agropecuaria había anunciado, antes del discurso, la continuidad de la protesta, planteando un condicionamiento a una posible negociación. Como respuesta a las manifestaciones opositoras, el gobierno -a través de la Federación Argentina de Municipios- organizó un acto en Parque Norte el 27 de marzo, dos días después del primer discurso. Allí, frente a militantes de su propia fuerza política, secundada por el gabinete nacional y por gobernadores (los oficialistas y los aliados), CFK declara haber percibido signos de que no estaba frente a un conflicto sectorial ("vi carteles, escuché voces, discursos, que poco tienen que ver con una conflictividad de un sector económico contra el Gobierno"), por lo cual necesita redefinir lo sucedido en los días previos:

Quiero analizar junto a ustedes que fue lo que disparó esto que se presenta como un conflicto con un sector económico que por algunas características

\footnotetext{
${ }^{213}$ Es imposible saber cuál o cuáles hubieran sido las reacciones si el discurso hubiese sido otro, pero lo cierto es que la ampliación de la protesta desde las rutas a los centros urbanos y metropolitanos ya se estaba organizando desde días antes. También es cierto que muchas de las crónicas de los diarios registran testimonios de personas que decían haber salido a protestar como reacción al discurso.
} 
que yo vi (...) parece algo más que eso, parece un conflicto político, fundamentalmente con aquellos sectores que condenan nuestra política de derechos humanos y aquellos que han perdido las elecciones

Y se pregunta y se responde:

¿De qué naturaleza es el conflicto para algunos sectores? De naturaleza política. Pero no política por partido político, política por modelo de país

Frente a ese cambio en la definición del conflicto, CFK produce dos movimientos complementarios sustanciales. Primero, refuerza el argumento de su función representativa:

Yo entiendo a los dirigentes del sector, de todos los sectores (...) representan los intereses de los sectores, unos los sectores populares, otros los sectores del capital, todos necesarios a la hora de construir una nación. Pero también quiero que sepan qué intereses represento yo. Yo represento los intereses, no solamente de los que me votaron, sino también de los que no me votaron. Yo represento, además, los intereses de lo que dije en la campaña electoral.

En segundo lugar, introduce referencias a los principios de legitimidad que la sostienen:

con la legitimidad que en este país (...) tenemos los que hemos sido electos por el voto popular, con la legitimidad que también nos da haber llevado adelante una política que va a empezar su quinto año de crecimiento consecutivo (...) con la legitimidad que nos da que en este proyecto (...) han crecido todos, el campo, la industria, los trabajadores...

Esta constatación es reforzada, a su vez, por otra que termina por darle una forma circular, coherente, al cambio en la percepción del tipo de cuestionamiento que se expresaba, a ojos de la Presidenta, en las protestas posteriores a su primer discurso:

Esta es la cuestión del modelo de país, que es en definitiva lo que uno propone cada cuatro años cuando va a elecciones, y entonces los argentinos deciden quién es su presidente o su presidenta. 
Podemos ensayar, a partir de estos discursos, tanto una lectura situacional cuanto una primera reconstrucción de los mecanismos discursivos que regulan la enunciación presidencial. Y formular el pasaje entre ambas.

En primer lugar, CFK ha ordenado dos tipos de relaciones entre tipo de conflicto/fundamentación de las decisiones políticas y ha formulado un desplazamiento entre ellas. Lo ha hecho como respuesta inmediata a la contestación que ha ofrecido la dirigencia agropecuaria y a las manifestaciones que se han producido en los centros urbanos.

A una primera relación:

conflicto económico sectorial $\longrightarrow$ racionalidad económica de la medida ${ }^{214}$

le sigue esta otra:

conflicto por modelo de país $\longrightarrow$ legitimidad de los representantes populares

Conviene subrayar la importancia de este desplazamiento porque será definitivo. En efecto, mientras la argumentación permanece en el orden semántico de la economía, la justificación de una medida de gobierno (en este caso, la implementación de retenciones móviles y el aumento de las alícuotas a partir de un determinado nivel de los precios internacionales) queda acotada a una racionalidad que se basta a sí misma, es decir, cuya necesidad o fundamento no debe remitirse a ninguna fuente externa de validación que no sea la razón que la motiva: la distribución del ingreso. Pero en cuanto lo que se pone en juego son "modelos de país" y el fundamento de una decisión debe remitirse a la "autoridad" de los representantes, a su

\footnotetext{
${ }^{214}$ En el primer discurso, la propia CFK había dicho: "uno puede ser peronista, antiperonista, no peronista, comunista, puede ser cualquier cosa, en política se puede ser cualquier cosa, pero en economía hay que tratar de ser lo más sensato y racional posible".
} 
"legitimidad", se produce un cambio de nivel: se discute sobre los mecanismos institucionales que sostienen al orden político ${ }^{215}$.

Si bien es la propia CFK la que habla de "legitimidad" no es nuestra intención proceder a una interpretación léxica, cómo respondiendo a la pregunta: ¿qué entiende CFK por legitimidad? Conviene en cambio que explicitemos una definición que sea coherente con el enfoque que estamos aplicando. Concebimos el fenómeno de la "legitimidad" no al modo weberiano, como pretensión de obediencia o justificación interna o subjetiva del sometimiento a una autoridad (Weber, 2002: 171-172). La "legitimidad" se refiere a las "condiciones que deben acompañar la adquisición y el ejercicio del poder político si se pretende justificar la obediencia al mismo" (Colom González, 2002: 171). La legitimidad remite, entonces, a un conjunto heterogéneo de condiciones (legales, normativas, morales, etc.) inscriptas en el/emergentes del orden político institucional, pero irreductibles a las percepciones subjetivas de los agentes sociales, por lo tanto, imposible de asimilar a un "requisito subjetivo" (Novaro, 2000: 133).

En el nivel de la discursividad, la legitimidad así definida se expresa como una relación privilegiada por parte de la "persona representativa" con los colectivos sociales y especialmente con aquellos que tienden a encarnar de manera más plena la generalidad social: "argentinos", "pueblo", “Nación”.

En ese sentido, identificamos al menos dos principios de legitimidad esgrimidos por CFK. En primer lugar, una legitimidad procedimental a la que corresponde, como interpretante, la figura del pueblo electoral (como aprehensión aritmética, agregativa: "los que me votaron pero también los que no me votaron") con el cual como líder tiene un lazo autorizado por el procedimiento electoral ("por la ley, por la Constitución"). En este sentido, la

\footnotetext{
${ }^{215}$ A propósito de este pasaje, Maizels (2014: 175) señala que el argumento esgrimido "le permite a Cristina Fernández convertir la discusión económica en una lucha por un "modelo de país" y, como hemos visto, lo vincula a una posición política en torno a los Derechos Humanos a partir de la identificación de los contradestinatarios como un grupo conformado por un sector económico (los nuevos oligarcas)".
} 
legitimidad se aplica a los fundamentos del lugar desde el cual se toman decisiones, pero no a la decisión en sí. Como una suerte de compensación, en segundo lugar, CFK expresa una fundamentación sustantiva de sus políticas: hay una legitimidad intrínseca de las medidas que apuntan a una redistribución del ingreso. Es decir, un principio de legitimidad sustancial, al que le corresponde, como interpretante, la figura del pueblo principio (como sujeto de derechos, fundado en la igualdad y en la posesión de derechos fundamentales) ${ }^{216}$. En un caso, la representación deviene del origen; en el otro, de la voluntad política que inspira la medida y de sus resultados ("con la legitimidad que nos da que en este proyecto (...) han crecido todos, el campo, la industria, los trabajadores...").

Tabla 3 Tipos de legitimidad/Interpretantes

\begin{tabular}{l|l|l|l|}
\hline $\begin{array}{l}\text { Tipo de } \\
\text { legitimidad }\end{array}$ & Fundamento & Interpretante & Identificación \\
\hline Procedimental & Ley & Pueblo electoral & Los ciudadanos \\
\hline Sustancial & Voluntad política & Pueblo principio & Sujeto dañado \\
\hline
\end{tabular}

Por supuesto, en ese marco, CFK no puede sino sustentar su posición de enunciación en un esquema que responde, punto por punto, a una perspectiva institucionalista ${ }^{217}$ de la representación, esto es, que asienta la posibilidad de

\footnotetext{
${ }^{216}$ Tomamos las figuras del "pueblo electoral" y del "pueblo principio" de Pierre Rosanvallon (2008: 192-193) quien no las propone necesariamente como figuras discursivas sino como "formas" bajo las que puede manifestarse la figura del "pueblo" en regímenes donde ya no es posible asimilar la idea de mayoría a una concepción monista de la "voluntad popular". Nos parece claro, igualmente, que tal y como las define el autor, y por el lugar que ocupan en su planteo, estas "formas" son interpretantes, en el sentido en que los definimos en el capítulo 2 de nuestra tesis.

${ }^{217}$ Tanto Gindin (2015) como Yabkobksy (2010) identifican este aspecto en los discursos de CFK. Señalamos una diferencia (de matiz,) con el análisis de esta última autora, quien interpreta, a propósito de estos mismos discursos, una suerte de pasaje hacia una concepción institucionalista de la representación, que se irá acentuando a medida que se desarrolle el conflicto, mientras que para nosotros esa concepción está presente desde el principio de los discursos de CFK. Más allá del análisis discursivo, Retamozo (2013: 154) entiende que el kirchnerismo desplegó un doble juego, en el que amalgamó una lógica populista y una lógica
} 
hablar en nombre de todos los argentinos en la autorización que ha recibido por parte de la ciudadanía en las elecciones:

Para entender que cuando un gobierno constitucional, en ejercicio de las facultades que le confiere la Constitución y las leyes, y esencialmente el voto popular, toma una medida que está en este marco de legalidad y legitimidad, puede ser, por allí, no aceptado, porque no tiene por qué haber aceptación, pero sí entendido (Discurso del 31 de marzo).

De hecho, hay una suerte de fórmula retórica que se repite en casi todos los discursos que componen nuestro corpus y que sólo puede explicarse, precisamente, por- el tipo de mecanismo institucional que coloca a una fuerza política y a una persona en el único lugar que el procedimiento electivo habilita para "representar" al conjunto social:

"Quiero convocar a todos los argentinos al diálogo, pero fundamentalmente al sector que hoy todavía corta algunos caminos, que todavía no ha levantado la medida de fuerza. Yo les pido, humildemente, como presidenta de todos los argentinos y en nombre de todos los argentinos, que levanten el paro para entonces sí dialogar" (Discurso del 27 de marzo)

"Yo les pido que, en nombre de las instituciones, en nombre de la calidad institucional, en nombre del pueblo, en nombre de todo lo que les ha tocado vivir a los argentinos, recapaciten un poco" (discurso del 31 de marzo)

"Quiero finalmente pedirles, rogarles encarecidamente a los que aún creen que es bueno cortar caminos para que no pasen alimentos, que es bueno cortar caminos para que no pasen instrumentos para las fábricas, que por favor, en nombre de todo el pueblo y en nombre de ellos mismos, que también son parte del pueblo, adviertan el mal que están haciendo." (Discurso del 1 de abril)

"Hoy vengo aquí, en nombre de todos los argentinos, a rendir homenaje al nacimiento de la Patria y a los próceres que la construyeron" (...) "En nombre de todos ellos, en nombre de los que hicieron Mayor, en nombre de todos los patriotas que murieron en la lucha por la defensa de la dignidad y de la Patria, los convocamos a esta nueva gesta del Bicentenario". (25 de mayo)

institucional: "Mientras la primera le posibilitó la conformación de un nuevo campo popular, articulando discursivamente un conjunto de demandas negadas por el orden social, la segunda ofreció respuestas institucionales, al absorber y recomponer las demandas particulares en un proceso de inclusión radical. Esto le otorgó la posibilidad de incorporar demandas de los movimientos sociales en un registro institucional que tuvo efectos en la construcción de un orden diferente que, como todo orden, es producto de las tensiones, los conflictos, los procesos destituyentes y reinstituyentes". 
"Y les pido en nombre de esa calidad institucional, que las instituciones de la República legítimamente elegidas por el voto popular en el Parlamento y en el Poder Ejecutivo sigan siendo las que deciden políticas" (Discurso del 16 de junio).

"Yo quiero, en nombre de la vigencia democrática, en nombre de la constitución, en nombre de las leyes de la república, que adviertan que si la historia primero fue tragedia, hoy se repite como comedia, y que ya los argentinos no queremos más comedias, queremos, por sobre todas las cosas, volver a recuperar la responsabilidad institucional y la vigencia de la constitución" (18/06)

En nombre de: esta fórmula condensa, como ninguna otra, el eje sobre el que se sostiene toda enunciación política. Para Latour (2003), el discurso político ${ }^{218}$ se caracteriza por un movimiento circular incesante, mediante el cual lo plural deviene singular y lo singular deviene, nuevamente, plural. Ese movimiento circular está orientado por una doble relación: de representación, mediante la cual un portavoz puede convertir una multiplicidad (la multitud que lo ha designado como tal) en unidad (un nosotros); y de obediencia, por la cual la unidad vuelve a convertirse en multitud. Si ese movimiento circular está inscripto en la propia institucionalidad del sistema representativo, el modo en que sea resuelto cada vez depende de un trabajo (es decir, una creación) plenamente discursivo. Por eso, la pregunta: “¿en nombre de quien, de cuáles agentes estamos hablando?”, opera como principio activo tácito de la enunciación política, así como también activa las preguntas por el autor, la autoridad y la autorización ${ }^{219}$.

\footnotetext{
${ }^{218}$ El autor utiliza de manera indistinta, las expresiones "habla política" (political talk), "enunciación política" (political enunciation), "discurso político" (political speech), "régimen de enunciación política" (enunciation regime). Es evidente que no está interesado en ofrecer precisiones terminológicas y que cuando emplea algunos términos familiares para nosotros ("enunciación") lo hace de manera empírica y pre-teórica, sin sostenerse en ninguna propuesta conceptual clara. Pero se entiende: lo que le interesa a Latour es defender la tesis -sugestiva, al menos como orientador teórico- de que lo "político" del "discurso" no deviene de la inscripción institucional en el juego regulado por el Estado, sino en una función que podríamos llamar de "performatividad sociológica": la producción incesante de agregados y asociaciones, es decir, la producción de lo social.

${ }^{219}$ Según Latour (2003: 61) "todas las demás formas de hablar pueden ser liberadas de su enunciador, pueden omitir o desligar a aquel que habla del peso de justificar su fuente de autorización".
} 
Podemos retomar el esquema básico de la economía discursiva de la representación y mostrar cómo CFK lo ha completado en el conflicto. El movimiento circular que Latour (2003: 72) concibe como consustancial al discurso político se corrobora bajo la forma de la repetición: aquellos "elementos" que consagran al enunciador político (presidencial) a ocupar un lugar único, cerrado y excluyente, son aquellos en nombre de los cuáles el enunciador habla. Por lo demás, en el devenir del conflicto se acentuó la reflexividad sobre la lógica misma de ese movimiento circular, haciendo que los contenidos concretos destacados en el esquema básico (elecciones, argentinos) queden subordinados a instancias más abstractas, fundantes, en un caso (la legitimidad) y representadas, en el otro: Ilustración 3 Dispositivo de enunciación presidencial en el conflicto del
campo

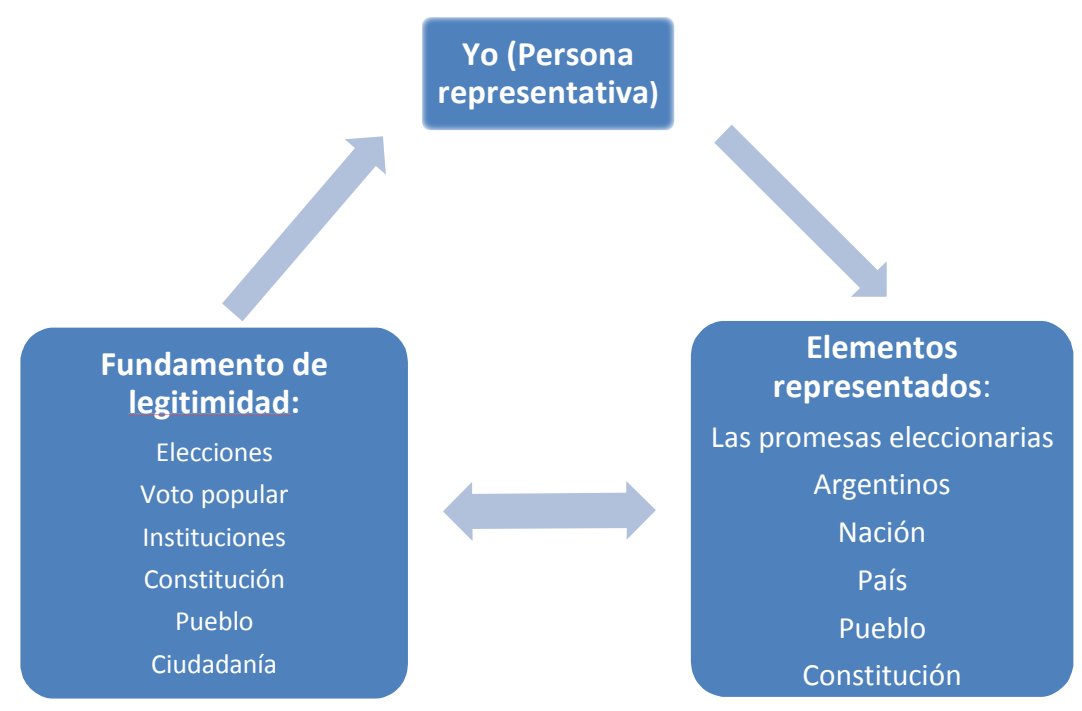

Es todo un mecanismo institucional el que es invocado como apoyo de esta modalidad de gestión de colectivos por parte de la Presidenta. Lo notable no es que CFK hable en nombre de los "argentinos". En definitiva, se trata de un enunciador político, y como tal: 
debe construir su posición en relación a las entidades del imaginario político; es más, discursos políticos competitivos están frecuentemente organizados como diferentes maneras de defender o representar los intereses de la Patria, el Pueblo, de la Nación. Y ello es posible porque estos colectivos singulares no tienen palabra. Cada enunciador puede entonces reclamarse como su auténtico representante (Sigal y Verón, 2008: 132).

Lo característico de estos discursos de CFK en el conflicto del campo es que el dispositivo de enunciación funciona de un modo auto-reflexivo que "hace hablar" a esos colectivos desde un lugar, por así decirlo, fuera de competencia: desde un lugar donde sólo cabe un enunciador. Si en situación de competencia electoral cualquier enunciador puede hacer hablar a las entidades del imaginario político en condición de equivalencia con sus competidores, las elecciones producen un cerramiento de ese lugar, una suerte de clausura para todos, menos - claro- para el ganador:

"Ese, y no otro, es el compromiso que hemos tomado con el pueblo argentino, compromiso realizado con legitimidad política, y por sobre todas las cosas con honestidad intelectual. ¿Por qué con honestidad intelectual? Porque cuando uno va a elecciones, cuando uno se somete a la compulsa popular en elecciones libres y democráticas, debe explicar cuál es su propuesta de país, cuál es su modelo social, para que ustedes, los argentinos y las argentinas decidan. $Y$ en octubre, del año pasado, Argentina decidió. $Y$ se trata, entonces, de otorgar la verdadera calidad institucional que nos merecemos y nos merecíamos desde hace mucho tiempo los argentinos, que nos cumplan la palabra, que nos cumplan las propuestas, que rindamos honor a la palabra empeñada" (Discurso del 3 de abril)

"Ese y no otro es el compromiso que he tenido toda mi vida y este y no otro es el compromiso que formulé ante ustedes, el pueblo de la patria, y que ustedes sellaron el 28 de octubre con el voto masivo de las urnas" (Discurso del 15 de abril)

“Porque la clave está en presentar las ideas de cada uno, los modelos de país de cada uno ante la ciudadanía, y cuando ésta elige y vota, si ese voto no nos ha sido favorable, a mejorar la propuesta electoral y esperar el próximo turno electoral" (Discurso del 17 de junio).

"A los que crean que pueden hacerlo mejor que nosotros, y seguramente habrá quien lo pueda hacer mejor que nosotros, los invitamos a que democráticamente se constituyan como partido político y en las próximas elecciones reclamen el voto del pueblo para ejecutar sus políticas y su modelo" (Discurso del 18 de junio) 
De modo que la economía discursiva de la representación, y la estructura básica que hemos descripto, están afectadas, también, por la temporalidad del sistema político. Ese cierre del lugar de enunciación es necesariamente limitado, doblemente limitado: tiene un plazo para quien lo ocupa, pero también para aquellos que aspiran a ocuparlo. Es cierto que estos fragmentos bien podrían pasar por "chicanas"; sin embargo, integradas en el mecanismo enunciativo que estamos describiendo revelan que si el lugar del poder es un lugar vacío, si ningún "individuo, y ningún grupo, puede serle consustancial” (Lefort, 1990:190) su ocupación -contingente, transitoria- debe traer anexada al menos el privilegio del contacto legitimado con los colectivos políticos -el pueblo de la patria, los argentinos- que expresan formas plenas de la generalidad social:

\begin{abstract}
"Cuando un ciudadano vota, cuando un ciudadano elige, está haciendo algo más que colocar a un hombre o a una mujer en un lugar institucional, está decidiendo también qué perfil de país, qué sociedad quiere construir. Yo estoy segura (...) que los argentinos queremos construir una nación donde el trabajo, la producción y la inclusión social vuelvan a ser banderas de toda la nación para todos y para todas" (Discurso del 9 de julio).
\end{abstract}

Pero las "elecciones" no son sólo la fuente de un mandato o el mecanismo que legaliza la transmutación de una expresión parcial en voluntad mayoritaria, sino que introducen un corte en el continuum del tiempo social, corte que produce un recomienzo de ciclo y que garantiza, hacia el futuro, la continuidad del lazo representativo para el gobernante y posterga la posibilidad de acceder a ese lugar a los opositores. Desde ya, no se trata de un mero arbitrio: es el "pacto democrático" el que -explica CFK- lo está garantizando:

“Creo que tal vez se ve cierto sesgo pre-democrático, diría. ¿A qué llamo "pre-democrático"? Yo siempre digo que el pacto democrático es esencialmente cuando la ciudadanía ha conferido una representación al Estado en cuanto al ejercicio de lo que pueden ser medidas de fuerza, etcétera, y que el resto está enmarcado en un sistema vigente en el cual cada uno peticiona ante las autoridades de cualquiera de los tres poderes para satisfacer sus demandas, pero nunca con la amenaza, la intimidación, y 
mucho menos, como he escuchado decir por ahí, el tener armas para defenderse" (Discurso del 24 de abril del 2008).

“También quiero convocar a la necesaria reconstrucción del sistema político argentino porque es necesario que todos, aún aquellos que tal vez están en las antípodas de nuestro pensamiento, puedan expresarse democráticamente a través de un partido político. Esta comprensión del ejercicio democrático en las diferencias de las ideas, es la que nos va a permitir construir la verdadera calidad institucional que tanto han reclamado y que todos debemos construir por respeto a la democracia, a las instituciones y, por sobre todas las cosas, a la voluntad popular" (Discurso del 14 de mayo).

La recursividad con la que CFK vuelve sobre los fundamentos de su legitimidad puede comprenderse más cabalmente como cuestión litigiosa si se la confronta con los discursos que está enfrentando; no sólo para asegurar la viabilidad y el efectivo cumplimiento de una política de estado, sino para sostener el privilegio (garantizado normativamente, pero "puesto en competencia” por la conflictividad misma) de su lugar de enunciación.

5.2.2. La representación disputada: competencia con el discurso de los dirigentes rurales y reinstalación de los "indicadores de certeza"

Sólo a modo de ejemplo, alcanza con recordar aquí que los dirigentes agropecuarios habían postulado la "unidad del campo" y se habían asumido como representantes de "los pueblos del Interior" antes, siquiera, de haber visto confirmadas esas pretensiones representativas en las movilizaciones multitudinarias que los tuvieron como primeros oradores; y también con “alianzas" tácticas con partidos y dirigentes de la oposición, que, circunstancialmente, se subordinaron a (y/o usufructuaron) la dirección política de los líderes de la Mesa de Enlace. Estos, que en su primer comunicado rechazaban "una nueva confiscación a la producción agropecuaria, con la excusa de "desacoplar" los precios internos de los internacionales, medida que conlleva una clara intención recaudatoria y de neto corte fiscal que discrimina a las provincias y a los pueblos del interior", ya avanzado el conflicto, en una "Carta a los argentinos", afirmaban: 
"Este camino que hemos emprendido no es sólo por nosotros. Es por todos los argentinos que queremos un país federal sin prácticas centralistas y unitarias. Porque vivimos y trabajamos en el interior y sabemos las necesidades que existen en los diversos pueblos y ciudades de las provincias" (Comunicado del 7 de mayo).

Esto que empezó siendo un conflicto por las retenciones de 48 horas, y que supuestamente a la reacción oficial del aquel 25 de Marzo (...) Aquel 25 de Marzo fue catalogado como los piquetes de la abundancia y los angurrientos lo que queríamos era ganar más plata y nada más... parecía que la cosa estaba focalizada ahí...Y aquello que empezó de esa forma por el tema de retenciones, está demostrado (...) que ya no es un problema de 80.000 productores sojeros, es un problema de millones de argentinos. Millones de argentinos que estamos viendo con preocupación el rumbo que está tomando esta situación. (Eduardo Buzzi, Acto en Armstrong, 2 de junio)

Esta pretensión de estar representando al Interior es verosímil, si así puede decirse, como expresión del imaginario histórico en el que se funden, o se confunden, el campo como símbolo de una actividad productiva y el campo como geografía no urbana y desvinculada del/subordinada al centro político nacional. Tal pretensión terminó por ser refrendada, desde la perspectiva de los dirigentes agropecuarios, por el multitudinario acto en Rosario, que constituyó la verificación cabal de que el conflicto había acortado el hiato entre una representación presumida -utilizada como mera estratagema en el espacio público para defender el interés sectorial- y la existencia del sujeto representado irreductible a las figuraciones segmentadas ("el sector más privilegiado") o bien peyorativamente englobantes (“la oligarquía”). Dos fragmentos de los discursos de Eduardo Buzzi, presidente de la Federación Agraria Argentina, y Alfredo de Ángeli, en el acto organizado el 25 de mayo de 2008, simultáneamente al acto oficial, pueden ilustrar este desplazamiento por el cual la carga de la representación es invertida:

Uno habla de lo propio pero lo podemos reproducir por miles, los miles de pueblos que gracias a la agricultura, la ganadería, los tambos, las economías regionales, el algodón, la caña de azúcar, la uva, cada una de esas economías hace que en esos pueblos viva gente y viva la esperanza. Cómo se puede ser tan necio de afectar el futuro de esos pueblos.(...) Están poniendo en crisis el destino de esos pueblos. (Discurso de Eduardo Buzzi) 
¿A quién distribuye la Sra. Presidenta? A los grandes, a los grupos concentrados, está ocupando la mesa para que le vayan a aplaudir a los actos (...) (Eduardo Buzzi)

Va a quedar en la historia argentina, que en el 2008 hubo dos actos nacionales, el del gobierno oficial que gobierna para un sector, y el del pueblo del interior y del campo que está acá en Rosario". (Alfredo de Ángeli).

Por contraste con esos discursos CFK realiza eso que, glosando con cierta libertad a Lefort (1990:191), podemos llamar reacondicionamiento de los indicadores de certeza $a^{220}$, y lo hace a través de una "operación de institución": señalando, una y otra vez, la diferencia entre "la posición del uno y del otro" como estando fundada no en una situación de hecho, sino en la legalidad institucional. Mientras los dirigentes agropecuarios (pero no sólo ellos: ya veremos que una operación similar realizan algunos discursos periodísticos) pretenden invertir la carga de representatividad (en el caso extremo: identificando a CFK con una fracción social, con una parte) 0 romper la asimetría presupuesta en la enunciación presidencial, colocándose como equivalentes (contraponiéndole una representatividad social no sectorial) CFK debe reponer aquella diferencia fundante como precondición de la enunciación autorizada ${ }^{221}$. Esa operación consiste en darle trascendencia interna al lugar del gobernante, compensando la fuerza contraria, que busca

\footnotetext{
${ }^{220}$ Lefort explica que como una suerte de compensación a la "pérdida de fundamento" a la que el advenimiento de la democracia somete a "la sociedad", corresponde a "la ideología" el trabajo de reacondicionar los indicadores de certeza, que son, a la vez, indicadores de la división, de la propiedad, de la familia, de la escuela, etc. Algo que, en conjunto, podemos identificar con lo que Rancière denomina "la lógica de policía", aunque Lefort admite que "la ideología no puede resumirse en la tentativa de producir y nombrar la diferencia y de postular a la institución como lugar de su dominio" sino que "pasa también por los discursos aparentemente subversivos que arrasan con el discurso dominante y pretenden a su vez abolir la división social en lo real, destruir la institución como tal y que deniegan, por último, el orden de lo simbólico" (Lefort, 1990: 191).

${ }^{221}$ Tal vez convenga repetirlo una vez más: el énfasis en la discursividad se justifica por la elección del nivel de análisis, aunque no desconocemos que la impugnación no se aplica sólo a las condiciones discursivas, sino a la legitimidad en la toma de decisiones colectivamente vinculantes.
} 
rebajarlo como dice Lefort, "al plano de lo real, como algo particular, al servicio de los intereses y apetitos de los ambiciosos" ${ }^{\text {"222. }}$

Para cerrar este apartado vamos a retomar la lectura situada del conflicto. Como lo mencionamos en el capítulo 4, una semana antes de enviar el proyecto de ley de retenciones al Parlamento, el Ejecutivo anunció la creación de un Fondo de Redistribución Social, por el cual se pondría en marcha un plan de construcción de hospitales, viviendas y caminos financiado con la diferencia entre el 35\% de retenciones (según la alícuota vigente al 11 de marzo) y el porcentaje correspondiente según la nueva "tabla" móvil (alrededor de 44\%). La importancia de ese anuncio, y de las expectativas que el oficialismo depositó en las medidas presentadas por la presidenta, fueron de tal magnitud que se trató del primer discurso pronunciado por CFK a través de la Cadena Nacional. Allí, CFK repasó la cronología del conflicto y -una vez más- explicó los objetivos que había perseguido la resolución 125: "La medida, explicó, tuvo por objeto dos finalidades esenciales: la primera y principal, la seguridad alimentaria, la soberanía alimentaria en la mesa de todos los argentinos (...) La segunda parte es la redistribución del ingreso, de aquellos sectores que mayor rentabilidad tiene por distintas circunstancias (...)".

Como una suerte de síntesis, la Presidenta concluyó: "separando todo lo que queda es esto: la reacción de alguien que se niega a contribuir en la redistribución del ingreso para los que menos tienen". $Y$ acto seguido dijo: "Yo les dije alguna vez que cuando uno toma estas decisiones como Presidenta de todos los argentinos, teniendo en cuenta el interés de todos...porque esta es la otra gran cuestión: no hubo una parte contra otra parte. Esto no es así: quien habla es la Presidenta de la República, no es un

\footnotetext{
222 Pero esa búsqueda de trascendencia, que necesita postular la unidad del Pueblo, "de un cuerpo social soldado a su cabeza" no necesariamente debe terminar por hacer surgir el totalitarismo, tal como sugiere Lefort. En tanto esa "soldadura" está restringida por la propia temporalidad limitada del calendario electoral, puede buscar encarnar formas totales (Nación, Patria, Pueblo) pero sólo de manera provisoria y contingente.
} 
parte, debe gobernar para todos los argentinos y cuando toma decisiones lo hace en beneficio de todos los argentinos".

Como ya lo reseñamos, los efectos del anuncio -quitarles a los ruralistas el argumento de que las retenciones tenían por única finalidad "hacer caja" y forzarlos a desistir de las medidas de fuerza- no fueron los esperados por el Gobierno. Los dirigentes de la Mesa de Enlace se quejaron porque "los anuncios no resuelven los problemas del sector que dieron origen al conflicto", que tiene "pocos visos de solución"223. Los días posteriores se movieron en un crescendo de tensión. El 14 de junio la Gendarmería detuvo a ruralistas en Entre Ríos, entre los que estaba Alfredo de Ángeli, tras lo cual la Mesa de Enlace convocó a un cese de comercialización y cortes de ruta por 48 hs. El 16 de junio nuevamente se produjeron cacerolazos en los principales centros urbanos en señal de apoyo al reclamo agropecuario. El 17, en lo que pareció ser una reacción inmediata a la escalada confrontativa, CFK, en un acto en casa de Gobierno organizado para recordar a las víctimas de los bombardeos a Plaza de Mayo de 1955, anunció que enviaría el proyecto de retenciones móviles al Congreso para que fuera tratado por los legisladores nacionales. Así, el Gobierno se vio forzado a ceder en su decisión, en línea con la propuesta que el vicepresidente Julio Cobos había expresado en una carta abierta. Al día siguiente del anuncio, Gobierno organizó en Plaza de Mayo una convocatoria multitudinaria bajo el lema: "Acto por la democracia". El 18 de junio, frente a más de cien mil personas, CFK condensó, de un modo dramático, la lógica del conflicto que aquí intentamos reconstruir:

\begin{abstract}
"Yo creía que realmente estaba ante la batalla por la redistribución del ingreso porque, tal vez, quienes tenían que resignar una pequeña parte de su renta extraordinaria disputaban y discutían; creía -les juro sinceramente- que estaba ante esa batalla, la de la lucha de los intereses, naturales en toda democracia donde hay conflicto social. Pero luego, cuando comenzaron a pasar los días y yo veía que desde un sector de la sociedad, desde una corporación, cuatro personas a las que nadie votó, a las que nadie eligió, se reunían, deliberaban, decidían y comunicaban al resto de los argentinos quién podía andar por las rutas del país y quien no (...) me di cuenta de que estaba frente a otro escenario (...) ya no era retenciones sí o retenciones no, ya
\end{abstract}

${ }^{223}$ Declaraciones reproducidas por Crítica de la Argentina, 10 de junio de 2008. 
no eran intereses; se estaba interfiriendo en la misma construcción democrática, esa que nos dice que son los representantes del pueblo, elegidos en elecciones libres, democráticas y sin proscripciones los que deciden, deliberan y ejecutan".

Lo que venimos diciendo hasta ahora puede resumirse de la siguiente manera: la confrontación en el espacio público (mediatizado) entre el Gobierno nacional y los dirigentes de las entidades patronales y gremiales agropecuarias tomó la forma de una disputa por la representación, la autoridad política y la legitimidad que inviste a aquellos que intervienen en un conflicto político para hablar en nombre de otros actores.

En sus discursos, CFK fue reforzando la estructura básica del dispositivo de enunciación presidencial, reafirmando la prerrogativa en virtud de la cual puede reclamar, con legitimidad legalizada (procedimental), un vínculo privilegiado con las entidades del imaginario político (colectivos de generalización y metacolectivos singulares) que expresan las formas más plenas de la generalidad social (la Nación, el Pueblo, la Patria, los Argentinos) y ejercer una relación -legítimamente- asimétrica con aquellos dirigentes que la están enfrentando, pues su representatividad los abarca, y por lo tanto la habilita a hablar en nombre de ellos mismos, que son, también, una parte del Pueblo, de la Nación, de la Patria, de los Argentinos ${ }^{224}$.

De ese análisis emerge una figura de liderazgo que si bien no renuncia a fundar la autoridad de su palabra en principios de legitimidad sustancial, ancla su dispositivo de enunciación en el conjunto de normas y procedimientos institucionales que, más allá del carisma o la tradición, la definen como líder nacional, por encima de los particularismos, las facciones y los intereses sectoriales.

\footnotetext{
${ }^{224}$ Habría que señalar hasta qué punto la lectura que estamos haciendo implica afirmar que, al menos en el conflicto, CFK no operó siguiendo una lógica antagonista, o aún más, populista.
} 


\subsection{Intervenciones sobre el espacio público y regímenes de visibilidad.}

Sin embargo, esa figura de liderazgo y ese principio de legitimidad que le es consustancial, aunque fundamentales, no fueron excluyentes. Por el contrario, a lo largo del conflicto, y por la dinámica misma de la conflictividad, el Gobierno desplegó formas de intervención sobre el espacio público que remiten a la clásica movilización de masas y en las cuáles se activaron otras figuras de liderazgo y se actualizaron, consecuentemente, otros órdenes de legitimidad para el discurso presidencial. De allí la necesidad de recurrir a una herramienta analítica complementaria al estudio del dispositivo de enunciación, que nos permita trascender los límites que un análisis centrado en la materia lingüística del discurso no puede mostrar, sino al costo de desplazar a esos otros órdenes significantes al secundario lugar del contexto ${ }^{225}$.

Desde este punto de vista, la comunicación presidencial puede analizarse según cómo hace variar los regímenes de visibilidad en los que se inserta. Un comunicado por Cadena Nacional en que el presidente habla solo frente a cámara, un acto realizado en Casa de Gobierno frente a un auditorio, un acto partidario realizado en un estadio o en una plaza: el régimen de visibilidad no puede variar sin que varíe, en un nivel, la discursividad política como dispositivo de ejercicio del liderazgo y de la representación. De lo que se trata, ahora, es de ver de qué manera el funcionamiento discursivo que hemos descripto se articula con los regímenes de visibilidad de los actos en los que la Presidenta pronunció sus discursos.

\footnotetext{
${ }^{225}$ Esto no desmerece, claro está, lo que el análisis del dispositivo de enunciación sí puede, en cambio, mostrar: "considerado en el marco de un análisis de la enunciación, el enunciado no es ya un contenido aislado (una opinión o una idea expresadas por un individuo) sino algo dicho por un enunciador determinado cuya posición se define en el interior de un proceso de intercambio. Toda palabra enuncia un contenido y, al mismo tiempo, se muestra (podemos decir, fatalmente) inscripta en un dispositivo enunciativo que sobre-determina lo que es dicho". (Sigal y Verón, 2008: 252). Cursivas nuestras.
} 
5.3.1. Estructuración de los regímenes de visibilidad: variación en las figuras del liderazgo y en sus principios de legitimidad

Entre el 12 de marzo y el 18 de julio de 2008, es decir, entre el día posterior al anuncio de la Resolución $\mathrm{n}^{\circ} 125$ y el día posterior a la derrota en el Congreso de la Nación, Cristina Fernández pronunció 124 discursos: casi un discurso por día a lo largo del conflicto. Lo hizo en razón de motivos diversos: en anuncios o inauguraciones de obras públicas, en presentaciones de planes gubernamentales, a propósito de la firma actas de acuerdo con sectores económicos, en actos oficiales, en reuniones diplomáticas, en encuentros regionales, en movilizaciones multitudinarias, en conmemoraciones de fechas históricas, en encuentros partidarios... Y lo hizo en escenarios diversos: habló en la Plaza de Mayo, habló en la Casa Rosada, habló en Parque Norte, habló en estadios municipales, aeropuertos, escuelas y hospitales... Y habló, también, a lo largo y a lo ancho del país: en Almirante Brown y en Merlo, en Jujuy y en Misiones, en Chaco y en Salta, en Capital Federal y en Tucumán. De ese total, poco más de treinta contienen alguna referencia a las protestas del sector agropecuario o a las vicisitudes del enfrentamiento y sólo 10 fueron intervenciones directas y explícitas sobre el conflicto. Entre ellas, deben contarse los primeros cuatro discursos que CFK le dedicó al enfrentamiento, condensados en la semana que se extendió entre el 25 de marzo y el 1 de abril de 2008.

Tabla 4 Intervenciones públicas directas en el conflicto

\begin{tabular}{l} 
1 \\
\hline $\mathbf{2}$ \\
\hline 3 \\
REFERENCIAS: \\
1-Etapas del conflicto \\
2-Discursos con referencias al conflicto \\
3-Intervenciones públicas directas sobre el conflicto \\
a) 25 de marzo, firma convenio AySa con municipios bonaerense \\
b) 27 de marzo, acto en Parque Norte \\
c) 31 de marzo, anuncio medidas compensatorias para pequeños productores \\
d) 1 de abril, acto en Plaza de Mayo \\
e) 14 de mayo, asunción de Néstor Kirchner como presidente del Partido Justicialista \\
f) 25 de mayo, acto en Salta (Cadena Nacional) \\
g) 9 de junio, anuncio del Plan de Reparación Social (Cadena Nacional) \\
h) 16 de junio, anuncio de envío al Parlamento del proyecto de ley de retenciones móviles (Cadena Nacional) \\
i) 18 de junio, acto por la democracia en Plaza de Mayo (Cadena Nacional) \\
j) 20 de junio, toma de juramento por el día de la Bandera, acto en Hurlingham (Cadena Nacional) \\
k) 9 de julio, aniversario de la Declaración de Independencia, acto en Tucumán. (Cadena Nacional)
\end{tabular}


Como puede observarse en la tabla 4 , si se considera la cronología analítica que propusimos en el capítulo 4 se constatará que los discursos de intervención sobre el conflicto coinciden con los picos de conflictividad (es decir, se concentran en la primera y en la tercera etapa) y aquellos discursos que refieren al conflicto pero no están anudados a la confrontación inmediata, con las etapas de tregua (básicamente, por la suspensión o flexibilización de las acciones directas). Lo cual, por un lado, puede resultar una obviedad, pero al mismo tiempo justifica que se las describa como "intervenciones" (sobre el espacio público, sobre el devenir del conflicto y sobre la temporalidad del sistema mediático) y a analizar tanto la composición del régimen de visibilidad como sus efectos sobre la dinámica del enfrentamiento.

Desde nuestro punto de vista en estas intervenciones CFK encarnó tres modalidades de liderazgo, y en esa variación hay que leer la influencia de distintos colectivos operando como interpretantes en reconocimiento del discurso presidencial ( $\mathrm{y}$, por eso mismo, funcionando como condiciones de producción de ese discurso). Desde ya, no podemos presumir los efectos de esa estrategia (finalmente, nuestro análisis se ubica en producción), pero sí podemos mostrar cómo esas variaciones están asociadas a tres niveles del fenómeno de la "representación" y de los órdenes de legitimidad en que los se ejerce:

1- la legalidad de la investidura presidencial que sustenta al "líder nacional", cuya función está directamente sostenida por el sistema electoral (cuyo interpretante es la ciudadanía);

2- la legitimidad del "líder político", que se juega en su capacidad de conducción de su fuerza política (cuyo interpretante es el militante partidario); 
3- la legitimidad del "líder plebiscitario", que moviliza fuerzas no encuadradas partidariamente, ni acotadas formalmente por su relación con el voto, y cuyo interpretante es el "pueblo" o "los argentinos" (o pueblo argentino, al menos según aparece en los discursos que hemos analizado) $)^{226}$.

Sobre el fondo de esa variación, debemos señalar una primera invariante: todos estos discursos fueron televisados por el propio Gobierno ${ }^{227}$, es decir que fueron concebidos para su mediatización: para insertar la palabra presidencial en el espacio público a través de su puesta en circulación en el sistema de medios. El enunciador sabe que se dirige de hecho ${ }^{228}$ a un colectivo que es, finalmente, otro interpretante de la discursividad pública: la audiencia, o mejor, los públicos mediáticos, definidos ya no por la igualación regulada por la Constitución (ciudadanos), por la adscripción a un sector político (partidario) o por la pertenencia encarnada en valores, afectos, tradiciones (pueblo argentino) 229 .

\footnotetext{
${ }^{226}$ Esta distinción por tipos de liderazgo la encontramos también en Novaro (2000: 241-242), quien los asocia a las identidades representadas. Para el autor, no es lo mismo lo que se representa en un liderazgo nacional, en un liderazgo partidario o en uno de opinión. En el caso del líder de partido se trata de una identidad fuertemente constituida, organizada incluso, y por lo tanto socialmente acotada. Mientras que para el liderazgo nacional, ese acotamiento no existe, y tampoco el que supone un conjunto sistemático de ideas: se representa a la nación, en tanto idea de unidad, y un proyecto que busca ser reconocido por todo el pueblo, la salvación de la república, el progreso económico u otras virtudes e ideales". Finalmente, los líderes de opinión, serían "el caso más inorgánico", pues "se referencian en proyectos políticos más parciales y efímeros y por lo tanto interpelan una identidad mucho más frágil, a la que le corresponden conjuntos sociales a la vez más difusos y con mucha mayor autonomía".

227 Desde el 2003, todos los actos oficiales fueron filmados y distribuidos por la empresa Prensa Satelital, propiedad de la productora "La Corte", encargada, a su vez, desde 2009, de la televisación del fútbol de Primera y Segunda División.

${ }^{228} \mathrm{O}$ sea, independientemente de que en su discurso introduzca marcas pronominales o interpelaciones explícitas.

229. Cabe recordar que cuando Manin, en Los principios del gobierno representativo (1998, en particular en el capítulo 6, "Metamorfosis del gobierno representativo") habla de "democracia de audiencia" está designando un conjunto de transformaciones que derivan en una "crisis de representación" que es la crisis de la "democracia de partidos" (1998: 241242). Entre las transformaciones, menciona el hecho de que la multiplicación de canales de comunicación política afecta la naturaleza de la relación representativa; se vuelve posible, entonces, una comunicación directa entre un candidato y sus posibles electores sin la mediación del partido. De hecho, para Manin, la democracia de audiencia es una forma de gobierno representativo emergente de una situación social en la que el voto tiene, preponderantemente, un carácter reactivo. De allí que, para el propio autor, "la única virtud de la metáfora de la audiencia es que expresa la idea de distinción e independencia entre los
} 
El público mediático es un interpretante sin identificación, y como tal es transversal, ubicuo, no excluyente: es, tal y como lo explicamos en el capítulo 2 , un regulador discursivo constitutivo del horizonte de destinación de los discursos políticos mediatizados. De lo cual se sigue una pre-condición de producción de la discursividad presidencial: más allá incluso de los contenidos específicos, siempre pre-supone a un Tercero (esos públicos mediáticos), que no necesariamente entra en el circuito de la comunicación ${ }^{230}$, pero cuya presencia bajo la forma de testigo/espectador (aunque espectral, latente) es un principio activo en la estructuración de esos espacios públicos de la representación (Ferry, 1989: 18). Por lo tanto, en estos casos, la mediatización está sobre-determinando los regímenes de visibilidad. De otra manera: estas intervenciones deben concebirse como un conjunto que contiene dos regímenes de visibilidad incrustados: el que constituye cada acto y el que se constituye por su mediatización.

La pregunta, entonces, es cómo varían los regímenes de visibilidad. Nosotros proponemos dos formas de variación.

En primer lugar, por la naturaleza de la relación que entablan el orador (el líder como persona representativa) y los colectivos presentes (el auditorio), que a su vez están condicionados por el tipo de acto en que se pronuncia el discurso. A esto, debemos agregar el rol asignado a la audiencia (públicos mediáticos). Lang y Lang (1983, citado en Dayan y Katz, 1995: 190) han distinguido entre acontecimientos que tendrían lugar incluso sin público y

que proponen los términos de una opción política y los que optan”. Cheresky (2009: 24), al respecto, utiliza el concepto de "autonomía ciudadana" para señalar que "la ciudadanía no está encuadrada en relaciones de disciplinamiento colectivo, que su identificación política y también social está sometida a evoluciones y cambios frecuentes según lo que suceda en la vida pública"

${ }^{230}$ García Negroni (1988) ha hablado del Tercero discursivo para referirse al adversario que no entra en el circuito de la comunicación, y que por lo tanto no tiene ni voz ni derecho a réplica. Esta relación fue definida como "destinación encubierta" (1988: 87) y puede identificarse por designaciones marcadas por la $2^{\circ}$ y $3^{\circ}$ persona del plural. La retoma que aquí hacemos, como puede advertirse, implica derivar esa figura del Tercero al nivel de las condiciones productivas; es decir, extra-discursivas en relación al discurso de referencia. 
acontecimientos escenificados expresamente para un público. A ese primer criterio lo cruzan con otro, que distingue a los acontecimientos según su función en "unificadores" (como una asunción presidencial, o el velorio de un ex presidente) o "polémicos" (un debate pre-electoral). Lo que surge es una clasificación combinada que da cuatro tipos de acontecimientos:

- Ceremonia (unificador/público como testigo)

- Espectáculo (unificador/público necesario)

- Debate esotérico (polémico/público como testigo)

- Acción antagonista (polémico/público necesario).

Dayan y Katz acuerdan con esta clasificación, pero manifiestan un leve reparo sobre el rol asignado al público por Lang y Lang; entienden, y en esto coincidimos, que cualquiera de esos acontecimientos, en tanto se disponen para su televisación, son "acontecimientos mediáticos"231. En ellos, por lo tanto, el "público" es constitutivo. Agregamos nosotros que si esa afirmación es llevada hasta sus últimas implicancias conceptuales, lo que cabe decir es que cualquiera de esos acontecimientos funciona como un "espectáculo": están dispuestos para un espectador al que no puede asignársele una identidad colectiva (podríamos decir: como entidad política es transversal).

Dando por sentado, entonces, que el público es necesario en cualquiera de sus variantes, vamos a proponer una clasificación de los regímenes de visibilidad instituidos por CFK en el conflicto con el sector agropecuario modificando la propuesta de Lang y Lang. Así, tenemos cuatro tipos de regímenes de visibilidad:

\footnotetext{
${ }^{231}$ Dayan y Katz (1995: 14) explican que "la diferencia más obvia entre los acontecimientos mediáticos y otras fórmulas o géneros de retransmisión es que, por definición, no son una rutina. De hecho, son interrupciones de la rutina; interfieren el flujo normal de las emisiones y de nuestras vidas. En directo, organizados fuera de los medios, en un localizaciones remotas, protagonizados por el Estado, planeados con antelación, “integran las sociedades en un latir colectivo y conjuran una renovación de la lealtad a la sociedad y a su autoridad legítima".
} 
- Monólogo esotérico (con rasgos polémicos).

- Ceremonia exotérica (con rasgos polémicos)

- Movilización ceremonial (con rasgos antagonistas).

- Ceremonia partisana (con rasgos antagonistas)

A continuación, desarrollamos esta clasificación general. El añadido entre paréntesis -los rasgos polémicos o antagonistas- no son consustanciales de estos regímenes de visibilidad, más bien resultan del modo en que los actos estructurados según estos regímenes se insertan en la dialéctica (temporal) del conflicto. Dedicaremos el próximo sub-apartado a explicar este punto.

a- Monólogo esotérico (con rasgos polémicos).

Se trata del régimen de visibilidad predominante en el conflicto (al menos, ponderado por la cantidad de actos). En este tipo de régimen de visibilidad se escenifica la figura del líder nacional, ubicado por encima de los intereses e identidades sectoriales, enmarcado en una escenografía que privilegia la visibilidad de símbolos patrios, reforzado por la presencia -en los laterales o detrás de CFK, pero siempre sobre el escenario- de representantes políticos electos por el voto popular (gobernadores, intendentes, legisladores) y por el cuerpo de ministros del gabinete nacional. Sin embargo, en todos estos actos el régimen de visibilidad aparece tensionado por la introducción, entre el auditorio, de representantes sectoriales (dirigentes sindicales, líderes de organizaciones sociales de derechos humanos, empresarios, banqueros, actores, etc.) colocados como interlocutores directos del orador y cuya identificación, como bien lo ha señalado Gastón Cingolani (2012: 60), desarma la potencia del interpretante ciudadanía, que queda relegada, como público mediático, a testigo de un diálogo que no la incluye, salvo por alguna indicación verbal bajo la tercera persona. 
Se abre, entonces, el espacio para una contra-identificación por la cual el líder nacional queda recortado sobre la representación sectorial ${ }^{232}$. Para sintetizar: el régimen de visibilidad se estructura como un monólogo del líder frente a un auditorio compuesto por "personas representativas" (cuyo valor político en el acto se define por su representatividad -económica, política, ideológica-) con quienes, desde la lógica de la distribución topográfica de lugares y el modo en que ella condiciona el contacto de mirada, conforman una suerte de circuito cerrado, lo cual se confirma en la proxemia que se va estabilizando (bajo la forma de gestos cómplices con algunos miembros presentes en el auditorio, sobreentendidos e incluso bromas).

Lo notable es que este tipo de escenificación resulta connatural para cierto tipo de actos (anuncios de obras públicas, lanzamiento de planes estatales, firma de convenios, presentación de proyectos de ley) cuyo implicados directos son colectivos segmentados (trabajadores de la construcción, vecinos de un municipio, estudiantes universitarios, etc.) pero el Gobierno lo ha extendido para los anuncios emitidos por Cadena Nacional. Esto puede verificarse comparando las primeras intervenciones de CFK (por caso, la del de 31 de marzo ${ }^{233}$ ) y la primera intervención enmarcada en este régimen de visibilidad emitida por Cadena Nacional (el 9 de junio de 2008). En uno y otro caso, el acto se abre con la voz en off del presentador oficial que identifica a los presentes (de manera individual a aquellos cuya jerarquía institucional es más alta; de manera genérica a los demás); en ambos casos, antes de que la Presidenta tome la palabra se oyen aplausos y cantos que se repetirán luego, como acentuación y apoyo a las palabras presidenciales. Si obviamos ciertas variantes de la escenificación, la única diferencia entre ambos es que, como dijimos, el del 9 de junio fue televisado por Cadena Nacional, lo cual lo salva

\footnotetext{
232 "En términos de la teoría peirceana, explica Cingolani, podríamos decir que se permuta un vínculo indicial por uno icónico, un pasaje del contacto a la identificación"; es decir, que los espectadores televisivos están siendo impulsados no sólo a escuchar a la Presidenta, sino a identificarse (o no) con los actores sociales convocados para formar parte del auditorio, y que con su sola presencia indican un apoyo a las políticas oficiales.

${ }^{233}$ Para un análisis semiótico de la mediatización (oficial y la efectuada por los canales de aire y por cable) de los primeros discursos de CFK ver el mencionado trabajo de Cingolani, 2012.
} 
de la inmediata intervención de los discursos periodísticos (comentarios, videographs, pantalla partida, planos cortos, etc.) tal como había sucedido en los primeros discursos y adelanta -ahora podemos saberlo- un movimiento estratégico en la mediatización de la figura presidencial: el uso regular de la Cadena Nacional, no como recurso excepcional para comunicar a la ciudadanía información trascendente, sino como táctica para sortear la intermediación de las instituciones periodísticas ${ }^{234}$.

\section{b- Ceremonia exotérica (con rasgos polémicos)}

Corresponden a este régimen a los actos del 25 de mayo, el 20 de junio y el 9 de julio. El aspecto ceremonial les viene dado por su estatus conmemorativo; inscriptos, como están, en una temporalidad cíclica, señalan la continuidad simbólica de la unidad nacional. Son lo que Abèles llama "ritos de consenso". Por lo tanto, invocan una identificación suprapartidaria, y allí el líder aparece como encarnación de las normas y la tradición. Si se trata de una ceremonia exotérica es porque el público presente no puede ser identificado, tal y como lo hemos apuntado en el apartado anterior, con un sector específico; es un colectivo indiferenciado que resulta un sustituto en presencia de la ciudadanía ausente. En su alocución del 9 de julio de 2008, en San Miguel de Tucumán, CFK dijo, hablándole a los asistentes al acto, pero también, por defecto, a quienes lo miraban por televisión:

Sé también -y ustedes tal vez lo saben mucho mejor que yo- de los obstáculos que siempre hay para quienes queremos llevar adelante gobiernos y políticas populares. Lo saben porque muchas veces fueron traicionados y abandonados, lo saben porque son, precisamente, los más humildes, los más vulnerables, los

\footnotetext{
${ }^{234}$ Considerando que, por ejemplo, entre 2008 y 2012, CFK utilizó la Cadena Nacional alrededor de 65 oportunidades (una cantidad excepcional si se la compara con el uso que hicieron sus antecesores) podríamos suponer que, a la relación adversativa con el periodismo (en particular con el Grupo Clarín) ha correspondido un reforzamiento de la centralidad de la figura presidencial en la televisión. De hecho, en esos años fue una constante la publicación de notas haciendo un racconto de la cantidad y modos de utilización de la Cadena Nacional. Ver, por caso, "Cristina amplía su record en el uso de la Cadena Nacional", La Nación, 28/08/2012.
} 
trabajadores, los obreros, nuestras clases medias las que siempre pagan el precio de políticas que no contemplen un desarrollo de país.

Nuevamente, la tensión permanece por la estructuración del eje de la mirada (Verón, 1984): la interlocución directa nunca incluye a los (tele)espectadores, que asisten a un acto que sólo los incluye por las menciones que pudiera hacer el orador.

\section{c- Movilización ceremonial (con rasgos antagonistas)}

Participan de este régimen las dos movilizaciones masivas que organizó el oficialismo en Plaza de Mayo, 1 de abril y el 18 de junio. Resulta central aquí la exterioridad por oposición a las arquitecturas cerradas de las instituciones (como Casa de Gobierno) o de los estadios en los que se realizaron las ceremonias partisanas. En Plaza de Mayo, la Presidenta asume el rol del líder político supra-partidario; su legitimidad no emana sólo de la regla institucional sino que es el efecto de la capacidad de conducción y del carisma:

Argentinos y argentinas: quiero agradecer esta presencia multitudinaria del pueblo argentino, que no ha venido a defender un color político o a un sector; agradezco la presencia de miles y miles de argentinos y argentinas que vienen a defender a su país, la Nación Argentina. (Discurso del 1 de abril)

El apoyo de la movilización refuerza y actualiza el liderazgo, que podemos considerar una variante del liderazgo nacional, es cierto, pero el contacto directo líder-pueblo que se pretende escenificar marca también que la adhesión no responde sólo a la capacidad de conducción de un espacio político sino a un factor que podemos llamar "popularidad" y que trasciende tanto la legalidad de la investidura como la pertenencia partidaria. Es precisamente en estos actos cuando la figura del pueblo aparece por dos vías: como entidad corporizada (es el interlocutor directo de la Presidenta, ya que se ha hecho presente en la Plaza) y como entidad del imaginario político (el 
"pueblo" como víctima del paro agropecuario y el "pueblo" como identidad supra-grupal, "que no ha venido a defender un color político o un sector") ${ }^{235}$.

Yo convoco a todos, a todos, aún a los que agravian e insultan, sólo les pido, si les hace feliz agraviarme síganlo haciendo, pero por favor no agravien más al pueblo, dejen las rutas para que se despejen y los argentinos puedan acceder a los alimentos, las fábricas a los insumos, los comercios a las mercaderías.

\section{d- Ceremonia partisana}

Si bien en los cuatro meses de conflicto en muchas ocasiones CFK pronunció discursos en actos que, por la simbología, podrían ser considerados partidarios (lanzamientos de planes de vivienda, inauguración de obras públicas, etc.) su presencia allí se justificaba en tanto presidenta, esto es, como líder nacional. La ceremonia partisana se define, en primer lugar, porque lo que escenifica es el liderazgo como capacidad de conducción de una fuerza política y la pertenencia a una identidad acotada, singular, de partido. Así como las movilizaciones ceremoniales, las ceremonias partisanas destacan, en el conflicto, por su excepcionalidad: no pueden convertirse en rutina ${ }^{236}$ pero tampoco someterse al calendario ritual. Son intercalaciones tácticas. Entre el 11 de marzo y el 17 de julio, el Gobierno organizó dos actos estructurados por este régimen de visibilidad: el 27 de marzo, en Parque Norte y el 14 de mayo, en el estadio de Almagro. Como tales, son actos para-institucionales, realizados en sitios cerrados de la topografía urbana. No obstante lo cual, en ellos CFK habla también como Presidenta y anuncia su voluntad de reflexionar "con todos ustedes" (los presentes) junto a "todos los argentinos",237 (acto en Parque Norte) y convoca "desde este espacio político a todos los argentinos, sin distinción de banderías, sin distinción de pertenencias, a debatir y a

\footnotetext{
${ }^{235}$ Veremos en el capítulo 7 que la composición de ese pueblo (al que se convocó a asistir a la Plaza sin banderas) será un elemento de disputa en la retoma periodística posterior.

${ }^{236}$ Pues si lo hacen refuerzan la paradoja de un presidente que se asume como representante de un sector.

${ }^{237}$ El eje del discurso, sin embargo, sigue siendo la tensión entre la particularidad sectorial y la universalidad encarnada por la Presidenta: "Yo entiendo también a los dirigentes del sector, de todos los sectores (....) Pero también quiero que sepan qué intereses represento yo. Yo represento los intereses, no solamente de los que me votaron, que fueron muchos, sino también de los que no me votaron."
} 
discutir en un marco democrático para profundizar la trasformación y el crecimiento para que siga dando trabajo a todos los argentinos" (acto en el estadio de Almagro). En tabla 5 sintetizamos la descripción que hemos desarrollado, vinculando el tipo de acto con las relaciones de liderazgo establecidas y los regímenes de visibilidad estructurados. 
Tabla 5: Regímenes de visibilidad según tipo de acto

\begin{tabular}{|c|c|c|c|c|}
\hline Tipo & Subtipos & Características & $\begin{array}{l}\text { Relación de liderazgo } \\
\text { (Líder/interpretante) }\end{array}$ & $\begin{array}{l}\text { Régimen de } \\
\text { visibilidad }\end{array}$ \\
\hline \multirow[t]{2}{*}{ Institucionales } & Protocolares & $\begin{array}{l}\text { Actos contemplados } \\
\text { en el protocolo } \\
\text { institucional (anuncio } \\
\text { de obras públicas, } \\
\text { inauguración de esas } \\
\text { obras, presentación } \\
\text { de proyectos de ley, } \\
\text { firma de convenios, } \\
\text { lanzamiento de planes } \\
\text { estatales, entrega de } \\
\text { viviendas, etc). } \\
\text { Espacios cerrados }\end{array}$ & $\begin{array}{l}\text { Líder } \\
\text { nacional/ciudadanos- } \\
\text { Nación }\end{array}$ & $\begin{array}{l}\text { Monólogo } \\
\text { esotérico }\end{array}$ \\
\hline & Conmemorativos & $\begin{array}{l}\text { Son aquellos que } \\
\text { tienen por función la } \\
\text { conmemoración de } \\
\text { acontecimientos } \\
\text { históricos } \\
\text { significativos para la } \\
\text { vida comunitaria y } \\
\text { cuya ocurrencia está } \\
\text { definida por el } \\
\text { calendario oficial. } \\
\text { Esto no quita que } \\
\text { pueda haber } \\
\text { innovaciones en ese } \\
\text { calendario. Espacios } \\
\text { abiertos }\end{array}$ & $\begin{array}{l}\text { Líder } \\
\text { nacional/ciudadanos- } \\
\text { Patria, País. }\end{array}$ & $\begin{array}{l}\text { Ceremonia } \\
\text { exotérica }\end{array}$ \\
\hline \multirow[t]{2}{*}{$\begin{array}{l}\text { Para- } \\
\text { institucionales }\end{array}$} & $\begin{array}{l}\text { Movilización } \\
\text { partidaria }\end{array}$ & $\begin{array}{l}\text { Son actos en los que } \\
\text { se refuerza el vínculo } \\
\text { del líder con su propio } \\
\text { espacio político. } \\
\text { Espacios cerrados. }\end{array}$ & $\begin{array}{ll}\text { Líder } & \text { de } \\
\text { partido/militante } & \\
\text { partidario } & \\
\text { (colectivo } & \\
\text { segmentado: } & \text { una } \\
\text { fracción) } & \end{array}$ & $\begin{array}{l}\text { Ceremonia } \\
\text { partisana }\end{array}$ \\
\hline & $\begin{array}{l}\text { Movilización } \\
\text { popular }\end{array}$ & $\begin{array}{l}\text { Actos en los que se } \\
\text { actualiza el vínculo } \\
\text { del líder con el } \\
\text { "pueblo" (como } \\
\text { colectivo no } \\
\text { partidario). Espacios } \\
\text { abiertos }\end{array}$ & $\begin{array}{l}\text { Líder } \\
\text { plebiscitario/Pueblo- } \\
\text { Patria }\end{array}$ & $\begin{array}{l}\text { Movilización } \\
\text { ceremonial }\end{array}$ \\
\hline
\end{tabular}




\subsubsection{Intervenciones sobre el espacio público: una dialéctica mediatizada.}

Para darle una forma cabal a la propuesta de pensar estos actos como intervenciones sobre el espacio público mediatizado nos resta describir el modo de su inserción en la dinámica del conflicto. En efecto, es preciso concebir estos actos, y su mediatización, como formando parte de una dialéctica temporal: un anudamiento del pasado y el futuro; una respuesta a la situación que podrá o no alterar el curso del conflicto.

La propia noción de "liderazgo" está atada a una temporalidad: la del proceso por el cual se constituye un "líder", a partir de las relaciones que va entablando con los diferentes actores políticos: su partido, la ciudadanía, la oposición, los movimientos sociales. Ollier (2011: 116-117) distingue la figura del "líder" (como individuo particular investido de un poder decisional) de la del "liderazgo" en tanto ésta última debe entenderse por la naturaleza de la acción decisional realizada por ese individuo". Liderazgo, pues, implica actividad/relación. Resulta una actividad que supone una relación que se activa para resolver determinado problema o para promover un resultado decisional deseado, que se desarrolla en un contexto y en un tiempo. En una democracia representativa, en situación de pluralismo de partidos, la temporalidad resulta un condicionante para la constitución de liderazgos, ya que éstos están atados, en gran medida, al período electoral y al control de los recursos estatales.

Particularmente en el caso del conflicto del campo, la temporalidad resulta una dimensión central. Como mostramos en el capítulo 4, desde el principio la conflictividad se fue activando de manera intermitente e imprevisible. El proceso está poblado de negociaciones que se anuncian pero que nunca se inician, o que se interrumpen sin ningún resultado; invocaciones urgentes, anuncio de treguas que se acortan, se rompen o se extienden de modo imprevisto, demostraciones de fuerza, leves gestos de conciliación y otros de desconfianza. Hasta las luchas más trascendentales, esas que ponen en juego 
el destino colectivo (y la disputa por la distribución de la riqueza parece ser una de esas luchas) están repletas de estos indicadores pedestres, donde tanto valen los acuerdos de gran escala como las mímicas de protocolo.

Y en esos vaivenes la palabra pública de CFK tuvo un valor central, porque en determinados momentos funcionó como respuesta a las acciones de la Mesa de Enlace y de los productores o bien como propuesta hacia el futuro. Así, bien pudo CFK declarar, el 7 de mayo, que tenía "aguante", que no iba "a defeccionar en esta lucha" y que convocaba "a todos los argentinos a estrechar filas", y apenas una semana después, el 14, hacer una convocatoria al diálogo que hasta los medios opositores celebraron ${ }^{238}$.

En la coyuntura, estos actos funcionaron bajo la lógica de un tacticismo urgido: en la perspectiva de los actores y de los comentaristas, obviamente, poco se vinculan con la construcción progresiva del liderazgo o con ceremonias de unificación social, y mucho con demostraciones de fuerza o de señales de predisposición al diálogo cuyos efectos suelen ser menos intensos que evanescentes.

Así, por ejemplo, el acto del 14 de mayo, convocado para la asunción oficial de Néstor Kirchner como presidente del Partido Justicialista, tras dos semanas en las cuáles la dirigencia agraria había retomado las protestas, con cortes de ruta parciales, cese de comercialización y el Gobierno había rechazado cualquier posibilidad de modificar el esquema de retenciones móviles. En ese acto, y en ese marco, finalmente el ex presidente apenas si ofició de presentador para el discurso final de CFK, en el que aludió a la necesidad de diálogo, de trabajo concertado, de superar los enfrentamientos que "sólo han servido para dividir al pueblo y para que, en definitiva, nuestro país, la

\footnotetext{
238 "El silencio de Néstor Kirchner fue ayer tan importante como el llamado de Cristina Kirchner al diálogo, sin rencores, a todos los sectores de la sociedad. Acorralada por el conflicto con el campo, la Presidenta necesitaba un escenario que le ofreciera las garantías para lanzar una convocatoria amplia que, en su esencia, tiene el reconocimiento tácito de las dificultades que atraviesa su gobierno, más allá del conflicto con el campo". Jorge Rosales, La Nación, 15 de mayo de 2008.
} 
República Argentina se llenara de fracasos y frustraciones", de reconstruir el sistema político. Y que fue interpretado como un gesto que trasladaba la responsabilidad por el futuro del conflicto a la dirigencia agropecuaria.

En relación a este acto, y a su interpretación inmediata, es sintomática la coincidencia en el diagnóstico de los editorialistas de Clarín y Página/12 el 15 de mayo de 2008. Mario Wainfeld escribió:

Cristina Fernández mencionó casi a la pasada el motivo de la tenida, la unción de Kirchner. Tal vez ni falta hacía: el acto era mirado por otros motivos, desde variados auditorios. El discurso de la Presidenta fue breve, contuvo una convocatoria a la frizada Concertación Plural y a otras fuerzas políticas. Tampoco era ése el eje, lo central eran el estilo, el tono, el ahorro (o la profusión) de alusiones al lockout que formalmente terminaría hoy.

Y en Clarín, Ricardo Roa, en la Carta del Editor al lector:

Kirchner pudo hablar y no quiso. $Y$ nada se esperaba tanto como sus definiciones. En su lugar, la Presidenta usó un lenguaje moderado, conciliador. Simplemente, el que cuadra con un jefe de Estado. Y eso tal vez sea suficiente para reiniciar las conversaciones. (Negritas en el original).

Otro ejemplo es estos movimiento tácticos fue el acto del 25 de marzo. Como ya lo hemos mencionado, entre el 11 y el 25 de marzo, y en relación al conflicto, lo primero que debe constatarse es su silencio. La especulación sobre las consecuencias efectivas de la protesta, el cálculo sobre el desgaste de la dirigencia agropecuaria y de sus bases, la decisión de gestionar la conflictividad en los márgenes de una compulsa corporativa, sin implicancias políticas mayores, en fin, la evaluación sobre el escenario y su futuro pueden haber incidido en la decisión de no exponer la figura presidencial a pesar de que, a esa altura, la protesta ya había superado en intensidad y duración sus propios antecedentes ${ }^{239}$. Pero fue precisamente ese silencio el que convirtió a

\footnotetext{
${ }^{239}$ En diciembre de 2006, la dirigencia agropecuaria, unificada contra el gobierno de Néstor Kirchner, había sostenido una protesta (cese de comercialización, concentraciones, cortes de ruta, pero sin suspender la producción) durante nueve días. Los reclamos se centraban en las políticas de precios en el mercado del trigo y la carne, en el impuesto a las ganancias y en el cierre de las exportaciones, medidas implementadas por Guillermo Moreno, que había asumido como Secretario de Coordinación Económica en abril de ese mismo año, con la misión
} 
un discurso repleto de auto-evidencias (un discurso, en fin, que apenas si hubiera quedado en los archivos protocolares), en el epicentro de la confrontación.

Lo mismo puede decirse del anuncio transmitido por Cadena Nacional el 9 de junio. El Gobierno decidió presentar un Plan de Reparación Social, financiado con los ingresos provenientes del aumento porcentual de los derechos de exportación, restándole a los ruralistas y a la oposición política uno de los argumentos más esgrimidos en su contra: la centralización de la recaudación impositiva sin una contraparte visible en obras para las provincias, sólo para "hacer caja". El día elegido (en conmemoración de los 52 años del fusilamiento de militantes peronistas perpetrado por el gobierno de facto del general Aramburu en José León Suárez) y el tenor del anuncio (la administración del Plan quedaría a cargo de intendentes y gobernadores, el dinero se destinaría a construir escuelas y hospitales) indicaban una vía de solución, o al menos eso pretendían. Apenas una semana después, por el contrario, el gobierno se vio constreñido a ceder en su decisión de no dar marcha atrás con la resolución 125 y anunció el envío del proyecto de ley al Congreso Nacional.

En cualquier caso, desde el punto de vista que aquí proponemos, lo que debe resaltarse es que esa temporalidad efervescente y las modalidades definidas para intervenir sobre el espacio público para condicionar al adversario o para contener y agrupar a la propia tropa están inextricablemente ligadas a la mediatización.

Por un lado, no pueden desvincularse de los ritmos mediáticos y de los relatos periodísticos, porque su modo de inserción y circulación a escala nacional se produce a través de la interrupción, desestructuración o reencauce del flujo

de negociar con los frigoríficos para contener el aumento del precio de la carne. http://edant.clarin.com/diario/2006/04/13/elpais/p-00601.htm 
mediático $^{240}$. Y porque la realización del acto incluye el cálculo de la distribución de los comentarios posteriores en el sistema de medios, de la editorialización, la tematización, que a su vez se convierten en insumos para la producción y modelización de las reacciones (públicas) del otro (sea adversario, aliado o testigo) ${ }^{241}$.

Por otro lado, estos actos son puestas en escena que buscan interpelar a los públicos mediáticos, o si se nos permite, a "la sociedad"; son irreductibles a un módulo polémico o bipolar, ensimismado. Desde el estadio de Almagro o desde el Salón Blanco de Casa de Gobierno, desde la Plaza de Mayo o desde Parque Norte, desde Tucumán o Salta: la mediatización televisiva le impone a cualquier acto, como ya lo señalamos, una forma triangular a la que queda incorporada, de modo constitutivo, la audiencia, independientemente del modo en que el orador invoque en su discurso la presencia de los destinatarios. Aun el discurso más orientado a reforzar la pertenencia partidaria queda atrapado por la lógica de esa forma triangular.

Finalmente, estos actos deben comprenderse como recursos de gestión del conflicto. Su función primera es incidir en las circunstancias inmediatas: reposicionarse o bien obligar a que el otro deba reorientar sus posiciones. 0 , por qué no, suspenderlo, ponerle un fin. De allí que sus rasgos polémicos, conciliadores o antagonistas no sean propiedades inherentes sino añadidos de coyuntura, y que, como tales, sólo puedan reconstruirse por el análisis del discurso. Al respecto, suele postularse que la "polémica" es un rasgo

\footnotetext{
${ }^{240}$ Esta idea de interrupción del flujo temporal aparece en Dayan y Katz (1995: 77), aunque el objeto de su descripción son acontecimientos que no podemos equiparar sin más con los que aquí estamos analizando: "El poder de la televisión no reside sólo en el modo en que estructura el flujo de la vida cotidiana, sino también en su consiguiente capacidad de interrumpir ese flujo. Los acontecimientos mediáticos son un ejemplo de esa dimensión interruptiva. Cancelan todos los demás programas, detienen el reloj de la televisión y mientras están en antena no pueden ser interrumpidos. Su representación pertenece a un 'tiempo sagrado' y deja en punto muerto toda actividad social".

${ }^{241}$ Esta observación tal vez pueda pasar por mera exégesis o especulación. Verosímil, original u obvia: especulación al fin. Sin embargo, cuando abordemos en el capítulo 7 la tematización del rol de los medios en los discursos de CFK podrá advertirse con facilidad que la previsión sobre los discursos periodísticos posteriores incide en la conformación de los discursos políticos precedentes.
} 
constitutivo del discurso político. Habría que considerar que es, antes bien, un rasgo inscripto en sus condiciones de circulación: aunque el enunciador no incurra en la polémica (considerada como recurso retórico), su discurso circulará, necesariamente, en un campo que lo "polemizará", en un horizonte de destinación que lo someterá a lecturas "adversativas". Las intervenciones de CFK están atadas a esta compleja trama. En el apartado final de este capítulo nos detendremos, precisamente, en la articulación entre sus definiciones del conflicto y la construcción del adversario.

En la siguiente tabla presentamos una re-clasificación de estas intervenciones ya no considerando el tipo de acto o el régimen de visibilidad, sino su inserción en la dinámica temporal del conflicto.

Tabla 6. Intervenciones según su inserción en la temporalidad del conflicto

\begin{tabular}{l|l|l|}
\hline Tipo & Característica (según su relación con la gestión del conflicto) & Sitio \\
\hline Dialécticas & Polémica. & $\begin{array}{l}\text { Estadio, casa } \\
\text { de Gobierno }\end{array}$ \\
\hline & $\begin{array}{l}\text { Antagonista. } \\
\text { Lineales }\end{array}$ & $\begin{array}{l}\text { Comentario/Lección. Reforzar los argumentos frente a un Estadio, Casa } \\
\text { auditorio. Se propone como una intermisión del conflicto de Gobierno. } \\
\text { invocando valores compartidos }\end{array}$ \\
\hline &
\end{tabular}

5.4. La definición del conflicto como activación litigiosa: construcción de un lazo adversativo asimétrico.

En el inicio de este capítulo anunciamos una clave de lectura; dijimos que en sus discursos CFK había activado algunas cuestiones litigiosas. En nuestra hipótesis, la articulación de estas cuestiones debía permitirnos explicar las variaciones del modo en que CFK construyó a sus adversarios. 
Primera observación, entonces: al variar la definición del tipo de conflicto varía necesariamente la definición del oponente (en términos de la teoría de la enunciación: el contradestinatario). En los discursos de CFK ese juego de variaciones fue pendular: osciló entre caracterizar las protestas del sector agropecuario como señales de una inveterada reacción sectorial en defensa de intereses y como una impugnación de los ejes vertebradores de su programa político, la redistribución de la riqueza y la defensa activa de los derechos humanos. Es importante subrayar la conjunción: y. En el juego oscilatorio, ambas caracterizaciones terminaron, generalmente, por coincidir.

En su primera intervención del 25 de marzo, por ejemplo, CFK había hablado de una "puja redistributiva con sectores económicos" definidos por sus atributos funcionales:

"Yo quiero llamar a todos estos sectores, los cuáles son parte de la Argentina, parte importantísima de la Argentina, son gente que produce, que trabaja, y que tiene la suerte de tener una excelente rentabilidad por políticas que han sido sustentadas por todos los argentinos" (discurso del 25 de marzo)

Las reacciones posteriores y las expresiones televisadas en los cacerolazos le habían hecho cambiar de percepción, ya no se trataba de una puja de intereses sino de un "conflicto político":

Quiero analizar, junto a ustedes, qué fue lo que disparó esto que se presenta como un conflicto con un sector económico que por algunas características que yo vi (...) parece algo más que eso, parece un conflicto político, fundamentalmente de aquellos sectores que condenan nuestra política de derechos humanos y aquellos que han perdido las elecciones" (discurso del 27 de marzo)

En esa primera etapa, CFK había impugnado la instrumentación política del conflicto por parte de actores que se escudaban en el reclamo legítimo de "pequeños productores". Aparecieron en sus discursos la figura de los "los grandes pooles" y de "intereses poderosos que no representan a grandes cantidades de gente" pero "que se valen de enfrentamientos artificiales entre los argentinos". A su vez, se planteaba una suerte de contradicción ética para 
aquellos dirigentes sectoriales que, como los representantes de la Federación Agraria, podían reclamar legitimidad en la representación de las franjas desfavorecidas del sector:

Cuando uno escucha a algunos dirigentes que dicen pertenecer al campo del pueblo y representar a los pequeños productores, digo yo, ise puede representar al pueblo y enorgullecerse de desabastecerlo? ¿Se puede pertenecer y representar a los pequeños productores que todos los días luchan contra los pools y las grandes concentraciones económicas? (discurso del 1 de abril)

La dilemática de la representación aparecía, entonces, por una doble vía. Por una parte, cuestionando la magnitud del aporte sectorial al funcionamiento de la economía; por el otro, denunciando los contenidos verdaderos (pero ocultados) en nombre de los que se estaba llevando adelante la protesta. Nuevamente, se podía advertir la oscilación entre el adversario sectorial, segmentado, cuantificable, imposibilitado por eso de aspirar a ser una entidad política, y el adversario propiamente político, pero que no puede aspirar a ser un representante político sino a condición de ocultar sus intereses.

Así por ejemplo, en un discurso del 11 de abril, CFK se detiene a desagregar la composición de los ingresos del Estado. Se trata de un argumento recurrente en sus alocuciones, la exposición de datos para fundamentar decisiones. En el discurso de nuestro ejemplo, ubica los aportes provenientes del cobro de derechos de exportación, “las tan meneadas retenciones”, en un cuarto lugar:

"Cuando uno ve lo que representan la totalidad de las retenciones para todos los productos, petróleo, derivados, agropecuarios (...), son el 13 por ciento; de ese 13, lo que corresponde a lo que podríamos denominar sector agropecuario es el 7,9 por ciento. 0 sea, de la totalidad de ingresos con que los argentinos contamos para hacer frente a tanta inequidad, a tanta falta de distribución, sólo un 7,9. Pero dentro de ese 7,9 por ciento, solamente el 3,9 corresponde a quienes producen, y el otro restante corresponde a las industrias" (discurso del 11 de abril)

Vemos así al discurso presidencial ubicar diferencialmente al sector agropecuario en la economía del país, para desarticular el discurso ruralista que considera al "campo" como el sinónimo de la Nación. En este sentido, 
podemos hablar de "descripción sociológica", es decir, "aquella que intenta identificar al "pueblo" "con una parte sociológicamente determinable de una población" (Rancière, 2007: 126) o "con actores sociales que poseen una ubicación diferencial particular” (Laclau, 2005: 307).

Este tipo de distinción es la que predomina en los discursos que estamos analizando. El tratamiento sectorial de los reclamos, la alusión a las responsabilidades de las elites dirigentes. Es decir, discursos en los que la construcción adversativa es débil, o bien inexistente. La contraparte aparece con mucha fuerza en los actos con regímenes de visibilidad de tipo polémico o adversativo. Tal es el caso, por ejemplo, del discurso del 16 junio, en el acto que simultáneamente fue un homenaje a las víctimas del bombardeo a Plaza de Mayo por parte de la "Revolución Libertadora" y el anuncio del envío del proyecto de ley de retenciones al Congreso. Como en otras oportunidades, CFK ensaya una lectura histórica en clave la oposición entre gobiernos democráticos y movimientos destituyentes:

\begin{abstract}
"Y yo creo que de allí en más, como antes también desde el 30, tal vez con golpes menos cruentos, se instaló en la Argentina la impotencia de aquellos sectores civiles que incapaces de organizar un proyecto político que fuera convalidado por el voto popular, utilizaban a las Fuerzas Armadas precisamente para interrumpir los procesos democráticos. (...)Creo que hoy el mejor homenaje que podemos hacer a esas vidas, y que lo podemos hacer también nosotros como argentinos, es que finalmente se pueda reconstruir en la Argentina un sistema político donde todos puedan sentirse representados y expresados. Porque la clave está en presentar las ideas de cada uno, los modelos de país de cada uno ante la ciudadanía, y cuando ésta elige y vota, si ese voto no nos ha sido favorable, a mejorar la propuesta y esperar el próximo turno electoral, esa es la clave. (Discurso del 16 de junio)
\end{abstract}

Estas citas nos llevan a una última observación: la oscilación entre esas dos definiciones fue pendular porque se estructuró en relación a un punto fijo, invariante. $Y$ ese punto fijo fue el dispositivo de enunciación presidencial que describimos en el primer apartado del capítulo. El lugar del enunciador presidencial en los discursos de CFK es excluyente, cerrado, y como tal mantiene el privilegio de la palabra representativa, que puede abarcar incluso a quienes la impugnan. Esto genera una estrategia de construcción del 
adversario fundada en una relación asimétrica. Y lo hace por dos motivos. En un caso, por el límite inherente a la representatividad corporativa, anclada como está a su funcionalidad:

"Yo creo que todos tienen derecho a reclamar y a demandar mayor rentabilidad y tal vez no importarle lo que pasa con el resto de la sociedad, pero yo quiero decirle a todos los argentinos que mi deber como Presidenta de la república, cuando uno aborda este tipo de negociaciones, es precisamente representar los intereses de todos" (Discurso del 23 de abril)

En el otro, porque las pretensiones de competir políticamente deben lidiar, primero, con la capacidad para “formar un partido político", y luego, con los tiempos electorales.

"Pero si además quieren cambiar el modelo económico de país, lo que deben hacer es organizar un partido político, presentarse a elecciones y ganarlas" (Discurso del 16 de junio).

El enunciador presidencial asume plenamente sus privilegios. Aquella idea de Manin según la cual el gobierno representativo es aquel en el cual ningún líder puede afirmar con absoluta certeza “nosotros, el Pueblo" (1998: 215) es, también relativa. La equivalencia formal entre quienes buscan representar a ese pueblo queda en suspenso por efecto de las elecciones. Precisamente, lo que estamos diciendo busca señalar la ruptura de esa equivalencia y ofrece razones para reflexionar con más detenimiento sobre la excepcionalidad del discurso presidencial en su condición genérica de “discurso político”.

\section{Reflexiones finales y pasaje al próximo capítulo}

Antes que recapitular los diferentes aspectos que hemos analizado, vamos a señalar aquellas cuestiones que hilvanan este capítulo con la hipótesis de nuestra investigación y que nos permiten, a su vez, vincularlo con el próximo. 
En primer lugar, hemos realizado un análisis heterogéneo, quizás necesariamente heterogéneo. $Y$ esto en dos aspectos. Por un lado, buscamos integrar el estudio de la construcción del dispositivo de enunciación presidencial analizando sus alocuciones orales. A su vez, intentamos mostrar cómo las variaciones en la configuración de la imagen de sí como líder político que proyectó CFK pueden (y aún más, deben) estudiarse en relación a los actos públicos en que esas alocuciones tuvieron lugar. Esos actos -su escenificación, la simbología en ellos desplegada, las locaciones, los asistentes- son parte constitutiva de los discursos.

El segundo aspecto en el que nuestro análisis es heterogéneo es en los criterios adoptados para la exposición. Como no se trataba de caracterizar las propiedades de una discursividad política (el discurso kirchnerista, o el discurso de (FK) sino de entender la disputa por la gestión de colectivos que CFK entabló con otros discursos que le disputaban el sentido del acontecimiento, creímos necesario integrar dos criterios: uno de tipo analítico (que nos permitió reconstruir todo lo que los discursos de CFK le deben a la posición institucional que ocupaba) y otro de tipo funcional: se trataba de entender cómo cada intervención se introducía en la dinámica propia del conflicto.

Considerando estos dos niveles, podemos decir que el análisis de la enunciación presidencial nos mostró cómo CFK enfrentó el conflicto como una disputa por la representación de los intereses ciudadanos y de los fundamentos de la legitimidad que sostenían sus decisiones. Esta distinción (que no es exhaustiva, aunque sí pertinente en relación al problema de la disputa por la gestión de colectivos) remite, por lo demás, a las condiciones de producción del discurso político como tipo discursivo específico:

las estructuras institucionales del Estado aparecen, a su vez, como formando parte de las condiciones de producción del discurso político: estas estructuras intervienen, pues, en la dimensión ideológica. En fin, el rasgo que lo define como tipo es la tematización explícita de la cuestión del control del campo institucional del poder dentro de la sociedad (Verón, 1980: 87) 
La cuestión entonces es entender cómo tematiza un enunciador determinado (en este caso, CFK) su relación con las condiciones de producción de su discurso. Nuestro análisis nos mostró que la Presidenta reafirmó, una y otra vez, un dispositivo de enunciación cerrado, excluyente, amparándose en la relación privilegiada y asimétrica de representación consagrada por las elecciones. De allí que su obligación no fuera sólo representar a una porción de la ciudadanía (aquella que la votó) sino también a aquellos que no la habían votado y que ahora impugnaban sus decisiones, su investidura, su legitimidad.

Pero esa suerte de proclamado ecumenismo representativo es ciertamente imposible, y más aún cuando aquellos que son representados rechazan públicamente -con declaraciones y con acciones directas- las decisiones tomadas en su nombre. Esa tensión apareció en nuestro análisis claramente cuando nos centramos en el estudio de los regímenes de visibilidad construidos en las intervenciones públicas de CFK. Pudimos identificar cuatro tipos de regímenes diferentes, asociados a tres tipos de liderazgo: líder nacional (como representante de los ciudadanos argentinos); el líder partidario (como representante de un colectivo militante); y el líder plebiscitario (como representante del pueblo dañado).

Lo que revelan los regímenes de visibilidad de las intervenciones públicas es un modo de resolver la competencia por la representación, en particular de aquellos colectivos formales (los argentinos, la ciudadanía, la sociedad) que por su propia entidad abstracta están "disponibles” para ser hablados por otros dirigentes.

Como esas intervenciones, por lo demás, fueron intervenciones mediatizadas, los destinatarios de los discursos presidenciales no pueden inferirse sólo de la construcción enunciativa. En una ceremonia partisana o en un acto protocolar, CFK insertaba sus discursos en la circulación mediática. Como lo 
hemos señalado tanto en este capítulo como en los capítulos teóricos, esos públicos mediáticos (sobre cuya composición todo enunciador elabora hipótesis) son sin embargo y en primer lugar un regulador discursivo constitutivo del horizonte de destinación de los discursos políticos mediatizados. De lo cual se sigue una pre-condición de producción de la discursividad presidencial: más allá incluso de los contenidos específicos, siempre pre-supone a un Tercero (esos públicos mediáticos), que no necesariamente entra en el circuito de la comunicación.

Y allí CFK habrá de enfrentar otra competencia: ya no la de los líderes rurales, sino la de las instituciones mediáticas que también tomarán parte en la disputa por la identificación de esos actores cuyas historias, cuyos rostros, cuyas intenciones se volvieron protagonistas de la escena pública. Los próximos dos capítulos, precisamente, estarán dedicados a indagar en las modalidades de gestión de colectivos de la prensa gráfica, y a la reconstrucción de esa zona de competencia por la representación que se instauró entre sus discursos y los de Cristina Fernández de Kirchner. 


\section{CAPÍTULO 6}

\section{DESDE ARRIBA Y DESDE ABAJO: LA GESTIÓN DE COLECTIVOS EN LA PRENSA GRÁFICA DURANTE EL CONFLICTO}




\section{CAPÍTULO 6}

\section{DESDE ARRIBA Y DESDE ABAJO: LA GESTIÓN DE COLECTIVOS EN LA PRENSA GRÁFICA EN EL CONFLICTO DEL CAMPO}

\section{Introducción}

Bien lo advirtió uno de los editores del diario Clarín a fines del año 2007, luego del discurso de renuncia de Cristina Fernández a su banca de senadora, días antes de asumir como Presidenta: el "relato" sobre la realidad estaba destinado a convertirse en uno de los temas de controversia pública durante el gobierno a punto de asumir:

Cristina Kirchner expresó su decisión de dar batalla en el terreno de la "interpretación y decodificación de qué es lo que se muestra", según su discurso del miércoles en el Senado. Para decirlo con palabras suyas de ese mismo día, la Presidenta electa intenta abrir un debate sobre "cuál es la Argentina que nos quieren hacer ver y cuál es la Argentina real". Esto supone una Argentina auténtica y otra falseada, sin concesión alguna a los matices entre una y otra variante (Cristina Kirchner renueva la batalla por la "construcción" de la realidad, por Julio Blanck, Clarín, 27/11/2007).

Podría decirse que CFK fue coherente con su planteo y que Blanck fue acertado en su pronóstico. En efecto, ya en sus primeras intervenciones durante el conflicto con el sector agropecuario la Presidenta cuestionó a "los medios" por la cobertura sesgada y prejuiciosa que estaban haciendo de las protestas de los productores:

Quiero también decirles que junto a esta Argentina, que vimos transmitida por los medios, casi en son de drama, hubo otra Argentina, también en la Semana Santa: dos millones y medio de argentinos que salieron de vacaciones, casi el cinco por ciento más que el año pasado" (Discurso del 27 de marzo de 2008).

Quiero decirles también a quienes tienen la inmensa responsabilidad, la respetabilísima profesión de informar a la sociedad, que lo hagan sin crear antagonismos, sin diferenciar en los colores de piel, por favor, no dividan a los argentinos porque los argentinos queremos estar unidos, solidarios, trabajando" (Discurso del 1 de abril de 2008). 
El cuestionamiento genérico, el llamado de atención sobre el rol de los medios, pronto se cerraría sobre el diario y el Grupo Clarín ${ }^{242}$, con el cual y contra el cual, desde entonces, el Gobierno establecería una polémica casi cotidiana con el trasfondo de una pelea por la gobernabilidad ${ }^{243}$. Pero incluso ese cerramiento, que anunciaba la confrontación por venir, no hizo sino consagrar, como tema de debate público, los mecanismos (mediáticos) de "construcción" de la actualidad; hizo ostensible -si es que ya no lo era- el carácter ilusorio de la mediación invisible del discurso de los medios sobre la realidad.

Entre los investigadores que se dedicaron a indagar la relación medios/política a lo largo del conflicto, se puede leer un consenso casi monolítico en el "protagonismo" excepcional que los medios tuvieron como orientadores de las percepciones colectivas (Barsky y Dávila, 2008244; Becerra y López, 2009245; Aroskind y Vommaro, 2010246; Hora, 2010247; Teubal y Palmisano, 2010; Kitzberger, 2011; Aruguete y Zunino, 2012).

Si se asume que la "actualidad" es un orden de realidad mediatizado; que es, como sugiere Derrida (1994), una "artefactualidad ${ }^{248}$; y que en ese preciso

\footnotetext{
${ }^{242}$ Fue en el acto del 1 de abril, en Plaza de Mayo, cuando CFK habló de los "generales multimediáticos que además de apoyar el lock out al pueblo, han hecho lockout a la información, cambiando, tergiversando, mostrando una sola cara".

${ }^{243}$ Como escribió Martín Sivak, resumiendo esa contienda diaria: "Desde la crisis del campo, Fernández de Kirchner desplegó en público una exégesis del diario: Clarín se volvió una lectura de Estado, un tema de Estado, una obsesión de Estado, un hostigamiento de Estado". (Sivak, 2015: 424).

244 "Desde el inicio de la protesta los medios de comunicación jugaron un notable papel en la nacionalización del conflicto y en la instalación pública de una dirigencia rural hasta ese momento casi desconocida para la sociedad" (Barsky y Dávila, 2008: 7-8)

245 "La intervención de los medios de comunicación en este conflicto resultó esencial y funcional a la representación de la realidad con formato binario". (Becerra y López, 2009: 16) 246 "Los medios de comunicación tuvieron un extraordinario protagonismo en ese período, orientando a la opinión pública, suministrando determinada información y ocultando otra, otorgando la palabra selectivamente a diversos actores" (Aroskind y Vommaro, 2010: 12-13)

${ }^{247}$ El piquete, como novedad en el repertorio de protesta, le permitió a la Mesa de Enlace "superar lo que durante mucho tiempo fue una de sus principales debilidades organizativas: la que deriva de la localización desconcentrada de sus bases de apoyo".(Hora, 2010: 109)

248 "El primer rasgo es que la actualidad, precisamente, está hecha: para saber de qué está hecha, no es menos preciso saber que lo está. No está dada sino activamente producida,
} 
sentido es construida del único modo que puede ser construida, a través de los "equipamientos mediáticos" que, por su parte, son la infraestructura del espacio público (Ferry, 1989; Kaufmann y Malbois, 2015), entonces el "protagonismo" de los medios es inevitable: "los medios" son, en primer lugar, productores de actualidad (Verón, 1987).

Entonces: si se asume esa premisa, el "protagonismo" de los medios durante el conflicto del campo no debe ser probado: en su dimensión mediatizada, allí donde las voces y los rostros de los productores se volvieron una secuencia familiar, allí donde un discurso presidencial podía compartir pantalla con los gestos de disconformidad de los piqueteros de Gualeguaychú, allí donde las manifestaciones en los centros urbanos podían convertirse en un solo acontecimiento simultáneo.

Sin embargo, cuando los/as investigadores/as afirman el "protagonismo" de los medios, se refieren a sus "efectos" sobre la ciudadanía: sobre sus percepciones, sus conductas, sus simpatías y sus antipatías. Pero mientras los efectos sobre la ciudadanía no pueden ser sino supuestos, inferidos, declamados en cambio es posible identificarlos en el discurso de otros actores: la Presidenta de la Nación, de muchos analistas y periodistas y, también claro, en muchos investigadores.

De entre esos "efectos" -no necesariamente de los medios, pero sí del propio conflicto- nos interesa uno que sido ha sido particularmente ostensible, en relación a la existencia, visibilidad, identidad, de dos de los colectivos emergentes: por un lado, el "campo"; por el otro, "los pequeños productores". Entre el "campo" -poderoso condensador simbólico, histórica y

cribada, utilizada y performativamente interpretada por numerosos dispositivos ficticios o artificiales, jerarquizadores y selectivos, siempre al servicio de fuerzas e intereses que los "sujetos" y los agentes (productores y consumidores de actualidad -a veces también son "filósofos" y siempre intérpretes-) nunca perciben lo suficiente. Por más singular, irreductible, testaruda, dolorosa o trágica que sea la "realidad" a la cual se refiere la "actualidad", ésta nos llega a través de una hechura ficcional". Entrevista con Jacques Derrida (Passages, $\mathrm{n}^{\circ}$ 57, septiembre de 1993, pp. 60- 75). Traducción de C. de Peretti en El Ojo Mocho. Revista de Crítica Cultural, Buenos Aires, número 5, primavera de 1994, pág. 12. 
socialmente arraigado 249 - y los "pequeños productores"250 -esos individuos antes conocidos como "chacareros", a los que de repente se les prestaba una atención casi antropológica- el imaginario político del conflicto se fue constituyendo en los intentos tensionados por encastrar los interpretantes paradigmáticos (campo, patria, interior, oligarquía) y los colectivos singulares que fueron apareciendo en las rutas, calles y superficies mediáticas (autoconvocados, pequeños productores).

Para algunos autores, "el campo" fue una "construcción mediática" (Giarracca y Teubal, 2010), que, como tal, "produjo un efecto de homogeneización que desdibujó las diferencias existentes entre las reivindicaciones de estas cuatro entidades". En esa línea de interpretación, sostienen que "la denominación "el campo" como actor monolítico opacó el hecho de que no se trata de "una entidad homogénea sino un sector integrado por muchos y variados subsectores en cuanto a los procesos productivos y la naturaleza de los actores sociales involucrados" (Teubal y Palmisano, 2010: 193; Aruguete y Zunino, 2012). Sobre ese lugar común queremos situar nuestro análisis ahora.

En este capítulo nos proponemos reconstruir la intervención de la prensa gráfica en el conflicto del campo, considerado en su dimensión de litigio. Nos interesa, en particular, identificar modos regulares de configuración de esos colectivos -concebidos como entidades del imaginario político- que protagonizaron las protestas en estos cuatro meses, y cuya existencia, forma, identidad, historia, fueron puestas en cuestión, discutidas, afirmadas y negadas.

\footnotetext{
249 Como lo explican Barsky y Dávila (2008: 78-79): “La expresión no sólo es de fácil identificación popular, sino que además recoge una dimensión histórica profunda, socialmente instalada, que vincula a un pasado nada lejano de gauchos, trabajadores criollos y chacareros inmigrantes que construyeron una parte decisiva de la Argentina moderna".

${ }^{250}$ Como lo explica Gras (2011:47): "las transformaciones materiales tuvieron su correlato en el mapa institucional en las identidades sociales y en las subjetividades", en particular en la de los productores agropecuarios.
} 
Para eso, trabajaremos en la identificación y descripción de dos modalidades de gestión de colectivos en el discurso de la prensa gráfica: de ascenso en generalidad, de descenso en singularidad En conjunto, contrastadas y sistematizadas, estas operaciones nos permitirán aprehender, en un nivel empírico, el solapamiento espacio-temporal en la gestión pública de una misma zona del imaginario político, entre las propias instituciones mediáticas y los discursos de CFK que analizamos en el capítulo 5.

La propuesta analítica que vamos a desarrollar es un intento por articular las dos hipótesis generales que hemos planteado en los capítulos previos:

a- La hipótesis según la cual el espacio público mediatizado es una zona emergente de cohabitación y competencia por la configuración del imaginario político del conflicto, zona cuya materialidad está constituida por las superficies mediáticas.

b- la hipótesis de que el conflicto se estructuró, en su dimensión significante, como un litigio político, y que, en ese nivel, se manifiesta en una controversia sobre las categorizaciones (identificaciones) de los actores en disputa.

\subsection{Posiciones de observación y dispositivos de enunciación en el estudio de la prensa gráfica}

A lo largo de este capítulo nos centraremos en el análisis de los discursos de cuatro diarios: Clarín, La Nación, Página/ 12 y Crítica de la Argentina. Nuestro corpus se compone de las notas editoriales y de análisis y opinión firmadas por periodistas del staff de cada diario, es decir, de aquellos textos que, en conjunto, considerados relacionalmente, componen la trama argumentativa de la línea editorial. Pero antes que indagar en las estructuras de intereses y relaciones de producción que sostienen el discurso de cada medio, nos 
interesa encontrar invariantes que revelen las restricciones que la institucionalidad del espacio público y de las propias organizaciones mediáticas imponen en los modos de posicionarse frente al escenario del conflicto.

Dicho esto, antes de avanzar en el análisis queremos detenernos en dos presupuestos analíticos, que también funcionan como hipótesis de trabajo. En primer lugar, según lo planteamos en el capítulo 2, cuando se habla de gestión de colectivos es preciso definir la/s posiciones de observación desde las cuáles se otorga entidad e identidad a esos colectivos. En segundo lugar, y atendiendo a la complejidad de la configuración discursiva del diario de interés general como producto textual, es preciso distinguir los niveles de funcionamiento discursivo que, más allá del espacio condensador de las tapas, le otorga a los medios su identidad y su lugar en relación a sus pares y competidores.

\subsubsection{Gestión de colectivos y posición de observación.}

Tal como lo planteamos en el capítulo 2, consideramos que el análisis de la gestión de colectivos debe asumir la existencia de tres posiciones de enunciación posibles:

- Interna: que permite describir el proceso de colectivización de las intenciones individuales en la construcción de un nosotros.

- Intergrupal: Producción de identidad colectiva en el interjuego (de confrontación, cooperación, distinción) con otros colectivos (es decir con otros "nosotros").

- Externa: que corresponde a la posición relativa, contingente, de certificación pública de la existencia de otros colectivos, sin asumir la posición de un "nosotros"

Cuando lo que se pone en juego es su existencia pública, los colectivos se constituyen en un entramado triangular: al proceso sociológico de 
conformación de un "nosotros" (proceso que Kaufman denomina de "colectivización interna"), y al proceso de alteridad y diferencia con otros colectivos (es decir, a la producción de identidad política, propiamente dicha) hay que incorporar, como dimensión de análisis y como material empírico, las "heteroatribuciones" que les otorgan a los colectivos una "certificación pública de existencia".

La existencia de un colectivo, y los modos en que, como entidad del imaginario, circula públicamente, depende también de este reconocimiento, un reconocimiento que es menos una cuestión moral que "una cuestión lógica $u$ ontológica: para existir en tanto que colectivo, un nosotros debe ser reconocido como un ellos o un de ellos homogéneo por las instancias externas que le proveen de una identidad, lo dotan de un pasado y de un futuro, o sea, lo aprehenden como un individuo colectivo" (Kaufmann, 2010: 85).

Las tres posiciones indicadas son, también, tres perspectivas posibles para el posicionamiento epistemológico en el estudio de la construcción de colectivos, y no solo el punto de vista del actor o los actores implicados. Nuestra hipótesis es que, al menos en relación al "campo" y a los "pequeños productores" -considerados como entidades del imaginario político- los diarios, más allá de las simpatías e intereses en juego, se posicionaron como observadores externos.

Dicho esto, bien vale señalar que cuando hablamos de posición de observación externa nos referimos a una construcción enunciativa; no estamos postulando una tesis cognitiva. La aclaración es importante porque pretende corregir una confusión corriente: la imposibilidad -epistemológica- de un discurso “objetivo" es compensada, en la práctica del periodismo, por técnicas retóricas que des-implican al enunciador de aquello que está enunciando. Es la ilusión positivista transplantada en una estrategia retórica ${ }^{251}$.

\footnotetext{
${ }^{251}$ Ese lugar de enunciación los define como instituciones, pero no debe confundirse con las relaciones de empatía, preferencia, o de estigmatización y cuestionamiento que las
} 


\subsubsection{Dispositivo de enunciación: desdoblamiento en la emisión}

Lo primero que se puede apuntar cuando se reflexiona sobre el dispositivo de enunciación del discurso de la prensa gráfica es que hay que distinguir al menos dos niveles de referencia, una suerte de desdoblamiento en el polo de la "emisión": el enunciador-institución (El, cuya referencia empírica serían los artículos firmados por periodistas miembros del staff del diario ) y el enunciador-periodista (EP, que emerge en las columnas editoriales, en la tapa, pero también en las notas no firmadas).

Por regla general, el EP está sobredeterminado por el El: si bien puede haber excepciones, usualmente el discurso de los EP nunca queda a cargo sólo del individuo que firma la nota, sino que es considerado una variación de la voz institucional ${ }^{252}$. Es esta subordinación del enunciador-periodista a la institución la que, para Servais (2013), introduce la pregunta por la legitimidad de la prensa y obliga a preguntarse por el modo en que el periodismo produce representación política:

Desde este punto de vista, la enunciación periodística es colectiva porque no pertenece a nadie, y porque pretende normas discursivas de puros enunciados de conocimiento, pero, en rigor, en la forma discursiva del discurso periodístico no tiene medios de apoyo a las verdades científicas, nada distingue epistemológicamente la ideología de la objetividad

Pero a causa de este desdoblamiento, el medio (como institución singular, sea un diario, un programa de televisión o de radio) se nos presenta, en un nivel segundo de enunciación, no como un "actor", sino como una superficie de emergencia de discursos de otros actores, externos al medio-institución, quién, en este punto, opera como selector de esas otras voces, y de

diferentes organizaciones de medios puedan tener, y tienen, con o contra distintos sectores, sino por una relación de exterioridad

${ }^{252}$ Sería interesante probar si esta distinción se confirma en análisis de reconocimiento: intuitivamente, podemos afirmar que los lectores suelen superponer la firma individual y la voz institucional, por lo que toda expresión vertida por un periodista será puesta a cargo de, o identificada con, la voz de la institución. 
articulador de esas voces en la superficie que administra. Esto no impide identificar posiciones unificadas bajo una identidad institucional definida a su vez por rasgos homogéneos e invariantes: la denominada línea editorial no sólo se manifiesta en opiniones puntuales sino con la configuración más o menos homogénea (en el nivel temático o de agenda) de aquella superficie.

Por nuestra parte, consideraremos que las afirmaciones puestas a cargo de un enunciador singular, incluso cuando este goza, en tanto personaje público, de reconocimiento individual ( sea Horacio Verbitsky, Julio Blanck, Joaquín Morales Solá o Jorge Lanata) no pueden ser estudiadas como radicalmente singulares: son, también, variaciones de la voz del medio, y eso autoriza a estudiarlas como tales.

Para proceder en la exposición, vamos a orientar el capítulo en dos direcciones complementarias, señaladas por las operaciones que identificamos.

En el primer apartado, vamos a reconstruir las modalidades de tratamiento de los colectivos que denominamos de ascenso en generalidad. En el segundo apartado, vamos a realizar otro contraste, en este caso, sobre el modo en que los diarios fueron presentando a los "pequeños productores". Hasta ahí, lo que podremos ver es cómo los diarios hablan de y hacen hablar a dos colectivos con atribuciones diferentes, pero con un punto en común: eran colectivos que podían autopresentarse independientemente de su "construcción" mediática. Finalmente, intentaremos revisar nuestro propio planteo para obtener una reflexión analítica en referencia a las hipótesis expuestas. 
6.2. Ascenso en generalidad: definición del conflicto, identificación de los colectivos y tematización de los escenarios de la disputa.

Una hipótesis para empezar: en sus primeros discursos (aquella serie que se extiende entre el 25 de marzo y el 1 de abril de 2008), menos que inaugurar una interpretación original del conflicto la presidenta Cristina Fernández realizó una selección sobre interpretaciones ya planteadas en las discusiones públicas desde el anuncio de la Resolución 125. En particular, sobre aquellos tópicos que, desde nuestro punto de vista, estructuran la forma litigiosa del enfrentamiento: el tipo de conflicto, el objeto de disputa y la identidad de quienes reclaman. CFK realizó un recorte sobre el imaginario político que ya se había configurado en las controversias de los días previos a sus intervenciones. Pero al mismo tiempo, esas primeras intervenciones establecieron nuevas condiciones para aquella disputa, pues ahora se trataba de contrastar o refrendar el tratamiento estatal, consagrado por las palabras de la Presidenta, para los actores que estaban resistiendo una medida gubernamental.

Los primeros cruces polémicos sobre la protesta se verifican apenas anunciada la resolución 125, y revelan el intento por provocar al adversario, pero también la necesidad de designarlo, nombrarlo, identificarlo y definir sus motivos y sus intereses, o por defender esos mismos motivos.

El 16 de marzo, Hugo Moyano, Secretario General de la Confederación General del Trabajo (CGT) criticó, por desproporcionadas y lesivas, las protestas de "la aristocracia del campo". Ese mismo día, Eduardo Buzzi, presidente de la Federación Agraria Argentina (FAA), había planteado en una entrevista con el diario Página/12 cuál era, para su organización, el eje del conflicto. Consultado por la radicalidad de las medidas de fuerza, Buzzi se defendía:

Es que estamos viviendo una agresión sobre los productores pequeños y medianos. (...) Necesitamos un modelo de producción agropecuario que 
reconozca al pequeño y mediano productor como actor principal del desarrollo de los pueblos del interior ${ }^{253}$.

La figura del "pequeño y mediano productor" no había aparecido, todavía, en la boca de los demás dirigentes agropecuarios, pero muy pronto se convertiría en el carnet de legitimidad de la protesta. Días más tarde, el propio Buzzi más sensibilizado por aquellas definiciones, tal vez por la propia historia de su organización-, en una columna de opinión publicada por el diario Crítica de la Argentina se defendía de las acusaciones de Moyano: “La oligarquía existe, pero no somos nosotros. Esta no es una protesta de repudio. Para el productor chico, es una protesta por su supervivencia".

El 20 de marzo, el diario Página/ 12, subrayaba en su tapa la paradoja ética de las protestas: “Piquetes Benz", titulaba, ilustrando la portada con una foto de un Mercedes Benz entre el humo de las gomas incendiadas en un corte de ruta $^{254}$. Al día siguiente, en una nota ubicada en página central, el periodista Fernando Krakowiak repasaba las contradicciones de la propia dirigencia agropecuaria, que, en 2008, recurría y alentaba las mismas medidas de acción directa que había objetado, e incluso pedido reprimir, durante la crisis de 2001:

Quienes están cortando rutas no son los desarrapados y excluidos que dejó el neoliberalismo de la década del ' 90 sino los chacareros que pelean por conservar las mieles de la soja. Ese cambio de actores hizo que Miguens modifique sorpresivamente su opinión y decida justificar los cortes. "El piquete está de moda. Es la medida que más duele", sostuvo ayer en Radio 10.

El 22 marzo, en una entrevista con Clarín, Elisa Carrió había declarado: “ ¿Saben que vi en las rutas? A los chacareros, a los que tienen la cara roja de estar al sol, a sus familias: no vi terratenientes. En octubre, esa gente votó a Cristina, y ella está descansando en El Calafate. Su ausencia como Presidenta es una irresponsabilidad".

\footnotetext{
${ }^{253}$ Cada vez que en una cita se destacan algunos pasajes en negrita, es por decisión nuestra.

${ }^{254}$ Un día después, el diario Crítica publicó un pequeño recuadro en el que revelaba que el dueño del Mercedes Benz era, en realidad, un arquitecto porteño que no participaba del piquete sino que circulaba casualmente por la ruta de camino a la ciudad de Salto, en donde coordinaba un proyecto inmobiliario.
} 
Las protestas contra la resolución 125 se habían multiplicado en cientos cortes de ruta en Córdoba, Buenos Aires, Santa Fe y Entre Ríos, activados, muchos de ellos, por productores ganaderos y lecheros no afectados directamente por la medida pero descontentos, cada uno con sus razones, por las políticas oficiales. La intensidad de la reacción era evidente; no lo era, en cambio, la posibilidad de su persistencia en el tiempo, menos aún sin una conducción política unificada. El 23 de marzo de 2008 las cuatro entidades agropecuarias hicieron público el tercer comunicado conjunto desde iniciado el conflicto. En ese comunicado, anunciaron oficialmente su conformación como "Comisión de Enlace Agropecuario". El comunicado se tituló: "El paro de la unidad":

\begin{abstract}
Asumimos que este es el paro de la unidad del campo. Por ello nos dirigimos a todos aquellos productores que se encuentran en las rutas reclamando justamente, y los instamos a continuar con los reclamos tendientes a solucionar los problemas que venimos padeciendo desde hace largo tiempo, por políticas erróneas aplicadas para granos, carnes, leche, trigo, economías regionales y un sinnúmero de actividades que realiza nuestro sector, que comprometen al crecimiento del interior y del país en su conjunto.
\end{abstract}

Hasta ese momento, la mención al "campo", al menos en la prensa gráfica con excepción, como veremos, de Página/12- había sido inercial, rutinaria: "El campo se urbaniza: arrancan las protestas en las ciudades" (Crítica de la Argentina, 24/03), "El campo arranca un paro de 2 días" (Clarín, 12/03), "El paro del campo" (La Nación, 20/03), "El campo amenaza con más cortes y el bloqueo de puertos y tambos" (Clarín, 17/03). La designación servía como un operador de síntesis de uso consuetudinario, pero no necesariamente como el intento deliberado por crear, ex nihilo, un sujeto político allí donde este no existía.

Por lo demás, nada hacía prever, y nadie podía preverlo, que el conflicto se extendería por cuatro meses ${ }^{255}$. Por eso, la declaración de la flamante

\footnotetext{
255 En su crónica del día 15 de marzo, Raul Dellatorre señaló en Página/12: “El nivel de movilización sorprendió a los propios dirigentes del campo, pero más aún a las autoridades del Gobierno, que no esperaban una respuesta tan contundente a la medida de fijar retenciones móviles a las exportaciones de los principales granos (soja, girasol, trigo y maíz)". Cursivas nuestras.
} 
Comisión de Enlace modificaba el escenario: anunciaba la efectiva voluntad política de una dirigencia que, envalentonada por la fuerza de las protestas, que empezaban a nacionalizarse, incluso de manera autónoma a la dirección de las propias entidades ${ }^{256}$, adoptaba el nombre como identificación e intentaba instaurarlo para bautizar un actor político "nuevo": el campo. Como se pudo comprobar luego, se trataba, sobre todo, de una declaración de intenciones que recién encontraría algún indicador de realidad en la pervivencia de las protestas, en movilizaciones y cacerolazos en los centros urbanos más importantes del país, y en masivos actos públicos en Armstrong (abril), Rosario (mayo) y Capital Federal (julio).

Aquella "novedad" era doblemente relativa: ni el nombre ni los actores sociales movilizados hacían su aparición en la esfera política y en el espacio público por primera vez en la historia, y menos aún en los años recientes. Novedoso, en cambio, según estos parámetros, era la proclamada "unidad”257: desde principios de la década de 1990, cuando gobernaba Carlos Menem, las cuatro entidades más importantes no llevaban adelante una protesta conjunta, a pesar de que, desde que el gobierno de Eduardo Duhalde, en 2002, reimplantó los derechos de exportación, la oposición a esa medida -al menos en declaraciones públicas- gozaba de un amplio consenso ${ }^{258}$. Por lo tanto, el plan de acción conjunto, la virulencia de las acciones directas, más

\footnotetext{
256 "No había ninguna protesta ni marcha prevista para hoy sábado, pero los propios productores decidieron avanzar por su cuenta, sin indicación de las organizaciones", señalaron ayer en una de las entidades gremiales, refiriéndose a los cortes de las rutas 8 en Pergamino y 51 en 25 de mayo, que hicieron unos 200 chacareros en cada caso. Las medidas de ese tipo continuarán hoy y mañana: ya están anunciados casi 50 cortes de ruta y protestas en distintos lugares del país". "Hubo cortes de ruta que no habían sido anunciados", Clarín, 1603-2008

${ }^{257}$ Como lo apunta Roy Hora (2010): "la capacidad de los grupos movilizados para trascender las diferencias de perspectivas e intereses que dividieron a los empresarios agrarios y a sus instituciones representativas en el pasado, y el considerable eco que el reclamo ruralista despertó más allá de sus núcleos de activistas, en particular entre la población urbana. Ambos fenómenos suponen novedades de considerable importancia histórica".

${ }^{258}$ Con excepción de la FAA, que venía planteando la necesidad de un esquema de retenciones segmentadas. De hecho, a fines del 2007, el propio Eduardo Buzzi le había acercado a Miguel Peirano, último ministro de economía de Néstor Kirchner, una propuesta de retenciones segmentadas a la soja, según el volumen de cosecha. Así, para las explotaciones de hasta 1500 toneladas por año se aplicaría una retención del 15\%; hasta 3000 toneladas, $20 \%$ y para aquellas unidades que produjeran más de 3000 toneladas, un $50 \%$ de retención.
} 
el hecho de que la unidad se declarase entre entidades con evidentes diferencias internas ${ }^{259}$, resultaba, sí, un factor político novedoso, puesto que, más allá de la declaración, reconfiguraba el escenario de negociación para el propio Gobierno Nacional.

De modo que, cuando CFK hizo su primer discurso, el 25 de marzo, el litigio ya estaba planteado: no se discutía sólo la pertinencia de la resolución 125, ni los ajustes técnicos necesarios para "mejorarla": se discutía, también, sobre la identidad de los actores y la legitimidad de la medida. Como lo vimos en el capítulo anterior, CFK propuso una lectura que recopilaba y resaltaba una interpretación similar a la que ya habían expresado medios afines al gobierno y funcionarios y dirigentes oficialistas: caracterizó a la protesta de las entidades agropecuarias como "piquetes de la abundancia", motorizados por "los sectores de mayor rentabilidad", por contraste con los "piquetes de la miseria y la tragedia de los argentinos" de los años 2001 y 2002. Dos días más tarde, en su discurso en Parque Norte, la Presidenta introdujo algunos matices, en particular hizo mención a los pequeños productores, que ya se estaban convirtiendo en el eje de la discusión, pues la Resolución 125 -tal como lo había planteado Buzzi en la entrevista con Página/12- no distinguía escalas de aplicación del aumento de la alícuota, y esa ausencia de distinciones había movilizado a un sector -orgánicamente representado por la Federación Agraria- con el que el gobierno había mantenido, hasta fines del 2007, una relación fluida. Y que, por lo demás, no podía asimilarse fácilmente a la imagen de una "aristocracia" o de una "oligarquía". "CCómo vamos a estar en contra de abordar el problema del pequeño productor?", se preguntaba CFK en su discurso. Y agregaba que el principal obstáculo era que: "detrás de los pequeños productores se esconden otros intereses, los de los

\footnotetext{
${ }^{259}$ Las diferencias entre las cuatro entidades fueron un tema de varias notas periodísticas, no sólo como curiosidad, sino como elemento que pesaba en las decisiones sobre el curso de la protesta. Los propios dirigentes agropecuarios, y en particular los de la Federación Agraria, se vieron obligados a explicar, varias veces, las razones de la unidad. Alfredo De Ángeli dijo en un acto que "si bien filosóficamente con algunas entidades no coincidimos sí tenemos en claro que la rentabilidad no tiene banderías gremiales, compañeros".
} 
grandes pooles, que son los que están diciendo que es el Estado el que se quiere llevar toda la ganancia".

En el marco de estas controversias (que son, en definitiva, las que le van dando forma y sustancia al litigio), en este apartado vamos a reconstruir una modalidad específica de gestión de colectivos, que -siguiendo a Rosanvallon (2008) y a Kaufmann (2010)- denominamos de ascenso en generalidad. Queremos entablar un diálogo crítico con aquellos autores que imputaron a "los medios" la "construcción" del "campo" como un actor colectivo homogéneo. En cambio, veremos que el discurso de los diarios trata de ese modo a todos los colectivos, como indicador de un lugar distanciado desde donde se observa el conflicto.

Cuando los diarios intervienen en la gestión de colectivos mediante un acercamiento de ascenso en generalidad

la multiplicidad de los individuos que lo componen y la modalidad de su agenciamiento son solapados en beneficio de las relaciones de oposición y de diferencia que lo contrastan con otros colectivos de mismo orden de generalidad. Así, se subraya su costado holista y realista: aparece como una totalidad concreta, apta para intervenir en la escena pública en tanto que tal (Kaufmann, 2010).

Tomaremos en consideración la clave de lectura sugerida (que en su primeros discursos Cristina Fernández realizó una selección sobre interpretaciones del conflicto que ya estaban circulando, pero que su propia intervención se convirtió en el punto de referencia contra el cual (o sobre el cual) se activaron las controversias posteriores. Siguiendo ese criterio, en este apartado trabajaremos sobre los textos publicados entre el 11 de marzo y el 4 de abril de 2008, pero introduciendo un corte: en primer lugar, analizaremos los artículos que los diarios publicaron antes del primer discurso de CFK, y en los cuáles ya caracterizaban el conflicto y definían a los protagonistas; en segundo lugar, vamos a analizar los textos publicados a partir del 26 de marzo, concebidos como efectos en reconocimiento de los discursos de CFK. 


\subsubsection{Posicionamiento de los diarios entre el 11 de marzo y el 25 de marzo.}

\section{Clarín}

Desde los primeros días del conflicto Clarín definió el aumento de las retenciones como una medida de carácter fiscal, sin por eso cuestionar la racionalidad del instrumento y también definió la reacción de la dirigencia agropecuaria como la defensa de un interés particular:

\footnotetext{
"sostener el superávit fiscal utilizando el dinero que ingresa por las retenciones para financiar la importación de energía, 65\% más cara por la suba del petróleo sin tener que salir a pedir crédito en los mercados internacionales". (El objetivo fiscal aparece muy claro detrás de la suba de las retenciones", Daniel Fernández Canedo, 13/03/2008).

"Por cierto, si las retenciones aportaron en 2007 el 10\% de la recaudación tributaria, con los valores de la última semana y el aumento, pasaron a representar $14,25 \%$. En la medida que la retención se apropie de una renta extra por el efecto de una devaluación o por mayores precios, no se queda con la comida de nadie". (Retenciones, ni ángeles ni demonios, por Silvia Naishtat 16/03/2008).
}

El conflicto fue leído como una disputa por los excedentes generados por los aumentos sostenidos de los precios de las commodities, pero no se lo conceptuó como una puja distributiva: al menos, no se suscribió la justificación esgrimida -tardíamente- por el Gobierno de que se trataba de una política de redistribución del ingreso.

La decisión de la Mesa de Enlace de extender por tiempo indeterminado el paro antes de la Semana Santa de 2008 expuso, para los editorialistas del diario, el pasaje de una protesta sectorial -que podía explicarse por la defensa de intereses económicos- a un conflicto político: lo que se estaba impugnando era la autoridad del Gobierno y no meramente la pertinencia técnica de una medida específica.

Todo indica (...) que una de las razones que pesaron para aumentar las retenciones es de orden fiscal, a saber, capturar una parte de los beneficios proporcionados por la fuerte suba de precios en el mercado mundial. (...) Los 
productores tienen buenas razones para protestar por la decisión gubernamental. Sin embargo, las actividades alcanzadas conservan un elevado margen de rentabilidad (...) Esto indica que el aumento de los impuestos a la exportación de ningún modo coloca al campo en situación crítica. Puede considerarse, por lo tanto, que la medida está teñida de emociones políticas.(Negociar para terminar con el conflicto agrario, editorial, 22/03/2008).

Hay que ser realistas. Una medida de fuerza por tiempo indeterminado no puede ser sostenida salvo que hubiera otros fines políticos que algunos han empezado a sospechar". (Las retenciones y la política, Carta del Editor al lector, por Ricardo Kirchbaum, 23/03/08)

A medida que los cortes de ruta se multiplicaron en diferentes provincias, en muchos casos sin la coordinación de la dirigencia agropecuaria, el diario cuestionó la metodología de acción directa, instando al Estado, incluso, a “intervenir garantizar el libre tránsito"260, pero haciendo equilibrio para no impugnar de lleno la "legitimidad" de las protestas.

"Nadie pone en duda la legitimidad de su queja (pero) los campesinos convirtieron su protesta en un festival de cortes de ruta, tractorazos y piquetes. Apelaron a la receta que tantas veces criticaron y que tanto los horrorizó de los encapuchados del clasismo". (La necesidad de un tiempo político distinto, por Edurado Van de Koy 23/03/2008)

Al mismo tiempo, criticó la ausencia de mediadores institucionales que encauzaran la negociación: el peso de la responsabilidad institucional, para el diario, recaía sobre el Gobierno:

(...) “Los productores reunidos en cientos de asambleas en las rutas y la Presidenta, se han expresado sin intermediarios. Así planteada la cuestión, se ha mostrado otra vez la inexistencia de escalones jerárquicos capaces de negociar y de interlocutores aptos y reconocidos. La situación contiene riesgos concretos que devienen de la índole del enfrentamiento y de cómo debe resolverse en una sociedad democrática. La inexistencia de mediadores institucionales propone un juego del todo o nada, muy peligroso". (¿Un choque a todo o nada?, Carta del Editor al lector, por Ricardo Kirchbaum, 24/03)

\footnotetext{
260 "El estado, a través de las autoridades nacionales y provinciales, debe intervenir para garantizar el libre tránsito y el orden, y, en forma urgente, desalentar la ofensiva camionera". Casi tres meses después, Néstor Kirchner recordaría irónicamente este editorial, luego de que el propio Clarín titulara en tapa que la Gendarmería había reprimido a los productores apostados en la ruta 14, cerca de Gualeguaychú: "Se agrava la crisis: hubo represión, detenidos, y el campo volvió al paro", 15/06/2008.
} 
El registro de la figura de los "productores" se estaba convirtiendo ya en un nudo controversial, pues esa figura contrastaba con las descripciones que algunos dirigentes oficialistas estaban haciendo de las protestas. Además "el pequeño productor" aparece, casi desde inicio del conflicto, directamente asociado a otro colectivo que se fue consolidando con el paso de los días: el de los autoconvocados.

\begin{abstract}
"Y más allá de la contundencia del paro del campo, empezó a agitarse un fantasma que asusta por los pasillos de más de un ministerio: el de los autoconvocados: chacareros, pequeños agricultores que no responden a ninguna agrupación y que terminaron asombrando con su presencia en las rutas hasta las propias entidades del campo (...)".(Un conflicto que llegó a su límite y que ya acorrala a los mandatarios provinciales" por Daniel Juri, 25/03/08).
\end{abstract}

Esa presencia de los pequeños productores, agrega el periodista, ha sido una primera "pulseada mediática" ganada por la dirigencia agraria: "la idea de que se trata de una protesta de terratenientes se hizo añicos frente a las imágenes que llegaron desde todo el paro".

En los artículos editoriales el conflicto fue definido como enfrentamiento de dos "partes". Se plantea, así, una equivalencia en un nivel -el económicopero se carga el peso de la responsabilidad institucional -nivel político- en el Gobierno, por no facilitar la negociación que solucione el conflicto.

En el nivel económico, además, en esta primera etapa, en varias de las columnas del diario se puede leer el reconocimiento al lugar privilegiado del campo en el modelo de dólar alto con el cual el Gobierno de Néstor Kirchner se aseguraba un alto ingreso de dólares, y que al tiempo que engrosaba las arcas fiscales beneficiaba, vía transferencia de ingresos, a los exportadores en particular, y al sector en general:

"El sector agroexportador es un claro beneficiario de ese dólar alto cuyo coste comparte con toda la sociedad. También es cierto que el campo cuenta con gasoil por debajo del precio internacional. $Y$ que eso se financia con dinero del superávit fiscal, fruto del pago de impuestos de la gran mayoría de 
los argentinos". (Socios de la recuperación, peleados en el momento de mayor abundancia, por Daniel Fernández Canedo, 25/03/08).

El gobierno unificó el frente del campo: tamberos, ganadores y cerealistas se sienten perjudicados por igual. $Y$ los ruralistas no aceptan que sus buenos rendimientos se basan en un dólar alto que se deprecia en casi todo el mundo menos en la Argentina: un subsidio indirecto para el sector (...) Es decir que toda la sociedad contribuye a la bonanza agraria". (Llegó la hora de negociar. Carta del Editor al Lector, por Osvaldo Pepe, 25/03)

De modo que no hay, por parte del diario Clarín, un tratamiento indiferenciado del "campo", no al menos uno que pueda concebirse, sin más, en concordancia con las declaraciones de la dirigencia agropecuaria. Por un lado, se habla del "sector agropecuario", y se lo distingue por su condición privilegiada, remarcando el beneficio, vía transferencia de recursos, del sostenimiento del dólar alto. Por el otro, se analiza la singularidad de la confluencia de distintos actores (el "frente del campo"), muchos de los cuáles no están afectados directamente por la Resolución 125.

\section{La Nación}

En La Nación, en esta primera etapa, se plantea una mirada que coloca al campo como una víctima de la "voracidad fiscal del Estado". El diario trata al Estado central como una facción, y lo acusa de recaudar dinero para fines particulares: se trata de aumentar la recaudación "para asegurar el control político del “Interior”.

La redistribución de los ingresos a favor de los pobres que invoca el Gobierno parece por ello un sofisma destinado a ocultar lo inocultable porque, si en los casos del trigo y las carnes podía hablarse todavía del consumo popular, en el caso de la soja el aumento ya no refleja otra cosa que la voracidad del Estado". (Nada para la sociedad, todo para el Estado. Por Mariano Grondona, 16/03/2008)

El sector agropecuario es descripto como principal responsable de la recuperación económica de la poscrisis de 2001, y se hace énfasis en los apoyo ganados por la dirigencia agropecuaria entre distintos sectores que legitiman la medida. 
Por eso, el Gobierno sólo vio en el campo más que una revolución económica y social de extraordinaria potencialidad, una excelente ocasión para financiar su propio proyecto en dirección de una economía cerrada al mundo y totalmente controlada por él y por los amigos del poder gracias a las retenciones". (La metáfora del zorro y el puercoespín, por Mariano Grondona, 23/03/2008):

La huelga comercial protagonizada por el sector agrario ha tenido manifestaciones tan amplias y sorprendentes, que superaron las expectativas de sus organizadores así como lo imaginado por el gobierno nacional. (...)A medida que transcurrían las horas, se iban sumando adhesiones de numerosos grupos autoconvocados, estacionados en rutas y asambleas populares en las plazas públicas. El interior, que había sido protagonista del triunfo kirchnerista en las elecciones de octubre último, pasó a conformar una protesta de características inéditas, prevista inicialmente para finalizar el miércoles pasado, pero que se prolongará por la presión de los productores (...) debido a la apropiación de fondos por parte del Estado nacional, único receptor de las retenciones a las exportaciones. (Dura respuesta del agro, editorial, 22/03).

Si Clarín se muestra preocupado por el impacto del conflicto en la "sociedad", concebida como tercera parte perjudicada por las medidas del agro, pero también por la incapacidad del Gobierno para darle un cauce institucional al conflicto, La Nación victimiza al sector agropecuario: el conflicto se entiende desde los ojos del actor perjudicado, al que se describe como un actor singular, unificado:

Fue necesario que el campo argentino se frenara en seco, unánime, estragado de furia, para que se buscara el puente más consistente con los productores rurales. El caso no es único ni aislado; el gobierno nunca retrocede hasta que el abismo está muy cerca. La Presidenta tiene un problema político, además del económico. Muchos de los productores enfurecidos de estos días (la mayoría, quizá) la votaron en octubre pasado, pero su gobierno los vapuleó ahora sin lástima. (El mundo y el submundo del kirchnerismo, por Joaquín Morales Solá, 22/03/2008)

Sin duda la resistencia del campo a decisiones tributarias cuasi confiscatorias ha constituido un hecho notable. Pero, con todo lo importante -y hasta desbordante- que ha sido como fenómeno social, parecería que se trata de la parte visible de un movimiento de raíces históricas y consustanciado con la nacionalidad que vuelve a ponerse en marcha.(Por una política para todo el país, Editorial, 24/03/2008) 
La lectura de los artículos de opinión y editoriales del diario confirman, en estos días, la identificación extendida entre los propios sectores agroexportadores, de que el campo es el Interior:

El interior, que había sido protagonista del triunfo kirchnerista en las elecciones de octubre último, pasó a conformar una protesta de características inéditas, prevista inicialmente para finalizar el miércoles pasado, pero que se prolongará por la presión de los productores. (Dura respuesta del agro, Editorial, 22/03/2008).

Es el interior que comienza a reclamar, de viva voz, por derechos económicos que se le han ido retaceando por muy largo tiempo". (...) La gente siente en carne propia que la extracción de las riquezas del interior por el unitarismo de facto ha crecido, pero sin que ello haya dado lugar a la contrapartida de obras que la justifiquen. (Por una política para todo el país, Editorial, 24/03/2008)

\section{Página/12}

En Página/12, en el período que estamos analizando, se desplegaron argumentos muy similares a los que utilizaría CKF en sus primeros discursos. En particular, en las notas del diario se fueron desarrollando, con insistencia, dos de los puntos que la Presidenta enfatizaría en sus intervenciones: el carácter corporativo de la protestas, que le restaba legitimidad frente a un gobierno electo en elecciones libres y democráticas, y la paradoja de que dirigentes que habían sido críticos impiadosos de las medidas de acción directa de los desocupados durante la crisis del 2001, optaran ahora por el mismo método de protesta:

Los datos hablan por sí solos: lo que se pulsea no son mendrugos. Se discute, entre Gobierno y representaciones corporativas, la captura de superganancias. Aquél tiene el deber (y el mandato) de representar al conjunto social, éstas hablan en nombre de sus afiliados. (...)La discusión en el ágora democrática debe registrar la nula legitimidad de los productores cuando hablan en nombre de terceros. Como ciudadano, cualquiera puede opinar, como dirigente es poco serio invocar derechos de quienes nada delegaron en ellos. (Los huevos de oro, por Mario Wainfeld, 23/03)

Ahora la situación es diferente. Quienes están cortando rutas no son los desarrapados y excluidos que dejó el neoliberalismo de la década del ' 90 sino 
los chacareros que pelean por conservar las mieles de la soja. (El piquete está de moda, Fernando Krakowiak, 22/03/2008)

Para los columnistas del diario el conflicto se planteó, también desde su inicio, como una controversia semántica: algo se estaba jugando en las definiciones sobre los actores de la protesta, y sobre los términos que se utilizaban para nominarla:

Un lock out se nombra con la proletaria expresión "paro". Un corte de rutas expandido se bautiza "tractorazo". Se llama "campo" al conjunto de entidades representativas de los productores, excluyendo tácitamente del pronombre colectivo a los castigados asalariados (...) (Dar vuelta la soja, por Mario Wainfeld, 16/03)

Lo primero que debería ponerse en claro es que la denominación "campo" define realidades muy diferentes. No es lo mismo tener cien hectáreas en la Pampa Húmeda que en las provincias del Nordeste. Tampoco son equiparables la situación del chacarero con la del invernador de ganado, la del exportador a granel que la del que vende al acopiador, la del propietario que trabaja su tierra con la del que la alquila a cambio de una renta para que la explote alguna corporación nacional o extranjera, y así de seguido. (Recordatorios, Pasquini Durán, 22/03)

No existe un solo campo. Las realidades son múltiples. La situación del pequeño y mediano productor es bastante diferente a la del grande. Cada vez más se expanden los pool de siembra y se verifica el desembarco de inversores con lógica financiera en el negocio agropecuario. Pero todos, más o menos según su posición relativa en el sector, han registrado un efecto riqueza considerable con el crecimiento fabuloso del precio de los campos. El piquete verde puede incorporar la consigna "Hasta la victoria, siembre". (Efecto riqueza, A. Zaiat, 22/03)

El énfasis en cuestionar la pertinencia, e incluso la legitimidad, del uso de una categoría bien amplia y genérica como la de "campo", para producir la percepción de que el conflicto enfrentaba dos posiciones bien definidas y homogéneas fue una constante en las notas de los principales articulistas del diario. En ese preciso sentido, los periodistas de Página/ 12 parecen asumir como propio (o bien, confirmar) el postulado de Bourdieu (1990:290), según el cual toda lucha política es inseparablemente "teórica y práctica", con el objeto de "conservar o de transformar el mundo social conservando o transformando las categorías de percepción de este mundo". 
Si en Clarín hay un registro del significado político que tiene la presencia de los pequeños productores en la interpretación del conflicto, y en La Nación esa presencia es el indicador de que la protesta está legitimada por el acompañamiento del “Interior”, en Página/12, en este período, los "pequeños productores" -como colectivo- son caracterizados como la coartada perfecta para legitimar una lucha que, en definitiva, no es de ellos:

La protesta del campo tiene la particularidad de haber logrado la movilización de pequeños productores que creen estar protagonizando el Grito de Alcorta y reclaman una reforma agraria junto con otros grandes chacareros que sólo pregonan la eliminación de las retenciones porque cuestionan la intervención del Estado por definición. Los discursos de izquierda y las prédicas liberales hasta ahora se han entrelazado sin inconvenientes. (Sigue el lockout en contra de las retenciones, por Fernando Krakowiak, 25/03/2008)

La unidad en el reclamo por los pequeños y medianos es conducida políticamente por los grandes, a quienes detestan. La dirigencia de la Federación Agraria y la de Confederaciones Rurales Argentinas, se pliegan al sesgo político impuesto por la SRA. Los huevos de oro, Mario Wainfeld, 23/03/2008)

Es recurrente que los periodistas de Página/12 produzcan esta lectura, que implica redefinir, desde fuera, lo que "realmente" están haciendo otros colectivos, con la paradoja de que se les señale que se están equivocando. Esto no sucede, no al menos en relación a los pequeños productores, en ninguno de los demás diarios. Este tipo de posicionamiento se repetirá, lo veremos más adelante, cuando se trata de analizar las protestas urbanas de la "clase media".

Conviene agregar, por lo demás, que a Wainfeld -ni a los demás periodistas del diario- no se le escapa que esa confluencia, a su entender paradójica, entre sectores que ocupan posiciones contradictorias en la estructura productiva del agro se debe, en buena medida, en la propia torpeza del gobierno: “(...)Unificar adversarios en un error en política, anche en política económica. Más allá de la "falsa conciencia" de la F.A.A, el gobierno hizo mal en posibilitar (acaso catalizar) su alianza fervorosa con las gentes bien de Luciano Miguens". 


\section{Crítica de la Argentina}

A diferencia de los otros diarios, en Crítica casi no hay columnas editoriales, ni de opinión, en el período que va del 11 al 25 de marzo. El tratamiento del conflicto en las notas del cuerpo del diario es más bien informativo, y en este punto, distanciado.

Aun así, algunos periodistas, especialmente quienes tienen cargos editoriales, interrogan el conflicto. Así, por ejemplo, en su columna semanal, Martín Caparrós sugiere que una modalidad diferente de aplicación del impuesto, exceptuando a los productores con menos de 200 hectáreas no hubiera afectado el volumen a capturar, pero le hubiera quitado "masa crítica" a la protesta. Hecho el planteo, escribe:

No se habría producido el desabastecimiento que afecta a cada vez más gente, no habrían salido por televisión esas imágenes de chacareros modestos preocupados por su fuente de trabajo, y el impuesto habría tenido otra legitimidad; habría sido un pequeño intento redistributivo. No lo hicieron". "La crisis se va a resolver de algún modo, aunque todavía no esté claro cuál. Lo que seguirá siendo, después, preocupante es la incapacidad: ¿van a seguir cometiendo errores tras errores? ¿Será que realmente no saben lo que hacen? ¿O todo tiene una lógica que no consiguen explicarnos? ${ }^{261}$ (EI juego de los errores, por Martín Caparrós, 21/03/2008)

También Maximiliano Montenegro, en su columna económica, pone en cuestión lo que considera el principal error en la aplicación de la Resolución 125. Retoma un informe elaborado por técnicos de la FAA, a propósito de la concentración de la tierra. El documento explica que no hay un único campo. Cita:

"De los más de 170 millones de hectáreas agropecuarias en todo el país, 74,3 millones están en poder de tan solo 4000 dueños. Si se tiene en cuenta que en total en el país hay unos 300.000 productores, apenas 4000 poseen casi la mitad de la tierra". Agrega: "Completemos el cuadro con datos del mismo

${ }^{261}$ En esta cita, por lo demás, aparece un rasgo que vamos a analizar con más detenimiento en el próximo capítulo: el periodista se ubica en un nosotros, un colectivo difuso (los periodistas del diario, los lectores del diario, los ciudadanos) en nombre del cual formula esa pregunta retórica. 
censo. El 69\% de las explotaciones agropecuarias del país tiene menos de 200 hectáreas, pero sólo representan el $3 \%$ de la superficie total. En el otro extremo, el $10 \%$ de las explotaciones, con más de 1.000 hectáreas, acaparan el 78\% de la superficie”. (Tanque australiano, palangana y cucharita, 22/03/2008)

Pero más allá de estas excepciones, en estos días, el diario informa sobre la protesta haciendo foco en las decisiones que va tomando la Mesa de Enlace. A medida que pasan los días y los focos de conflicto se despliegan por todo el país, Crítica empieza a publicar noticias variadas sobre la situación del sector agropecuario: por ejemplo, el 18 de marzo, aparece una que informa sobre la desproporción del pago de impuestos que favorece a los propietarios de los campos más caros del país ("Pago fácil”, firmada por Maximiliano Montenegro). Ese mismo día, el diario publica un recuadro de opinión, que ya citamos, de Eduardo Buzzi, titulado:"El campo no es la oligarquía” en la que el presidente de la F.A.A plantea la diferencia entre "grandes actores", como los pooles y los fideicomisos, y los productores chicos, y la desigualdad derivada de la estructura impositiva.

El 20 de marzo Crítica publica una nota titulada: “Los militantes de tierra adentro", una crónica del corte de ruta en San Pedro, hasta ese momento el punto álgido de la protesta agropecuaria. Si bien el corte de ruta sobre el que informa la nota ha sido convocado por la Sociedad Rural del lugar, es la primera vez que se centra el foco de interés en ese actor nuevo, al que todavía no se le encuentra una definición precisa.

La segunda nota que tiene estas características es del 23 de Marzo de 2008. Se trata de una entrevista a dos hermanos, productores santafesinos, que relatan cómo viven su participación en una protesta por primera vez en su vida. El título de la nota: “Muchos tuvimos que ir al psicólogo pa' que nos sacara el nerviosismo". En un pasaje de la entrevista, dicen: “Da bronca tener que hacer esto; lo nuestro es trabajar el campo, no protestar, no somos piqueteros". 


\subsubsection{Los diarios en reconocimiento: efectos de los discursos de CFK entre el $25 / 03$ y el $4 / 04$.}

Como vimos, antes de que Cristina Fernández hablara por primera vez, en los diarios ya se registraban los tópicos controversiales del conflicto: el tipo de medida que significaba la resolución 125 , sus verdaderas motivaciones, el estatus del campo como actor social, la legitimidad de las protestas y de las metodologías de acción directa y la función que estaban desempeñando los pequeños productores. La sucesión de 4 discursos entre el 25/03 y el 1/04, las protestas en los centros urbanos, algunas escenas de peleas entre manifestantes pro-campo y militantes del Frente para la Victoria en la Plaza de Mayo, le dieron al conflicto un perfil menos circunscripto al reclamo sectorial. La irrupción de las clases medias y de sectores de neto perfil antikirchnerista en los cacerolazos porteños implicaba, también, una cercanía geográfica con el público lector de los propios diarios.

Lógicamente, luego del primer discurso de CFK la interpretación del conflicto tuvo un punto de referencia central contra el cual contrastarse. Desde ese momento, el tratamiento de los diarios pareció entablar un diálogo más o menos explícito con los discursos de la Presidenta. A veces, en la forma típica de un interdiscurso polémico (Dascal, 2000) ${ }^{262}$. Otras, bajo referencias difusas, pero que sin embargo entablaban un diálogo, si no con CFK, sí con los tópicos litigiosos que ella iba reactivando. Como durante esa álgida semana y durante el mes de abril el Gobierno inició su propia "batalla cultural" contra el Grupo Clarín, y también cuestionó públicamente la cobertura televisiva, el

\footnotetext{
262 Para la autora, un intercambio polémico involucra al menos dos personas (aunque podríamos pensar en dos "enunciadores", en tanto podría tratarse de organizaciones colectivas) que "que emplean el lenguaje para dirigirse una a la otra, en una confrontación de actitudes, opiniones, argumentos, teorías". Señala que, en esa definición, se destacan el aspecto interactivo (intercambio, diálogo) y el contenido de la interacción, según sea percibido por los participantes, por lo cual es importante, como condición de posibilidad, que los dos participantes estén en condiciones de responder el discurso del otro. A partir de esa definición, propone tres tipos ideales de polémicas: discusión, disputa y controversia (Dascal, 2000: 8). El intercambio polémico que reconstruimos puede ser ubicado en un intermedio entre la disputa y la controversia: esto es, un intercambio que se desata a partir de un tópico específico, bien delimitado (disputa), que luego se expande a otros sub-tópicos, revelando diferencias más profundas de concepciones (controversia), pero que, como debate, no tiene una solución, sino que se disuelve por el paso mismo del tiempo (disputa).
} 
posicionamiento en relación a la caracterización oficial del conflicto se vio asimismo condicionado pues los propios medios ingresaban, como entidades del imaginario, al debate público.

\section{Clarín}

Luego de los discursos presidenciales, Clarín reafirmó su postura inicial: la escalada del conflicto necesitaba, más que antes, de la mediación institucional para evitar que la prolongación de las medidas de acción directa desembocaran en más escenas de violencia. Nos interesa destacar que, a partir de los discursos de CFK, los editorialistas del diario retoman la discusión sobre la composición de la protesta, y lo hacen de dos modos.

Por un lado, en términos polémicos directos, cuestionando la descripción de la propia Presidenta:

No hay productores impostados en los cortes como vimos por la TV. Tildarlos de oligarcas y golpistas es un prejuicio que se retroalimenta con otro estereotipo gorila del lado contrario: el que ve al peronismo como un enemigo. Persistir en esta polarización puede ser una forma de hacer política y ejercer el poder. Pero conlleva el riesgo de no resolver nunca este enfrentamiento. No se debe vivir toda la vida con la sangre en el ojo. No se debería. (Estereotipos y enfrentamientos, por Ricardo Roa, Del editor al lector. 27/03/08)

Con el de ayer en Plaza de Mayo, la Presidenta le dedicó cuatro discursos consecutivos al campo. No todos fueron iguales. Pero en su conjunto dejan una conclusión inevitable: el Gobierno siente claramente el impacto de la protesta, que lleva hoy tres semanas. (...) La Presidenta volvió a hablar y no le habló al campo, al que había menospreciado poniendo a la soja en la categoría de un yuyo más difícil de matar que la coca y a los productores como representantes de la vieja oligarquía terrateniente. Se declaró víctima de una conspiración y llegó a comparar la protesta con la que le hicieron a Isabel Perón un mes antes de ser derrocada. Que hoy, dijo, no está escoltada por tanques sino por generales mediáticos. (Un discurso con fantasmas, por Ricardo Roa, Carta del editor al lector, 2/04/08).

Por el otro, glosando los discursos de CFK, señalando un aspecto que se había tornado ya un eje de discusión, ya no sólo técnica, sino política: 
En cambio, separó a los pequeños de los grandes productores, intentando así una diferenciación que, en los hechos, es difícil de hacer pero que no se intentó de entrada. Se supone que en el diálogo propuesto puede haber medidas que sostengan esa distinción. Democracia e instituciones, por Ricardo Kirchbaum, 28/03/2008)

Las jornadas que se han vivido han dejado algunas experiencias que deberían ser muy tenidas en cuenta por la dirigencia política y social. (...) En primer lugar, la composición social de las protestas rurales mostraron que el campo no es un conjunto homogéneo, y que cualquier política pública debería tener en cuenta las diferencias de situación y posibilidades de los destinatarios. (...)(Oportunidad para un diálogo que es indispensable, Editorial, 30/03/2008).

También pueden leerse, todavía, artículos en los que se vuelve a ubicar diferencialmente al sector agropecuario como un actor económico privilegiado que defiende sus intereses particulares:

Sería injusto no celebrar la decisión del Gobierno de (...) facilitar un espacio de negociación con las entidades del campo, que pusieron al país al borde de una crisis de desabastecimiento. Pero no hay que perder de vista que lo que aquí se negocia son los intereses particulares de un sector, que se cuenta entre los más favorecidos del modelo económico." (Objetivos, Punto de vista por Walter Curia. 29/03/2008)

En relación a los cacerolazos, Clarín no dejó de ver en ellos la expresión de un descontento político que encontraba en el conflicto con el sector agropecuario una coyuntura útil para expresarse, pero que indicaba la existencia de intereses oportunistas de la oposición política (aunque no se los identifica con claridad).

Las medidas de fuerza del campo han salido del cauce sectorial y son ya una brasa ardiente, con móviles políticos. En esto hay que ser claros porque no hay excusas: los cambios deben buscarse por el voto. $Y$ este gobierno ha sido electo hace poco. Es ahora cuando todos los actores deben demostrar respeto institucional. Nadie puede hacerse el desentendido, salvo que tenga ocultas otras intenciones. (Democracia e instituciones, por Ricardo Kirchbaum, 28/03/2008)

Por otra parte, luego del discurso presidencial se produjeron protestas urbanas en apoyo al paro agrario que dieron cuenta de que en algunos sectores existe un malestar con el Gobierno, independiente del tema agrario. (...) Este malestar fue alimentado, en estos días, por la actuación agresiva de elementos vinculados al oficialismo en manifestaciones que se 
realizaban en las rutas y en la Plaza de Mayo.(...) En este clima, en los discursos de dirigentes, productores y ciudadanos, reaparecieron formulaciones de viejas antinomias sociales y económicas que, aunque estén perimidas en la formación real de la sociedad, siguen teniendo vigencia en el imaginario colectivo, y pueden ser causa de enfrentamientos estériles. (Oportunidad para un diálogo que es indispensable, Editorial, 30/03/2008).

Las protestas urbanas, con las marchas a Plaza de Mayo o al Congreso, y con los cacerolazos, modifican la fisonomía del conflicto, lo transforman. Frente a esto, el diario parece calibrar su equidistancia: por un lado, denuncia a los oportunistas, reconoce motivos ocultos, incluso "anti-democráticos"; por el otro, la masividad de las protestas es explicada como consecuencia del comportamiento del propio Gobierno y de sus sectores aliados (en particular, en las organizaciones sociales lideradas por Luis D’Elía y Emilio Pérsico, “elementos vinculados al oficialismo”). Y allí encuentran justificación.

A medida que el conflicto se prolongó, se sucedieron tres situaciones: por un lado, los efectos del desabastecimiento se volvieron sensibles en los aumentos de precios; en segundo lugar, se amplió la base social (de clase media urbana) de las protestas; finalmente, el gobierno intensificó las críticas explícitas al diario, acusándolo de la cobertura sesgada. Incluso en ese contexto el Clarín no varió su posición de observador externo, intentó sostener una crítica “equidistante”263 pero empezó a cargar con mayor intensidad la responsabilidad del conflicto en el gobierno, al que acusó, también, de incurrir en comportamientos facciosos.

El cacerolazo del martes pasado tuvo como protagonistas a los opositores a Cristina, a los fatigados por el estilo atropellador del kirchnerismo, a los que se enfurecen por la inflación dibujada. También estuvieron los solidarios con el reclamo del campo, los antiperonistas y los ofuscados por la política de derechos humanos. No son la base social de Cristina, no la votaron y nunca los quisieron ni a ella ni a Kirchner. No ponen en peligro su estabilidad, pero el daño político que le ocasionaron es grande. El tiempo dará la medida de su profundidad y alcance. (Cristina, De la Rúa y el ¿paralelo? imposible entre dos cacerolazos, por Julio Blanck, 31/03/2008).

\footnotetext{
${ }^{263}$ La confrontación más directa con el Gobierno, en estos meses, no se dio a propósito del conflicto del campo, sino por los cuestionamiento al rol del periodismo y por el anuncio de una futura Ley de Medios. Trataremos este aspecto con detalle en el capítulo 7.
} 
Sin necesidad de buscar razones ocultas, podemos señalar que casi en simultáneo con la primera tregua, el Gobierno empieza hablar públicamente de su intención de promover una nueva "Ley de Medios". Lo hace al tiempo que agudiza sus críticas cada vez más explícitas al Grupo Clarín, al canal de noticias TN y al propio diario. En ese marco, empieza a tomar forma lo que ya a fines de 2007 se anunciaba como escenario conflictivo: la pelea por el relato, que ahora encontraba un punto de referencia concreto, económicamente sensible, políticamente irresoluble y simbólicamente prolífico:

\begin{abstract}
"Ya terminó el paro del campo, se abrió una tregua y quizás esté por florecer el clásico jardín de números con que el Gobierno suele mostrar que la realidad es tan bella y placentera como la imagina. (...) Pero la batalla por la interpretación de lo que sucedió en estas tres semanas fragorosas está planteada. Se trata de deducir, de explicar, de convencer a la opinión pública acerca de quién ganó y quién perdió, a quién le asistía la razón y quién era el vehículo de lo perverso". (Empezó la batalla política por el relato de una crisis que dividió a la sociedad, por Julio Blanck 04/04/2008)
\end{abstract}

\title{
La Nación
}

Frente a los discursos de CFK y los cacerolazos y marchas en los principales centros urbanos del país, especialmente en Capital Federal, La Nación publicó varios editoriales y artículos de análisis y opinión en los que, como respuesta a las caracterizaciones que la Presidenta había desarrollado en sus discursos, reforzaba la lectura que ya había planteado en los días previos. Por un lado, una justificación de las acciones directas amparada en la épica del campo como el motor de la recuperación económica en la poscrisis. Por el otro, por la composición y la motivación de los protagonistas: una clase media que se autoconvoca espontáneamente ${ }^{264}$.

\footnotetext{
264 "Es cierto que los cortes que organiza el campo son tan incómodos como los de los piqueteros, escribió el periodista Adrián Ventura. "Pero las manifestaciones de los productores no responden a ninguna motivación ideológica ni a un liderazgo político, sino que son brotes espontáneos de una clase media rural, como advierte Rosendo Fraga, que creció mientras las clase media urbana se debilitaba. Ese sector es el que tecnificó el campo,
} 
Nada justifica que los ánimos se solivanten hasta la violencia o impidan cumplir con lo que manda el respeto por el orden público (...) $\mathrm{Ni}$ el desprecio con el que se ha tratado al sector de la economía que genera más riquezas para todos y ha demostrado ser el más dinámico de la producción nacional, el más abierto a incorporarse a la sociedad del conocimiento. La legitimidad de la protesta agropecuaria se ha objetivado de múltiples maneras. El hecho de que ya ha sido a esta altura la más importante que se recuerde (...) se explica, entre otras razones por la conjunción de voluntades de todas las gamas de la producción agrupecuaria del país (...) También por la llamativa espontaneidad con la cual productores autoconvocados han realizado actos, marchas y cortes de caminos y rutas fuera de la agenda de las entidades que ayer extendieron las medidas por tiempo indefinido. (El paro del campo, editorial, 26/03)

A su vez, se trataba de interpretar -veremos que esto también sucede en los otros diarios- la reacción de las clases medias urbanas que decidieron movilizarse para protestar contra el Gobierno, pues había allí una confluencia centro-interior que reforzaba aún más la base social de la protesta.

Ciertamente, la ausencia de "voceros" en estas manifestaciones -como sucede, por lo demás, cuando se producen episodios de manifestaciones colectivas de protesta de este tipo- habilita el espacio para la representación en su sentido más estricto: hay allí un colectivo al que hay que hacer hablar, al que hay que dotar de racionalidad, de razones, motivos, necesidades y deseos.

La Nación, en ese marco, cuestiona la identificación de los manifestantes con la "oligarquía”, e identifica, por su parte, al campo no por su capacidad productiva, sino por su poder de resistencia. También aquí, como lo viéramos en relación a Clarín, se establece un interdiscurso polémico con las definiciones de CFK:

¿Fue la oligarquía argentina la que se congregó en Villa Crespo, en la provincia de Misiones, o en el Monumento a la bandera, en Rosario? ¿Pertenecen a ese exclusivo club los campesinos que llevaron sus tractores a las rutas? (...)El malhumor social de los centros urbanos encontró -es cierto- un eje en la

aumentó la productividad y reclama que se respeten las ganancias por los riesgos que asumió". (Provocar no resuelve los problemas26/03/2008). Esta contradicción entre lo espontáneo y lo organizado como criterio de valoración de la legitimidad de la protesta ha sido tratado en detalle en el libro Campos de batalla, en particular en los artículos de Vommaro (2010) y Nardacchione (2010) 
protesta del campo, el único sector social en condiciones de sublevarse a un gobierno que hizo de la obediencia política un dogma. También pudo haber influido la noción tal vez inscripta en el inconsciente social, de que desde el campo se construyó la Argentina y que los campesinos reconstruyeron el país cada vez que este fue destruido. (El verdadero mensaje de las cacerolas, Joaquín Morales Solá, 27/03/2008)

Ya vimos que, antes de los primeros discursos de CFK, Página/ 12 había hecho de la definición del "campo" un tópico de debate: era necesario saber quiénes estaban llevando adelante los piquetes para valorar sus motivos, que definen la legitimidad (o no) de las medidas. Las definiciones que CFK hizo del sector tuvieron una serie de réplicas en La Nación, réplicas que sin embargo no fueron homogéneas. Por una parte, se cuestiona la pretensión del Gobierno de diferenciar entre pequeños y grandes productores: la unanimidad de la protesta indica que esa diferencia no existe; el campo es un "todo armónico e interactivo", por lo cual intentar dividirlo es una herramienta política arbitraria e impracticable:

No se privó tampoco [Cristina Fernández], de menear de nuevo la supuesta diferencia entre grandes y pequeños productores o entre la "aristocracia" de los ruralistas y el "gobierno popular" que ella supuestamente encarna. ¿Quiénes son la aristocracia de los productores? ¿Acaso la Sociedad Rural, a la que aludió cuando señaló que las medidas oficiales afectaban sólo a los grandes productores? (...) Si el campo argentino (uno de los más avanzados del mundo en tecnología por las inversiones constantes) fuera como lo describió ayer la Presidenta, no existiría la unanimidad de la protesta rural ni el rechazo de los productores a cualquier gesto conciliador de sus propios dirigentes. (Una oración distinta a la del martes, por Joaquín Morales Solá, 28/03/2008)

Estas propuestas, así como los discursos de la presidenta Cristina Kirchner, demuestran que existe una intención política de dividir al campo. Los productores grandes, así como algunos medianos y chicos, integran un todo armónico e interactivo favorable a la productividad, fruto de la exitosa economía agraria del conocimiento, que tanto provecho ha dado al país. ( $L a$ clara intención de dividir al campo, Editorial, 4/04/2008)

"Dividir a los productores en grandes, por un lado, y pequeños y medianos, por otro, constituye una gran simplificación. No sólo por ser grande un productor ha de ser rentable, ni por ser pequeño o mediano lo será en menor cuantía, como lo muestra, por ejemplo, la diferencia en su favor entre quienes trabajan su propio predio y aquellos que lo arriendan.(...) Pretender establecer un límite entre unos y otros no es solamente arbitrario y discriminatorio, sino impracticable. Al irrumpir en esta delicada red de decisiones, mediante el ordenamiento estatal del mercado, se fractura uno de 
los fundamentos de la expansión agrícola nacional de los últimos 20 años (Agricultores grandes y pequeños, Editorial, 12/04/2008)

Pero al mismo tiempo (literalmente, en columnas de opinión publicadas en mismos días que aquellas caracterizaciones) se pueden leer descripciones más cercanas a las que han hecho, por ejemplo, Clarín, o incluso Página/12, aunque sin la sospecha de que la confluencia entre productores de escala diferente obedezca a una estrategia digitada desde la Sociedad Rural o las grandes compañías exportadoras, tal como sostiene Página:

La rebelión de los productores agropecuarios y la reacción popular suscitada el martes a la noche por el discurso de Cristina Kirchner generaron en la cúspide del poder algo que podría denominarse 'perplejidad sociológica'. En efecto, los Kirchner y sus funcionarios se preguntaron, desorientados: ¿qué les pasa al campo y a la clase media que mejoraron drásticamente su situación económica bajo nuestro gobierno y ahora nos repudian?(...) La sociedad argentina se ha diversificado notablemente en los últimos años; 'el campo' encierra muchas situaciones y tensiones singulares que resisten la generalización (y así tantos otros sectores). (Los riesgos de generalizar y dividir, columna de opinión de Eduardo Fidanza, 27/03/2008).

Néstor Kirchner supone que el suyo es un caso distinto. No piensa que está frente a un grupo disperso y plural de productores de soja, quejosos porque las retenciones móviles les harán ganar cada vez menos.(...) Kirchner ve el problema de otro modo y por eso anoche recrudecía su enojo con los huelguistas rurales. Allí donde la sociología describe a un entramado agrario polifacético, que ha mutado en los últimos 15 años por la creciente demanda internacional y la renovación de las tecnologías, el ex presidente supone un enemigo enmascarado, la oligarquía vacuna, el viejo agente del golpismo que otra vez pretende desafiar a la democracia. (Cada vez más fisuras en el frente oficial, Carlos Pagni, 31/03/2008)

Nos interesa apuntar este matiz, esta variación, entre artículos del mismo diario (aunque no discutan entre ellos) para señalar que, desde el punto de vista del establecimiento de una línea editorial, es interesante prestar atención a cómo funciona el medio como superficie de emergencia, articulando, si así puede decirse, los discursos de actores que, pudiendo considerarse cercanos -por ideología, por concepción del mundo, por vínculos políticos o partidarios- expresan ideas divergentes. Borrat (2005) se refiere a este hecho señalando que los periódicos son "narradores polifónicos". Así, por ejemplo, mientras que para la columna editorial el "campo", como vimos, es un "todo orgánico", por lo cual es arbitrario definir entre "pequeños y 
medianos", se publica una nota a Gustavo Grobocopatel, en la que este importante empresario agroindustrial que cuestiona duramente al Gobierno, que habla en nombre del "campo", pero que lo define de esta forma:

La única certeza que dan las retenciones móviles es que no vale la pena esforzarse. La protesta de "El Campo" (defino "El campo" como 400.000 pymes, los pueblos del interior que en su mayoría viven del campo, los maestros, los trabajadores de Uatre, los camioneros que transportan granos, la industria y los servicios relacionados que según algunos estudios casi $40 \%$ de la mano de obra de la Argentina) no es sólo porque se lo pone en peligro de subsistencia: tiene otros condimentos". (...) El 'campo' tiene una compleja realidad, tratar de estigmatizarla, ideologizarla, es un grave error. En el campo hay grandes y chicos, ricos y pobres, los que crecen o decrecen. Está muy atomizado: los 20 productores más grandes no llegan a sumar el 3 por ciento de la producción total. Hay gente de ideas muy diferentes, pero todos amamos lo que hacemos y nuestra forma de vida. (El campo se siente decepcionado, por Gustavo Grobocopatel. 26/03/2008).

Que las columnas editoriales sean la síntesis de una posición institucional, no es algo que merezca ser puesto en duda. Pero eso no implica que sean la expresión transparente de la voluntad política de sus lectores. Por eso, un argumento puede aparecer contrastado en las mismas páginas por alguien que, sin embargo, está acuerdo en el punto central: la legitimidad y hasta la necesidad de la protesta del "campo".

\section{Página/12}

En la semana que se abre con el primer discurso de CFK, el 25 de marzo, y hasta declarada la primera tregua por parte de la Mesa de Enlace, en Página/12 se consolidó una lectura del conflicto según la cual los "pequeños productores" estaban oficiando de coartada para una protesta en la que, objetivamente, se dirimía el interés de los "grandes". Esta lectura está directamente asociada a la percepción de que las manifestaciones de apoyo y simpatía con el sector agropecuario ${ }^{265}$ habían encontrado una buena

\footnotetext{
265 "Piquete y cacerola en versión campestre", se tituló la crónica del 26 de marzo, sobre las manifestaciones del día anterior. Y las primeras líneas referían a un canto que entonaban los manifestantes: "El campo, unido, jamás será vencido". En los días siguientes, Página/12
} 
justificación en la presencia de los pequeños productores en los cortes de ruta.

Lo que se juega: Los dirigentes "del campo" ayudan poco. Los grandes se invisibilizan en el discurso escudándose detrás de los pequeños mientras se valen de su bronca. La intransigencia de las cuatro entidades no se puede explicar por motivos económicos (a muchos de ellos les sigue yendo bomba) ni por estar "desbordados" por sus bases, argumento que ningún líder que aspira a negociar puede invocar gratuitamente. Digámoslo paradojalmente para luego explicarlo: ya no se discute lo que se discute.(...)Se ha establecido una suerte de caso piloto. Los propietarios agropecuarios quieren recuperar parte del poder que perdieron en estos años, alienados de Palacio aunque no del crecimientos y sus pitanzas (Una giornata particolare, por Mario Wainfeld $(26 / 03 / 2008)$

Desde el punto de vista político, la Federación Agraria tendrá que hacer una reflexión seria y rigurosa sobre el papel que está cumpliendo, como mano de obra de la derecha oligárquica para piquetear aquí y allá. Son la coartada perfecta, el mascarón de proa de la nave que transporta una ideología que está de contramano de todas las posiciones que la Federación Agraria defendió durante todos estos años. (Mandatos, por José María Pasquini Durán, 27/03/2008)

Si bien los columnistas del diario cuestionan los errores del Gobierno en la gestión del conflicto, y señalan como principal inconsistencia la falta de matices en la aplicación del impuesto (pues esta indistinción favorecía la confluencia de sectores con intereses contrapuestos) también analizan y valoran la presencia de los pequeños productores desde una lógica estrictamente instrumental. La recurrencia en este tipo de argumentos muestra bien el funcionamiento del litigio: es necesario reponer, permanentemente, los indicadores de certeza para determinar quién es quién es la disputa.

(...)Los chacareros le pusieron rostro humano a la extorsión de los grandes capitalistas agropecuarios. El enconado Eduardo Buzzi permitió que Luciano Miguens pareciera un hombre sereno y razonable. Buzzi había dicho que contaba con el apoyo de Víctor De Gennaro y Hugo Yasky, pero la mesa nacional de la CTA, que ambos integran, lo desmintió en forma implícita al respaldar las retenciones, como mecanismo redistributivo ante "las extraordinarias ganancias de los sectores concentrados" y rechazó el "intento

publicó varias crónicas en las que se intentaba mostrar el corte de clase (alta, acomodada, antikirchnerista) de los cacerolazos. 
de desestabilización institucional" (Acero inoxidable, por Horacio Verbitsky, $30 / 03 / 2008)^{266}$.

Del mismo modo, los articulistas de Página/ 12 insisten con discutir sobre la definición del “campo", de su composición y de los imaginarios sociales movilizados en el conflicto.

El sector agropecuario siempre se consideró el único forjador del país debido a que los hombres que dominaron la actividad en el siglo XIX, con métodos y desprecio humanitario de espanto, fueron los que constituyeron las bases para el Estado moderno. El modelo agroexportador fue la estructura económica que acompañó la conformación y consolidación de Argentina como país entre la Generación del Ochenta y la década del veinte. Así construyeron una imagen, que se difundió con bastante éxito a centros urbanos, que expresa la posesión de todos los atributos para considerarse los hacedores de la patria. El resto, por lo tanto, tiene que agradecerle su sacrificio como buenos hijos. Ese vínculo filial de retribución por el pan acercado a las mesas de la ciudad reclama subordinación. (Forjadores de la patria, por A. Zaiat, $29 / 03 / 2008)^{267}$

Si La Nación publica artículos en los que se afirmaba la legitimidad de la protesta en que era protagonizada por la clase media del interior, franja social que con su impulso y dinamismo había motorizado el crecimiento del sector agropecuario, en Página/ 12 se hace una crítica de su función política, cuyo efecto más importante sería el de servir de base social para la emergencia de un "nuevo bloque de poder":

Gran parte de los pequeños productores del núcleo rico de la pampa húmeda tiene comportamientos similares a los de la clase media urbana. Aspira a poseer el status de vida de hacendados y a la vez trata de imitar pautas de consumo de la clase acomodada. Expresa terror de retroceder en esa escalera

\footnotetext{
266 También en esta nota: “El lockout agropecuario permitió que asomen y se mezclen otros intereses políticos y económicos que nada tienen que ver con las retenciones. La simplificación hace que se pierda de vista que lo central radica en un conflicto de intereses y de poder que tiene un único titular posible: redistribución de las riquezas.(....) Pero hay que desenmascarar también a quienes, siendo los principales explotadores de los campesinos, pretenden hablar en nombre de éstos y sumarlos como tropa política propia, usando una metodología perversa propia del clientelismo que critican. (Diálogo y negociación, por Washinton Uranga, 31/03/2008).

267 "En el campo ya no existen sólo terratenientes y minifundistas, criaderos e invernaderos de hacienda, porque igual que en el resto de la economía aparecieron grupos concentrados, nacionales y extranjeros, de capitalismo agrario que mezclan variados intereses de las finanzas, la producción y la comercialización, y formas de explotación también distintas al pasado siglo XX, con polo de enormes riquezas, con reactivación de capas medias del campo y también extremos de fragilidad y pobreza, expuestos en síntesis para no entrar en detalles que no vienen al caso.(...) Mandatos. Pasquini Durán, 27.03.
} 
de ascenso social y por eso a veces reacciona con virulencia hacia los integrantes del escalón inferior y también hacia el Estado. Pero igualmente quiere y exige que ese Estado lo proteja. Con sus contradicciones a cuesta, se siente acechado y defiende su porción del capital frente a los enemigos que supone que lo rodean. (Pequeño productor, por Alfredo Zaiat, 4/04/2008)

La reacción destemplada de un sector del campo no hay que entenderla entonces por la suba de unos pocos puntos en las retenciones porque, haciendo bien las cuentas, no afectan la rentabilidad esperada cuando decidieron la siembra. La suba de los precios internacionales en los últimos meses más que supera la tibia intervención estatal vía retenciones móviles. El saldo del piquete del desabastecimiento fue el alumbramiento de un nuevo bloque de poder, que ha tenido como partero la invalorable colaboración de los pequeños productores liderados por la que en otros tiempos planteaba opciones progresistas Federación Agraria (El parto de un nuevo bloque de poder, Alfredo Zaiat, 13/04/2008)

La clase media y un nuevo bloque de poder: la crítica persistente a la utilización del término "campo ${ }^{268}$ ", de la que los periodistas del diario hicieron una causa específica, no apuntaba, está claro, a impugnar las generalizaciones inherentes a las categorías que, como los colectivos, identifican a conjuntos de actores; la batalla semántica que Página/12 libró en un frente, no podía ser total, sino a costa de resignar la posibilidad de nombrar a los actores que protagonizan (y protagonizaron) el conflicto. Entonces, el problema no era la abstracción generalizante, inherente a los colectivos, sino su utilización para una causa política promovida por los sectores dominantes y antikirchneristas.

\section{Crítica de la Argentina}

Tal como lo señalamos en el apartado anterior, Crítica fue, de los diarios que estamos estudiando, el que más atención le prestó a las figuras emergentes del conflicto, a los productores y a los piquetes. No lo hizo bajo una

\footnotetext{
268 Podemos decir que, en términos generales, para Página/ 12 (como actor colectivo) corresponde hablar del "campo" solo si se incorpora a los sectores subalternos (aquellos que sobreviven en una economía de subsistencia). No sólo porque enuncia esa consideración, sino porque a lo largo del conflicto hace aparecer en sus páginas a estos actores, los hace hablar, los contrasta.
} 
modalidad reflexiva -no al menos en la pluma de sus periodistas ${ }^{269}$ - ni teorizando o discutiendo conceptualmente los términos con los que se estaba interpretando el conflicto, sino con crónicas en las que se puede entrever la mirada extrañada del habitante de la ciudad interesado en un fenómeno en principio ajeno y novedoso.

Cuando el conflicto tuvo sus réplicas urbanas, particularmente en el centro de Capital Federal, con los cacerolazos y los enfrentamientos en Plaza de Mayo entre los manifestantes que apoyaban el reclamo agropecuario y cuestionaban al gobierno y las organizaciones sociales afines al kirchnerismo, en Crítica empezaron a aparecer más columnas de opinión, análisis y toma de posición por parte de su director y de sus periodistas más importantes.

En estos artículos no se despliega una mirada cercana ni empática con el paro agropecuario; no hay argumentos que busquen legitimar las protestas del sector (como por ejemplo en La Nación). Hay, en cambio, una posición crítica con las actitudes políticas del Gobierno, y una posición contemplativa, condescendiente, con las clases medias, en nombre de las cuáles se intenta interpretar el conflicto, y una actualización de las controversias sobre la composición de la protesta agraria

\begin{abstract}
A la tarde, el Gobierno le echó leña al fuego. La Presidenta habló de "piquetes de la abundancia" e insistió con la idea rectora: "La huelga es a los argentinos". Una de las expresiones más argentinas del autoritarismo es el movimentismo: quienes no están conmigo (con nosotros, los argentinos) son traidores”.(...)“¿Cómo sigue, entonces, esta historia? ¿Seguirán al acecho las hordas de millonarios imperialistas contra el Gobierno progresista y redistributivo? ¿Intentarán un golpe de Estado? Realmente creo que no. No lo necesitan. Ellos saben bien con quién siguen ganando cada día más dinero". (La única verdad no es la realidad, por Jorge Lanata, 26/03/2008)
\end{abstract}

\footnotetext{
${ }^{269}$ En Crítica, la reflexión y el análisis sobre el conflicto, sobre las políticas agropecuarias, sobre la reacción de la clase media, estuvo a cargo, mayoritariamente, de invitados -desde Maristella Svampa o Ezequiel Adamovsky, Eduardo Azcuy Ameghino o Claudio Lozanoprovenientes de las ciencias sociales (sociología, ciencia política, economía). Un análisis de conjunto de estos artículos (que son escritos a nombre propio y en función de su rol de intelectual con un saber específico) impide trazar una posición ideológica o política bien definida; la superficie de Crítica, en este aspecto, se caracterizó por su heterogeneidad, y cierta equidistancia de las posiciones en discusión.
} 
“El martes a la noche algunas decenas de miles de personas de todo el país protestaron contra la soberbia. La mayoría no tenía ni tendrá jamás negocios en el campo (...) Pero están hartos de la soberbia (...) de los que se apuran a señalar al enemigo. Lo que se veía en las rutas no eran millonarios: era gente del campo que en la última elección había votado por Lavagna o por Cristina". (Soberbia, por Jorge Lanata, 27/03/2008) ${ }^{270}$.

Si en Página/12 el rol de los pequeños productores y el de su conducción gremial es presentado como funcional a los intereses de los grandes empresarios del campo, que los utilizan como instrumento al servicio de una causa ajena, en Crítica (como también en Clarín, según lo vimos) la actitud de los productores que protagonizaban los cortes de ruta, tanto los afiliados a la Federación Agraria como los denominados autoconvocados, es presentado como un efecto de la impericia del Gobierno:

\begin{abstract}
“El gobierno se dio cuenta tarde de que en el campo la oligarquía terrateniente y los grandes pooles de siembra no eran lo mismo que los pequeños productores”. (Error, Maximiliano Montenegro, 1/04/2008).

“Disparó un conflicto que hace 23 días no existía, que tuvo en vilo al país y dejó la sensación de que podía haberse evitado: la propuesta final que hizo a los pequeños productores es exactamente la misma que la Federación Agraria había hecho antes del paro. Y el Gobierno la desestimó por considerarla inviable". (...) "Dio lugar a un movimiento de alcance por ahora desconocido: "el campo", con muchas diferencias internas, pero un planteo de reivindicaciones 'federales contra el poder unitario que paga la chequera de la Rosada', como dijeron ayer en la Asamblea de Gualeguaychú". (Cosecha final, sin firma, 3/04/2008).
\end{abstract}

La pregunta por la uniformidad de la protesta, por su composición, por las razones la unidad, fueron tratadas de modo incidental, a diferencia de Página/12, que hizo de estos temas tópicos recurrentes en sus principales columnas de opinión y análisis. De todas formas, se pueden leer, en estos días, algunas notas en las que estas preguntas encuentras algunas respuestas:

\footnotetext{
${ }^{270}$ Como en el discurso previo de CFK, aquí la televisación de las manifestaciones se vuelve una referencia, una suerte de prueba de verdad. Para un análisis sobre las variantes de la televisación de estas protestas (Cingolani y Fernández, 2010).
} 
Las espadas mediáticas del kirchnerismo demonizaron a Buzzi, a quien acusaron de haber saltado a los brazos de una oligarquía golpista que -en el imaginario oficial- desafiaba a todo el sistema político (...) Esa oligarquía existe. Es difícil saber si es menos democrática que los socios empresarios del gobierno. Pero en su gran mayoría no eran los chacareros que cortaron las rutas"(...)". (Amigos y enemigos, por Maximiliano Montenegro, 29/03/2008)

“¿Están juntos o solo amontonados? La unidad del campo fue en gran medida mérito del gobierno nacional que no discriminó entre chicos y grandes. (...) (...) El conflicto también parió nuevos protagonistas: los productores autoconvocados y dirigentes de base. (...). (El juego a la derecha, por Reynaldo Sietecase, 3/04/2008).

No es sencillo reconocer en Crítica una línea editorial clara. Las tapas del diario funcionaron como principal discurso editorial, en sentido coherente con las notas de opinión Jorge Lanata que transcribimos más arriba. Sin embargo, esa coherencia se diluye en el tratamiento de otros columnistas. Sólo para fijar una “imagen” del lugar confuso (al menos, para el análisis) que asumió el diario podemos decir planteó una suerte de equidistancia no neutral, tal y como puede leerse en el siguiente párrafo:

\begin{abstract}
Seamos condescendientes. El gobierno de Cristina comete la mayor equivocación política de la era $\mathrm{K}$. Una medida inevitable, como la suba de retenciones en un contexto de precios internacionales por las nubes, se implementa sin conducción política, sin distinguir entre terratenientes 0 grandes pool de siembra y pequeños chacareros. Desconcertado frente al durísimo lock out del campo, el Gobierno reconoce el descuido y lo corrige. Pero mientras tanto, el oficialismo disfraza el grosero error de gestión con la retórica de una lucha contra la feroz oligarquía que amenaza al gobierno popular. (Cosquillas, Maximiliano Montenegro, 5/04/2008)
\end{abstract}

Crítica no se identificó nunca plenamente con ninguna de las partes en conflicto. No impugnó las retenciones como política de estado (como por ejemplo lo hizo La Nación) ni se identificó con las consignas del Gobierno (como, por ejemplo, lo hizo Página/12). En algunas columnas de Lanata es posible vislumbrar la voluntad de representar la voz de los sectores medios disconformes con el kirchnerismo, pero al mismo tiempo, casi de manera superpuesta, otro periodista importante del diario como Eduardo Blaustein pudo escribir: 
Sospecho -sé- que no es necesario alinearse. Pero se hace complicado, muy especialmente siendo que desde siempre tiendo a creer que cualquier salida al escenario abierto con la primera asunción $\mathrm{K}$, traumática o no, será una salida por derecha, hacia más inequidad de la que tenemos". Creo en la racionalidad de las retenciones y descreo de la voluntad, las intenciones y la habilidad del Gobierno en sofisticar sus políticas a favor de los chacareros. Creo que hay caceroleros (¿por qué unos miles deberían representar 'la gente'?) que se manifiestan con las mejores intenciones y creo que hay sectores con ganas de quebrar el progresismo que quede del actual Gobierno (...) No se trata de 'gente' sino de culturas de la fragmentación: al menos en Capital, altura Callao y Santa Fé, más de uno tiene proyectado en el cráneo una Cristina Puta y Montonera". (Cansado de llorar por Cris, Eduardo Blaustein, 29/03/2008)

\subsubsection{La gestión de colectivos como ascenso en generalidad}

En este primer apartado analizamos comparativamente cómo los diarios produjeron la gestión de colectivos desde una posición de observación que, siguiendo a Kaufmann (2010), llamamos de heteroatribución o heterocategorización. Hablamos de "posición de observación" porque en ella está imbricada la resolución discursiva de un posicionamiento institucional frente a los colectivos que protagonizan el conflicto.

Sería apropiado señalar, en sentido contrario a la idea de que el discurso mediático le dio consistencia al campo, que ese mismo discurso, a lo largo del conflicto, refrendó, día tras día, la consistencia de otros tantos colectivos igual de heterogéneos, igual de plurales, igual de contradictorios e irreductibles a la unidad impuesta por el nombre: "Argentina", "Interior", "país".

Los fragmentos que examinamos se caracterizan porque el enunciador -que nosotros identificamos con la institución mediática- habla de o hace hablar a esos colectivos como si fueran totalidades concretas. En este punto, el discurso de los medios de comunicación -y de la prensa gráfica en particularno difiere de las modalidades que otras instituciones (como por ejemplo, la 
Iglesia, o los expertos académicos) cuyos discursos participan del interjuego de certificación pública de existencia de los colectivos de los que hablan ${ }^{271}$.

En ese sentido, el ascenso en generalidad implica:

- Descripción que individualiza desde fuera por las funciones que cumple en el entorno más amplio.

- Hetero-categorización.

- Hetero-atribución

- Ratificación distante de un colectivo en $3^{\circ}$ persona (un ellos que no es un adversario)

Se trata, ahora, de indagar en lo que podría considerarse el reverso de la heteroatribución normativa. El discurso periodístico también procede por inmersión en la particularidad: en las biografías, los nombres, las fechas, las vestimentas, etc. Recuperando las historias individuales a través de las cuáles se puede hacer un pasaje a lo colectivo. La escala microscópica no anula el efecto genérico: también así se producen imágenes de lo colectivo.

\subsection{Los pequeños productores según los diarios: la representación por descenso en singularidad.}

Ya señalamos que la figura del pequeño productor se convirtió, rápidamente, en un símbolo del conflicto: fue Eduardo Buzzi quien, para refutar la idea de un conflicto movilizado por la "aristocracia del campo", dijo en una entrevista que la Resolución 125 era una "agresión sobre los pequeños y medianos productores". A partir de allí, las imágenes que llegaban desde las rutas confirmaban el diagnóstico de Buzzi: la cara visible de la protesta eran,

\footnotetext{
271 Sólo estamos señalando una equivalencia funcional genérica. No se nos escapa que para que accedan al espacio público, las instituciones necesitan de los medios (esas otras instituciones) para ganar visibilidad. Esa dependencia, y el modo de resolverla, es lo que para Marcinkowsky y Steiner, como vimos en el capítulo 1, caracteriza -en un nivel de análisis sistémico- a la mediatización.
} 
en efecto, productores que, genéricamente, podían ser reconocidos como pequeños y medianos.

Ya avanzado el conflicto, el 29 de marzo, el todavía Ministro de Economía Martín Lousteau declaró a la prensa luego de una reunión con dirigentes rurales: "Propusimos trabajar en determinar quién es el pequeño productor y cuáles son las necesidades del que siembre en las áreas marginales". Ese mismo día, José Crettaz, en el diario La Nación, explicaba las dificultades para llegar a un acuerdo sobre los reintegros: "Pero la propuesta no satisface a la Federación Agraria Argentina que insiste con la modificación del esquema de retenciones móviles y crecientes. Los reintegros son difíciles de aplicar porque no hay consenso acerca de lo que es, objetivamente, un "productor pequeño”. Días más tarde, en Página/12, Alfredo Zaiat escribía: “En estos días en los que la figura del pequeño productor ha pasado a ocupar el centro de la escena del conflicto, la definición de quienes integran esa categoría no es tan clara. Ni para los funcionarios que prometieron compensarlos ni para los propios dirigentes del sector".

La figura del pequeño productor, entonces, apareció, al mismo tiempo, como una categoría funcional, definida por propiedades socio-económicas, y como una entidad del imaginario político, es decir, cuya presencia condicionaba una definición sobre los fundamentos, el objeto, de la propia protesta. Para el Gobierno, su definición podía garantizaba o amenazaba la sustentabilidad económica de la Resolución 125, pues de la determinación de un límite en la escala de las unidades productivas dependía la cantidad de agentes que recibirían las compensaciones con las que se intentaba aminorar el conflicto $^{272}$. El "pequeño productor" se había convertido en el protagonista de las medidas de lucha, pero su definición -técnica, objetiva- parecía un problema irresoluble.

\footnotetext{
${ }^{272}$ Como explicó CFK en uno de sus discursos: "Uno, cuando ve estos números, y observa que son 84.000 los productores y que con estas medidas se contempla y se deja la misma rentabilidad, como si no hubiera existido la Resolución 125 , y que 62.500 , el 80 por ciento, de todo el sector tampoco las aceptan [las decisiones del Gobierno], uno siente que hay otros cuestionamientos, que van más allá de la medida".
} 
La existencia del "pequeño productor" podía ser una ecuación, un problema de medida, de definición de límites objetivables, para su caracterización económica; pero no lo fue, en ningún caso, para su aparición pública en las superficies mediáticas, ni para la propia identificación interna de los grupos de autoconvocados. Por eso decimos que la del "pequeño productor" se convirtió en una entidad del imaginario político del conflicto.

Los medios de comunicación, considerados en tanto estructuradores del espacio público ${ }^{273}$ tienen la capacidad de producir una operación de la cual las otras instituciones carecen: el descenso en generalidad, esto es, la producción de imágenes de lo colectivo a partir de lo singular, la promoción de lo banal a la dimensión de lo social ${ }^{274}$. Esto sería lo contrario de un acercamiento estadístico, normativo, a la composición de lo social. Cuando se estudia esta operación de manera sistemática y comparada, se accede a otra modalidad de representación política muy específica. Las particularidades consideradas ejemplares le dan consistencia a las entidades del imaginario. Como lo plantea Rosanvallón (2008: 276):

(...) Representar significa en ese caso constituir públicamente un problema a partir de un ejemplo, contar experiencias de vida en las que muchos se puedan reconocer. Es dar, de esa manera, una lenguaje articulado a lo que vive cotidianamente la gente y constituirla, por eso mismo, plenamente en su condición de ciudadanos.

La instalación de la figura del "pequeño productor" fue un hecho políticamente trascendente. Esa figura, por un lado, se definía por sus funciones económicas. Pero por el otro, operó en el plano significante rompiendo con el efecto mítico de otra figura clásica, "la oligarquía". Desde el punto de vista discursivo, la figura del "pequeño productor" fue una "introducción en el campo de la experiencia de un visible que modifica el

273 Kaufmann y Malbois (2015) hablan, como vimos en el capítulo 2, del equipamiento mediático del espacio público como condiciones de posibilidad para la aparición del público) ${ }^{274}$ La literatura y la cinematografía realizan, es verdad, operaciones similares, aunque apoyados en otra temporalidad, que no coincide con la actualidad. 
régimen de lo visible" (Rancière, 2007:126), expandida por la mediatización del conflicto. En términos de la teoría de los discursos sociales mientras la figura de la "oligarquía" funcionaba plenamente en el nivel simbólico (es decir, en un plano argumental, desencarnado) las imágenes de la televisión operaron en un nivel indicial, (que es el nivel de significación de la corporalidad, el nivel de los hechos singulares). En el choque significante, la eficacia política del segundo -al menos para orientar la mirada sobre los protagonistas del conflicto- se imponía a la del primero

En la mayoría de los casos, la operación de descenso en generalidad aparece en las crónicas de los piquetes, aunque no exclusivamente: también hay informes especiales en los que se intenta auscultar a los individuos que componen las protestas. Sin perder la dimensión narrativa y reflexiva, las crónicas se insertan en esquemas previos a través de los cuáles han intentado definir las "identidades colectivas" de los manifestantes: las descripciones, por lo tanto, se adecuan a las definiciones previas sobre los grupos que fueron delineando los propios medios.

Lo que haremos será reconstruir las diversas formas en que se opera, en el discurso periodístico, el descenso en singularidad como modo de representación de los agregados sociales.

\section{Clarín}

Clarín retrató la protesta seleccionando y presentando historias que, en conjunto, muestran el punto de vista del pequeño y mediano productor afectado por la medida, y que le otorgan a la protesta un matiz de clase media, es decir, una posición que queda lejos de los grandes productores, empresas multinacionales, pooles de siembra; aquello que, en conjunto, se puede denominar oligarquía ${ }^{275}$ pero también de los actores subalternos del

\footnotetext{
${ }^{275}$ Oligarquía, sí, pero moderna: no patricia, sino profesionalizada. Un actor remozado, bien retratado por Silvia Naishtat en una nota titulada, precisamente: "Los nuevos apellidos del
} 
sector, aquellos que viven en situación de subsistencia, los perdedores del modelo del agronegocio (que, en nuestro corpus, sólo tuvieron espacio para presentar su punto de vista en Página/12).

Podría decirse que, así como en Página/12 la figura del pequeño productor fue tratada como el instrumento de los intereses de los grandes propietarios, solapados en la legitimidad de los más chicos, en Clarín este rastreo de biografías es coherente con un punto de vista identificado con la posición de las "bases" y los “autoconvocados".

Ejemplar, en este punto, es un artículo publicado el 30/03, y se titula: Chacareros y contratistas, la nueva clase media del interior ${ }^{276}$, que a su vez

\footnotetext{
campo": "Cuando en 2004 José Alfredo Martínez de Hoz vendió la estancia familiar a Andrés Garfunkel, salió a la superficie un fenómeno iniciado varios años atrás y es el lento desplazamiento de muchos apellidos patricios del campo argentino. La estancia del ministro de la dictadura militar, establecida en 1854 cerca de Mar del Plata y admirada por un castillo estilo escocés y líneas góticas, llegó a contar 12.500 hectáreas en la zona que luego se llamó Chapadmalal. La familia Blaquier, los Rodríguez Larreta, los Menéndez Behety en el Sur conservan su peso específico. Pero hay nuevos actores que no se reconocen en la imagen tradicional y están asociados a la modernización", interpreta el investigador del Conicet Roy Hora. En ese conjunto estarían los Grobocopatel, los Elsztain y Alvarado, con empresas que manejan más de 100.000 hectáreas entre propias y alquiladas. Algunos peldaños más abajo se encuentran los pool de siembra como los de David Lacroze, Jorge Cazenave o Enrique Gobbée. Están también los industriales que vendieron sus empresas y apostaron al campo como refugio para sus inversiones. Es el caso del ex Supermercados Norte, Alberto Guil, o la familia Reyes Terrabusi. Hay otra generación que mezcla sus negocios en las privatizadas y los del sector agropecuario como Eduardo Eurnekian y Gabriel Romero, el dueño de la Hidrovía".

${ }^{276}$ La nota está firmada por Héctor Huego, empresario agropecuario y periodista, director del suplemento Rural del diario, cuya figura merece un comentario aparte. Huergo, a diferencia de los otros periodistas de Clarín cuyas notas hemos citado, es un ideólogo de la "revolución tecnológica productiva" en el agro, tanto que se adjudica haberla impulsado. En una entrevista concedida a la revista Crisis varios años después del conflicto, explicó sus diferencias con La Nación: "La Nación es más tradicional. La innovación está más representada en Clarín Rural. En la Feria nos asociamos y La Nación va ganando, porque penetró y maneja los hilos de la exposición. La diferencia es que para nosotros los actores principales de este negocio son los proveedores de tecnología. El productor es el capataz de una línea de montaje a la que concurren just in time los elementos necesarios para producir y el tipo conduce ese proceso, y cobra bien por eso. Pero la base es lo que hacen desde los Monsanto hasta los Profértil, los Vassalli y los Pauny, que son fábricas nacionales de tractores, más John Deere, más los que traen las sembradoras y los que inventaron el silo-bolsa. La clave son los agentes generadores de competitividad que todos los días está superándose. ¿Qué haría para consolidar el proceso? Ecualizar un poco más. Parte de la guita que vaya a infraestructura: hagamos rutas".
} 
forma parte de un "Informe especial” publicado en las páginas centrales del diario $^{277}$.

Se ensayan teorías para explicar la naturaleza de la protesta. La más simplista, es la que la acusa de intento de golpe de estado a la oligarquía, los terratenientes o los grupos concentrados. Seguro que si hay algún nostálgico del pasado estará ahora medrando con la situación. Al igual que a los dirigentes de la oposición, que tratan de llevar agua para su molino. A todos ellos, los del campo los miran con desconfianza. (...)

El interdiscurso polémico con un tercero excluido 278 ("se ensayan teorías"), sirve de base para hacer una presentación de estos nuevos actores. Primer movimiento, entonces: ubicar a los productores en el entramado de controversias y actores que intervienen en el conflicto. Este procedimiento, más allá de los elementos específicos de este artículo (la exaltación del emprendedorismo, el coraje de asumir riesgos, la capacitación permanente ${ }^{279}$ ), es sin embargo generalizado en todos los diarios: la descripción de los productores está guiada por el contraste o la adecuación a las caracterizaciones que de ellos han hecho el Gobierno (a través de CFK), dirigentes oficialistas, y otros medios de comunicación.

El artículo, en los pasajes que estamos glosando, realiza operaciones de heteroatribución, aunque ofreciendo detalles que muestran las fuerzas internas que le dan existencia y consistencia a este colectivo:

Esta raza de nuevos productores se caracteriza por cierta tendencia autista, acostumbrados a la soledad de la siembra en una noche de invierno (...) como en todo el mundo, su punto de partida es una raya entre dos jalones: la lluvia y los precios. (...) Pero los mueve una mística extraña en una sociedad que

\footnotetext{
${ }^{277}$ En este informe, se puede leer una nota (la única de este tipo) en la que se analiza la situación del empleo en el sector, con especial énfasis en las bajas remuneraciones y en las contrataciones irregulares, firmada por Ismael Bermúdez: "Trabajo rural, muchos en negro y mal pagos"

${ }_{278}$ García Negroni (1988: 87) indica que, en el discurso político, los adversarios pueden recibir tratamientos enunciativos diferentes, pero señala que esas variaciones (que ella identifica como destinatario implícito, destinatario encubierto, destinatario indirecto) se sostienen sobre una invariante: el adversario, dice, es siempre un tercero discursivo. Como tal, no entra en el circuito comunicativo, no se lo interpela. Se lo conjura, pero no se le da opción a réplica.

${ }^{279}$ La nota destaca que los "nuevos actores del agronegocio" se capacitaron en el exterior, desarrollaron "por prueba y error" nuevos sistemas de cultivo, como la siembra directa, y "abrazaron" la "oleada de al biotecnología por todas las ventajas que ofrecía"
} 
clama por la asistencia estatal. Estos chacareros, la nueva clase media del interior, con una ambición de crecimiento que suena 'desmedida' (...) Esta es la base económica de los chacareros modernos. Constituyen una red de 300.000 productores chicos, medianos y grandes, acompañados por sus proveedores de insumos, equipos y servicios. (...) Así brotó la figura del contratista, profesionales que constituyen la clave distintiva de la nueva agricultura argentina".

Hecha la presentación general, el informe se completa con varios recuadros que retratan historias individuales, "historias de protagonistas". Por ejemplo: “Una vaca vieja cuesta igual que un par de zapatillas de marca", retrato de Liliam Girabundo, productora santafesina:

"Liliam Gribaudo sabe bien de qué se trata cinchar a un ternero a punto de ser parido, a las dos de la mañana, mientras su marido, Enrique Bossio, mete los fórceps dentro del vientre de una vaca (...) Viven en Landeta, al centro de Santa Fe, en un establecimiento de 160 hectáreas"

O esta otra: “El piquete es desgastante”, entrevista a José Emilio Osiscka, un productor que trabaja 300 hectáreas heredadas en el Chaco. Gana entre 3000 y 4000 pesos por mes, y a quien le “da rabia que digan que esto es un piquete de la abundancia: no somos productores de la pampa húmeda. Acá, en 100 hectáreas hay hasta cuatro tipos de suelo, que no se pueden explotar sin tecnología”. Agrega el periodista:

"Actualmente, Osiska está en riesgo de sufrir un remate bancario de su campo. Lleva esa espada pendiendo sobre la cabeza desde los 80 , saltando de refinanciación en refinanciación. Por eso, dice, 'da bronca que ahora, después de las inundaciones y las sequías, de la falta de políticas adecuadas, cuando por fin tenemos una pequeña bonanza, nos quieran meter la mano en el bolsillo".

Ya avanzado el conflicto, el diario vuelve a publicar un informe, esta vez en el suplemento Zona (que se publica integrado en las páginas del diario, y no separado, como por ejemplo el Rural). Esta vez, se trata de mostrar a los productores convertidos en activistas políticos, "los coroneles de la protesta". La nota se titula: En la segunda línea del campo convive un gran mosaico político, (22/06)".

"Estos dirigentes ocupan la segunda línea de la dirigencia rural, son los "coroneles de la protesta", y actúan como correa de transmisión entre el 
pensamiento de los chacareros y el de las federaciones, que luego llevan el mandato a las discusiones con funcionarios del Gobierno.(...) Dueños de tierras, herederos de generaciones gringas, de clase media para arriba, militantes de partidos de derecha, radicales o partidarios de Elisa Carrió, conforman un abanico multicolor de ideologías e intereses ideológicos. Matices variados pero confundidos en una sola pelea: la de hacer un paro que puso en vilo a la administración Kirchner, desacostumbrada a ceder posiciones y muchos menos bajo presión. (...) Niegan ser golpistas y juran tener vocación democrática, aunque cerca de ellos también partieron propuestas de escraches a legisladores y el "cierre" del Congreso si allí no se anulaban las retenciones

Hecha la presentación general, y el contraste con los discursos que llegan desde fuera, se registran las historias individuales, recopiladas en distintos cortes de ruta en las provincias de Buenos Aires, Córdoba, Santa Fe y Entre Ríos.

Cambié las naranjas por la soja: “Militante del Partido por la Equidad y la Democracia (que lidera el intendente de Morón, Martín Sabatella) Silvio Corti fue candidato a Jefe Comunal de San Pedro, al frente de una alianza con la Coalición Cívica que sacó el $12 \%$ de los votos. Aclara que "con Carrió hay pocas coincidencias, pero apostamos a una propuesta local”.

Esta mirada por "debajo", que busca describir la protesta desde la posición de los sujetos singulares, que tienen nombre y apellido, que tienen costumbres, hábitos, se sostuvo a lo largo del conflicto. En un artículo publicado en mayo, durante la tercera etapa del conflicto, se retrata a "las mujeres del campo", aquellas que no tienen el protagonismo mediático de los dirigentes, pero que sin embargo también trabajan la tierra y movilizan los piquetes:

En los 90 fueron chacareras quienes lucharon contra los remates de tierra. Ahora están involucradas desde grandes ruralistas a pequeñas productoras. Como María Ratto, de 43 años, quien con otras cinco vecinas conforman la primera línea femenina del piquete de Pergamino. Se encargan de la comida, de armar panfletos y de poner en circulación la comunicación grupal. "Un día me sorprendí teniendo que parar camiones. Pero salió bárbaro", dijo a Clarín Ratto, de la Federación Agraria. (...) Ella es nutricionista y posee 30 hectáreas. María es monotributista y la facturación -asegura- no le alcanza ni para acceder a los beneficios del Estado (De estancieras a piqueteras: el paro del agro llevó a las mujeres a las rutas, por Natasha Niebieskikwiat, 20/05/2008).

Y unos días después, Silvia Naishtat, escribió un retrato del "nuevo sujeto político" del conflicto, el productor, que funciona como una síntesis perfecta 
del intento por caracterizar sociológicamente, por arriba, y biográficamente, por abajo, a los productores pequeños:

“La carpa tiene una heladera moderna, tevé última generación y una muy buena parrilla. ¿Son los piquetes de la abundancia, como dijo la Presidenta? Para Enrique Seminaro, ingeniero agrónomo, expresa cómo viven estos agricultores, que trabajan poco campo propio y mucho ajeno y se convierten en nómades en tiempos de siembra y cosecha (...) Con la prolongada protesta, no sólo cambiaron sus rutinas: se transformaron en nuevo sujeto político. (El agricultor que se hizo visible, por Silvia Naishtat. 1/06)

\section{La Nación}

En La Nación, las crónicas de los cortes de ruta funcionaron como prueba de que la protesta del sector no podía ser reducida a una reacción de grupos aferrados al privilegio de su renta extraordinaria. Hay un énfasis en la selección de historias individuales que muestren la heterogeneidad en el apoyo a la protesta, a través de las prácticas de los productores que mantenían activos los piquetes.

La primera nota publicada en el cuerpo del diario, buscando un contrapunto con los discursos de CFK fue publicada el 27/03, con un título más propio del suplemento Campo: La familia agropecuaria se moviliza en las rutas, firmada por Fernando Bertello. En la nota se relata la vida en un corte de ruta en Saladillo, provincia de Buenos Aires:

Josefina Balbiani no tiene nada que ver con el campo, pero ayer estaba acá, junto a Jacinta, su hija de un año. 'Soy maestra de inglés y ama de casa', expresó y aclaró: 'Estamos defendiendo nuestros derechos' Josefina repetía así un ritual que ya hizo costumbre desde hace varios días: alzar la voz en contra del último aumento de las retenciones a las exportaciones de granos. Siente que su ciudad, de uno 35.000 habitantes, tiene en el agro el pulmón que le da vida. Como ella, ayer casi 4000 personas se manifestaron espontáneamente a la altura del kilómetro 188, en la ruta 205. Como ella, había cientos de familias con sus hijos.

Acá no abundan terratenientes, sino más bien productores como Trellini [se refiere a una mujer productora con 110 hectáreas] y hasta un estrato de 
agricultores medianos temerosos por el impacto de las nuevas medidas oficiales.

Unos días después, el 30/03 (el mismo día del informe especial de Clarín, que citamos más arriba), se publica una crónica sobre el piquete de Gualeguaychú, buscando nuevamente contrastar las caracterizaciones realizadas por CFK.

No son frecuentes lectores de diarios. No tienen camionetas $4 \times 4$ como muchos de sus compañeros de protesta, políticos o empresarios. Algunos no terminaron el colegio. Varios votaron a Cristina Kirchner en octubre. Son la otra cara del "piquete de la abundancia", tal la definición presidencial que los irritó el martes pasado. (...)Hay que ver, en medio de la furia colectiva entrerriana, la mirada serena de Antonio Roberto Naef, un campesino de 65 años que llegó hasta 3er. grado de la primaria y no se parece en nada a productores del porte de Gustavo Grobocopatel. "Mire, ahí está mi máquina, amigo. Se viene abajo como el dueño", dice, y muestra su motivo de orgullo: un Rastrojero modelo 77. "(...) Naef no es analista político (explota 25 hectáreas propias en el distrito Pehuajó Sur, Gualeguaychú), pero no se rehúsa a opinar. "Este es el principio de un final. Va a caer este gobierno; el pueblo lo va a voltear. Son usureros". (Gualeguaychú, el piquete donde conviven el Rastrojero y las 4X4, por Francisco Olivera, 30/03/2008),

Al día siguiente, el diario publica una nota con entrevistas a "los nuevos militantes del cacerolazo", jóvenes estudiantes que participaron en las manifestaciones posteriores a los discursos de CFK. La nota comienza directamente por la historia de Jorge González Bergéz, estudiante de agronomía de 24 años, hijo de un productor agropecuario, quien se sumó a las protestas el 25 de marzo, luego del discurso de Cristina Fernández:

"Desde entonces, González Bergez participa de todas las movilizaciones a favor del campo. De hecho, es uno de los jóvenes que encabeza las marchas de los nuevos "ceceroleros", el grupo de manifestantes que en algunos barrios transformaron el reclamo en un deja vu de la mayor crisis de la historia argentina reciente.

"Conforman todos juntos un extraño universo. Entre los jóvenes, hay hijos de productores, espontáneos en su accionar, y universitarios de Agronomía, más politizados y con un discurso orgánico. Entre los que superan los 35 años, hay vecinos descontentos que aprovechan para hacer oír otras quejas y dirigentes opositores que se acercan para seducir a cualquiera". ("No somos golpistas" dicen los nuevos militantes del cacerolazo, por Juan Pablo Morales y Agustín Cronenbold, 31/03/2008)

Las movilizaciones y actos fueron un momento propicio para reforzar la caracterización de la heterogeneidad de la protesta. Luego del acto en 
Rosario, en una nota titulada Masivo respaldo al agro en Rosario, José Crettaz escribió.

“Ni en los más absurdos delirios de los últimos 75 días de protestas y negociaciones los ruralistas esperaban convocar a tanta gente. Una masa heterogénea reunió a vecinos de Rosario, chacareros de distintos tamaños procedentes de todo el país (pero sobre todo de la Pampa Gringa: Buenos Aires, Santa Fe, Entre Ríos y Córdoba), jóvenes de la Federación Agraria que pedían 'reforma agraria ya', grandes producotres con camperones de gamuza enrolados en algunas de las cientos de sociedades rurales del país, los piqueteros Raúl Castells y Juan Carlos Alderete

La cobertura del acto se completa con una serie de entrevistas publicadas en recuadros a diferentes asistentes. Transcribimos una como ejemplo:

"Soberbia, eso sobra": Ignacio Grondona y su esposa Cecilia, que viven de la producción agropecuaria y la exportación de carne, son jóvenes y no ocultan para nada su enojo. "Estoy acá porque no estoy de acuerdo con la política agropecuaria oficial, entre otras cosas malas que tiene este Gobierno", arranca Ignacio, barba candado y boina, con tono franco y mirada serena. Su esposa, rubia y vestida de sport, comparte sus sueños de cambio, aunque ambos son muy críticos de la coyuntura. "No nos gustan las formas de la Presidenta. No estamos hablando de un porcentaje de retenciones, sino de un modo de gobernar. Soberbia, necedad, eso sobra", interrumpe Cecilia sin soltar la bandera argentina.

Así como en Clarín, La Nación publicó muchas notas con estas historias de productores afectados por las políticas del Gobierno, pero también con voces de empresarios, presidentes de asociaciones del sector, pero lo hizo principalmente en sus suplementos específicos (Rural, en Clarín; Campo, en La Nación). Estos suplementos oficiaron como espacios en los que "el sector" pudo expresarse, y dar las discusiones más álgidas y explícitas. La diferencia entre ambos es su relación con la línea editorial de los respectivos diarios. Comparado con las posiciones expresadas en los editoriales y en las columnas de análisis y opinión, el suplemento Rural de Clarín es un panfleto, que asume plenamente la reacción de la dirigencia agraria como propia, y donde se delinea una épica de la protesta ${ }^{280}$. El suplemento Campo de La Nación, en cambio, es una continuidad reforzada del posicionamiento del diario.

\footnotetext{
${ }^{280}$ Para que se entienda la diferencia, jamás en las páginas del cuerpo del diario, apareció una toma de posición como esta que transcribimos, en la que se muestra un grado máximo de politicidad, en el sentido de identificación de un "nosotros" que incluye al propio
} 


\section{Página/12}

Por la misma razón que, para La Nación, la presencia de pequeños productores legitimaba la protesta (por cuanto probaba que no se trataba de una reacción destemplada de un sector privilegiado) para Página/12 la confluencia de la Federación Agraria junto a la Sociedad Rural evidenciaba la "falsa conciencia" de los productores más chicos, quienes ("mano de obra de la derecha oligárquica”, escribió Pasquini Durán) objetivamente terminaban defendiendo y consolidando el modelo contra el cual decían luchar.

El acercamiento a las experiencias de los productores en los cortes de ruta, como en las demás notas que estamos analizando, se efectúa como en dos movimientos: una descripción general de la composición del corte y luego una selección de testimonios. La diferencia -previsible- es que los cronistas de Página/12 no son condescendientes con los sujetos que retratan: un distanciamiento que evita dotar de épica, ni de justos motivos, a sus retratados.

La primera nota de este tipo fue publicada antes de los primeros discursos de CFK. El cronista empieza exponiendo es un efecto de contraste entre la intensidad del corte y la situación de una ciudad muy próspera:

\footnotetext{
Pergamino no es todo el campo argentino. Está ubicado en plena pampa húmeda, en una de las regiones más productivas del planeta para la actividad rural. Sin embargo, la protesta de sus agricultores es igual de ruidosa que en otros puntos del país. Entre la bronca del piquete y las imágenes de la ciudad surge una brecha. (Crónica del piquete en Pergamino, por David Cufré, 23/03/2008).
}

suplemento: "Durante los últimos diecisiete años, Clarín Rural, se dedicó a relatar la Segunda Revolución de las Pampas (así la bautizamos nosotros) que nos explotaba en los teclados. A decir verdad, nosotros no 'solo la relatamos. Fuimos protagonistas, porque estas páginas se poblaron de ideas (propias y ajenas) que contribuyeron a la epopeya (...). De la siembra directa, del rastrojo, de la materia orgánica, el fósforo puesto al costado, debajo de la semilla". Al gran yuyo argentino, salud!, por Héctor Huego, 5/05/2008. Los subrayados en negrita fueron agregados por nosotros. 
Luego, realiza una descripción del corte de ruta:

No se ven en el piquete grandes terratenientes. La gente que está allí podría ser perfectamente la que en diciembre de 2001 encabezó el cacerolazo en cualquier barrio de clase media porteño. Las decisiones se toman en asamblea, reina un ambiente de cooperación y existe una convicción inquebrantable contra cualquier argumento de que el reclamo es justo. Uno de los referentes es Jorge Solmi, director nacional de Federación Agraria. (...) Pero no menos de la mitad de los presentes son autoconvocados

Y finalmente, la presentación de algunas de las personas que participan de las medidas de lucha:

El último jueves, en el piquete de Pergamino había básicamente productores de entre 40 y 300 hectáreas. Explotaciones pequeñas que a Teresa Caldentein, por ejemplo, dueña de 60 hectáreas junto a su esposo y sus dos hijos adolescentes, y de otras 70 hectáreas en sociedad con sus tres hermanos, le alcanzan para vivir en Pergamino como una familia de clase media. "Por qué no puedo progresar, por qué no me puedo comprar una $4 \times 4$ ", arremete. El día anterior Teresa pasó por una de las seis concesionarias de la ciudad para pagar cash su propia camioneta. "Vendimos una antigua propiedad de mi familia y gastamos todos los ahorros de años", detalla. Teresa, que además es empleada estatal, cuenta que su esposo se mueve en un Volkswagen Gol 2006 y en su casa tiene banda ancha y aire acondicionado

Otras crónicas mostraron la faceta más revulsiva de los activistas, recortando la mirada sobre las expresiones violentas y homofóbicas, de los "neopiqueteros rurales", que no tienen contemplación ni se detienen en giros diplomáticos: "Kretina resentida, patotera y con sus mercenarios pagos", cita el cronista a uno de sus entrevistados ${ }^{281}$.

\begin{abstract}
“¡No se dejen gobernar por esa puta, por esa guerrillera puta!", dice y aplaude al corte la mujer mayor, nada sutil, cabello batido que esquiva unas gomas en el medio de la ruta 9 desde un Toyota Corolla cremita último modelo. La mujer aplaude y recibe los gestos de la hombría que acaba de cortar ambas manos de la autopista del sur que une Buenos Aires con Rosario. Es sábado a las 9 de la mañana, y el corte que acaba de apropincuarse fue pergeñado minutos antes desde Piñero, en el cruce de la ruta A012, y la provincial 14. Página/12 está presente en el momento en el que siete u ocho camionetas último modelo y un rastrojero diésel recorren los veinte kilómetros que hay entre el cruce y la 9. (Crónica de un día cortado, sin firma, 15/06/2008)
\end{abstract}

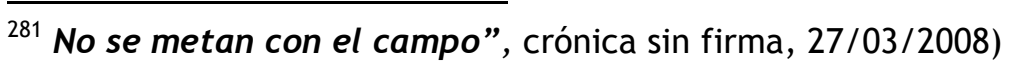


Un rasgo característico de Página/ 12 (sólo compartido por Crítica, aunque de manera menos sistemática, más intermitente), es que realizó estas operaciones de descenso en generalidad, pero aplicadas a las manifestaciones en apoyo del Gobierno. Estas crónicas buscan contrarrestar los estereotipos que los "grandes medios" proyectan sobre los manifestantes de los actos oficialistas, alimentando la oposición entre los piquetes rurales (espontáneos, autoconvocados) y los actos oficiales (organizados por el aparato del PJ, repletos de personas movilizadas como contraprestación de un plan social). Son varias crónicas que giran sobre esta controversia; glosamos una que es paradigmática:

\begin{abstract}
"Señores del campo: Vinimos a la plaza y no nos pagó nadie", decía un cartel casero, de cartón, que llevaba un hombre con el uniforme del SAME, con su esposa y sus dos hijos. La frase traslucía el sentimiento de ofensa por uno de los argumentos que usaron los caceroleros que apoyaron el lockout de los productores agropecuarios y que fue tomado por muchos medios de comunicación y una parte de la izquierda. Para esos caceroleros, solamente ellos son ciudadanos manifestantes conscientes y civilizados, en tanto los que se les oponen serían todos "acarreados", "matones", o "ejércitos civiles" a sueldo del Gobierno -como dijeron algunos dirigentes de la Federación Agraria en los cortes-, ladrones y narcotraficantes. El hombre del cartelito no estaba en ninguna columna y se paseó por toda la concentración para que lo leyera todo el mundo. Era una forma espontánea de dignificar su decisión de ir al acto. (Contraluces del contracorte, por Luis Bruchstein, 2/04/2008)
\end{abstract}

Podríamos concluir que, así como La Nación y Clarín fueron señalados por ejercer la vocería no oficial del sector agropecuario, Páginal 12 asumió entonces la responsabilidad política de hablar en nombre de los otros, vituperados, ignorados por los medios. Las propias notas del diario, que sin dudas tematizó el apoyo mediático a los ruralistas como un fenómeno con real incidencia en el devenir del conflicto, facilitan y alientan esa lectura. Inclusive, la declaración de Luciano Miguens citada al inicio del capítulo también confirma esta percepción: los medios, decía el titular de la SRA, nos tratan muy bien. Página asumió una tarea (política) de representación como reacción defensiva frente a una actitud especular (es decir, igual, pero invertida). 


\section{Crítica de la Argentina}

Crítica fue, de los diarios que estamos estudiando, el que más rápidamente retrató a los productores que protagonizaban los cortes de ruta. El 20 de marzo, publicó una crónica que narra la cotidianidad de un corte que refleja como "el reclamo de las bases desbordó y arrasó a la dirigencia".

“Alberto Otero se despertó a las cinco de la mañana del séptimo día del paro del campo. Tomó unos mates y cuando salió de su casa todavía estaba oscuro. (...)Alberto es un productor agropecuario de camisa color maíz, canas y mocasines, padre de dos hijas. (...) A las nueve de la mañana empezaron a llegar al cruce entre las rutas 9 y 121 camionetas con doble cabina, chatas, autos, y tractores con calcomanías: No a las retenciones (...) Ganaderos, productores de cereales, fruta, miel, chicos, esposas, madres, campesinas, acopiadores. Parecía que no faltaba nadie en la ruta 9. ( Los militantes de tierra adentro, por Maru Ludueña.)

A fines de marzo el diario publicó otra nota, "La red de 'gringos' autoconvocados", firmada por Mauro Federico. La nota es más ambiciosa que la anterior, y que muchas de las otras crónicas que estamos analizando, porque no busca mostrar una situación puntual, sino caracterizar un fenómeno nuevo:

“'El campo somos todos'. Esa es la consigna. Ellos la siguen. Los productores agropecuarios independientes tienen termómetro propio. Se llaman, se encuentran, se organizan y salen a las rutas. Son muchos los que no tienen entidad de base. Se autodenominan 'gringos' y están enojados”.

"En zonas como Junín, Vedia, Villegas, Venado Tuerto, Chacabuco, los productores formaron una organización poderosa que se autogestiona y se autoconvoca a través de su red de teléfonos celulares (...) Los gringos se turnan. Mientras algunos permanecen en las rutas y ocupan las casillas que montaron delante y detrás del corte, otros trabajan en los campos".

Como vimos en los casos anteriores, luego de la caracterización general, se retratan los casos ejemplares, representativos: 
"Con 52 años y dos hijos ingenieros agrónomos, Jorge Auzmendi es uno de los referentes del movimiento: 'Acá estamos todo el día, en dos turnos, de 8 a 20 y de 20 a 8', explicó el integrante de la Sociedad Rural local ${ }^{282}$.

El acercamiento en términos de descenso en generalidad que se puede leer en las crónicas del diario permite trazar una línea coherente con el posicionamiento que describimos en el primer apartado del capítulo. Sin condescendencia, ni buscando exaltar el emprendedorismo del movimiento agrario, pero tampoco retratar deliberadamente las expresiones más reaccionarias de los "piqueteros rurales":

\begin{abstract}
“'No somos gorilas ni golpistas ni buscamos un nuevo 20 de diciembre', bramó el jefe de la FAA (...) Buzzi fue recibido por una ovación que él mismo se encargó de acallar cuando saludó con un 'compañeros y compañeras', y que luego con una sonrisa reemplazó por 'chacareros y chacareras'. El auditorio era heterogéneo: chacareros con bombachas de gaucho y mujeres que habían ido al corte luciendo carteras vistosas y a sus cachorros Yorkshire. Un look distinto del que tenían los ruralistas de Alcorta del siglo pasado". (...) “En la asamblea había productores de Buenos Aires, La Pampa, Córdoba, Santa Fé y Chaco, entre otras provincias. También se mezclaban e intercambiaban impresiones sojeros, lecheros y chancheros". (Lo bautizaron el segundo Grito de Alcorta, Mariano Martín. 31/03/2008)
\end{abstract}

Como lo apuntamos respecto de Página/12, en Crítica también hubo espacio para la inversión de la controversia, ya no sobre la identidad de los piqueteros rurales, sino de los asistentes a los actos oficiales. Cada vez que hubo una manifestación en Capital Federal, la cobertura del diario buscó cubrir el espectro de las posiciones:

No parece que el acting -el entusiasmo que le están poniendo los morochos al canto y a los bombos- esté tarifado en el financiamiento presunto de este centenar largo de integrantes de la CTA que se vinieron desde Jujuy (...) Son cien militantes de una organización barrial, la Tupac Amarú, agitando pancartas con el Che, fogosos, mucho redoblante y nadie que lleve la batuta (...) "No encuentro, por ahora, -y la plaza se va apretando- al aparato, encuentro fragmentos. Hay grupos de pibes del Partido de la Victoria, camisetas azules. En una plaza en la que predomina -predomina, no hegemoniza- la piel oscura o la de clase media que sufrió el descenso, estos pibes son carapálidas. Me acerco a Juan Pablo, entreriano de Villaguay. Conoce de cerca el asunto de los pequeños y medianos y me dice que sí, el

\footnotetext{
${ }^{282}$ La nota se completa con un recuadro titulado: "Qué buscan y qué defienden", en el que se lee que Oscar Moncho, un productor de la zona de Carmen de Areco dice: "Nosotros ya no peleamos por las retenciones. Nuestra lucha es por un modelo de país".
} 
Gobierno la pifió en no diferenciar discursos...". (No solo de aparato vive la plaza, por Eduardo Blaustein, 02/04/2008). ${ }^{283}$

Ahí, entre los pliegues que se forman al costado de los sindicatos, de las organizaciones sociales, en fin, del aparato duro de la movilización, hay solos y solas que vienen un poco porque sí. Si hubiera que ponerles un nombre serían 'autoconvocados', pero habría que ver si esas etiquetas explican algo (...). Paula Hoffman, 31 años, gerente de gestión comercial del Banco Nación; Diego Caeiro, empleado en un local de ropa; Marcelo Sunthein, secretario general de la Comunidad de Homosexuales Argentina; Carlos Prado, empleado de una compañía de seguros; Adriana, que vino con sus hijos adolescentes porque esto le hace acordar a su militancia de joven en una unidad básica. $Y$ el autor remata: "Y todos están ahí, en los márgenes de la movilización, sin cámaras, sin necesidad aparente de tenerlas". Solos y solas, por Alejandro Seselovsky.

La singularidad de la voz del cronista, la retoma irónica de los lugares comunes y prejuiciosos (el tarifado presunto del acompañamiento popular, la reducción de la movilización al "aparato") es una marca de la heterogeneidad enunciativa del propio diario, que más allá de las tapas y de las columnas de opinión de su director, nunca asume plenamente una posición definida.

\subsubsection{Las instituciones mediáticas: la representación como política de la presencia y el individuo como socius}

En este segundo apartado buscamos mostrar una modalidad de representación extendida en la prensa gráfica, en un sentido genérico y ampliado. Denominamos a esa modalidad de descenso en generalidad: el discurso del periodismo -usualmente, a través de textos inscriptos en el género de la

\footnotetext{
${ }^{283} \mathrm{El}$ uso de la primera persona en este texto no es excepcional. En Crítica, muchos de los columnistas y periodistas (Martín Caparrós, Reynaldo Sietecase, Miguel Bonasso, el propio Jorge Lanata) escriben desde la primera persona. Más allá de eso, en este caso puntual, también revela una preocupación personal de Blaustein por discutir las estereotipaciones. En su libro Años de rabia (2013:264), cuenta cómo vivió el conflicto siendo periodista del diario: "Esa libertad la disfruté particularmente durante el "conflicto del campo", que Lanata (...) convirtió en una especie de fiesta o circo, de festival carnavalesco con vacas en tapa, abusando de la expresión "la guerra gaucha" y bajando verticalmente una orden imperativa: acá no se escribe "lock-out" patronal, sino "paro del campo". Pese a las buenas coberturas de Rodolfo González Arzac sobre el conflicto, la línea editorial -desde las portadas- se sobreimprimía ese tono de fiesta campera, pura joda, una mirada plenamente antigubernamental del conflicto, no muy lejana de la mirada Clarín/TN".
} 
crónica, aunque no solamente- hila casos individuales considerados ejemplares representativos de un colectivo. Si bien consideramos que se trata de una operación discursiva extendida, que no se circunscribe a nuestro problema de estudio, en este caso ofrece una prueba más de cómo se desarrolla el litigio político.

Puede que la operatoria que hemos descripto no sea compleja, aunque sí reveladora: en todos los casos, la caracterización de la identidad de los protagonistas tiene como referencia interdiscursiva otras caracterizaciones (discursos sin autor original, pero que circulan en las superficies mediáticas como lugares comunes, estereotipos, prejuicios), y, en la mayoría de los casos, otra caracterización: la que hiciera CFK en sus primeros discursos, identificando a los piquetes rurales como "piquetes de la abundancia", y subrayando el lugar privilegiado que los sectores levantiscos ocupaban en la estructura económica.

El hecho de que los cuatro diarios hayan realizado esta inmersión en la particularidad para caracterizar formas de comportamiento colectivo, para describir la composición de la protesta, para definir la identidad de los grupos de productores, permite avanzar en la hipótesis de que estamos frente a un modo de proceder anclado en lógicas institucionales: una de las maneras en que los medios participan en la construcción de lo social -que no puede ser sino produciendo imágenes de identidades colectivas- es conectando, sin ningún método de control de generalización estadístico, lo singular y lo general. Desde ya, la comparación muestra, también, la arbitrariedad de la selección de casos, que no puede ser sino indicador de la toma de posición del medio frente al conflicto y a los actores en conflicto. Más allá de esta obviedad, lo importante es que los medios, como instituciones, pueden proceder de esta manera, pues sólo en ellos una operación de esta característica se inserta en el espacio público, se objetiva, se consagra. Por eso no alcanza con apuntar al contenido polémico (en términos retóricos): las 
controversias actualizan -o directamente: producen- al espacio público, pero sólo sobre la base de un equipamiento mediático.

Rosanvallon señala que el descenso en generalidad forma parte de una política de la presencia. El concepto de "política de la presencia" (Rosanvallon, 2009: 269-277) indica un modo diferente, por parte del discurso político, de construir su propia legitimidad construyendo una generalidad como "inmersión radical en lo concreto del mundo", en el "reconocimiento de que cada situación conlleva un elemento de originalidad irreductible" pero que puede funcionar como superficie de identificación. La política de la presencia pone de manifiesto "el hecho de que la relación de identidad entre los ciudadanos y los gobernantes ya no puede seguir siendo pensada en términos sociológicos". Así, por ejemplo, el candidato (o el líder electo) menciona que el día anterior conoció a "Marta" -un individuo singular, único, pero que al mismo tiempo, es igual a otros. Los medios practicaron, antes que las organizaciones políticas, esa "política de la presencia", esa representación por descenso en generalidad. Como escribió el propio Rosanvallon (2009: 288): "Los medios son, por naturaleza, los instituyentes funcionales de la proximidad. Pero también constituyen el mecanismo de su desvío cuando se erigen en absolutos." Explica que si bien la presencia tiene ante todo un sentido directamente carnal, contribuye asimismo a producir identidad colectiva de nuevo modo. La generalidad, en estos casos, está construida por un campo de atención, por una preocupación de proximidad (Rosanvallon, 2008: 267)

El hecho de que una experiencia o una situación particular se extraigan del olvido y del anonimato puede dar forma a la comunidad virtual de todos aquellos que viven experiencias similares. Agreguemos que, en los casos que estamos estudiando, cada uno de los individuos retratados no valen como singularidades, sino en tanto aquello que Ricoeur (2000: 91) llama socius: "aquel a quien llego a través de su función social". Cada uno de los productores citados, interesan como individuos sociales, como miembros de 
una categoría. En términos semióticos, como símbolo: están en lugar de sus congéneres, los representan. La operación de descenso en generalidad, en términos de la teoría de los discursos sociales, es el pasaje del índice -de lo singular irreductible: del individuo en tanto tal- al símbolo -a la generalidad, a la ley: al individuo como caso, como ejemplo. Por otra parte, cada historia adquiere valor en función del conflicto: lo que interesa es el enlace entre una vida privada y un asunto público.

\section{Reflexiones finales y pasaje al próximo capítulo.}

En este capítulo partimos de una hipótesis contra-intuitiva: planteamos que los diarios que estamos estudiando intervinieron en el conflicto desde una posición de observación externa. Dado que para la mayoría de los analistas que trabajaron sobre estos mismos textos, con más o menos prolijidad y método, la principal característica de la cobertura mediática del conflicto del campo fue el involucramiento faccioso de los medios, nuestra hipótesis puede pasar por ingenua o innecesariamente benevolente con estos actores cuya razón de ser habría sido reorientar deliberadamente las percepciones sociales en función de intereses particulares, subyacentes, ocultos.

Sin embargo, creemos que el planteo no es incompatible con un posicionamiento crítico, axiológico, sobre el desempeño de los medios. No, al menos, si se trata de evaluarlos como "actores políticos". Que se entienda: un medio, el que sea, puede operar a favor del gobierno, puede presionar a un juez, puede ofrecerse como plataforma para la visibilidad de un partido opositor, puede cuestionar acciones de los sindicatos, o puede, como empresa, formar parte de una cámara empresaria, desde la cual operar en función de sus intereses particulares. Puede y así, de hecho, sucede. Pero al menos los medios que conocemos como medios de masas, y en particular, los periódicos independientes de interés general, funcionan como entidades diferenciadas no porque sus intereses y simpatías no se superpongan o se 
enlacen estratégicamente con las de otros actores -dominantes o subalternossino porque, en tanto instituciones, los medios hablan como si fueran Otros. Esa otredad es la que define su ubicación diferencial en la trama de relaciones institucionales del espacio público

Nuestra intención no fue avanzar a partir de aquella caracterización (los diarios como actores políticos), sino indagar en los condicionamientos institucionales que el espacio público, por una parte, y la propia dinámica de competencia y funcionamiento del sistema mediático, la impone a los medios (prensa gráfica de interés general, en este caso), particularmente cuando se trata de presentar públicamente un conflicto que involucra a colectivos cuyo estatus como entidades del imaginario político es, también, un objeto controversial, litigioso.

En cualquier caso, la posición de enunciación que estamos identificando es históricamente contingente y relativa: una estrategia de vida civil para cierto tipo de medios de comunicación, como son los diarios de interés general. La primera característica de esta posición de observación es la restricción (enunciativa) para incorporarse en un colectivo de identificación: un nosotros. Esto tiene un correlato trascendente que limita las posibilidades de caracterización, sin más, del discurso periodístico con el discurso político, ya que aunque crítica u opositora, la palabra periodística (al menos, en el contexto en el que la estamos estudiando) construye un "ellos", pero al no estar sostenido por un nosotros, no se trata necesariamente -o mejor, no está construido como- un adversario. Ese "ellos" no es un colectivo frente al cual se establece una frontera identitaria.

Es posible identificar esta posición de observador externo como derivado enunciativo de algunos reguladores deontológicos típicos del periodismo profesional (objetividad, neutralidad), en tanto posición de observación no debe confundirse como una toma de posición. De allí que se lo puede hallar 
por igual en discursos de medios ideológicamente enfrentados u opuestos ${ }^{284} \mathrm{o}$ en artículos firmados por periodistas sobre cuya ideología no es necesario especular:

Ya resulta por demás extraño el lockout más violento de la historia del país que se acerca a cumplir 100 días. Un grupo de empresarios del campo, de las zonas más privilegiadas y ricas de la actividad agropecuaria, protestan por la suba de las retenciones como si estuvieran al borde de la quiebra. No es así. El Gobierno presenta el conflicto como si sólo una parte no tuviera vocación de diálogo. No es así.(...) A esta altura, los integrantes de la Mesa de Enlace de las cuatro entidades del campo que impulsaron, avalaron y profundizaron semejante desorden social dicen que ellos no son responsables de este caos y que lo hacen por la patria. No es así. (No es así, Alfredo Zaiat, 13/06/2008)

El observador externo se mueve usualmente en una escena marcada por dos colectivos o sujetos ("el Gobierno"/"los reclamantes"; "el Gobierno"/"los ruralistas"), identificados por la tercera persona del plural o del singular, un "ellos" que no puede remitirse fácilmente al módulo bipolar típico del discurso político ya que no hay un "nosotros" que lo sostenga. Por lo cual, no puede asociarse sin más a los destinatarios del discurso político: no se trata de para-destinatarios, ni de pro destinatarios, ni de contra-destinatarios. Precisamente, es esa ausencia explícita de un "nosotros" lo que define la "exterioridad" desde la cual se construye el enunciador.

En otros términos: si se concibe al esquema de pronominalización no el nivel de las marcas lingüísticas sino como esquema (abstracto) de roles (Landowski, 1985), veremos que están sobredeterminados por el tipo de dispositivo comunicacional (en el sentido en que lo define Charaudeau ${ }^{285}$ ). De ahí que

\footnotetext{
284 “El gobierno y los productores del campo decidieron tensar al máximo la soga. La apuesta es quién se quiebra primero. A ese punto crítico se ha llegado, con todas las consecuencias económicas y políticas que arrastra un conflicto de esta virulencia" ( “Una guerra a todo o nada?, Ricardo Kirchbaum, Clarín, 26/03/08). O bien: "El Gobierno, desde el vamos, no fue hábil para espigar entre los reclamantes. Soportó, en algún sentido alentó, que se unieran en la protesta. Ayer sucedió que recibieron apoyos ajenos a la lógica corporativa." ("Una giornata particolare", Mario Wainfeld, Página/12, 26/03/08).

${ }^{285} \mathrm{El}$ autor francés define al espacio comunicacional, caracterizado por un dispositivo que implica restricciones a priori sobre la identidad de los participantes, sus roles, su estatus y las relaciones que establecen entre ellos
} 
podamos identificar un "ellos" en estos discursos, pero sin que ese lugar quede definido por un antagonismo: ese “ellos”, conceptualmente, no señala un colectivo frente al cual se establece una frontera identitaria. Igualmente, no se registra una escenificación explícita de la interacción con el destinatario, sea este el "lector”, el “público", etc. Se trata, nuevamente, de figuras que regulan como "desde fuera" la enunciación, que operan como hipótesis de destinación ${ }^{286}$, pero que no emergen explícitamente en el discurso. En este sentido es que podemos vincularlo con la noción de Tercero Discursivo según la propone García Negroni (1987: 87) para designar a los destinatarios que no entran en el circuito comunicativo, a quienes no se les da voz ni derecho a réplica: no hay, en la superficie discursiva, interpelación en $2^{\circ}$ persona ni inclusión en un colectivo de identificación.

Es esta posición de observación -que, repetimos, no debe confundirse con las simpatías o antipatías, y los consecuentes tratamientos sesgados- de la que deriva un modo de posicionarse frente a los colectivos identificados como protagonistas de las disputas ${ }^{287}$.

Los colectivos son tratados, en algunos casos, como totalidades a las que se le asignan propiedades (capacidad volitiva, deseos, intenciones, etc). Es una perspectiva externalista que no permite distinguir los grupos que pueden ser legítimamente considerados como un "sitio" de autoridad y de responsabilidad y los ensambles arbitrarios de individuos que son

\footnotetext{
${ }^{286}$ La idea de "hipótesis de destinación" es ambigua pero la consideramos necesaria. Es ambigua porque, en el marco de una teoría que prescinde del estudio de la perspectiva del actor, y que no considera a la "intención" como una variable explicativa, esta noción puede prestarse a confusión; finalmente, ¿quién elabora esa hipótesis y actúa en consecuencia? Sin embargo, lo que pretendemos definir no es una estrategia subjetiva, sino las condiciones que modelan la producción de un discurso, y más específicamente, de un discurso que circula en el espacio público bajo condiciones de mediatización.

287 "El sector agroexportador es un claro beneficiario de ese dólar alto cuyo coste comparte con toda la sociedad. También es cierto que el campo cuenta con gasoil por debajo del precio internacional". (Clarín, Socios de la recuperación, peleados en el momento de mayor abundancia, por Daniel Fernández Canedo, 25/03). "El sector agropecuario siempre se consideró el único forjador del país debido a que los hombres que dominaron la actividad en el siglo XIX, con métodos y desprecio humanitario de espanto, fueron los que constituyeron las bases para el Estado moderno". (Forjadores de la patria, por A. Zaiat, Página/12, 29/03/2008)
} 
abusivamente tratados como homogéneos. Pero que, de todas formas, resulta una instancia necesaria para su reconocimiento. En este sentido, como lo plantea Kaufmann:

L]a existencia de un colectivo depende fundamentalmente de su reconocimiento -un reconocimiento que es menos una cuestión moral que una cuestión lógica u ontológica. Para existir en tanto que colectivo, un nosotros debe ser reconocido como un ellos o un de ellos homogéneo por las instancias externas que le proveen de una identidad, lo dotan de un pasado y de un futuro, o sea, lo aprehenden como un individuo colectivo. Es en el juego público de discursos, de las visibilidades y las atribuciones recíprocas que "los colectivos-en lo sucesivo-entre ellos" conquistan la "manifestación” necesaria a su existencia. La unidad de un colectivo depende de sus "cara-a-cara" exteriores, que le proveen la certificación pública de su existencia y que, al hacerlo, le permiten constituir un colectivo en primera persona, es decir, un nosotros". (Kaufmann, 2010) $)^{288}$

El discurso del periodismo está ceñido por las restricciones institucionales que, en el caso de la prensa gráfica, le "impide” (por convención histórica) situarse en un "nosotros" inclusivo, incorporarse en un colectivo de identificación singular, una identidad política asumida por otros actores colectivos implicados directamente en un conflicto. Entonces, la lógica del dispositivo de enunciación si bien puede anclarse en el juego de pronombres no implica la inserción en un campo de lucha: el del periodismo de interés general -y esto hay que computarlo como variable de sus condiciones sociales productivas- es un discurso que no puede construir un adversario sin violentar sus propias lógicas comunicativas. Para funcionar bajo una lógica adversativa deben transformarse, en principio, alguna o ambas de las dos dimensiones según las que cabe caracterizar un tipo discursivo: o bien se modifican, en algún nivel, las estructuras institucionales que son sus soportes organizacionales, 0 bien se transforman, en cierto nivel, las demandas/expectativas cristalizadas asociadas a esas estructuras institucionales.

\footnotetext{
288 Conviene no confundir es rol de "instancias externas" que los medios juegan en el reconocimiento de los colectivos con el discurso -ideológico- de los propios medios sobre la "neutralidad", la "independencia" y la "objetividad", y que suelen usarse como carta de ciudadanía política, de legitimación.
} 
Esto permitiría avanzar en una hipótesis: si lo que estamos diciendo es acertado, cuando el discurso periodístico (sea que quede a cargo del El o del EP) se incluye en un "nosotros", está ingresando en el campo discursivo de lo político. O sea, el discurso periodístico se "politiza" (en este preciso sentido: adquiere propiedades del discurso político) cuando construye un adversario, $o$ lo que es su reverso necesario, cuando se incluye en un colectivo de identidad; es decir, cuando modifica las presuposiciones estructurales que regulan su enunciación, cuando desdobla la destinación. Esto no debe confundirse con la polémica: la polémica -como función retórica- no siempre construye un adversario en términos políticos; y si bien es una operación típica del intercambio discursivo en espacios políticos no es una propiedad exclusiva del “discurso político" (Dascal, 2010) ${ }^{289}$.

Precisamente, en el próximo capítulo podremos analizar situaciones -quizá excepcionales, aunque no por eso menos significativas- en las que el discurso del periodismo "pisa" el umbral de la politicidad, asumiéndose como parte de un colectivo de identidad, aunque no necesariamente un colectivo partidario o de facción. Situaciones en las que -ahora sí, no por excepción ni casualidadse trata de hablar de y de hablarle a esa entidad que, todavía, ordena el horizonte de destinación del periodismo llamado nacional: el país, la nación, la Argentina.

\footnotetext{
${ }^{289}$ Sostiene Dascal (2010): “¿Es realmente necesario convencer a alguien de que el discurso polémico ocupa un lugar central en nuestras vidas públicas y privadas? Creo que no. Donde miremos, estamos inmersos en un polemizar sin fin: desde las discusiones domésticas cotidianas, hasta las disputas sobre los espacios para estacionar o los espacios de oficina; desde los disensos políticos hasta los conflictos laborales y las decisiones políticas; desde leves desacuerdos hasta disputas amargas; desde la crítica de libros hasta los debates en el congreso y las controversias científicas; en materia de gustos literarios, en los lugares de trabajo, en los parlamentos, en nuestros hogares". Traducción nuestra.
} 


\title{
CAPÍTULO 7
}

\author{
LA DISPUTA POR LA \\ REPRESENTACIÓN, ENTRE \\ LOS PÚBLICOS POLÍTICOS Y \\ LOS PÚBLICOS MEDIÁTICOS.
}




\section{CAPÍTULO 7}

\section{LA DISPUTA POR LA REPRESENTACIÓN, ENTRE LOS PÚBLICOS POLÍTICOS Y LOS PÚBLICOS MEDIÁTICOS.}

Introducción: entre la disputa por el relato y la disputa por la representación

En las discusiones entre el Gobierno de Cristina Kirchner y los medios de comunicación más importantes durante el conflicto del campo (e incluso, en ciertas controversias entre los propios diarios) pueden distinguirse dos tópicos polémicos que remiten a la conformación histórica de las instituciones de medios y a la profesionalización del periodismo. Por una parte, una disputa que podemos denominar "por la agenda” y que, al menos desde fines de 2007, CFK nombró con el posteriormente célebre concepto de "relato". Por el otro, una disputa que podemos denominar “por la representación” y que, desde nuestro punto de vista, se expresa como una competencia por la legitimidad en la toma pública de la palabra para hablar en nombre de otros actores colectivos.

Estas controversias se expresaron predominantemente por dos vías. Por una parte, a medida que el gobierno, y CFK en particular, fue definiendo públicamente su decisión de avanzar en políticas activas para regular el sistema de medios, los principales diarios opositores (Clarín, La Nación) reaccionaron echando mano al habitual recurso de denunciar un ataque a la libertad de prensa ${ }^{290}$. En segundo lugar, en esa reacción de defensa, los diarios y sus periodistas más conspicuos debieron desplegar una serie de auto-

\footnotetext{
${ }^{290}$ Habitual, al menos, para Clarín. Si bien hay muchos ejemplos, uno alcanza: cuando en febrero de 1987 el entonces Presidente Raúl Alfonsín cuestionó públicamente al diario por una serie de informes sobre la desocupación, Joaquín Morales Solá, por entonces principal editorialista del matutino escribió que esas con esas críticas Alfonsín "inauguró tal vez una etapa que premiará y azotará en público al periodismo independiente". Ver Sivak (2015: 114 y ss.).
} 
reflexiones sobre la función del periodismo en sistemas democráticos. Nuestro objetivo es mostrar cómo esa auto-percepción se corresponde con el modo en que, efectivamente, estos diarios buscan encarnar la "voz" de la sociedad, y, en ese movimiento, producen la competencia por la representación de los colectivos no encuadrados, paradigmáticamente interpelados como "argentinos". Así, buscaremos mostrar nuestra hipótesis del espacio público mediatizado como zona de cohabitación y competencia por los horizontes de destinación.

De modo que este capítulo estará organizado en dos grandes apartados. En el primero, vamos a reconstruir el escenario de interlocución polémico que se fue configurando entre mediados de marzo y principios de abril de 2008, a medida que CFK y el gobierno certificaban, a través de discursos, gestos públicos y medidas, su voluntad de confrontar con Grupo Clarín. Tal como lo dijimos, de ese escenario nos interesa un efecto puntual: los discursos de los diarios Clarín y La Nación, que puestos a polemizar con el Ejecutivo van tematizando y confirmando un imaginario dominante sobre el lugar y rol de la prensa en democracia. Ese imaginario se sostiene en tres pilares: el postulado que ubica a la libertad de prensa como condición de posibilidad de la democracia; el postulado que ubica a la prensa como intermediario entre los poderes políticos y la sociedad; y el postulado según el cual el rol de la prensa es informar sobre los hechos del mundo.

En el segundo apartado buscaremos reconstruir, mediante un análisis discursivo, los modos efectivos en que los diarios ejercen su pretendido rol intermediario. Es en esas modalidades de la representación, cuando los diarios pueblan su imaginario de entidades colectivas que también son las entidades que el discurso político busca encarnar. En esa superposición el espacio público mediatizado se revela como la zona de cohabitación y competencia por un "horizonte de destinación" que, como lo adelantamos en el capítulo 2, corresponde, punto por punto, con el interpretante democrático de la "ciudadanía". 


\subsection{Acción y reacción: la confirmación de un imaginario institucional dominante}

Entre el 20 de marzo y el 4 de abril de 2008, el Gobierno de Cristina Kirchner realizó una serie de movimientos que fueron anunciando e instalando el escenario de polémica y confrontación que, en el quinquenio siguiente, se convertiría en el trasfondo cotidiano de la disputa política a nivel nacional con el Grupo Clarín. Si la "madre de todas las batallas" se encarnaría en la Ley de Servicios de Comunicación Audiovisual, que apuntaba a la reorganización de la economía política del sistema de medios, en estos días intensos entre marzo y abril de 2008 -cuando la Ley era, todavía, un mera posibilidad ${ }^{291}$ - CFK procedía públicamente como lo había hecho hasta el momento: promoviendo un debate sobre los deberes y responsabilidades de los medios de comunicación. Si la bala era para Clarín, las esquirlas inevitablemente rozaban al "periodismo" y a los medios de comunicación como instituciones y como discurso autorizado del espacio público.

Hubo, entonces, al menos cuatro movimientos que aceleraron el enfrentamiento con Clarín y La Nación, pero que, por efecto de una inevitable onda expansiva, se convertiría en una diatriba sobre el "rol de los medios": el primero, fue la renovación de las autoridades del COMFER, que además pasó a la órbita de la Secretaría de Medios, a mediados de marzo de 2008; el segundo, fue la crítica de CFK al ilustrador Hermeregildo Sábat y al diario Clarín, en el acto del 1 de abril; tercero, la reunión de CFK con el decano de

\footnotetext{
291 “El round actual entre el Gobierno y Clarín, escribió Eduardo Aliverti el 14 de abril de 2008 en Página/12, aunque también terminará en nada, es lo más parecido que se vio a un combate de, al menos, semifondo. Nadie tiene el medidor adecuado para saber cuánta importancia o interés le presta la sociedad a este tema. Es presumible que poco, porque "la gente" se siente ajena, desinformada y confundida respecto de los intereses que se juegan en el finteo. $Y$ cualquiera sabe, al fin y al cabo, que lo que quiera que sea circula dentro de los medios pero nunca hacia el espacio exterior". Más allá de la incredulidad de Aliverti, es interesante notar que "la gente" y "la sociedad" ofrecen los términos de contraste para mensurar la viabilidad o inviabilidad de una decisión; y que esa presencia confirma, para nosotros, la estructura triangular del espacio público político mediatizado.
} 
la Facultad de Ciencias Sociales de la Universidad de Buenos Aires, Federico Schuster, para relanzar el Observatorio de Medios, el 4 de abril; cuarto, la confirmación pública de Gabriel Mariotto -reciente interventor del COMFER, en reemplazo de Julio Bárbaro- sobre la decisión de avanzar en la sanción de una nueva ley de medios.

Vamos a detenernos en las reacciones de Clarín y La Nación ante cada uno de estos movimientos.

a- Cambios en la dirección del COMFER.

A mediados de marzo de 2008 el gobierno decidió que el Comité Nacional de Radiodifusión (COMFER) pasara de la órbita de la Secretaría General de la Presidencia a la Secretaría de Medios de la Nación, dependiente del entonces Jefe de Gabinete de Ministros, Alberto Fernández. Días antes, el organismo había emitido una resolución que obligaba a las empresas de televisión por cable a incluir en los primeros 15 lugares de su grilla a los canales de aire y a las señales de noticias. Este solo movimiento alertó al diario La Nación, que entrevió en ese movimiento la confirmación de que el de Cristina Kirchner, como lo había sido del de Néstor Kirchner, era un gobierno de raigambre autoritaria:

Lamentablemente, el pensamiento que subyace tras estas resoluciones, que se suma a la falta de conferencias de prensa de la titular del Poder Ejecutivo, a la limitación para dar entrevistas a determinados medios o periodistas, al incesante fustigamiento de aquellos medios que intentan reflejar la realidad con independencia del poder político y no lo que el Gobierno quiere ver, da cuenta de síntomas de una mentalidad fascistoide, que pretende que la Presidencia de la Nación sea el único intérprete del ser argentino y que se adueñe de una comunidad informativa que no le pertenece ${ }^{292}$.

La noticia también fue tratada por Crítica de la Argentina, aunque para el diario dirigido por Jorge Lanata los cambios en el COMFER apenas si indicaban la prevalencia creciente de Alberto Fernández en el organigrama

\footnotetext{
${ }^{292}$ A partir de esta cita, toda vez que haya un destacado en negrita es un agregado nuestro.
} 
gubernamental, su "apetito" de poder (el diario lo asimilaba a un "pacman"), y una señal de que el Gobierno iba a prestar una atención más específica a su relación con las empresas de medios. De hecho, Crítica fue el único diario que, ya desde este momento, informó con regularidad de las tensiones en el vínculo con el Grupo Clarín por la posible compra de las acciones de Telecom Argentina y de una inminente licitación para operar el llamado triple-play.

\section{b- Generales multimediáticos y mensajes cuasi-mafiosos}

El 1 de abril de 2008, el Gobierno organizó el primer acto en Plaza de Mayo desde la asunción de Cristina Kirchner. El acto buscó escenificar el apoyo popular y ciudadano a Cristina, en el marco del conflicto con el agro, luego del apoyo que el PJ había organizado en Parque Norte unos días antes. Fue durante este acto que, por primera vez, actores vinculados al gobierno (como Hugo Moyano) mostraron carteles con la sentencia: "Clarín Miente". Y fue en este acto, que CFK interpretó el dibujo del caricaturista de Clarín, Hermenegildo Sábat, como una amenaza "cuasi-mafiosa y denunció que el país estaba presenciando una intentona golpista. "Esta vez, dijo CFK en su discurso, no han venido acompañados por tanques, esta vez han sido acompañados por algunos generales multimediáticos que además de apoyar el lock-out al pueblo, han hecho lock-out a la información, cambiando, tergiversando, mostrando una sola cara".

El diario, a través de sus editores y de editoriales, hizo mención al hecho dos días después. Primero, a través de Ricardo Roa, uno de sus editores generales, quien el 3 de abril escribió, en su Carta del Editor al Lector:

La democracia se sostiene gracias a la crítica, la difusión de información, el intercambio de perspectivas sobre los problemas cotidianos. Y el papel del periodismo es exhibir el abanico de miradas y provocar el debate para encontrar el mejor camino, el de mayor consenso. Todo esto fue puesto en controversia por la Presidenta en Plaza de Mayo. (El diario de Yrigoyen, por Ricardo

Roa,

Clarín,

$3 / 04 / 2008)$ 
Y al día siguiente, el 4 de abril, la editorial estuvo dedicada al mismo tema:

La libertad de prensa es un presupuesto indispensable para el desenvolvimiento de una sociedad democrática, ya que a través de su ejercicio se pueden expresar informaciones $y$ opiniones sin condicionamientos, manipulaciones y censura. A través de la práctica de la libertad de prensa la esfera pública permite el acceso a conocimientos, a ponderaciones críticas y al desarrollo de la madurez cívica. Sabiamente, nuestra Constitución le brinda toda la protección y le asigna a esta libertad un rango prioritario. (Libertad de prensa y democracia, Editorial, Clarín, 4/04/2008)

La Nación, por su parte, publicó una nota editorial el 2 de abril, en la que cuestionaba a la Presidenta por "dividir a los argentinos":

Insinuar que quienes no piensan como el Gobierno son golpistas, además de una falacia que roza la calumnia, constituye un temerario ataque a la libertad de expresión (...) Es innegable la legitimidad de origen de la Presidenta, apoyada en las urnas por el 45 por ciento de los ciudadanos que concurrieron a sufragar en los comicios de octubre último. Tanto como que más de la mitad de los ciudadanos no la votaron y no por ello le deben menos respeto, del mismo modo que las autoridades elegidas tienen el deber de oír sus demandas.

\section{c- El Observatorio contra la Discriminación}

El 4 de abril, Página/ 12 publicó una nota informando sobre una resolución del Consejo Directivo de la Facultad de Ciencias Sociales de la Universidad de Buenos Aires. La Resolución, firmada el 1 de abril, se presentaba como un informe sobre la cobertura mediática del conflicto y denunciaba el sesgo informativo, las expresiones xenófobas de algunos periodistas e instaba al Gobierno a reactivar un organismo que hasta entonces había cumplido un rol decorativo: el Observatorio de Medios, dependiente del Instituto Nacional contra la Discriminación (INADI) ${ }^{293}$.

\footnotetext{
${ }^{293}$ En sus artículos resolutivos, el texto -que sólo presentaba conclusiones, pero sin exhibir las "pruebas" de su análisis- decía que el Consejo Directivo resolvía: "Exhortar al Comité Federal de Radiodifusión (COMFER) para que en el ámbito de sus facultades: 1-realice campañas por
} 
El 5 de abril, Cristina Fernández convocó al decano de la Facultad de Ciencias Sociales, Federico Schuster, a una reunión para dialogar sobre el mentado "Informe". Horas más tarde, CFK realizó un acto de entrega de viviendas en la Casa Rosada, y allí se refirió sobre la reunión con Schuster y aprovechó para explicar que había convocado a todas las universidades nacionales a participar del Observatorio contra la Discriminación en Radio y Televisión. En ese acto, Cristina dijo, además que:

Yo creo que los argentinos tenemos derecho a reflexionar esencialmente sobre quiénes son los titulares del derecho a la libertad de información y de la libertad de prensa; si son realmente las grandes empresas de comunicación o es el ciudadano y la ciudadana de a pie que merece que todas las historias y todos los relatos diferentes y plurales que una sociedad tiene acerca de determinados acontecimientos sean difundidos de la misma manera.

El relanzamiento del Observatorio generó la reacción de los principales diarios, que entendieron que el Gobierno estaba dispuesto a avanzar más allá de la confrontación retórica.

En Clarín, Roa fue nuevamente el encargado de la defensa gremial. En una nota titulada “¿Quién discrimina a quién?", explicó que un Observatorio dependiente de un Gobierno era una "contradicción en sí misma": su destino cuando no su propósito no declarado- era convertirse en un "comisariato político". Para el periodista, el Gobierno estaba reaccionando tarde y mal al impacto que le generaba el conflicto con el campo:

Todo esto surge a partir de la crisis con el campo y del modo como la manejó y como le pega al Gobierno. El relato desde el poder consistió en declararse víctima de una conspiración y asociar la protesta a una maniobra golpista.

vía de la utilización de espacios para la difusión de cuestiones de interés público (art. 72 Ley 22.285) que pongan en conocimiento de la comunidad argentina la existencia de reglas antidiscriminatorias y " 2 -roceda a realizar las actividades previstas en la Propuesta № 208 del Plan Nacional contra la Discriminación, aprobado mediante el Decreto $N^{\circ}$ 1086/05 por medio del Observatorio de la Discriminación en Radio y Televisión, y de acuerdo a sus objetivos, en los espacios referidos en el punto anterior publique el seguimiento de los contenidos de las emisiones de radio y televisión referidas en los considerandos y difunda las conclusiones respectivas". 
Fue claramente un intento de no pagar costos políticos por un error propio y a la vez imponer una realidad distinta a la que había y reproducían los medios

En los días siguientes, Julio Blanck y Ricardo Kirchbaum firmaron dos artículos en los que si bien deslizaban alguna leve autocrítica genérica al "periodismo y a los periodistas”, y valoraban la existencia de Observatorios independientes, sostenían que en lugar de un organismo gubernamental, la primera crítica y el control más eficaz sobre el quehacer del periodismo es el que ejerce diariamente su público:

El control sobre los medios puede tomar diversas formas. Una, la más extendida, casi instintiva, es el juicio cotidiano que hace el público. Los elige o los descarta. Los toma como hábito y los incorpora a su vida familiar y laboral, o los desecha porque no cree o no se identifica con ellos. Otras formas tienen que ver con los límites que fijan las leyes, que todos estamos obligados a cumplir por igual. $Y$ otras más se remiten a formatos de matriz profesional y académica, como los observatorios de medios, que por su misma razón de ser se mantienen distantes de las empresas periodísticas y también de los gobiernos. (La miopía política contaminó un arma eficaz contra la discriminación, por Julio Blanck, 11/04/2008)

Con la recuperación de la democracia, el periodismo pudo ensanchar su espacio de libertad y los sucesivos gobiernos construir una relación con los medios. Los errores que el periodismo ha cometido y comete deben ser corregidos con la aplicación de pautas propias de la profesión. Son los medios y los periodistas los que deben regularse y actuar con responsabilidad democrática. Y el mejor fiscal es el lector de cada día. Nunca se ha arreglado nada con operaciones políticas y artilugios legales que terminan inexorablemente explotando en las manos de sus promotores. (De antinomias y oportunistas, por Ricardo Kirchbaum, 15/04/2008)

La reacción de La Nación se expresó en una lógica similar, y con similares argumentos: el Observatorio expresaba la intención de controlar a la prensa independiente, lo que, en definitiva, constituía una amenaza no sólo para el periodismo, sino para la propia democracia:

Hasta qué punto vivimos en una verdadera democracia o "hasta qué punto vivimos, en realidad, en una mera democracia electoral, en la cual el que obtiene más votos en los comicios supone que manda y el otro (...) debe aceptar las cosas como son. Estamos más cerca del segundo escenario, si se tiene en cuenta la obsesión de controlar a la prensa, o al menos, de insinuarlo, por medio del relanzamiento del Observatorio de Discriminación en los medios. Con esta herramienta, el Gobierno pretende asegurarse un "relato mediático que brinde cabida a todas las opiniones". (La obsesión de controlar a la prensa, Editorial, La Nación, 10/04/2008) 
Para La Nación, la voluntad de control atentaba contra la existencia de un sistema de medios independientes que informara a "los ciudadanos acerca de los movimiento de quienes ejercen funciones de gobierno", ya que esa función de contralor que le cabe a la prensa es una "manera de reforzar la estructura constitucional que coloca a los integrantes del poder público bajo la mirada escrutadora y vigilante de los ciudadanos:

Para que la "gente común" comprenda sin dificultad el lenguaje de los gobernantes y sepa de inmediato "de qué se trata" -por emplear la expresión clásica que resumió el espíritu de las jornadas de mayo de 1810- es necesaria la existencia de un sistema de medios informativos que articule constructiva y adecuadamente a los ciudadanos con el poder. Para eso no hacen falta, desde luego, organismos intimidatorios o controladores. Basta, simplemente, con que unos y otros hablen sin dobleces y reflejen sin distorsiones sus diferentes y particulares visiones de la realidad en un garantizado contexto de libertad, pluralismo y transparencia (Vigilar a la prensa libre no es una tarea propia del Estado, editorial, La Nación, 19/04/2008)

\section{d- Mariotto al COMFER: la madre de todas las batallas}

El 23 de marzo, en uno de sus panoramas periódicos sobre la relación entre el Gobierno y los medios, el periodista Diego Schurman escribió en el diario Crítica de la Argentina, a propósito del nombramiento de Gabriel Mariotto en el COMFER: "Su desembarco efectivo parece estar atado a la relación coyuntural del Gobierno con Clarín. En tiempos de zozobra, el Gobierno insinúa batallas". Como ya lo apuntamos, en esta etapa el único diario que le dedicó atención a las internas de palacio sobre la política mediática fue Crítica. Casi un mes después, en ese mismo diario, Eduardo Blaustein entrevistó al propio Mariotto. “Aunque en el período $\mathrm{K}$ se fortaleció el poder del Grupo Clarín, desde Cristina para abajo -dice en nuevo responsable del Comfer- está tomada la decisión política de sancionar una nueva ley de Radiodifusión", sintetizaba la bajada de la nota. Y en esa entrevista, Mariotto soltará una frase -un anuncio, un augurio y un gran título- que, sin querer pero queriendo, se convertirá en el leit motiv de los tiempos por venir: 
"Nosotros venimos a aportar las herramientas jurídicas y técnicas para la toma de una decisión que es vital para la democracia. Para mí, la ley de Radiodifusión es la madre de todas las batallas. $Y$ hay que darla de una buena vez por todas"294.

\subsubsection{Cuatro gramáticas revelan un funcionamiento ideológico}

Eliseo Verón propuso en diferentes trabajos $(1986 ; 2004 ; 2008)$ que cuando se indaga en las relaciones entre un conjunto discursivo y sus condiciones de producción o de reconocimiento, y esas condiciones corresponden a los mecanismos de base del funcionamiento de una sociedad, se plantean dos problemáticas complementarias aunque diferentes: la de lo ideológico y la del poder. En la hipótesis de Verón, lo ideológico es una dimensión de análisis que se hace visible cuando se indagan las marcas que el "sistema productivo" deja en los discursos. Y que el poder es una dimensión que se visibiliza cuando se indagan en las relaciones de ese discurso con sus condiciones de reconocimiento. Así, "los diferentes tipos de discurso se distinguen por una estructuración diferente de su dimensión ideológica, es decir, por la relación que guardan con sus condiciones de producción” (Sigal y Verón, 2008: 22).

Para Verón la diferencia entre lo ideológico y el poder se define por las relaciones que pueden establecerse entre un discurso, $\mathrm{o}$ un conjunto discursivo y sus condiciones de producción o de reconocimiento, respectivamente, pero siempre que esas condiciones refieran a "los mecanismos de base de funcionamiento de la sociedad". En cursiva destacamos lo que nos parece la clave de este enfoque de Verón: sin hipótesis sobre esos "mecanismos de base" es imposible, o bien incorrecto, disponerse a analizar efectos "ideológicos" o de "poder".

\footnotetext{
294 "El estado tiene que tener la mayoría en Papel Prensa", entrevista de Eduardo
} Blaustein. Crítica de la Argentina. 14/04/2008. 
En una lectura detallada de esta hipótesis, Emilio de Ípola (1979) realizó un cuestionamiento puntual pero importante a las reflexiones de Verón. Por un lado, dice que acuerda con la distinción entre lo ideológico (adjetivo: dimensión de análisis) y la ideología (sustantivo: configuración histórica identificable). Pero por el otro, señala que le parece incorrecta la distinción tajante planteada por Verón, que remite cada problemática (lo ideológico, el poder) a los mecanismos de base del funcionamiento social en relación a la producción de un discurso, en un caso, y a su reconocimiento, en otro. Para De Ípola, los condicionamientos ideológicos también se visibilizan en las "lecturas" (efectos en reconocimiento): "sostenemos -a diferencia de Verónque la lectura 'en recepción' de lo ideológico consiste en el análisis de los efectos que un determinado discurso produce sobre las condiciones sociales de producción de otros discursos" (De Ipola, 1979: 172).

Podría plantearse, sin pretensión de intervención salomónica, que cuando se estudian efectos de lectura, lo ideológico y el poder operan simultáneamente, aunque se visibilizan en marcas distintas. $Y$ esto por una razón teórica con consecuencias metodológicas: en el marco de la teoría de los discursos sociales, la distinción entre producción y reconocimiento es un problema de método, se opera por la intervención del análisis. Sólo se puede verificar la circulación de un discurso por la producción de otro discurso como efecto de reconocimiento. De modo que, como bien dice De Ípola, el primer discurso pasa a formar parte de las condiciones de producción de aquellos que se generan como lecturas, es decir, como efectos.

Para explicarnos: en nuestro caso, ubicamos los discursos de Clarín y La Nación como "discursos en reconocimiento" de los discursos y decisiones del gobierno de Cristina Fernández ${ }^{295}$. Un efecto de poder, en este caso, consiste en el hecho de que los dos diarios retoman las críticas de CFK, es decir, reaccionan frente a ellas. De otro modo: el efecto se verifica en que los

\footnotetext{
295 Que esta decisión es arbitraria lo demuestra el hecho de que todos los cuestionamientos de CFK a la cobertura televisiva del conflicto, tranquilamente puede considerarse como un efecto en reconocimiento, también. Igualmente, su calificación de mensaje cuasi-mafioso a la caricatura de Hermenegildo Sábat.
} 
diarios efectúan una autoreflexión sobre el rol de la prensa; se identifican como actores, explican cuál es su función social:

Todos tienen el derecho a cuestionar el modo como los medios hacemos periodismo, incluyendo desde luego a los oficiales y los paraoficiales. Y a la forma en que son interpretadas las noticias. Pero es autoritario aspirar, en un sistema democrático, a que los medios expresen sólo aquello que el poder quiere ver, leer y escuchar. (Ricardo Roa, Clarín, 11/04/2008).

No está mal que nos cuenten las costillas a los periodistas y a los medios, que se opine de nuestro trabajo, tal como se hace en América del Norte y en Europa. La gente tiene motivos para desconfiar de nosotros, aquí y en todas partes (Cómo evaluar a los medios, Roberto Guareschi La Nación, 10/04/2008)

Pero al mismo tiempo, en estos discursos, se manifiesta un modo singular de estructurar la relación de las instituciones de medios, y de los periodistas, con "los mecanismos de base de funcionamiento de la sociedad": con el sistema democrático, con la relación gobernantes-gobernados, con la circulación de ideas. Digamos, entonces, que los discursos de los diarios permiten indagar ese nivel de lo ideológico bajo la forma de la reafirmación de un imaginario (institucional y profesional).

La existencia de un sistema de medios periodísticos independientes permite que los ciudadanos se mantengan informados acerca de los movimientos de quienes ejercen las funciones de gobierno y ésa es una manera de reforzar la estructura constitucional que coloca a los integrantes del poder público bajo la mirada escrutadora y vigilante de los ciudadanos. La prensa es, entonces, por naturaleza, uno de los agentes sociales que ayudan a observar, vigilar y controlar a los miembros del Gobierno. (Vigilar a la prensa libre no es tarea propia del Estado, La Nación, 19/04/2008)

Por el lugar que los medios ocupan como estructuradores del espacio público el periodismo es un interlocutor predilecto de los actores políticos y es en ese espacio que unos y otros ponen en ejercicio operaciones de representación y mediación de colectivos sociales. Pero mientras que la "legitimidad" del periodismo (es decir, el conjunto de principios o condiciones que lo habilitan para hablar en nombre de una generalidad social) está sostenida por su "rol externo" al juego político, por su rol de observador (rol plenamente 
ideológico y que puede constatarse en las expectativas sociales sobre su deber profesional), una vez que queda colocado como contrincante, como competidor en la arena política, el problema de cómo validar su legitimidad cambia de estatus: el periodismo ve cómo le son transferidas las exigencias de legitimidad que operan tradicionalmente sobre las instituciones del sistema político.

En ese interjuego polémico, de acciones y reacciones, identificamos cuatro gramáticas $^{296}$ que sostienen el imaginario dominante (podríamos decir, tranquilamente, hegemónico) del periodismo en Argentina:

- Gramática 1: concebir al periodismo ("prensa independiente") como un garante del funcionamiento democrático, como una condición de posibilidad. Esto incluye la concepción de los medios como órganos de contralor del poder político. La prensa, entonces, como institución cívica.

- Gramática 2: La misma idea de "prensa independiente" que remite a un imaginario históricamente consolidado, aunque eso no lo torne empíricamente cierto, que tematiza el vínculo entre el periodismo y los gobierno y los partidos políticos.

- Gramática 3: La asunción de que la legitimidad de la prensa, por vía indirecta, la funda el control/preferencia del lector. De modo que, como institución cívica, la prensa actúa como intermediaria de la ciudadanía.

- Gramática 4: La reacción ante el término "relato", utilizado en primer lugar por CFK, y que, en las reacciones de los diarios confirmó la

\footnotetext{
296 Las gramáticas son modelos de reglas que describen operaciones de producción o de lectura de un discurso, considerado no en su individualidad, sino como "miembro" de una clase. Es decir, una gramática es una herramienta analítica que sirve para detectar invariantes discursivos.
} 
“ideología de la representación"297 con la que opera el periodismo, y que consiste en reafirmar el credo positivista de una relación directa entre el acontecimiento y el discurso que lo cuenta.

En los discursos editoriales y en las editorializaciones de Clarín y La Nación estas cuatro gramáticas ordenan las respuestas (defensivas, autoindulgentes) frente a los cuestionamientos del Gobierno. A nosotros nos interesa centrarnos en la gramática 3. Queremos indagar en los modos en que, a lo largo del conflicto, estos diarios ejercieron esa representación del público del que se consideran intermediarios, y contrastarlo con el modo en que Página/ 12 hace lo suyo. Si el imaginario dominante sobre el periodismo (o el imaginario que buscan consolidar los medios de referencia dominante) se expresa como autorreflexión, también es posible verificar que ese imaginario "regula" los discursos de interpretación del conflicto, y allí se actualiza y se confirma a sí mismo. Pero -y quizás más importante- es en los modos específicos, en los micro-funcionamientos discursivos, donde puede verificarse la competencia por la destinación entre Clarín y La Nación y los discursos de CFK durante el propio conflicto. En esos micro-funcionamientos el espacio público se revela como zona de cohabitación y competencia, ya no sólo por la agenda, sino por la identificación y por la representación de la ciudadanía.

\footnotetext{
${ }^{297}$ Según plantea Verón en el prólogo a la $3^{\circ}$ edición de Construir el Acontecimiento (2002: 2) los medios de comunicación no pueden ponerse a discutir el problema de la legitimidad de la información, "y deben atenerse a una ideología de la representación cuyo eje fundamental sigue siendo la sacrosanta 'objetividad'”. Según Verón, "al desbordar la multiplicidad de los modos de construcción, la eficacia de las invariables del discurso termina por producir una unificación imaginaria y valiéndose del poder de su designación, el acontecimiento se impone en la intersubjetividad de los agentes sociales. Los medios informativos son el lugar en donde las sociedades industriales producen nuestra realidad". Ya no se trata de desandar "la ilusión" que vincula las versiones subjetivas de una experiencia y la versión social de un acontecimiento elaborado por los medios. Son los periodistas, agentes productores de la "actualidad", quienes asumen ese malentendido y lo incorporan como ideología, como sentido común, como conjunto de principios no cuestionados, como dóxa, diría Bourdieu: "conjunto de creencias fundamentales que ni siquiera necesitan afirmarse en forma de dogma explícito y consciente de sí mismo" (Bourdieu, 1999: 29).
} 
Esa modelización del espacio público como zona de competencia fue bien desarrollada por Muraro (1997), quien hizo hincapié en el fundamento de legitimidad inconmensurable que sostiene, como pilar invisible, a uno y otro discurso, y a la relación de creencia presupuesta en el vínculo que cada actor sostiene con ese público, o bien con su público ${ }^{298}$. Esa competencia, que en cierta manera ordenó una fase de funcionamiento de los espacios públicos durante el siglo XX, y no sólo en Argentina, a veces -y este es el caso que estamos estudiando- se expresa como una disputa por representar, aunque para Pierre Rosanvallon (2011: 114) es precisamente esa la competencia entre "la prensa” y “los representantes", diferentes "modos de representación":

"En el fondo, los medios y las organizaciones equivalentes son los que ilustran realmente la teoría jurídica de la representación orgánica: la opinión no existe en sí misma, no adquiere consistencia si no es reflejada por ellos, si no es organizada bajo la forma de un sondeo de opinión, de una investigación, de una acción colectiva o incluso de un proceso de interpelación. La tensión inherente a la noción misma de representación -dividida entre la visión "antigua" del mandato estricto y la "moderna" de órgano- es reproducida en el seno mismo del conflicto de legitimidad siempre latente entre los poderes de control y los gobernantes. Esta noción de órgano no podría, por eso, comprenderse de manera estrecha. Sólo tiene un sentido dinámico, como expresión de un trabajo, abierto y permanente; no tiene nada de sustancial. Los medios son un órgano movedizo, imperfecto, y siempre aproximado de la opinión pública”299

\footnotetext{
298 Sin embargo, agrega Muraro (1997:74) "la existencia de fuentes de legitimidad diferentes no excluye la competencia permanente entre periodistas y políticos, tal como, a lo largo de varios siglos, las doctrinas políticas y teológicas acerca de la diferencia de origen del poder espiritual y del poder temporal no lograron evitar que las disputas entre reyes y Papas fueran permanentes. Puesto que resulta imposible transmitir información acerca de un acontecimiento cualquiera sin formular de manera implícita o explícita un diagnóstico y un pronóstico acerca de los asuntos públicos, y también un juicio de valor al respecto, los periodistas realizan tareas que se superponen con la de los políticos"

${ }^{299}$ Es probable que esa afirmación de Rosanvallon (y por extensión, nuestro propio análisis) sea pertinente para una era que empieza a desvanecerse con la difusión de Internet. Como con lucidez lo anticipó Jean Marc Ferry (1989), antes que la extinción del "diario", las prácticas mediáticas basadas en Internet trastocan la institucionalidad de las relaciones entre el sistema político y "la prensa": "la perspectiva que aquí se abre -la de un espacio en que la comunicación política es mediatizada, por cierto, pero sin que por eso el público deba estar representado-, los mecanismos dudosos de la democracia aclamativa serían parcialmente reducidos, así como también el proceso de consagración del "cuarto poder", un poder eminentemente "público", en verdad, y cuán indispensable para la democracia, pero que también puede llegar a ser exorbitante, desde el momento en que compite con el poder político normalmente vinculado con la calidad constitucional del poder público".
} 


\section{2- Operaciones de representación y encarnación de entidades del imaginario político.}

Ya enumeramos una serie de hechos que fueron delimitando un espacio de controversia entre el Gobierno y algunas empresas de medios entre mediados de marzo y principios de abril. El tratamiento mediático se había convertido para el Gobierno en un doble problema: por una parte, la cobertura televisiva era condescendiente con los ruralistas, legitimaba de hecho la protesta; por el otro, el Gobierno no podía dejar de ver en esa cobertura (en particular la del canal de noticias TN) una señal por elevación, por parte de Clarín, por las negociaciones para ingresar en Telecom. El informe presentado por la Facultad de Ciencias Sociales le otorgaba aval académico a ese malestar, en particular porque permitía presentarlo en la forma de un discurso ético, científicamente fundamentado, contra la xenofobia de los medios: no sólo se alentaba la simpatía por el lock-out (cuyos efectos se confirmaban en los cacerolazos de fines de marzo) sino que además había claras muestras de discriminación. Una y otra cosa eran inseparables. En los primeros días de abril ya se empezaba a hablar públicamente del proyecto de una nueva "ley de medios".

Desde el diario Clarín, como vimos, Julio Blanck criticó el uso "interesado e instrumental" del Observatorio, una herramienta útil para la lucha contra la discriminación pero que, para el periodista, estaba puesta al servicio del control de la prensa. En esa nota, escribió:

Los medios, y los periodistas, no tenemos razón alguna para mantenernos al margen de ese escrutinio. Nadie nos otorgó privilegios, aunque algunos de nosotros se pretenden intocables. Pero no es el Gobierno quien debe ejercer ese control, en tanto la prensa es una herramienta que tiene la sociedad para controlar al poder, para interpretarlo y criticarlo". (8 de abril). 
No es necesario ser concesivo con esta concepción idealizada e interesada de la función de "los medios" para conceder, en cambio, el valor que merece esta afirmación de Blanck. La sociedad, como tal, carece de consistencia sociológica. Es, en este preciso sentido, irrepresentable. Como lo explica Rosanvallon a propósito de la "representación-órgano" (2007: 139) "la voluntad de la nación (o de la sociedad) sólo existe construida y organizada, no puede ser concebida como la simple superposición de voluntades particulares". Pero que "la sociedad", "como objeto unitario e inteligible que funda sus procesos parciales" sea una "imposibilidad" (Laclau, 1990: 104) no le resta importancia a la función que cumple como una suerte de respaldo fiduciario de la palabra de los actores sociales en general, y de los periodistas, en este caso particular. En la relación establecida entre el enunciador (que, pese a la firma, no es el periodista individuo) y el colectivo sociedad, lo que se manifiesta es la dimensión institucional de la prensa, lo cual explicaría la estructura indirecta y desdoblada de la enunciación periodística.

\subsubsection{Contextos enunciativos de la comunicación en el espacio público}

El recurso a una fuente de legitimación externa, que coloca al diario y al periodismo como una voz sustituta, como un intermediario, así como las discusiones y las refutaciones de esa pretensión, acompañan el surgimiento de la prensa de masas en su forma moderna ${ }^{300}$.

\footnotetext{
300 Es sumamente interesante contrastar dos casos paradigmáticos (porque son fundacionales en sus respectivos países) que muestran los desfasajes entre el imaginario de la intermediación, que se gestó temprano en el siglo XIX en Europa, y las dificultades, o directamente las imposibilidades, de convertirlo en un modo de comportamiento efectivo. Son casos que muestran la convivencia tensionada entre un imaginario institucional que permite a las organizaciones de prensa escrita concebirse como realizando una función específica y diferenciada (regulando, si se quiere, los intercambios en el seno del espacio público) y un comportamiento faccioso, que las devuelve al rol de portavoces interesados de grupos de opinión o de partidos políticos. Nos referimos al diario La Presse, fundado en Francia en 1837, y al diario Crítica, fundado en Argentina en 1913. Ver, al respecto, los
} 
Ese imaginario no siempre se expresa de modo explícito ni auto-reflexivo: en la mayoría de los casos, se lo actualiza ejerciendo la representación. Es, precisamente, la necesidad de justificar el fundamento de la toma pública de la palabra de la que hace uso el periodismo lo que interesa en este caso: ¿en nombre de quién/quiénes habla un diario, una columna editorial, un columnista estrella, un editor general, cuando enuncia verdades universales, cuando prescribe comportamientos, deberes y responsabilidades de los funcionarios públicos? ¿Por qué esa palabra no puede fundarse en un derecho individual de hablar, de expresarse? Si un medio cualquiera, un diario en este caso, es el intermediario de sus anunciantes, quienes están interesados en el público lector en tanto potencial consumidor, el destinatario de un diario de interés general no puede reducirse a esa figura sin atributos de ciudadanía.

La respuesta de Blanck, entonces, es algo más que un artilugio innoble o cínico ${ }^{301}$ para encubrir la que sería una -o la única- validación correcta: "hablo porque me paga mi empleador para que diga lo que más le conviene a los intereses de la empresa". Esa reducción radical del imaginario profesional e institucional (históricamente consolidado, socialmente efectivo: consagrado) a un mero cobertor corredizo de las fuentes materiales del discurso periodístico, desconoce la implicancia que tiene eso que Kaufmann y Malbois (2015) llaman los tres "contextos enunciativos de la comunicación en el espacio público":

\section{a- El espacio público como "marco regulador"}

En primer lugar, el propio espacio público como marco o cuadro regulador enunciativo, al que los discursos que allí se ponen en circulación deben adaptarse. En consecuencia, estas no pueden ser "radicalmente singulares",

estudios correspondientes de Thérenty y Vaillant (2001; particularmente páginas 13 y 18) y de Silvia Saítta (2013; particularmente capítulo 2).

301 Podrá ser cínico o innoble desde el punto de vista de la intención del actor, pero no como argumento públicamente esgrimido. 
pues con el propósito de sostener su enunciación, "tienen que reclamar, en última instancia, un público de ciudadanos" ${ }^{302}$. El marco del espacio público define, entonces, la entidad colectiva del horizonte de destinación, e impone una "gramática de la toma del palabra pública" (Bastien y Neveu, 1999: 38) que, generalmente, reposa sobre una demodalización del discurso, es decir, sobre el ocultamiento de la singularidad del enunciador por la movilización de principios superiores comunes, diversamente definidos -la evocación, por ejemplo, del bienestar de las generaciones futuras, o de colectivos objetivados de diferentes maneras -como la opinión pública medida por los sondeos que autorizan esa palabra

\section{b- El "lugar" enunciativo estabilizado por cada medio}

En segundo lugar, el cuadro enunciativo situado, relativo a la posición particular ocupada por un medio dado en la esfera mediática: "la enunciación periodística mantiene entonces una referencia oblicua al Público, ya que ella lo aprehende bajo una descripción y una cualificación específicas, las que privilegia el órgano mediático del cual ella porta la palabra". En este nivel corresponde considerar como condicionamiento el propio "contrato de lectura" (Verón, 1985) del medio, el lugar que ocupa en el "campo periodístico" (como referencia dominante, marcador de agenda, interlocutor privilegiado de los estratos gubernamentales, etc.)

c- El "ethos previo" del sujeto

Un tercer contexto enunciativo, que sería el que dibuja el "ethos previo" del sujeto parlante, "y que otorga, a ciertos periodistas, especialmente aquellos con una expertise específica, el derecho de hablar en su propio nombre, y de

\footnotetext{
302“'A diferencia del público real y del agregado de individuos heterogéneos, potencialmente versátiles o incultos, que son susceptibles de componerlo, el público es la figura "mayúscula", noble y abstracta de la legitimidad democrática" (Kaufmann y Malbois, 2015: 12). Donde las autoras dicen público, nosotros podemos decir: la sociedad, la gente, el país.
} 
escapar por eso mismo, a la deferencia que conduce a sus pares a "perderse" completamente en el enunciador colectivo del cual son el relevo".

En lo que refiere a nuestra argumentación, lo que nos interesa no es la identidad específica de esa fuente de legitimidad (en este caso, "la sociedad") sino lo que su invocación (regular, invariante) revela: un imaginario profesional apoyado sobre el supuesto de la interposición, podríamos decir, de un tercero en el vínculo entre el Gobierno y el propio medio. 0, mejor tal vez, un imaginario según el cual el periodismo se interpone, para prestar un servicio, entre el Gobierno y ese tercero, la ciudadanía, la sociedad civil, el pueblo. Este postulado puede ser fundamentado a partir de un ejemplo.

En un pasaje del segundo tomo de su historia del diario Clarín, Martín Sivak (2015: 179-180), relata ese momento en el que un medio decide cómo encarnar a ese tercero:

"A mediados de la década de 1980 Guareschi [Roberto, editor general del diario entre 1990 y 2003] había usado la palabra "gente" en un título por primera vez, para presentar una encuesta de percepción de prestigio y poder. En el mundo práctico del periodismo, gente ofrecía la ventaja de su brevedad. Fungió en reemplazo de los argentinos o la sociedad; además, el término "pueblo" -que, en la percepción del editor, ya no pertenecía al peronismotampoco había sido frecuente en los títulos del diario. La redacción incorporó la palabra: "Esto le importa a la gente", se impuso, por momentos, como imperativo. Los redactores debían pensar en la gente: representarla, mencionarla, darle entidad"303

\footnotetext{
${ }^{303}$ Que la resolución discursiva sea banal, no significa que no sea el signo de una racionalidad política fundada en un condicionamiento sociológico: "Internamente, Magnetto se aferró a otra palabra de ese tiempo: el multitarget. Los estudios de mercado destacaban la diversidad social del lectorado del matutino. Un estudio de la empresa comparó la estratificación en 1996 y en 2002. En 1996, el alto y medio llegaba al $45 \%$, contra el $50 \%$ del bajo y $5 \%$ del marginal. En 2002, poscrisis de diciembre de 2001, el alto y medio bajaron a 30\%, el bajo se mantuvo inalterable y el marginal subió a $30 \%$. En términos absolutos, tenía más lectores en el segmento $A B C 1$ que La Nación, más lectores populares que Crónica y descollaba entre la clase media". Esta amplitud de segmentos de lectores le planteaba al diario una serie de desafíos. En la entrevista que le concede a Sivak, Guareschi explica que "debía ser un diario multitarget, apoyado en la clase media, pero sin perder llegada a los sectores más altos. Si no cambiábamos corríamos el peligro de perder lectores en todo el espectro socio-económico". (Sivak, 2015:181). Esta versión debería contrastarse con la que desarrolla Gabriel Vommaro (2008: 137-139) puesto a indagar en las razones estratégicas que llevan al diario a sistematizar su rol de vocero de una porción de la ciudadanía: "El público aparecía así como
} 
Como se ve, si la identidad específica del tercero (la gente, que no es el pueblo) es una cuestión importante, más interesante -al menos, desde el punto de vista analítico que estamos desarrollando- es que esa forma específica no puede concebirse como una mera contingencia, pues el diario siempre se concibe, y luego se sitúa, como intermediando un interés ajeno, como representante de algo, lo cual, en definitiva, es el indicador de que, como lo explica Servais (2013: 49):

el hecho de que el discurso periodístico provenga de una comunicación mediática significa que los enunciados son legitimados por una institución (el medio) y que la cuestión que se le presenta al enunciador no es '¿quién es usted?’, sino: ‘¿En nombre de quien está hablando?’. La enunciación de la prensa es atravesada por la dimensión institucional del espacio público donde ella tiene lugar, y es sobre esta dimensión institucional que reposa, in fine, su legitimidad, la de los sus locutores y el crédito del que gozan sus enunciados.

En lo que sigue queremos identificar y comparar los modos (y los momentos) en que el medio o el periodista intentan hacerse cargo el punto de vista de ese público (concebido como interpretante, no como target) en nombre del cual toman la palabra. Este abordaje ofrece otro indicador complementario sobre la interpretación que en cada diario se va desarrollando sobre el conflicto, y el grado mayor o menor de competencia por los imaginarios políticos entre cada diario y los discursos de la Presidenta.

En otros términos, entendemos que la "lectura" del conflicto -y el posicionamiento consecuente- que hace cada medio tiene un correlato en las modalidades enunciativas y en la frecuencia en que el propio medio asume la representación de un tercero. $Y$ a mayor frecuencia, más zonas del imaginario político (más espectro del horizonte de destinación) puesto en competencia con los discursos de la Presidente. Y viceversa: a menor frecuencia del

\footnotetext{
la fuente principal de la legitimación de las transparencia mediática, pero en este caso no se trataba sólo de las "audiencias", sino también de un público constituido como ciudadanos "independientes" cuyo derecho a la información objetiva y cuya expresión podían ser garantizados por las empresas mediáticas". Para Vommaro (2008: 138) el diario desarrolló este perfil como estrategia de presión sobre el gobierno de Alfonsín (y luego de Menem) para que se habilitara la privatización de Canal 13.
} 
recurso a un tercero como origen de una preocupación que el medio y el periodista expresarían, mayor acuerdo con las políticas oficiales.

\subsubsection{El "público" encarnado: la "sociedad" y los “argentinos"}

\section{Clarín}

En su análisis comparativo sobre "la construcción" del conflicto por parte de La Nación, Página/ 12 y Clarín, Juan Pablo Cremonte (2010: 258-260), sostiene que "Clarín eligió construir el conflicto como un enfrentamiento entre dos grupos, en el que la 'gente' quedaba por fuera"304. En el capítulo anterior pudimos ver que la figura del "enfrentamiento" entre dos “posiciones" es común a todos los diarios; la diferencia se establece en cómo se valora e interpreta el tipo de relación, entidad, legitimidad y responsabilidad asignada a los actores enfrentados.

Mientras que Página/ 12 (en particular, en la firma de Mario Wainfeld) señaló una y otra vez la asimetría en las legitimidades de la que estaban investidos la Presidenta, por un lado, y los representantes de la Mesa de Enlace, por el otro, en Clarín se desarrolló la idea de que los actores enfrentados habían sido "socios" en la recuperación económica, que el "sector agropecuario" se había visto beneficiado con la transferencia de recursos que el Gobierno aplicaba para mantener su modelo de dólar alto, pero en particular se subrayó la responsabilidad institucional mayor que le cabía al Gobierno, que, a diferencia del “campo", no podía proceder como parte (debía “despojarse de

\footnotetext{
${ }^{304}$ En este trabajo, Cremonte señala (y en esto estamos de acuerdo) que incluso con la radicalización del conflicto y de las críticas del Gobierno al propio diario, Clarín "nunca asumirá como propia la posición de los ruralistas". Es muy interesante contrastar esta conclusión con los análisis que, en el mismo libro, hacen Nuria Yabkosbsky (67-118) y Gabriel Vommaro (181-216), quienes en sus análisis utilizan los textos editoriales y las columnas del diario como "voceros" de los intereses del agro. Una diferencia sustancial -y metodológicamente decisiva- es que de los tres, sólo Cremonte excluye de su análisis al suplemento Clarín Rural cuyo contrato de lectura no encastra ni se condice con el del diario, y cuya inclusión, en cambio, produce un sesgo importante en la consideración de los demás artículos.
} 
ciertos atavismos que lo mantienen ensimismado", según un editorial), sino que debía velar por el conjunto de la ciudadanía afectada por el conflicto. Así lo decía Ricardo Kirchbaum, Editor General del diario:

"La existencia de conflictos en una sociedad democrática no debe asustar a nadie. Los disensos y sus manifestaciones concretas son los que ponen en funcionamiento los sistemas de mediación y representatividad que la armonizan. El problema se plantea cuando desaparecen o no existen las fórmulas de negociación (....) El conflicto planteado debe resolverse mediante una negociación en la que prime el interés común y no el temor de cómo presentan los medios el día después de ese acuerdo. (...) También se debe recordar los efectos de la protesta sobre la sociedad. La responsabilidad institucional no debe ser subordinada a otro tipo de intereses más inmediatos. La democracia es un bien común que todos debemos resguardar contra cualquier acechanza." (Responsabilidad institucional, 11/05/2008).

Más allá de la concepción sobre el rol o la función del "conflicto" en las democracias, y más allá de la reafirmación de la posición intermedia que ya había desarrollado en otras columnas el propio Kirchbaum, vamos a reparar en las modalidades de invocación de figura de "la sociedad". Hablamos de invocación, aunque en rigor, se trata de una estrategia de posicionamiento, de allí que convenga reconstruirla como dispositivo de enunciación: la cuestión es ver cómo se ubica a sí mismo el medio en la trama de relaciones del conflicto.

Distinguimos al menos dos formas que asume este recurso. La primera, consiste en ubicar a la "sociedad" como colectivo afectado (como víctima) del conflicto, a causa de la incapacidad del Gobierno para dar una solución y de los representantes del agro para ceder en su intransigencia:

Tanto el Gobierno como el agro han mantenido desde el inicio actitudes confrontativas dando lugar a un conflicto que no beneficia a nadie, y mucho menos a la sociedad (...) Se ha planteado, por lo tanto, un juego del cual solo pueden resultar perdedores. Gobierno y entidades representativas del agro tienen, en primer lugar, la responsabilidad de resolver el conflicto planteado en la actualidad y evitar que el mismo perjudique a la población. (Negociar para evitar el conflicto agrario, Editorial 22/03/2008.)

$\mathrm{Ni}$ las organizaciones rurales, en este caso, ni los estamentos del sistema político, están teniendo la capacidad ni la inteligencia ni la generosidad para resolver el más grave conflicto desde 2003. Unos, porque han sido desbordados por sus bases y porque el protagonismo en los cortes, más la 
notoriedad mediática que hoy fabrica un líder y mañana lo sepulta, han desnudado una situación que ni el más febril agitador revolucionario podía imaginar en la Argentina: las bases del campo, alzadas, intransigentes, y sin conducción. (...) “Y los que fracasaron apenas ayer, se sienten hoy autorizados a tomar las mismas cacerolas que los echaron a ellos, en una puerta giratoria fatal, ya no para la política sino para toda la sociedad”. (¿Otra oportunidad perdida?, Del editor al lector, por Ricardo Kirchbaum, 30/03/2008).

El dispositivo de enunciación de esta modalidad reposa sobre ciertos elementos típicos (por ejemplo, elisión del sujeto enunciador, aunque la firma, en ciertos casos, compense ese borramiento) y, más importante, la estructuración de una relación triangular con dos colectivos bien identificados (Gobierno/organizaciones rurales, en cuyo interior se distinguen "las bases", como otra entidad) y una tercera entidad, un colectivo de generalidad difuso, en ese sentido no-identitario: la sociedad.

La otra forma -que también aparece con frecuencia en La Nación- es la de un colectivo que se expresa, que reclama, que tiene necesidades. Siguiendo a Kaufmann (2010) podemos decir que se trata de un enfoque instrumentalista, que trata a los grupos como si tuvieran "estados intencionales", y externalista, pues "no permite distinguir los grupos que pueden ser legítimamente considerados como un "sitio" de autoridad y de responsabilidad y los ensambles arbitrarios de individuos que son abusivamente tratados como homogéneos".

El horizonte de un acuerdo de nuevo se alejó. El Gobierno de Cristina Fernández y la dirigencia rural parecen metidos en una pelea a matar o morir, mientras una sociedad observa angustiada un destino que no tiene ningún norte. Resulta difícil de entender que esta crisis suceda cuando la economía argentina ofrece para todos, quizá, una oportunidad excepcional. (Un conflicto agravado y sin norte, por Eduardo Van der Kooy, 30/03/2008).

La posición presidencial recogió una extendida ponderación porque la sociedad necesita y reclama, precisamente, debate y discusión para avanzar en la resolución no sólo del conflicto agrario sino de los grandes problemas argentinos". (Negociar para desactivar el conflicto, Editorial, 18/05/2008).

Si mañana realmente el campo desensilla y libera los retenes de las rutas, si los transportistas, a su vez, cesan con sus contrapipquetes, si el Gobierno abandona la facción y se aboca a encontrar una solución duradera para el conflicto, si los dirigentes rurales trabajan, también, para un acuerdo y no para futuros e inciertos destinos electorales, la sociedad toda respirará 
aliviada. (Política e inteligencia, Del editor al lector, por Ricardo Kirchbaum, $8 / 06 / 2008)$

Más allá de simpatías o antipatías con el Gobierno o con los reclamos del campo, esta sociedad atisba que se están poniendo en juego demasiadas cosas. ... Esa suma de factores comienza a tornar incomprensible el pleito para la mayoría de la sociedad. No existe peor pecado en la política que volverse incomprensible. ...La dinámica del paro pareciera haber rebasado a esos dirigentes [rurales]. Es una impresión que se afianzó desde que arrancó la protesta. Esos dirigentes siguen juntos sólo por espanto al Gobierno. (Una sociedad rehén del conflicto, por Van der Kooy, 18/06/2008).

La "sociedad", entonces, pasa de ser víctima pasiva de un enfrentamiento ajeno, a manifestarse, a demandar, a reclamar. Pero, ¿cómo puede el diario, o sus periodistas, tener una idea tan cabal de lo que pretende, reclama, necesita la sociedad? En estos textos que estamos glosando no se ofrecen “indicadores prácticos” (por ejemplo encuestas de opinión; Vommaro, 2008) como pruebas. Son textos en los que se verifica aquello que Bourdieu llama “efecto de oráculo", por el cual "el portavoz hace hablar al grupo, en nombre del cual habla, hablando así con toda la autoridad de este ausente inasible" (Bourdieu, 1990: 167).

Hay, sin embargo, textos en los que el diario se coloca como intérprete de las "señales" que diariamente se construyen para conocer el comportamiento colectivo. Las encuestas de opinión pública, por su puesto, pero también ciertos datos que surgen de una observación analítica de la realidad:

La Argentina necesita el diálogo. Lo advierten muchos intendentes, decenas de legisladores y lo entienden cada vez más gobernadores. Con el valor de sus testimonios o con la prudencia de sus silencios. Sólo los Kirchner parecen no advertir esa necesidad. La Presidenta y el ex presidente prefieren seguir la lógica de la confrontación que comenzó a generar preocupación en buena parte de la sociedad. (...) Pero el que paga el costo más grande de este conflicto es el Gobierno. Lo dicen las encuestas, que son instrumentos virtuales, pero lo indican también otras señales más concretas. (Evitar la profecía autocumplida, recuadro de punto de vista por Fernando González, $11 / 05 / 08)$

"Los sectores más intransigenes del Gobierno, del ruralismo y de parte de la oposición política transmiten la idea de que, a raíz del conflicto con el agro, el país está dividido en dos bloques enfrentados. Y utilizan esta visión para justificar su lógica de confrontación. Sin embargo, la realidad es otra. Las encuestas de opinión pública y la impresión que surge de fuentes como 
cartas de lectores y opiniones de líderes políticos y sectoriales representativos, indican que más de la mitad de las opiniones son críticas al enfrentamiento en curso, y claman por una solución. Se percibe también un creciente cansancio con las posiciones confrontativas lo cual evidencia que gran parte de la ciudadanía aspira a un sistema político basado en la convivencia, la tolerancia democrática de las diferencias y la canalización institucionalizada de los conflictos". (La mayoría contra el enfrentamiento, Editorial, 17/06/2008)

Como puede apreciarse, en todos estos textos -editoriales, columnas de análisis, recuadros de puntos de vista, etc.- se verifica la heterogeneidad enunciativa del discurso periodístico, la tensión irresuelta entre los dos grados de enunciación que hemos distinguido: el que corresponde al Enunciador Periodista y al Enunciador Institución. La mayoría de los textos citados están firmados, pero en ninguno el enunciador toma a cargo sus apreciaciones; y en todos los casos hay un bien superior a salvaguardar, que es el que justifica los diagnósticos y las soluciones. Como bien lo ha marcado Servais (2013: 167) la heterogeneidad enunciativa de la prensa no es accidental, sino constitutiva "de una escritura en la cual el sujeto produce una palabra que no le es propia”.

Queremos dejar constancia, de todos modos, de una serie de textos que, al respecto, son excepcionales, no necesariamente porque rompan con estos esquemas sino porque pisan el umbral de lo que denominamos la "politicidad" del discurso periodístico: el exacto punto en que el medio y los periodistas se asume/n como parte de un colectivo de identificación:

Ahora arranca una vigilia de grupos $\mathrm{K}$ como custodios de la propiedad privada de la plaza. Como si no estuviese fresca la imagen lamentable de D'Elía golpeando a los que no piensan como él. El afán de plantar allí una bandera única fue siempre quimérica. La plaza no es de unos en detrimento de otros. Es de todos. Es de nosotros". (Una plaza sin exclusiones, carta del editor al lector, por Ricardo Roa, 29/03/2008)

Tanto ruido retumba en la economía. En la presión sobre el dólar, el derrumbe de los bonos, cierta retracción del consumo y en las inversiones que se frenan. El Gobierno paga políticamente estos desatinos. Pero los mayores costos van a la cuenta de todos." (Una factura a pagar por todos, carta del editor al lector, por Ricardo Roa, 08/05/2008). 
El impacto que está teniendo este conflicto sobre el país es superior a cualquier interés político o sectorial y el deterioro no se solucionará de un día para el otro, aunque los argentinos sigamos pensando que siempre habrá un mago que con un truco nos lleve a la puerta del paraíso. (Política e inteligencia, Del editor al lector, por Ricardo Kirchbaum, 8/06/2008).

Cuando el propio medio no se ve obligado a -o elige- identificarse como actor, el único colectivo de identidad en el que el periodismo parece poder incluirse sin violentar el imaginario que estructura la enunciación de la prensa gráfica de interés general, es el de argentinos, es decir, el de habitante-ciudadano de una nación. Puede que no sea el aspecto más polémico del discurso de la prensa, pero lo cierto es que esa operatoria de identificación indica el exacto punto de cruce, de emergencia del espacio público como zona de competencia por los imaginarios políticos: esos “argentinos" pueden, en definitiva, ser los mismos que la presidenta de la Nación invoca en sus discursos como sujetos de su representación, y, en particular, cuando cuestiona el accionar de los propios medios:

Yo sinceramente espero que todos los argentinos podamos gozar de la libertad de prensa y de la libertad de información, a toda la información, esencialmente a la que tiene un relato diferente al que quiere instalarse que es el relato de que a los argentinos nos va todo mal. (Discurso del 4 de abril de 2008)

Todas estas cosas en las que estamos trabajando los argentinos y que tal vez desde algunos lugares por intereses que muchas veces no alcanzamos a descifrar o tal vez sí, intentan plantear una Argentina enfrentada, una Argentina desarticulada, una Argentina diferente a la que la realidad nos muestra todos los días, más allá de las dificultades no vivimos en un paraíso, siempre lo digo, pero me parece que sería bueno que la cuota de responsabilidades la pongamos todos. (Discurso del 24 de abril de 2008)

¿Pero son, efectivamente, los mismos colectivos? Así planteada la pregunta puede llevarnos a confundir el colectivo construido en el discurso como destinatario y los actores sociales que, eventualmente, pueden encarnarlos. Lo importante, en todo caso, es que el horizonte de destinación sí parece ser el mismo: la Presidenta y los medios -al menos, estos medios-configuran ese horizonte como nacional y ciudadano. 


\section{La Nación}

La Nación también es un diario que despliega las operaciones de representación que estamos describiendo de manera recurrente, sistemática. Pero su imaginario político está poblado por entidades mejor delineadas en sus formas que "la sociedad" que Clarín invoca tan regularmente como colectivo dañado por el conflicto. Entre otras razones, porque La Nación aunque con algunas excepciones- no concibe al "conflicto" como fuente de daños; el origen de los efectos negativos del enfrentamiento (suba de precios, violencia, falta de diálogo) surge de la actitud facciosa del Gobierno nacional. Sin embargo, esto no lleva, necesariamente, a una victimización de la sociedad (como sucede en Clarín), aunque la diatriba ideológica (contra el populismo $0^{305}$, el peronismo ${ }^{306}$, el estatismo ${ }^{307}$ ) sea sistemática y radical.

En las citas que insertamos a continuación se puede reconocer el mismo efecto de oráculo que identificamos en Clarín, estrategia enunciativa en la cual el enunciador se coloca en posición de intérprete de las voliciones de un colectivo que no participa directamente del enfrentamiento. Pero hemos seleccionado algunos ejemplos que permiten contrastar esta operación de representación, de tal modo que se pueda ver cómo se articula con el posicionamiento del propio medio en relación a los colectivos que protagonizan el enfrentamiento:

Hay que sentarse a hablar ya. Es imperioso que baje la tensión. La sociedad toda lo está pidiendo más allá de cualquier discusión sectorial (...) Hay algo

\footnotetext{
305 "Los populismos anacrónicos deben ceder su lugar a los sueños e ideales que movilizan a quienes aspiran a convivir en la diversidad". El país y la Plaza de Mayo, Editorial, 1/04/2008. 306 "El peronismo parece creer que la Argentina es sólo peronista. La movilización de ayer bloqueó la ciudad con un número bíblico de colectivos rentados. (...)Los argentinos que no simpatizan con el actual oficialismo o que son simplemente indiferentes quedaron abandonados por su gobierno (....)". El acto, un gesto de debilidad, J.M. Solá, 2/04/2008 307 "El campo, unánime, acaba de responder por todos aquellos que, por una razón o por otra, protestan contra la presión del Estado", escribía Mariano Grondona en una columna dominical titulada, sin las sutilezas alegóricas a las que el periodista muy propenso, Todo para el Estado, nada para la sociedad (16/03)
} 
que en estas horas de desasosiego nos hermana a todos, a todos sin distinción alguna. Las mayorías silenciosas les están exigiendo a los protagonistas que demuestren que la paz entre los argentinos es un bien supremo, inalterable, que trasciende demandas, heridas y orgullos personales. Los ánimos de la población están esperando esa imagen esperanzadora con todos alrededor de una mesa. (Hora de gestos de paz, opinión, por Fernán Saguier, $30 / 03 / 2008$ )

Este primer texto se estructura según un modelo de enunciación triangular, idéntico al que reconstruimos para Clarín: el enunciador se coloca en el vértice del triángulo, el mismo lugar que ocupa "la sociedad" (que, en este caso, equivale a “las mayorías silenciosas”), desde donde transmite (pero bajo la modalidad de una prescripción) a los protagonistas del conflicto la necesidad del diálogo. La diferencia con los textos de Clarín es que esa posición se yuxtapone con la inclusión en un colectivo de identificación ("argentinos") que, podremos verlo enseguida, es un rasgo característico de la gestión de colectivos en La Nación.

Esa posición mediadora es sin embargo infrecuente, lógicamente infrecuente: La Nación concibe al conflicto como un enfrentamiento de partes en el que una tiene razón. La representación, sustentada en la interpretación de los movimientos profundos de los ánimos de la sociedad, entonces, se acomoda a aquella clave de intelección:

Sin duda la resistencia del campo a decisiones tributarias cuasi confiscatorias ha constituido un hecho notable. Pero, con todo lo importante -y hasta desbordante- que ha sido como fenómeno social, parecería que se trata de la parte visible de un movimiento de raíces históricas y consustanciado con la nacionalidad que vuelve a ponerse en marcha. Es el interior que comienza a reclamar, de viva voz, por derechos económicos que se le han ido retaceando por muy largo tiempo". (...) "La gente siente en carne propia que la extracción de las riquezas del interior por el unitarismo de facto ha crecido, pero sin que ello haya dado lugar a la contrapartida de obras que la justifiquen. (Por una política para todo el país. Editorial, 24/04/2008).

El gobierno nacional se equivoca al pretender dividir al agro, y buscar que la opinión pública le dé la espalda, fomentando la vetusta antinomia campociudad. Es evidente que la mayoría de la población está acompañando a los productores en su legítimo reclamo". (La dignidad del campo, 10/05/2008) 
Llevamos casi 100 días extenuantes, llenos de angustia e insoportablemente tensos. El país se ha dividido en palabras, humores, posiciones radicalizadas. Nadie salió ganando. Todos sentimos que hemos perdido demasiado.(...) En este test de temperamento y templanza la población esperaba del Gobierno que fuera árbitro y no parte, que contribuya a distender los ánimos y apurara una solución que el hombre común imploraba", y cuestiona "al campo" que "se equivoca cuando habla de discutir el 'modelo', porque "no se puede discutir el modelo mientras se está arriba de una ruta" y porque " se fue de boca" (El conflicto y sus enseñanzas, por Fernán Saguier, $14 / 06 / 2008)$

La Nación no se asume, ni se comporta estrictamente como vocero del sector agropecuario (es decir, como vocero de una facción), no obstante su explícito apoyo a la protesta ${ }^{308}$. Pero una cosa no quita la otra: como bien lo detectó Ricardo Sidicaro en su estudio sobre las ideas del diario a lo largo del siglo XX, "el diario no era instrumento de esos actores, ni tampoco su vocero, pero mantenía con ellos una comunidad de ideas y de maneras globales de pensar la sociedad y la política” (Sidicaro, 1993: 524). Para el análisis del discurso del periodismo, la diferencia, sutil, es importante.

En primer lugar, no parece ser que el reclamo se reduzca a una reacción sectorial, sino a un hondo y amplio movimiento que viene desde el Interior del país. En segundo lugar, ese movimiento es apoyado por "la gente", por "la mayoría de la población", mayoría que también, por su parte, percibe que es el Gobierno el que se ha comportado como "parte” allí donde tendría que haber sido "árbitro". La Nación asume la voz de estas mayorías de hombres comunes que ansían la paz y que no son kirchneristas: "los argentinos que no simpatizan con el actual oficialismo".

\footnotetext{
${ }^{308}$ Aquí, como en Clarín, es importante distinguir la línea editorial del suplemento Rural de la línea editorial del diario. Claramente, en La Nación estos dos espacios en buena medida se superponen: el suplemento es la continuación de la línea periodística, política e ideológica, aplicada a un sector específico, y no un injerto como, muchas veces, sucede con el suplemento Campo en Clarín. Aun así, persiste una diferencia que aunque observable sólo en el detalle, es sin embargo importante, pues el cuerpo del diario es un espacio más heterogéneo que el suplemento (entendemos que la afirmación es banal) y menos proclive al discurso épico, que, por su parte, se superpone con el discurso de los propios actores (usualmente, empresarios y dirigentes políticos) que hablan en sus páginas.
} 
Conviven en este diario una suerte de ecumenismo nacionalista y las diatribas más radicalizadas y doctrinarias (en el sentido de cuerpo de ideas orgánico, sistemático, inflexible: es decir, explicitadas en fórmulas bien articuladas sobre el rol del Estado en la economía, sobre los males del populismo, sobre las libertades públicas), las ironías más destempladas contra el Gobierno, y la defensa más cerrada de la protesta del sector agropecuario.

Si hay un tópico recurrente en las editoriales del diario es la unidad nacional, y el riesgo de ruptura de esa unidad. El postulado de la nacionalidad como trascendencia y los peligros implicados en los intentos por fragmentarla, dividirla, parecen formar, por su parte, una unidad (de pensamiento). Como la unidad sólo puede ser postulada, la única manera de probarla es evidenciando las estrategias de aquellos que intentan romperla:

Hay sin duda algo mucho más grave y triste que una desafortunada política tributaria. Es la posibilidad de ver dividida y enfrentada a una sociedad a partir de argumentos artificiales y falaces. Las penosas imágenes de corridas y enfrentamientos violentos y los discursos plagados de crispación y resentimiento registrados en las últimas horas como una derivación del conflicto entre el campo y el gobierno nacional nos obligan a serenar los ánimos y retomar el camino del diálogo. (...) Nuestra nación está próxima a cumplir dos siglos de existencia, aunque como cualquier otra se construye día a día. (Urge reconstruir el diálogo, Editorial, 27/03/2008)

Si bien la crisis tendía anoche a descomprimirse, todos los argentinos podemos extraer lecciones. Una, si no la principal, es que no debemos caer más en las antinomias ni debemos hablar más, como la misma Presidenta lo hizo, de una y otra Argentina. La Argentina es una sola. Es la que, antes de que pronunciara su discurso, entonó el Himno Nacional en Parque Norte y en las rutas desde las cuales los hombres de campo seguían el mensaje presidencial. Esa es la única Argentina, no una signada por anticuadas luchas de clases ni por pugnas entre unitarios y federales. (La invitación al diálogo, Editorial, 28/03/2008

El presupuesto de una nacionalidad trascendente, que sólo se puede revelar cuando se verifican divisiones y enfrentamientos, es el fundamento conceptual desde el cual en La Nación se construye el colectivo de identificación "argentinos".

Es hora de que el país se eleve por encima de sus disputas y de sus desencuentros. $\mathrm{Y}$ es hora de que los argentinos aprendamos a transitar las 
calles y las plazas de la República con total fidelidad a nuestras convicciones, pero también con entero respeto por las convicciones de los demás. (...) La Plaza de Mayo debe dejar de ser un espacio que nos separa y debe volver a ser un pedazo de historia que nos une. Los populismos anacrónicos deben ceder su lugar a los sueños e ideales que movilizan a quienes aspiran a convivir en la diversidad. Que todos nos encontremos en ella, aun en la diversidad, a la hora de imaginar un país mejor. En la Plaza de Mayo caben el dolor y la esperanza. Porque la Plaza de Mayo somos todos" (El país y la Plaza de Mayo, Editorial, 1/04/2008).

Los argentinos estamos acostumbrados a utilizar el odio como instrumento político. (...) Estos sectores "culpables absolutos" de la desgracia nacional, han ido cambiando, como es natural, a lo largo del tiempo: fueron identificados, sucesivamente, como los "oligarcas", los "yrigoyenistas", los "peronistas", los "anti-peronistas", los "comunistas" (...) los "represores", "los entregadores del patrimonio nacional". En los últimos días pareció haber sonado, por momentos, la hora del campo. Y se tuvo la sensación de que la cascada de reproches provenientes de la tribuna presidencial empezaba a caer sobre el heterogéneo y casi indefinible sector agropecuario. (...) Persiste el odio, persiste la obsesión por dividir a los argentinos". (El odio como arma política, Editorial, 5/04/2008).

Las circunstancias han querido que este 25 de mayo encuentre a los argentinos divididos, pendientes de cómo un conflicto entre las autoridades nacionales y el sector más dinámico de nuestra economía se dirime en sendas manifestaciones populares en Salta y Rosario. A escasos dos años del Bicentenario de nuestro nacimiento a la vida independiente, sería bueno recordar que sin un genuino sentimiento de unión nacional y sin un espíritu de diálogo y búsqueda de consensos no hay pueblo que pueda reconocerse como Nación. (La patria ante un nuevo desafío, Editorial, 25/05/2008).

En estas editoriales el diario se asume como parte del colectivo "argentinos", pero lo hace desde una posición pedagógica y prescriptiva, es decir, enunciado verdades universales ("los argentinos estamos acostumbrados a utilizar el odio como instrumento político") y marcando, en tono imperativo, líneas de conducta a seguir ("Y es hora de que los argentinos aprendamos a transitar las calles y las plazas de la República con total fidelidad a nuestras convicciones"), dos modalidades enunciativas que, no casualmente, indican una toma de distancia y la asunción de una prerrogativa, la de indicar reglas de comportamiento. La nacionalidad también se aprende, y por lo tanto, también se enseña. En este sentido, el diario efectiviza la "sustitución de sujeto” (Bourdieu, 1990: 168): sustituye por su propia visión del mundo la del grupo del cual se presume que es la expresión. 
Como puede apreciarse por las fechas, son los momentos de movilización y competencia por la ocupación del espacio público, y por lo tanto, aquellos momentos en que cualquiera de las entidades abstractas del imaginario del propio diario (la Argentina, el País, la Nación, la Sociedad) se encarnan en sujetos concretos y las diferencias se visibilizan, cuando el diario insiste sobre el postulado de la unicidad:

Las imágenes de las dos concentraciones multitudinarias que tuvieron lugar ayer frente al Monumento de los Españoles, en Palermo, y en la Plaza del Congreso ofrecieron la triste sensación de un país fracturado, dividido por dos maneras diferentes de entender nuestra realidad y su proyección. Tal impresión, sin embargo, no debería llevarnos a la desesperanza: hubo dos plazas, pero hay una sola nación. (....)Los chacareros y los representantes de la clase media urbana que se dieron cita en el acto del campo son tan argentinos como las personas de extracción más humilde que acompañaron el mensaje del presidente del Partido Justicialista. (Dos plazas, una misma nación, editorial, 16/07/2008)

De los diarios analizados, La Nación es el único que trabaja, de modo regular, sobre el presupuesto de una argentinidad, como emanación de la idea de una Patria, y el que sobre ese principio construye el colectivo "argentinos" como víctima (según puede apreciarse en la columna de Morales Solá glosada más arriba) o como colectivo de identificación: "estamos acostumbrados a utilizar el odio como instrumento político", "tenemos que aprender lecciones", a quienes el 25 de mayo "nos encuentra divididos". No se trata ya, entonces, de hacer hablar a la "sociedad", sino de hablar en nombre de todos, pero desde dentro.

\section{Página/12}

Si se pondera comparativamente la propensión indicada por la frecuencia- de los columnistas de Página/12 a asumir una posición de representación similar a la que vimos en Clarín y La Nación, el resultado será significativamente menor. Hay un motivo que podría esgrimirse como variable a priori para explicar este hecho: a diferencia de sus competidores, Página/12 como 
ejemplar del género periodismo de interés general, es un diario que no tiene editoriales: la institución no se expresa en un texto anónimo, por eso colectivo, sobre los acontecimientos ${ }^{309}$.

En cambio, el diario tiene numerosos columnistas especializados, que diariamente desarrollan interpretaciones sobre el conflicto. Nuevamente aquí parecer volverse útil la distinción entre Enunciador Periodista y Enunciador Institución, no sólo porque expresa la necesidad de afinar los instrumentos analíticos más allá de los saberes incorporados por el propio investigador (que permiten ahorrar la energía que demanda reconstruir el desarrollo de una línea editorial), sino también porque en este caso particular la menor recurrencia a evocar necesidades y daños de un tercero como fundamento de un postulado prescriptivo expresa una concepción del periodismo y de los deberes y responsabilidades de los medios.

Pero que Página/ 12 no recurra con frecuencia, en la pluma de sus articulistas, a operaciones de representación, no significa que no lo haga. A lo largo del conflicto del campo, de hecho, se pueden distinguir dos modalidades de referencia al tercero que están sintomáticamente asociadas a la propia deriva del conflicto: después del acto del 25 de mayo de 2008, y sobre todo a lo largo del mes de junio, en cierta manera la interpretación de las movilizaciones de protesta en apoyo al reclamo del sector agropecuario se matizan, sin dejar nunca de impugnar la legitimidad de los dirigentes agropecuarios, la lesividad de las acciones directas, la necesidad de impuestos

\footnotetext{
309 Lo cual plantea una dificultad analítica, que nosotros -como la mayoría de los investigadores que han tratado estos mismos textos- asumimos sólo parcialmente, referida a la uniformidad ideológica atribuible al conjunto de textos, como para considerarlos (abusivamente) fragmentos de una línea editorial. El género "editorial”, en cierta manera, facilita esa tarea. Sin embargo, conviene no olvidar nunca la reflexión que, al respecto, expuso Ricardo Sidicaro sobre las dificultades que se le presentaron para analizar las editoriales del diario La Nación: originalmente, intentó pensar esos textos escritos por diversos autores, no siempre con firma, como una orquesta. Pero no le pareció correcta, porque: "Lo atractivo de esa particular empírea que eran los editoriales del diario provenía, justamente, del hecho de que se trataba del pensamiento de La Nación en la medida en que esa columna unificaba objetivamente los aportes de los autores inspirados en teorías disímiles, y hasta opuestas, construyendo un singular intelectual colectivo que, al fusionar en principio ideas presentadas como yuxtapuestas, generaba por los efectos de contigüidad, una estructura ideológica diferente a la de cada uno de los fragmentos que articulaba".
} 
como los derechos de exportación y el carácter de clase de los reclamos. El matiz, entonces, no aparece como variación en las posiciones políticas originales (como contradicción, como corrección de opiniones previas) sino por la admisión de dos condiciones impuestas por el propio conflicto.

En primer lugar, que la masividad de las movilizaciones y su extensión y multiplicación geográfica, expresan algo más que un cerrado y egoísta reclamo sectorial que, objetivamente, puja por una distribución regresiva del ingreso amparado en demandas por el bien común (democratización, federalismo, equidad distributiva), sino que indica un “descontento" ampliado que debe ser tenido en cuenta para ajustar errores y evitar el ensimismamiento del Gobierno ${ }^{310}$. Segundo, que la prolongación del conflicto estaba generando un "malestar" en amplias franjas de la ciudadanía, y que el Gobierno tenía una responsabilidad sobre ese malestar.

La primera modalidad de representación -que, repetimos, no es sistemática, no aparece permanentemente, pero por esa misma razón es significativa- es similar a la que ya identificamos en Clarín: hablar por aquellos sectores que están sufriendo -como víctimas- los efectos de los cortes de ruta y el consecuente desabastecimiento por las protestas coordinadas por la Mesa de Enlace. La diferencia con Clarín es que aquí no hay ninguna sanción salomónica: no es el "conflicto" el que daña el bienestar social, sino las decisiones de la dirigencia agropecuaria, que no tienen ni razón, ni legitimidad y son desproporcionadas en relación al daño que producen.

El lockout de estos días no es el primero ni el segundo que enfrenta a este gobierno. En el largo ínterin las commodities siguieron en alza, las retenciones pudieron ser absorbidas. El Estado sostuvo alto el dólar, baratos los combustibles sólidos. El esfuerzo fiscal fue compartido por el conjunto

\footnotetext{
310 “Encerrado en su propia lógica, el kirchnerismo traspapeló su privilegiada percepción de la opinión pública. A veces da la impresión de que está tan distante que no repara cuánto tiempo dilapidó y cuánto espacio ha cedido. En muchos puntos tiene más razón que sus adversarios que no se han caracterizado por la buena fe y la conducta democrática. Pero aun así, son un sector social que expone razones y que expresa a miles de argentinos portadores de derechos y autoestima. Y la obsesión monotemática es lógica en las corporaciones pero fatal para el gobierno de todos. (Yuyos recalentados, por Mario Wainfeld, 1/06/2008).
} 
de la sociedad. Los patrones, solitos, se encargaron de mantener deprimidas las pitanzas de los peones, un clásico rebusque para potenciar sus ganancias. No se lucieron a la hora de formalizarlos, tampoco. (Los huevos de oro, por Mario Wainfled, 23/03/2008)

No importa nada, salvo preservar la rentabilidad del capital. En este caso, "nada" implica vaciar góndolas de supermercados y estantes de los almacenes. Pocas medidas patronales han sido de tan manifiesto desprecio hacia el prójimo. Y lo que no deja de asombrar es que la mayoría de los medios pueda considerar "justa” semejante agresión a la población. (No importa nada, por Alfredo Zaiat,26/03/2008) ${ }^{311}$

Las coberturas usualmente esconden la lesividad de las acciones, un tópico nada menor. (...) La autocrítica puesta en acto por Cristina fuerza a mirar del otro lado a corporaciones que se han arrogado el rol de suplir al voto popular, dejar sin efecto el contrato electoral de la flamante Presidenta y obrar una medida de acción directa desmesurada. El desabastecimiento es una agresión tremenda a la sociedad, muy desproporcionada al derecho que se invoca. (En el campo las espinas, Mario Wainfeld, 30/03/2008).

El hecho concreto es que este paro salvaje generó un desabastecimiento cuyas víctimas, por vía inflacionaria, son los sectores más desprotegidos de la población.(...) El hecho concreto es que salieron a disputar el espacio público en defensa de sus intereses, a costa de joderle la vida a la mayoría de la sociedad porque esto no es un corte de calles en el centro porteño que perjudica la llegada puntual al trabajo. ¿Están a favor o en contra del hecho concreto? Díganlo de frente. Todo lo demás es anecdótico mientras no haya esa toma de posición definida frente a un episodio de esta magnitud. (Primero lo primero, por Eduardo Aliverti, 31/03/2008)

La segunda modalidad se empieza a hacer visible durante el segundo ciclo del paro agrario, y en particular después del acto del 25 de mayo en Rosario. Si bien ocasionalmente, durante el primer ciclo del conflicto algunos articulistas (Mario Wainfeld, José María Pasquini Durán y Alfredo Zaiat) deslizaban leves cuestionamientos al manejo que el Gobierno en general, y el Ejecutivo en particular, hacían del conflicto, la perspectiva de la prolongación indefinida de la protesta, la intransigencia de las partes, las escenas de tensión y enfrentamientos en algunos cortes de ruta, $y$, en particular, la percepción de que el conflicto estaba asumiendo, ahora sí, una dinámica facciosa, perjudicial para el propio Gobierno, parecen incidir en la forma en que esos

311 Esta columna de análisis fue publicada nuevamente por el diario el día 28 de marzo, porque el día anterior, durante su discurso en Parque Norte, CFK lo mencionó y utilizó para reforzar la defensa de las retenciones y cuestionar las consecuencias de la protesta del sector agropecuario. 
mismos articulistas plantean la necesidad de una solución rápida para el conflicto.

Anoche, a las 23.15, las entidades convocaron a un nuevo "paro" de comercialización de granos y hacienda. La medida de fuerza empezó a las 0 de hoy y finalizará a las 24 del próximo miércoles. Ese día habrá una "jornada de protesta" en todo el país, con marchas "en cada pueblo" y con la invitación a sumarse a comercios, industrias y trabajadores. Seis horas antes de ese anuncio, el Ejecutivo había culpado de todos los sucesos del día a los ruralistas. La sociedad quedó fracturada (Otro lockout para festejar el día del Padre, por David Cufré, 15/06/2008)

En ese escenario, el tercero aparece ya no sólo como víctima de la protesta agraria sino como colectivo que demanda, necesita, la resolución del conflicto.

Alberto Fernández desgranó bien su discurso político aunque debería computar que nadie tendrá la paciencia de escucharlo media hora seguida, que su verba será editada y trabajar en consecuencia. $Y$ también reparar en que buena parte de la sociedad civil anhela algo más que tecnicismos y belicosidad, que su ansiedad primera es menos enfrentamientos y más tranquilidad. Las estocadas para la tribuna adicta pueden ser un golazo en contra ante auditorios mucho más populosos. (Yuyos recalentados, por Mario Wainfeld, 1/06/2008)

¿Hasta cuándo, hasta dónde?, se interrogaban los argentinos, damnificados o no por el pleito, azorados porque nadie parecía encontrar la cuota de sentido común para restablecer las cosas a sus debidas dimensiones. Ayer, martes 17 , durante una ceremonia oficial con motivo del $53^{\circ}$ aniversario del bombardeo antiperonista a Plaza de Mayo, la presidenta Cristina mostró el coraje político necesario para hacerse cargo de la incertidumbre pública y calmarla con una fórmula que ella explicó así: "Los problemas en la democracia se resuelven con más democracia” (Más, por Pasquini Durán, $18 / 06 / 2008)$

El Gobierno invoca la representación de todos los argentinos, con derecho. Pero en su acción parece soslayar que la zozobra en la gobernabilidad no es neutral sino que damnifica especialmente a las gentes de a pie. La paz social, la tranquilidad cotidiana, son una necesidad de los humildes, que viven, trabajan y se proveen día tras día. El ambiente excitado entusiasma a dirigentes oficialistas y opositores, a quienes se ve en su salsa. Es más que dudoso, para la modesta mirada impresionista de quien esto escribe, que eso conjugue con la sensación expandida entre otras personas, ansiosas por saber que vendrán jornadas sosegadas, que habrá suministros, que no faltarán certezas. (...)El saldo provisorio, a los ojos del cronista, es acre y contradictorio. Su percepción es que el encarnizamiento de la brega política es disonante con los anhelos cotidianos mayoritarios, más allá de la disputa sobre las razones en juego. Que los vaivenes fácticos agobian a la mayoría 
de los argentinos, más ávidos por un cierre de la miniserie que por el capítulo que ya vendrá. (Yuyos de la amargura, por Mario Wainfeld, 15/06/2008).

Señalamos, una vez más, que no estamos describiendo una operación discursiva permanente ni que pueda considerarse característica de la línea editorial de Página/12. Si algún valor analítico tienen estos párrafos es que muestran la introducción de una posición externa al enfrentamiento, no sólo como colectivo dañado sino como espectador que reclama tranquilidad, que se interroga sobre el fin del conflicto, que anhela días menos crispados, que está desconcertada por un acontecimiento que no termina de comprender bien. Las formas específicas de ese tercero son variables aunque a nuestro entender su función es la misma: sociedad civil [que anhela algo más que tecnicismos y belicosidad]; la sociedad [desconcertada, fastidiosa]; los argentinos [que se interrogan azorados]; los humildes [que necesitan la paz social]; la mayoría de los argentinos [agobiados por vaivenes fanáticos; ávidos por el fin del conflicto].

Un rasgo común a esta modalidad -pero cuya aparición es ubicua en todos diarios- es que los colectivos que encarnan esa posición de externalidad son invocados como fuente de legitimidad (si se nos permite, como prueba) de los análisis e interpretaciones de los periodistas. Una variante bastante excepcional de esta modalidad aparece cuando el colectivo postulado, y cuya posición frente al conflicto es analizada, es la clase media. En Página/12, la clase media es tratada sin condescendencia, con el mismo recelo que recibe en los discursos presidenciales, y similar al que, en el propio diario, se dispensó a los pequeños productores:

Claro que, si de eso hablamos, no podemos soslayar la estulticia, la "falsa conciencia" de argentinos de clase media, mimetizados en la intolerancia y el racismo proverbiales de su oligarquía. La expresión 'negro de mierda' se escuchó decenas de veces en boca de "la gente", sin que tanto movilero proclive al editorial respecto de Luis D’Elía abriera la boca o siquiera lo señalara. (En el campo las espinas, por Mario Wainfeld, 29/03/2008)

El hastío por esta disputa de casi tres meses que ha empezado a manifestar gran parte de la clase media se debe no sólo a la reiteración de discursos, modos y exabruptos de los actores, sino a que observa con su particular 
sensibilidad de bolsillo que el principal problema económico hoy no es la situación del campo. Sabe que lo fundamental es la evolución de los precios domésticos, cuestión a la que el Gobierno debería empezar a dedicar más energía que a contestar la sucesión de incoherencias del variopinto elenco de dirigentes agropecuarios. (Las recetas de los magos de la city, por Alfredo Zaiat, 8/06/2008)

\section{El conflicto del campo reactivó la preocupación de algunos sectores} intelectuales afines al kirchnerismo por el comportamiento de la clase media, $y$, como si se tratara de una misma cuestión, por el tratamiento condescendiente de los medios más importantes con aquellos comportamientos (Bracco, 2013; Garguín, 2013) ${ }^{312}$. Desde ya, no se trató -ni se trata- de una preocupación analítica, sino que, como bien se pudo corroborar en los años posteriores, en las sucesivas protestas (usualmente “cacerolazos”) en las principales ciudades en 2012 y 2013, se trataba de un problema político ${ }^{313}$. Como escribió Martín Rodríguez (2014:35):

La ubicación de la clase media tras el conflicto de la 125 permitió pensar de un modo irreversible que se trata de un conjunto de fuerzas que actúan como jueces conservadores que desempatan entre el orden democrático y la economía de mercado y cuya tendencia al equilibrio irrumpe sobre proyectos peronistas a los que despierta de sus sueños. Pasó con Menem, pasó con el kirchnerismo. Es una clase fuera de la política (...) Un partido civil que toca la "campana" de la economía"

En cualquier caso, si nos remitimos a los artículos públicados por Página/12 a lo largo del conflicto, queda claro la "clase media" fue un objeto de preocupación. Pliegues, curvas y contracurvas de los diarios: también en Página, el periodista José Natanson publicó el día después de que CFK enviara el proyecto de ley de retenciones al Congreso una nota en la que analizaba la relación del kirchnerismo con la clase media, titulada: "Si no supiste amar".

\footnotetext{
312 Garguín sostiene que "Como en 2001, pareció autoevidente la relación entre cacerolazo y clase media. Nuevamente, la prensa mostró poco interés por delimitar de manera sociológicamente precisa los respectivos apoyos, y prevaleció una tendencia a confundir clases medias urbanas con las movilizaciones en apoyo del campo de los barrios más ricos de las ciudades".

${ }^{313}$ A partir del año 2012 comienzan a sucederse en las grandes ciudades de Argentina una serie de protestas, bajo la modalidad de "cacerolazos", que expresan en común un fuerte rechazo hacia el gobierno de Cristina Fernández de Kirchner. Entre septiembre de 2012 y febrero de 2015 Acosta y Gotfrid (2015) contabilizan nueve movilizaciones de protestas de las clases medias urbanas contra el gobierno de Cristina Fernández.
} 


\section{Reflexiones finales: un ministerio sin misterio.}

La convergencia sobre el espacio público pone a los discursos políticos y a los discursos periodísticos a "trabajar" bajo el supuesto de un Tercero (el público, la ciudadanía, el paradestinatario) que, antes que constituirse, de diversas maneras, como una figura discursiva o como un "actor" empírico, es una hipótesis reguladora asociada a las estructuras institucionales del sistema político y el sistema de medios, pero sobre todo es un condicionante regulador de los discursos que intervienen en el espacio público bajo condiciones de mediatización. Si el campo discursivo de lo político implica un enfrentamiento, la construcción de un enemigo, también es cierto que la lógica del sistema electoral y del espacio público impide un ensimismamiento: en cambio, impone, como dice Naishtat, la "construcción de una audiencia" (1999), o el conocimiento de que allí, del otro lado, hay colectivos que no están incorporados en la tensión bipolar amigo-enemigo. El campo discursivo del periodismo, en cambio, no se funda, a priori, sobre un vínculo adversarial (cuando lo hace, se solapa con el campo discursivo político), pero eso no quita que pueda estar sometido a las condiciones que impone una lectura política.

Si en su forma dominante el conflicto entre el Gobierno nacional y las patronales agropecuarias adquirió una forma binaria o sucesivas formas binarias (el pueblo/sector; el interior/gobierno central; campo/gobierno; redistribución del ingreso/rentabilidades extraordinarias; maximización de la caja/federalización), el análisis de las manifestaciones públicas de CFK (así como las de los dirigentes de la Mesa de Enlace) nos mostraron que la forma política del conflicto, aunque polarizada, siempre propendió a volverse ternaria. No sólo porque había algo en disputa sino porque en todo momento lo que se puso en juego -al menos, siempre que fue necesario exponer mediáticamente posiciones- fue el reconocimiento y la búsqueda de apoyo de un tercero: "la ciudadanía”, "la opinión pública”, “la gente”, “el pueblo argentino". 
La hipótesis que venimos proponiendo indica que esa forma ternaria no puede teorizarse sin referencia al espacio público mediatizado. Es decir, no se explica sólo por principios de funcionamiento inherentes al espacio público bajo condiciones de pluralismo político como tal, que por su misma constitución sería refractario al ensimismamiento del enfrentamiento binario (tal la tesis de Naishtat ${ }^{314}$ ) sino por la presencia de las instituciones de medios, que no sólo actúan como "testigos", sino como indicadores de la presencia de los ausentes.

En ese marco, además, el solapamiento espacio-temporal en la gestión pública de una misma zona del imaginario político convierte a dos discursos institucionales inconmensurables si se atiende a las "condiciones de autorización”, a sus fuentes de legitimidad ${ }^{315}$, en objetos comparables.

Por eso, cualquiera de las figuras del Tercero ("la gente”, “la ciudadanía”, “el público”, “los argentinos”, “la sociedad” etc.) invocadas en los discursos pronunciados en el espacio público se solapa, en lo inmediato, con los públicos mediáticos. Pero a su vez, también las instituciones mediáticas tienden a darle entidad (forma, identidad, voliciones, una "estructura de sentimientos") a ese Tercero, y muchas veces -eso pudimos comprobarlo aquí mismo- bajo la forma de víctima o principal perjudicado por una disputa que, en su núcleo esencial, le sería ajena. Es allí, precisamente, donde “los medios" despliegan de manera manifiesta su vocación representativa, ese juego de "ventriloquia usurpadora" del que habla Bourdieu.

\footnotetext{
${ }^{314}$ A la que también suscribe Nardacchione (2005:86): "La construcción del sentido político de las acciones de protesta es, de manera creciente, una 'tarea plástica' en la búsqueda de legitimación frente a un Tercero, cuya figura es el destinatario ineludible de la acción política que necesita resolver de manera superadora el antagonismo dual".

315 Está claro, al menos para nosotros, que "las condiciones de autorización" son inconmensurables cuando se trata de dirigentes políticos electos, dotados de la autorización legal para representar los intereses ciudadanos. Es probable que cuando se trata de dirigentes políticos con aspiraciones electorales pero sin cargo, su voz esté en condiciones de competencia más simétrica con la de los periodistas con los que, eventualmente, debe "competir" o "compartir" espacios de intercambio y discusión.
} 
En su análisis la representación política, Bourdieu (1990: 160) dice que "el grupo existe cuando se ha dotado de un órgano permanente de representación (...) capaz de sustituir (hablar por es hablar en lugar de) al grupo serial, hecho de individuos separados y aislados, en renovación constante, no pudiendo actuar y hablar sino por ellos mismos".

El proceso de delegación se completa por una segunda operación, mediante la cual la "realidad social así constituida", es decir, el tipo de institución u organización que se constituye como representante (la Iglesia, el partido, una federación de pequeñas y medianas empresas) otorga mandato a un individuo. Bourdieu dice que esta doble operación es una suerte de "caja negra": en su interior, se producen procesos inobservables, que sólo pueden inferirse porque transforman la situación inicial.

A ese proceso lo denomina "el misterio del ministerio": una doble delegación que consagra a un individuo para hablar en nombre de un grupo, que como tal sólo existiría a través de la representación ejercida por ese individuo; el cual, por su parte, sólo puede operar esa transformación porque ha sido investido por una organización. Se produce entonces una relación de sustitución: el mandatario actúa como sustituto del grupo de mandantes: "el mandatario está de alguna manera en una relación de metonimia con el grupo, es una parte del grupo que puede funcionar en tanto que signo en el lugar de la totalidad del grupo".

¿Qué sucede cuando el grupo representado carece de consistencia sociológica? Sigal y Verón (2008: 133) dicen que las entidades del imaginario político, en particular los colectivos singulares -la patria, el País, la sociedad, la gente, el pueblo- no tienen palabra: son entidades imaginarias mudas. De allí que todo enunciador político pueda o pretenda reclamarse como su representante. Ya vimos que la propia CFK instauró, durante el conflicto, un dispositivo de enunciación que la posicionaba en un lugar privilegiado para hablar en nombre de esos colectivos; ese dispositivo se configuraba en base a la 
legitimidad electoral, que produce un cierre en la competencia por la encarnación de esas entidades. Ese dispositivo se configuró como reacción, en buena medida, a los intentos de los dirigentes de la Mesa de Enlace, que buscaron encarnar la voluntad de "millones de argentinos" y de "los pueblos del interior" que sufrían la expoliación del Estado. Esa disputa por la representatividad está en la base del litigio: se estructura sobre la pregunta de quiénes somos nosotros, quiénes son ellos, por qué hacen lo que hacen.

Cuando Verón (1987) enumera los tipos de entidades del imaginario político distingue "colectivos que no funcionan como operadores de identificación de los actores en presencia sino que corresponden a entidades más amplias y que el enunciador político coloca habitualmente en posición de recepción: por ejemplo, 'ciudadanos', 'trabajadores', argentinos'”. Se trata de colectivos asociados habitualmente al paradestinatario, y que aparecen en otros tipos de discurso, aunque su funcionamiento en otros contextos es diferente al del discurso político. Precisamente, lo que puede verse con los ejemplos que hemos expuesto, es que esos colectivos son los que entran en disputa.

Ahí, en la configuración de esas entidades que no hablan, sino que sólo existen cuando son habladas, es donde los medios efectivizan su trabajo (o una parte de su trabajo) de representación, que, de todas formas, tiene en su base la misma operación que Bourdieu identifica como el misterio del ministerio. Pero aquí es necesario señalar una diferencia importante: el periodismo es, si se lo mira desde este punto de vista, un ministerio sin misterio, al menos, lo será en tanto y en cuanto aquellos colectivos no se incorporen en un movimiento que lo reconozca como representante.

Hay, claro, una ventriloquia usurpadora. Esta mala fe estructural es, desde nuestro punto de vista, fundante del lugar que los medios -al menos, los diarios de interés general que aquí estudiamos- asumen como observadores externos al juego político. Su legitimidad -que no es procedimental- sólo puede sostenerse como servicio a un tercero, en nombre del cual se habla. 
Pero esa usurpación no puede reconocerse como tal: es necesario todo un mecanismo que no puede ser sino discursivo para que esa representación, por un lado, sea consagrada, y por el otro, se legitime por medio de su invisibilización. 
REFLEXIONES FINALES 
“Todas las instancias mediáticas, más allá de las diferencias de orientación política y de sofisticación que las distinguen, deberían poder materializar de manera creíble al Público del cual ellas se asumen voceros (...) Es por eso que la presentificación del Público no es solamente, en democracia, un imperativo ontológico; ella es también una tragedia política”

Laurence Kaufmann y Fabienne Malbois (2015)

\section{REFLEXIONES FINALES}

Bien vale, llegados a este punto, una declaración sincera: ofrecer conclusiones no sólo es difícil por el prurito de pretender cerrar algo que, indefectiblemente, siempre queda abierto, sino porque quien escribe está tentado de creer que todo ha sido dicho ya. En el largo recorrido de esta tesis, además, elegimos cerrar cada capítulo con reflexiones que nos sirvieron como recapitulación, pero también como correas de transmisión a los capítulos siguientes. Si tuviéramos que ofrecer unas conclusiones, las nuestras ya han sido expuestas. Por eso, en estas páginas finales vamos a limitarnos a sintetizar el razonamiento formal de nuestra investigación. Se mezclan, en él, ciertos presupuestos a partir de los cuáles realizamos el estudio y otros que son efectos del análisis. Se trata, entonces, no de recapitular, sino de proyectar: al fin y al cabo, si algún valor pudiéramos presumir de lo que hemos escrito, es el de que alguien en el futuro, pueda retomar algunas ideas para reflexionar más y mejor.

\section{Un punto de partida}

En esta tesis buscamos estudiar el funcionamiento de un fragmento del espacio público mediatizado, aquel que se produce y que puede ser reconstruido como sistema de intercambio interdiscursivo entre discursos políticos y discursos periodísticos. Nuestro punto de partida -nuestro caso, nuestra invariante referencial- fue el "conflicto del campo", que por su excepcionalidad -duración, liminalidad, intensidad, inserción social- se nos 
presentaba como un acontecimiento muy útil para estudiar disputas por la gestión de colectivos.

Entre marzo y julio de 2008, el Gobierno Nacional argentino enfrentó una fenomenal reacción de las principales organizaciones gremiales del sector agropecuario, que decidieron oponerse de ese modo a una resolución ministerial que definía un aumento de los derechos de exportación y modificaba el esquema de cómputo de esos impuestos. La reacción corporativa se reforzó muy rápidamente con un intenso movimiento de protesta al que se sumaron partidos políticos de la oposición, asociaciones empresarias y gremiales y sectores activos de las clases medias urbanas en todo el país. El llamado “conflicto del campo" tuvo una extensión geográfica y una duración inédita en la historia argentina, afectó el abastecimiento de alimentos, la circulación de bienes y de personas y redefinió, por su intensidad, las coordenadas políticas que ordenaban las relaciones entre el gobierno y la oposición de allí en adelante. El conflicto reveló un proceso de cambio que se venía produciendo en los modos de producción económica, de sociabilidad y de funcionamiento institucional en las ciudades y pueblos del llamado "interior” del país.

En el devenir del conflicto las superficies mediáticas -la televisión, las radios, los diarios, las páginas de internet- se convirtieron en escenarios complementarios, simultáneos -a veces yuxtapuestos- de las rutas, las plazas y las mesas de negociación. A partir de cierto momento, el propio rol de los medios de comunicación se convirtió en un eje más de la disputa, en particular por la abrupta ruptura de la relación relativamente cordial y de mutua conveniencia, que hasta entonces habían mantenido el gobierno de Néstor Kirchner y el grupo de medios más importante del país, Clarín.

Podríamos decir: durante el conflicto, el Gobierno tuvo que enfrentar dos frentes de batalla: el político y el mediático. 
En esos escenarios, hubo dos discursos institucionales que fueron particularmente importantes: los discursos presidenciales de Cristina Fernández de Kirchner y los discursos periodísticos. Entre estos discursos se produjeron intercambios que modelaron una zona de interlocución en la que no sólo se puso en juego la circulación de "información" o de "recursos cognitivos" para "comprender" el conflicto: allí emergió una controversia sobre las identidades grupales y los colectivos sociales que parecían confrontar modelos de país antagónicos.

Estos elementos le dieron forma al problema de nuestra investigación: los modos en que los actores e instituciones del sistema político y del sistema de medios intervienen en la gestión de colectivos sociales, es decir, el modo en que producen y sostienen en el tiempo el contacto con esas entidades del imaginario político y social que ordenan el horizonte de destinación de los discursos que se producen y circulan en el espacio público: "la ciudadanía”, el "público", "la gente", los "consumidores", "los productores" y otros colectivos sociales presupuestos en la instancia de reconocimiento de los discursos producidos por ambos sistemas.

\section{Lo público mediatizado}

Asumido como rasgo de un modo de ser y estar de la vida en comunidad, lo público no describe una ontología, sino un límite relativo. No existe un lenguaje unificado, ni un contexto epistemológico unívoco para reflexionarlo como problema o para invocarlo como horizonte deseable (Rabotnikof, 2005), por lo cual cada vez que se requiere el concepto se corre el riesgo de reiniciar una discusión desde cero. No fue eso, claro, lo que hicimos en esta investigación. Nos interesó, en cambio, reflexionar a partir de la identificación de dos efectos que la mediatización ha tenido sobre lo público y por extensión sobre los discursos sociales mediatizados: la multiplicación y expansión de los ángulos de visibilidad de lo colectivo al romper con los límites inmanentes del campo de experiencia individual, y la progresiva 
consolidación del "público" como un Tercero, esto es, no como un sujeto colectivo concreto e identificable en la topografía social sino como un regulador discursivo.

Retomamos, así, los tres sentidos básicos relacionados con el concepto de lo público que ha identificado Rabotnikof (1997; 2005): uno asociado a lo "común y lo general" (lo que concierne a la comunidad, lo colectivo, opuesto a lo individual y lo particular); el segundo, hace referencia a lo visible $o$ manifiesto (en contraposición a lo oculto y lo secreto); el tercero que se refiere a lo abierto (como accesibilidad, en oposición a lo cerrado). Sin dudas, se trata de propiedades que definen un ideal normativo del espacio público, pero al mismo tiempo sintetizan desplazamientos (históricos, conceptuales e ideológicos) sobre las discusiones en torno a él, y las problemáticas que son activadas en esas discusiones.

En nuestro caso, se trató de entender qué rol juegan las tecnologías mediáticas y las instituciones de medios en relación a las características de cada propiedad. 0 incluso más específicamente: ¿la mediatización afecta las tres propiedades del espacio público? Y si lo hace, ¿qué efectos tiene la mediatización sobre las exigencias, normativas y descriptivas, implicadas en cada una de tales propiedades? Es factible pensar que la mediatización impregna las tres propiedades que ha propuesto Rabotnikof, pero no las coloniza ni las absorbe, sino que las traslada, por efecto de las rupturas de escala (Verón, 2002:132), al ámbito inaprensible de lo colectivo, las coloca por encima de los contextos de la semiosis interindividual. Este efecto de base produce un desdoblamiento (y no un reemplazo) de lo público, que por lo tanto no queda reducido a su faz mediatizada. Por lo mismo, la crítica normativa, ética o moral, no puede aplicarse a la mediatización, sino a las instituciones de medios. En relación a ellas esas tres propiedades pueden ser traducidas como exigencias deontológicas: ¿qué temas merecen ser tratados y quién decide cuáles son esos temas? ¿Cómo mostrar el mundo y qué no puede ser visibilizado? ¿Quiénes acceden a ese campo de lo visible y por qué? 


\section{Las instituciones y el entorno de lo público}

Las instituciones y actores políticos y los actores del sistema de medios se encuentran en una situación de cohabitación espacio temporal y competencia discursiva, situación que redunda en la producción cotidiana de una zona emergente de intercambio, pues los discursos producidos por esos actores y esas instituciones se dirigen al "entorno de lo público", concebido como horizonte de destinación.

Nuestra investigación trabajó bajo ese supuesto, pero circunscribimos el análisis a dos tipos de discurso específicos: el discurso político presidencial y el discurso del periodismo de la prensa gráfica. Como los discursos presidenciales de CFK que estudiamos fueron discursos televisados, tratamos con dos series discursivas que tanto en su materialidad como en sus condiciones de producción, circulación y reconocimiento, están mediatizados.

En un contexto dominado por la mediatización masiva, las instituciones de medios producen "lo público" como un entorno en el que, a través de ellas, otros actores sociales buscan hacer circular sus discursos. En este sentido puntual, los medios de comunicación son instituciones de intermediación pública. Esto instaura dos condiciones de producción que es común a todos los discursos que se generan en los medios o que deben circular sobre las superficies mediáticas para cobrar existencia pública: la imprevisibilidad de los efectos (que replica, en la escala colectiva, la no linealidad de la circulación del sentido) y la exigencia consecuente de poner en circulación puntos de vista generalizables, sostenibles públicamente, que se enfrentan a la imposibilidad de controlar el acceso a su discurso y deben lidiar, en cambio, con el fantasma de un destinatario colectivo. Si el horizonte de destinación que se estructura por efecto de la mediatización del espacio 
público es indefinido ${ }^{316}$ las condiciones de producción de los discursos están, en cambio, estructuralmente condicionadas por funcionamientos institucionales precisos (reglas, recursos), relaciones de propiedad, vínculos políticos.

El esquema básico de nuestro análisis entonces podría presentarse de esta manera:

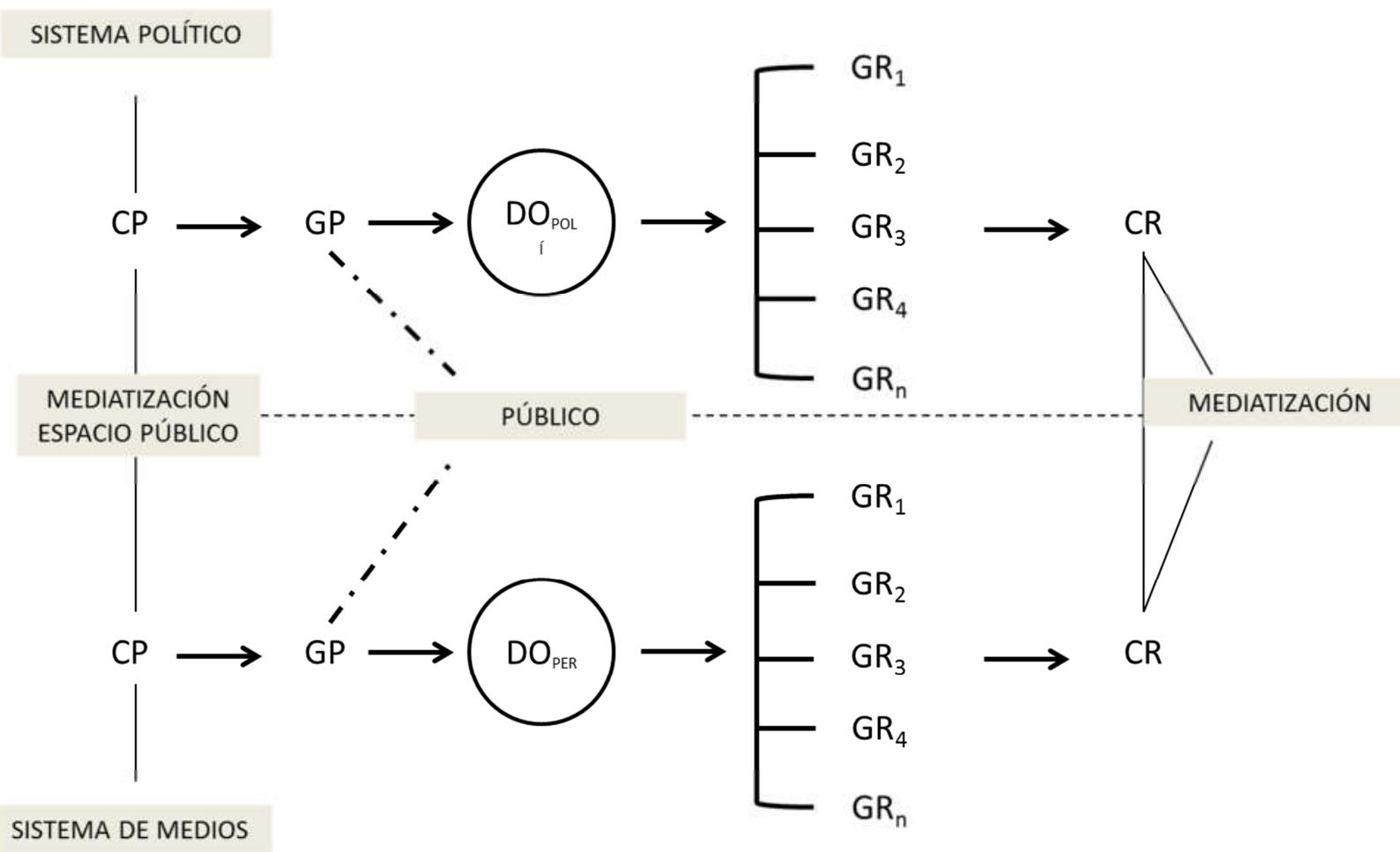

Siguiendo la figuración de un fragmento de la semiosis propuesto por Verón (2013: 293), trabajamos sobre dos tipos de discurso (DOpol/DOper) con propiedades específicas, definidas, en parte, por los dispositivos institucionales que son sus condiciones de producción (CP). Esos dispositivos

\footnotetext{
${ }^{316}$ La "indefinición" de la que hablamos debe entenderse en este preciso sentido: quien habla no puede controlar las condiciones de circulación de su discurso, que queda disponible para ser retomado, intervenido, puesto a circular nuevamente por otros agentes. Es esta condición estructural ( $y$ estructurante) de funcionamiento del espacio público mediatizado la que parece ser modificada por la utilización del análisis de big data, las métricas analíticas y otras estrategias relacionadas con la minería de datos que contienen la promesa de la posibilidad de acercamiento casi individualizado y certero a los posibles destinatarios de discursos políticos y de los discursos de los medios de comunicación
} 
institucionales "regulan" de modo cualitativamente diverso a los discursos producidos por los actores sociales. Sin embargo, nuestra hipótesis de trabajo fue que entre las condiciones de producción que, en un nivel, regulan estos discursos, hay que considerar su puesta en circulación en el espacio público vía su mediatización. Es decir, la mediatización tiende a imponer condiciones de producción similares a discursos que, considerados en relación a las estructuras organizacionales en las que son generados, son muy diferentes.

Ahora bien, "la mediatización" es un proceso estructural que se actualiza en instancias singulares: un mensaje presidencial a través de la Cadena Nacional, una nota de análisis sobre ese mensaje publicada en un diario; o bien, en la expectación del discurso presidencial, o en la lectura de la nota de análisis. Como se ve, la mediatización debe entenderse como mecanismo de base del sistema de producción de discursos en el espacio público, porque sus efectos aparecen en todas las fases de la cadena semiótica: en producción, en la circulación, y en el reconocimiento.

Un principio teórico con implicancias metodológicas de la teoría de los discursos sociales es que las condiciones de producción dejan marcas en los discursos, y que esas marcas, una vez identificadas (en función de una hipótesis) se convierten en huellas. Digamos, si el circuito de producción se despliega en el tiempo (hacia adelante) el análisis tiende a realizar el recorrido inverso. De allí la idea de que se analizan productos para estudiar procesos (Verón, 2004: 125). En cualquier caso, nosotros partimos también de una hipótesis: la mediatización produce lo público como horizonte de destinación; ese horizonte de destinación está regulado por la figura del "público", concebido no como "receptor" ni tampoco como una magnitud sociológica asociada a variables estadísticas o demográficas, sino como un Tercero que rompe la estructura cerrada de la comunicación privada e instituye espacios públicos de representación. 
La convergencia sobre el espacio público coloca a los medios y a la política a "trabajar" bajo el supuesto de ese Tercero que será (discursivamente) encarnado de diversas formas, pero que no es una unidad capaz de actuar subjetivamente: su forma de ser, su ontología, es del orden de la terceridad: es un interpretante instituido por las reglas (formales) y por la experiencia (histórica) del funcionamiento de la democracia, que se configura, en su forma básica y genérica, como una estructura triangular. Si lo político se funda en una distinción irreductible nosotros/ellos, o bien, como lo propone Arditi un "pluriverso de oposiciones de amigos/enemigos que cambian continuamente, y que designan hostis (es decir, colectivos de identidad públicos), el orden de la política tiende a asumir un forma triádica, y eso se explica, entre otras razones, porque no hay política sin instancias de intervención pública (Naishtat, 2004), sin institución de una "audiencia". Por eso planteamos que es una hipótesis reguladora (es decir, que regula la producción) asociada a las estructuras institucionales del sistema político y el sistema de medios.

Ese Tercero, entonces, se inscribe en los mecanismos de base de la producción discursiva de tales instituciones. Por lo tanto, sería posible identificar gramáticas de producción (GP) también similares, al menos en la construcción de destinatarios, o bien de un tipo específico de destinatario: aquel que también recibirá esos discursos a través de un dispositivo de mediatización.

Así planteado asunto, cualquiera de las figuras del Tercero invocadas en discursos pronunciados en el espacio público (“la gente”, "la ciudadanía”, "el público", “los argentinos”, "la sociedad”, etc.) se solapa, en lo inmediato, con los públicos mediáticos. Por su parte, también los medios deben instanciar, configurar, consagrar una forma específica de ese tercero y muchas veces bajo la forma de víctima o principal perjudicado por una disputa que, en su núcleo esencial, le sería ajena. Es allí, precisamente, 
donde "los medios" despliegan de manera manifiesta su vocación representativa

Sólo considerados desde esta perspectiva del funcionamiento de los conflictos políticos públicos, las instituciones mediáticas producen una “mirada" externa (en este caso, al juego político), que no equivale a imparcial. Esa externalidad indica la presencia de aquel tercero, que es, también, el horizonte de destinación de los actores políticos en el conflicto.

La posición de observación externa se manifiesta en un dispositivo de enunciación, que es la resolución discursiva de una lógica de funcionamiento institucional por la cual se reproduce, desde los medios, su diferencia con los actores e instituciones del sistema político.

Desde ese "lugar" institucionalizado los medios intervienen (a través de una gama variada pero finita de operaciones discursivas) sobre los discursos públicos de otros actores. Este estatus "extra-político" no se define sólo negativamente, como no-poder, sino que se deslinda de la lógica partisana que rige al campo político.

Por nuestra parte indagamos en tres de esas operaciones. Las denominamos de ascenso en generalidad (a través de hetero-atribuciones, se produce una descripción que individualiza desde fuera por las funciones que un colectivo cumple en el entorno más amplio); de descenso en generalidad (a través del rastreo de particularidades ejemplares, produciendo imágenes de lo colectivo a partir de casos singulares) y de representación. Cuando se la considera empíricamente (en los micro-funcionamientos discursivos) la representación se nos aparece como el acto de hablar en lugar de otros $\mathrm{y}$, consecuentemente, de hacerlos hablar.

Esos otros, son, a veces, entidades colectivas con presencia en el mundo social. En otros casos, son interpretantes del imaginario político: argentinos, 
Nación, país, sociedad, gente, pueblo, entidades mudas que, como tales, están "disponibles" para ser hablados por otros actores. Cuando los colectivos representados, tienen, por su parte, presencia sociológica, su capacidad para presentarse públicamente como un nosotros no excluye que sean, al mismo tiempo, hablados por otros actores e instituciones.

De allí que se pueda detectar un efecto de representación simultáneo: los colectivos que son hechos hablar, están ellos mismos siendo representados por otros actores.

De modo que el solapamiento espacio-temporal en la gestión pública de una misma zona del imaginario político convierte a dos discursos institucionales inconmensurables si se atiende a las "condiciones de autorización" -el discurso presidencial, el discurso del periodismo en la prensa gráfica- a sus fuentes de legitimidad, en objetos comparables.

\section{Zona de intermediación: una reflexión que cierra para volver a empezar}

En una reflexión sobre el rol del periódico en su contexto de surgimiento como producto e institución moderna en el siglo XIX, Therenty y Vaillant (2001) resaltan su diferencia con el rol del editor en el trabajo de dar a publicidad -o sea, poner en circulación- textos literarios. Esa diferencia, señalan los autores, es que el periódico era -y es- un fenómeno "mediático". Notable señalamiento, que para nosotros, hoy, queda incorporado en el plano de lo obvio: ¿de qué otro modo concebir lo específico del periódico sino por su carácter "mediático"? Los autores explican que ese carácter mediático del periódico significa que no sirvió para transferir el discurso de la esfera privada a la esfera pública sino que se trató de un discurso que, desde el principio, estuvo situado en el corazón del espacio público, y que funcionó como un "instrumento de mediación y de intermediación entre las personas" (2001: 11). El periódico, así como la publicidad comercial, son dos de los 
nuevos "discursos intermediarios" del siglo XIX (Traversa, 2011). La intermediación no es el traslado de un mensaje. Es la articulación de las distancias por la puesta en circulación de los discursos. En retrospectiva, esto implica la emergencia de instituciones articulan la producción y el reconocimiento de bienes (materiales y simbólicos) en sociedades que se industrializan y se urbanizan, se vuelven crecientemente complejas y diferenciadas.

La intermediación funciona en el plano del dispositivo tecnológico y en el plano del discurso de la institución mediática. Los dispositivos de comunicación son, en esencia, dispositivos de cambio y ruptura de escala: trasladan los órdenes significantes (las imágenes, el contacto, las palabras) al ámbito inaprensible de lo colectivo, los coloca por encima de los contextos de la semiosis interindividual (Verón, 2002: 132). Cuando Tocqueville, hacia mitad del siglo XIX, decía que "sólo un diario puede poner el mismo pensamiento, al mismo tiempo, entre miles de lectores"317, seguramente pensaba en la función de la prensa política en Estados Unidos, pero también estaba definiendo la capacidad articulatoria del dispositivo de lo escrito impreso para reponer lazos comunitarios por sobre las distancias geográficas.

El dispositivo no es la institución. La mediatización es un proceso histórico que se despliega a través de la inserción de las tecnologías de comunicación en el tejido social, pero que no se deja entender sólo por ellas. Debe entenderse, también, como un doble movimiento -que no es homogéneo ni sigue los mismos ritmos en cada país, y probablemente tampoco en cada región- por el cual las instituciones mediáticas adquieren autonomía, se despegan del sistema político, el periodismo desarrolla una deontología profesional, gana un lugar de enunciación; y, al mismo tiempo, de manera correlativa, se constituye un mercado cultural, una industria de medios y un sistema mediático. La intermediación institucional que gestiona discursivamente el periodismo es no solo la articulación espacio-temporal,

${ }^{317}$ Citado en Pasley (2001:4) 
sino la ocupación de un "lugar de enunciación" y la producción de estrategias discursivas para gestionar los discursos (las opiniones, las quejas, los consejos) de otros actores e instituciones.

Novedad histórica de la era de los medios que, como tal, demanda un contexto epistemológico diverso de aquel que nutrió las reflexiones clásicas sobre el espacio público como horizonte deseable. Así lo entendió Ferry (1998: 19-20) cuando propuso una "redefinición sociológica" del espacio público que no suele ser asumida en toda su radicalidad:

El "espacio público"(...) es, en sentido lato, el marco "mediático" gracias al cual el dispositivo institucional y tecnológico propio de las sociedades posindustriales es capaz de presentar a un "público" los múltiples aspectos de la vida social (...) Por "mediático" entiendo lo que mediatiza la comunicación de las sociedades consigo mismas y entre sí (...) El "público" es, virtualmente, toda la humanidad y, de modo correlativo, el "espacio público" es el medio en el cual la humanidad se entrega a sí misma como espectáculo.

La radicalidad de esta definición depende, claro está, de un modo de leerla. Si ensayamos una interpretación intransigente, inflexible, ella sugiere, como señalamos en el primer capítulo, el retorno a una suerte de grado cero analítico del espacio público, en un sentido histórico y conceptual. Histórico, porque hay que tomar la mediatización como un dato a partir del cual reflexionar sobre el espacio público para evitar que el "punto ciego" del análisis sea eso que el propio Ferry llama "nostalgia de un espacio público tal como habría podido ser" (1998:18). La imagen de un espacio público mediatizado no puede ser la de una esfera de intercambios comunicativos sometida a una fuerza externa, la de los medios, que la somete a una presión selectiva ajena a los intereses vitales de los ciudadanos.

Las tecnologías digitales, los dispositivos y las aplicaciones móviles (los teléfonos celulares, los smartphones, las aplicaciones de mensajería instantánea), las plataformas con base en Internet (Facebook, Twitter y otras) nos han permitido entenderlo: la mediatización opera como un conjunto de 
condiciones productivas que, como tales, también afectan la lógica de funcionamiento de las instituciones de medios.

Consecuentemente, el grado cero deberá ser, también, conceptual, ya que es necesario reconsiderar los conceptos con los que se pretende estudiar y caracterizar el complejo institucional de los medios, empezando, quizás, por el propio concepto de medios.

La expansión mediática del espacio público, que comenzó en el siglo XIX y se profundizó a lo largo del siglo XX, no sólo implicó la irrupción de la racionalidad comercial, del entretenimiento impregnando y diluyendo los límites normativos con que había sido concebido (o reconstruido) el espacio público clásico, con sus umbrales morales intrínsecos y sus temas prioritarios. Consolidó, al mismo tiempo, el protagonismo del periodismo porque le abrió un espacio de "representación" fáctica del "público". Como dice Ferry (1998: 22), "el recurso a esa norma de sustitución que es la opinión pública en el sentido de los sondeos (...) reviste un significado sistemático: legitima de manera efectiva cierto poder político de la prensa, pues esta es la que, por excelencia, puede "representar" en calidad de "opinión pública" un aspecto de la sociedad civil sociológica y políticamente distinto del "cuerpo electoral". Si algún valor heurístico tiene hablar de los medios en general, y del periodismo en particular, como una "institución política" (es decir, si ese término en algo puede ayudar a comprender la inserción del periodismo en la vida social) es en la medida en que -tal y como lo hacen las instancias políticas institucionales- apunta a una comunicación privilegiada con un "público" potencialmente interesado en los problemas de la vida política.

Las instituciones mediáticas, y el periodismo en particular, mantienen un privilegio en la administración de la dinámica de ese espacio público mediatizado. $O$ al menos, lo mantuvieron hasta ahora. Precisamente, es ese privilegio el que parece estar en riesgo con la irrupción y consolidación de internet y de las "nuevas tecnologías" y los "nuevos medios" interactivos que 
introducen la posibilidad de discursos mediatizados pero que pueden evadir la intermediación de las instituciones de medios para insertarse en la circulación colectiva. El propio Ferry, con notable lucidez prospectiva, señalaba que las "tecnologías telemáticas" contenían un potencial renovador ya que abrían la perspectiva "de un espacio en que la comunicación política es mediatizada, pero sin que por eso el público deba estar representado", poniendo en crisis los fundamentos (sociales, tecnológicos) sobre los cuales el periodismo moderno había asentado su lugar de "portavoz" o de "mediador" de la opinión pública.

El proceso de desintermediación habilitado por la convergencia digital plantea la posibilidad cierta de que se transformen las condiciones de ejercicio de la intermediación periodística en el espacio público y las condiciones sobre las cuáles el sistema político interviene públicamente para interpelar a la ciudadanía. Del otro lado, es decir, desde la lógica de los actores sociales la mediatización habilitada por las llamadas "redes sociales" permitiría visualizar interacciones públicas en las que los actores que conforman esa potencial "ciudadanía" hablan: entre ellos, por ellos, pero también sobre aquellos que hablan -y han hablado hasta ahora- al mismo tiempo, en su nombre. 
ANEXOS 


\section{ANEXO I: SOBRE ALGUNAS DIFICULTADES EN LA DEFINICIÓN DE CRITERIOS DE SELECCIÓN DEL CORPUS DE PRENSA GRÁFICA}

La decisión de realizar un corte analítico a través del concepto de gestión de colectivos nos planteó una serie de problemas metodológicos, tanto para resolver la composición del corpus de artículos de la prensa gráfica como para desarrollar el análisis empírico. Queremos en estas páginas dar cuenta de esas dificultades.

En términos operativos, la gestión de colectivos se manifiesta como una zona de enunciación (tanto en términos del dispositivo de enunciación como en términos de "rasgo", según Steimberg, 1998). El problema que esto nos planteó es que como tal se trata de un fenómeno incidental y ubicuo, que no se circunscribe a un género específico, y esto hace que el corpus que construimos, además de extenso, fuera bastante heterogéneo: desde editoriales clásicas, pasando por recuadros de análisis y opinión de los editores de los periódicos, notas de opinión y análisis de articulistas invitados (o sea, que no pertenecen al staff del diario), crónicas, informes ${ }^{318}$.

Tal como lo planteamos en la Introducción, por el tipo de abordaje que quisimos hacer, el criterio de selección, lógicamente, no podía ser ni aleatorio ni representativo; fue intencional, y directamente vinculado un criterio de corte que establecido después de una lectura general y en función del análisis del conflicto. Las notas que conformaron el corpus fueron aquellas en las que se planteaban las preguntas "litigiosas": sobre la identidad de los protagonistas, sobre sus razones, sobre su historia, sobre sus estrategias. Puntualmente, aquellas notas a través de las que se puede reconstruir el

\footnotetext{
${ }^{318}$ En un aparte, colocamos los suplementos "rurales", en particular los de Clarín y La Nación; en el caso de Clarín, porque el suplemento "Rural" no se condice necesariamente con la línea que van desplegando los editorialistas en el cuerpo del diario, durante el conflicto, ese suplemento fue un injerto fanático; en el caso de La Nación, porque aunque el suplemento "Campo" es más coherente con las posición editorial del diario, el posicionamiento editorial es cualitativamente distinto.
} 
modo en que se va configurando el colectivo "campo" y el colectivo "pequeños productores".

Se presenta entonces una suerte de disyuntiva: por la cantidad de material, el tratamiento cuantitativo a partir de la definición de categorías conceptuales parece ofrecer una solución para la selección de las notas; pero en cambio no la ofrece para el análisis, ya que la gestión de colectivos -tal como creemos haber mostrado- es un "trabajo" discursivo que se despliega de manera regular pero no equivalente en todas las notas: cada artículo no es igual a otro; por eso, una selección aleatoria corre el riesgo cierto considerar como unidades iguales a textos que no lo son. Elegimos, entonces, evitar el problema que muy bien detectó Darnton (citado en Wijfjes, 2009: 4): “los cientistas sociales leen diarios como nadie lo hace, contando cada artículo como si fuera igual al otro, clasificándolo en relaciones cuantitativas (por ejemplo, negativas o positivas) con los partidos, las personas o las instituciones. $Y$ al hacer eso, pasan por alto la importancia única de ciertos artículos".

Más allá de eso, seleccionamos (en lo que sería una especie de sub-corpus) aquellas notas en las que los diarios se posicionan frente a (representando, hablando por) "la sociedad"/"el país"/"los argentinos". Originalmente, este punto completaba la comparación entre los medios.

El problema inmediato que se presentó se vincula con el tratamiento de los distintos tipos textuales, ya que eso impacta en el tratamiento de los propios medios y en el modo en que decidimos ordenar la exposición. Originalmente, había proyectado que la exposición avanzara por periódico (primero Clarín, después La Nación, después Página y después Crítica) y en un último parágrafo hacer una comparación. Cuando intenté estudiar los dispositivos de enunciación del discurso periodístico, había distinguido dos niveles de análisis: 
- el medio como "actor"; este corte tiene a su vez otra distinción entre el Enunciador institución y el Enunciador-Periodista.

- el medio como "superficie de emergencia" de discursos de otros actores (acá, puntualmente, considerando solamente las notas firmadas por individuos $\mathrm{u}$ organizaciones externas al diario).

Cuando se leen los diarios según esta lógica, el discurso del "medio" se vuelve aún más heterogéneo; no es que no pueda distinguirse una línea editorial, sino que las voces externas van colando, en algunos casos, opiniones disonantes; y en otros, más interesante aún, modos de gestión de colectivos diversos: por ejemplo, mientras que las editoriales de La Nación abundan en definir al "campo" como un todo orgánico, hay notas de actores externos que, aun estando a favor de la protesta, plantea la necesidad de considerar al campo en su heterogeneidad.

De modo que, según los tipos textuales analizados, varía también el objeto (el diario como actor, el diario como superficie de emergencia). Lógicamente, el punto de fuga de todos los artículos es la unidad que conforma el diario como objeto (textual e institucional).

Por otra parte, establecí un segundo corte de comparación, para poder manipular el corpus. Así como el propio conflicto, en los diarios también pueden percibirse "picos de intensidad" (en cantidad de notas publicadas y en el tipo de notas) en relación con los picos conflictivos. De ahí la posibilidad de un corte por fases: esto me permitía ordenar el capítulo dedicado al análisis de los cuatro diarios (capítulo 6) no en función de los "colectivos" sino de los períodos del conflicto, es decir, ofrecía un criterio extrínseco, que desbordaba los tipos textuales; y luego, desdoblar cada fase según cómo los medios gestionaron los colectivos "campo" y "pequeños productores". Idealmente, esto me facilitaba la intención de mantener el orden proyectado del capítulo (o sea, ir avanzando en el análisis y descripción por diarios). 
Aun así, persistió el problema de cómo ponderar los diferentes tipos textuales, ya que si ordenaba el análisis por "fases", la comparación no podía considerar la especificidad de cada género (consideraría, por ejemplo, de manera indistinta, las editoriales y las notas de opinión y a las crónicas de los piquetes rurales; y también, claro, las notas de los articulistas externos al medio).

La solución que implementé tiene que ver con el capítulo 7. Decidí tomar como referencia, en este último capítulo, sólo las notas editoriales y artículos de opinión de los periodistas de los diarios, y a partir de allí contrastar los modos en que en los dos tipos de discurso aparece la gestión de la "sociedad" y "los argentinos" como grandes interpretantes disputados. Es en estas notas, por lo demás, cuando el discurso periodístico se mimetiza con el político, cuando aparecen con regularidad componentes de politicidad. Por ejemplo, la inclusión del medio o del periodista en un "nosotros inclusivo". 


\section{ANEXO II: CORPUS DE ARTÍCULOS PERIODÍSTICOS}

\section{CLARÍN}

\begin{tabular}{|c|c|}
\hline & MARZO \\
\hline FECHA & TÍTULO/AUTOR \\
\hline $13 / 03 / 2008$ & $\begin{array}{l}\text { El campo arranca un paro de } 2 \text { días contra el aumento de las retenciones, por } \\
\text { Matías Longoni }\end{array}$ \\
\hline 13/03/2008 & $\begin{array}{l}\text { El objetivo fiscal aparece muy claro detrás de la suba de las retenciones, por } \\
\text { Daniel Fernández Canedo. }\end{array}$ \\
\hline $16 / 03 / 2008$ & Desafío político a Cristina. Por Ricardo Kirchbaum \\
\hline $16 / 03 / 2008$ & Retenciones, ni ángeles ni demonios, por Silvia Naishtat \\
\hline $17 / 03 / 2008$ & $\begin{array}{l}\text { Se endurece el paro del campo y entra menos ganado a Liniers, por Matías } \\
\text { Longoni. }\end{array}$ \\
\hline 19/03/2008 & Intransigencia y acumulación, por Ricardo Kirchbaum \\
\hline $21 / 03 / 2008$ & Las retenciones y la política, Kirchbaum, Carta del editor al lector \\
\hline $21 / 03 / 2008$ & El campo amenaza con más cortes y el bloqueo de puertos y tambos \\
\hline $21 / 03 / 2008$ & Los riesgos de una escalada, Punto de vista, de Gustavo Bazzan,: \\
\hline $21 / 03 / 2008$ & $\begin{array}{l}\text { En } 11 \text { días de protesta, se frenaron negocios por } 300 \text { millones de pesos, por } \\
\text { Matías Longoni }\end{array}$ \\
\hline $21 / 03 / 2008$ & Editorial: Negociar para superar el conflicto agrario \\
\hline $21 / 03 / 2008$ & La necesidad de un tiempo distinto. Columna editorial, Van der Kooy: \\
\hline $24 / 03 / 2008$ & Enrevesados, recuadro de Punto de Vista, por Daniel Juri \\
\hline $24 / 03 / 2008$ & Recuadro: Carrió: “No vi terratenientes en las rutas”. \\
\hline $24 / 03 / 2008$ & Aliados o enemigos, según las causas, \\
\hline $25 / 03 / 2008$ & Tres gobernadores quieren negociar ya con el campo \\
\hline $25 / 03 / 2008$ & Del editor al lector. Osvaldo Pepe: “Llegó la hora de negociar”. \\
\hline $25 / 03 / 2008$ & Pase de facturas, recuadro de Punto de Vista, por Silvia Naishtat \\
\hline $25 / 03 / 2008$ & $\begin{array}{l}\text { Daniel Juri. “Un conflicto que llegó a un límite y ya acorrala a los mandatarios } \\
\text { provinciales”. }\end{array}$ \\
\hline $25 / 03 / 2008$ & Editorial: “Evitar una escalada en el conflicto agrario” \\
\hline $26 / 03 / 2008$ & Del editor al lector. Kirchbaum. ¿Un choque a todo o nada? \\
\hline $26 / 03 / 2008$ & Hubo cacerolazos en la Capital y en muchas ciudades del Interior \\
\hline $26 / 03 / 2008$ & Ataques de grupos piqueteros a los manifestantes en la Plaza de Mayo. \\
\hline $26 / 03 / 2008$ & $\begin{array}{l}\text { El prolongado conflicto tiene un costo inevitable para Cristina, por E. Van der } \\
\text { Kooy }\end{array}$ \\
\hline $26 / 03 / 2008$ & $\begin{array}{l}\text { El campo intensificó el paro y se endureció después del discurso, por Matías } \\
\text { Longoni }\end{array}$ \\
\hline $26 / 03 / 2008$ & $\begin{array}{l}\text { Socios de la recuperación, peleados en el momento de mayor abundancia, por } \\
\text { Daniel Fernández Canedo }\end{array}$ \\
\hline $27 / 03 / 2008$ & Estereotipos y enfrentamientos, por Ricardo Roa, Del editor al lector. \\
\hline $27 / 03 / 2008$ & Género, recuadro “Punto de vista”, por Walter Curia. \\
\hline $27 / 03 / 2008$ & Un pleito que sigue escalando y que convoca viejos fantasmas, por Eduardo van \\
\hline
\end{tabular}




\begin{tabular}{|c|c|}
\hline & \\
\hline $27 / 03 / 2008$ & Piqueteros K y manifestantes se volvieron a enfrentar en la Plaza. \\
\hline $27 / 03 / 2008$ & Las cacerolas se escucharon otra vez en los barrios de la zona norte porteña. \\
\hline $28 / 03 / 2008$ & $\begin{array}{l}\text { El día que el peronismo volvió a hacerse oír en Parque Norte, por Santiago } \\
\text { Fioriti y Leonardo Míndez }\end{array}$ \\
\hline $28 / 03 / 2008$ & $\begin{array}{l}\text { Un cambio político de Cristina en el momento límite del conflicto, análisis de } \\
\text { Van der Kooy }\end{array}$ \\
\hline $28 / 03 / 2008$ & $\begin{array}{l}\text { Los dirigentes podrían levantar el paro, pero en los cortes se resisten, por } \\
\text { Matías Longoni. }\end{array}$ \\
\hline $28 / 03 / 2008$ & Las entidades, unidas en la cúpula pero con una interna al rojo vivo \\
\hline $28 / 03 / 2008$ & Después de oír el discurso, los chacareros ratificaron los cortes \\
\hline $28 / 03 / 2008$ & Cacerolas en Santa Fe y Callao, cantos de apoyo a Cristina en Plaza de Mayo \\
\hline $28 / 03 / 2008$ & $\begin{array}{l}\text { Consensos y discrepancias entre los dirigentes rurales, columna de Marcelo } \\
\text { Bonelli. }\end{array}$ \\
\hline $28 / 03 / 2008$ & Democracia e instituciones, por R.Kirchbaum: \\
\hline $29 / 03 / 2008$ & Una plaza sin exclusiones, carta del editor al lector, por Ricardo Roa \\
\hline $29 / 03 / 2008$ & Los ruralistas definen hoy si aceptan seguir dialogando, por Marcelo Canton. \\
\hline $29 / 03 / 2008$ & Objetivos, punto de vista por Walter Curia. \\
\hline $29 / 03 / 2008$ & $\begin{array}{l}\text { Dividida, la izquierda se movilizó para pegarle por igual al Gobierno y al } \\
\text { campo, por Santiago Fioriti. }\end{array}$ \\
\hline $29 / 03 / 2008$ & La convocatoria al diálogo, bien recibida por la gente. \\
\hline $29 / 03 / 2008$ & Lo importante en el último minuto, nota de opinión por Héctor Huergo. \\
\hline $29 / 03 / 2008$ & El campo opina de punta a punta. \\
\hline $29 / 03 / 2008$ & En las rutas de todo el país. \\
\hline $29 / 03 / 2008$ & Al norte de Rosario, los autoconvocados \\
\hline $30 / 03 / 2008$ & Sigue el paro: quedó en riesgo la negociación. \\
\hline $30 / 03 / 2008$ & ¿Otra oportunidad perdida?, Del editor al lector, por Ricardo Kirchbaum. \\
\hline $30 / 03 / 2008$ & Oportunidad para un diálogo que es indispensable, Editorial \\
\hline $30 / 03 / 2008$ & conflicto agravado y sin norte, por Eduardo Van der Kooy. \\
\hline $30 / 03 / 2008$ & $\begin{array}{l}\text { Cristina, De la Rúa y el ¿paralelo? Imposible entre dos cacerolazos, por Julio } \\
\text { Blank. }\end{array}$ \\
\hline $30 / 03 / 2008$ & El campo volvió al paro y está en riesgo el diálogo con el Gobierno. \\
\hline $30 / 03 / 2008$ & Los productores reclaman un gesto antes de volver a la negociación \\
\hline $30 / 03 / 2008$ & $\begin{array}{l}\text { Preocupación y reproches en Olivos por la crisis de las nuevas retenciones, por } \\
\text { Walter Curia. }\end{array}$ \\
\hline $30 / 03 / 2008$ & Chacareros y contratistas, la nueva clase media del interior, por Héctor Huego \\
\hline $30 / 03 / 2008$ & $\begin{array}{l}\text { Retenciones móviles anunciadas justo en el momento de la cosecha, por Silvia } \\
\text { Naishtat. }\end{array}$ \\
\hline $30 / 03 / 2008$ & Trabajo rural: muchos en negro y mal pagos, por Ismael Bermúdez \\
\hline $30 / 03 / 2008$ & $\begin{array}{l}\text { Por qué el "pool" de siembra es ahora el malo de la película, por Gustavo } \\
\text { Bazzan. }\end{array}$ \\
\hline $31 / 03 / 2008$ & $\begin{array}{l}\text { Si el campo no levanta el paro, el Gobierno dice que no dialogará, por Marcelo } \\
\text { Bonelli. }\end{array}$ \\
\hline $31 / 03 / 2008$ & Impuestos que se van en pagar deuda, por Daniel Muchnik \\
\hline $31 / 03 / 2008$ & $\begin{array}{l}\text { Cómo se puede destrabar el conflicto con el campo, columna de opinión de } \\
\text { Osvaldo Barsky. }\end{array}$ \\
\hline
\end{tabular}




\begin{tabular}{|l|l|}
\hline & \multicolumn{1}{|c|}{ ABRIL } \\
\hline Fecha & \\
\hline $01 / 04 / 2008$ & Cambió el tono ¿hay avance?, Por Ricardo Roa \\
\hline $02 / 04 / 2008$ & Cristina criticó al campo y a la prensa en un acto masivo \\
\hline $02 / 04 / 2008$ & Un discurso con fantasmas, por R. Roa \\
\hline $02 / 04 / 2008$ & $\begin{array}{l}\text { Los Kirchner dieron una muestra de poder refugiados en el peronismo, por } \\
\text { Eduardo Van der Kooy. }\end{array}$ \\
\hline $02 / 04 / 2008$ & $\begin{array}{l}\text { En el campo tienen dudas sobre la efectividad de las últimas medidas, Por Matías } \\
\text { Longoni. }\end{array}$ \\
\hline $03 / 04 / 2008$ & El diario de Yrigoyen, por Ricardo Roa. \\
\hline $03 / 04 / 2008$ & La tregua se decidió en Gualeguaychú frente a varios miles de productores. \\
\hline $03 / 04 / 2008$ & $\begin{array}{l}\text { Cristina, desafiada por un tiempo político nuevo y desconocido. Por Eduardo Van } \\
\text { der Kooy. }\end{array}$ \\
\hline $03 / 04 / 2008$ & Retenciones: errores políticos y técnicos con alto costo oficial \\
\hline $04 / 04 / 2008$ & $\begin{array}{l}\text { Empezó la batalla política por el relato de una crisis que dividió a la sociedad, } \\
\text { por Julio Blank. }\end{array}$ \\
\hline $04 / 04 / 2008$ & Libertad de prensa y democracia, Editorial \\
\hline $05 / 04 / 2008$ & Iniciativa del kirchnerismo para controlar a la prensa \\
\hline $05 / 04 / 2008$ & Cristina avaló un informe con críticas para el periodismo \\
\hline $06 / 04 / 2008$ & Los nuevos apellidos del campo, por Silvia Naishtat \\
\hline $06 / 04 / 2008$ & Encauzar el conflicto por vías institucionales, Editorial \\
\hline $08 / 04 / 2008$ & Quién discrimina a quién?, por Ricardo Roa \\
\hline $11 / 04 / 2008$ & $\begin{array}{l}\text { La miopía política contaminó un arma eficaz contra la discriminación Por: Julio } \\
\text { Blanck }\end{array}$ \\
\hline $11 / 04 / 2008$ & El mensajero del poder, columna de opinión, 11 de abril. Ricardo Roa \\
\hline $12 / 04 / 2008$ & Los dirigentes salieron a defender la negociación ante las bases \\
\hline $13 / 04 / 2008$ & Confrontación o diálogo, dilemas de la democracia, editorial. \\
\hline $15 / 04 / 2008$ & De antinomias y oportunistas, Ricardo Kirchbaum \\
\hline $18 / 04 / 2008$ & La ilusión de controlar la prensa Por José Antonio Romero Feris \\
\hline $25 / 04 / 2008$ & La realidad y el relato presidencial, por Ricardo Roa \\
\hline $25 / 04 / 2008$ & $\begin{array}{l}\text { Cristina rechazó críticas del campo y volvió a atacar a los medios, por Atilio } \\
\text { Bleta }\end{array}$ \\
\hline
\end{tabular}

\begin{tabular}{|c|l|}
\hline & \multicolumn{1}{c|}{ MAYO } \\
\hline FECHA & \multicolumn{1}{c|}{ TíTLO/AUTOR } \\
\hline $04 / 05 / 2008$ & Los que sufren el parate en el interior, \\
\hline $04 / 05 / 2008$ & Qué se esconde detrás del debate sobre la futura ley de radiodifusión \\
\hline $04 / 05 / 2008$ & Entre la crisis y el tercer hombre, por Eduardo Van der Kooy. \\
\hline $04 / 05 / 2008$ & La soja no es enemiga del maíz y del trigo, Héctor Huergo \\
\hline $05 / 05 / 2008$ & Al gran yuyo argentino, isalud!, por H. Huergo \\
\hline $08 / 05 / 2008$ & Crece la tensión: el campo volvió al paro. \\
\hline
\end{tabular}




\begin{tabular}{|c|c|}
\hline $08 / 05 / 2008$ & tura a pagar por todos, carta del editor al lector, por Ricardo Roa. \\
\hline $08 / 05 / 2008$ & La protesta vuelva a las rutas: frenan el paso de camiones con cereales. \\
\hline $09 / 05 / 2008$ & Ya nada será como fue, por R. Kirchbaum \\
\hline $09 / 05 / 2008$ & $\begin{array}{l}\text { La construcción del relato oficialista volvió a tropezar con la dura realidad, } \\
\text { análisis de Julio Blanck }\end{array}$ \\
\hline $11 / 05 / 2008$ & Los gobernadores abren una vía de diálogo con el campo. \\
\hline $11 / 05 / 2008$ & Responsabilidad institucional, por Ricardo Kirchbaum. \\
\hline $11 / 05 / 2008$ & Evitar la profecía autocumplida, por Fernando González. \\
\hline $11 / 05 / 2008$ & $\begin{array}{l}\text { Entre chacareros se respiran ganas de volver a los cortes totales de ruta, por } \\
\text { Luis Ceriotto. }\end{array}$ \\
\hline $15 / 05 / 2008$ & Cristina llamó al diálogo: hay debate en el campo \\
\hline $15 / 05 / 2008$ & Giro en el mensaje del gobierno que puede ayudar a destrabar el conflicto \\
\hline $15 / 05 / 2008$ & La protesta pasó de las tranqueras a la city, Silvia Naishtat. \\
\hline $15 / 05 / 2008$ & La incertidumbre volvió a colocar al dólar en la agenda de los argentinos. \\
\hline $16 / 05 / 2008$ & Nadie tiene ganado el paraíso, por Ricardo Kirchbaum. \\
\hline $16 / 05 / 2008$ & $\begin{array}{l}\text { Kirchner retocó la estrategia y el campo se arriesga al aislamiento, por Julio } \\
\text { Blanck }\end{array}$ \\
\hline $17 / 05 / 2008$ & El gran salto atrás, por Ricardo Roa. \\
\hline $18 / 05 / 2008$ & Cuanto peor... ipeor!, por Ricardo Kirchbaum. \\
\hline $18 / 05 / 2008$ & Negociar para desactivar el conflicto agrario, editorial. \\
\hline $18 / 05 / 2008$ & Una sociedad rehén del conflicto, columna editorial de Eduardo Van der Kooy \\
\hline $20 / 05 / 2008$ & $\begin{array}{l}\text { Salida a mano: cambiar el sistema de retenciones sin que se note mucho, por } \\
\text { Alcadio Oña. }\end{array}$ \\
\hline $22 / 05 / 2008$ & En la segunda línea del campo convive un gran mosaico político \\
\hline $22 / 05 / 2008$ & $\begin{array}{l}\text { De estancieras a piqueteras: el paro del agro llevó a las mujeres a las rutas, por } \\
\text { Natasha Niebkiewiat }\end{array}$ \\
\hline $22 / 05 / 2008$ & $\begin{array}{l}\text { Mejor, democracia de adversarios, columna central de opinión, por Hugo } \\
\text { Quiroga }\end{array}$ \\
\hline $23 / 05 / 2008$ & La base increible de un acuerdo, por Ricardo Kirchbaum \\
\hline $25 / 05 / 2008$ & Confianza y credibilidad, por Ricardo Kirchbaum \\
\hline $25 / 05 / 2008$ & El gobierno y la crisis de confianza, por Eduardo van der Kooy \\
\hline $26 / 05 / 2008$ & Rosario, Salta y después, Del editor al lector, por O. Pepe \\
\hline $26 / 05 / 2008$ & Chacareros de estrato social diferente y enojos parecidos, por Mauricio Bártoli. \\
\hline $26 / 05 / 2008$ & Quejas salteñas, entre las banderas foráneas y la “invasión” de micros \\
\hline $26 / 05 / 2008$ & Cristina encabezó su propia acto en Salta, pero evitó criticar al campo \\
\hline $26 / 05 / 2008$ & La oposición jugó su propio partido para capitalizar los efectos de la protesta \\
\hline $27 / 05 / 20085$ & Síndrome de “campofobia”, por Ricardo Roa. \\
\hline $27 / 05 / 20085$ & Expectativas, gente en las rutas y cortes esporádicos en el interior. \\
\hline $28 / 05 / 2008$ & El campo volvió al paro y no se venderán granos ni hacienda, por Matías Longoni \\
\hline $28 / 05 / 2008$ & Pagar entre todos, por Marcelo Cantón \\
\hline $29 / 05 / 2008$ & $\begin{array}{l}\text { Entre el paro del interior para el lunes y la alternativa del diálogo, nota de } \\
\text { Matías Longoni }\end{array}$ \\
\hline $29 / 05 / 2008$ & El conflicto del campo ya hace caer la actividad económica del interior \\
\hline $29 / 05 / 2008$ & El retorno del verticalismo, por Ricardo Roa \\
\hline $30 / 05 / 2008$ & El gobierno cambió las retenciones pero para el campo es insuficiente \\
\hline $30 / 05 / 2008$ & Los nuevos apotegmas, por Ricardo Roa \\
\hline
\end{tabular}




\begin{tabular}{|c|c|}
\hline & JUNIO \\
\hline FECHA & TITTULO/AUTOR \\
\hline $01 / 06 / 2008$ & El agricultor que se hizo visible, por Silvia Naishtat. \\
\hline $01 / 06 / 2008$ & Urge revertir la dinámica del enfrentamiento, editorial \\
\hline $01 / 06 / 2008$ & Los dilemas del poder bifronte, por Julio Blanck. \\
\hline 02/05/2008 & Sobre el país y el campo \\
\hline $03 / 06 / 2008$ & En un acto ante 30000 personas, los ruralistas avisaron: "Vamos a seguir" \\
\hline $03 / 06 / 2008$ & La pelea entre el Gobierno y el campo tiene historia, columna de Jorge Gelman. \\
\hline 06/05/2008 & Tras el discurso de Cristina los cortes de ruta se endurecieron \\
\hline $08 / 06 / 2008$ & Política e inteligencia, Del editor al lector, por Ricardo Kirchbaum. \\
\hline $08 / 06 / 2008$ & Una oportunidad para el diálogo y la grandeza, editorial \\
\hline $10 / 06 / 2008$ & El gobierno lanzó un plan social con el dinero de las retenciones \\
\hline $10 / 06 / 2008$ & ¿La tercera es la vencida?, por Ricardo Roa \\
\hline $10 / 06 / 2008$ & 90 dias después, no hay nada para festejar, por Julio Blank \\
\hline $12 / 06 / 2008$ & Costes de un juego peligroso \\
\hline $12 / 06 / 2008$ & Los camioneros profundizan la protesta y hay más de 200 cortes \\
\hline $12 / 06 / 2008$ & Horizontalidad \\
\hline $15 / 06 / 2008$ & Se agrava la crisis: hubo represión, detenidos y el campo volvió al paro \\
\hline $15 / 06 / 2008$ & Democracia y diálogo, por Ricardo Kirchbaum \\
\hline $15 / 06 / 2008$ & Extremar los esfuerzos para revertir el conflicto, Editorial \\
\hline $16 / 06 / 2008$ & $\begin{array}{l}\text { "Vamos a respetar la decisión que tomaron las cuatro entidades" entrevista a A } \\
\text { de Ángeli. }\end{array}$ \\
\hline $17 / 06 / 2008$ & El hartazgo de la gente, por Ricardo Roa, Del Editor al Lector. \\
\hline $17 / 06 / 2008$ & Masivo cacerolazo y protestas en todo el país. \\
\hline $17 / 06 / 2008$ & Rosario, Córdoba y Mendoza fueron los epicentros de las protestas en el interior. \\
\hline $17 / 06 / 2008$ & La mayoría, contra el enfrentamiento. Editorial \\
\hline $18 / 06 / 2008$ & En 45 minutos el ex presidente criticó 11 veces el papel de los medios \\
\hline $18 / 06 / 2008$ & $\begin{array}{l}\text { En su primera conferencia de prensa Kirchner habló de Cobos, das Neves y } \\
\text { Cristina }\end{array}$ \\
\hline $18 / 06 / 2008$ & Revertir la confrontación para superar la crisis \\
\hline $18 / 06 / 2008$ & El viejo truco de volver a la política, por Julio Blanck \\
\hline $18 / 06 / 2008$ & La sociedad argentina pide que le den una tregua, por Susana Decibe \\
\hline $18 / 06 / 2008$ & El pueblo no es una esencia estática, por Darío Roldán \\
\hline $19 / 06 / 2008$ & Cristina pidió ante una multitud en la Plaza que liberen las rutas. \\
\hline $19 / 06 / 2008$ & Todo un salvavidas político, por Ricardo Roa \\
\hline $19 / 06 / 2008$ & $\begin{array}{l}\text { El campo decidió extender el paro y le pidió respeto a la Presdienta, por Matías } \\
\text { Longoni }\end{array}$ \\
\hline
\end{tabular}




\begin{tabular}{|l|l|}
\hline $20 / 06 / 2008$ & El brete del ultraverticalismo, por Ricardo Kirchbaum \\
\hline $20 / 06 / 2008$ & Kirchner ya puso en movimiento su máquina de convencer diputados \\
\hline $21 / 06 / 2008$ & Un pensamiento que falta, por Ricardo Roa \\
\hline $21 / 06 / 2008$ & Cinco historias que reflejan el impacto de la falta de alimentos \\
\hline $21 / 06 / 2008$ & Los ruralistas ya comenzaron a presionar sobre los legisladores \\
\hline $22 / 06 / 2008$ & Un país pendiente del milagro político, por E. Van der Kooy. \\
\hline $22 / 06 / 2008$ & Esta es la oportunidad, por Ricardo Kirchbaum \\
\hline $22 / 06 / 2008$ & Los ruralistas, ¿deciden solos o asesorados?, por Silvia Naishtat \\
\hline $22 / 06 / 2008$ & En la segunda linea del campo convive un gran mosaico político \\
\hline $23 / 06 / 2008$ & La hora del desafío democrático, por Osvaldo Pepe \\
\hline $23 / 06 / 2008$ & La puja por una renta que financian los ciudadanos, por Daniel Muchnick \\
\hline $24 / 06 / 2008$ & El campo lo hizo: las contradicciones y sorpresas en 110 días de conflicto \\
\hline $24 / 06 / 2008$ & En las tolderías del Congreso reinan la cumbia y la cámara de fotos digital \\
\hline $24 / 06 / 2008$ & Por el conflicto con el campo, un nuevo escenario político, editorial \\
\hline
\end{tabular}

\begin{tabular}{|c|l|}
\hline & \\
\hline FECHA & \multicolumn{1}{c|}{ JULULIO } \\
\hline $01 / 07 / 2008$ & Que se doble pero no se rompa, Ricardo Kirchbaum. \\
\hline $02 / 07 / 2008$ & Cristina: "La timba financiera pasó a la timba de los alimentos" \\
\hline $03 / 07 / 2008$ & Un ciclo para que sea aprovechado, por Héctor Huergo \\
\hline $04 / 07 / 2008$ & Las acciones y las ausencias, por Ricardo Kirchbaum \\
\hline $04 / 07 / 2008$ & Kichner: "Yo no aprieto diputados, les recuerdo por qué los votaron" \\
\hline $04 / 07 / 2008$ & Diputados: el kirchnerismo impuso su proyecto y hoy lo lleva al recinto \\
\hline $05 / 07 / 2008$ & Ruralistas: vieron el debate por TV y dicen que los cambios no alcanzan \\
\hline $05 / 07 / 2008$ & Reaparecieron las cacerolas, pero no muchas \\
\hline $06 / 07 / 2008$ & Concesiones y conclusiones, por Ricardo Kirchbaum \\
\hline $06 / 07 / 2008$ & Nada será igual tras acercarse al abismo, por Silvia Naishtat \\
\hline $06 / 07 / 2008$ & El kirchnerismo cedió más y logró un ajustado triunfo en diputados \\
\hline $06 / 07 / 2008$ & El nuevo escenario acelera la "sojización", por Héctor Huergo \\
\hline $06 / 07 / 2008$ & Una resolución que terminó recalentando la interna de la mesa de enlace, por \\
\hline $06 / 07 / 2008$ & Marcelo Bonelli \\
\hline $07 / 07 / 2008$ & Tucumán: violencia con ruralistas, furia y escrache a diputados K \\
\hline $07 / 07 / 2008$ & En las provincias, calma y fastidio \\
\hline $07 / 07 / 2008$ & Un pool y un productor chico debaten frente a frente qué pasa en el campo \\
\hline $11 / 07 / 2008$ & Ficciones y realidades, por Ricardo Kirchbaum \\
\hline $11 / 07 / 2008$ & Compensaciones: les pagarían menos a los productores más chicos \\
\hline $11 / 07 / 2008$ & Desobediencia peronista: una ola que cada día crece un poco más \\
\hline $12 / 07 / 2008$ & Solá: "Moreno es un ignorante, Kirchner decididamente no lo es" \\
\hline $12 / 07 / 2008$ & Intolerancia y democracia, por Ricardo Kirchbaum. \\
\hline $13 / 07 / 2008$ & Ficción y realidad, por Fernando González \\
\hline $13 / 07 / 2008$ & Mucho cambió para los Kirchner, por Eduardo van der Kooy \\
\hline $14 / 07 / 2008$ & El conflicto del campo ya invadió Youtube \\
\hline
\end{tabular}




\begin{tabular}{|l|l|}
\hline $15 / 07 / 2008$ & El Gobierno y el campo buscan ganar la calle con dos actos \\
\hline $15 / 07 / 2008$ & Retenciones, el poder del Gobierno, por Alcadio Oña \\
\hline $16 / 07 / 2008$ & La calle fue del campo pero la ley saldría igual. \\
\hline $16 / 07 / 2008$ & Demasiados errores juntos, por Ricardo Roa \\
\hline $16 / 07 / 2008$ & El campo logró una respuesta masiva en el acto de Palermo \\
\hline $16 / 07 / 2008$ & El agro sacó ventaja en la calle, donde manda el PJ, por Silvia Naishtat \\
\hline $16 / 07 / 2008$ & Dos actos llenos de antagonismo que no son un buen presagio \\
\hline $16 / 07 / 2008$ & "Senadores, voten a favor del pueblo que representan" \\
\hline $16 / 07 / 2008$ & Otra vez un discurso para mantener la propia épica \\
\hline $16 / 07 / 2008$ & "Los productores no son nuestros enemigos" \\
\hline $16 / 07 / 2008$ & El Gobierno, en un microclima de euforia \\
\hline $16 / 07 / 2008$ & Las dos veredas: protagonistas enfrentados en un día caliente \\
\hline $16 / 07 / 2008$ & Por qué fueron: mucha pasión, pocas consignas y un fuerte orgullo patriótico \\
\hline $17 / 07 / 2008$ & Crisis política: con el voto negativo de Cobos el Senado rechazó las retenciones \\
\hline $17 / 07 / 2008$ & Una durísima derrota que pone al Gobierno frente a un futuro incierto \\
\hline $18 / 07 / 2008$ & Momentos de negociar y buscar consenso, editorial. \\
\hline
\end{tabular}




\section{LA NACIÓN}

\begin{tabular}{|c|c|}
\hline & MARZO \\
\hline FECHA & TÍTULO/AUTOR \\
\hline $16 / 03 / 2008$ & Nada para la sociedad, todo para el Estado. Por Mariano Grondona. \\
\hline $16 / 03 / 2008$ & El mundo y el submundo del kirchnerismo, por Joaquín Morales Solá \\
\hline $22 / 03 / 2008$ & Dura respuesta del agro, editorial \\
\hline $23 / 03 / 2008$ & "El paro de la unidad", comunicado de la Mesa de Enlace \\
\hline $23 / 03 / 2008$ & El gobierno se acerca bastante a una crisis política, por Carlos Pagni \\
\hline $24 / 03 / 2008$ & Cambios en el juego del poder, por Carlos Pagni \\
\hline $24 / 03 / 2008$ & De la protesta del campo al lenguaje de los fierros, por Fernando Laborda. \\
\hline $25 / 03 / 2008$ & Se agrava la protesta del agro y crece la tensión en el interior, por José Crettaz \\
\hline $26 / 03 / 2008$ & Cacerolazos e incidentes tras las críticas de la Presidenta al campo \\
\hline $26 / 03 / 2008$ & Incidentes tras el discurso presidencial \\
\hline $26 / 03 / 2008$ & Una cacería piquetera en pleno centro para poder ganar la Plaza \\
\hline $26 / 03 / 2008$ & Una forma de actuar que se agotó, por Carlos Pagni \\
\hline $26 / 03 / 2008$ & Los ruralistas profundizarán el reclamo, por José Crettaz \\
\hline $26 / 03 / 2008$ & El campo se siente decepcionado, por Gustavo Grobocopatel \\
\hline $26 / 03 / 2008$ & Hastío entre productores y turistas en el corte entrerriano \\
\hline $26 / 03 / 2008$ & La familia agropecuaria se moviliza en las rutas \\
\hline $26 / 03 / 2008$ & Provocar no resuelve los problemas, por Adrián Ventura. \\
\hline $26 / 03 / 2008$ & El paro del campo, editorial. \\
\hline $27 / 03 / 2008$ & Nuevos incidentes y protestas; generalizado llamado al diálogo \\
\hline $27 / 03 / 2008$ & El verdadero mensaje de las cacerolas, por Joaquín Morales Solá \\
\hline $27 / 03 / 2008$ & Fue una provocación, por Beatriz Sarlo \\
\hline $27 / 03 / 2008$ & Adhesión popular en Córdoba al paro \\
\hline $27 / 03 / 2008$ & $\begin{array}{l}\text { Nuevos choques de kirchneristas y caceroleros por el control de la Plaza, por Gabriel } \\
\text { Sued. }\end{array}$ \\
\hline $27 / 03 / 2008$ & Los riesgos de generalizar y dividir, por Eduardo Fidanza- \\
\hline $27 / 03 / 2008$ & En la 14 resistirán un posible desalojo, por Francisco Olivera \\
\hline $27 / 03 / 2008$ & Tamberos, obligados a tirar leche; algunos la regalan, por Fernando Bertello \\
\hline $27 / 03 / 2008$ & Los comerciantes de Junín acompañan la protesta, por Pablo Tomino \\
\hline $27 / 03 / 2008$ & El empresariado abogó por el diálogo, por Alejandro Rebossio \\
\hline $27 / 03 / 2008$ & Un discurso cargado de deslices, por Carlos Pagni. \\
\hline $27 / 03 / 2008$ & El agro le respondió a la Presidenta con sus cuadros técnicos, por José Crettaz.. \\
\hline $27 / 03 / 2008$ & Urge reconstruir el diálogo, Editorial. \\
\hline $28 / 03 / 2008$ & La Presidenta pidió que levanten el paro y ya hay acercamientos. \\
\hline $28 / 03 / 2008$ & La Presidenta llamó al campo a dialogar, por Mariana Verón. \\
\hline $28 / 03 / 2008$ & Una oración distinta de la del martes, por Joaquín Morales Solá \\
\hline $28 / 03 / 2008$ & El pecado original del matrimonio presidencial, por Fernando Laborda. \\
\hline $28 / 03 / 2008$ & Hora de gestos de paz, opinión, por Fernán Saguier. \\
\hline $28 / 03 / 2008$ & Los ruralistas debaten cómo seguir, por José Cretazz, \\
\hline
\end{tabular}




\begin{tabular}{|l|l|}
\hline $28 / 03 / 2008$ & Ni el pedido presidencial disipó la bronca en Gualeguaychpú, por Fernando Olivera \\
\hline $28 / 03 / 2008$ & Respaldo empresario al discurso \\
\hline $28 / 03 / 2008$ & Un dualismo inaceptable, por Álvaro Abós. \\
\hline $28 / 03 / 2008$ & No cede la protesta en la cuenca del salado, por Fernando Bertelo. \\
\hline $28 / 03 / 2008$ & La invitación al diálogo, Editorial \\
\hline $29 / 03 / 2008$ & El campo suspendió la huelga y emprendió una difícil negociación \\
\hline $29 / 03 / 2008$ & Un libreto nuevo, por José lgnacio Lladós. \\
\hline $29 / 03 / 2008$ & De pasado y de porvenir, por Santiago Kovadloff. \\
\hline $29 / 03 / 2008$ & Pesimismo del agro por las tratativas, por Mariana Verón. \\
\hline $29 / 03 / 2008$ & A pesar de las diferencias, los ruralistas se mantienen unidos, por José Crettaz, \\
\hline $29 / 03 / 2008$ & Con furia y decepción, los ruralistas retomaron el corte en Gualeguaychú \\
\hline $29 / 03 / 2008$ & El día en que la Plaza tuvo turnos para todos \\
\hline $29 / 03 / 2008$ & El gobierno está a tiempo de corregir el rumbo, por Cristian Mira \\
\hline $29 / 03 / 2008$ & La gesta de federalismo contra el centralismo, por Jorge Ugolini \\
\hline $30 / 03 / 2008$ & Volvió el paro y la Presidenta suspendió su visita a Londres. \\
\hline $30 / 03 / 2008$ & Un ciclo de política que parece haber terminado, por Joquín Morales Solá \\
\hline $30 / 03 / 2008$ & Los ruralistas retomaron la huelga, por Roberto Seifert \\
\hline $30 / 03 / 2008$ & Diálogo que no llegó a ser negociación, por Cristian Mira. \\
\hline $30 / 03 / 2008$ & Volvieron los cortes de ruta en el Interior. \\
\hline $30 / 03 / 2008$ & $\begin{array}{l}\text { Gualeguaychú, el piquete donde conviven el Rastrojero y las 4X4, por Francisco } \\
\text { Olivera. }\end{array}$ \\
\hline $30 / 03 / 2008$ & Quién es quién en el sector agropecuario, \\
\hline $30 / 03 / 2008$ & “No somos golpistas" dicen los nuevos militantes del cacerolazo, por Juan Pablo \\
& Morales y Agustín Cronenbold. \\
\hline $31 / 03 / 2008$ & Ante la gravedad de la crisis, el Gobierno analiza medidas. \\
\hline $31 / 03 / 2008$ & Condicionan la negociación por los cortes, por Mariana Verón \\
\hline $31 / 03 / 2008$ & Cada vez más fisuras en el frente oficial, por Carlos Pagni. \\
\hline $31 / 03 / 2008$ & La Iglesia, limitada a gestiones oficiosas \\
\hline $31 / 03 / 2008$ & Se endurece el reclamo en el interior bonaerense. \\
\hline
\end{tabular}

\begin{tabular}{|c|l|}
\hline & \multicolumn{1}{c|}{ ABRIL } \\
\hline FECHA & \multicolumn{1}{c|}{ TITULO/AUTOR } \\
\hline $01 / 04 / 2008$ & Compensarán a pequeños productores \\
\hline $01 / 04 / 2008$ & Un discurso diseñado para romper la unidad del campo. \\
\hline $01 / 04 / 2008$ & Negociar a destiempo, análisis, por Miguel Rodríguez Yebra. \\
\hline $01 / 04 / 2008$ & Gueleguaychú, tierra de descontento. \\
\hline $01 / 04 / 2008$ & El agro contribuye “mucho con el país”, según una encuesta \\
\hline $01 / 04 / 2008$ & Detrás de las protestas. \\
\hline $01 / 04 / 2008$ & Tras el anuncio, se acentuó el reclamo en las provincias. \\
\hline $01 / 04 / 2008$ & El país y la Plaza de Mayo, editorial \\
\hline $02 / 04 / 2008$ & El acto, un gesto de debilidad, por Joaquín Morales Solá \\
\hline $04 / 04 / 2008$ & La clara intención de dividir al campo, editorial \\
\hline $04 / 04 / 2008$ & El estado y el campo, por Enrique Martínez \\
\hline $05 / 04 / 2008$ & El odio como arma política, editorial. \\
\hline
\end{tabular}




\begin{tabular}{|l|l|}
\hline $05 / 04 / 2008$ & El campo ganó fuerza y apoyo de la ciudadanía, nota de opinión \\
\hline $05 / 04 / 2008$ & La tentación autoritaria, por Tomás Eloy Martínez \\
\hline $05 / 04 / 2008$ & Cristina Kirchner volvió a criticar a los medios de prensa \\
\hline $05 / 04 / 2008$ & El poroto de la discordia, por Malena Gainza \\
\hline $10 / 04 / 2008$ & ¿Cómo evaluar a los medios?, por Roberto Guareschi \\
\hline $10 / 04 / 2008$ & Advierten que los medios no son parte del sistema político \\
\hline $10 / 04 / 2008$ & La obsesión de controlar a la prensa, Editorial \\
\hline $10 / 04 / 2008$ & Otra vez, unitarios y federales, por Luis Alberto Romero \\
\hline $12 / 04 / 2008$ & Agricultores grandes y pequeños, editorial \\
\hline $14 / 04 / 2008$ & El campo insiste con la baja de retenciones, por José Cretazz \\
\hline $15 / 04 / 2008$ & En el interior, no bajan la guardia, por Mercedes Colombres \\
\hline $16 / 04 / 2008$ & Las batallas del campo, columna de opinión de María Sáenz Quesada. \\
\hline $16 / 04 / 2008$ & Para el campo, el tiempo de las reuniones tiene un límite \\
\hline $16 / 04 / 2008$ & Cristina dijo que las “elites” deben ser “solidaras”. Por Fernando García Soto. \\
\hline $19 / 04 / 2008$ & Vigilar a la prensa libre no es una tarea propia del Estado, editorial. \\
\hline $20 / 04 / 2008$ & Fuerte protesta de los ruralistas en Córdoba”. \\
\hline $20 / 04 / 2008$ & “En Las Parejas se empiezan a sentir los efectos de la crisis”. \\
\hline $20 / 04 / 2008$ & Una redistribución que no es tal. Editorial \\
\hline $20 / 04 / 2008$ & ¿Qué es peor, engañar o engañarse?, columna editorial de Mariano Grondona. \\
\hline $23 / 04 / 2008$ & Nuevas críticas de la presidenta al agro. Por José Cretazz. \\
\hline $25 / 04 / 2008$ & Por una política para todo el país. Editorial. \\
\hline $25 / 04 / 2008$ & Los golfos adultos, columna de opinión de Luis Gregorich. \\
\hline $26 / 04 / 2008$ & Retenciones, un privilegio de la Nación \\
\hline
\end{tabular}

\begin{tabular}{|c|l|}
\hline & \multicolumn{1}{|c|}{ MAYO } \\
\hline FECHA & \\
\hline $03 / 05 / 2008$ & La futura ley de radiodifusión, editorial \\
\hline $03 / 05 / 2008$ & Retenciones o desarrollo rural, ese es el dilema.. \\
\hline $04 / 05 / 2008$ & "Vuelve a tensarse la relación con el campo". \\
\hline $04 / 05 / 2008$ & Los productores dan un ultimátum, por Juan Pablo Morales desde Gualeguaychú. \\
\hline $04 / 05 / 2008$ & $\begin{array}{l}\text { En el interior de Buenos Aires, prometen resistir “hasta el final”, por Mercedes } \\
\text { Colombres,”. }\end{array}$ \\
\hline $06 / 05 / 2008$ & Nuevas críticas de la Presidenta a la prensa. \\
\hline $07 / 05 / 2008$ & Más tensión entre el agro y el Gobierno, por Mariana Verón. \\
\hline $07 / 05 / 2008$ & El campo se prepara para un nuevo plan de lucha, por José Crettaz. \\
\hline $07 / 05 / 2008$ & El costo emocional, por Guillermo Oliveto, opinión editorial \\
\hline $08 / 05 / 2008$ & “A nosotros no nos van a mover!” \\
\hline $09 / 04 / 2008$ & Una protesta cortó el tránsito de camiones que transportaban granos. \\
\hline $09 / 04 / 2008$ & Dos estilos enfrentados, por Carlos Pagni. \\
\hline $09 / 04 / 2008$ & Ofensiva del Gobierno ante la protesta, por Mariano Obarrio \\
\hline $09 / 04 / 2008$ & Serie de notas bajo el cintillo: EL paro del campo, \\
\hline $09 / 04 / 2008$ & El divorcio con la clase media, por Fernando Laborda. \\
\hline $09 / 04 / 2008$ & La imposibilidad de una historia común, por Eduardo Fidanza \\
\hline $10 / 05 / 2008$ & Endurecen el Gobierno y el campo su enfrentamiento. \\
\hline $10 / 05 / 2008$ & El agro busca “federalizar” la protesta, por Fernando Bertello. \\
\hline
\end{tabular}




\begin{tabular}{|l|l|}
\hline $10 / 05 / 2008$ & Las movilizaciones mantienen la fuerza de la protesta rural. \\
\hline $10 / 05 / 2008$ & La dignidad del campo, editorial. \\
\hline $12 / 05 / 2008$ & Un nuevo actor político. \\
\hline $12 / 05 / 2008$ & La clave pasa por querer participar, por Fernando Bertello. \\
\hline $12 / 05 / 2008$ & Los productores en un nuevo escenario, por Félix Sammartino. \\
\hline $24 / 05 / 2008$ & Sobre la supuesta existencia de la renta agraria, por Pedro Isern \\
\hline $25 / 05 / 2008$ & Un país mejor todavía es posible, por Sergio Berenztein. \\
\hline $25 / 05 / 2008$ & La luz se va apagando, por J. Morales Solá \\
\hline $25 / 05 / 2008$ & El agro expone su poder en Rosario \\
\hline $25 / 05 / 2008$ & La patria ante un nuevo desafío, editorial. \\
\hline $26 / 05 / 2008$ & Masivo respaldo al agro en Rosario, por José Crettaz. “ \\
\hline $26 / 05 / 2008$ & Críticas entre mate, bandera y bombos \\
\hline $26 / 05 / 2008$ & “Nadie nos pagó para venir acá”. \\
\hline $26 / 05 / 2008$ & “Soberbia, eso sobra” \\
\hline $26 / 05 / 2008$ & La pelea es de todos: " \\
\hline $26 / 05 / 2008$ & Una jornada que llegó para vivificar el sentido de la patria, por Luis Alberto Romero. \\
\hline $26 / 05 / 2008$ & La Presidenta llamó a la unidad nacional. \\
\hline $26 / 05 / 2008$ & Una movilización oficial para contrarrestar el acto en Rosario. \\
\hline
\end{tabular}

\begin{tabular}{|c|l|}
\hline & \multicolumn{1}{c|}{ JUNIO } \\
\hline FECHA & \\
\hline $01 / 06 / 2008$ & El campo, más duro, debate si prolonga la huelga \\
\hline $01 / 06 / 2008$ & La retracción económica golpea al interior \\
\hline $01 / 06 / 2008$ & Miguens: "La gente está harta de este conflicto" \\
\hline $02 / 06 / 2008$ & Fuerte presión de las bases para que se extienda el paro \\
\hline $02 / 06 / 2008$ & Se generaliza la crisis, por Carlos Pagni \\
\hline $02 / 06 / 2008$ & El agro aún tiene margen para no vender, por Fernando Bertello \\
\hline $03 / 06 / 2008$ & Buzzi pidió al Gobierno un cambio de rumbo (en tapa) \\
\hline $03 / 06 / 2008$ & Córdoba, impactó con la movilización de 80.000 personas \\
\hline $03 / 06 / 2008$ & Fuerte adhesión al paro del comercio y la industria. \\
\hline $03 / 06 / 2008$ & Cortes de ruta, bronca y tractores en Gualeguaychú. \\
\hline $04 / 06 / 2008$ & Cristina acusó a los pooles de siembra en un foro mundial \\
\hline $04 / 06 / 2008$ & La peor forma de enfriar la economía, por Morales Solá. \\
\hline $05 / 06 / 2008$ & Un nuevo actor dispara la radicalización del conflicto, por C. Pagni \\
\hline $07 / 06 / 2008$ & Violentas peleas en bloqueos de rutas \\
\hline $07 / 06 / 2008$ & Demonización de los pooles de siembra, editorial. \\
\hline $07 / 06 / 2008$ & Apunten a los pooles, nota de tapa del Suplemento Campo \\
\hline $08 / 06 / 2006$ & El agro ya tiene un partido y eventuales nuevos candidatos. \\
\hline $08 / 06 / 2006$ & Tres Arroyos, la tierra próspera en la que hoy cosechan bronca \\
\hline $09 / 06 / 2008$ & Condicionado levantamiento del paro \\
\hline $13 / 06 / 2008$ & Celebración del conflicto, por Martín Bohmer \\
\hline $14 / 06 / 2008$ & El conflicto y sus enseñanzas, por Fernán Saguier. \\
\hline $14 / 06 / 2008$ & Suplemento Campo: El futuro de la unidad. \\
\hline $14 / 06 / 2008$ & De protagonistas, técnicos e internas latentes. \\
\hline $14 / 06 / 2008$ & Cómo se toman las decisiones, por José Cretaz. \\
\hline
\end{tabular}




\begin{tabular}{|l|l|}
\hline $14 / 06 / 2008$ & Un país dividió en dos, por Jose Sammartino, \\
\hline $15 / 06 / 2008$ & "Después de una dramática jornada el campo decidió volver al paro".. \\
\hline $15 / 06 / 2008$ & Kirchner fue a la Plaza de Mayo al final de un día de cacerolazos \\
\hline $15 / 06 / 2008$ & Se endurecen los cortes en el interior \\
\hline $15 / 06 / 2008$ & Dos ciudades, una sola reacción. \\
\hline $15 / 06 / 2008$ & Gracias al gobierno, De Ángeli tuvo ayer su 17 de octubre, por Carlos Pagni \\
\hline $15 / 06 / 2008$ & La siembra del odio y del resentimiento, editorial \\
\hline $16 / 06 / 2008$ & El campo no es un partido, por Bartolomé de Vedia \\
\hline $17 / 06 / 2008$ & Conmovieron al país cacerolazos masivos en contra del Gobierno. \\
\hline $17 / 06 / 2008$ & Más tensión y cacerolazos en todo el país. \\
\hline $18 / 06 / 2008$ & Giro en la crisis: fue al congreso el aumento de las retenciones. \\
\hline $19 / 06 / 2008$ & El campo extiende el paro después de un duro ataque de la Presidenta. \\
\hline $19 / 06 / 2008$ & Nadie hizo tanto por dividir el país, por Joaquín Morales Solá. \\
\hline $19 / 06 / 2008$ & Cien días de irresponsabilidad, por Natalio Botana. \\
\hline $19 / 06 / 2008$ & La polémica entre Cristina y los caceroleros, por Mariano Grondona. \\
\hline $19 / 06 / 2008$ & Qué tiene la renta rural de extraordinaria \\
\hline $23 / 06 / 2008$ & El congreso y las retenciones. Editorial \\
\hline $28 / 06 / 2008$ & Retenciones y renta extraordinaria \\
\hline $28 / 06 / 2008$ & Prohibido crecer. \\
\hline $28 / 06 / 2008$ & \\
\hline $29 / 06 / 2008$ & Viaje al interior de los protagonistas, por Mariano Grondona \\
\hline $29 / 06 / 2008$ & No se debe gravar la renta financiera, editorial \\
\hline
\end{tabular}

\begin{tabular}{|c|l|}
\hline & \\
\hline FECHA & \multicolumn{1}{c|}{ JULIO } \\
\hline $05 / 07 / 2008$ & Para el agro, el proyecto oficial es insuficiente \\
\hline $05 / 07 / 2008$ & Sigue el estado de alerta en el interior \\
\hline $05 / 07 / 2008$ & Custodia piquetera en Olivos \\
\hline $05 / 07 / 2008$ & Violencia o diálogo, por Enrique Olivera \\
\hline $06 / 07 / 2008$ & Retenciones a pequeños productores, editorial \\
\hline $06 / 07 / 2008$ & Ya nada será como antes \\
\hline $06 / 07 / 2008$ & Los Kirchner creen que "pasó lo peor" \\
\hline $06 / 07 / 2008$ & La noche más larga del kirchnerismo \\
\hline $06 / 07 / 2008$ & Para el agro, el resultado de la votación no fue una derrota \\
\hline $06 / 07 / 2008$ & De Kirchner a Uribe, el otro modelo \\
\hline $09 / 07 / 2008$ & Se fracturó la CGT tras la reelección de Moyano \\
\hline $09 / 07 / 2008$ & Un símbolo de la crisis kirchnerista \\
\hline $12 / 07 / 2008$ & Solá: "Soy kirchnerista si ellos aceptan mi libertad de acción" \\
\hline $12 / 07 / 2008$ & El kirchnerismo avanza en el Senado \\
\hline $12 / 07 / 2008$ & Presión del agro para que el Senado rechace las retenciones \\
\hline $12 / 07 / 2008$ & Crece el malestar y en el interior vuelven las manifestaciones \\
\hline $12 / 07 / 2008$ & Anomia u orden público, editorial \\
\hline $13 / 07 / 2008$ & El destino de las retenciones está en manos de 7 senadores \\
\hline $13 / 07 / 2008$ & El agro espera reunir al menos a 60.000 personas \\
\hline
\end{tabular}




\begin{tabular}{|l|l|}
\hline $13 / 07 / 2008$ & Buzzi: "Está fracasando el modelo económico" \\
\hline $13 / 07 / 2008$ & La protesta tiene ritmo propio en Tucumán \\
\hline $13 / 07 / 2008$ & El nuevo mapa del poder peronista \\
\hline $13 / 07 / 2008$ & Fopea critica el trato a la prensa \\
\hline $13 / 07 / 2008$ & Retenciones: el deber de los senadores \\
\hline $13 / 07 / 2008$ & La paz social en la Argentina está en vilo \\
\hline $16 / 07 / 2008$ & Contundente acto del agro en Palermo \\
\hline $16 / 07 / 2008$ & "Aceptaremos el resultado, sea cual sea" \\
\hline $16 / 07 / 2008$ & Dos plazas, una misma nación \\
\hline $17 / 07 / 2008$ & $\begin{array}{l}\text { Tras una dramática sesión, el vicepresidente Cobos desempató la votación al } \\
\text { rechazar el proyecto oficial de retenciones }\end{array}$ \\
\hline $17 / 07 / 2008$ & Más de 15 horas que expusieron dos visiones antagónicas del país \\
\hline $17 / 07 / 2008$ & La derrota en su versión más increíble \\
\hline $17 / 07 / 2008$ & Radical K y caudillo de la zona sojera santiagueña \\
\hline $17 / 07 / 2008$ & La cultura del patoterismo \\
\hline
\end{tabular}




\section{PÁGINA/12}

\begin{tabular}{|c|c|}
\hline & MARZO \\
\hline FECHA & TITULO/AUTOR \\
\hline $15 / 03 / 2008$ & Peones rurales, por Alfredo Zaiat. \\
\hline $16 / 03 / 2008$ & Entrevista a Eduardo Buzzi, \\
\hline $16 / 03 / 2008$ & Dar vuelta la soja, por Mario Wainfeld. \\
\hline $16 / 03 / 2008$ & Polítca y Retenciones, por Marcelo Zlotogwiazda. \\
\hline $21 / 03 / 2008$ & El piquete está de moda" \\
\hline $21 / 03 / 2008$ & Descontrol rural, por Alejandra Dandan. \\
\hline $22 / 03 / 2008$ & Recordatorios, por J.M Pasquini Durán. \\
\hline $22 / 03 / 2008$ & Efecto riqueza, por Alfredo Zaiat. \\
\hline $23 / 03 / 2008$ & El dinero no hace la felicidad. \\
\hline $23 / 03 / 2008$ & El desafío, por Horacio Verbitsky. \\
\hline $23 / 03 / 2008$ & Los huevos de oro, por Mario Wainfeld. \\
\hline $23 / 03 / 2008$ & Crónica del piquete en Pergamino, por David Cufré. \\
\hline $24 / 03 / 2008$ & El que no llora no mama, por Fernando Krakowiak. \\
\hline $25 / 03 / 2008$ & Sigue el lock-out contra las retenciones, por Fernando Kracowiak. \\
\hline $26 / 03 / 2008$ & Una giornata particolare, por Mario Wainfeld \\
\hline $26 / 03 / 2008$ & No importa nada, recuadro de opinión, por Alfredo Zaiat. \\
\hline $26 / 03 / 2008$ & La plaza de las trillizas, por sandra russo. \\
\hline $26 / 03 / 2008$ & Piquete y cacerola en versión campestre, por Julián Bruchstein. \\
\hline $26 / 03 / 2008$ & No hay un solo campo, \\
\hline $26 / 03 / 2008$ & Contra la oligarquía del campo \\
\hline $26 / 03 / 2008$ & Unidos contra las retenciones \\
\hline $27 / 03 / 2008$ & Mandatos, por J.M. Pasquini Durán. \\
\hline $27 / 03 / 2008$ & El golpe inflacionario, por Alfredo Zaiat. \\
\hline $27 / 03 / 2008$ & La segunda batalla de las cacerolas, por Emilio Ruchansky. \\
\hline $27 / 03 / 2008$ & Momento de meditación, \\
\hline $27 / 03 / 2008$ & No a los agronegocios, por Mocase. \\
\hline $27 / 03 / 2008$ & La culpa es de la soja, Miguel Teubal \\
\hline $27 / 03 / 2008$ & "No se metan con el campo", \\
\hline $28 / 03 / 2008$ & Las cartas sobre la mesa, por Mario Wainfeld. \\
\hline $28 / 03 / 2008$ & "Contra el abuso latifundista”, por Alejandra Dandan. \\
\hline $28 / 03 / 2008$ & Dolor país, por Sandra Russo. \\
\hline $28 / 03 / 2008$ & “Acá todos somos el campo", \\
\hline $28 / 03 / 2008$ & Del monocultivo a las retenciones, \\
\hline $28 / 03 / 2008$ & El grito de figueroa alcorta", por Matías kulfas y \\
\hline $28 / 03 / 2008$ & La hija de la pavota", por pino Solanas \\
\hline $29 / 03 / 2008$ & Forjadores de la patria, por Alfredo Zaiat. \\
\hline $29 / 03 / 2008$ & Encrucijadas, por J.M. Pasquini Durán. \\
\hline $30 / 03 / 2008$ & Acero inoxidable, por Horacio Verbitsky. \\
\hline
\end{tabular}




\begin{tabular}{|l|l|}
\hline $30 / 03 / 2008$ & La asamblea más dura por Emilio Ruchansky. \\
\hline $30 / 03 / 2008$ & En el campo las espinas, por Mario Wainfeld. \\
\hline $30 / 03 / 2008$ & Hasta un elefante, columna de opinión de José Natanson. \\
\hline $30 / 03 / 2008$ & Nuevas memorias de marzo, por Nicolás Casullo. \\
\hline $30 / 03 / 2008$ & Estamos todos locos, por Ernesto Tenembaum \\
\hline $30 / 03 / 2008$ & Dias de déjà vu, por Fernando Krakowiak. \\
\hline $31 / 03 / 2008$ & Otro día agitado por el conflicto agrario. \\
\hline $31 / 03 / 2008$ & Primero lo primero, por Eduardo Aliverti. \\
\hline $31 / 03 / 2008$ & Diálogo y negociación, por Washington Uranga. \\
\hline $31 / 03 / 2008$ & $\begin{array}{l}\text { El frankenstein sojero contra su creador, entrevista a Norma Giarraca. Por } \\
\text { Javier Lorca. }\end{array}$ \\
\hline $31 / 03 / 2008$ & “Mas duros nos vamos a poner”. \\
\hline $31 / 03 / 2008$ & El lado oscuro del boom de la soja, por Darío Aranda. \\
\hline $31 / 03 / 2008$ & La ruta de la Federación Agraria, por Darío Aranda. \\
\hline
\end{tabular}

\begin{tabular}{|c|l|}
\hline & \multicolumn{1}{c|}{ ABRIL } \\
\hline FECHA & \multicolumn{1}{c|}{ TITULO/AUTOR } \\
\hline $01 / 04 / 2008$ & Sobre regateos y omisiones, por Mario Wainfeld. \\
\hline $01 / 04 / 2008$ & Los grobo sonríen, por alfredo zaiat. \\
\hline $01 / 04 / 2008$ & El capitalismo agrario y la captura de rentas, por Marcos Novaro. \\
\hline $01 / 04 / 2008$ & Cortes de ruta: no todo es lo mismo, por Roberto Gargarella. \\
\hline $01 / 04 / 2008$ & Lo histórico y lo actual, por Norberto galasso. \\
\hline $02 / 04 / 2008$ & LA GENTE EMPIEZA A CRITICAR AL CAMPO, por Raúl Kollman. \\
\hline $02 / 04 / 2008$ & LA PLAZA A RAS DEL PISO, por Mario Wainfeld. \\
\hline $02 / 04 / 2008$ & CONTRALUCES DEL CONTRACORTE, por Luis Bruchstein. \\
\hline $02 / 04 / 2008$ & ENTRE LA REPETICIÓN Y EL OLVIDO, por Ricardo Forster. \\
\hline $02 / 04 / 2008$ & OPORTUNIDAD DE REFLEXIONAR. \\
\hline $02 / 04 / 2008$ & UNA DISPUTA POR EL EXCEDENTE, por Alejandro Rofman \\
\hline $03 / 04 / 2008$ & ASADO Y PRESENTE, por Fernando Krakowiak. \\
\hline $03 / 04 / 2008$ & LA ASAMBLEA DE LA SOJA, por Alfredo Zaiat. \\
\hline $03 / 04 / 2008$ & EL ARGUMENTO DE LOS LIBERAL-DEMÓCRATAS, por Philipe Kitzberger y \\
& Sebastián Etchemendy. \\
\hline $03 / 04 / 2008$ & LA GUERRA DE LOS DISCURSOS POR EL CAMPO \\
\hline $03 / 04 / 2008$ & “La próxima llegamos a la Plaza”, crónica del acto en Armstrong. \\
\hline $05 / 04 / 2008$ & Pausas, por Paquini Durán. \\
\hline $05 / 04 / 2008$ & Pequeño productor, por Alfredo Zaiat. \\
\hline $06 / 04 / 2008$ & Más allá de los yuyos, por Mario Wainfeld \\
\hline $07 / 04 / 2008$ & En medio del campo, \\
\hline $07 / 04 / 2008$ & La historia se repite, por Ezequiel Adamovsky \\
\hline $10 / 04 / 2008$ & La polémica por un poroto \\
\hline $10 / 04 / 2008$ & Efectos del monocultivo, Por Héctor Sejenovich, Verónica Hendel y Ezequiel \\
& Grinber \\
\hline $10 / 04 / 2008$ & Ideología, intereses y democracia, por Guillermo Wierzba \\
\hline 0
\end{tabular}




\begin{tabular}{|l|l|}
\hline $13 / 04 / 2008$ & Punto de inflexión, por Horacio Verbitsky. \\
\hline $13 / 04 / 2008$ & El parto de un nuevo bloque de poder, por Alfredo Zaiat, \\
\hline $15 / 04 / 2008$ & Narración y objetividad, por Horacio González \\
\hline $16 / 04 / 2008$ & Qué clase de lucha es la lucha del campo?, por Eduardo Gruner \\
\hline $18 / 04 / 2008$ & El modelo del agronegocio. \\
\hline $19 / 04 / 2008$ & Fumosos, por José María Pasquini Durán \\
\hline $20 / 04 / 2008$ & El campo también significa trabajo infantil, por MarioWainfeld. \\
\hline $20 / 04 / 2008$ & Res pública, por Mario Wainfeld \\
\hline $20 / 04 / 2008$ & Un plan para las familias del campo, por Roberto Navarro \\
\hline $20 / 04 / 2008$ & Nueva historia vieja, por Nicolás Casullo \\
\hline $22 / 04 / 2008$ & Comunicación y libertad de expresión, por Washinton Uranga \\
\hline $24 / 04 / 2008$ & Sin arraigo no hay patria, escrita por Pueblos que laten \\
\hline $25 / 04 / 2008$ & No hay dos sin tres, por Mario Wainfeld. \\
\hline $26 / 04 / 2008$ & Redistribuciones, por Pasquini Durán. \\
\hline $26 / 04 / 2008$ & Es la política, por Alfredo Zaiat. \\
\hline $27 / 04 / 2008$ & La morada de los Fernández, por M. Wainfeld. \\
\hline $27 / 04 / 2008$ & Cisnes negros, por Mario Wainfeld. \\
\hline $27 / 04 / 2008$ & Lo que hay y lo peor, contratapa por J.P. Feinmann. \\
\hline
\end{tabular}

\begin{tabular}{|c|l|}
\hline & \multicolumn{1}{c|}{ MAYO } \\
\hline FECHA & \\
\hline $04 / 05 / 2008$ & No hay el campo, sino cuatro con internas, por Fernando Krakowiak. \\
\hline $04 / 05 / 2008$ & Actores ocultos, por H. Verbitsky \\
\hline $04 / 05 / 2008$ & Intereses comunes, por Horacio Verbitsky, \\
\hline $08 / 05 / 2008$ & La ley de la ruta, parte II \\
\hline $08 / 05 / 2008$ & El test de las retenciones, por Alfredo Zaiat \\
\hline $08 / 05 / 2008$ & Los aliados financieros de los grandes sojeros, por Raul Dellatorre \\
\hline $09 / 05 / 2008$ & Quién sufre con este paro, por Raul Dellatorre \\
\hline $10 / 05 / 2008$ & Lamento sojero donde antes había algodón, por David Cufré \\
\hline $10 / 05 / 2008$ & Este país ya no les sirve \\
\hline $10 / 05 / 2008$ & “Los ruralistas se volvieron locos". \\
\hline $10 / 05 / 2008$ & Aguantes, por J.M. Pasquini Durán. \\
\hline $10 / 05 / 2008$ & Invisibles, por Alfredo Zaiat. \\
\hline $17 / 05 / 2008$ & Cómo esconder millones de toneladas, por Raúl Dellatorre \\
\hline $17 / 05 / 2008$ & Altanerías, por J. M. Pasquini Durán \\
\hline $17 / 05 / 2008$ & Lugares comunes, por Alfredo Zaiat \\
\hline $11 / 05 / 2008$ & El día de la escarapela, por Horacio Verbitsky \\
\hline $23 / 04 / 2008$ & Ni con el gobierno ni con las entidades patronales “del campo \\
\hline $26 / 05 / 2008$ & “Si no hay soluciones, vuelven las acciones”, crónica del acto en Rosario \\
\hline $26 / 05 / 2008$ & Mucha agenda para un feriado, por Mario Wainfeld \\
\hline $26 / 05 / 2008$ & Campestres \\
\hline
\end{tabular}




\begin{tabular}{|l|l|}
\hline $26 / 05 / 2008$ & “El país no reconoce propietarios”, por Martín Piqué \\
\hline $26 / 05 / 2008$ & La oposición en la tribuna, por Werner Pertot \\
\hline $26 / 05 / 2008$ & A elegir, por Eduardo Aliverti \\
\hline $26 / 05 / 2008$ & De payadores y payasos, por José Natanson \\
\hline $26 / 05 / 2008$ & La parte por el todo, por Sandra Russo \\
\hline $27 / 05 / 2008$ & Cambio de lógica en un conflicto prolongado, por Raul Dellatorre \\
\hline $27 / 05 / 2008$ & La voz de los que no tienen voz, por Alejandro Rofman \\
\hline $27 / 05 / 2008$ & Empecemos a discutir la derecha, por Nicolás Caullo \\
\hline $27 / 05 / 2008$ & Suman presión las asambleas, por Sebastián Premici \\
\hline $28 / 05 / 2008$ & La espiral que no cesa, por Mario Wainfeld \\
\hline $28 / 05 / 2008$ & El campo protesta y la tierra trabaja, por Alfredo Zaiat \\
\hline $28 / 05 / 2008$ & El escenario del 25, por Ricardo Forster \\
\hline
\end{tabular}

\begin{tabular}{|c|l|}
\hline & \multicolumn{1}{c|}{ JUNIO } \\
\hline FECHA & \\
\hline $01 / 06 / 2008$ & Yuyos recalentados, por Mario Wainfeld \\
\hline $01 / 06 / 2008$ & Sábado, Gualeguaychú, música en el corte, por Mariano Blejman. \\
\hline $01 / 06 / 2008$ & ¿El campo al poder? Por José Natanson. \\
\hline $02 / 06 / 2008$ & Una única seguridad, por Eduardo Aliverti: \\
\hline $03 / 06 / 2008$ & Un campo más ancho de lo que parece \\
\hline $03 / 06 / 2008$ & Ricos transformados en piqueteros, por Rubén Dri. \\
\hline $04 / 06 / 2008$ & Reflexiones en el horizonte del campo, \\
\hline $04 / 06 / 2008$ & Democracia y conflicto social Norma Giarraca \\
\hline $04 / 06 / 2008$ & Una nueva junta nacional de granos, Marisa Duarte \\
\hline $05 / 06 / 2008$ & Las guerras de los dos lockouts \\
\hline $05 / 06 / 2008$ & La respuesta constitucional, por Roberto Gargarella \\
\hline $05 / 06 / 2008$ & El liberalismo y la sustracción, por Vicente Palermo \\
\hline $06 / 06 / 2008$ & Ya no todos piensan lo mismo, F. Krakowiak. \\
\hline $06 / 06 / 2008$ & Más allá del campo y las retenciones \\
\hline $07 / 06 / 2008$ & Maniobras, por Pasquini Durán \\
\hline $07 / 06 / 2008$ & Las recetas de los magos de la city, por Alfredo Zaiat. \\
\hline $08 / 06 / 2008$ & Crónica de un día cortado \\
\hline $09 / 06 / 2008$ & Podría pasar, por Eduardo Aliverti \\
\hline $10 / 06 / 2008$ & Ofensiva, por Pasquini Durán. \\
\hline $10 / 06 / 2008$ & Sobre el modelo y la radicalización, \\
\hline $10 / 06 / 2008$ & Sobre los usos y abusos del “campo", por Juan Manuel Abal Medina \\
\hline $10 / 06 / 2008$ & La construcción de la “patria” sojera, por Jorge Altamira \\
\hline $13 / 06 / 2008$ & No es así, Alfredo Zaiat \\
\hline $14 / 06 / 2008$ & Ciclos, por Pasquini Durán \\
\hline $15 / 06 / 2008$ & Otro lockout para festejar el día del Padre, por David Cufré. \\
\hline $15 / 06 / 2008$ & Los yuyos de la amargura, Mario Wainfeld. \\
\hline $15 / 06 / 2008$ & Radiografía de la pampa, por Horacio Verbitsky. \\
\hline $15 / 06 / 2008$ & Una tarde de cacerolas, por Diego Martínez. \\
\hline $17 / 06 / 2008$ & Contraataque K con otro acto en Plaza de Mayo. \\
\hline $17 / 06 / 2008$ & Sobre el lenguaje y las instituciones, \\
\hline $17 / 06 / 2008$ & Gelatina institucional, por José Natanson: \\
\hline
\end{tabular}




\begin{tabular}{|l|l|}
\hline $17 / 06 / 2008$ & “No respondemos a las entidades", por Laura Vales. \\
\hline $17 / 06 / 2008$ & Si no supiste amar, por José Natanson. \\
\hline $18 / 06 / 2008$ & Más, por Pasquini Durán \\
\hline $18 / 06 / 2008$ & Un país sin historia, por Luis Bruchstein \\
\hline $19 / 06 / 2008$ & Las palabras de la plaza, \\
\hline $19 / 06 / 2008$ & Las mil caras de la “otra gente" en la Plaza, \\
\hline $19 / 06 / 2008$ & Provocación a quien? Por Sandra Russo. \\
\hline $21 / 06 / 2008$ & "Muchos pretenden ser jeques árabes" \\
\hline $21 / 06 / 2008$ & La política en manos de la oposición mediática \\
\hline $22 / 06 / 2008$ & La salida al Congreso y a la calle, Mario Wainfeld. \\
\hline $22 / 06 / 2008$ & Soberbia, por Horacio Verbitsky \\
\hline $22 / 06 / 2008$ & De “rebeliones y sus significados" \\
\hline $22 / 06 / 2008$ & Los "peones" de sol a sol \\
\hline $22 / 06 / 2008$ & El grito de Alcorta: 25 de junio de 1912, por Norma Giarraca. \\
\hline $22 / 06 / 2008$ & El 'partido del campo' y las nuevas formas de la restauración, por Ricardo \\
& Forster \\
\hline $25 / 06 / 2008$ & La rapiña del "campo", por el Consejo Asesor Indígena \\
\hline $25 / 06 / 2008$ & La violencia legítima, por Marcos Novaro \\
\hline $25 / 06 / 2008$ & Los medios son parte del conflicto, por María Cristina Mata \\
\hline $29 / 06 / 2008$ & Que la soja no tape la realidad del campo \\
\hline
\end{tabular}

\begin{tabular}{|c|l|}
\hline & \multicolumn{1}{c|}{ JULIO } \\
\hline FECHA & \\
\hline $05 / 07 / 2008$ & La primera, por Horacio Verbitsky \\
\hline $05 / 07 / 2008$ & Volver a empezar, por Daniel Miguez \\
\hline $05 / 07 / 2008$ & Espejo y horizonte, por Mario Wainfeld \\
\hline $05 / 07 / 2008$ & La redistribución de la palabra, por Martín Piqué \\
\hline $06 / 07 / 2008$ & Rutinas que dan gusto, por Mario Wainfeld \\
\hline $06 / 07 / 2008$ & Siempre fuimos compañeros \\
\hline $10 / 07 / 2008$ & A la ley de juego, quiero retruco \\
\hline $11 / 07 / 2008$ & El piquete que está solo y espera, por Mariano Blejman \\
\hline $12 / 07 / 2008$ & Concentración, por A. Zaiat. \\
\hline $12 / 07 / 2008$ & Banderas, por Sandra Russo \\
\hline $13 / 07 / 2008$ & La tierra del estanciero, por Mario Rappoport. \\
\hline $13 / 07 / 2008$ & Entre Ríos viceversa, por Mariano Blejman \\
\hline $13 / 07 / 2008$ & Los gordos de 20.000 hectáreas \\
\hline $14 / 08 / 2008$ & Kirchner y los intelectuales \\
\hline $14 / 08 / 2008$ & Las comillas y la revuelta de las palabras \\
\hline $16 / 07 / 2008$ & Manifestaciones, por Pasquini Durán \\
\hline $16 / 07 / 2008$ & Dos actos en simultáneo antes de que sesione el senado, por Mario Wainfeld \\
\hline $16 / 07 / 2008$ & La marcha de los invisibles, por Luis Bruchstein \\
\hline $16 / 07 / 2008$ & Del otro lado del zoológico, por Marta Dillon. \\
\hline $16 / 07 / 2008$ & Dos marchas, dos vidas, por Alejandra Dandan \\
\hline $18 / 07 / 2008$ & El cuentito, por Sandra Russo \\
\hline $18 / 07 / 2008$ & Agro, economía y negocios, por Claudio Scaletta. \\
\hline $20 / 07 / 2008$ & ¿Tuvo sentido el conflicto?, por Edgardo Mocca \\
\hline
\end{tabular}




\section{CRÍTICA DE LA ARGENTINA}

\begin{tabular}{|c|c|}
\hline & MARZO \\
\hline FECHA & TITULO/AUTOR \\
\hline $15 / 03 / 2008$ & Arrancó la semana santa para el campo \\
\hline $16 / 03 / 2008$ & Más espinas entre el campo y el Gobierno \\
\hline $16 / 03 / 2008$ & "El campo protesta como las privatizadas", entrevista a Mario Rapoport \\
\hline $18 / 03 / 2008$ & Pago fácil, por Maximiliano Montenegro \\
\hline $18 / 03 / 2008$ & El campo no es la oligarquía, por Eduardo Buzzi \\
\hline $18 / 03 / 2008$ & El campo no para de parar \\
\hline $19 / 03 / 2008$ & "Paró el campo, nomás!". \\
\hline $20 / 03 / 2008$ & Los militantes de tierra adentro, por Maru Ludueña \\
\hline $20 / 03 / 2008$ & El campo va a un paro sin fin \\
\hline $21 / 03 / 2008$ & La tropilla de Néstor cabalga por el campo \\
\hline $21 / 03 / 2008$ & El piquetero que no era piquetero ni rural \\
\hline $21 / 03 / 2008$ & El pac-man va por los periodistas \\
\hline $21 / 03 / 2008$ & Riña de gallos por las retenciones \\
\hline $22 / 03 / 2008$ & Tanque australiano, palangana y cucharita, por M. Montenegro \\
\hline $22 / 03 / 2008$ & Guerra de camiones vs. Tractores \\
\hline $22 / 03 / 2008$ & Muchos tuvimos que ir al psicólogo pa' que nos sacara el nerviosismo \\
\hline $23 / 03 / 2008$ & "El modelo corre un serio peligro", entrevista a Eduardo Curia \\
\hline $23 / 03 / 2008$ & Dueños de la tierra, por Agustín Álvarez \\
\hline $23 / 03 / 2008$ & Medio complicado, por Diego Schurman \\
\hline $24 / 03 / 2008$ & Chacareros y choferes de armas tomar, por Diego Genoud \\
\hline $24 / 03 / 2008$ & Los tamberos se sumarán hoy al paro \\
\hline $24 / 03 / 2008$ & "La pregunta es para qué se usan las retenciones", entrevista a Silvio Corti \\
\hline $25 / 03 / 2008$ & El campo se urbaniza: arrancan los cacerolazos \\
\hline $25 / 03 / 2008$ & En la ruta del choque, por Susana Viau \\
\hline $26 / 03 / 2008$ & Habló Cristina y Cosechó tempestades \\
\hline $26 / 03 / 2008$ & La única verdad no es la realidad, Jorge Lanata. \\
\hline $26 / 03 / 2008$ & "Este es el piquete de la abundancia" \\
\hline $26 / 03 / 2008$ & Las cacerolas en la guerra gaucha \\
\hline $26 / 03 / 2008$ & Se fueron todos, por Martín Caparrós \\
\hline $27 / 03 / 2008$ & “Una revancha para Cristina”, Nicolás Wiñazki \\
\hline $27 / 03 / 2008$ & "Los batatas modelo 2008" \\
\hline $27 / 03 / 2008$ & Sin quererlo, vuelvo a quedar del lado K, por Eduardo de la Serna \\
\hline $27 / 03 / 2008$ & El juego de los errores, por Martín Caparró. \\
\hline $27 / 03 / 2008$ & "El estado debe intervenir más", entrevista a Mercedes Marcó del Pont \\
\hline $27 / 03 / 2008$ & Las retenciones no son el problema, columna por Claudio Lozano. \\
\hline $27 / 03 / 2008$ & Soberbia, por Jorge Lanata, Contratapa. \\
\hline $27 / 03 / 2008$ & Tractorazo a ritmo de cuarteto \\
\hline $27 / 03 / 2008$ & Más de cien cortes en todo el país \\
\hline
\end{tabular}




\begin{tabular}{|l|l|}
\hline $28 / 03 / 2008$ & “Les pido que levanten el paro para dialogar”. \\
\hline $28 / 03 / 2008$ & El día que los camioneros pasaron. \\
\hline $28 / 03 / 2008$ & Las protestas, entre las cacerolas y los blogs \\
\hline $28 / 03 / 2008$ & Cuando los gauchos vienen bajando \\
\hline $28 / 03 / 2008$ & Un dirigente que vale por dos, por Natalia Suazo \\
\hline $29 / 03 / 2008$ & Amigos y enemigos, por Maximiliano Montenegro. \\
\hline $29 / 03 / 2008$ & Otro fin de semana en alerta \\
\hline $29 / 03 / 2008$ & A la moda de Van Damme, por Ariel Palacios. \\
\hline $29 / 03 / 2008$ & Cansado de llorar por Cris, por Eduardo Blaustein \\
\hline $30 / 03 / 2008$ & Pocos palos y mucha variedad de zanahorias. \\
\hline $30 / 03 / 2008$ & El clima del conflicto, recuadro de opinión, por Ignacio Miri. \\
\hline $30 / 03 / 2008$ & Paro, piquete y un poco de diálogo \\
\hline $30 / 03 / 2008$ & Hay muchas diferencias tranqueras adentro \\
\hline $30 / 03 / 2008$ & Una propuesta para solucionar la crisis, por Nicolás Salvatore. \\
\hline $30 / 03 / 2008$ & Lo bautizaron el segundo Grito de Alcorta, por Mariano Martín. \\
\hline $30 / 03 / 2008$ & Se viene una etapa muy complicada”, entrevista a Buzzi. \\
\hline $30 / 03 / 2008$ & El tiempo no para, por Susana Viau \\
\hline $31 / 03 / 2008$ & Hasta aquí llegó el amor (antes de la guerra), por Diego Genoud. \\
\hline $31 / 03 / 2008$ & Cristina y el sueño de la Plaza de Mayo propia. \\
\hline $31 / 03 / 2008$ & Piquete duro para esperar la oferta, por Agustín Álvarez. \\
\hline $31 / 03 / 2008$ & Lo que hay que saber para entender el conflicto campo vs. Gobierno. \\
\hline $31 / 03 / 2008$ & Con buena leche se mantiene la unidad, \\
\hline $31 / 03 / 2008$ & Entre sojización y cacerolas, días extraños por Maristella Svampa \\
\hline $31 / 03 / 2008$ & La red de 'gringos' autoconvocados, por Mauro Federico. \\
\hline $31 / 03 / 2008$ & Qué buscan y qué defienden. \\
\hline
\end{tabular}

\begin{tabular}{|c|l|}
\hline & \multicolumn{1}{c|}{ ABRIL } \\
\hline FECHA & \multicolumn{1}{c|}{ TITULO/AUTOR } \\
\hline $01 / 04 / 2008$ & “No se piensen como propietarios del país”, por Diego Genoud \\
\hline $01 / 04 / 2008$ & Itinerarios. \\
\hline $01 / 04 / 2008$ & Una medida para los más chicos, por Agustín Álvarez \\
\hline $01 / 04 / 2008$ & Error, por Maximiliano Montenegro. \\
\hline $01 / 04 / 2008$ & No hay un plan, por Nicolás Arceo \\
\hline $01 / 04 / 2008$ & Poroto de la discordia, por Daniel Raffo \\
\hline $01 / 04 / 2008$ & Hay que ser ingenioso, por Ricardo Delgado \\
\hline $01 / 04 / 2008$ & Es difícil de aplicar, por Javier González Fraga \\
\hline $01 / 04 / 2008$ & Paro hasta el miércoles, \\
\hline $01 / 04 / 2008$ & El campo intelectual no quiere parar \\
\hline $02 / 04 / 2008$ & “No agravien más al pueblo, dejen las rutas”, \\
\hline $02 / 04 / 2008$ & Todos unidos contra la soja, por Marcelo Larraquy. \\
\hline $02 / 04 / 2008$ & No sólo de aparato vive la Plaza, por Eduardo Blaustein. \\
\hline $02 / 04 / 2008$ & Solos y solas, por Alejandro Seselovsky. \\
\hline $02 / 04 / 2008$ & Durmiendo con el enemigo. \\
\hline
\end{tabular}




\begin{tabular}{|c|c|}
\hline $02 / 04 / 2008$ & La plaza es un pañuelo, columna de opinión de Susana Viau \\
\hline $02 / 04 / 2008$ & Campo fértil para negociar una tregua, \\
\hline $02 / 04 / 2008$ & Un Plan Nacional Agropecuario, por Claudio Lozano \\
\hline $02 / 04 / 2008$ & Falta debate, columna de opinión de Eduardo Azcuy Ameghino \\
\hline $02 / 04 / 2008$ & En la ruta de los cortes, por Josefina Licitra \\
\hline 03/04/2008 & Cosecha final \\
\hline 03/04/2008 & La gauchada dura treinta días \\
\hline $03 / 04 / 2008$ & Y en el medio de mi pecho, todo el rencor para Cristina, por Daniel Capalbo, \\
\hline $03 / 04 / 2008$ & Soldado que huye \\
\hline $03 / 04 / 2008$ & Los costos del paro \\
\hline $03 / 04 / 2008$ & Cuasi carta cuasi abierta a la señora Cuasi, por Martín Caparrós \\
\hline $03 / 04 / 2008$ & Sexo \& Política. \\
\hline $03 / 04 / 2008$ & El juego a la derecha, por Reynaldo Sietecase. \\
\hline $04 / 04 / 2008$ & Quién paga \\
\hline $04 / 04 / 2008$ & Cristina contra los poderosos \\
\hline $05 / 04 / 2008$ & ¿Nace el partido del campo?, por Damian Glanz. \\
\hline $05 / 04 / 2008$ & La capital nacional del piquete, por Diego Genoud. \\
\hline $05 / 04 / 2008$ & Una sencilla descomunal maraña, por Emilio García Mendez \\
\hline $05 / 04 / 2008$ & "Tienen prohibido dar buenas noticias" \\
\hline $05 / 04 / 2008$ & "Acordamos con Cristina", entrevista a Félix Schuster \\
\hline $05 / 04 / 2008$ & Nunca alcanza, por Jorge Lanata \\
\hline $06 / 04 / 2008$ & Una de generales y multimediáticos, por Jorge Lanata \\
\hline $09 / 04 / 2008$ & Más allá de las falsas antinomias, por Miguel Bonasso \\
\hline $14 / 04 / 2008$ & Clarines de guerra, por Diego Schurman \\
\hline $14 / 04 / 2008$ & $\begin{array}{l}\text { "El estado tiene que tener mayoría en Papel Prensa", entrevista a Gabriel } \\
\text { Mariotto }\end{array}$ \\
\hline $19 / 04 / 2008$ & No ata los perros con chorizos, por Maximiliano Montenegro \\
\hline $19 / 04 / 2008$ & Anuncio para seducir a los más chicos. \\
\hline $20 / 04 / 2008$ & Patinando por el largo camino de la tregua \\
\hline $20 / 04 / 2008$ & ¿Qué campo queremos?, por Eduardo Azcuy Amghino, \\
\hline $21 / 04 / 2008$ & $\begin{array}{l}\text { El campo tiene bronca y se prepara para dar pelea, por Rodolfo González } \\
\text { Arzac. }\end{array}$ \\
\hline $21 / 04 / 2008$ & “Autoconvocados: ‘Si hay que volver a las ruta, volvemos”. \\
\hline $21 / 04 / 2008$ & “Estábamos armados para resistir”, entrevista a Alfredo De Ángeli \\
\hline $23 / 04 / 2008$ & La teoría de los dos demonios, por Diego Genoud \\
\hline $25 / 04 / 2008$ & Cristina y su planteo diario \\
\hline $26 / 04 / 2008$ & La versión K de civilización o barbarie, por Maristella Svampa \\
\hline $27 / 04 / 2008$ & Las entidades por el sí, los productores no tanto. \\
\hline $28 / 04 / 2008$ & "El campo no le cree al gobierno" \\
\hline
\end{tabular}

\begin{tabular}{|c|c|}
\hline & MAYO \\
\hline FECHA & TITULO/AUTOR \\
\hline
\end{tabular}




\begin{tabular}{|l|l|}
\hline $04 / 05 / 2008$ & “Este es el corralito del campo". \\
\hline $04 / 05 / 2008$ & ¿Donde quiere llegar, Kirchner?”. \\
\hline $05 / 05 / 2008$ & $\begin{array}{l}\text { Cosecharás tu siembra, por Alejandro Bercovich, Claudio Zlotnik y Mariano } \\
\text { Martin. }\end{array}$ \\
\hline $05 / 05 / 2008$ & No al pool de siembra. Entrevista a Carlos Bara, autoconvocado. \\
\hline $05 / 05 / 2008$ & "La gente dijo acá se acabó"m etrevista a Ángel De Ángeli \\
\hline $08 / 05 / 2008$ & Una sola ruta que separa dos Argentinas \\
\hline $09 / 05 / 2008$ & La segunda guerra rural arrancó en el puerto \\
\hline $09 / 05 / 2008$ & Gualeguaychú ataca \\
\hline $12 / 05 / 2008$ & Cuando la realidad no es la única verdad \\
\hline $12 / 05 / 2008$ & ¿De qué polarización hablamos?, por Maristella Svampa. \\
\hline $16 / 05 / 2008$ & Los tractores vienen marchando, por Susana Viau \\
\hline $19 / 05 / 2008$ & Masivo escrache en Villa María. \\
\hline $19 / 05 / 2008$ & Viaje al interior de la otra cosecha perdida, por Andrés Fidanza. \\
\hline $20 / 05 / 2008$ & El campo hizo otra gauchada \\
\hline $26 / 05 / 2008$ & Una multitud celebró el 25 de mayo con el campo \\
\hline $26 / 05 / 2008$ & Gobernar en democracia es reconocer el derecho a decir no, Jorge Lanata. \\
\hline $26 / 05 / 2008$ & Encuentro de dos mundos, por Rodolfo González Arzac. \\
\hline $26 / 05 / 2008$ & “Nos hicieron cartera como a un yacaré”, reseña sobre el discurso de De \\
\hline $26 / 05 / 2008$ & Yo no soy el Gobierno, por Miguel Bonasso \\
\hline
\end{tabular}

\begin{tabular}{|c|l|}
\hline FECHA & \multicolumn{1}{c|}{ TITULO/AUTOR } \\
\hline $01 / 06 / 2008$ & "Los del gobierno son unos verdaderos bandidos", entrevista. \\
\hline $02 / 06 / 2008$ & Engordar el chanchito para tener más aguante. \\
\hline $02 / 06 / 2008$ & $\begin{array}{l}\text { "No estamos en contra de los pooles de siembra". Entrevista a Miguel } \\
\text { Saredi,. }\end{array}$ \\
\hline $03 / 06 / 2008$ & Armstrong, pueblo chico, acto grande. Por Rodolfo Gonzalez Arzac. \\
\hline $08 / 06 / 2008$ & "Sin las retenciones seríamos jeques árabes", entrevista. \\
\hline $08 / 06 / 2008$ & ¿Quién dijo que no se puede debatir este conflicto? \\
\hline $08 / 06 / 2008$ & El Gobierno discute quién gobierna, por Jorge Lanata \\
\hline $08 / 06 / 2008$ & Ruralistas le hacen un corte a la Mesa \\
\hline $09 / 06 / 2008$ & Los números de la Federación Agraria \\
\hline $10 / 06 / 2008$ & Un golpe de efecto para ponerle un moño \\
\hline $10 / 06 / 2008$ & "No atamos los perros con chorizos", entrevista. \\
\hline $12 / 06 / 2008$ & Aquí no ha pasado nada, ni nadie. \\
\hline $12 / 06 / 2008$ & Trastienda del paro. \\
\hline $15 / 06 / 2008$ & $\begin{array}{l}\text { El conflicto del campo aceleró los cambios en las comunicación del } \\
\text { Gobierno, por Diego Schurman. }\end{array}$ \\
\hline $15 / 06 / 2008$ & Néstor fue a tomar la plaza, por Nicolás Wiñazki \\
\hline $15 / 06 / 2008$ & Gaucho preso solo sirve para otra guerra \\
\hline $15 / 06 / 2008$ & Una tarde fría que se cocinó a la cacerola \\
\hline $18 / 06 / 2008$ & Cristina los mandó a llorar al Congreso \\
\hline
\end{tabular}




\begin{tabular}{|l|l|}
\hline $18 / 06 / 2008$ & El juego de la oca que no es juego ni tiene ocas, por Jorge Lanata \\
\hline $18 / 06 / 2008$ & "Queremos discusión", entrevista a la Mesa de Enlace \\
\hline $18 / 06 / 2008$ & Una plaza lista para que reviente, por Javier Romero \\
\hline $19 / 06 / 2008$ & "No se arregla nada con las cacerolas". \\
\hline $19 / 06 / 2008$ & El amor no llega a las rutas \\
\hline $19 / 06 / 2008$ & "Pedimos respeto a la Presidenta" \\
\hline $19 / 06 / 2008$ & 2008 no es 2001, por Maristella Svampa \\
\hline $21 / 06 / 2008$ & Yendo de la ruta a la plaza del Congreso, por Andrés Fidanza \\
\hline $21 / 06 / 2008$ & ¿Nueva tregua o fin del conflicto?, por Rosendo Fraga. \\
\hline $21 / 06 / 2008$ & En Rufino, cortar la ruta es cosa seria, \\
\hline $21 / 06 / 2008$ & Cristina habla tanto que parece cadena perpetua, por Nicolás Wiñazki, \\
\hline $28 / 06 / 2008$ & Volvió la política, por Susana Viau \\
\hline $28 / 06 / 2008$ & Por un día fue Plaza del Kongresito, por Javier Romero \\
\hline $28 / 06 / 2008$ & El toro Alfredito y el pingüino Nestitor, por Maxi Montenegro \\
\hline
\end{tabular}

\begin{tabular}{|c|l|}
\hline & \multicolumn{1}{c|}{ JULIO } \\
\hline FECHA & \multicolumn{1}{c|}{ TITULO/AUTOR } \\
\hline $06 / 07 / 2008$ & Cómo ganar contando las moneditas \\
\hline $09 / 07 / 2008$ & Se vienen los gringos, se vienen \\
\hline $09 / 07 / 2008$ & Otra marcha piquetera, sin carpas ni incidentes \\
\hline $10 / 07 / 2008$ & La vaca loca va a terapia. \\
\hline $10 / 07 / 2008$ & Un duro entre los más duros, por Rodolfo González Arzac \\
\hline $10 / 07 / 2008$ & De las rutas a Palermo sin escalas \\
\hline $10 / 07 / 2008$ & Saladillo se puso muy picante \\
\hline $15 / 07 / 2008$ & Para saber quien tiene la multitud más larga \\
\hline $16 / 07 / 2008$ & Cada tres del campo, uno de Kirchner. \\
\hline $16 / 07 / 2008$ & El agro copó Palermo y pidió el apoyo de los senadores, crónica del acto en \\
& Palermo por Rodolfo González Arzac. \\
\hline $16 / 07 / 2008$ & Hay pañuelo, chori, boina y rayban, por Martín Caparrós. \\
\hline $16 / 07 / 2008$ & El aparato, la historia de siempre, por Susana Viau. \\
\hline $16 / 07 / 2008$ & "Basta de comandos civiles para agredir" \\
\hline $19 / 07 / 2008$ & La sociedad se mueve, por Claudio Lozano \\
\hline
\end{tabular}




\section{BIBLIOGRAFÍA}

ABOY CARLÉS, Gerardo (2003), "Repensando el populismo", en Política y Gestión, № 4.

ABOY CARLÉS, Gerardo (2005), "Populismo y democracia en la Argentina contemporánea. Entre el hegemonismo y la refundación", en Estudios Sociales, $N^{\circ} 28$, Universidad Nacional del Litoral.

ALEXANDER, J (1981): "The mass news media in systemic, historical and comparative perspective", en Katz y Szcsko (eds): Mass Media and Social Change. Londres. Sage.

ALONSO, P. (2010): Jardines secretos, legitimaciones públicas. El partido Autonomista Nacional y la política argentina de fines del siglo XIX. Buenos Aires: Edhasa.

ALTHEIDE, D.L. y SNOW, R.P. (1979): Media Logic. Beverly Hills: Sage.

AMOSSY, R. (2000): "Lo plausible y lo evidente: doxa, interdiscurso, tópicos", en L'argumentation dan le discuours. Discours politique, littérature d'idées, fiction. Paris. Nathan. Capítulo 3

ARCHENTI, MARRADI, PIOVANNI (2007): "Estudios de caso/s", en Metodología de las ciencias sociales. Buenos Aires. Emecé, pp. 237-246.

ARDITI, B. (2007) "Post-hegemonía: la política fuera del paradigma postmarxista habitual", Contemporary Politics, Vol. 13, No. 3.

ARENDT, Hannah (2003): Conferencias sobre la filosofía política de Kant. Buenos Aires: Paidós.

ARFUCH, L (1987): "Dos variantes en el juego de la política en el discurso electoral de 1983", en Verón et al: El discurso político. Lenguajes y acontecimientos. Buenos Aires. Hachette.

ARONSKIND Y VOMARRO (comps) (2010): Campos de batalla. Las rutas, los medios y las plazas en el nuevo conflicto agrario. Buenos Aires. Prometeo.

ARONSKIND, R(2010): "Cambio estructural y conflicto distributivo: el caso del agro argentino", en Aronskind y Vomarro (comps) (2010): Campos de batalla. Las rutas, los medios y las plazas en el nuevo conflicto agrario. Buenos Aires. Prometeo.

ARUGUETE, Natalia y ZUNINO, Esteban (2012): "La responsabilidad de los actores en la cobertura mediática del 'conflicto del campo' de 2008: un 
estudio de caso a partir de la realidad argentina", en Intersecciones en Comunicación 6, Pp. 27-56

ASIAIN, Andrés (2008): "Retenciones a la exportación, una mirada más allá de la cuestión fiscal” en Realidad Económica 236.

AWAD, Gloria (2010) Informer, relier : le journalisme en tant que modèle moderne de médiation, Communication, 28(1):40-70.disponible en : http: //communication.revues.org/2025?lang=en

BACZKO, B (2005): Los imaginarios sociales. Memorias y esperanzas colectivas. Buenos Aires, Nueva Visión.

BAKER, K.M. (1987) “Politique et opinión publique sous l'Ancien Régime", en Annales. Economies, Societés, Civilisations. 42e année, N. 1, 1987, pp 41-71

BALSA, Javier (2008): "Ideología de los productores rurales pampeanos. Su análisis en términos de las disputas hegemónicas", en Revista Realidad Económica, $\mathrm{n}^{\circ}$ 237, Julio-Agosto de 2008.

BARBIER, F y LAVENIR, C. (1997): Historia de los medios. De Diderot a Internet. Buenos Aires, Colihue.

BARRERA, Carlos (2004): Historia del periodismo universal. Barcelona, Ariel.

BARROS, S. (2005), "Espectralidad e inestabilidad institucional. Acerca de la ruptura populista", en Estudios Sociales N 30, UNL, Santa Fe.

BARSKY, O. y DÁVILA, M. (2008): La rebelión del campo. Sudamericana. Buenos Aires.

BARSKY, Osvaldo (2011): "El conflicto agrario argentino desde la resolución 125", en Muzlera, Jorge, Poggi Marina y Carreras Doall, Ximena (comps.): Aportes, sujetos y miradas del conflicto agrario argentino (1910-2010). Buenos Aires, Circus.

BASTIEN François y NEVEU, Eric (1999): "Introduction. Pour une sociologie politique des espaces publics contemporains", en Espaces publics mosaïques Acteurs, arènes et rhétoriques des débats publics contemporains. Renne. Presses universitaires de Renne.

BASUALDO, Eduardo y ARCEO, N. (2009). "Características estructurales y alianzas sociales en el conflicto por las retenciones móviles". En:, La crisis mundial y el conflicto del agro, Buenos Aires, Editorial La Página.

BECERRA, M (2010): "Las noticias van al mercado. Etapas de intermediación de lo público en la historia de los medios de la Argentina", en Lugones, G. y 
Flores, J. (comp): Intérpretes e interpretaciones de la Argentina en el Bicentenario. Bernal: Universidad Nacional de Quilmes.

BECERRA, M y LÓPEZ, S (2010): "La contienda mediática", en Revista de Ciencias Sociales, $\mathrm{n}^{\circ} 16$, UNQ.

BÉLANGER, André (1998): La comunicación política, o el juego del teatro y de las arenas, en Gauthier, Gosselin y Mouchon: Comunicación y política. Gedisa. Barcelona.

BIGLIERI, P: "El retorno del pueblo argentino: entre la autorización y la asamblea. Argentina en la era K”, en Biglieri y Perelló: En el nombre del pueblo. Buenos Aires. UNSAM.

BITONTE, María Elena (2010): "Ni unidos ni dominados, sencillamente, sordos. Algunas peculiaridades de la retórica de Cristina Fernández". Trabajo presentado en el Congreso Regional de la Cátedra UNESCO en Lectura y Escritura, 2010, Universidad Nacional de General Sarmiento.

BLAUSTEIN, E. (2013): Años de rabia. El periodismo, los medios y las batallas del kirchnerismo. Buenos Aires. Ediciones B.

BORRAT, Héctor: “El periódico, actor del sistema político", mímeo, 1989. Disponible en http://ddd.uab.cat/pub/analisi/02112175n12p67.txt

BOURDIEU, P. (1999): "El lenguaje autorizado: las condiciones sociales de la eficacia del discurso ritual”, en ¿Qué significa hablar?, Madrid. Akal.

BOURDIEU, Pierre (1990): Sociología y cultura. Barcelona: Grijalbo

BOVET Alain y MALBOIS Fabienne, (2011) “(En)jeux du cadre de participation dans la discussion publique médiatisée ", dans $M$. Bürger, R. Micheli \& J. Jacquin (sous la dir. de), La parole politique en confrontation dans les médias, Bruxelles, De Boeck, 2011, p. 51-86.

BRACCO, Olga (2014): “De progresistas y reaccionarios: Representaciones mediáticas sobre la clase media en la Argentina contemporánea". Tesina de Licenciatura en Sociología, Facultad de Humanidades y Ciencias de la Educación, UNLP. Disponible en: http://www.memoria.fahce.unlp.edu.ar/tesis/te.972/te.972.pdf.

CALIFANO, B. (2009): Medios y Políticas de Comunicación en Argentina bajo el gobierno de Néstor Kirchner (2003-2007). Facultad de Ciencias Sociales. Carrera de Ciencias de la Comunicación. UBA

CALVET, L.J (2007): Historia de la escritura : De Mesopotamia hasta nuestros días 
CARLÓN, M. (2004): Sobre el dispositivo. Buenos Aires: Gedisa.

CEFAï, Daniel (2002): "Qu'est-ce qu'une arène publique? Quelques pistes pour une aproche pragmatiste". En Cefaï, D. y Joseph, I. (coords.). L'heritage du pragmatisme. Conflits d'urbanité et épreuves de civisme. La Tour d'Aigues: Éditions de l'Aube, pp. 51-81.

CEFAï, Daniel y PASQUIER, Dominique (2003): "Les sens du public", Introducción a Les sens du public. Publics politiques, publics médiatiques. Paris. PUF.

CHARAUDEAU, P (2002) “_Para qué sirve analizar el discurso político”?”, en De Signis, $n^{\circ} 2$, Abril de 2002. Barcelona. Gedisa.

CHARAUDEAU, P. (2004): "Tiers où es-tu?", mímeo, disponible en http: //www.patrick-charaudeau.com/Tiers-ou-es-tu,91.html

CHARAUDEAU, Patrick (2003): El discurso de la información. La construcción del espejo social. Barcelona. Gedisa. 2003.

CHARTIER, R. (1995): “Espacio público y opinión pública”, en Espacio público, crítica y desacralización en el siglo XVIII. Barcelona: Gedisa.

CHERESKY, I (2006): "La ciudadanía y la democracia inmediata », en Ciudadanía, Sociedad Civil y participación política. Buenos Aires. Miño y Dávila.

CHERESKY, I. (2009) Poder presidencial, opinión pública y exclusión social. Buenos Aires: Manantial.

CHILTON, Paul y SCHÄFFNER, Christina (2001): “Discurso y política”, en Van Dijk, Teun: El discurso como interacción social. Vol 1. Barcelona. Gedisa.

CINGOLANI, G (2009): "Mediatización de la figura presidencial: espacios, estrategias y transiciones", en Pentálogo inaugural CISECO. Jarapatinga, Brasil. Septiembre de 2009. Mimeo.

CINGOLANI, G (2012): "A midiatizacao da figura presidencial: espacos, estratégias e trasicioes", en Fausto Neto, Mouchon, Verón (comps.): Tranformacoes da midiatizacao presidencial. Sao Caetano do Sul. Difusao Editora.

CINGOLANI, G. (2014): “¿Qué se transforma cuando hay mediatización?”, mimeo.

COOK, Timothy (1998): Governing with the news. The news media as a political institution. Chicago. University of Chicago Press. 
COUSO, Claudia (2008): "La conformación de un imaginario de «modelo de país» en el discurso presidencial de CFK. El lugar del sector rural”, en Labvoratorio. Revista sobre estudios sobre cambio cultural y desigualdad social, 22, pp. 45-50. Disponible en: http://publicaciones.sociales.uba.ar/index.php/lavboratorio/article/view/94

CREMONTE, Juan Pablo (2007): “El estilo de actuación pública de Néstor Kirchner", en Rinesi, Nardacchione y Vommaro: Los lentes de Victor Hugo. Transformaciones políticas y desafíos teóricos en la Argentina reciente. Buenos Aires, UNGS-Prometeo.

CREMONTE, J.P (2010): "Cada cual atiende su juego. La construcción del conflicto entre el Gobierno Nacional y las entidades agropecuarias en Clarín, La Nación y Página 12", en Aronskind y Vommaro, op.cit.

DAGATTI, Mariano y MAIZELS Ana Laura (2011): "Figuras del estadista: ethos, saber e identificación política en los discursos de Néstor Kirchner y Cristina Fernández", ponencia presentada en IX Jornadas de Sociología. UBA. 8 al 12 de Agosto de 2011. Mímeo.

DARNTON, R (2003): "Una de las primeras sociedades informadas: las novedades y los medios de comunicación en París en el siglo XVIII", en El coloquio de los lectores. Ensayos sobre autores, manuscritos, editores y lectores. México D.F.: Fondo de Cultura Económica.

DASCAL, M (2010): "Types of Polemics and Types of Polemical Moves" en S. Cmejrkova, J. Hoffmannova, O. Mullerova, and J. Svetla, Dialogue Analysis VI vol. 1. Tubingen: Max Niemeyer, 15-33. Disponible en http://www.tau.ac.il/humanities/philos/dascal/publications.html

DAYAN, Daniel (2000): Televisión, el casi-público. Versión original: "Televisión, le presque public", Rev. Réseaux $n^{\circ}$ 100-Cent/Hermés Science Publication. Traducción de Natalia Ferrante y Gastón Cingolani. Mímeo.

DAYAN, Daniel, "Televisión: le presque public", en Revista Réseaux n 100CENT/Hermès Science Publication - 2000

DAYAN, D y KATZ, E (1995): La historia en directo. La retransmisión televisiva de los acontecimientos. Barcelona. Gustavo Gili.

De DIEGO, Julia y D'AMICO, María Laura (2009): Las presiones del poder. Censura directa y derecho a la información en el gobierno de Néstor Kirchner. La Plata : CECPS.

DE ÍPOLA, Emilio (1982): Ideología y discurso populista. Buenos Aires: Folios. 
DE MARTINELLI, G(2008): "Pools de siembra y contratistas de labores. Nuevos y viejos actores sociales en la expansión productiva pampeana reciente". En: Javier Balsa, Graciela Mateo y María Silvia Ospital, ed., Pasado y presente en el agro argentino, Buenos Aires, Lumiere.

DUCROT, Oswald (2001) : El decir y lo dicho. Buenos Aires, Edicial.

DUNCAN, Tim (1980): La prensa política: Sud América, 1884-1892, en Ferrari y Gallo (comps): La Argentina del Ochenta al Centenario, Buenos Aires: Sudmericana.

EDELMAN (2002): La sociedad del espectáculo. Manantial. Buenos Aires.

EISENSTEIN, E. (1990): "Sobre la revolución y la palabra impresa", en Porter, R. y Mikulás. T: La revolución en la historia. Barcelona: Crítica.

ENTMAN, R. (2009): “The mediatization of politics in History", en Voerman, P. y Wifjes, H: Mediatization of politics in History. Groningen: Peeters.

FABBRI, P. y MARCARINO, A. (2002): “El discurso político", en De signis $\mathrm{n}^{\circ} 2$, Abril de 2002. Barcelona. Gedisa.

FERNÁNDEZ Mariano (2009): “Televisión en la era de la política: más allá de la perspectiva de la video política", en Actas de las V Jornadas de Jóvenes Investigadores. Instituto Gino Germani-Facultad de Ciencias Sociales (UBA).

FERNÁNDEZ Mariano, CINGOLANI Gastón: (2010a): Televisión y política: espacio público, puestas en escena y regímenes de visibilidad. Oficios Terrestres $\mathrm{N}^{\circ}$ 25. Facultad de Periodismo y Comunicación Social. UNLP.

FERNÁNDEZ y CINGOLANI (2010b): “Televisión, identidades y ciudadanía. Estrategias políticas y estrategias audiovisuales en cuatro actos de Cristina Fernández." Primeras Jornadas de Debates Actuales de la Teoría Política Contemporánea. Ciudad de Buenos Aires. UBA. 11/03/2010. http://teoriapoliticacontemporanea.blogspot.com/search/label/ldentidad

FERNÁNDEZ, M. (2010): “Discurso político y discurso periodístico: lógicas de mediación entre identidades colectivas", presentado en XIV Jornadas de Nacionales de Investigadores en Comunicación. Universidad Nacional de Quilmes. Disponible en www.redcomunicación.org

FERNÁNDEZ, Mariano (2011a): “Legalidad de la representación y representación del liderazgo en cuatro actos de Cristina Fernández. Gestión de colectivos y construcción de regímenes de visibilidad", en Derqui, Alcira (comp.): "Capitalismo del siglo XXI, crisis y reconfiguraciones. Luces y sombras en América Latina”. UBA. Ebook. ISBN: 978-950-29-1296-7 
FERNÁNDEZ, Mariano (2011b): El discurso político y la politicidad de los discursos. Una hipótesis de trabajo sobre la gestión de colectivos de identidad en periodismo y política. Revista Question. Vol 1, No 30 (2011) Disponible en http://perio.unlp.edu.ar/ojs/index.php/question

FERNÁNDEZ, Mariano y STOESSEL, Soledad (2012): “¿Una estrategia populista?: el discurso de los dirigentes agropecuarios durante el conflicto del campo en Argentina (Marzo-Julio de 2008)", ponencia presentada en las VII Jornadas de Sociología, organizadas por la Universidad Nacional de La Plata, 5, 6 y 7 de diciembre, 2012

FERNÁNDEZ, M. (2013): "Mediatización de la política en la Argentina kirchnerista: figura presidencial, periodismo militante y disputas por la toma pública de la palabra", en Derqui, A. (comp): Actas X Jornadas de Sociología. UBA.

FERNÁNDEZ, M (2014): “Sobre la mediatización: revisión conceptual y propuesta analítica", en La trama de la comunicación. Vol 18, año XVIII. UNR.

FERRY, J. (comp). [1989] (1998): El nuevo espacio público. Barcelona: Gedisa

FRASER, Nancy (1990): "Rethinking the Public Sphere: A Contribution to the Critique of Actually Existing Democracy”, Social Text, No. 25/26, (1990), pp. 56-80

GARCÍA NEGRONI, M. M (1988): "La destinación en el discurso político: una categoría múltiple”, en Lenguaje en contexto I (1/2), pp 85-111.

GARGUÍN, Enrique (2013): "La clase media en el discurso público" Cuestiones de Sociología, $\mathrm{n}^{\circ} \quad 9 . \quad$ Disponible: http://www.cuestionessociologia.fahce.unlp.edu.ar/

GAUTHIER, Gosselin y Mouchon (1998): Comunicación y política. Barcelona. Gedisa.

GIARRACA, Norma, TEUBAL, M. (2008). "Paro agrario: crónica de un conflicto alargado," Realidad económica, № 237

GIARRACA, Norma; TEUBAL, Miguel (coord.) (2011): Del paro agrario a las elecciones de 2009. Tramas, reflexiones y debates. Buenos Aires, Antropofagia.

GIDDENS, A (1995): La constitución de la sociedad: bases para una teoría de la estructuración. Buenos Aires: Amorrortu.

GOFFMANN, Erving (2006): Frame Analysis. Los marcos de la experiencia. Madrid. CIS. 
GOODY, Jack (1990), La lógica de la escritura y la organización de la sociedad. Madrid: Alianza.

GOODY, Jack y WATT, Ian (1968): "Las consecuencias de la cultura escrita", en Goody, Jack (comp.): Cultura escrita en sociedades tradicionales. Barcelona: Gedisa.

GRANDI, Roberto (2002): "El sistema de medios y el sistema político", en De Signis, $\mathrm{n}^{\circ} 2$, Abril de 2002. Barcelona. Gedisa

GRAS, Carla (2010): “Actores agrarios y formas de acción política en la Argentina contemporánea”, en Aronskind y Vommaro, op. cit.

GRAS, Carla (2011): "Conflicto agrario, actores sociales y la construcción política del campo", en Muzlera, Jorge, Poggi Marina y Carreras Doall, Ximena (comps.): Aportes, sujetos y miradas del conflicto agrario argentino (19102010). Buenos Aires, Circus.

GRAS, Carla y BIDASECA, Karina (2011): El mundo chacarero en tiempos de cambio.Herencia, territorio e identidad en los pueblos sojeres. Buenos Aires. Ediciones Cicus.

GRAS, Carla y HERNÁNDEZ, V. (2009). 'Son los piquetes de la abundancia'. Actores y Estado en el conflicto agrario en Argentina. LASA 2009. Río de Janeiro.

GROYS, Boris (2008): Bajo sospecha. Una fenomenología de los medios. Valencia, Pre-Textos.

GUBERN, Roman (1991): El simio informatizado. Buenos Aires. Eudeba.

GUESPIN, Louis (1976): “Types de discours ou fonctionnements discursifs?", en Langages $\mathrm{n}^{\circ} 41$, Tiypologie du discours politique, pp. 3-12. 1976. Disponible en http://www.persee.fr/web/revues/home/prescript/article/lgge_0458726x_1976_num_10_41_2301

HABERMAS, Jürgen ([1962] 2006), Historia y crítica de la opinión pública. La transformación estructural de la vida pública. Barcelona, Gustavo Gili.

HABERMAS, Jürgen (2005): Facticidad y validez. Sobre el derecho y el Estado democrático de derecho en términos de teoría del discurso. Madrid, Trotta.

HALPERIN DONGHI, T (1985): José Hernández y sus mundos. Buenos Aires, Sudamericana.

HALLIN, Daniel y MACINI, Paolo (2004): Comparing media systems. Three models of media and politics. Cambridge: Cambridge University Press. 
HEINICH, Natalie y SCHAEFFER, Jean-Marie (2004): “Art, creation, fiction. Entre philosophie et sociologie. Nimes, Éditions Jacqueline Chambon.

HELMS, Ludger (2008): "Governing in the Media Age: the impact of the mass media on executive leadership in contemporary democracies", en Governmente and opposition, vol. $43, \mathrm{~N}^{\circ}$, pp 26-54.

HERNÁNDEZ, Valeria (2007): “El fenómeno económico y cultural del boom de la soja y el empresariado innovador", en Desarrollo Económico, Vol. 47, $\mathrm{n}^{\circ}$ 187, octubre-diciembre, Buenos Aires, pp. 331-365.

HJARVARD, Stig (2008): The mediatization of society. A theory of the media as agents of social and cultural change. Nordicom Review 29, (2008) 2, pp. 105134.

HJARVARD, Stig (2013): A midiatização da cultura e da sociedade. Sao Leopoldo. Ed. UNISINOS.

HORA, Roy (2010): “La crisis del campo del otoño de 2008”, en Desarrollo Económico, vol. 50, nro. 197, abril junio de 2010. Pp. 81-111.

IÑIGO CARRERA, Nicolás (2011): “El enfrentamiento social como constituyente de las clases sociales como sujetos", en Muzlera, Jorge, Poggi Marina y Carreras Doall, Ximena (comps.): Aportes, sujetos y miradas del conflicto agrario argentino (1910-2010). Buenos Aires, Circus.

KABAT, Mariana (2008): "Viudas e hijas de las retenciones K", en El aromo, Maryo-Junio de 2008.

KANT, Immanuel (1784): “Respuesta a la pregunta ¿qué es la ilustración?, en Filosofía de la historia-Qué es la ilustración. Terramar, La Plata, 2004.

KAUFMANN, Laurence (2010) "Faire 'être collectif' “: de la constitution à la maintenance. En Raisons pratiques 20, pp. 331-372, 2010

KEPPLINGER, Hans (2006): "Mediatization of politics, theory anda data", en Journal of CommunicationVolume 52, Issue 4, Article first published online: 10 JAN 2006

KERBRAT ORECCHIONI, Catherine (1986) : La enunciación. De la subjetividad en el lenguaje. Buenos Aires. Hachette.

KITZBERGER, P (2005): "La prensa y el gobierno de Kirchner frente a la opinión pública", en AA.VV: Argentina en perspectiva. Reflexiones sobre nuestro país en democracia. Buenos Aires. La Crujía. 
KITZBERGER, Philip (2010): “The media activism of Latin American's Leftist Governments: Does Ideology Matter?” , en GIGA Working Papers, n 151, GIGA Research Unit: Institute of Latin American Studies.

KITZBERGER, Philip (2011): “' 'La madre de todas las batallas': el kirchnerismo y los medios de comunicación”, en Malamud y De Luca (coord.): La política en los tiempos de Kirchner. Buenos Aires. Eudeba.

KROTZ Friedrich (2007): “The meta-process of 'mediatization' as a conceptual frame." Global Media and Communication 2007; 3; 256. Online version: http://gmc.sagepub.com

LACLAU, Ernesto (2005): La razón populista. Buenos Aires. Fondo de Cultura Económica.

LANDI, Oscar (1998): Reconstrucciones. Las nuevas formas de la cultura política. Buenos Aires. Planeta.

LANDI, Oscar. (1992) : Devórame otra vez. Qué hizo la televisión con la gente. Qué hace la gente con la televisión. Buenos Aires, Planeta.

LANDOWSKY, E. (1985): «Eux, nous et moi: régimes de visibilité", Mots, Le «nous» politique, $\mathrm{N}^{\circ} 10$; pp. 9-16.

LATOUR, B. (2003): "What if we were talking politics a Little?", en Contemporary Political TheoryK, 2/2, páginas 143-164. Disponible en www.palgrave-journals.com/cpt

LATOUR, Bruno (2008): Reensamblar lo social. Hacia una teoría del actor-red. Buenos Aires: Manantial.

LEFORT, C. (1991) La invención democrática, Buenos Aires: Nueva Visión.

LEROI GOURHAN, A. (1988): Evolución y Técnica. Vol. 1. Madrid: Taurus.

LIVINGSTONE Sonia (2004), "Du rapport entre audiences et publics", Réseaux, 2004/4 no 126, p. 17-55.

LIVINGSTONE, S. (2009): "On the mediation of everything: ICA presidential address 2008", Journal of communication, 59 (1). Pp. 1-18. Disponible en http://eprints. Ise.ac.uk/21420

LUHMAN, N. (1998): Sistemas sociales. Lineamientos para una teoría general. México D.F.: Antrophos

LUHMANN, N (2008): La política como sistema. México. Universidad Iberoamericana.. 
LUHMANN, N. (2000): La realidad de los medios de masas. México D.F.: Anthropos.

LUNDBY, KNUT (2014): Mediatization of communication. Handbooks of Communication Science. Berlín/Boston, De Gruyter Mouton

MAINGUENEAU, Dominique (1980) Introducción a los métodos de análisis del discurso, Buenos Aires, Hachette.

MAINGUENEAU (2002) “Problèmes d'ethos”, Pratiques, 113-114

MAINGUENEAU, Dominique (2003) ¿"Situación de enunciación" o "situación de comunicación"? en Revista Discurso.org, Año 2, №5

MAIZELS, Ana Laura (2014): “Argumentación e imagen de sí de la Presidenta argentina, Cristina Fernández, en el marco de la crisis con el sector agropecuario", en RÉTOR, 4 (2), pp. 153-181, 2014

MALBOIS, Fabienne y KAUFMANN, Laurence (2015): “De l'espace public comme organisation. L'architecture feuilletée des énonciations publiques” Revue française des sciences de l'information et de la communication [Online], 6 | 2015, Online since 23 January 2015, connection on 10 August 2015. URL : http: //rfsic.revues.org/1333

MANIN, Bernard (1998): Los principios del gobierno representativo. Madrid. Alianza.

MARCINKOWSKI, Frank (2014): "Mediatisation of politics: reflections on the state of the concept”, en Javnost-The public. Vol. 21 (2014). No. 2. Pp. 5-21.

MARCINKOWSKI, Frank y STEINER, Adrian (2014): "Mediatization and political autonomy: a systems approach", en Esser Frack y Stromback Jesper: Mediatization of politics, understanding the transformation western democracies", Londres, Palgrave Macmillan.

MARINO, Santiago (2005) "Análisis crítico de la política de comunicación en la Argentina kirchnerista”, en Actas del Seminario Políticas de Comunicación del Mercosur, 2005, Uruguay. Publicado por Universidad de la República. Mimeo.

MARTINEZ, Fabiana (2008): "Radicalización de antagonismos: discursos presidenciales durante el conflicto con el campo", en Actas XII Jornadas Nacionales de Investigadores en Comunicación, Fac. de Ciencia Política y RR.II., UNR. Octubre de 2008, Disponible en http//www.redcomunicacion.org/memorias/index.php

MASTRINI, Guillermo y BECERRA, M. (2006): "La concentración mediática en argentina. De eso no se habla". Disponible en www.censuradirecta.org.ar Fecha de consulta: 14 de marzo de 2013. 
MASTRINI, G. (2008): “Al final del período. Los límites del progresismo: las políticas de comunicación durante el gobierno de Néstor Kirchner" en Publicado en ECO-PÓS- v.11, n.1, janeiro-julho 2008, pp.78-95

MASTRINI, G. (2010): "Regulación de las comunicaciones", en Aroskind y Vommaro (comps.): Campos de batalla..... Buenos Aires, UNGS-Prometeo.

MAZZOLENI, G. (1987): "Media logic and Party Logic in Campaign Coverage: The Italian General Election of 1983". European Journal of Communicatoin 2 (1): 81:103.

MAZZOLENI, G. y SCHULZ, W. (1999): “'Mediatization' of politics: a challenge for democracy”, en Political Communication, 16: 247-261.

MCCHENESNEY, Robert y NICHOLS, John (2005): “The rise of professional journalism. Reconsidering the roots of our profession in an age of media crisis", on line: http:/inthesetimes.com/article/continued/2427/the_rise_of_professional_jou rnalism

MOCHKOFSKY, Graciela (2011): Pecado original. Clarín, los Kirchner y la lucha por el poder. Buenos Aires, Planeta.

MONTENEGRO, Maximiliano (2009): Es la Ekonomía, estúpido. La historia secreta de las decisiones, trampas y falacias del kirchnerismo.

MONTERO, Ana Soledad(2009) : "Puesta en escena, destinación y contradestinación en el discurso kirchnerista (2003-2007)", en Revista Discurso y Sociedad, Vol. 3(2) 316- 347

MONTERO, A. S.(2012): Y al final un día volvimos! Los usos de la memoria en el discurso kirchnerista (2003-2007)

MONTERO, A. S. y VINCENT, L. (2013): “Del 'peronismo impuro' al 'kirchnerismo puro': la construcción de una nueva identidad política durante la presidencia de Néstor Kirchner en Argentina (2003-2007)", en POSTData 18, $N^{\circ} 1$, Abril/2013, pp. 123-157.

MOUCHON, Jean (1999): Política y medios. Los poderes bajo influencia. Barcelona. Gedisa.

MUÑOZ, M. y RETAMOZO, M.(2008): "Hegemonía y Discurso en la Argentina contemporánea. Efectos políticos de los usos de "pueblo" en la retórica de Néstor Kirchner", en Revista Perfiles Latinoamericanos, Núm. 31, México.

MURARO, Heriberto (1997): Políticos, periodistas y ciudadanos. Buenos Aires. FCE. 
NAISHTAT, F (1999): “Acción colectiva y regeneración democrática del espacio público", en Quiroga, Villavicencio y Vermeren (comps): Filosofías de la ciudadanía. Sujeto político y democracia. Rosario. Homo Sapiens. Disponible en: http://www.ub.es/escult/docus2/naishtat.pdf

NAISHTAT, F (2004): Problemas filosóficos en la acción individual y colectiva. Una perspectiva pragmática, Buenos Aires, Prometeo.

NARDACCHIONE, Gabriel (2005): “La acción colectiva de protesta : del antagonismo al espacio público", en Schuster, Naishtat, Nardacchione y Pereira (comps.): Tomar la palabra. Estudios sobre la protesta social y acción colectiva en la Argentina contemporánea", Buenos Aires, Prometeo-UNSAM.

NARDACCHIONE, Gabriel y Taraborelli, Diego (2010): "La importancia de los aliados: un estudio sobre el conflicto rural (marzo-julio 2008)", en Aronskikd y Vommaro (comps): Campos de batalla. Las rutas, los medios y las plazas en el nuevo conflicto agrario. Prometeo. Buenos Aires.

NASSEHI, Armin (2011): "La teoría de la diferenciación funcional en el horizonte de sus críticas”, en Revista Mad, Universidad de Chile, $\mathrm{n}^{\circ} 24$, mayo de 2011, pp 1-29.

NOVARO, Marcos (2000): Representación y liderazgo en las democracias contemporáneas. Buenos Aires. Homo Sapiens.

NOVARO, Marcos (2011): "La cultura política y el sentido común bajo el kirchnerismo", en Malamud y De Luca (coord.): La política en tiempos de los Kirchner. Eudeba, Buenos Aires.

O'DONNEL, Guillermo (2004): “Accountability horizontal: la institucionalización legal de la desconfianza política. Revista Española de Ciencia Política. Núm. 11, Octubre 2004, pp. 11-31

OLLIER, María Matilde (2005), "Liderazgo presidencial y jefatura partidaria: entre la confrontación y el pacto (2003-2005)", en Revista Temas y Debates, $\mathrm{N}^{\circ}$ 10, Año 9, Noviembre, Universidad Nacional de Rosario.

ONG, Walter (1982), Oralidad y escritura. México D.F., Fondo de Cultura Económica, 2006.

ORTíz, Sebastián (2010): La patria terrateniente. Nueva Burguesía agroindustrial y construcción del partido del campo. Buenos Aires. Peña Lillo y Ediciones Continente.

PANERO, Marcelo (2009): "Empresarios Agropecuarios y Participación Política en Argentina. La Sociedad Rural Argentina y la nueva elite rural", ponencia presentada en el 21 Congreso Mundial de Ciencia Política Santiago de Chile, 
12 al 16 de julio de 2009. Disponible en http://paperroom.ipsa.org/papers/paper_2441.pdf

PASLEY, Jeffrey, The thyranny of printers. Newspapers politics in the early American Republic. Charlottesville y Londres, University of Virginia Press, 2001.

PASQUINO, G (1983): “Démocratie et représentation. La naissance des parties et la democratie", en L'interrogation democratique. Paris. Espace International Philosophie. Centre George Pompidou.

PATROUILLEAU, M (2010): “Discurso y narración en las dinámicas de constitución identitaria. La experiencia kirchnerista en Argentina", en Revista Confines, 6/11, Enero-Mayo 2010.

PEIRCE, Charles (1987): Obra lógico-semiótica. Madrid, Taurus.

PÉREZ, Sara (2013): "Ser mujer y ser Presidenta: la construcción discursiva de la imagen de Cristina Fernández de Kirchner en el discurso presidencial, 20072011", en Balsa (comp.): Discurso, política y acumulación en el kirchnerismo. CABA: Ediciones del CCC Centro Cultural de la Cooperación Floreal Gorrini y Bernal: Universidad Nacional de Quilmes.

PETRIS, J.L (2005): “¿Los medios “median” o “mediatizan”?, en Reflexión Académica en Diseño y Comunicación $\mathrm{N}^{\circ} \mathrm{VI}$, Buenos Aires, Universidad de Belgrano.

PITKIN, H. F. (1985): El concepto de representación. Madrid, Centro de Estudios Constitucionales.

PIZZORNO, A. (1985): “Sobre la racionalidad de la opción democrática", en Los límites de la democracia, Buenos Aires, Clacso.

QUÉRÉ, L. (2003): “Le public comme forme et comme modalité d'experience", en Cefaï y Pasquier (comps): Le sens du public. Publics politiques, publics médiatiques. Paris. PUF.

QUÉRÉ, Louis (2006): “Entre fait et sens, la dualité de l'événement”, Réseaux 2006/5 (no 139),p. 183-218.

RABOTNIKOF, N (2005): En busca de un lugar común. México D.F.: Universidad Nacional Autónoma de México, Instituto de Investigaciones Filosóficas,

RABOTNIKOF, Nora (1997): El espacio público y la democracia moderna. México DF. Instituto Federal Electoral.

RAITER, A (2009): "Yo hablo, ustedes entiendan. Interdiscurso y presuposición en los discursos de Cristina Fernández de Kirchner”. Mimeo. 
RAITER, Alejandro (2013); “EExiste una lógica discursiva kirchnerista? Constancias y alternancias", en Balsa, J. (comp.): Discurso, política y acumulación en el kirchnerismo. CABA: Ediciones del CCC. Universidad Nacional de Quilmes.

RANCIÈRE, Jacques ([1996] 2007): El desacuerdo. Política y filosofía. Buenos Aires. Nueva Visión.

RANCIÈRE, Jacques (2000): "Política, subjetivación e identificación", en Arditi, Benjamín (2000): El reverso de la diferencia. Identidad y política. Caracas. Nueva Sociedad.

RANCIÈRE, Jacques (2006): "The Politics of Aesthetics / The Aesthetics of Politics", disponible en http://www.16beavergroup.org/mtarchive/archives/001877print.html. Mimeo.

RETAMOZO, Martín (2013): “Discursos y lógica política en clave K. En Balsa. J (coord.) Discurso, política y acumulación en el kirchnerismo. Buenos Aires (Argentina): UNQui - CCC.

RINESI, E, NARDACCHIONE, G, y VOMMARO, G. (2007): Las lentes de Victor Hugo. Transformaciones políticas y desafíos teóricos en la Argentina reciente. Buenos Aires, UNGS-Prometeo.

RINESI, E (2010): “Política y corporaciones”, en Aronskind y Vommaro, op.cit.

RODRÍGUEZ, Martín (2014): Orden y progresismo. Los años kirchneristas. Buenos Aires, Emecé.

ROFMAN, Alejandro (2010). "El modelo agrario rentístico financiero, sus características". En: Aronskind y Vommaro (comps.). Campos de batalla. Las rutas, los medios y las plazas en el nuevo conflicto agrario. Buenos Aires: Ed. Prometeo.

ROMÁN, Claudia (2010): "La modernización de la prensa periódica, entre La Patria Argentina (1879) y Caras y Caretas (1898)”. En Historia crítica de la literatura argentina, Tomo 3, Buenos Aires, Emecé.

ROMÁN, Claudia: “La prensa periódica. De La Moda (1837-1838) a La Patria Argentina (1879-1885)", en Historia crítica de la literatura argentina. Tomo 2. Buenos Aires, Emecé.

ROSANVALLON, Pierre (2008): La legitimidad democrática. Imparcialidad, reflexividad y proximidad. Buenos Aires. Manantial.

ROSANVALLON, Pierre (2011): La contrademocracia. La política en la era de la desconfianza. Buenos Aires: Manantial 
RUIZ, Fernando (2010): “Fronteras móviles: caos y control en la relación entre medios y políticos en América Latina", en Sorj Bernadro (comp): Poder político y medios de comunicación. De la representación política al reality show. Siglo XXI. Buenos Aires.

SAÍTTA, Silvia (1998): Regueros de tinta. El diario Crítica en la década de 1920. Buenos Aires. Siglo XXI Editores.

SÁNCHEZ RUIZ (2005): Medios de comunicación y democracia. Norma. Buenos Aires.

SARLO, Beatríz (2011): La audacia y el cálculo. Kirchner 2003-2010. Buenos Aires. Planeta.

SARTELLI, E. (comp.) (2008): Patrones en la ruta. Ediciones RyR. Buenos Aires.

SARTORI, Giovanni (1998): Homo videns. Madrid. Taurus

SCHUDSON, M (2002): "The news media as political institutions", en Ann. Review Political Science, 2002, 5:249-69.

SCHUDSON, Michael ([1978] 2012): Discovering the news. A social history of american newspapers. Lexington: Basic Books

SCHUDSON, Michael (1998): “¿Es trucha o hamburguesa? Política y telemitología”, en Veyrat-Masson (comp): Espacios públicos en imágenes. Barcelona: Gedisa.

SCHULZ, W (2004): "Reconstructing mediatization as an analytical concept", European Journal of communication, 19; 87.

SERVAIS C. (2013): “Énonciation journalistique et espace public. Une hégémonie pleine de voix?", Communication,2013, 32, 2, URL http: //communication.revues.org/5058.

SERVAIS, Christine (2013): “Appel au peuple, appel du public. Décrire la réception comme une adresse", Questions de communication, collection “Actes”, pp. 167-180.

SIDICARO, Ricardo (1993): La política mirada desde arriba. Las ideas del diario La Nación 1909-1989. Buenos Aires, Sudamericana.

SIGAL, Silvia (2006): La Plaza de Mayo. Una crónica. Buenos Aires. Siglo XXI

SIGAL, Silvia y VERÓN, Eliseo (2008 [1986]): Perón o Muerte. Los fundamentos discursivos del fenómeno peronista. Eudeba: Buenos Aires. 
SIMMEL, J (2002): Sociología. Ensayo sobre las formas de socialización. Buenos Aires. Siglo XXI.

SIVAK, Martín (2015): Clarín. La era Magnetto. Buenos Aires. Planeta.

SORJ Bernadro (comp): Poder político y medios de comunicación. De la representación política al reality show. Siglo XXI. Buenos Aires

SORLIN, Pierre (1992): “Le Mirage du Public", en Revue d'histoire moderne et contemporaine, n' 39.

STIEGLER, B (1990): « Les temps de la lecture et les nouveaux instruments de la mémoire. Disponible en http://arsindustrialis.org/node/1935

STIEGLER, B. (2002): El tiempo y la técnica. Vol 1. Euskal Herria: Hiru Argitaletxea.

STRÖMBACK, J (2008): "Four phases of mediatization: an analysis of the mediatization of politics", en The International Journal of Press/Politics 2008; $13 ; 228$.

SVAMPA, Maristella (2011): “Argentina, una década después. Del 'que se vayan todos' a la exacerbación de lo nacional-popular”, en revista Nueva Sociedad, $\mathrm{N}^{\circ} 235$, septiembre-octubre de 2011, pp. 17-34.

TAYLOR, Charles (1992): "Modernity and the Rise of the Public Sphere", The Tanner lectures on Human Values, Stanford University

TEJERINA MONTAÑA, Benjamin (2003): "Las teorías sociológicas del conflicto social. Algunas dimensiones analíticas a partir de K. Marx y G. Simmel”, página 62. Reis, 55/91, pp. 47-63.

THERENTY, M.E. y VAILLANT, A. (2001) : L'An I de l'ère mediatique. Analyse litteraire et historique de La Presse de Girardin. París : Nouveau Monde.

THOMPSON, J.P. (1998): Los media y la modernidad. Buenos Aires: Paidós.

TORRE, J. C. (2003): "Los huérfanos de la política de partidos. Sobre los alcances y la naturaleza de la crisis de representación partidaria", en Desarrollo Económico, Vol. 42, № 168 (Enero-Marzo, 2003), pp. 647-665.

TOURAINE, A(1989): “Comunicación política y crisis de representatividad”, El nuevo espacio público.Barcelona. Gedisa.

TRAVERSA, Oscar (2011): "Comentarios acerca de la aparición de La Presse", en Figuraciones. Teoría y crítica de artes, $\mathrm{n}^{\circ}$ 9, diciembre de 2011. Disponible en 
http://www.revistafiguraciones.com.ar/numeroactual/recorrido.php?idr=57\&i $\mathrm{dn}=9$

VALDETTARO, Sandra (2007): "Medios, actualidad, mediatización”, en Boletín de la Biblioteca del Congreso de la Nación Nro 123, "Medios y Comunicación", Bs As, Biblioteca del Congreso, Argentina, Publicaciones Periódicas, 2007. Disponible en www.cim.unr.edu.ar

VAN AELST, MADDENS et al (2008): "Politicians in the News: Media or Party Logic? Media Attention and Electoral Success in the Belgian Election Campaign of 2003, European Journal of Communication 2008 23: 193.

VERÓN, Eliseo (1980): "Discurso, poder, poder del discurso", Annais du Primeiro Coloquio de Semiótica, San Pablo-Río de Janeiro, Ediciones Loyola, PUC.

Verón, E. ([1975] 2004): “Ideología y comunicación de masas: sobre la constitución del discurso burgués en la prensa semanal", en Fragmentos de un tejido. Barcelona, Gedisa.

VERÓN, E ([1984] 2004): "Cuando leer es hacer: la enunciación en el discurso de la prensa gráfica”, en Fragmentos de un tejido. Barcelona. Gedisa.

VERÓN, E. (1987): "La palabra adversativa. Observaciones sobre la enunciación política", en AA.VV., El discurso político. Lenguajes y acontecimientos. Buenos Aires. Hachette

VERÓN, E. (2004): Fragmentos de un tejido. Barcelona. Gedisa.

VERÓN, E. (2012): “La mediatización ayer y hoy”, en Carlón, Mario y Fausto Neto, A: La política de los internautas. Buenos Aires: La Crujía.

VERÓN, E.(1998): "Mediatización de lo político. Estrategias, actores y construcción de colectivos", en Mouchon, Gauthier (comps): Comunicación y política. Barcelona. Gedisa.

VERÓN, Elieso (1999): “Destinatarios”, en Efectos de Agenda. Barcelona. Gedisa.

VERÓN, Eliseo ([1991] 2004b): “Los medios en recepción: desafíos de la complejidad”, en Fragmentos de un tejido. Barcelona: Gedisa.

VERÓN, Eliseo (1994): “Mediatización, comunicación política y mutaciones de la democracia”, en Revista Semiósfera, 1994, n² 2.

VERÓN, Eliseo (1997): “Esquema para el análisis de la mediatización”. 
VERÓN, Eliseo (1998): “Mediatización de lo político. Estrategias, actores y construcción de colectivos", en Mouchon, Gauthier (comps): Comunicación y política. Barcelona. Gedisa.

VERÓN, Eliseo (2001): "Conversación sobre el futuro", en Espacios mentales. Efectos de agenda 2. Barcelona: Gedisa.

VERÓN, Eliseo (2001): El cuerpo de las imágenes. Buenos Aires: Norma.

VERÓN, Eliseo (2001a). "Vínculo social, gran público y colectivos de identificación. A propósito de una teoría crítica de la televisión", en El cuerpo de las imágenes. Norma. Buenos Aires.

VERÓN, Eliseo (2001b): “Los públicos entre producción y recepción: problemas para una teoría del reconocimiento", exposición presentada en Cursos da Arrábida, Portugal, 27 al 31 de Octubre de 2001. Mimeo.

VERÓN, Eliseo (2004): La semiosis social. Fragmentos de una teoría de la discursividad. Barcelona: Gedisa.

VERÓN, Eliseo (2011), “Los cuerpos efímeros”, en Papeles en el tiempo. Buenos Aires, Paidós.

VERÓN, Eliseo (2013): La semiosis social 2. Ideas, momentos, interpretantes. Buenos Aires: Paidós.

VERÓN, Eliseo. ([1984] 2001): "El living y sus dobles. Arquitecturas de la pantalla chica", en castellano en El cuerpo de las imágenes. Buenos Aires: Norma.

VERÓN, Eliseo. ([1988] 2004b): “Prensa gráfica y teoría de los discursos sociales", en Fragmentos de un tejido. Barcelona: Gedisa.

VILLULA, Juan Manuel (2009): “Apuntes críticos para el debate sobre el conflicto agrario de 2008", ponencia presentada en las VI Jornadas Interdisciplinarias de Estudios Agrarios y Agroindustriales Buenos Aires - 11, 12 y 13 de Noviembre de 2009 Facultad de Ciencias Económicas, Universidad de Buenos Aires

VINCENT, Lucía (2011): "La disputa por la mediación durante el kirchnerismo en Argentina", en Confines, vol 7, núm 13, Enero-Mayo de 2011, pp 49-81. Tecnológico de Monterrey, México.

VINCENT, L. (2013): “En la Argentina llegó la hora de hablar con la verdad": el diario La Nación como contradestinatario en las elecciones de 2005". Ponencia presentada en el XI Congreso Nacional de Ciencia Política, Universidad Nacional de Entre Ríos, Paraná, 17 al 20 de julio de 2013 
VIRILIO, Paul (1989): La máquina de visión. Madrid. Cátedra.

VOMMARO, Gabriel (2008b): Mejor que decir es mostrar. Medios y política en la democracia argentina. Buenos Aires. Biblioteca Nacional/UNGS:

VOMMARO, Gabriel (2010). “'Acá el choripán se paga': movilización política y grupos sociales en el reciente conflicto en torno a las retenciones a las exportaciones de granos". En Campos de batalla. Las rutas, los medios y las plazas en el nuevo conflicto agrario. Aronskind y Vommaro (comps.). Buenos Aires: Ed. Prometeo.

VOMMARO, Pablo (2008): "Lo que quiere la gente". Los sondeos de opinión en el espacio de la comunicación política en Argentina (1983-1999). Prometeo: Buenos Aires.

WAISBORD, Silvio (2013): Vox Populista. Buenos Aires. Gedisa.

WEBER, Max (1964): Economía y Sociedad. México. FCE

WEIL, Georges (1944): El periódico. Orígenes, evolución y función de la prensa periódica. México, Unión tipográfica editorial hispano americana (Uteha).

WOLTON, Dominique (2000): Internet, ¿y después?, Barcelona, Gedisa.

YABCOBSKY, Nuria (2010) "Nosotros, ellos... Todos. Los sentidos de la representación política y los recursos discursivos utilizados para ganar legitimidad en el conflicto", en Aroskind y Vommaro: Campos de batalla. Prometeo.

ZIMMERMAN, Eduardo (1997): "La prensa y la oposición política en la Argentina de comienzos de siglo: el caso de "La Nación" y el Partido Republicano". En Documentos de Trabajo, $\mathrm{n}^{\circ}$ 7, Universidad de San Andrés, Agosto de 1997.

ZUNINO, E. (2010): “El conflicto Campo-Gobierno en Clarín: un análisis sobre la selección de los temas y la valoración de la noticia", en Revista Question, FPyCS.

UNLP. http://www.perio.unlp.edu.ar/question/files/zunino_1_informes_27/

ZUNINO, Edi (2009): Patria o medios. La loca Guerra de los Kirchner por el control de la realidad. Buenos Aires. Sudamericana. 